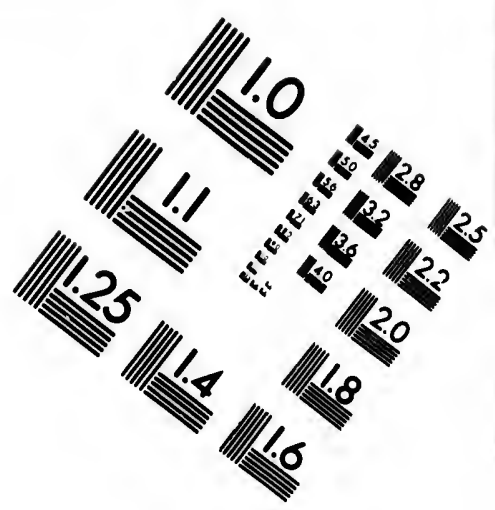

TEST TARGET (MT-3)
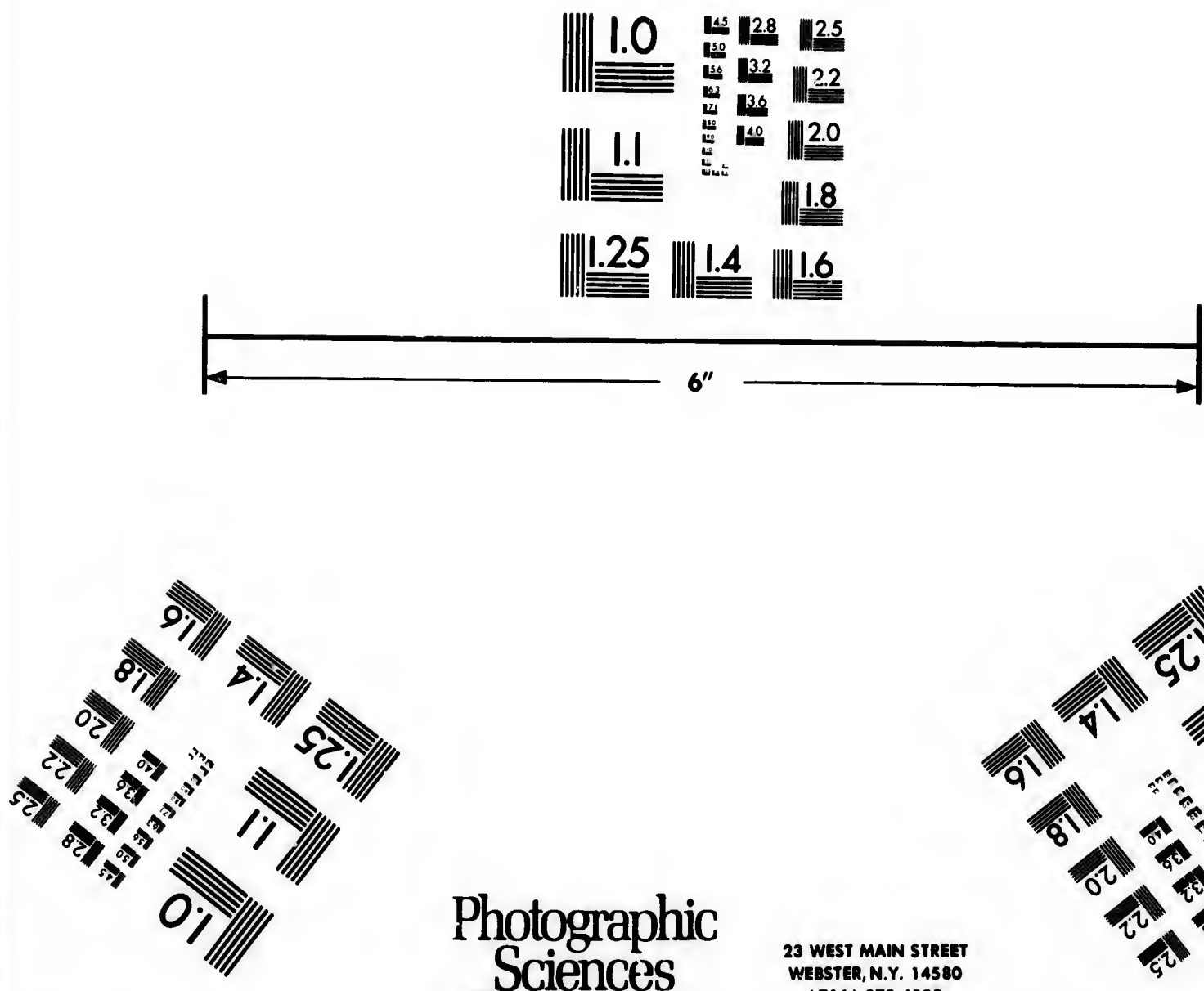

Photographic Sciences Corporation
23 WEST MAIN STREET WEBSTER, N.Y. 14580

(716) 872-4503

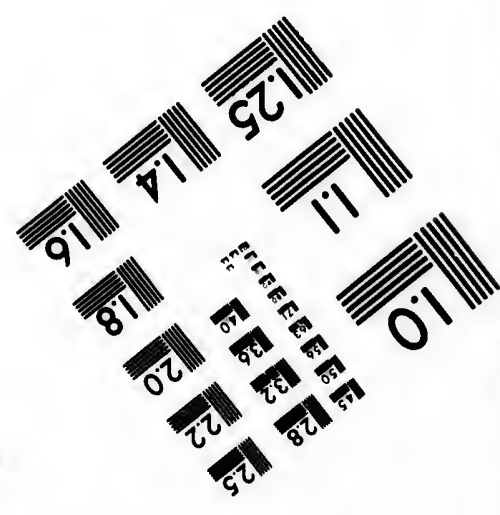




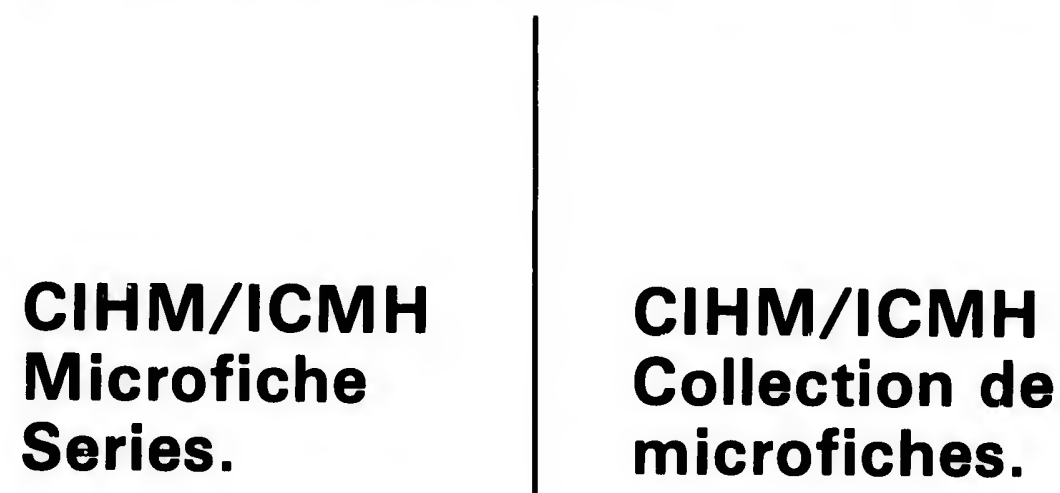

Canedian Institute for Historical Microreproductions / Institut cenadien de microreproductions historiques
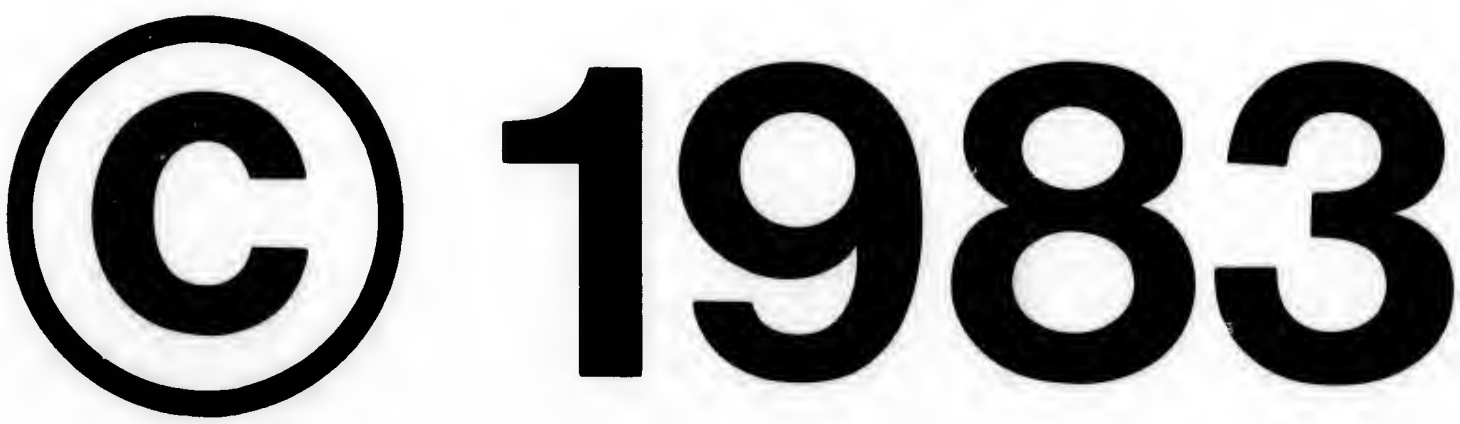
The Institute has attempted to obtain the best original copy available for filming. Features of this copy which may be bibliographically unique, which may alter any of the images in the reproduction, or which may significantly change the usual method of filming, are checked below.

Coloured covers/

Couverture de couleur

Covers damaged/

Couverture endommagée

Covers restored and/or laminated/

Couverture restaurée et/ou pelliculée

Cover title missing/

Le titre de couverture manque

Coloured maps/

Cartes géographiques en couleur

Coloured ink (i.e. other than blue or black)/

Encre de couleur (i.e. autre que bleue ou noire)

Coloured plates and/or illustrations/

Planches et/ou illustrations en couleur

Bound with other material/

Relié avec d'autres documents

Tight binding may cause shadows or distortion along interior margin/

La re liure serrée peut causer de l'ombre ou de la distortion le long de la marge intérleure

Blank leaves added during restoration may appear within the text. Whenever possible, these have beon omitted from filming/

II se peut que certaines pages blanches ajout6es lors d'une resteuretion apparaissent dans le texte. mais, lorsque cela était possible, ces pages n'ont pas été filmées.

Additional comments:/

Commentaires supplémentaires:
L'Institut a microfilmé le meilleur exemplaire qu'il lui a été possible de se procurer. Les détails de cet exemplaire qui sont peut-être uniques du point de vue bibliographique, qui peuvent modifier une image reproduite, ou qui peuvent exiger une modification dans la méthode normale de filmage sont indiqués ci-dessous.

Coloured pages/

Pages de couleur

Pages damaged/

Pages endommagées

Pages restored and/or laminated/

Pages restaurées et/ou pelliculées

Pages discoloured, stained or foxed/

Pages décolorées, tachetées ou piquées

Pages detached/

Pages détachées

Showthrough/

Transparence

Quality of print varies/

Qualité inégale de l'impression

Includes supplementary material/

Comprend du matériel supplémentaire

Only edition available/

Soule édition disponible

Pages wholly or partially obscured by errata slips, tissues, etc., have been refilmed to ensure the best possible image/ Les pages totalement ou partiellement obscurcies par un feulllet d'errata, une pelure, etc., ont été filmbes a nouveau de façon à obtenir la meilleure image possible.

\section{be}

$$
\text { sid }
$$

\section{oty}

sio

Th

\section{sh}

$$
\text { Tip }
$$

M8

$$
\text { be }
$$

$$
\begin{aligned}
& \text { rig } \\
& \text { req }
\end{aligned}
$$


The copy flimed here has been reproduced thanks to the generosity of:

\section{Library of the Public \\ Archives of Canada}

The Images appearing here are the best quality possible considering the condition and legibility of the original copy and in keeping with the filming contract specifications.

Original copies in printed paper covers are flimed beginning with the front cover and ending on the last page with a printed or illustrated impression, or the back cover when appropriate. Ail other original coples are filmed beginning on the first page with a printed or illustrated impression, and unding on the last page with a printed or illustrated impression.

The last recorded frame on each microfiche shall contain the symbol $\rightarrow$ Imeaning "CON. TINUED"), or the symbol $\nabla$ (meaning "END"). whichever applies.

Maps, plates, charts, etc., may be filmed at different reduction ratios. Those too large to be entirely included in one exposure are filmed beginning in the upper left, hand corner, left to right and top to bottom, as many frames as required. The following diagrams illustrate the method:
L'exemplaire filme fut reproduit grâco à la gónórosité de:

La bibliotheque des Archives publiques du Canade

Les images suivantes ont été reproduites avec le plus grand soin, compte tenu de la condition et de la netteté de l'exemplaire filmé, et en conformité evec les conditions du contrat de filmage.

Les exemplaires originaux dont la couverture en papier est imprimée sont filmés en commençant par lo premier plat et en terminant soit par la derniere page qui comporte une empreinte d'Impression ou d'illustration, soit par le second plat, selon le cas. Tous les autres exemplaires originaux sont filmés en commençant par la premiere page qui comporte une empreinte d'impression ou d'illustration et en terminant par la derniere page qui comporto une telle empreinte.

Un des symboles suivants apparaîtra sur la derniere image de chaque microfiche, selon le cas: le symbole $\rightarrow$ signifie "A SUIVRE", le symbola $\nabla$ signifie "FIN".

Les cartes, plenches, tableaux, etc., peuvent être filmés d des taux de réduction différents. Lorsque le document est trop grand pour etre reproduit en un seul cliché, il est filmé partir de l'angle supérieur gauche, de gauche de droite, et de haut en bas, en prenant le nombre d'images nécessaire. Les diagrammes suivants illustrent la méthode.

\begin{tabular}{|l|l|l|}
\hline 1 & 2 & 3 \\
\hline
\end{tabular}
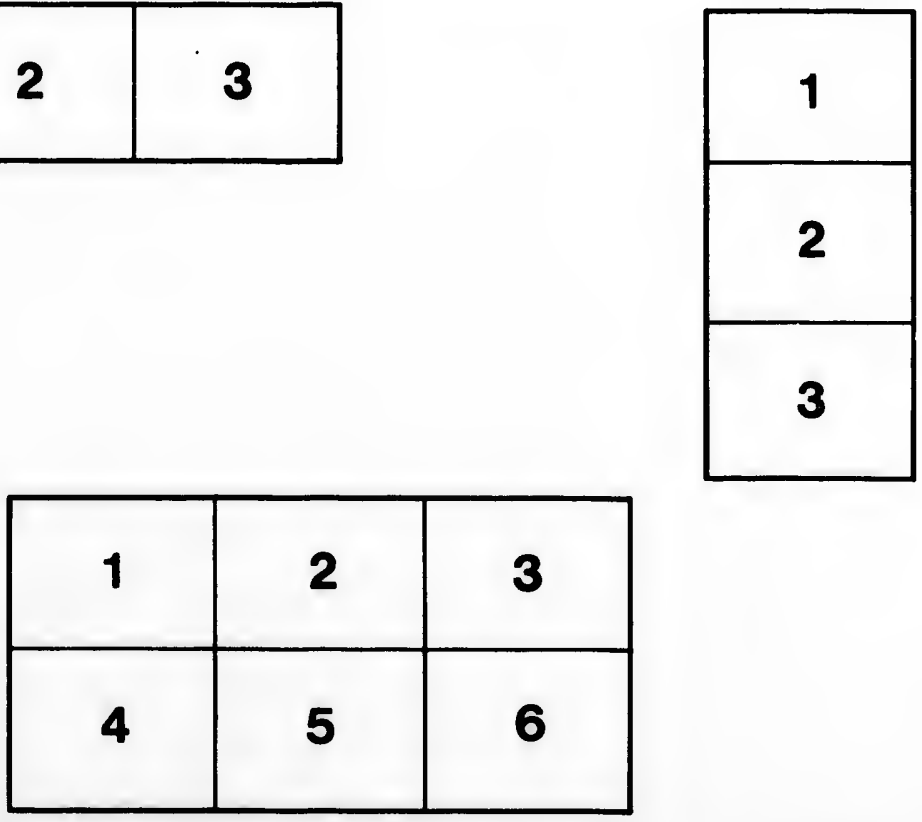


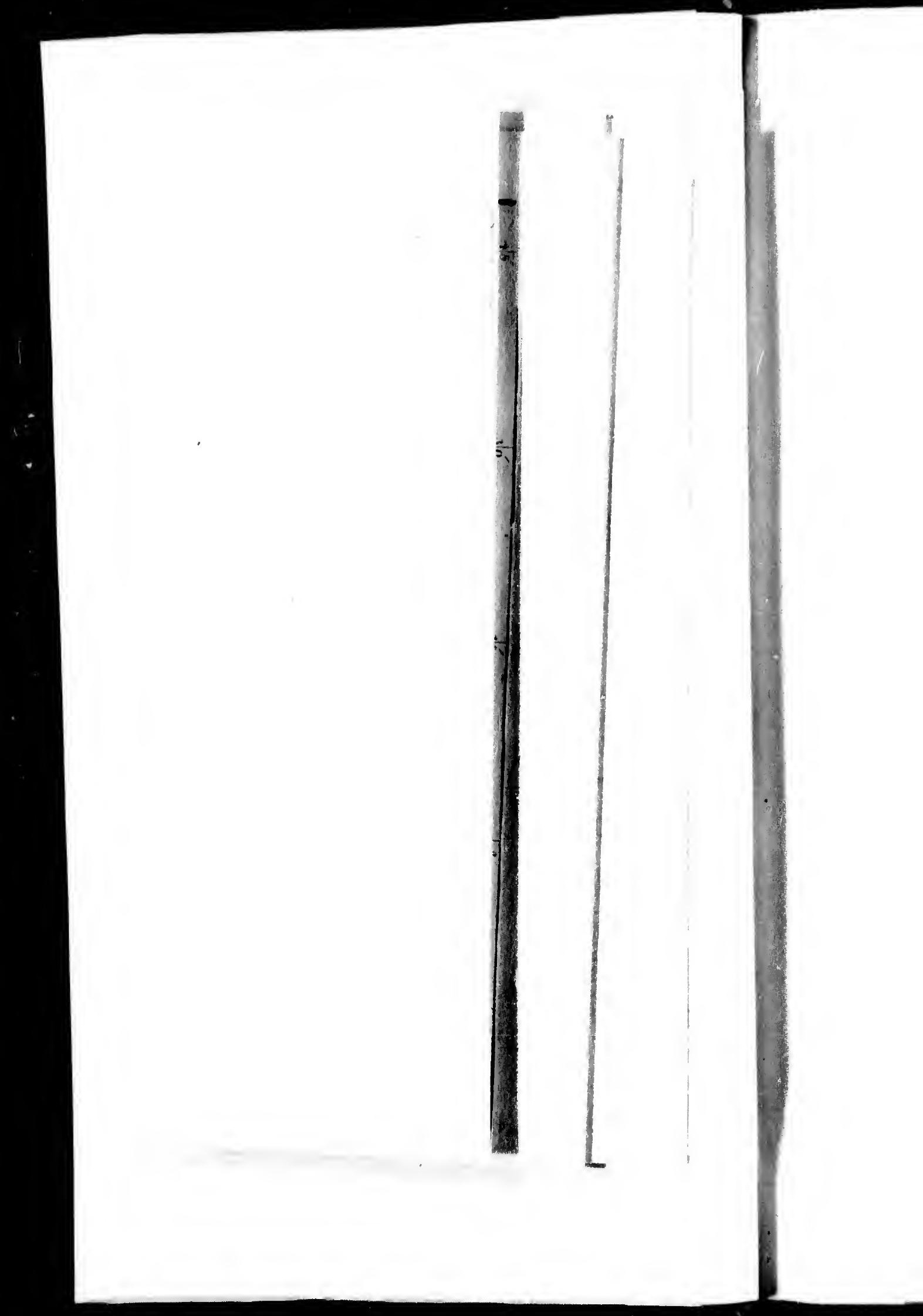




\section{Carillon.}

(The crumbllng fortress of Ticonderoga was bullt h.p. the French engineer, Lot. blulere. In 1775, and called by the Erench Carlllon, whlch means "Chime of Bells." Thls nume was choseu, so the legeud runs, from the distant muslc of the waters of the outlet of Lake George as thes descend through the rocky chasm a mille fiom the fort. The rour of the fall conld be plainly. heard ln the walls of "Tl." Petortisnque was the Indias naune for Iake Chomplatu.)

A hundred fifty yenrs age, Along Petonbonque's tide,

$\Delta$ gallant band of Freuchmen eafled To humble England's pride.

A rocks steep that looked abroad,

Wherc Champlaln's waters"shone, They elrcled with a hrlstilug fort And called lt Carillon.

Whence camc the name 80 sweet and dear To beaceful hearts in France?

Why chose these soldiers of Montcalm Thls nume of old romance?

Perchauce that man magnificent, Victim of wars' ariscliance.

Recalled the days of sunny youth In loved but distant France.

Pelchance through chambers of hls coul The chlldhood mem ries rolled,

How far away the Anjelus At worn ana even tolled.

Thus, Carllon, sweet chlme of bells, Thy vlbrant name was won

From land-locked waters thund'ring down Like booin of distant gun.

And oft 8 s undnlating notes Stole 'neath the mountalns' brow,

They mingled with the winds that swept Thiough plnes with sobbling sough.

So, though with sad, prophetic volce, Thy rushing waters told

Of savage n'ars' riudletive glut Aud race-hate uncontrolled;

Still, Carllion, thy name shall last And thine, Lotbiniere,

A mem'ry of the mighty strife That thrilled the natlons there. -R. H. Gesner In Boston Transcript. 


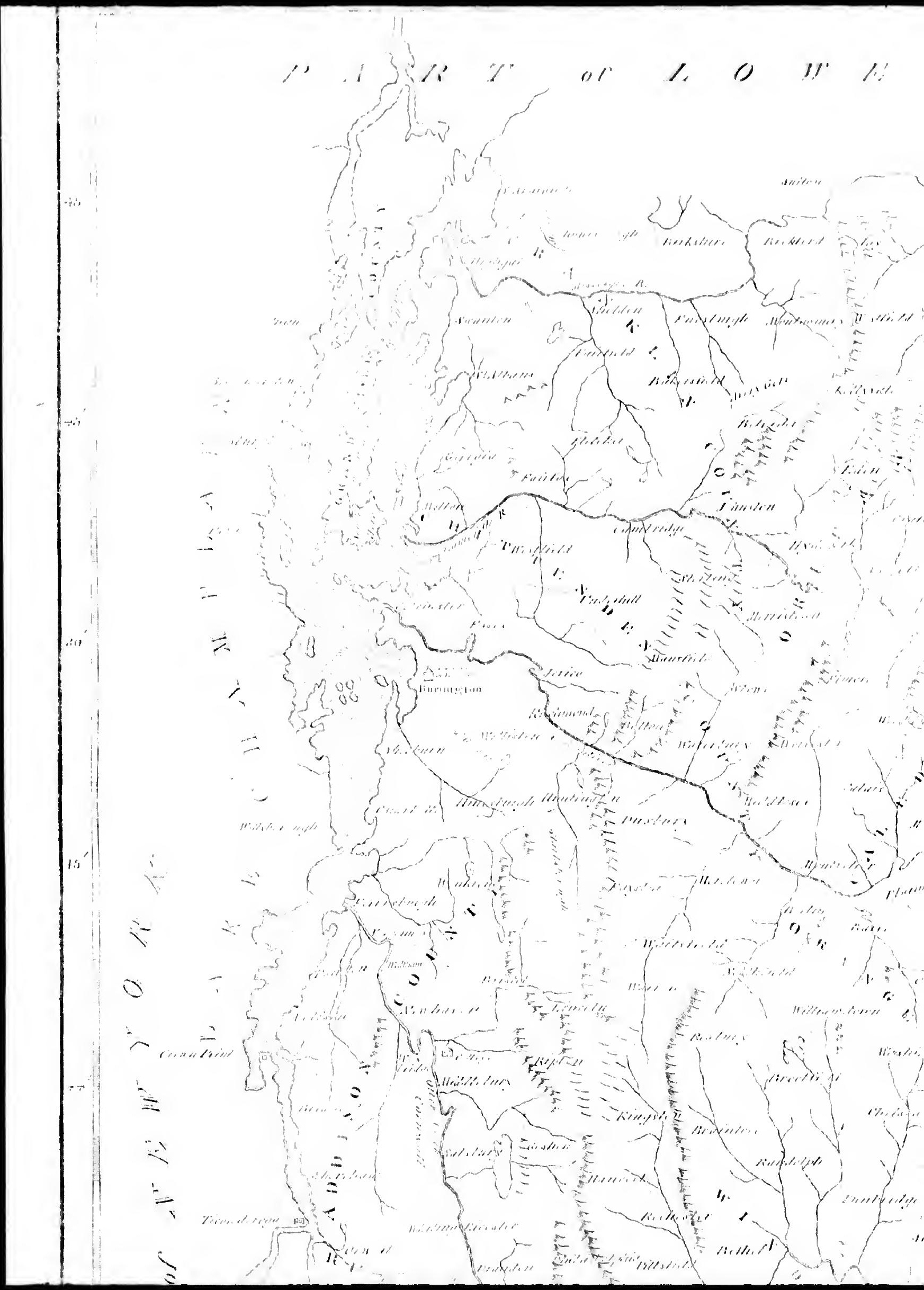



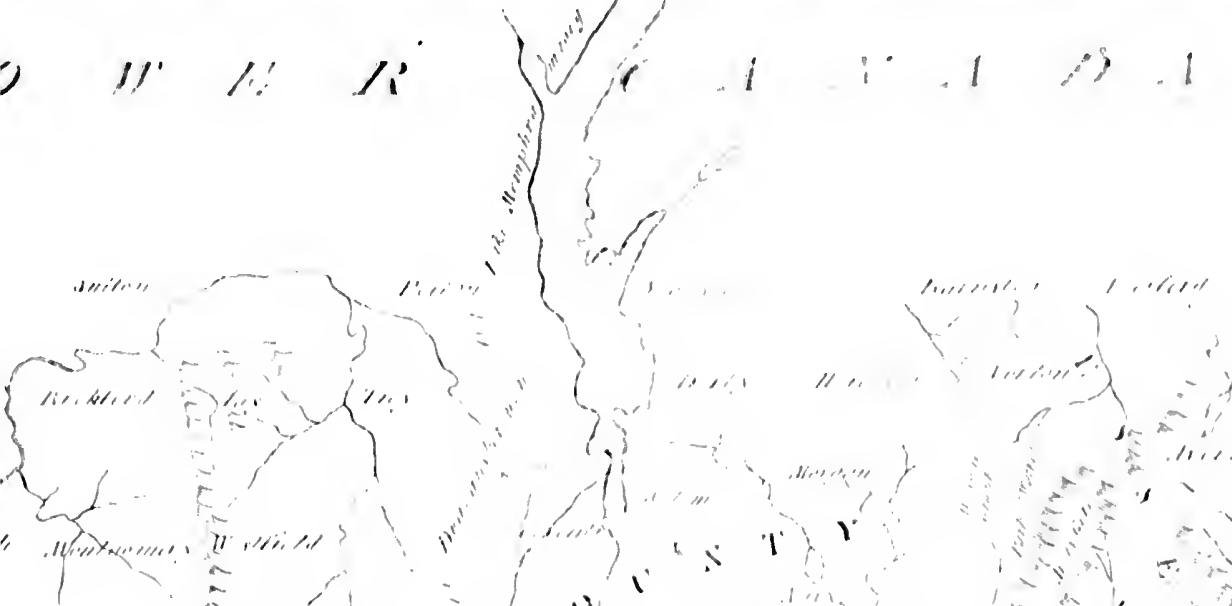

a.

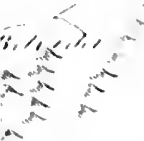

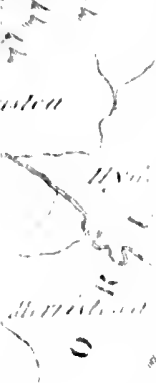

$i^{\prime}$
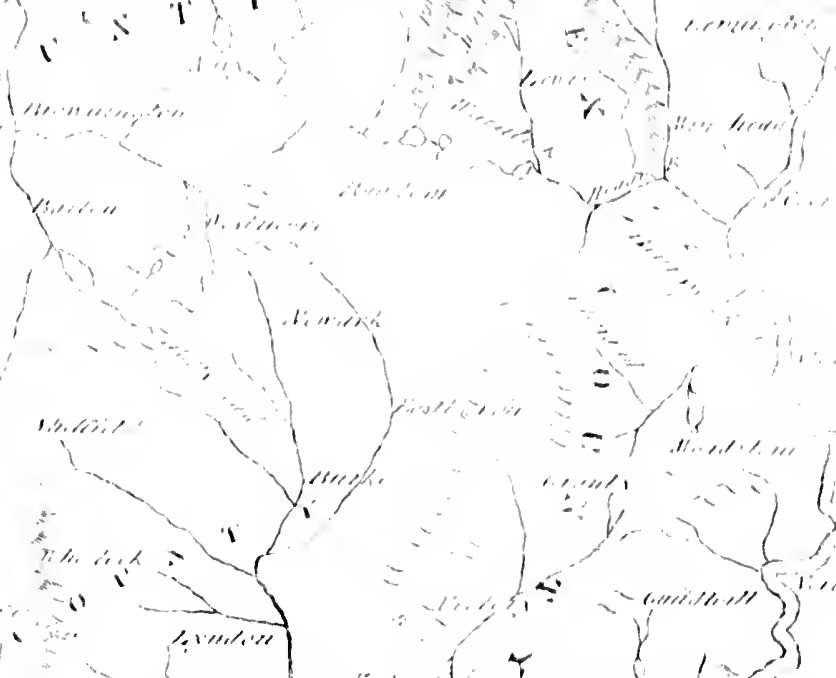

Giri,

:

(n)

$20 \int^{2}$

$f^{\prime \prime} ", \quad \cdots$
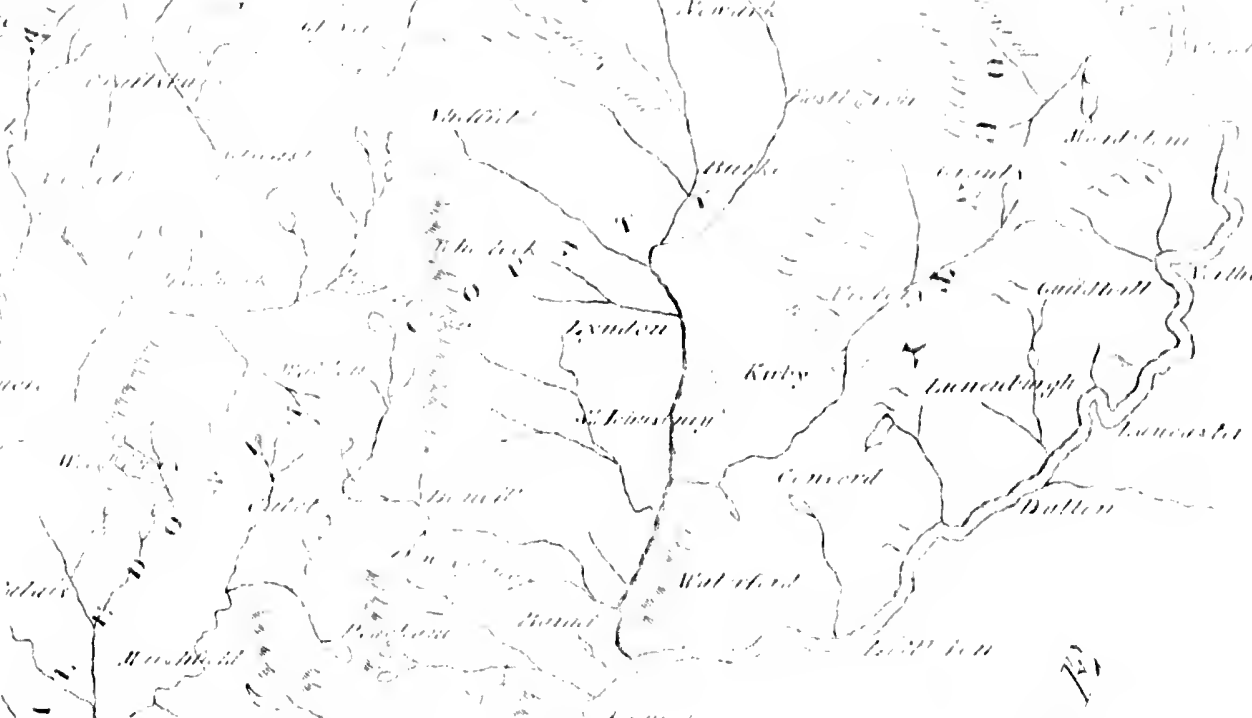

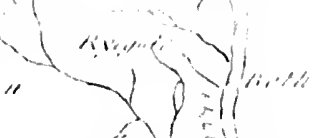

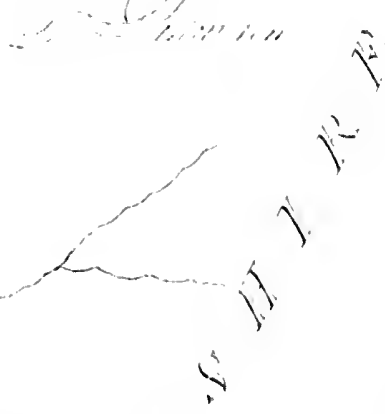

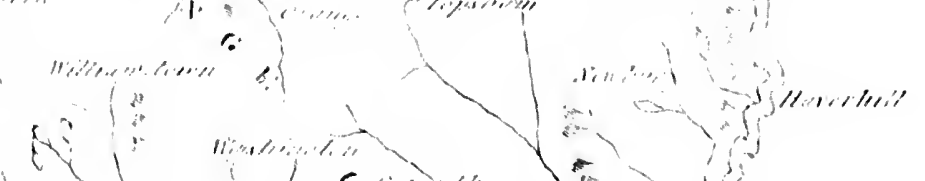

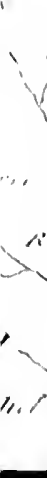




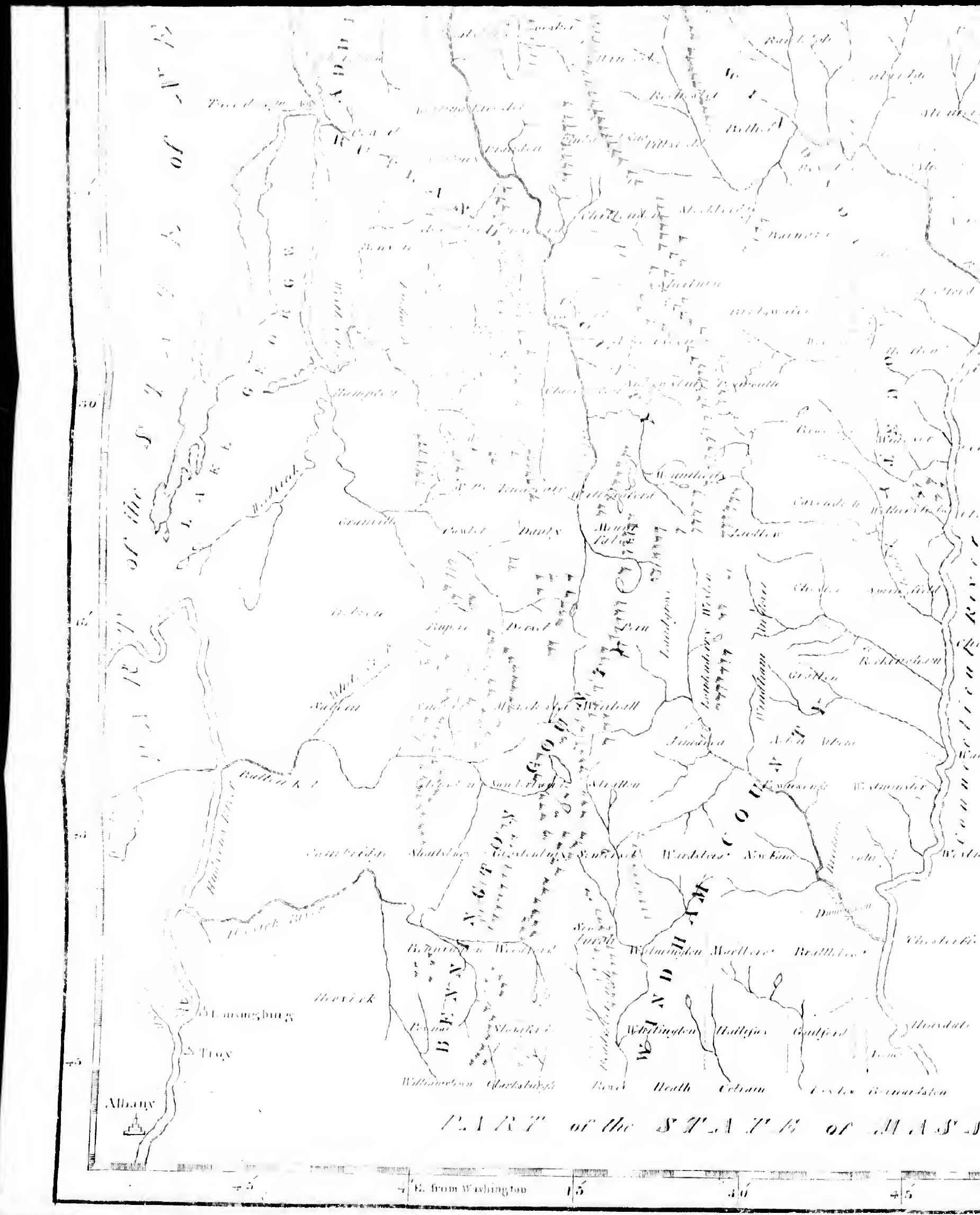




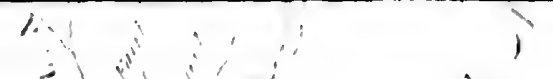

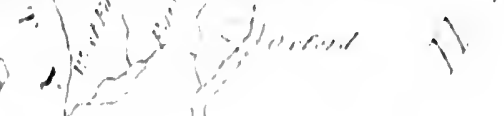

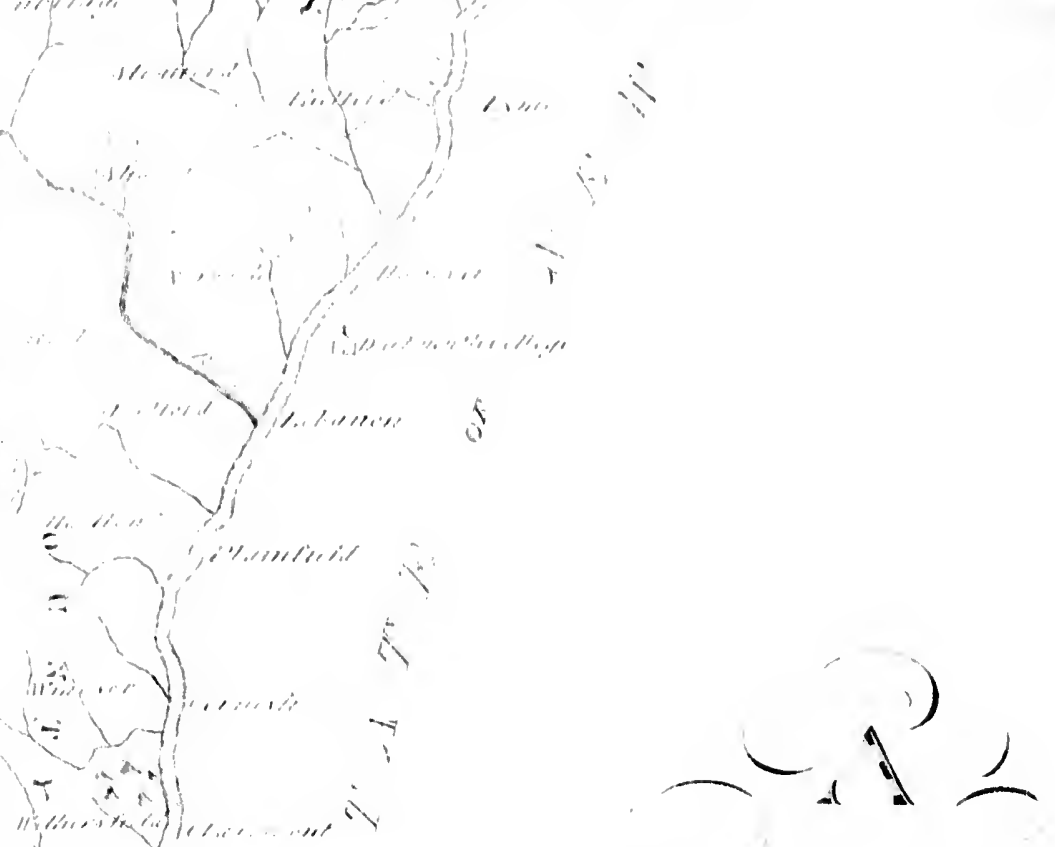

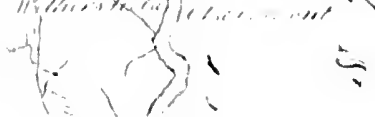

d of 1hat

ix...

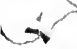

(j)

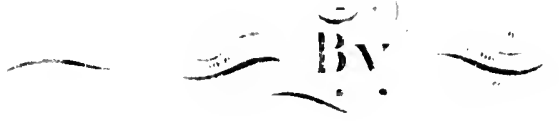

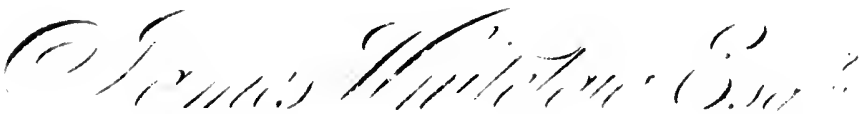

$+1302-$

(n)

srole wi Hiles

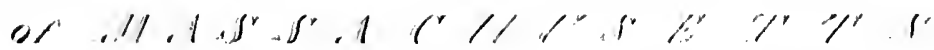




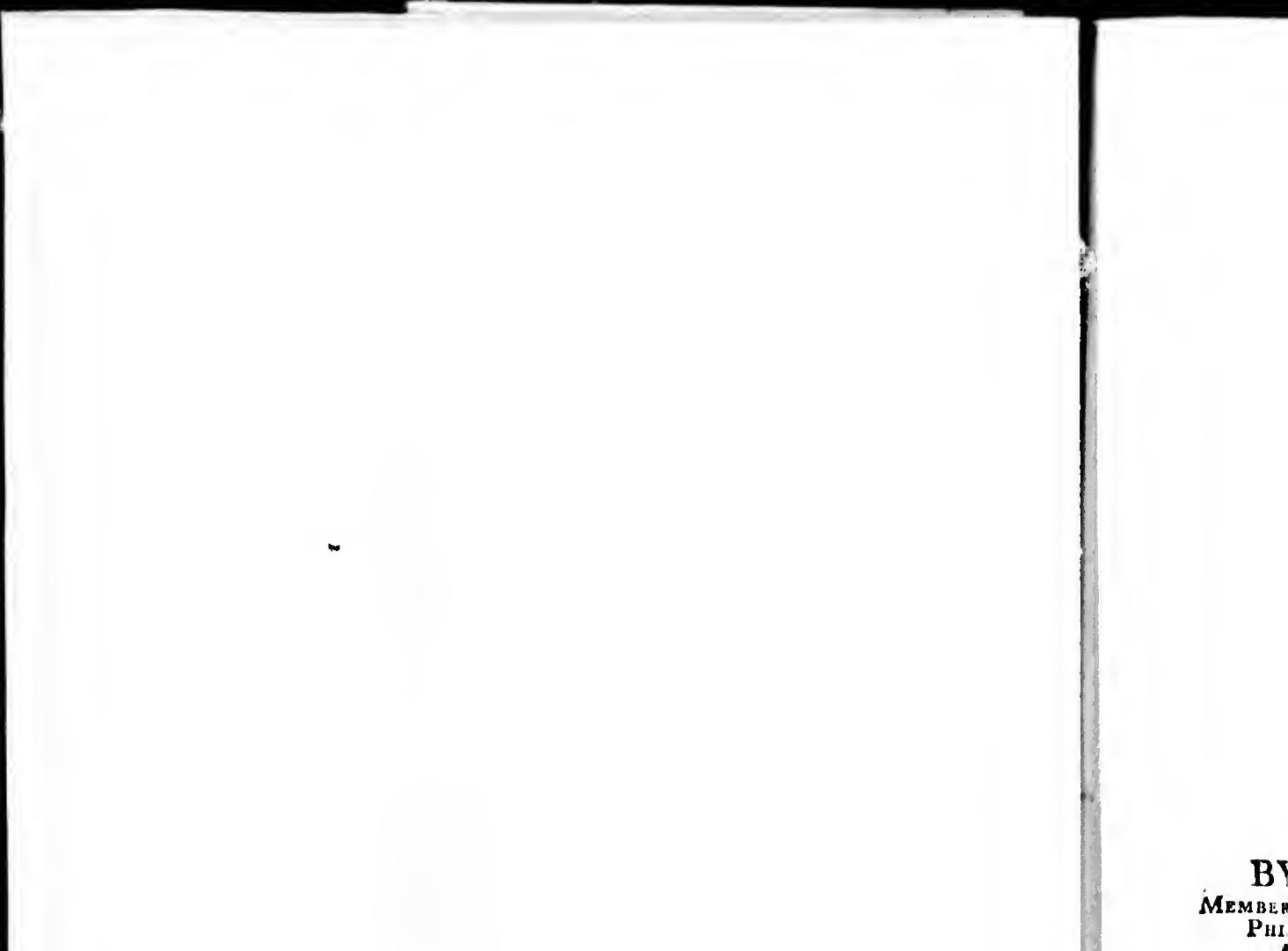

THE

SOLO AT 


\title{
NATURAL AND CIVIL
}

\author{
H I S T O R Y
}

\author{
OF \\ $\mathbb{V} \mathbb{R} \mathbb{M} \mathbb{N} \mathbb{T}$
}

\section{BY SAMUEL WILLIAMS, LI. D. Member of tue Meteorological Society in Germant, ortae Philosophacal Socieix in Puliadelith, and or the Academy of Artsand Sciences in Mass.ichuserto.}

IN TWO VOTITMES.

$:::::::::::$

VOLUME I.

:::::::::::

THE SECOND EDITION, CORRECTED AND MUCH ENLARGED.

BURLINGTON, VT. PRINTED BY SAMUEL MILLS.

Solo at mis Bookstori in Burlington, by Milis and White, Middebury, Isaiah Thomas, Jun. Worcrater, Thomas ANd ANdrews, Boston, 'illomas and Whipfle and S. SAwter and Co. NewhukgPort. 


\section{DISTRICT OF VERMONT, to wit.}

BE it remembcred, that on the twenty fifth day of February, in the thirty third ycar of the lndependence of the

(L. S. United States of America, Samucl Mills of Burlington in Faid District, hath deposited in this Office, the title of a Book, the right whereof he claims as proprictor, in the words following, to wit :

“ The Natural and Civil History of Vermont. By Samuel Williams, “I.L. D. Member of the Metcorological Socicty in Germany, of the "Philosophical Soclety in Philidelphia, and of the acadcmy of arts " and Scienses in Massachusetts. In two Volumes. Volume I. 'The "second cdition, corrected and much enlarged."

In cenformity to the act of the Congress of the United States, ene titled "an act for the ellcouragement of learning, by sccuring the copics of Maps, Charts and Books, to the authors and proprietors of such copies, during the tines thercin mentioned,"

$$
\text { CEPH S SMIIH, Jun. }
$$

rlirk of the Diftict of Vermont.

\section{A true Copy of Record,}

\section{CEPHAS SMITH, Jun, Clerk.}

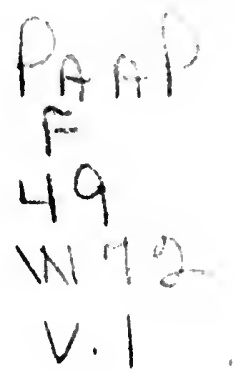


TO THE CITIZENS OF THE STATE OF

\section{VERMONT,}

THE FOLLOWING OBSERVATIONO

ONTHEIR

\section{NATURAL AND CIVIL}

\section{HISTORY,}

ARE HUMBI.Y INSCRIBED;

AE A TESTIMONY OF RESPECT FUR THEIR

MANY VIRTUES,

AS AN ATTEMPT TO PROMOTE

A MORE PARTICULAR ACQUAINTANCE

WITH THEIR OWN AFFAIRS,

AND WITH THE MOST ARDENT WISHES FOR

THEIR FURTHER IMPROVFMENT

AND PROSPERITY,

BY THEIR OBEDIENT

AND HUMBLE

SERVANT,

Rutland, July 16, 1794.

THE AUTHOR. 
sine

bus

$\mathrm{Am}$ and this inqu som solı the natu and biste was the thei plate and histc take: meri have fully amin $T$ curic the $f$ was curat custc amor 


\section{PREFACE.}

00000

THREE centuries have passed away since America was first discovered by Colun. bus. From that time until now, the affairs of America have engaged the attention of historians and philosophers. The matural productions of this continent, have been one object of general inquiry. Among the Spanish writers, there are some good essays on the natural history of the southern parts of America. In Canada, some of the physicians and Jesuits were attentive to the natural productions of that part of the continent ; and have left some valuable picces on the natural bistory of New France. 'This kind of knowledge was not much attended to, by the first settlers of the British colonies; and we have but few of their ancient writings, in which it was contem. plated at all. Obliged to depend upon transient and partial accounts; the best writer upon natural history, M. de Bufton, has fallen into nuany mistakes respecting the natural productions of $A$. merica, which, more accurate observations would have corrected. 'The subject instead of locing fully explored, is yet a treasure but little cxamined.

The Man of America was an object still more curious and important. But the age in which the first discoveries and settlements were made, was not enough enlightened, to afford cither ac. curate or impartial observations, on the manners, customs, language, abilities, or state of society, among the Inclians. Prejudiced by their sordid 
manners, and cnmged by their barbaritics, the men of liurope never looked for any thing good in such men: And while interest and revenge juined to destroy that unhappy race, but fer were able to consider their customs or rights with calmmess, or dareal to say any thing in their firor. It is not more thun half a century, since this subject has been properly attended to by philosophers : And their conclusions huve been of the most opposite and contrary kinds. Sime have with greal zeal advanced, that the perfec. tion of man was to be fornd in the savage state; while otlieris have as womly contended, that this was the lowest state of degradation and abase. ment, to which the human race can possibly be reduced. Such opposite and contrary systems make it recessary to examinc this part of the nutural history of man, with great care and impartiality; that we may distirguish what was valuable in that stage of society, and what was His?dvantareous and degrading.

A:s object of sill higher magnitude and importance, has been presented to our view by the American Revolution. The first settlers in the British colonies were !eft in a great measure by their sovereigns, to take cure of themselves. The only situntion which they conld take, while they were cleming the woods and forming their set. tements, was that of equality, industry, and connmy. In such a situation evory thing tenAcd to jroduce, and to establish the spirit of fredom. Their employments, custems, man. ners, and hobits; their wants, dangers, and interests, were nearly the sane; tisese, with every obser circumstance in their situation, operated 
with a steady and certiin tendency, to prescrve that equality and freedom, which nature had made. This spirit of frecdom was in some degree ehecked by the customany interpositions of royal authority: But these were too irresular and contradictory, to become matters of veneril. tion, to alter the natural feelings of $\mathrm{men}$, or to change the nitural course and tendency of things : And while the ministers of kings were lookingrs into their laws and records, to decide what should be the rights of $\mathrm{men}$ in the colonics, na. iure was establishing a system of freedom in $A$. merica, which they rould neither comprehend or discern. The American Revolution explained the business to the world, and served to confirm what nature and society had before produced.

HAVING assumed their rank among the nations of the earth, the states of America now present to the world a new state of society; founded on principles, containing arrangements, and producing effects, not visible in any nation bcforc. The uncommon and increasing prosperity which has attended it, has ascertained its spirit and tendency : The pcople are distinguished by the spirit of inquiry, industry, econony, cnterprize, and reguluity : The government is dependent upon, but guides, and reverences the people: And the whole cotintry is rapidly increasing in numbers, cxtent, wealth, and power. The highest perfection and felicity, which man is permitted to hope for in the present life, may rationally be expected in such a state of society: And it becomes of course the object of universall inquiry and attention.

To represent the state of things in Americas 
in a proper light, particular accounts of each part. of the federal union seem to be necessary ; and would answer other valuable purposes. An able historian, the Reverend Dr. Bclknap, has obliged the world with the history of New Hampshire. The following treatise is designed to describe the operations of nature and socicty, in the adjacent state of V'ermont. This is the youngest of the states, an inland country, and now rapidly changing from a vast tract of uncultivated wilderness, to numerous and extensive seitlements. In this stage of society, industry and economy scem to produce the great. est effects, in the slyortest periods of time.

$T_{H E}$ manner in which the work has been ex. ccuted, I am apprehensive will require much candour in the reacler. In the variety of subjects which lave come under contemplation, I cannot flatier myself, that I have been free from errors aid mistakes : And the reason why several of the subjects are so imperfectly considered, was because I had not the ability or information to state them otherwise.

THE American war considered with respect to its causes, operations, or effects, presents to our view some of the most important: events, which have taken place in modern times : But neither of these particulars can be comprehended in the history of any particular state. To give such an inmperfect view of this subject as could be properly contained in the history of Vermont, did not appear eligible. No further accounts therefore of the war, are inserted, than what appeared necessary to explain the subject, which I had more particularly in view. 
TH E controversies which took place between the states of Vermont, New York, and New Hampshire, were of the most dangerous nature : and they were agitated for a while, with a violence greatly unfavorable to the peace and safety of the whole union. Most of the wars which have taken place among mankind, have been occasioned by disputes respecting territory and jurisdiction : And however just or proper it might be for any nation, to give up part of its territory and dominion to its neighbours, such a sacrifice was scarcely ever made without compulsion and force To have expected New York would voluntarily give up part of her territory, when the decisions of the king, and the law were in her favor, was to expect that which is never done by any sovereign or nation, while they have power to prevent it. To have expected the people of Vermont would voluntarily submit to a government, which set aside their titles to the lands which they had purchased of the crown, and made valuable by their labours and sufferings, was to look for that, which no people ever ought to submit to, if it is in their power to avoid it. When the states of NewYork, New Hampshire, and Vermont, had engaged in a controversy of this kind, it was more agreeable to the course of human affairs to expect it would produce a civil war, than to look for so much wisdom and moderation among either of the contending parties, as to prevent it.

$I_{N}$ relating these controversies, I have felt a constant anxiety, lest I should misrepresent the proceedings of either of those states. I had not the interests or the passions which those parties

ros. $x$. A 
produced, to guard against ; nor am I appre: hensive that prejudice has misled me, in relating any of those matters. But it is not improbable that I have not had compleat information in some particulars, respecting those complicated controversies ; and may have mistaken the views If this should be found to be the case, it will give me great pleasure to receive such further information, as shall enable me to correct any mistakes. Those who point out to us our eirors, perform the same friendly offic:, as those who help us to new truths.

Th E most important of all our philosophical speculations, are those which relate to the history of man. In most of the productions of nature, the subject is fixed, and may always be found and viewed in the same situation. And hence a steady course of observation, serves to discover and ascertain the laws by which they are governed, and the situation they will assume in other periods of time. It is probable the ac. tions and affairs of men are subject to as regular and uniform laws, as other events :' And that the same state of society will produce the same forms of government, the same manners, customs, habits, and pursuits, among different nations, in whatever part of the earth they may reside. Monarchy, freedom, superstition, truth and all the general causes which actuate mankind, seem every where to bear the same aspect, to operate with the same kind of influence, and to produce similar effects; differing not in their nature and tendency, but only in the circumstances and degrees, in which they influence dif-

ferei ing alter with man rem: petu cout those mors tutes ent a the $\mathrm{s}$ in di there state the $\mathrm{c}$ its $\mathrm{e}$ impr porta plate wher distin in co the subm The temp mote lative the as the $p$ The mong to be 
ferent nations. But nothing is stationary, noth. ing thut depends upon the social state, is so unalterably fixed, but that it will change and vary with the degradition or improvement of the hu. man race. And hence, while the nature of man remains unaltered, the state of society is perpetually changing, and the men of one age and country, in many respects appear different from those of another. And as men themselves are more or less improved, every thing that constitutes a part of the social state, will bear a differ. ent appearance among different nations, and in the same nation in different circumstances, and in different periods of time. To ascertain what there is thus peculiar and distinguishing in the state of society in the Federal Union, to explain the causes which have led to this state, to mark its effect upon human happiness, and to deduce improvement from the whole, are the most inportant objects which civil history can contem. plate in America : And they are objects, every where more useful to inen, than any refinements, distinctions, or discoveries, merely speculative.

I have wished to keep such objects in view, in considering the state of society in this part of the continent : But it is with diffidence that I submit the attempt to the view of the public. The disposition of America is to favor such attempts and publications, as are adapted to pro. mote any valuable public purpose : But speculative and useless essays cannot much engage the attention of a people, whose main object is the prosperity and improvement of their country. The public sentiment will be a just decision, among which of these, the following work ought to be placed. 


\section{ADVERTISEMENT}

TO THE

\section{SECOND EDITION.}

00000000

THE Booksellers have desired me to prepare the History of Vermont for another edition. The favorable reception which the pub. lic gave to the work, has lead me to wish to make it more perfect; and my friends have suggested that it would be of use to insert a more particular account of the Wars, which have taken place in this part of the continent. From the earliest settlement of the Erglish and French coloni:s, contests arose, which gave rise to a course of such events. The passage from the one country to the other, lay through lake Champlain. This circumstance rendered this part of the country the field of hostile operations, and bloody campaigns. I have endeavored to collect an account of these transactions; but have not had all the advantiges of authentic documents and public libraries, to make these researches so compleat as I wislied. In making these collections, and some necessary additions to the natural and civil history of the State, the sizes of the papers increased so much beyond what I expected, that it was thought best to publish them in two volumes.

$I_{N}$ the narrations, the reade: will find a miIuteness of dates, facts, and circumstances, not common in European productions; and not very entertaining in itself. This method was.

To c ings, coun pleas view Vern is no appre

$J_{u}$

* Lette

SIR, your po of Vert
ding to 
adopted with choice, and by design. Persuaded that the American commonwealth is yet in the early years of its infancy, and unable to compre. hend to what extent, magnitude, and dignity it may arise; the author of these sheets views the history of a particular state, rather as a collection of facts, circumstances, and records, than as a com. pleat and finished historical production. 'The more important the United States shall become in the future periods of time, of the more iniportance it will be to be able to find a minute and au. thentic account of the facts, proceedings, and transactions, from whence the grand fabric arose. To collect and record such facts and proceed. ings, so far as they relate to this part of the country, is what I have attempted. It gave me pleasure to find that the first cssay was not view in an unfavorable light by the people of Vermont ; $*$ and I entertain the hope that what is now offered to the public, will meet with their approbation.

$$
\text { July 4, } 1807 .
$$

* Letter from the Speaker of the General Assembly, to the Author of the Hist ory of Vermont.

W1 NDSOR, OCT. I2, I795.

SIR,

THE Pepresentatives of the People entertain a lively sense of your polite attention, by presenting them your Natural and Civil History of Vermont; and of the service you have rendered your country, by adding to the republic of letters so valuable a book.

1 am directed, Sir, by them to return you their thanks, with their sinccre wishes, that your labor in this work, may prove as bencficial to your selt, as it must be useful to your fellow citizens.

I am, Sir, with great respect and esteem, Your most obedient servant,

Tho Rev. Dr. Samurz. Williams, L. L. D. 1.. R. MORRIS, Speaker. 


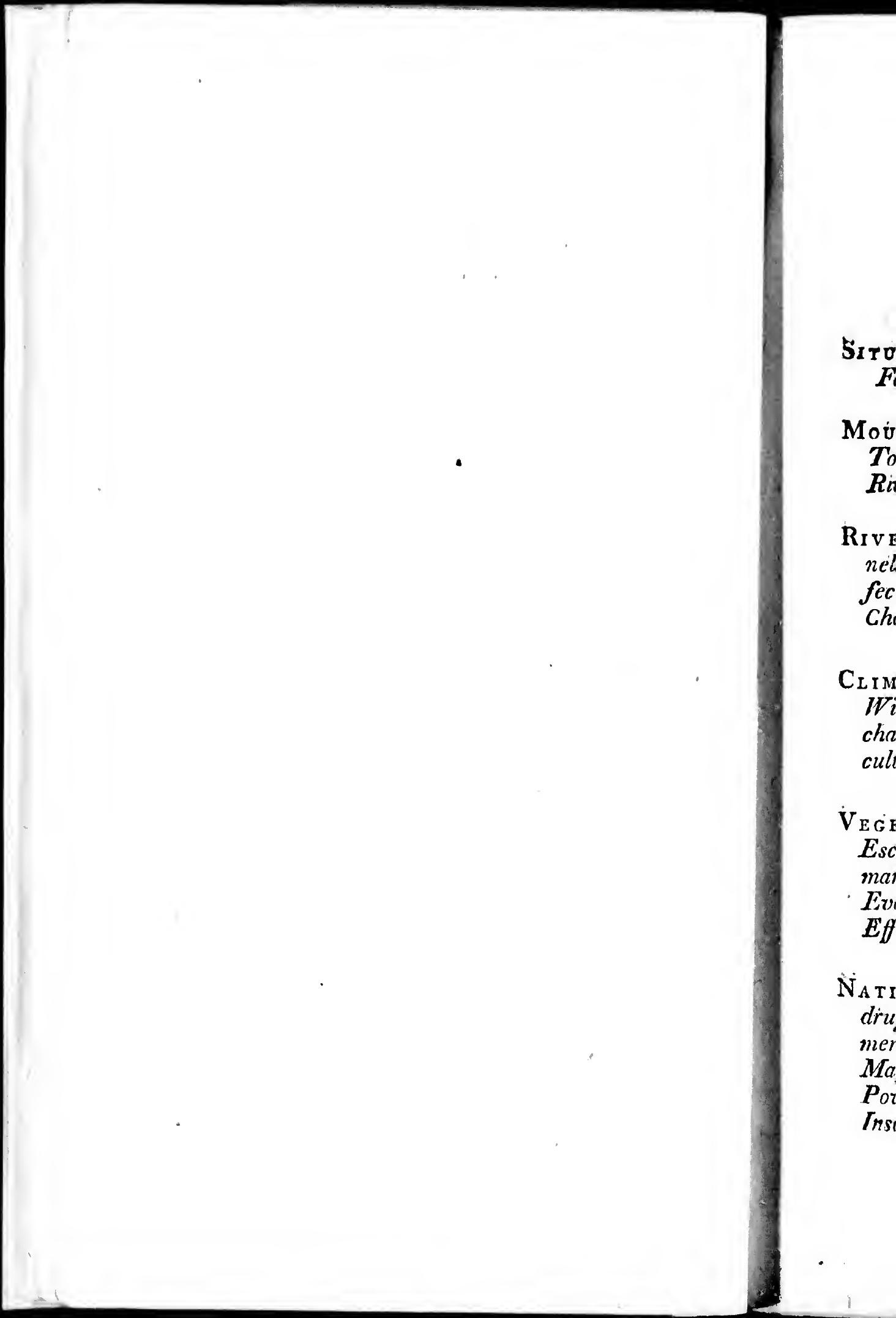




\title{
CONTENTS.
}

\author{
000000 \\ CHAPTER I.
}

Srruarion, Boundaries, Area, Soil, and toge. Face of the Country. 21 CHAPTER II:

Moùitains....Their Dircction, Altitude, Tops, Caverns, the origin of Springs and Rivers.

\section{CHAPTER III.}

Rivers a d La kes.... The Situation, Channe's, Intorvales, Courses, Depths, and Ef: fects of the Rivers. An account of Lake Champlain, and Memphremagog:

\section{CHAPTER IV.}

Cirmate....An account of the Temperature, Winds, Rain, Snow, and Weather. The change of Climate which has attended the cultivation of the Country.

\section{CHAPTER V.}

Vegetable Productions... Forest Trees, Esculent and Medicinal Vegetables. Remarks on the Magnitude, Number, Age, Evaporation, Emission of Air, Heat, and Effects of the Trees. 


\section{CHAPTER VII.}

Original Inha bitants.... The Employments, Civil Government, System of War, Education, Manners, and Customs of the Indians; the Advantages, and Disadvantages of the Savage State.

CHAPTER VIII.

OrIgINaL INHABITANTs.... Observations on the origin of the Indians, their Antiquity, progress of Society, and tendency to Dissolution.

\section{CHAP'TER IX.}

Fikst Settaments and $W^{T}$ ars with THE INDIAN3.... Discoveries and settlements in their country by the French. Origin and progress of War between the Natives and the Europeans. Influence of the Priests. French Expeditions. Proceedings of the Governor of New York. Destruction of Montreal by the Iroquoise. From the year 1535, to 1689.

Page.

CHAPTER X.

War....The first War between the English and French Colonies, assisted by the Indians; from the year 1689 to 1750 . Effect of the Revolution in favor of William and Mary. Plans of the French. Destruction in Nerv Hampshire, छ Schenectady. First attempt to reduce Canada. Sentiments of the Indians on that occasion. French Expedition against the Mohawks. Destruction of Decrfield. Se-

fea

ant

$E$ a

Ba

tor

$m i$

ita.

in

cal

Wa

the

par

me

the

pro

$\mathrm{He}$ cond Expedition against Canada. Proceedings of Schuyler. Third attempt to 
reduce Canada. Procecdings at Csivego and Lake Ontario. Buildings and setici. ment at Fort St. Frederick at Crown Point. Capture of Fort Massachusetts. Proposed expedition against Crozun Point. Attempt upon the Fort at Charlestown. 287 CHAP'IEL XI.

W A R.......From the year 1750, to 1757. Conferences at Paris. Measures of the French. Embassy and defeat of Wash. ingtori. Views of the English and French colonies. Congress and plan of Union at Albany. Council of Generals and Governors at Alexandria. Expedition and defeat of Braddock. Success of Monckton and Winslou, in Nova Scotia. Proposed Expedition to Niagara. Procecedings of Buron Dieskau at Lake Champlain. Victory of Johnson at Lake George. Termination of the campaigns of 1755. Military arrangements of the British ministry in 1756. Capture of Oszuego by Montcalm. Inactivity of the Earl of Loudon. 339 CHAP'IER XII.

W a R....Progress and events of the War in the years 1757 and 1758 . Loudon's preparations for the campaign. Montcalm's measures with the Indians. Designs upon the English. Putnam's account of IVclbl's proceedings. Conquest of Fort William Henry. Savage massacre of the prisoners. Reflections on Montcalm's conduct. Result of the campaign in 1757. Change of the British councils and ministry. VI. I. B 
Conquest of Louisbourg. Abercrombie's Pase. attempt and defeat at Ticonderoga. Cap. ture of fort Frontcnac by Bradstreet. Of Fort Du Quesne by Forbes. Amherst assumes the command.

\section{CHAP'TER XIII.}

$W_{\text {A R.... Progress and events of the } W \text { ar in }}$ the years 1759 and 1760. Plan of the campaign for 1759. Conquest of Quebee. by general Wolfe. Captuie of Ticonderoga and Crown Point by general Am. herst. Expedition against the Indian

An

$\mathcal{N}$ village of St. Francois by major Rogers. Proceedings on Lake Champlain. Cap̈ture of Niagara by general Johnson. Reflections on the campaign of 1759 . Measures of Vaudrieul at Montreal, in 1760. I'lan and proceedings of general Amherst, General Mirray's defeat at Qucbec, and arrival at Montreal. Haviland's arrival at the river St. Lazurence. Capitulation and surrender of Canada to gencral Amherst. Reflections on the origin of these Wars. Their efects on the morals, literature, population, settle. ment, and pulitical stat of the colonies.

Obse

St

A dis

cul

GAR

In

Mont

$W$

Mon

al

Inscr

M 


\section{APPENDIX.}

No. I.

Sage.

An account of the variation of the Magnetic

Needle in the Eastern States.

No. II.

Observations on the change of climate in Ellrope and other places.

No. III.

In account of Frogs dug out of the earth at Burlington.

No. IV.

Observations on the fascinating powver of Serpents.

No. V.

A dissertation on the colours of men, particularly on that of the Indians of Anerica. 493.

No. VI.

Garrangula's Speech. A specimen of Indian policy, eloquence, and manners.

No. VII.

Monument of Lord Viscount How $\mathrm{E}$, in Westminster. Abbey. .

No. VIII.

Monument erected to the memory of General WoLf E, in Westminster Abbey. 505

No. IX.

Inscription on the tomb of the Marquis $\mathrm{DE}_{\mathrm{E}}$ Montcalm, at Quebec. 


\section{Bitu \\ twee \\ of $n$ \\ mint \\ east \\ altog \\ the \\ New \\ part \\ to th \\ eight \\ state \\ miles \\ line b \\ It wa \\ King \\ Geor! \\ thern \\ setts, of $\mathrm{M}$ \\ the no}


NATURAL AND CIVIL

\section{HISTORY OF VERMONT,}

\section{nacaran}

\section{CHAPTER I.}

Bituation, Boundaries, Area, Soil, and Face of the Country.

THE State of Vermont is situated be. tween 4.2 degrees 4.4 minutes, and 45 degrees of north latitude ; and between 1 degrce 43 minutes, and 3 degrees 36 minutes of longitude, east from the meridian of Philadelphia. It is altogether an inland country; surrounded by the States of Newhampshire, Massachusetts, Newyork, and the Province of Canada. That part of the State of Vermont which is nearest to the sea const, is at the distance of seventy or eighty miles, from any part of the ocean.

ON the south, Vermont is bounded by the state of Massachusetts. This line is forty one miles in length, and was a part of the divisional line between Massachusetts and Newhampshire. It was derived from the decision of a former King of Great Britain. On March 5, 1740, George the second, resolved, "That the northern boundary of the Province of Massachusetts, be a similar curve line, pursuing the course of Merrimack river, at three miles distance, on the north side thereof, beginning at the Atlantic 
occan, and ending at a point due north of $\mathbf{P a}$ tucket falls; and a straight line drawn thence duc west, until it meets with his' Majesty's other governments." "The point three miles north of Patucket falls, was found to be in the town of Dracut. From that point, the surveyor, Iichard Hazcr, in the months of February and Miarch, 1741, ran the divisional line between Massachusetts and Newhampshirc. He was diected by Mr. Belcher, at that time governor of both those provinecs, to allow ten degrees for the westerly variation of the magnetic needle. The magnctic variation, at that time and piace, was not so great, as the surveyor assumed : And when he arrived at Connecticut river, a distance of fifty five niles, instead of being in a west line, he had deriated to the north 2 minutes 57 seconds of latitude. This error in the clirection of the line, occasions a loss of 59,873 acres to Newhimpshire; and of 133,897 acres to Vermont.*

ThE castern boundary of Vermont, is form. al by the west bank of Connecticut river. This line, following the course of the river, is about two hundred milcs; and is derived from the decree of George the third. On the 20th of July, 1764, his Majesty ordered and declared, " 'The western banks of the river Connecticut, from where it enters the Province of Massachu. setts Bay, as far north as the forty fifth degree of northern latitude, to be the boundary line between the two Provinces of Newhampshire and Newyork."

THE north line of the State begins at the lat.. *Appendir No. 5.

the

whe

erec

stan

yea

bec.

nor

of $t$

astr

num

of 1 :

4.4

Cor

latit

Adr

stra

$8 \mathrm{de}$

tion

401

17

Con

that

on $t$

the

wou

fron 
itude of 45 degrees north, and runs upon that parallel, from Lake Champlain to Connecticut river. This line is ninety miles and one quarter of a mile long, and divides this part of the United States from the Province of Canada. Much pains was taken by the Provinces of Newyork and Canada, to ascertain the latitude of 45 by astronomical observations. This was done by commissioners from both Provinces, in the month of September, 1767. At the place where the line crosses Lakc Champlain, they erected a monument of stone, which is yet standing. The line was afterwards run in the year 1772 by . I. Carden and I. Collins of Quicbec, but with great error. By order of Governor Tichenor, in 1806, I examined the situation of this line in the eastern part of the state. By astronomical observations I found the monument they had erested on the eastern bank of lake Memphremagog, was in the latitude of 4.4 degrees 53 minutes 4.6 scconds; and at Connecticut river, their monument was in the latitude of 44 degrees 47 minutcs 59 seconds. Admitting their line to have been run in a straight course, this would imply an crror of 8 degrees 52 minutes 19 seconds in the direction ; and occasions the loss to Vermont of 401973 and an half acres of land; equal to 17 44-100ths townships. The direction of Connecticut river is from the northeast, and on that account if the divisional line was continued on the parallel of 4.5 degrees till it intersected the river, one or two more townships of land would accrue to Vermont. This line ariseth from the proclamation of George the third, of 
October 7, 1763, determining the southern boundary of the province of Quebec ; and from the treaty of peace between Britain and the States of America, in 1783.

Beginning at the southwest corner of the town of Pownal, the wesi line of Vermont runs northerly, along the western boundaries of the townships of Pownal, Bennington, Shaftsbury, Arlington, Sandgate, Rupert, Pawlet, Wells, and Poultney, as the said townships are now held and possessed, to the river commonly cal. led Poultney river; thence down the same, through the middle of the deepest channel there: of, to East Bay ; thence through the middle of the deepest channel of East Bay, and the waters thereof, to where the same communicate with Lake Champlain; thence through the middle of the deepest channel of Lake Champlain, to the eastward of the islands called the Four Brothers, and to the westward of the Islands called the Grand Isle, and Long Isle, or the Two Heroes, and to the westward of the Isle la Mott, to the forty fifth degree of north latitude. This line is about one hundred and seventy miles in length ; and results from the declaration of the commissioners of Newyork, of October 7, 1790 ; and the concurring act of the General Assembly of the State of Vermont, passed October 28, 1790.

Computing by the latifudes, the length of the State from the southern to the northern bounda. $r y$, is one hundred and fifty seven miles and an half. The mean width from east to west is about sixty five miles. This will give 10,237 and an half square miles, or $6,552,000$ acres, as 
the superficial area containcd within the boundaries of Vermont; but a considerable deduction must be made, to exclude the waters, and reduce it to the just quantity of land.

The land included within these limits, is of a very fertile nature, fitted for all the purposes and productions of agriculture. The soil is deep, and of a dark colour ; rich, moist, warm, and loamy. It bears corn and other kinds of grain, in large quantities, as soon as it is cleared of the wood, without any ploughing or preparation : And after the first crops, naturally turns to rich pasture or mowing.

The face of the country exhibits very different prospects. Adjoining to our rivers, we have the wide extensive plains, of a fine level country. At a small distance from them, the land rises into a collection and chain of high mountains, intersected with decp and long vallies. Descending from the mountains, the streams and rivers appear in every part of the country, and afford a plentiful supply of water. 


\section{CHAPTER II.}

Movn т a ns....Their Direction, Altitude, Tops,

Caverns, the Origin of Springs and Rivers.

IN the formation of our mountains, nature has constructed her works on a large.scale ; and presents to our vis objects, whose magnitude and situation, naturally engage our attention. Through the whole tract of country which lies between the west side of Connecticut river, and the east side of Hudson's river, and Lake Champlain, there is one continued range of mountains. These mountains begin in the Province of Canada : From thence, they extend through the States of Vermont, Massachusetts, and Connecticut, and terminate within a few miles of the sea coast. Their general direction is from N. N. E. to S. S. W. and their extent is through a tract of country, not less than four hundred miles in length. They are one continued range or collection of mountains, appearing as if they were piled one upon another. They are generally from ten to fifteen miles in width, are much intersected with vallies, abound with springs, and streams of water, and are every where covered with woods. Their appearance, is among the most grand and majestic phenomena, which nature exhibits. From the perpetual verdure which they exhibit, they are called the Green Mountains; and with great propriety their name has been assigned to the State. 
The altitude of mountains, has been one of the curious inquiries, which the philosophers of this century have been solicitous to determine. The most common method of measuring their heights, has been by the Barometer. I clo not know that in many cases, a better method could have been applied. 'The theory however of this, is not attended with certainty, or precision : And in its appiication, it has generally given very different altitudes, to the same nountain. Geometrical mensurations admit of greater certainty and simplicity, whore they can be applied : But the dificulty and expenec of making such mensurations, have prevented any great progress from being made, in this part of the natural history of the earth. In North Ancri$\mathrm{ca}$, the height of most of our mountains, remains yet to be determined. In Decentier, 1792, I attempted to ascertain the altitucle of Kellington Peak, one of the highest of the giren mountains, by a geometrical process ; and hed the happiness to succeed in the inensuration. The measures stood thus,

Height of Kellington Peak above the Fect. plain at the State Fouse in Rutland, by geometrical mensuration, - - 2813 Height of the State House above the waters of Lake Champlain, decluced from the mensuration of the falls of Otter Creek, and a computation of other descents, - - - 371

Descent of the water from that part of Lake Champlain where the current begins, to St. John's, a distance of fifty miles, estimated at 12 inches toamile, 
Falls between St. John's and Chamble, estimated, - - - -

Descent of the water from the bason of

Chamble to Quebec, a distance of one

hundred and eighty miles, estimated

at twelve inches to a mile, - $\quad 180$

Admitting the waters of the river St. Lawrence at Quebec, to be of the same level as the sea, the altitude of Kellington Peak, by these measures and computations, is 3454 feet above the level of the ocean. The altitude at which a perpetial congelation takes place in this latitude ( 4.3 degrees 30 minutes) is about 8066 feet above the level of the sea. This is probably iour fifths of a mile higher than the tops of our highest mountains.* But although they

- Mount Blane in Savoy, is the highest mountain in Eurepe, and probably the highest in the other hemisphere. In 1787 its altitude wao found by $M$. de Saussure to be 15,673 English feet above the level of the sea. In the southern parts of America, $M$. Bouguer found the highest part of the Cordilleras, to be 20,590 feet in height ; this is the highest of any upon the globe. In Virginia, according to Mr. Jefterson, the meuntains of the Blue ridge, and of these the Peaks of Otter, are thought to be of the greatest lieight, encasured from their base. "From data," saith he, "which may found a tolcrable conjecture, we suppose the highest peak to be about 4000 feet perpendicular." (Notes on Virginia, Phila. Edit. p. 18.) The white mountains in the northeasterly part of Newhampshire, are generally esteemed to be the highest lands in Newengland. Their altitude has not been determined by geometrical mensuration, but there is one cireumstance attending their phenomena, which may serve to denote their altitude, with much prubability. From the observations which have been made of their tops, it appears that the altitude of the highest of the white mountains, is below the point of perpetial congelation. On June 19, 1774, on the south side, in one of thic gullies, the snow was five feet deep. On September 1,1783 , the topa of the mountain was covered with ice and snow, newly formed. In 1784 , snow was seen on the south side of the largest mountain, until July I 2th. in $179 \%$, the snow lay until the month of August. In general, the mountain begins to be covered with snow as early as September; but it goes off again, and seldom becomes fixed until the end of October, or the beginning of Noventber: But from that time, it remains until July. (Beiknap's Hist. Ncwhampshire, 3.46,47.) From these observations it is apparent, that the white mountains rise nearly to the line of ferpetual congelation in that latitude, but do not fully come up to $: t$. These mountains are in the latitude of 44 degrees I 5 minutes north. The line of perpetual congelution in that latitude, as deduced from the observations which have been

thus differ winte are al bring tains. $T_{1}$ very appe: mons pässa have don,

made in coldnes dimilar -hort of estimat is prob 


\section{HISTORY OF VERMONT.}

are far below the freczing point in summer, their phenomena and productions are very much affected by the degree of cold, to which they are constantlv 'xposed.

THE tops of our mountains are generally composed of rocks, covered over with moss. The trees appear to be very aged, but they are of a small size ; and all of them are of the species called evergreens ;'pine, 'spruce, hemlock and fir ; intermixed with shrubs and bushes. The powers of vegetation regularly diminish, as we approach the summit of an high mountain ; the trees degenerate in their dimensions; and frequently terminate in a shrubbery of spruce and hemlock, two or three feet high ; whose branches are so interwoven and knit together, as to prevent our passing between them. 'Trees thus diminished, with shrubs and vines bearing different berries, and a species of grass called winter grass, mixed with the moss of the rocks, are all the vegetable productions, which nature brings forth on the tops of our highest moun. tains.

THE sides of our mountains are generally very irregular, and rough; and some of them appear to have large apertures, or openings among the rocks. Among these subterraneous pässages, some caverns of a considerable extent have been found. One of these is at Clarendon, on the southeast side of a mountain, in the

made in Europe, is 7872 feet above the level of the sea. From the greater coldness of the American climate, the point of perpetual congelation in $d$ dimilar American latitude, cannot cxceed, bot must rather fall something short of this. The altitude therefore of the white mountains, cannot bs estimated as more than 7800 feet above the level of the ocean; and thi; is probably the altitude of the highest mountrins.iti the oastern states. 
westerly part of the town. The mouth of the cave is not more than two and an half feet in diameter. In its descent, the passage makes an angle with the horizon of 35 or 40 degrees ; but continues of nearly the same diameter, through the whole length, which is thirty one feet and an half....At that distance from the inouth, it opens into a spacious room ; twenty feet long, twelve feet and an half wide; and eighteen or twenty feet high. Every part of the floor, sides, and roof of this room, appear to be a solid rock, but very rough and uneven. The water is continually percolating through the top, and has formed stalactites of various forms; many of which are conical, and some have the appearance of massive columns...-.At the north part of this room, there is another aperture of about forty inches diameter, very rough and uneven. 'This aperture is the beginning' of another passage, through the internal parts of a solid rock : The direction of this passage is oblique, and full of stops or notches, and its length about twenty four feet. Descending through this aperture, another spacious room opens to view. The dimensions of this apartment are twenty feet in width, thirty in length, and twenty in height. In the spring of the year, the whole of this lower room is full of water ; and at all other seasons, water is to be found in the lower parts of it.-.-No animal has been found to reside in this cave, and it evidently appears to be the production of nature, untouch. ed by the hand of man...-. Another of these caverns is at Danby, and a third at Dorset. These are said to be more curious than this at Claren.

don, $\mathrm{b}$ There All of ture ; by an. $\mathrm{ON}_{\mathrm{N}}$ ations is the stream mong of thes and $\mathrm{ri}$ throug in gen the mo do the And attract, ceptacl constar effect, ascent surface in larg: eviden most a ery wh or thir That $t$ wards to the : tion wl the ma expres: the ear 
don, but they have not been properiy explored. There are others in different parts of the statc : All of them are the genuine productions of nature; never altered by art, and never inhabited by any of the human race.

$O_{N E}$ of the most curious and inportant opcrations which nature carries on in the inountains, is the formation of springs and rivcrs. All our streams of water in Vermont, have their rise among the green mountains: From a number of these uniting, are formed all those brooks and rivers, which run in different directions through the various parts of the country : And in general, the origin of rivers is to be found in the mountains, or high lands. In what manner do the mountiuns serve to produce these effects ? And whence is it, that the highest mountains attract, collect, become the reservoirs, the receptacles, or the source, of the largest and most constant collections of water? One part of this effect, seems to be derived from the constant ascent of the waters, from the bowels to the surface of the earth. That water is contained in large quantities in the bowels of the earth, is evident from the springs which are found in almost all declivities ; and from those which every where supply wells, at the depth of twenty or thirty feet from the surface of the earth. That these waters are constantly ascending towards the surface of the earth, and going off into the atmosphere, is evident from the evaporation which is constantly taking place, and from the manner in which heat, or as it is generally expressed, a drought affects both the surface of the earth, and the springs, by raising and dissi- 
pating the water from both. If this ascent of the waters be obstructed by any strata of clay, rocks, or any other substance, through which they cannot pass, they will collect in such quantities, as to form or find for themselves a channel, through which they may be discharged. The place of this discharge can only be on the side of a hill, or in some ground below the level of that place, wherc they are thus collected : And at such a place the waters would continue to issue out, as long as they continued to ascend, whatever might be the severity or duration of a drought. In some such way, it appears probable to me, that some of the springs are formed in the mountains, by waters which are ascencling towards the surface of the earth ; but which, instcad of going off at the top, have their clischarge in small quantities, at the sides of the mountains. Any strata of clay, rocks, or of any other matter, which would retain the watcr when it descends in rain or dew, and produce a spring from their descent, would also prevent the ascending water from passing thro' them, and might produce a spring from their ascent. This ascent of the waters from the bowcls to the surface of the carth, is a constant, powerful, and unceasing opcration of nature : And scems to be the only cause, which is adequate to the formation of those springs, which are perennial. Such springs could scarcely be formed, or preserved, by the waters which descend in rain, because they are so little affected in the severest droughts : In these seasons, instead of being replenished by rain, the earth to the depth of many feet, is much exhausted of

its w

upon first

M and $\mathrm{r}$ wate whic of th earth field, tions and $t$ the $\mathrm{c}$ thick and $v$ stagn der it and $\mathrm{c}$ from with ried stagn desce natur: the $m$ small A conde the a coldn is fai pleasi are of fog sprin 
its water by heat. And no rain can crer fall upon the surface of the carth, which was not first carried off from it, by evaporation.

Mountares serve also to form small streanis and rivulets, by preventing the evaporation of water from their surfaces. The rapours out of which the clouds and rains are formed, are all of them first raised from the surface of the earth. When the evaporation is in an open field, exposed to the sun and wind, the exhalations are soon carried off into the atmosphere, and the surface of the earth is left clry. When the evaporation is from lands covered orer with thick trees and bushes, the influence of the sun and winds are much prevented ; and the waters stagnate upon-the surface of the earth, and render it wet and miry, in the form of swamps, and confined waters. When the evaporation is from the sides and tops of mountains, coverced with vegetables, the waters are but slowly carried off by the heat and wind; nor cin they stagnate, but will be gradually and constantly descending down the sides of the mountians, in natural or artificial channels : And in this way, the mountains will also be constantly producing small streams or rivulets.

A similar effect will also be produced by the condensation and collection of the vapours in the atmosphere, occasioned by the height and coldness of the mountains. When the vicather is fair and clear, and the atmosphere screne and pleasant in the vallies, the tops of the mountains are often obscured, and covered with a thick fog or cloud. In the cool mornings of the spring and fall, the vapours form a thick fog on 
the sides and tops of the mountains, which do not dissolve and disappear, until the sun has risen several degrees above the horizon, and the heat is considerably increased. In damp and rainy weather, the largest part of the clouds scem to collect, and dissolve upon the mountains. In winter the snows fall sooner, lie deeper, and continue longer on the mountains, than. on any other part of the country. These phenomena denote a greater, and a more constant collection of vapours and clouds by the mountains, than takes place any where else ; and it seems to be occasioned by the greater degree of cold, which prevails in those elevated situations. The highest parts of our mountains generally abound with rocks, and are covered with large quantities of thick green moss ; so extensive, compact, and thick, as to reach from one rock to another, and of so firm a contexture as to bear the weight of a man, without being broken. These immense beds of moss retain the moisture supplied by the clouds and rain : And while part of it runs down the sides of the mountains, part will be detained by the spungy surface, to penetrate and sink into the earth. On this account, and for want of a more rapid evaporation, several of our mountains are constantly wet on their tops, and have marshy spots, which are frequented by the aquatic birds. The roads over these mountains are frequently very wet and miry, when the valleys b.'nw are dry. When the waters thus supplied by the clouds and rain, meet with any strata which prevent their descent, they collect in such quantities as to form a channel, and issue out the $r$ can natur come must when lesse: mucl origi conte are's raise other those in th supp vege by $\mathrm{e}$ Dr. to sh 
at the sides of the mountain in the form of springs and rivulets. All those springs, which are intermitting, scem to be thus formed by the rains, or descending waters: And the more constant and regular the rains are, the more permanent and steady will these springs be : Such kinds of intermitting springs are to be found in great numbers, on the sides of all high mountains. They never fail to run while the rains continue in their usual quantities; but when the rains cease, and a severe drought comes on, these springs are always found to fail.

Is each of these ways, the mountains supply water for the springs and streams, out of which, the rivers are formed: And they are such as can never fail, while the present economy of nature shall subsist. But as the country becomes cultivated, some of the smaller streams must decrease ; 'and it is not improbable that when the woods shall be cut down, some of the lesser springs will wholly disappear.

$T_{\text {HE }}$ writers on natural history have bcen much divided in their opinions respecting the origin of springs and rivers. M. De La Hire contends that the water from which the rivers are supplied, 'must be derived from the sea, and raised through the pores of the earth : That no other source - would be sufficient to produce those immense streams, that constantly appear in the form of brooks and rivers ; or that could supply the vast quantitics that are employed in vegetation, or discharged into the atmosphere by evaporation. Hist. de l'Acad. 1713. p. 56. Dr. Halley, on the other hand, has said much to show that the vapors which are exhaled fiom 
the sea, and driven upon the lands by the winds; and return in the form of rains, are more than sufficient to supply the earth with all the water that it needs ; and to form the fountains, springs, and rivers, which are perpetually discharging themselves into the ocean. Phil. Trans. Vol. 2. p. 128.

Boтн these theories agree in deriving the water originally from the sea; nor does there seem much difficulty in admitting the principle of either : The former seems most naturally to account for those perennial springs, which nevcr fail when the rains have ceased for months; and the latter serves to explain the cause of those, which are temporary, or intermitting.

Is the plains, hills, and mountains in this part of the continent, there is scarcely a place in which water may not be found at the depth of thirty or forty feet from the surface of the earth ; nor does there appear to be any more difficulty to have a well with permanent water, in the one than in the other of these situations. It must therefore be admitted as a well established fact, that the earth at that depth is well saturrated with water ; nor does it fail, nor is the temperature of the earth at that depth much affected, in the hottest, or in the dryest season that we ever have. It may be presumed therefore that the effect of the solar heat, and the evaporation produced by it, does not extend much below that depth; and that every where below, the earth is saturrated with water by the attraction or affinity that takes place between the particles of the one and those of the other.

IT is customary with the farmers in the 
New England states to avail themselves of this process of nature, and to form a perennial spring for their oivn convenience. The method of proceeding is this, on the side of a hill they dig a well, till they come to a sufficient quantity of water, generally from eighteen to forty feet below the surface. A passage is then dug from the bottom of the well to the side of the hill, that the water may find a regular discharge through the artificial channel, when it is received and retained in troughs or other receptacles for the use of their cattle. In this way artificial springs are often formed, which do not fail in our dryest summers, but become perennial, and are in every respect as permanent and useful as those which are formed by nature. From whence is the water derived that supplies these artificial perennial springs? Not certainly from rains and showers, which are casual, accidental, and variable ; but from waters which are always In the earth at that depth, and lie too far beneath the surface to be much affected by rain or drought.

$I_{F}$ in this way we are able to form artificial perennial springs, is it to be much doubted but, that nature does the same in a much more extensive and perfect manner? And would not this be always the effect, when the water in our hills and mountains can find or force for itself a passage, at the side or bottom of the declivity ? The phenomena seem to denote such operations and effects. In all our mountains perennial springs are found issuing at their sides or bottoms. In our most extensive and sandy plains perennial springs are often found at the bottom E 
of their declivities. These springs continue, when the whole plain for many miles round is so parched and burnt up with drought, that vegetation almost ceases. Could these springs be supplied with water derived from rain, when it has ceased for months; or has not been enough to preserve the vegetables from perishing? From what other source then could they be supplied, but from the water which is permanently and plentifully in the bowels of the earth, and is not dissipated or wasted by evaporation or heat? 
HISTORY OF VERMONT.

\section{CHAPTER III.}

Rivers and raxes.... The Situation, Chantnels, Intervales, Courses, Depths, and Effects of the Rivers. An account of Lake Cham. plain, and Memphremagog.

ALL the streams and rivers of Vermont, have their origin among the green mountains. About thirty five of them have an easterly direction, and fall into Connecticut river. About twenty five run westerly, and discharge themselves into Lake Champlain: Two or three, running in the same direction, fall into Hudson's river. In the northeasterly parts of the: state, there are four or five streams which have a northerly direction, and run into the lake! Memphremagog; from thence, through the river St. Francis, they are emptied into the river St. Lawrence.

Тнг most considerable' streams on the west side of the green mountains, are Otter creek, Onion river, the river Lamoille, and Michiscoui...-Otter creek riśes in Bromley; runs northerly about ninety miles, and falls into Lake Champlain at Ferrisburgh ; and in its course receives about fifteen smaller strearhs. There are large falls in this river at Rutland, Pittsford, Middlebury, and Vergennes. Between these falls, the current is very slow, the water is deep, and it is navigable for the largest boats. Vessels of any burden may come up to the falls at Vergennes, five miles from its mouth. The head of this river in Bromley is not more 
than thirty feet from the head of Batton Kill, which runs in a contrary direction, and falls into Hudson's river.

ONION river, was formerly, called the French river, and by the Indians, Winooski. It rises in Cabot, about fourteen miles to the west of Connecticut river, and thirty miles to the east of the heights of the green mountains. A small southerly branch rises in Washington and Corinth, not more than ten miles from Connecticut river. From this southerly branch, Onion river runs northwesterly, about seventy five miles, and empties itself into Lake Champlain, between Burlington and Colchester. 'This riv er receives fourteen smaller streams, and is navi. gable for small vessels, five miles from its mouth.. It has several falls, between which it is navigable for boats.... At one of these falls in Waterbury; , the channel of the river becomes. very narrow, and passes : between a high ledge of rocks on each side. A huge unshapely rock, in some ancient; time, hath fallen from one of these ledges, in such a manner, that the whole river now runs under it. The rock forms a kind of natural bridge, but one that can never be of any use ; as neither the shape of the rock, or the situation of , the adjacent banks, will ever admit of a road either to, or: over the rock. A. bout six miles from its mouth, between Burlington and Colchester, the channel of this riv. er is formed by a solid rock. The channel through the rock, by estimation, is fifteen rods in length, fifty feet wide, and seventy feet deep. Every appearance seems to denote that this channel was formed by the water, which in this

plac

Oni

mon

the

side

at B

Indi

they

men

$\mathbf{T}$

Glov

runn

fourt

plain

mout

nituc

smoc

a ricl the 1 : to be to th moill Blacl a dir that into

$M$

nortl in $\mathrm{B}$ has $c$ runni west, state plain river 


\section{HISTORY OF VERMONT.}

place could not have had any other passage..Onion river is one of the finest streams in Ver. mont. It runs through a most fertile country, the produce of which for several miles on each side of the river, is brought down to the Lake at Burlington. It was along this river, that the Indians formerly travelled from Canada, when they made their attacks upon the frontier settlements on Connecticut river.

T: $=$... $r$ Lamoille prconods from a pond in Glovir. ac general coursc is westerly : After running about seventy five miles, and receiving fourteen lesser streams, it falls into Lake Champlain at Colchester, five miles north of the mouth of Onion river ; and is of the same magnitude as that. The river Lamoille is a fine, smooth, and pleasant stream ; and runs through a rich, level, fertile, country. The height of the land in the northeast part of the state, seems to be: about Greenborough. About six miles to the southwest of the origin of the river Lamoille, is Scotland pond : From this proceeds Black river, which, for five or six miles runs in a direction opposite to, and nearly parallel, with that of the river Lamoille, and discharges itself into the lake Memphremagog.

Micriscour is the Indian name of the most northerly river in the /state. It has its source in Belvidere, and runs nearly nor theast until it has crossed the north line of $f$ Vermont : After running to some distance in Canada, it turns west, and then southerly, and then reenters the state in Richford ; and falls into Lake Champlain at Michiscoui bay, in Highgate. This river is navigable for the largest boats to the 
falls at Swanton, seven miles from its mouth. Michiscoui, Lamoille; and Onion river, are nearly of the same magnitude.

$O_{N}$ the east side of the green mountains, the rivers are not so large as those on the twest, but they are nore numerous. The largest of them are Wantastitquek or West river, White river, and Poousoomsuck. Wartastitquek has its main source in Bromley, about three miles southeast from the head of Otter cheek. Its course is to the southeast; it receives seven or éght smaller streams; and after running about thirty seven miles, falls into Connecticut river at Brattleborough. At its mouth this river is about fifteen rods wide; and ten or twelve feet deép.

Th E north branch of White river, rises in Kingston, The south branch has its source in. Philadelphia. From' Kingston, the general course of this river is southerly ; its length:about fifty miles; it receives six or seven lesser. streams; and falls into Connecticut river at Haitford. White river abounds with falls and rapids ; at its mouth it is about eighteen rods. in width, but not more than ten feet in depth.

Poovs oomsuck, rises from a pond in Westmore. Its course is southerly it is made up of ten lessen streams : and after running about forty five miles, it joins Connecticut river in Barnet $_{i i}$ It is there twelve rods wide, and eight: feet deep.

CoNNECTICUT river, into which these stredms fall, forths the eastern boundary of the state. The original Indian name, which it still

'The

twen five Whe rods creas cours distar from south miles great dische With this is states. flows dred rich $n$ dred 1 Conne navig: excep Massa king the ric by its 
bears, signifies the long river.* This river has its source in a ridge of mountains, which extend northeasterly to the gulph of St. Lawrence. The head of its northwestern branch, is about twenty five miles beyond the latitude of forty five degrees ; and so far it has been surveyed. When it first enters the state, it is about ten rods wide ; and in the course of sixty miles in. creases in its width to twenty four rods. Its course between Vermont and Newhampshire, a distance of two hundred miles, is southwesterly; from thence to its mouth, the course is more southerly. After running about four hundred miles through the country, and receiving a great number of other streams a:d rivers, it discharges itself into the ocean at Seabrook.... With respect to its length, utility, and beauty, this is one of the finest rivers in the eastern states. In the months of April or May, it over. flows its banks; and for a length of three hun. dred miles, forms and fertilizes a vast tract of rich meadow. Vessels of eighty or one hundred tons, go up this river as far as Hartford in Connecticut, fifty miles from its mouth. It is navigable for boats, three hundred miles further, except the falls which the states of Vermont, Massachusetts, and Conriecticut, are now making navigable by locks. While it increases the richness, and serves to transport the produce, by its perpetual majestic movement through an

- The names which the original inhabitants assigned to our mountains, plains, and valleys, are mostly lost. Many of our rivers, bays, and falls of water, are yet known by their ancient Indian names. On account of their originality, antiquity, signification, singularity, and sound, these names ought to be carefully preserved. In every respect they are far preferable to the unmeaning application, and constant repetition of an ims proper Engliob aame. 
immense tract of country, it is always adding beauty and grandeur to the prospect.

' $\%$ this account of our rivers, some observations may be added respecting their operations and effects.... Their first operation secms to have been, to form themselves a channel. The highest waters descend along the mountains, until they mect with some obstacle to obstruct their motion. Whatever this obstacle may be, it operates as a dam, and serves to collect the waters into a small pond or lake. Two causes are constantly raising the waters, in such collections : The earth is perpetually brought down by the waters, to the bottom of such ponds; and the water is constantly rising by its own accumulation. When it is raised above the banks, the waters find their passage in the low. est part, and begin to form a channel there ; and a channel thus formed, will constantly be made more and more deep, by the perpetual running of the water. A similar operation must take place through the whole course of the river, from its first rise and source, to its final discharge into the waters of the ocean. Their channels must at first have been formed by their waters ; which, constantly accumulating. and struggling for a passage, approach, or dis. charge themselves into the nearest situation they could take to the centre of the earth.

$I_{N}$ this descent and passage to the ocean, all the large rivers in this part of America, have also formed large tracts of intervale lands. By intervales we mean those low lands, which are adjacent to the rivers, and are frequently overflowed by them in the spring and fall, or whenev.

Ther the o the $\mathrm{b}$ when heigh the o that $\mathrm{t}$ ers. slime the s] ous a quent years, al anc readil and : depth the st vales, are ey not b ers. ar to same down, by wh not fa coursi 
cr the waters are raised to their greatest height. These intervales are level, and extensive plains; of the same altitude as the banks of the river; in width they often reach from a quarter of a mile, to a mile and an half, sometimes on one, and sometimes on both sides of the river. There are frequently two strata of the intervales, the one four or five feet higher than the other ; the highest of which is not overflowed, but when the waters are raised to an uncommon height; but they are level, and extensive like the other. Both of them have many indications, that they were formed by the waters of the rivers. The soil is always of that rich mud and slime, which is brought down by the rivers in the spring. In digging into these lands, various appearances of decaying vegetables are frequently found. 'The strata formed at particular years, are easily distinguished ; and the original and new made soil are so different, as to be readily known. The limbs and trunks of large and sound trees, are often found at various depths ; sometimes so low as forty feet below the surface. The small islands in these intervales, are of a different soil, and less rich ; and are evidently the tops of small hills, which have not been covered by the inundations of the rivers. These long and level surfaces are peculiar to the banks of rivers, and consist of the same rich manure which is yet annually brought down, and deposited by the waters. The cause, by which they are now annually increased, could not fail to have produced such effects, in the course of a long series of years.

Is these intervales there are several places, F 
where another curious phenomenon occurs. The rivers have changed their courses, their ancient channels are left dry, and they have formed new ones. In the uncultivated parts of the country, where the operations of nature liave not been altered or changed, the traveller finds many places where the rivers formerly rolled, which are now dry, and at a considerable distance, sometimes a mile or more from the present beds of those rivers. In some of these ancient channels, the waters must have run for a long number of ages; as they have worn the surface of the stones as smooth as those, which are to be found on the sea shores. In some places the former chamels are left dry, abounding with smooth stones and rocks : In others, the channels are converted into ponds, or overgrown with bushes or trees. $\Lambda$ ppearances of this kind are common in all the mountainous parts of the country; and something of the same kind, is constantly taking place in most of our rivers. In all large streams, the channel is more or iess affected every year : Strips of land, one or two rods in width, and of some miles in length, are often carried off in the spring; ; and additions are made to the banks in other places. 'The lands thus formud, in some places, in the course of a few years amount to several acres, aitil are of an uncommon richness and fertility; but they are always attended with an equal loss in some other part of the river.

THE depth of the channels which our rivers have formed, depends upon a variety of circumstances : The nature of the soil, the declivity of the river, the situation of the adjacent banks,

the $q$

been the $g$ raisir genes form passi form depth ty, or chanr

Conn is for banks chanr scare ment

IT

whicl are to visibl which strean even ; only 1 much the w: treme severa into th scent, Rocki nectic bar of consta 
the quantity of water, \&rc. Their channels have been formed two ways, by the wearing away of the ground in some places, and by forming or raising the intervale lands in others; but most generally the channels of our rivers have been formed in both these ways. In large streams passing through the intervales which they have formed, and moving with a gentle force, the depth of the channels appear to have a similarity, or at least a resemblance. The cleptl of the channels in such situations, in sundry plices in Connecticut river, Ottercreck and Onion river is forty or fifty feet below that of the adjacent banks. But the alteration in the denth of these channels, is so gradual and slow, that it has scarcely been perceptible, since the first sittlement of the country by the Englis: :

Ir is not only in the channels and intervales, which the rivers have formed, that their effects are to be seen ; but their operations are also visible, upon the stoncs and rocks. The stones which have been constantly washed by the streams are always found to be smooth and even ; and the rocks in many places, are not only become smooth and slippery, but they are much worn away by the constant running of the water. There is anuthr phenomenon extremely curious, derived rom this cause ; in several rivers, there are holes or cavities, wrought into the solid body of large rocks, by the descent, or circular motion of the water. At Rockingham, there is a remarkable fall in Connecticut river, where the water passes over a bar of solid rock ; and which it must have been constantly passing over, ever since the river 
began to flow. In the rocks at these falls, there are several cavitics, which appear to have been: formed by the circular motion of small stones, constantly kept in action by the force of the de. scending waters. Some of these cavities are two or three feet in diameter, and from two to four leet in depth ; and probably they are yet increasing. Such phenoniena are not uncommon wherever there are deep falls in our rivers. But the most singular appearances of this nature which I have ever seen, are at Cavendish, upon Black river, near the house of Salmon Dutton. Here, the channel of the river has been worn down, one hundred feet; And rocks of very large dimensions, have been underınined, and thrown down, one upon another. Holes are wrought into the rocks, of various dimen. sions, and forms : Some of them are cylindrical, from one to eight feet in diameter, and from one to fifteen feet in depth : Others are of a spherical form, from six to twenty feet diameter, worn almost perfectly smooth, into the solid body of a rock.

How long a period nature has been employcd in carrying on these opcrations, we can scarcely hope to determine. All the circumstances relating to the channels of rivers, and the intervales which they have formed, are such as denote periods of time very remote, and of the highest antiquity. It can scarcely be sup. posed that in the formation of the intervales, the annual increase has amounted to the tenth part of an inch. At present, the freshets in the spring and fall, and throughout the year, do not annually deposit the one half of this quantity of

earth state, the is perio crcas feet, effect such assur or pr clusi solid unifo every const ever form mucl tury, concl ning prese the a put $t$ actio: cnabl can 1 W to the river, at the the $r i$ the la the $\mathrm{C}$ Fairl 
earth, upon the intervales. At no place in this state, is there any appearance that the surface of the intervales has been raised an inch, in the period of ten years. But admitting such an increase, where the depth of the intervales are fifty feet, the period necessary to produce such an effect, would be six thousand years. But in all such kinds of computation, the data which we assume, are not marked with sufficient certainty or precision, to leave us satisfied with the conclusion. The effects of the rivers upon the solid rocks, seem to be more slow, regular and uniform. There art situations in this, and in every part of America, where the water has been constantly flowing over a solid body of rock, ever since the channels of the rivers were first formed. If we knew from observation, how much such rocks were worn away in one century, by the waters, we could form a pretty just conclusion how long the waters have been running in those places. If the philosophers of the present age will make accurate observations of the altitude and situations of such rocks, and put their observations upon record in the transactions of their philosophical societies, they will enable posterity to solve a problem, which we can hardly expect to determine in our day.

WHIL the one half of our rivers pass off into the occan to the south, through Connecticut river, the other haif find their way to the ocean, at the northeast, through Lake Champlain and the river St. Lawrence.---Lake Champlain is the largest collection of waters in this part of the United States. Reckoning its length from Fairhaven to St. John's, a course nearly 
north, it will amount to about one hundred and fifty miles. Its width is from one to cighteen miles, being very different in different places; the mean width may be estimated at five miles. This will give one thousand square miles, or six hundred and forty thousand acres, as the area of its surface. Its depth is sufficient for the navigation of the largest vessels. It contains several islands ; one of them, the Grand Isle, is twenty four miles long, and from two to four miles wide.

Tine waters which form this lake, are collected from a large tract of country. All the streams, which arise in more than one half of Vermont, flow into it. There are several, which also fall into its eastern side, from the province of Canada. It is probable the rivers which flow into the west side, are as large, numerous, and extensive, as those on the east. The waters therefore, from which Lake Champlain is formed, seem to be collected from a tract of country, of a larger extent, than the whole state of Vermont.

THERE are many marks and indications that the surface of this lake, was formerly thirty or forty feet higher than it is now. The rocks in several places appear to be marked, and stained, with the former surface of the lake, many fect higher, than it has been, from its first discovery by Sir Samuel Champlain, in 1608. Fossil shells, the limbs and bodies of trees, are fre. quently found at the depth of fifteen or twenty feet in the earth; this is the case not only along the shores, but in the low lands at the distance of two or thrce miles from them. The

soil i of the form cums the il water sprea are.

$\mathrm{T}_{\mathrm{I}}$ lake, in rel charg collec lake, Ther forme in the The was $t$ rence this $\mathrm{c}$ ter, w face $c$ same $A_{\mathrm{T}}$ heigh gener until monly tion i carly comn middl and ext 
soil in many places near the shore, is evidently of the same factitious kind, as the intervales formed by the rivers. 'These, and other circumstances, have left no doubt in the minds of the inhabitants along the lake shore, that the waters of it were formerly much higher, and spread to a much greater extent, than they now are.

TII $\mathrm{E}$ operations of nature with respect to the lakc, must have been the same that they were in relation to the rivers. When the waters discharged by the streams, amounted to such a collection, as to rise above the shores of the lake, they would overflow at the lowest part. There, the channel would bigin ; and being formed, it would become more and more decp, in the same manner as the channel of a river. 'The channel which this lake found, and formed, was to the northward ; into the river St. Lawrence ; and through that into the ocean. When this channel, by the constant running of the water, was worn down thirty or forty feet, the surface of the lake would naturally subside the same space.

A $\mathrm{T}$ present there is but little alteration in the height of the waters, through the year. They generally rise from about the twentieth of $A$ pril until the twentieth of June. 'Their rise is commonly from four to six feet, the greatest variation is not more than eight fect. The lake is early frozen round the shores, but it is not commonly wholly shut up with the ice, until the middle of January.* Between the sixth and the

* When the ice is become of its grentest density and firmzess, large and extensive cracks or openings irill suddenly take place. These crack. 
fifteenth of April, the ice generally goes off ; and it is not uncommon for many squarc miles of it, to disappear in one day.

THE north line of Vermont passes over the south part of the lake Memphremagog. This lake is about forty miles in length, and two or three miles wide. It lies chiefly in the Province of Canada, and has a northerly direction. 'The river St. Francis forms a communication bctween the lake Memphremagog, and the river St. Lawrence. Round this lake, there is a rich soil, and a fine level country.

in the ice, generally run in an oblique direction, from one Cape to another, and often to the distance of ten or fifteen miles. Sometimes the ice will separate on each side, to the distance of five or six feet; at other times it will lap over, or more commonly be thrown up in ridges four or five feet high; and it is often broken into picces of two or three feet d:ameter, all round the edges. These openings often prove dangerous to the traveller. They seem to be produced, by the occasional rise and fall of the waters, in the lake; which as they cannot remove, must operate to elevate and depress, and thus to bend and break, the extensive and solid body of ice, which must have assumed the spherical form, which the waters bad when they werc tirst frozen. 


\section{CHAPTER IV.}

Crimate. An account of the Temperature, Winds, Rain, Snow and Weather. The change of Climate which has attended the Cultivation of the Country.

IHE temperature of any particular place, depends chicfly upon the latitucle, the cultivation of the country, the elevation of the place above the adjacent lands, and its proximity to the ocean. The latitude of Vermont is between 4.2 degrees 4.4 minutes, and 45 degrees north. Much the largest part of the state has never been cultivated. A large part of the land, is a range of mountains, much higher than the adjacent parts of the country : And the state is from eighty to one hundred and sixty miles from the ocean.

$T_{H E}$ most common method of determining the mean degree of heat which prevails in any part of the earth, is by thermometrical observations. In the years $1789,90,91$, I made a course of meteorological observations at Rutland, about the latitude of 43 degrees, $36 \mathrm{~min}$ utes. The greatest height of Farenheit's thermometer during that period, was 93 and a half degrees, on July 13, 1791. The least height was 27 below 0, on December 19, 1790. These may be esteemed as near the extremes of heat and cold, in this climate. The mean heat, deduced from the whole number of observations, was 43 and a half degres.

Tнв temperature of the climate inay also be G 
determined by observations of the heat which prevails in deep wells and springs. The heat of the atmosphere, is derived from the heat, which takes place at the surface of the earth. In passing through the atmosphere, the solar ray's do not communicate any'heat to the particles of air. 'The rays must first fall upon the earth, be stopped, and collected, before they produce their effect : And no greater heat can ever be communicated to the atmosphere, than was first communicated to the surface of the earth. Hence we find the temperature of those wclls and springs, which are so far beneath the surface of the carth, as not to be much affected by the heat in summer, or by the cold in winter, is the same as the mean temperature of that climate ; or the mean heat of the atmosphere, in that place. The temperature of the water in the deep wells in this place, is exactly the same as the mean heat of the atmosphere. I have repeatedly examined the temperature of the water in a well near the State House, by estimation forty five feet in depth, and I have always found the heat to be 43 and a half degrees, without any variation in summer or winter.*

* On a Journey from the University at Newhaven in Connecticut, to Burlington upon Onion river, I made the following observations upon the temperature of the wells; which may serve to show in what manner the heat decreafes, as we advance towards the north, in a country but little cultivated.

Ptace.

Newhaven, Middletown Hartford, Stockbridge, Pittsfield, Tinmouth, Rutland Uurlington,
President's well,

Goodwin's Inn, Bull's Inn,

Judge Edwards's, Strong's Inn, Judge Mattock's Spring, Buell's Inn, Keyes' Inn,

leaves, seeds a produc the birc make tions $u$ observa relative ferring animals two sm the tim their fri

A viers

Trces and $S$ Eider,

Gnoseberry

Currant,

Raspberry, Strawberry

Wild Cher

Wild Plun

Apple Tre

A viere

Seeds ar Flax, Spring Wh Winter $W$

Oats,

Pess,

Barley,

Rie,

Indian $O_{0}$ iday, 
ANOTHER view of the climate may be taken from the common operations of nature, the vegetable and animal productions. The times when the trees and plants put forth their buds, leaves, flowers and fruit, or when the different seeds are planted, spring up, are in blossom, produce their fruit, and are gathered in ; when the birds of passage, or other migratory animals, make their approach or departure. Observations upon such phenomena, are anong the best observations we can ever have, to ascertain the relative temperatures of different climates. Re. ferring those which relate to the migration of animals, to the description of the birds, one or two small tables will serve to give us a view of the times, when different vegetables produce their fruit, in this part of the continent.

\section{T ABLE I.}

$A$ view of the Climate, taken from the state of Vegetation in the Trees and Shrubs.

\begin{tabular}{|c|c|c|c|c|c|c|c|c|}
\hline Trces and Shrubs. & Buds. & & Leave & & Flon & rs. & Maturi & \\
\hline Eider, & April & 5 & April & 14 & June & 15 & & \\
\hline $\begin{array}{l}\text { Gooseberry, } \\
\text { Curr?nt, }\end{array}$ & $\begin{array}{l}\text { April } \\
\text { April }\end{array}$ & $\begin{array}{l}6 \\
6\end{array}$ & $\begin{array}{l}\text { April } \\
\text { April }\end{array}$ & $\begin{array}{l}16 \\
16\end{array}$ & $\begin{array}{l}\text { May } \\
\text { May }\end{array}$ & 9 & July & 2 \\
\hline Raspberry, & April & 6 & April & 17 & May & 27 & July & \\
\hline Strawberry, & April & 20 & April & 20 & May & 6 & June & \\
\hline Wild Cherry, & April & 20 & April & 28 & May & 4 & June & 28 \\
\hline Wild Plumb, & April & 20 & May & 4 & May & 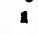 & August & 12 \\
\hline Apple Tre & April & 22 & Miจy & 7 & May & 12 & Augusi & \\
\hline
\end{tabular}
TABLE II.

$A$ view of the Climate, taken from the finits of the rield.

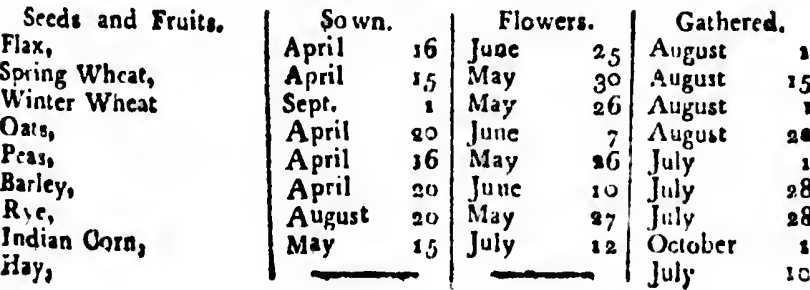


Tine frosts commonly cease about the be. ginning of June, and come on again between the first and the middle of September. When they first come, they appear not on the hills, or lighest parts of the trees, but in the low and wet lands, and on the lowest parts of the trees. When a fog lies along the low lands adjoining. to a river, when the winds are high, and when the lands are but partly or newly cleared, the frosts are retarded or prevented; and do not appear so soon, or so great, as in clear, low, and wet places. These circumstances seem to explain the reason why the frosts are first seen not on the high, but on the low lands. The dews and vapours are the most dense and abundant, in those places; much more so than they are at higher altitudes, or upon the hills. The first cffects of the frost are not sufficient to freeze the leaves of the trees, or other vegetables. The cold at first avails only to effect the congel. ation of the dew and vapour ; as these are chiefly to be found in the low and moist lands, and not higher than the lowest limbs of the trees, these are the places where the first effccts of the frosts appear, A high wind serves to prevent these effects, by carrying off the dew and vapours ; and a feg detains the heat in amazing quantities, and prevents its flowing off from the surface of the earth, either so rapiclly, or in such quantities, as to occasion a frost.

$I_{N}$ those places where the earth is not coverad with snow, the frost penetrates several feet below the surface. In the winter of 1789 there was but little snow at Rutland; and the sur. face of the earth was frozen almost the wholc 
winter. On March the 19th the ground was frozen to the depth of three feet and eight inches. The ice in the lakes and stagnant waters, is generally frozen in the course of the winter, about thirty inches thick ; in the rivers and streamis it is about twenty four ; and commonly goes off the last week in March.

THE severest cold of our winters never kilis any of our young trees, and seldom freezes any, of our young cattle, although they are not housed during the winter. Nor is the cold so affecting to the human body, as the extremes, and sudden changes from heat to cold, on the sea coasts. From the time that the winter first sets in, until it breaks up, we have generally a settled steady cold ; for the most part without any thaw, and with but a few days in which the snow melts at all. During this period we become accustomed to the weather, and every thing in our feeling, and clothing is adapted to a steady and severe cold. Such a steady, equal temperature, is far more comfortable than those great and sudden changes which take place, where the extremes of heat and cold are frequently succeeding each other.

$T_{H E}$ temperature of the American climate is so different in different parts of the same state, and often in the same latitude, that it cannot be well understood, but by viewing it in its variations through the different parts of the northern continent. The following table is designed to exhibit such a comparative view. 


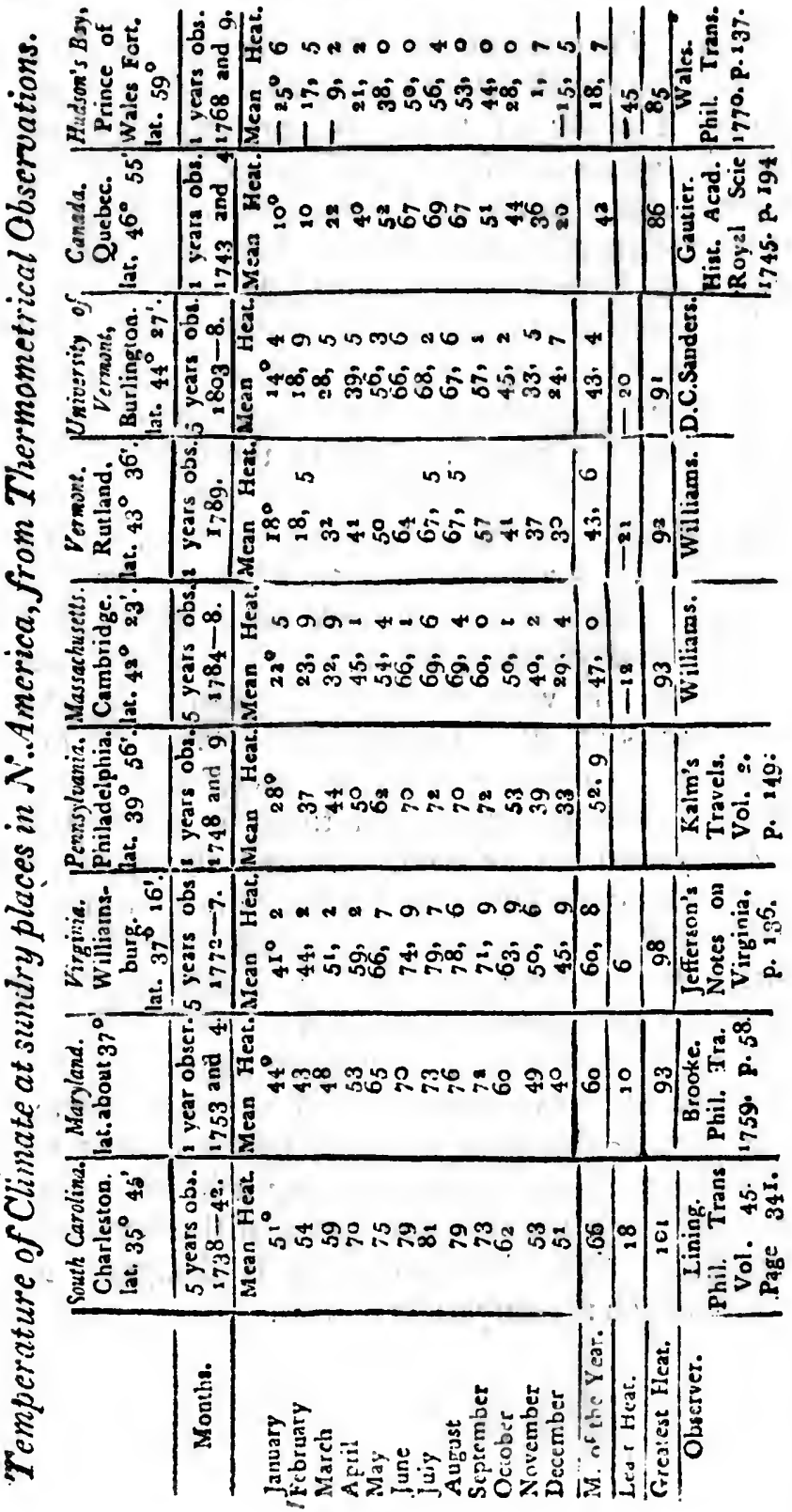

The

the $\mathrm{s}$ their vance so fai know The regul there sever whic and $\mathrm{i}$ abou eight come nigh serve ter, a year. the inter 
$T_{\text {H }}$ winds in North America receive their general direction from the situation of the sea coasts, mountains, and rivers. 'These are very much from the southwest to northeast. The most prevalent of our winds, are either parallel with, or perpendicular to this course; or rather, they are from the northeast, east, southwest and northwest. More than one half of the winds which blow during the year, are from that quarter which lies between the southwest and northwest. 'The west and northwest winds are dry, cooling and elastic. These winds always begin at the sea coast. Those from the south and soutwest are more warm, moist and relaxing. The easterly winds seldom extend so far from the sea coast as Vermont. They not only lose their distressing chill and dampness, as they advance into the country, but they seldom reach so far as Connecticut river ; and they are unknown on the west side of the green mountains. The winds seem to observe something like a regular course, during the day. At sunrise there generally seems to be a calm; about seven or eight o'clock, the wind begins to rise, which at nine or ten becomes a fresh breeze; and increases until one or two o'clock : From about three or four, the wind decreases until eight or nine in the evening; when it again becomes calm, and continues thus through the night. This general routine seems to be observed more generally in the latter part of winter, and in the spring, than at other times of the year. But there are times in those seasons of the year, when the wind rages without much intermission for two or three days together. 
A general table of thei arections at different places upon the continent, will give the best views of their comparative courses. 


\section{HISTORY OF VERMONT.}

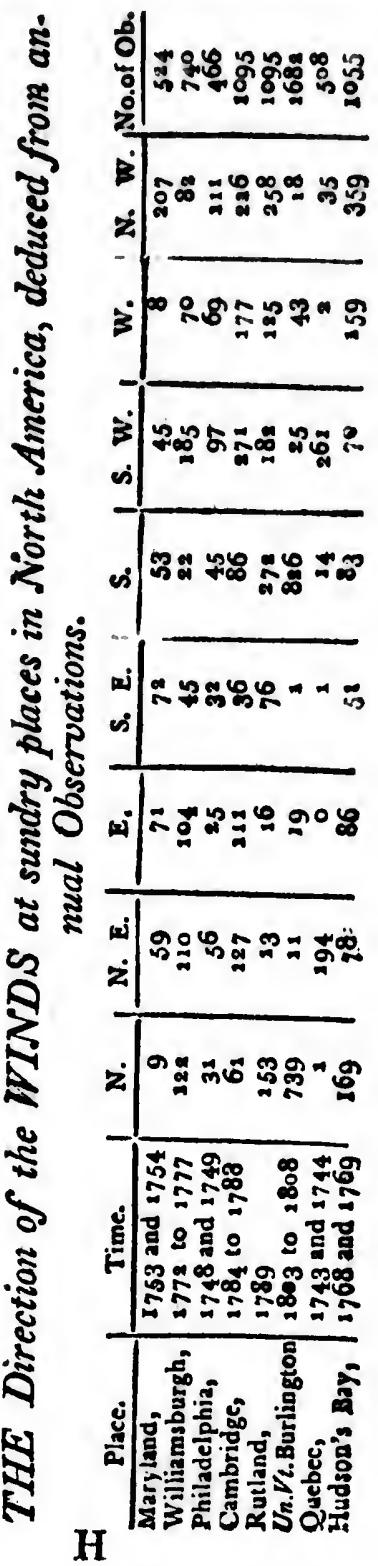


THE quantity of rain which falls ar those places in North America where meteorological observations have been made, has been found to be more than double to that which generally falls in the same latitude in Europe. We cannot well account for this, without supposing that the immense forests of Amcrica, supply a larger quantity of water for the formation of clouds, than the more cultivated countries of Europe. Many parts of America do however, suffer severely by drought : this is very seldom the case in Vermont. The lands are naturally moist, the mountains supply water for regular rains, and the heat of the sun is not so intense as suddenly to disperse the vapours, dry up the waters, or parch the land. These kinds of ob. servations will be reduced to the smallest compass, and give the most complete comparative view, by exhibiting them in the form of a genc. ral table.

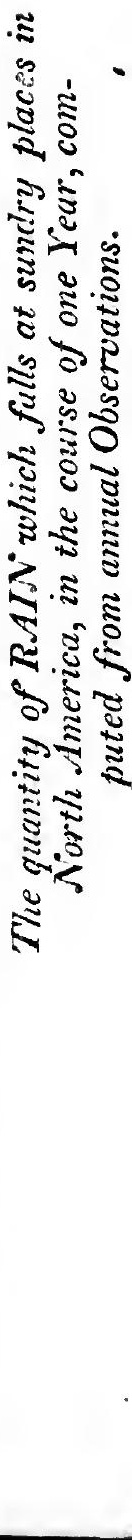




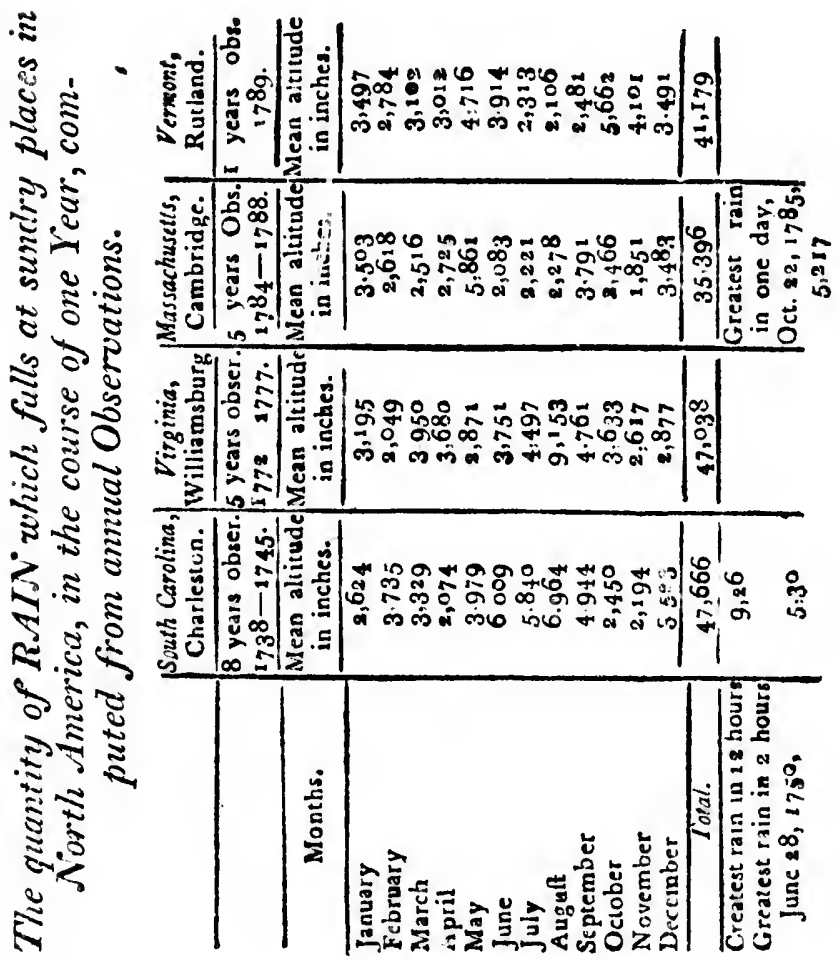


DURING thrce months in the year, this part of America is covered with snow. On the mountains the snow is generally from two and an half to four and an half feet deep; and does not go off until after the middle of April. In the lower grounds, the snow for the most part, is from one, to two and an half feet deep ; and remains until about the twentieth of March.... The advantage derived io the earth from the quantity and duration of the snow, is every where apparent. As soon as it is melted on the mountains, the earth appears to be greatly fertilized : the spring comes on immediately; and the vegetables of every kind are green and flourishing. With a very little cultivation, the earth is prepared for the reception of the seed ; and the vegetation becomes extremely quick and rapid.

Tнг effects being so apparent, a general opinion seems to have taken place, that the snow communicates to the carth some nitrous salts or enriching substance which tends to increase its fertility. In February 1791, I melted as much snow as afforded six gallons of water. The snow was collected as it was falling: Being evaporated there remained cleven grains of calcarious earth, five grains of an oily substance, and two grains of saline matter. The fertilizing effect of snow, cannot therefore be derived from any nitrous salts, which it receives or contains when it is falling through the atmosphere. Suspecting it might acquire some saline mixtures by laying on the earth, January 30,1792 , in an open field covered with grass, I collected as much of the snow which lay next to the earth,

If th

same a cor the $\mathrm{c}$ snow quan

I co

will

eigh

matt

teen of $\mathrm{sr}$

from cr al its

cart] heat heit mos 


\section{HISTORY OF VERIIONT.}

as produced six gallons of water. This snow spread over an area of sixteen square feet, and had lain upon the ground fifty nine days. Upon evaporating the water there was not more saline matter, or calcarious earth, than in the former experiment; but a much larger quantity of oily substance. The oil was of a dark brown colour not inflammable, and weighed four penny weights and nine grains, troy weight. From the former experiment, it appears that the biggest part of this oily matter accrued to the snow after it had fallen upon the earth: And to this oily substance, is probably to be insuted that dirty or sooty appearance, which the snow is generally observed to have, after it has begun to thaw. If the snow which I removed contained the same quantity of oil as that which I ex:mined, a considerable nutriment might be preserved to the earth from this calise. 'The depth of the snow was thirty inches: The depth of that quantity which I collected to melt, as nearly as I could determine, was three inches. This will give two ounces, three pennyweights and eighteen grains, as the gus sity of mucilaginous matter, which would have is scended upon sixteen square feet of the earth, from the quantity of snow that was then urm the ground.

WHILE the snow this prevents all waste from the surface of the carth, it periorms anothcr and more importan: office, that of preserving its internal heat. The internal parts of the carth through the territory of Vermont, are heated to about the forty fourth degree of Farenheit's thermometer. When the heat of the atmosphere is greater than this, a part of that 
heat will flow into the carth, and thus the heat of the earth will be increased. When the heat of the atmosphere is less than forty four degrees, the heat will flow out of the earth into the atmosphere, and in this way the internal parts of the earth will be losing their heat, or becoming colder. This is the case during the winter months ; or rather, from the middle of October, to the beginning of April. Hence the surface of the earth when exposed to the atmosphere, becomes frozeh to a greater or less depth, according to the degree and duration of the cold. The snow tends very much to prevent this. By covering over the surface of the ground a considerable depth, the snow by its nature and colour, prevents the internal heat of the earth from flowing into the colder atmosphere, and the atmosphere from coming into ccntact with the earth. In this way while the earth is cov. ered with a deep snow, its heat is preserved, and the surface, in the coldest weather, is kept warm. To ascertain to what degree the heat of the earth was affected, by the quantity of snow that lay upon it, on January 14, 1791 (an extreme cold winter) I dug through the frozen surface in a plain open field, where the snow had been driven away by the wind, and found the ground was frozen to the depth of three feet and five inches. In the woods, where the snow was three feet deep, I found on the same clay the heat of the earth, six inches below the surface, was thirty nine degrees. The surface of the carth had been frozen to this depth, be.. fore it was covered with snow. The frost was not only cxtracted, but the surface of the eartit?

was

point, it wa:

$\mathrm{TH}$ cial e in all are ne of di grow will $\mathrm{P}$ sever these roots tivcly at the enricl and $\mathrm{p}$ the $\mathrm{e}$ and $\mathrm{n}$ is in ation, imme $\mathrm{T}_{\mathrm{I}}$ and snow small hours or he of the ly fri unco quent comn very April 


\section{HISTORY OF VERMON'I. $6 ;$}

was heated seven degrees above the freezing point, in consequence of the snow with which it was covered.

Th Is will help us to account for the beneficial effects, which are derived from the snow, in all cold climates. Different degrees of heat are necessary, for the preservation and growth of different vegetables. None of them will grow when they are frozen ; and most of them will perish when the cold at their roots is very severe. A thick covering of snow prevents these effects. The earth is kept open, and the roots of the vegetables are preserved comparativcly warm. The snow is continually melting at the surlace of the earth : It moistens, and enriches the soil ; keeps off the frost and wind, and prevents all evaporation from the surface of the earth. The earth thus prepared by heat and moisture, and a collection of all its effluvia, is in a fit state for that sudden and rapid vegetation, which takes place in all cold climates, immediately upon the melting of the snow.

Тн $\mathrm{F}$ weather is generally fair in the winter ; and often, with an hazy atmosphere. The snows are frequent, but they generally come in small quantities, and are over in one or two hours: They are not attended with high winds, or heary storms ; but they come from all points of the compass, except the east ; very firequently from the west, and northwest. Hail is not uncommon in the winter, but rain is not fre. quent. About the middle of March the spring; commences. The winds and weather are then very unsettled until the begiming of April. In April and May the weather becomes mild and 
pleasant, attended with frequent showers. In the summer months the weather is generally fuir, clear and settled. 'The winds are mostly from the south, and southwest; the heat in the middlle of the day is often very uncomfortable, but the nights are alınost ever cool and pleasant. From the beginning of September, until the middle of October, we have commonly the most agreeable season, with moderate westerly winds, and a clear sky. The lattcr part of October and November, are generally cold, wet and uncomfortable; attended with frequent rains, some snow and high winds.

THENDER and lightning are common in the months of May, June, July and August; but seldom in the other months. The Aurora Borealis is the most common in the months of March, September and October ; but it is not unusual at other times of the year. Heavy and Jong storms of snow, or rain, are scarcely ever known : But sudden and violent whirlwinds or hurricanes sometimes arise, and do much dam. age in the fall; but we seldom receive any injury from the hail. Annual courses of meteorological observations properly reduced, will afford the most complete information of the weather, and meteors, in the different parts of North America. 


\section{HISTORY OF VERMON'T. 69}

In

ally

stly

the

ble,

ant.

the

20st

ids,

ber

un-

ins,

the

but

ora

of

not

and

ver

or

ni-

in.

eo-

vill

the

of

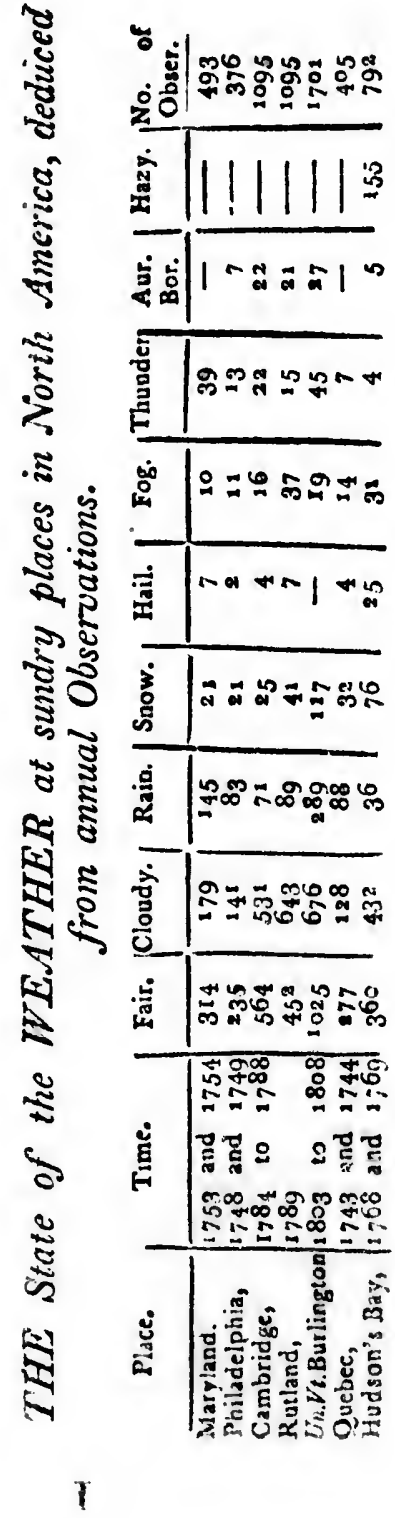


' $\mathrm{I}$ н в above accounts are designed to exhibit a just view of our climate. But instead of re. maining fixed and settled, the climate is per. petually changing and altering, in all its circumstances and affections : And this changc instead of being so slow and gradual, as to be a matter of doubt, is so rapid and constant, that it is the subject of common observation and experience. It has been observed in every part of the United States ; but is most of all sensible and apparcint in a new country, which is suddenly changing from a state of vast uncultivated wilderness, to that of numcrous settle. ments, and extensive improvements. When the scitlers move into a new township, their first business is to cut down the trees, clear up the lands, and sow them with grain. The earth is no sooner laid open to the influence of the sun and winds, than the effects of cultivation begin to appear. The surface of the earth becomes more warm and dry. As the settlements increase, these effects become more general and extensive : the cold decreases, the earth and air become more warm; and the whole temperature of the climate, becomes more equal, uniform and moderate. At the same time the lands and roads become more clry and hard : the stagnant waters disappear, smail streams and rivulets dry up, and the redundant watcis are carried off. The number and quantity of the snows decrease; the winds receive new directions, and the weather and seasons become much altered. These changes every where attend the cultivation of the country; and have formed a remarkable change of climate in those states. which have been long settled. 
IN this change of climate, the first effect which is generally observed, is an alteration in the temperature. The cold of the winters decrease; the rivers are not frozen so soon, so thick, or so long, as they formerly were ; and the effects of extreme cold, in every respect, appear to be diminished. A remarkable change of this kind, has been observed in all the settled parts of North America. The bays and rivers in New England, are not frozen so hard, or so long, as they were at the first settlement of the country.* At the first settlement of Philadelphia, the river Delaware was commonly covered with icc, about the middle of November, old style. $\dagger$ It is not now commonly covered with ice, until the first week in January. Sinilar observations have been made with regard to the ice in Hudson's river. $\neq$ 'The baron Lahontan gave this account of the river St. Lawrence, at Quebec, in 1690 : "I put to sea the twentieth of November, new style, the like of which was never seen in that place before. The ice had covered the river on the thirteenth and fourteenth of November, but was carried off by a sudden thaw." $\|$ 'The river is not frozen over now until the latter end of December, or the begiming of January. The ancient people at Quebec, in 1749, informed $\mathrm{Mr}$. Kalm, that the winters in Canada were formerly much colder, than they were then.\$ Similar observations have been made in almost every part of North

* New England's Prospect, by W. Wood ; written in $2633, \mathrm{P} \cdot 4$.

+ Kalm's Travels, Vol. i. p. 4IO.

I Smith's History of Ncwyork.

ii Voyages to North America, p. 165.

Kalm's Travels, Vul. II. p. 382. 
America, where settlements and cultivation have taken place.

A I TночGH the general effect has been every where apparent, it is not an easy thing to ascer. tain the degree, to which the temperature has changed, in any particular place. When ottr ancestors first came into America, thermometers were not invented : And they have not left us any accurate meteorological remarks or observations, from which we can determine the exact degree of cold, which prevailed in their times. Upon looking over the most ancient writers of New Fngland, the only account I have found, which will afford any distinct information upon this subject, is the following passage ; referring to years previous to 1633 . "The extremity of this cold weather lasteth but for two months, or ten weeks, begrinning in December, and breaking up the tenth day of Zebruary (21st new stile) which hath becoine a passage very remarkable, that for ten or a dozen years, the weather hath held himself to his day, unlocking his icy bays and rivers, which are never frozen again the same year, except there be some small firost until the midclle of March." The winter is less severe now in several respects : The extrenity oi the cold weather does not come on so soon by several wceks; the bays at Boston, instcad of being anuually cover. ed with ice, are but selaom frozen to this degree; and they do not continue in this state a longer time than eight or ten days. In the year 1782, the harbour between Boston and Charlestown was frozen to such a degree, that

* Wocd's Prosfect, p. 4.

horses

or six an effec cient as manent this sta I found moricet was 28 grces. frecrin could 1 less de is 13 c the me: ten wee 1630. which for sev mean degrees grees degrees the pre If this temper ycar 1 from te A p the clin equally carth. affecter licets, ing m: 
horses and sleighs passed over the ice, for five or six days. This was the begiuning of such an effect, as that which is mentioned in the an. cient account. The ice became fixed and permanent on February second ; and continued in this state until February 10th. During that time I found the lowest degree of Farenheit's ther. moneter to be -9 degrees; the greatest degree was 28 degrces: and the mean heat was 13 degrces. It may be presumed therefore, that the frecring of the bays of which Wood speaks, could not have taken se, or continued, in a less degree of cold th... this. This will give us 13 degrees of Farenheit's thermometer, as the mean heat which took place during eight or ten weeks of the winter, so far back as the ycar 1630. By the meteorological obscrvations which I made in the University at Cambridge for seven years, from 1780 to 1788 , I found the mean heat in the month of 1)cember was 29 degrees 4 tenths; in January it was 22 degrees 5 tenths; and in February it was 23 degrees 9 tenths. These numbers express the present temperature of the winter at Boston. If this computation be admitted, the change of temperature in the winter, at Boston, from the year 1630 to the year 1788 , must have been from ten to twelve degrees.

A permanent alteration in the temperature of the climate or atmosphere, supposes an alteration equally great and permanent, in the heat of the carth. Whether the heat of the earth is thus affected by cultivation, and what will be its effects, I endeavoured to ascertain in the following manner. On the 23d of May, 1789, I sunk 


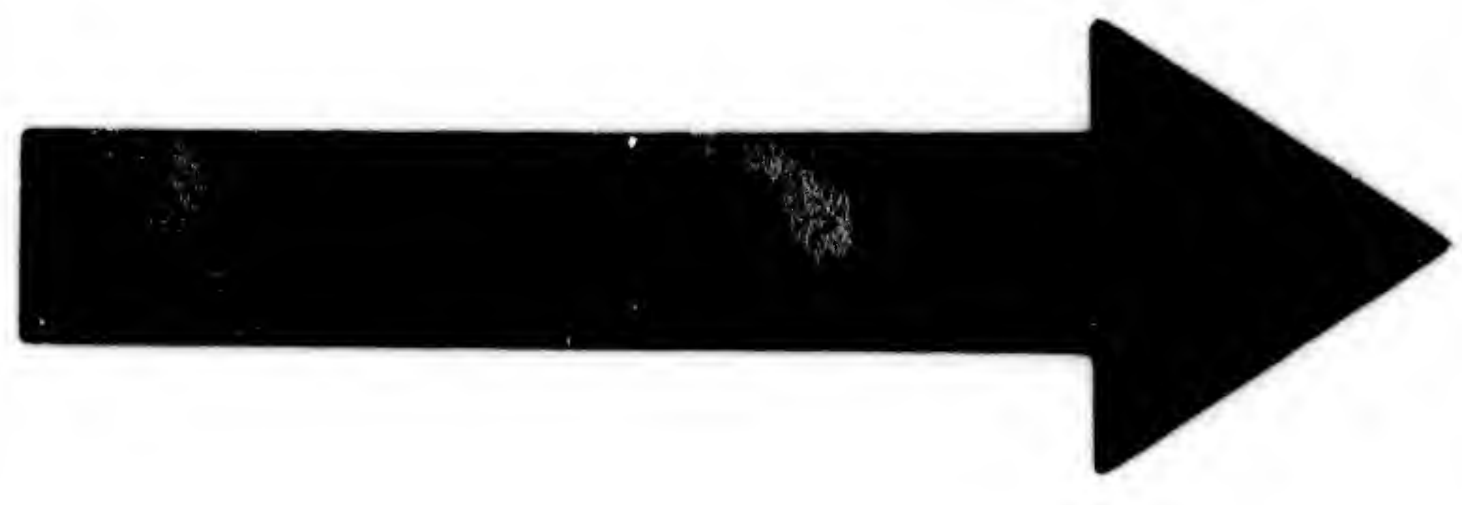




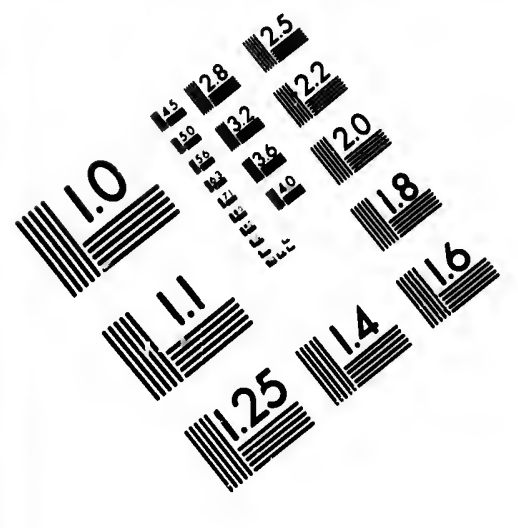

\section{IMAGE EVALUATION TEST TARGET (MT-3)}
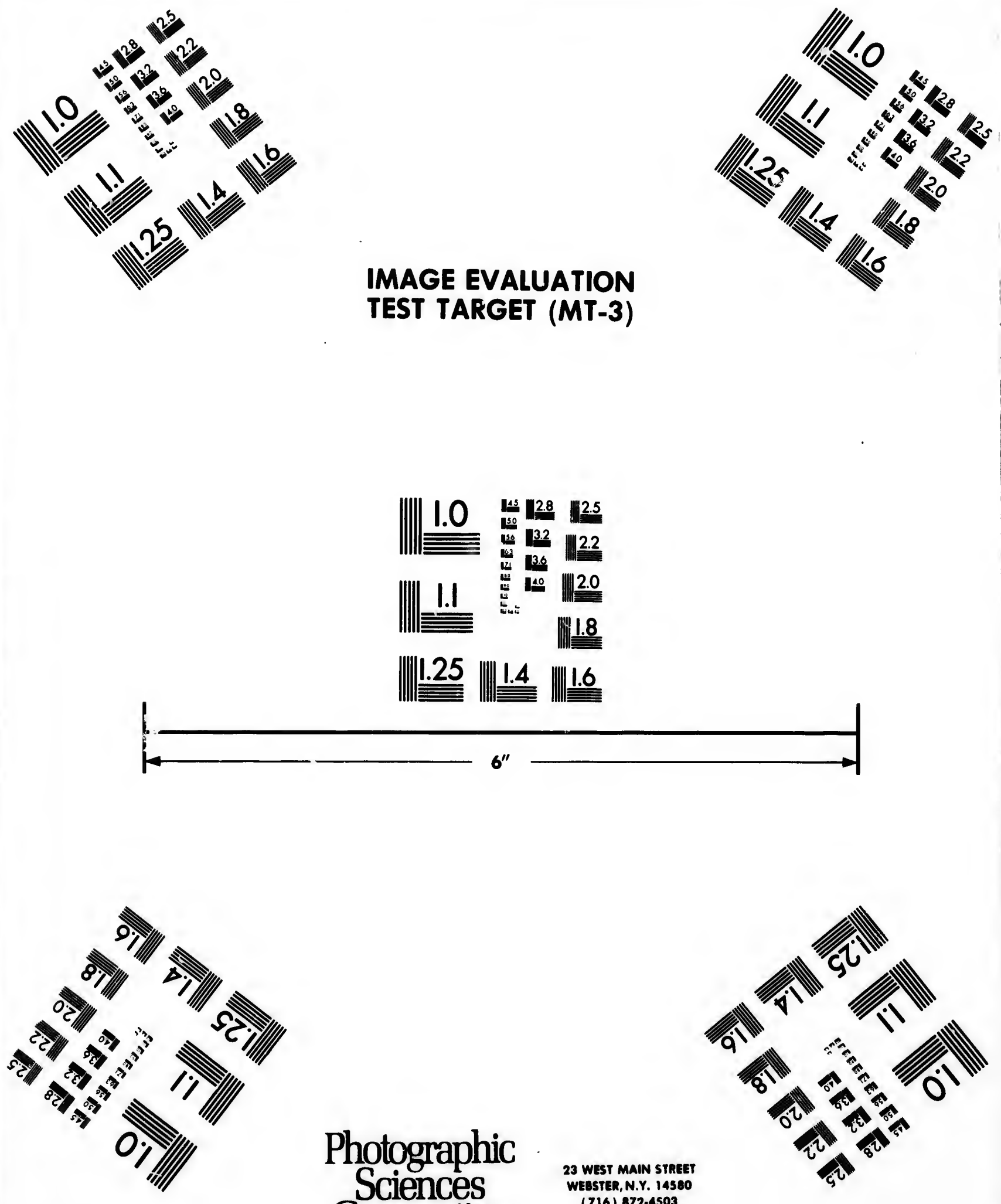

Photographic Sciences Corporation
23 WEST MAIN STREET WEBSTER, N.Y. 14580 (716) 872-4503

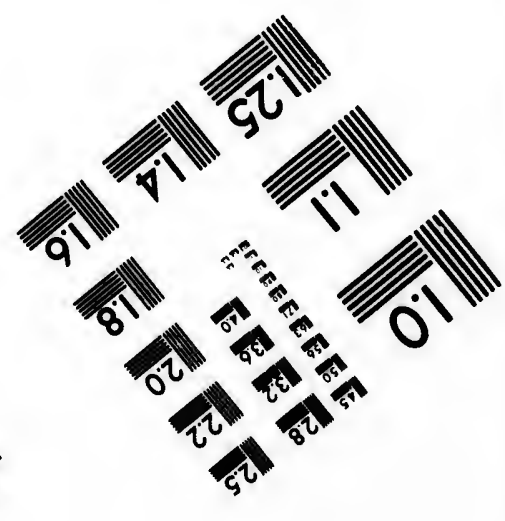




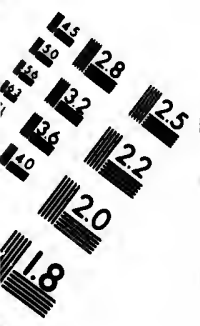

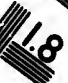


a thermometer to the depth of ten inches below the surface of the earth. Upon repeated trials the quicksilver stood at fifty clegrees : this was in a level open field, used for pasture or grazing, and fully exposed to the sun. The same experiment was then made in the woods, where the surface of the earth was covered with trees, and never had been cultivated. 'To ascertain the gradual increase of heat at each place, the observations were often repeated. The result was as follorvs.

Time. Heat in the'Heat in thelDifference.

\begin{tabular}{|c|c|c|c|}
\hline & Pasture. & Woods. & \\
\hline$\overline{\text { May }}$ & $50^{\circ}$ & $46^{\circ}$ & $6^{\circ}$ \\
\hline & & & \\
\hline June & 64 & 51 & 13 \\
\hline 27 & 62 & 51 & 11 \\
\hline July & 62 & 51 & 11 \\
\hline Aurust & $651-2$ & $\begin{array}{lll}55 & 1-2\end{array}$ & 10 \\
\hline August & 68 & 58 & 10 \\
\hline September 15 & $\begin{array}{lll}59 & 1 & -2\end{array}$ & 55 & 4. 1-2 \\
\hline $\begin{array}{l}\text { September } 15 \\
\text { October }\end{array}$ & $591-2$ & 55 & $41-2$ \\
\hline October & $59 \begin{array}{ll} & 1-2\end{array}$ & 55 & 41.2 \\
\hline November 15 & 49 & 49 & 0 \\
\hline November & $\begin{array}{lll}43 & \\
43 & 1 & -2\end{array}$ & 431.2 & $\begin{array}{l}0 \\
0\end{array}$ \\
\hline
\end{tabular}

$T_{\text {H }}$ effect of cultivation with regard to the heat of the earth, so far as it can be collected from these experiments, appears to be this : Exposing the land to the full force of the solar rays in this latitude, will produce an heat at the depth of ten inches below the surface, ten or cleven degrees greater than that which prevails in the uncuitivated parts of the country; and

this effe sufficien This ad ficient $t$ tempera heat pre be com mospher cultivate consequ degrees vated sta tions tha duced $b$ change o eastern $\mathrm{F}$ Anot part of $t$ the culti in the $m$ the surfa becomes waters i have bee settlemes small str which a were ple rivers, $h$ and larg: est of ou the chal Fields o: most rap in lands, 
this effect continues while the solar rays are sufficient to increase the heat of the earth. This additional heat in the earth, will be sufficient to produce the same alteration in the temperature of the air ; for whatever degree of heat prevails in the earth, nearly the same will be communicated to the lower parts of the atmosphere. Thus the earth and the air, in the cultivated parts of the country, are heated in consequence of their cultivation, ten or eleven degrees more, than they were in their uncultivated state : It should seem from these observations that the effect, or the degree of heat produced by cultivation, is the same with the change of climate, that has taken place in the eastern part of Massachusetts.

A о от нк remarkable effect which makes part of the change of climate, and always attends the cultivation of the country, is an alteration in the moisture or wetness of the earth. As the surface of the earth becomes more warm, it becomes more dry and hard, and the stagnant waters disappear. Alterations of this kind, have been common and great, in all the ancient settlements in the United States. Many of the small streams and brooks are dried up : Mills, which at the first settlement of the country, were plentifully supplied with water from small rivers, have ceased to be useful. Miry places, and large swamps, are become among the richest of our arable lands. In the new settlenents the change is effected in two or three years : Fields of corn and wheat are attended with the most rapid vegetation, and the greatest increase, in lands, where the waters five or six years ago, 
were stagniant, and in such quantities as to be spread over the largest part of the ground. One of the first effects of cultivation is the dispersion of these waters, and a change in the soil, from the appearance of a swamp, to that of a dry and fertile field.

THERE are two ways in which cultivation operates, to produce this effect. By the cutting down of the trees, the dispersion of a vast quantity of fluid, emitted by their evaporation, is prevented ; and by laying the lands open to the influence of the sun and winds, the evapor. ation of the stagnant waters is greatly promoted. The effect of the first, from experiments which will be related when the vegetable productions are considered, may be estimated at three thousand and eight hundred gallons of water thrown off from the trees on one acre, in the space of twelve hours, in hot weather. To as. certain the effect which might arise from the latter, on June 27 th, 1789 , a fair, calm and hot day, I placed a china saucer on the ground in the woods, where it was covered from the solar rays by the trees, the leaves of which at the height of ten or twelve feet, were very thick. Another saucer in all respects similar to this, was placed on the ground in an open field adjoining, where it was fully exposed to the wind and sun. I poured into each of them equal quantities of water; at the end of three hours the evaporation from the latter, was to that from the former, as six eight tenths to one. With regard then to the moisture or wetness of the country, it appears that settlement and cultivation will be sufficient to prevent the discharge

of three water, $o$ the hot dispersi from th been dis may juc duced the caus A ch ifest in the anci Whethe annual we cann al obser has beet At the earth w: than thr in large and selc This is ous par them $\mathbf{f}$ carried In thos long se declinir frequen they we ing ves duratio of temy mosphe 


\section{HISTORY OF VERMONT.}

$o$ be

One sion from and

tion

cut-

vast tion,

to por. ted. hich ions laree rater the as. the hot 1 in olar' the ick. his, adind jual urs om ith the

of three thousand and eight hundred gallons of water, over one acre of land, in 12 hours, during the hot weather; and at the same time to effect the dispersion of 6 times and 8 tenths as much water from the surface of the earth, as would have been dispersed in its uncultivated state. If we may judge upon a matter which cannot be reduced to exact calculation, it should seem that the cause was here equal to the effect.

A change in the climate hath also been manifest in the apparent decrease of the snow, in all the ancient cultivated parts of the United States. Whether there has been any alteration in the annual quantity of rain in any part of America, we cannot determine, for want of meteorological observations ; but a great decrease of snow. has been observed in all the ancient settlements. At the first settlement of New England, the earth was generally covered with snow for more than three months in the year. It began to fall in large quantities by the first of December, and seldom went off until some time in March. This is yet the case in the inland and mountainous parts of the country. The snow covers them for three months, and is scarcely ever carried off by a thaw until the spring comes on. In those parts of the country which have been long settled and cultivated, the snows have been declining for many years. They are neither so frequent, deep, or of so long continuance, as they were formerly : And they are yet declin$\mathrm{mg}$ very fast in their number, quantity, and duration. This event is derived from the change of temperature, which has taken place in the atmosphere ; and probably will keep pace exactly. $\mathbf{K}$ 
with it. There has also been an apparent alteration in the direction of the winds. The prevalency and extent of the westerly winds, seem to be abating: Or rather the easterly winds are certainly increasing in their frequency and extent. These winds are now very fiequent in the spring, in all that part of the country, which lies within sixty or seventy miles of the sea coast. Half a century ago, the casterly winds seldom reached farther than thirty or forty miles from the sea shore. They have now advanced as far as the mountains, which are generally eighty or an hundicd miles from the ocean. As the country becomes settled and cleared, they are found to advance more and more, into the internal parts of the country. It can hardly be doubted, but that this event is owing to the increasing cultivation of the country. As the woods are cut down, the earth and atmosphere become more heated than the ocean : The direction of the winds will of course be from the sea, towards the land. As the country becomes more settled and cleared, it is probable these winds will continue to advance further towards the west.

Tre same causes which produce a change in the heat of the earth, in its wetness, in the snow and winds, will produce as great a change in the weather and seasons. While the state of a country remains unaltered, the general course and appearance of nature will be the same, from one age to another. Summer and winter, spring and fall, the productions of the earth, the state of the-air and weather, will be subject to but little annual alteration or change. But when

the wh ing, th with th taken parts came i er wer in abo and co Durin and co the en up. once ; from 1 summ month ration. begin kinds A re place, has be changer able a with much tempe spring unfor greatl of the mode few $v$ ratior 


\section{HISTORY OF VERMONT.}

alter.

prevaem to is are d ex. ent in which e sea winds milcs anced erally .. As they to the lly be ine in. $s$ the phere ie dian the omes these vards

ange a the ange ate of purse from pring state but rhen

the whole face and state of a country are changing, the weather and seasons will also change with them. This is an event that has already taken place in the most ancient and cultivated parts of America. When our ancestors first came into New England, the scasons and weathcr were uniform and regular. The winter set in about the beginning of December, old style, and continued until the middle of February. During, that time the weather was generally fair, and cold, and without much change. Towards the end of February the winter generally broke up. When the spring came on, it came on at once; without repeated and sudden changes from heat to cold, and from cold to heat. The summer was extremely hot and sultry, for a month or six weeks ; but it was of a short duration. The autumn commenced about the beginning of September ; and the harvest of all kinds was gathered by the end of that month. A very different state of things now takes place, in all that part of New England, which has been long settled. The seasons are much changed, and the weather is become more variable and uncertain. The winter is intermixed with great and sudden thaws, and is become much shorter. The changes of weather and temperature, are great and common in the spring ; and at that season there is generally an unfortunate fuctuation between heat and cold, greatly unfavorable to vegetation, and the fruits of the earth. 'The summers are become more moderate in respect to the extreme heat of a few weeks ; but they are of a much longer duration. The autumn commences, and ends, 
much later than formerly : the harvest is not finished until the first week of November ; and the severity of winter does not commonly take place, until the latter end of December. But the whole course of the weather is become more uncertain, variable and fluctuating than it was in the uncultivated state of the country.

Ir is in these particulars, the change that has taken place in the heat of the earth, in its wet. ness, in the snow, winds, weather and seasons, that the change of climate in North America has principally appeared. That this change of climatc is much connected with, and greatly accelerated by the cultivation of the country, cannot be doubted. But whether this cause is sufficient to account for all the phenomena, which have attended the change of climate in the various parts of the earth, seems to be un. certain.*

- Appendix No. II. 


\section{CHAPTER V.}

Vegetable Productrons....Forest Trees, Esculent and Medicinal Vegetables. Remarks on the Magnitude, Number, Agc, Evapora. tion, Emission of Air, Heat, and Effect of the Trees.

WHEN the Europeans first took possession of North America, it was one continued forest, the greatest upon the earth. The country was cvery where covered with woods, not planted by the hand of man; but derived from, and ancient as the powers of nature. The great variety of plants and flowers, the immense numbers, dimensions, and kinds of trees, which spread over the hills, valleys and mountains, presented to the eye, a most magnificent and boundless prospect. This is still the case with the uncultivated parts of the country.

Mu $\mathrm{CH}_{\mathrm{H}}$ the largest part of Vermont is yet in the state, in which nature placed it. Uncultivated by the hand of man, it presents to our view a vast tract of woods, abounding with trees, plants, and flowers, almost infinite: in number, and of the most various species and kinds. It would be the employment of many years, to form a complete catalogue of them. I shall not attempt to enumerate any, but those which are the most common and useful.

\section{FOREST TREES.}

THE Trees which are the most large and common are the

White Pine. Pints Strobus. 
Yellow Pinc. Pinus Pinca.

Pitch Pine. Pinus Treda.

Latch. Pinus Larix.

Hemlock. Pinus Abies.

$\left.\begin{array}{l}\text { White Sprucc. } \\ \text { J3lack Spruce. }\end{array}\right\}$ Pinus Canqdensis.

Fir. Pinus Balsame'a.

White Maple. Accr Negrundo.

Red Maplc. Acer Rubrum.

Black Milule. Acer Saccharinum.

$\left.\begin{array}{l}\text { White Becch. } \\ \text { Red Beech. }\end{array}\right\}$ Fagus Sylvatica.

White Ash. Fraxinus Excelsior.

Black Ash. Iraximus Americana.

White Birch. Betula Alba.

Black Birch. Betula Nigra.

Red or Yellow Birch. Betula Lenta.

Alder. Betula Almus.

White Elm. $\}$ Ulmus Americana.

Red Elm.

Hlack Oak. Quiercus Nigra.

White Oak. Quercus Alba.

Red Oak. Quercus Rubra.

Chesnut Oak. : Quercus Prinus.

White Hiccory, or Walnut. Juglans Alba.

Shagbark. Juglans Alba, cortice squamosa,

Butternut. Juglans Alba, cortice cathartico.

Chesnut. Fugus Castinea.

Buttonwood. Plantainus Occidentalis.

Basswood, or lime trec. Tilic Anericana.

Hornbeam. Carpinus Betulus.

Wild Cherry, several species.

Sassafras. Laurus Sassafras.

White Cedar. Thuja Occidentalis.

Red Cedar. Junip̧erus Virginiana

Cho

Part

Pig

Bar

$\mathrm{Mu}$

Blac

Fox

Bla

Rec

$\mathbf{U}_{\mathrm{pl}}$

Ru

Bra 


\section{HISTORY UF VERMONT.}

White Poplar, or Aspen. Populus Tremula.

Blick Pophar, or Balsam. Populus Nigra.

Red Willow. Salix.

White Willow. Salix Alba.

Hackmatack.

\section{ESCULENT.}

THE following are small Tiees, Shrubs or Vines, zaluable on account of their salubrious and pleasant liruit.

Red Piumb.

Ycllow Plumb. $\{$ Pruntus Sylvestris.

Thorn Plumb.

Pllack Cherry.

$\left.\begin{array}{l}\text { Red Cherry. } \\ \text { Chole Cherry. }\end{array}\right\}$ Cerasus a'ylvestris.

Juniper. Juniperus Sabina.

Hazienut. Corylus Avellana.

Black Currant. Ribes Nigrum.

Wild Gooseberry. Ribes Gilosularia.

Whortlcberry.

Bilberry.

Biuebcrry

Chokeberry,

Vuccinium Corymbosum.

Partridgeberry. Arbutus Viridls.

Pigeonberry. Cissus.

Barberry. Berberis Vulgaris.

Mulberry. Morus Nigra.

Black Grape. Vitis Labrusca.

Fox Grape. Vitis Vulpina.

Black Raspberry. Rubus Idaus.

Red Raspberry. Rubus Canadensis.

Upright Blackberry. Rubus Fruticosus.

Running Blackberry. Rubus Moluccanus.

Brambleberry. Rubus Occidentalis. 
$\left.\begin{array}{l}\text { Cranberry. } \\ \text { Bush Cranberry. }\end{array}\right\}$ Vaccinium oxycoccos.

Strawberry. Fragaria Vesca.

Dewberry. Rubus Cesius.

Cloudberry. Rubus Chamamorus.

THESE fruits are in great abundance in the uncultivated parts of the country; but they secm to arrive to their highest perfection of numbers, magnitude and richness, in the new fields and plantations. There are other vegetables which are also esculent, and valuable, chief. ly on account of their roots or seeds. Among these are the

Artichoke. Helianthus Tuberosus.

Ground nut. Glicine Apios.

Long Pótatoe. $\}$ Convolvulas Batatas.

Wild Leek.

Wild Onion.

Wild Oat. Zizania Aquatica.

Wild Pea.

Wild Hop. Humulus Lupulus.

Indian Cucumber. Medeola.

\section{MEDICINAL.}

Many of the vegetables which are indigenous to this part of America, are applied to Medicinal purposes. Of this nature are the

Bitter Sweet. Solanum.

Angelica. Angelica Sylvestris.

Black Elder. Sambucus Nigra.

Red Elder. Viburnum Opulus.

Sarsaparilla. Aralia.

Pettymorrel. Aralia Nigra. 
Solomon's Seal. Convallaria.

Maiden Hair. Adicnthus Pedatus.

Arsmart. Polygonum Sagittatum.

Wild Rose. Rosa Sylvestris.

Golden Thread. Nigella.

the

Mallow. Malva Rotundifolia.

Marshmallow. Althaa.

Lobelia, several species.

Senna. Cassia Ligustrina.

Clivers. Gallium Spurium.

Blue Flag. Iris.

Sweet Flag. Acorus.

Skunk Cabbag.. Arum Americanum.

Garget. Phytolacca Decandra.

Blood Root. Sanguinaria.

Pond Lily. Nymphara.

Elccampane. Inula.

Black Snake Root. Actea Racemosa.

Seneca Snake Root. Polygala Senega.

Pleurisy Root. Asclepias Decumbens.

Liquorish Root.

Dragon Root. Arum.

Ginseng. Panax Trifolium.

Ginseng was formerly esteemed a plant in. digenous only to China and Tartary. In 1720, it was discovered by the Jesuit Lafitan, in the forests of Canada ; and in 1750, it was found in the western rats of New England. It grows in great plenty and perfection, in Vermont. The root has many virtues; but we do not find them to be so extraordinary, as the Chinese have represented. It was a valuable article in the commerce of Canada in the year 1752, and large quantities were purchased in this state but vol. $x$. L 
a few ycars ago; an injudicious method of col. lecting, curing and packing it, has greatly injured its reputation; this, with the large quantities in which it was exported, have nearly de. stroyed the sale.

To this account of medicinal plants, it may not be improper to subjoin those, which in their natural state, are found to operate as poisons: the most of which, by proper preparations, become valuable medicines. Of these we have the

Thorn Apple. Datura Stramonium.

Henbane. Hyoscyamus Niger.

Nightshade. Solanum Nigrum.

Ivy. Hedera Helix.

Croping Ivy. Rluus Ralicans.

Swamp Sumach. Rhus Toxicodendrum.

Baneberry. Actea Spicato.

White Hellebore. Voratrum Album.

$I_{N}$ addition to these, there is a great variety of plants and flowers, the names and virtues of which, are unknown. Some of our vegetables descrve a particular description, on account of their uncommon properties: Thus, the Bayberry (myrica cerifera) is distinguished by a fine perfume, and a delicate green wax. The Prickly $A$ sh is valuable for its uncommon aromatic properties. The Witch Hazel (hamamelis) is endowed with the singular property of putting forth its blossoms, after the frost has destroyed its leaves. 'The Indian Hemp (asclepias) may be wrought into a fine, and strong thread. 'The Silk Grass another species of the asclepiars, contains a fine soft down, which may be carded and spun into an excellent wickyarn. 'The ber.

ries of

great in sev useful botani and sc getabl most the $w$ canno ance To I shal numb and $e$ M tree $v$ tree, dime ones They has I the $q$ mos 
ries of the common Sumach (rhus) are used to great advantage in medicinal applications, and in several kinds of dyes. It would be a very useful, but a laborious employment, for the botanists to give to the world an enumeration, and scientific description of our indigenous vegetables. The Flora Americana, would be the most valuable addition, that could be made to the works of the celebrated Linnaus: But it cannot be completed without the united assistance of wealth, genius, time and labour.

To this imperfect catalogue of our vegetables, I shall add some remarks on the magnitude, number, age, evaporation, emission of air, heat, and effect of the trees.

Magnitude. The magnitude to which a tree will arrive, depends upon the nature of the tree, and of the soid. The following are the dimensions of such trees as are esteemed large ones of their kind, in this part of America. They do not denote the greatest, which nature has produced of their particular species, * but the greatest of those which are to be found in most of our towns.

\begin{tabular}{|c|c|c|}
\hline Trees. & Diameter. & Height. \\
\hline $\begin{array}{l}\text { Pine, } \\
\text { Maple, } \\
\text { Buttonwood, } \\
\text { Elm, } \\
\text { Hemlock, } \\
\text { Oak, } \\
\text { Basswood, } \\
\text { Ash, } \\
\text { Birch, }\end{array}$ & $\begin{array}{cc}\text { Feet. } & \text { lnch. } \\
6 & 0 \\
5 & 9 \\
5 & 6 \\
5 & 0 \\
4 & 9 \\
4 & 0 \\
4 & 0 \\
4 & 0 \\
3 & 0\end{array}$ & 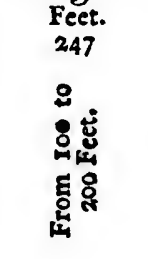 \\
\hline
\end{tabular}

- A white Pine was cut at Dunstable in Newhampshire, in I736, the diameter of which was seven feet, eight inches. 
NumBer. The number or thickness of the trees, seems to depend chiefly on the richness of the soil. In some parts of the country they are so thick, that it is with difficulty we can ride among them. In other places, they have resolved themselves into trees of large dimensions, which are generally at the distance of eight or ten feet from each other. On one acre, the number of the trees, is commonly from one hundred and fifty to six hundred and fifty; varying in their number, according to the richness of the soil, and the dimensions the trees have attained. Estimating a cord to be four feet in height, and width, and eight feet in length, the quantity of wood which is generally found on one acre, is from fifty to two hundred cords ; where the large pines abound, the quantity of wood is much larger than what is here stated; but these trees are never measured as cord wood, but always applied to other purposes.

AGE. There is a circumstance attending the growth of trees, which scrves to denote their age, with great accuracy. 'The body of a tree does not increase by an universal expansion of all its internal parts, but by additional coats of new wood : And these are formed evcry year, by the sap which runs between the bark, and the old wood. When a trce is cut down, this process of nature becomes apparent in the number of parallel circles, or concentric rings, which spread from the centre to the circumference of the tree. In many observations made by oth. ers, and by myself, upon trees whose ages were known, the number of these circles was found to agree exactly with the age of the tree. By

this $\mathrm{m}$

the pir forest, hundre age.

general I am sin Hubbar has mad has alw tree of some of one tho the pine In the $n$ this me decays which a the mo and thu the sam the pros lowing been of state of its age time of nearly vegetal has att: heart.

Ev are oth getable their e 
this method of computation, I have found the pine to be the most aged tree of our forest, several of which were between three hundred and fifty and four hundred years of age. The largest trees of other species, are generally between two and three hundred years. I am since informed by James Whelpley, Esq. of Hubbardton that this is not correct; that he has made many observations of this kind, and has always found the Oak to be the most aged tree of the forest. By their rings or circles some of these trees appeared to him to be more than one thousand years of age ; and that some of the pines were of more than 600 years growth. In the more advanced periods of vegetable life, this method of computation often fails : The decays of nature generally begin in the central, which are the most aged parts. From them, the mortification gradually extends to others; and thus, the internal parts of the tree, die in the same order in which they were produced; the progress of death, regularly and steadily following the same order and course, which had been observed in the progress of life. In this state of a tree, no computation can be made of its age : But it seems most probable, that the time of its natural increase and decrease, are nearly the same ; and that the natural period of vegetable life, is double to that, which the tree has attained, when it first begins to decay at the heart.

Evaporation. Besides the growth, there are other processes carried on by nature in vegetables, of which we have no suspicion, until their effects become apparent. This is the case 
with the evaporation which takes place from the woods, during the summer months. Every tree, plant and vegetable, is then pouring into the atmosphere, an amazing quantity of fluid. On the 12th of June, 1789, I put the end of one of the limbs of a small maple tree, into a bottle containing about one pint. That part of the limb which was within the bottle, contained two leaves, and anc or two buds. 'The mouth of the bottle was stopped with beeswax, that no vapour might escape. In five or six minutes, the inside of the bottle was clouded, with a very fine vapour; and in about half an hour, small drops began to collect on the sides, and run down to the bottom. At the end of six hours, I weighed the water which had been collected in the bottle during that time, and found it amounted to sixteen grains, troy weight. The tree on which this experiment was made, was eight inches and an half in diameter, and thirty feet in height. To make an estimate of thc quantity of water, thrown off from this tree into the atmosphere, in a given portion of time, I endeavoured to ascertain the number of leaves which it contained. With this view (after I had made some other experiments) I had the tree cut down ; and was at the pains to count thic leaves, which it contained : the whole number amounted to twenty one thousand one hundred and ninety two : Admitting the evaporation to be the same from the other leaves of the tree, as it was from those on which the experiment was made, the quantity of water thrown off from this tree in the space of twelve hours, would be three hundred and thirty nine thouwhich is in this pint of $\mathrm{v}$ seren tho such pint culation that from trees, thre five gallor ed in the hours.

'This zant to th of juice, our trees, $A$ man $m$ found tha the mapl seven gall birch whi rate of fiv eight or $n$ the rate of hour ; an charge col 
n the very into fluid. fone bottle of the d two th of at no xutes, 1 very small run lours, lected it aThe , was thirty of the e into me, I leaves fter I d thic count numhunporaof the periarown hours, thou-

sand and seventy two grains. Upon examining the number and dimensions of the trees, which covered the ground where I made the experiment, I think it would be a moderate computation, to estimate them as equal both in magnitude and extent, on every square rod, to four such trees as that which I had examined. This will give six hundred and forty such trees, for the quantity of wood contained on one acre. This estimation is less than the quantity of wood, which is generally found upon one acre of land in this part of America. The weight of one pint of water, is one pound avoirdupoise, or seven thousand giains, troy weight; and eight such pints make one gallon. Making the calculation upon these principles, it will be found that from one acre of land thus covered with tiees, three thousand eight hundred and seventy five gallons of water are thrown off and dispersed in the atmosphere, in the space of twelve hours.

'TH is computation, will not appear extravagant to those, who have seen the great quantity of juice, which naturally flows out of some of our trees, when they are tapped in the spring. A man much employed in maling maple sugar, found that for twenty one days together, one of the maple trees which he tended, discharged seven gallons and an half each day. A large birch which was tapped in the spring, ran at the rate of five gallons an hour, when first tapped; eight or nine days after, it was found to run at the rate of about two gallons and an half per hour; and at the end of fifteen days, the dis. charge continued in nearly the same quantity. 
The sap continued to run four or five weeks, and from the remarks which were made, it was the opinion of the observer, that it must have yielded as much as sixty barrels.

The consequence of this waste of the juices was the death of the tree, the ensuing summer. I have this account from the Hon. Paul Brig. ham, Esq. These accounts serve to show, what a quantity of fluid, is naturally contained in some of our trees; and from a source so plentiful, a copious cvaporation might naturaily be expected.

Limision of Air. Another curious ope. ration, which nature carries on in vegetables, of the highest use, but wholly invisible to us, is the emission of a large quantity of air. The tress, vegetables and fiowers, while they are discharging a large quantity of water into the atmosphere, are, at the same time emitting or throwing off a much larger quantity of air. On the 15 th of June, 1789 , I put the same part of the maple trec into a bottle, as I had done in the experiment of June 12th. The bottle, with the limb of the maple thus enclosed, was then filled up with water; and immersed ii a large drinking giass, which had been filled before: In this situation the bottle was inverted, and fixed so as to have its mouth about three inches under the surface of the water, in the drinking glass. In fifteen minutes, air bubbles began to appear around the leaves of the maple ; and soon after to ascend to the upper part of the bottle, and collect into large bubbles ; which, as they increased, resolved themselves into one. At the end of six hours, I found the quantity of water which had been forced out of the bottle,

by the to sixty fore, es from th of wates ty one the sam teen tho gallons, twelve 1 ered wit this air $i$ It has b times as air of th mospher tion of a of bodie: ways, th so greatl. soon bec inhabitan Nature purpose, new cour bles perp and in th from one wanted.

HEA $\mathrm{T}$. rations an the great ferent ve heat, or greatest

vor. I 


\section{HISTORY OF VERMONT.}

by the air which was collected in it, amounted

eeks, it was have

juices niner. Brig. , what isome iful, a ected. 5 opeles, of us, is

The re disthe atting or r. On part of one in e, with is then a large efore : d, and inches rinking egan to ; and of the which, to one. ntity of bottle, to sixty one grains. The quantity of air therefore, estimated by its bulk, which was emitted from the limb of the tree, was to the quantity of water thrown off from the same limb, as six. ty one to sixteen. Making the calculation in the same manner as before, this will give fourteen thousand seven hundred and seventy four gallons, as the quantity of air, thrown off in twelve hours, from one acre of land, thus covered with trees. The purity and salubrity of this air is as remarkable as the quantity of it. It has been found that an animal will live five times as long in this kind of air, as in common air of the best quality. The purity of the atmosphere, is constantly impaircd by the respiration of animals, by combustion, the putrefaction of bodies, and by various other cau es. In such ways, the air over large and populous cities, is so greatly and constantly ccr upted, that it wou'd soon become unwholesome and noxious to the inhabitants, if it was not removed, or purified. Nature has made abundant provision for this purpose, in the immense quantities of air, which new countries supply. The trees and vegetables perpetually produce it, in large quantities, and in the purest state; and the winds carry it from one country to another, where it is most wanted.

HEAT. The principle by which these operations are carried on, and which seems to have the greatest effect in vegetation, is heat. 'Dif. ferent vegetables require different degrees of heat, or different climates, to give them their greatest degree of increase; and perfection. VOL. I. M 
All of them cease to grow, when their roots are. in a statc of congelation." As soon as the warmth of the spring comes on, the sap begins to ascend in their trunks, and branches : A fermen. tation takes place in all their juices, and the ve. getation becomes more or less rapid, as the heat of the season advances. In Vermont, about the tenth of May, the Maple, which is one of the most numerous and forward trees of the forest, begins to put forth its leaves. In one or two days after, the whole body of the woods, appear of a beautiful light green ; and are constantly growing of a darker colour, for ten or fifteen days, when the darkest shades become fixed: During this period; the juices of the trees appear to be in a state of high fermenta. tion, thcir internal heat increases, and the effects of their vegetation appear in an infinite variety of buds, leaves and flowers. To ascertain the degrees of heat, in different trees, at different times of the year, and to mark their effects on the leaves, and fruits, the following experiments were made. With an auger, of one inch diameter, I bored an hole twelve inches long, into the body of the tree : In this hole, I enclosed a thermometer of Farenheit's scale, stopping the orifice with a cork, until the quicksilver hai acquired the degree of heat, which prevailed in the internal part of the tree. 'The result of these experiments, is set down in the following table. that th same: is a he probal in $\sin$ degree the $\mathrm{fc}$ vegeta the sat ferent not, c: in diff in tree by wh 


\section{HISTORY OF VERMONT.}

s are rmth o as. men. e ve. 5 the it, a. $s$ one of the one bods, con. r fifcome the cntaffects uriety $n$ the erent s on rents diinto sed a of the haui ed in It of wing

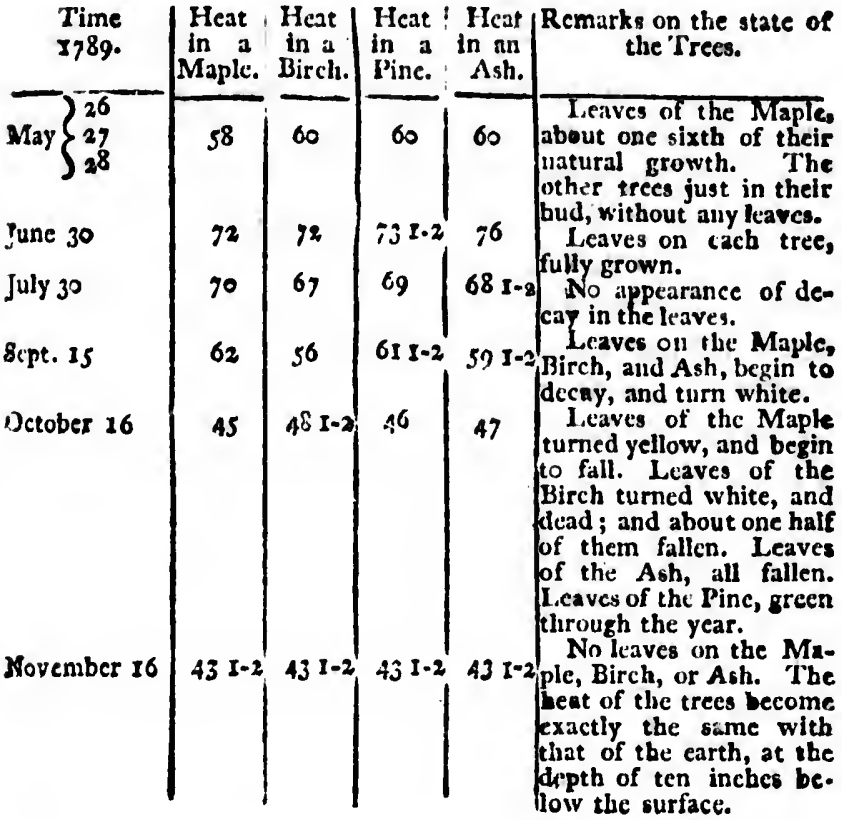

From these observations it should secm, that the temperature or heat of trecs, is not the same as that of the earth, or atmosphere ; but is a heat, peculiar to this class of bodies. It is probably the same, in all trees of the same kind, in similar circumstances and situations. The degree and variations of it, seem to depend on the fermentation of the juices, and the state of vegetation. It is not improbable the heat of the same kind of trees, may be different, in different latitudes: Whether this is the case or not, can be known only by observations, made in different countries. This heat which prevails in trees, seems to be the great principle or agent, by which the two fluids of water and air, are 
separated from one another, and emitted from the trees. The quantity of water evaporated from the trees on one acre, in twelve lours, we have found to be three thousand eight hundred and seventy five gallons : That of air, fourteen thousand seven hundred and seventy four gal. lons. Before the evaporation, both these fluids seem to have existed together in a fixed state; making a common mass, every where dispersed through the body, limbs, and leaves of the trees. When the heat of the internal parts of the trees, became from fifty eight to sixty degrees of Far. enheit's thermometer, the buds were formed, the leaves put forth, and the one fluid, seems to have been separated, or formed into the two fluids, of water and air. It seems probable from this, that both these fluids had the same oriegin, that heat was the principle, or cause by which they were separated ; and that about fifty eight, is the degree of heat, which is necessary to be. gin the scparation of the air from the water.

EFfEcr. The effect of this perpetual vegetation, growth, and decay of vegetables, is an extreme richness and fertility of soil. Neither destroyed or removed by the hand of man, the vegetable productions of the uncultivated parts of America, return to the earth by decay and death, and corrupt on the surface from which they grew. It is not only from the earth, but from the air and water, that trees and plants de. rive their nourishment, and increase : And where no waste has been occasioned by man or other animals, it is not impossible that the vegetables may return more to the earth, than they have taken from it and instead of serving to im. 
poverish, operate to render it more rich and fer. tile. 'Thus does the soil, in the uncultivated parts of the country, from age to age derive increase, richness and fertility, from the life, growth, death and corruption of her vegetables. This effect has been so great in America, that when our lands are first cleared of the wood, we always find a black, soft, rich soil, of five or six inches depth; wholly formed of decayed or rotten leaves, plants, and trees. The extreme richness of this factitious soil, produces a luxuriancy of vegetation, and an abundance of increase in the first crops, which exceeds any thing that can afterwards be procured, by all the improvements of agriculture.

Powers of Vegetable Life. The power with which nature acts in the productions of vegetable life, in this part of America, may be deduced from such circumstances as have been mentioned : From the immense extent of our forests ; from the magnitude, number, and variety of our trecs, and plants; from their rapid increase, and duration ; and from the total want of sandy deserts, and barren places. 'These and other circumstances, denote an energy, a power in the vegetable life, which nature has never exceeded in the same climate, in any other part of the globe. 


\section{CHAP'TER VI.}

Natrve Animals. An account of the Quadrupeds; with Observations on their Linumeration, Origin, Migration, Species, Magnitude, Disposition, and multiplying Power. The Birds, Fishes, Reptiles and Insects.

THE uncultivated state of America was favourable to the productions of animal life. A soil naturally rich and fertile, and powers of ve. getation extremely vigorous, produced those immense forests, which spread over the continent. In these, a great variety and number of animals had their residence. Fed by the hand and productions of nature, unmolested but by a few and unarmed men, the productions of animal life every where appeared, in the various forms of quadrupeds, birds, fishes, and insects ; and their increase and multiplication, became quick and rapid.

\section{RUADRUPEDS.}

OF that species of animals which are known by the name of quadrupeds, America contains nearly one half : Of these about thirty six, are found in Vernont. Otrr forests afford shelter and nourishment for the moose, bear, wolf, deer, fox, wild cat, racoon, porcupine, woodchuck, skunk, martin, hare, rabbit, weasel, ermine, squirrel, mole, and mouse. In our rivers, ponds, and lakes, the beaver, muskrat, mink, and otter, are to be found in large numbers. 
'T' $\mathrm{e}$ largest animal which is known in Vermont is the Moosc. It scems to be of the satne specics as the Elk ; and in its general form, it re. sembles the horse. His head is large, the neck short ; with a thick, short, and upright mane, the eyes are small, the ears are a foot long, very broad, and thick ; uncler the throat, there is a fleshy protuberance; the nostrils are large ; the upper lip square, and hangs over the lower. His horns are palmated, and when fully grown are about four or five feet from the heal to the extremity : 'There are several shoots or branchcs to each horn, which grencrally extend about six fect in width from each other. The horns weigh from thirty to fifty pounds, aurl are shed every year. The hoofs of the Moose are cloven; his gait, is a lorig shambling trot; his course, very swift, and straight. When he runs, the ratling of his hoofs, is heard at a considerable distance ; in miry places, his hoofs are sprend several inches from one another; and it is with the greatest ease, that he leaps over the highest of our fences. The Monse is generally of $\mathbf{a}$ grey, light brown, or mouse colour. The food of this animal is grass, shrubs, the boughs and bark of trees, especially the becch, which they seem to prefer above all others, and a specics of maple which is called moose wood. In sumi-. mer, they keep pretty much in families. In the winter, thicy herd together to the number of twenty or thirty, in a company : They prefer the coldest places; and when the snow is deep. they form a kind of yard; consisting of several acres, in which they constantly trample down the snow, that they may morc easily range 
round their yard; and when they cannot come at the grass, they live on the twigs and bark of the trces. Their defence is chiefly with their fore feet, with which they strike with great force. The female is less than the male, and gencrally without horns. The rutting season is in autumn : The female generally brings forth two at a birth, in the mointh of April, which follow the dam a whole year. One of these animals in Vermont, was found by measure, to be seven feet high. The largest, are estimated by the hunters, to weigh thirteen or fourteen hundred pounds.

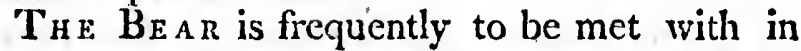
this part of America, and is always of a black colour. It is not an animal of the nost fierce, and carnivorous disposition. There have been instances, in which children have been devoured by the bear ; but it is only when it is much irritated, or suffering. with hunger, that it makes any attack upon the human race. At other times, it will destroy swine and young cattle, but has not been known to make any attack up. on men ; but always aims to avoid their pursuit. The food of this animal is corn, sweet apples, acorns, and nuts. In the end of autumn, the bear is generally very fat, and chooses for the place of his retreat the hollow of a rotten tree, or some natural den, or cavern in the earth. In sutch a situation he uses no exercise, appears to be asleep, loses but little by respiration, and is always found without any provision; and it is not until the warmth of the spring returns, that he leaves his retreat, or goes abroad in quest of food. This animal is valuable for its flesh, 
grease, and skin. The female generally bears two cubs a year. The bear arrives to a great magnitude in this part of the continent. The largest, of which the hunters give us any cer. tain information, weighed four hundred and fifty six pounds.

$\mathrm{ONE}_{\mathrm{N}}$ of the most common and noxious of all our animals, is the WOLF. In the form of his -body, the wolf much resembles the dog. He has a long head, a pointed nose, sharp and erect cars, a short and thick neck, with sharp and strong teeth. His eyes generally appear sparkling ; and there is a mildness, and a fierceness in his looks. The colour of the wolf in Vermont, is a clirty grey ; with some tinges of yellow about his ears, and legs. 'This animal is extremely fierce, sanguinary, and carnivorous. When a number of them associate, it is not for peace, but for war and destruction. The animal at which they most of all aim, is the sheep. When they can find a flock of these, they seem to delight in slaughter; teafing their flesh, and sucking their blood, after they are fully sitisfied with the fat of their tender parts. They attack the deer, foxes, rablits, and are enemies to all other animals; and their attacks are generally attended with the most horrid hoivlings. They generally flee beiore the face of the hunter; but when they have once tasted of human flesh, they become more fierce, and daring, and seem to be inflamed with greater fury. In such a state, there have been instances in Vermont, in which the wolves have ventured to make their attacks upon men; bit they generally retire upon their approach. They are not often to be seen in tho VOL. I. N 
day, but in the night venture into our yards, and barns. 'These animals are yet in great numbers, in this state; they destroy many of our sheep, in the night ; and find a safe retreat in our woods, and mountains ; but are gradually decreasing; as our settlements increase, and extend. 'The wolf is a very prolific animal. The female is in season in the winter, but the male and female never pair. 'The time of gestation, is about three months and an half ; and the young whelps are found from the beginning of May, until the month of July. The hunters have sometines found in their dens, a male, a female, and a litter of nine young whelps. One of the largest wolves in Vermont, weighed ninéty two pounds. 'There is nothing valuable in these animals but their skins, which afford a warm and clurable fur.

The DeER is one of our nost common and valuable animals. In the spring he sheds his bair, and appears of a light red; this colour gradually grows darker until autumn, when it becomes a pale, or cinerous brown; and remains thus through the winter. His horns are slender, round, projecting forwards, and bent into a curve ; with branches or shoots on the interior side. 'These branches do not commence, until the decr is three years old ; from which period, a new one rises every year; and by this circumstance, the hunters cornpute their aye. Thesc horns are cast every spring; the new ones, in the course of a year, will grow two feet in length, and weigh from two to four pounds. The amorous season with these animals, is in the month of September. From

Sept

to se

the $\mathrm{d}$

forth

the 1

two,

fawn

whit

gent

unim

are :

cst 1

of 1

thre

num

flesh

deer

nent

the

horn

this

ed,

are

than

cies

of $t$

bee

I

mel

this

foul

']

rath

con

fou

mal 
September to March, the bucks and does herd to ether; carly in the spring they separate, and the does secrete themsclves in order to bring: forth their young; which generally happens in the month of April. The female generally bears two, and sometimes three, at a birth. The fawns are red, most beautifully spotted with white. 'They are easily' tamed, and become as gentle and domestic as a calf. 'The deer is an unimal of great mildness, and' activity. They are always in motion; and leap over our high. cst fences, with the greatest ease. The largest of which I have a particular account, weighed three hundred and cight pounds. The deer are numerous in Vermont; and on account of their flesh and skin, are of much value. The reindeer is not to be found in this part of the continent. But there seems to be another species of the American deer, distinguished chiefly by its horns, and often by its colour. The horns of this deer are never extensive, broad, and branch. ed, like those of the common deer : But they are round, thick, but little curved, and not more than ten or twelve inches in length. This species is generally larger than the other: Several of then have large white spots, and some have been killed which were wholly white

$T_{H E}$ Fox abounds much in this part of $\mathbf{A}$. merica. The form, disposition, and habits of this animal, are every where known. IVe have four kinds of foxes in Vermont.

Tн $\mathrm{R}$ Red fox hears upon a yellowish, or rather a straw colour. 'This is esteemed the common fox, and is the most frequently to be found. At its full growth in tlic fall, this animal weighs twenty pounds. 


\section{NATURAL AND CIVIL}

Th е Grey Fox resembles the other in form, and magnitude, and appears to differ from it only in colour, which is of a beatutiful silver grey.

The C'ross f'ox resembles the other in form, and magnitude ; but has a black streak, passing transversely from shoulder to shoulder; with another along the back, to the tail. The other parts of this ainimal are of a red, or more gener. ally of a rrey colour.

TH Е Black Fox is the largest, and most val. uable of all. The fur of this fox is the nost finc, soft, and rich, of any. One of the largest of the black foxes, was found to weigh twenty three pounds.

The Fox is a very voracious animal ; de. vouring all kinds of poultry, birds, and animals, which they can ovcrcome. Flcsh, fruit, honcy, and every part of the firmer's clairy are cicroured by him with great avidity. 'This aninzal is very prolific. The female is in" scason every year, in the winter; and generally preduccs in the month of April ; the litter is gencrally from three to six.

The Catamount, seems to be the same animal, which the ancients called Lynx, and which is known in Siberia, by the name of Ounce. In the form of its body it much resembles the common cat, but is of a much larger size. It is gencrally of a yellow grey colour, bordering upon'a red or sandy ; and is larger than our largest dogs, This seems to be the most fierce and ravenous of any animal, which we have in Vermont. Some years ago, nne of these animals was killed at Bennington. It took a large calf out of a pen, where the fence

was fou back. rocks, in heig: high th them in the gro the me ribs, b: leaped ncss, : hin the but w mals h they ne taken. iniorm activit ters es our an estima The 1 of the body were W mal, i cats ; mensi fiercel secms as th found $\mathrm{T}_{\mathrm{r}}$ tingu 


\section{HISTORY OF VERMONT. $10 \$$}

mas four fect high, and carried it off upon its back. With this load, it ascended a ledge of rocks, where one of the leaps, was fifteen feet in height. Tivo hunters found the cat upon an high tree. Discharging his musket, one of them wounded it in the leg. It descended with the greatest agility, and fury; dicl not. attack the men, but seized their dog by one of his ribs, broke it off in the midcile, and instantly leaped up the tice again with astonishing swift. ness, and dexterity. The other hunter shot hin through the head, but his fury did not cease, but with the last remains of life. These animals hare been ofie; secn in Vermont; but they nerer vere very numerous, or easily to be taken. Of their fecindity, I have no particular inimmation. On account of their ficrceness, activity, and carnivorous disposition, the hunters esteem them the most dangerous of any of our animals. 'The weight of one of them, was estimited by the hunter, at one hundred pounds. The length of his body was about six feet, that of the tail, three; the circumference of the body was two feet and an half, and the legs were about thirteen inches long.

WHAT is called the $W_{I L D} C_{A T}$, is an animal, in most respects similar to our common cats ; but different in its disposition, and dimensions. It is much larger, stronger, and fiercer, than any of our domestic cats; and seems to be of the same disposition, and colour, as the wolf. One of the largest of them was found by the hunter, to weigh fifty seven pounds.

The $B_{L A C K} C_{A T}$ does not appear to be distinguished from the former, in any other respect 
than its colour. It is altogether black, and seldom grows to so large a size, as the former. It seems to be of a distinct species; is as fierce and ravenous as the other kind. These animals are frequently found in the woods; very wild, cetremcly fierce in combat, of grcat activity and strength; but never can be tanned, or made to associate with our common cats. They are valuable only on account of their furs. 'The biack cat wais called by the Indians, the Wool. leneeg: The largest of which 1 have any account, weighed twenty three pounds.

AN отнER animal which does not greatly dir. fer in appearanec from a wild cat, hats been called the Wolverine. 'The body of this aninal is about two feet and an half in length. It has a short tail, and is of the same collour as the re alf. 'This animal is of a very fierce, and canivorcus disposition. Conccaling himself among the rocks and bushes, or taking a station upon the limb of a tree, he watches for the approach of prey. If the deer, or the moose comcs within his reach, he darts upon their backs, fastens up. on their neck, and with grreat dexterity opens their jugular vein with his tceth. This animal is scarce, and not to be found but in the nor. thern, and most uncultirated parts of the state I have no account of its fecundity, magnitude, or othis particulars.

The Racoon, in its shape or general form, resembles the fox, but has a larger body, with thicker and shorter legs. The fect have five long and slender toes, armed with shirp claws. 'The milles have gencrally a large whitish stripe, and - Semaless a smaller one, which runs across

the for annula retired great: : the bo and of of the It is 0 excell Thi comm most o with bout $\mathrm{f}$ the qu nttacke tween arounc no po them said. Acsh, they a stick any at can tl the $\mathrm{f}$ they to an the $\mathrm{p}$ grey male of $g e$ ally of th 


\section{HISTORY OF VERMONT. 107}

d seler. It fierce iimals wild, $y$ and ide to are

'The,

Woo!

ac.

y dir.

call.

a:l is

has a

$\because$ olf.

reus

ihe in the ch of ithin s up. pens imal nor. tatc ude,

orm, with five aws. ipe, ross

the forchead. The tail is long, and round, with annular stripes in it. This animal dwells in the retired part of the woods, runs up the trees with great agility and ventures to the extremes of the boughs. Its fur is tinick, long, and soft; and of a diurk grcy colour. The weight of one of the largest in Vermont, was thirty two pounds. It is often found in hollow trecs, and its flesh is excellent food.

Tha Porcupine, or Hedgchog, is not uncommon in Vermont. What is singular and most distinguishing in this animal, are the quills with which he is armed. 'These quills are about four inches in length; and of the size of the quills of a pigeon. When the porcupine is nttacked by an enemy, he places lis head between his fore feet, and erects, these quills all around, in the form of an hemisphere. He has no power to eject theth from his body, or clart them against his enemy, as has been firequently said. But they are so loosely inserted in his flesh, and of such a particular construction, that they are easily extracted, and like a barbcd dart stick fast, and work themselves into the flesh of any animal that touches their extremities; nor can they be easily withdrawn, without tearing the flesh, but by incision. On this account they prove extremély dangerous to the dog, or to any other animal that makes an attack upon the porcupine. The colour of this animal, is grey : His motion is extremely slow. The fe. male produces her young every year ; the time of gestation is about forty days, and she generally brings forth thrce or four at a birth. One of the largest of these animals, weighed sixteen 
pounds: The flesh is said to be anreenlic, and wholesome meat.

Another animal, which we frequently find in the ficlds, is the Woonchuck. 'This inimal is about sixteen inches in lerigth ; its body is Iarge, and round ; its leors anc short ; and its fore feet are broad, and fitced lor the purpose of burrowing into the cartl. 'The colour of the woodchuck is brown, his fint is extreme, the 'flesh is wholesome and paliatable food, his fur is not very valuabie. 'This animal resicics in a hole which he digs in the ground, and feeds upon grass, corn, beans, and other vegret:bles. The female generally produces four or live at a birth. One of the fattest which I have: secm, weighed eleven pounds : I belicve this was one of the largest sizc.

The SrUNK is one of the most extraordina. ry animals, of which wc have any account. It seems to be of the same species with the polecat, but is of a less size, and cliffers from it in sevcral respects. It hair is long, and shining, of a clouded or dity white, intermixed with spots of black. Iis tail is long, and bushy, like that of the fox. It lives chicfly in the woods, and hedges, but often burrorss under barns and out houses. When undisturbed, this animal is without any ill scent, or disagreeable eflluvia. Their natural evacuations are not more nauseous, than those of other aninals. Whole nests of them will lie under the floor of a barn, and so long as they are unclisturbed, no disilgrceable odour will be perceived during the whole winter. 'Their flesh, when it is properly dressed, is swect and nourishing. When pursued or attacked,

the sk by a s fence. and in So od scente can lo the sk fects $t$ round tract odious after a remed Dr. $M$ ed flui is con rior $\mathrm{p}$ circul: constr veloci totally produ ly am these half, I can

$\mathrm{T}_{\mathrm{H}}$ clima mont, est $p$ brow colou

*A vo 


\section{HISTORY OF VERMONT. 109}

find imal dy is d its $\mathrm{ssc}$ of it the the uir is

the skunk discovers its extraordinary powers, by a singular and most effectual method of defence. It emits a fluid of the most nauseous and intolerable scent, that has ever been known. So odious, subtle, and penetrating, is this ill scented matter, that there is no animal which can long endure it, or will venture to approach the skunk, when he is throwing it out. It infects the air to the distance of half a mile all around : And no method has been found, to extract the scent out of any object, on which the odious fluid has been thrown. Time and air, after a long period, affords the only complete remedy. By accurate dissection lately made by Dr. Mitchell, it has been found that this ill scented fluid, is entirely distinct from the urine. It is contained in two bags, situated in the posterior parts of the body ; and surrounded by the circular muscles in such a manner, that by their constriction, the fluid is forced out with great velocity and force. The urinary organs are totally distinct from these bags.* The female produces a litter every year ; and they generally amount to five or six in number. One of these animals weighed seven pounds and an half, but whether it was one of the largest size, I cannot determine.

The Martin is an animal, peculiar to cold climates. It is found in large numbers in Ver. mont, but chiefly in the most retired, and thickest parts of the woods. Its colour is a dark brown, with tinges of yellow; sometimes the colour approaches to a black : The fur is fine,

- American Museum, Vol. V.p. 48 ?.

VOL. I.

$\mathrm{O}$ 
soft, and much estcemed. This animal is from eighteen to twenty inches in length. A large one was found to weigh five pounds and one quartcr of a pound. The female produces from three to six young ones, at a litter. The mar. tin and sable denote the same animal in Ver. mont.

THE $H_{\Lambda R E}$ is auout eiginteen inches in longth: It is always of a white colour, and has a fine, and beautiful fur: Its flesh is a very nourishing, and delicious food. This animal is very prolific. The time of gestation is about thirty days : The female bears three or four at a birth, and has several litters in the course of a year. A large hare weighs eight pounds. 'The hun. ters find large numbers of these animals, in this part of the country:

'Гн hare, but in greater numbers. His colour, both in summer and winter, is a light grey, or dirty white. The length of the rabbit, is about six. teen or seventeen inches; ore of the largest of them, weighed seven pounds. The rabbit is more prolific than the liare. The female bears sooner, and has from four to eight, at a litter. These animals are readily found, in every part of the state.

The Weasec has the form and appearance, of a squirrel ; but is more slim, and active. His eyes have an uncommon sprightliness ; his look is keen, and piercing; and his motions are so quick, and various, that the eye can scarcely follow them. This animal is of a red or brown colour, and has a white belly. Its fur is very fine, and soft. His food is corn, nuts, eggs, inches weigh three, aprea ped, dimen the $w$ weig.? tiful $v$ black. dark 1 the ba parts sprigl and $\mathrm{d}$ anim: natur cies ; $\mathrm{T}_{\mathrm{I}}$ comn fourt tail, silve nest food, of th of ol the 


\section{HISTORY OF VERMONT. I ।}

and all kinds of small animals. The weasel is often found in hollow trees, and he frequently enters into houses, barns, and other buildings, in search of grain, chickens, mice, and young animals. In Vermont, the weasel is about twelve inches in length ; very narrow and slim, and weighs about twelve ounces. The female bears three, four, or five, $: a$ a birth ; but they do not appear to be very $\mathrm{t}$ chinerous.

'THE FIRINE is the most beautiful quadruped, which is seen in our woods. In its form, dimensions, activity, and fecundity, it resembles the weasel, but is rather larger ; one of them weighed fourteen ounces. Its colour is a beautiful white : The tail is tipped with a beautiful black. Some of these animals have a stripe of dark brown, or mouse colour, extending along the back, from the head to the tail ; the other parts being perfectly white. 'This little, brisk, sprightly and beautiful animal, has the most fine and delicate fur, that can be imagined ; and the animal itsclf is one of the greatest beauties of nature.

Of the SQuirREL we have four or five species ; grey, black, red, striped, and flying.

$\mathrm{T}_{\mathrm{E}}$ Grey Squirrel is the largest, and most common. This squirrel is about thirteen or fourteen inches in length, with a large bushy tail, as long as the body. It is of a beautiful silver grey colour, and has a fine soft fur. Its nest is in the crotch, or hollow of a tree; its food, corn, acorns, and nuts. It lays up a store of these provisions against winter, in the hollow of old trees. The female bears her young in the spring; and has generally three or four at a 
birth. The largest of these grey squirrels, when they are fully fatted in the fall, weigh three pounds and an half.

$\mathrm{T}_{\text {H }}$ E Black Squirrel resembles the former in every respect, but its colour, and size. It is wholly black, without any change in its colour, at any time of the year. Its size is something less than that of the grey squirrel : the largest I have known, weighed but two pounds and an half.

Th E Red Squirrel does not appear to differ from the black, in any other particular, but the colour.

'I' $\mathrm{H}$ E Striped Squirrel is smaller than either of the other. The largest of these docs not weigh more than nine or ten ounces. This squirrel digs a hole in the ground, for the place of his residence. He provides a store of nuts, acorns, and com, against winter. 'These are carefully deposited in his nest ; and he resides in the earth during the severity of the season.

$\mathrm{T}_{\text {н }}$ Flying Squirrel is the most curious, and beautiful of all ; and of the same size as the striped one : This squirrel has a kind of wings, by which he will pass from one tree to another, at the distance of thirty or forty feet. None of our animals have a more fine or clelicate fur, than this little squirrel. He feeds on the buds, and seeds of vegetables; and generally has his nest in decayed, and rotten trces.

The Mole, Shrew Mouse, Ground Mouse, and Field Mouse, ale to be found in this part of America : they are so small, and well known, that they do not require a particular description. The hunters inform me, that

there

the $y$

The ge now $b$ since, the sta

' 1 'H are to others the lan in the

ON. these, ural co the wo is appl of all c lar des $\mathrm{T}_{\mathrm{H}}$ four $\mathrm{fc}$ sixty clined betwe broad. in the led ir inches ed, lil the $t$ the $p$ feet a purpc an in is co to th: 
rels, eigh

in

It is our, ling gest an

iffer the

ther not his lace uts, are des and the gs, ler, of ur, $\mathrm{ds}$, his

there are several kinds of mice to be found in the yoods, which have not been described. The grey rat, the black rat, and the water rat, have now become common; though but a few years since, they were not to be found in any part of the state.

'lн е quadrupeds which have been described, arc to be found only upon the land. There are others of an amphibions nature, which live upon the land, or in the water; these are to be found in the rivers, ponds, and lakes.

$O_{N E}$ of the most sagacious and useful of these, is the $B E \Lambda \vee F R$. On account of his natural constitution and instincts, his social nature, the works he performs, and the uses to which he is applied, the beaver is the most extraordinary of all our animals, and deserves a more particu. lar description.

$T_{H E}$ Amcrican beaver is between three and four feet in length, and weighs from forty to sixty pounds. His head is like that of a rat, inclined to the earth ; his back rises in an arch' between his head and tail. His teeth are long, broad, strong, and sharp. Four of these, two in the upper, and two in the under jaw, are called incisors. These teeth project one or two inches beyond the jaw, and are sharp, and curved, like a carpenter's gouge. In his fore fect the tocs are separate, as if designed to answer the purposes of fingers and hands : His hind feet are accommodated with webs, suited to the purpose of swimming. His tail is a foot long, an inch thick, and five or six inches broad : It is covered with scales, and with a skin similar to that of fish. 


\section{NATURAL AND CIVIL}

IN no animal does the social instinct and habit appear more strong, or univessal, than in the beaver. Wheresoever a number of these animals are found, they immediately associate, and combine in society, to pursue their common business, and welfare. Every thing is done, by the united counsels, and labours, of the whcle community. Their societics are generally collected together, in the months of June and July; and their numbers when thus collected, frequently amount to two or three hundred; all of which, immediately engage in a joint effort, to promote the common business and safety of the whole society; apparently acting under a common inclination, and direction. When the beaver is found in a solitary state, he appears to be a timid, inactive, and stupid animal. Instead of attempting any important enterprize, he contents himself with digging a hole in the earth for safety and concealment. His genius scems to be depressed, his spirits broken, and cvery thing cnterprizing is lost in an attention to personal safety; but he never looses his natural instinct to find or form a pond.* When combined in society, his disposition, and powers assume their natural direction, and are exerted to the highest advantage : Every thing is then undertaken, which the beaver is capable of performing.

THe society of beavers seems to be regulated and governed, altogether by natural dispositions,

- A young beaver was tamed in the southern part of this state. He became quiet, inoffensive, and without any disposition to depare. But was most of all pleased, when he was at work, forning a dam, in a Gnall stream near the house.

and lav operati mutual under agreem ever se and ag domini regulat activity appear: influen and $m$ perfect perfect tachme to pres regulat cieties

IVH their fi affairs The $\mathrm{b}$ spend anothe law of find a poses. runnir of the be a is alw have and 0 undis 


\section{HISTORY OF VERMONT. 115}

and laws. Their society, in all its pursuits and operations, appcars to be a society of peace and. mutual affection ; guided by one principle, and under the same direction. No contention, disagreement, contrary interests, or pursuits, arc ever seen among them ; but perfect harmony and agreement, prevails through their whole dominions. The principle of this union and regulation, is not the superior strength, art, or activity of any individual : Nothing has the appearance, among them, of the authority, or influence of a chief, or leader. Their association and management, has the aspect of a pure and perfect democracy ; founded on the principle of perfect equality, and the strongest mutual attachment. This principle seems to be surficient to preserve the inost perfect harmony, and to regulate all the proceedings of their largest societies.

WHEN these animals are collected together, their first attention is to the public business and affiirs of the society, to which they belong. The beavers are amphibious animals, and must spend one part of their time in the water, and another upon the land. In conformity to this law of their natures, their first employment is to find a situation, convenient for both these purposes. With this view a lake, a pond, or a running stream of water, is chosen for the scene of their habitation, and future operations. If it be a lake, or a pond that is selected, the watcr is always of such depth, that the beavers may have sufficient room to swim under the ice; and one, of which they can have an entire, and undisturbed possession. If a stream of water is 
chosen, it is always such a stream, as will form a pond, that shall be every way convenient for their purpose. And such is their foresight and comprehension of these circumstances, that they never form an erroneous judgment, or fix upon a situation that will not answer their designs and convenience. Their next business, is to construct a dam. This is always chosen in the most convenient part of the stream; and the form of it, is either direct, circular, or with an. gles, as the situation and circumstances of the water and land, require : And so well chosen is both the place, and the form of these dams, that no engineer could give them a better situation and form, either for convenience, strength, or duration. The materials of which the dams are constructed, are wood, and earth. If there be a tree on the side of the river, which would naturally fall across the stream, several of the beavers set themselves with great diligence, to cut it down with their teeth. Trees to the bigness of twenty inches cliameter, are thus thrown across a stream. They next, gnaw off the branches from the trunk, that the tree may assume alevel position. Others, at the same time, arc cutting down smaller trees, and saplings, from one to ten inches diameter. These are cut into equal and convenient lengths. Some of the beavers drag these pieces of wood to the side of the river, and others swim with them to the place, where the dam is to be built. As many as can find room, are engaged in sinking one end of these stakes ; and as many more in raising, fixing, and securing the other end. While many of the beavers are thus labouring upon 
form nt for it and they upon esigns is to in thit? d the th an. f the hosen Jams, situangth, dams there vould f the ce, to bigrown bransume e, arc from. $t$ inf the de of the nany one raisVhile upon

the wood, others are equally engaged in carrying on the earthern part of the work. The earth is brought in their mouths, formed into a. kind of mortar with their feet and tails, and spread over the vacancies between the stakes. Saplings, and the small branches of trees, are twisted and worked up with the mud and slime, until all the vacancies are filled up; and no crevice is left in any part of the work, for the water to find a passage through. The magnitude and extent of the dams, which the beavers thus construct, is much larger than we should imagine was possible to be effected, by such labourers, or instruments. At the bottom, the dam is from six to twelve feet thick; at the top, it is generally two or three feet in width. In that part of the dam, which is opposed to the current, the stakes are placed obliquely; but on that side where the water is to fall, the stakes are placed in a perpendicular direction ; and the dam assumes the same form, and position, as the stakes. The extent of these works, is from fifty to an hundred feet in length; and always of such an height, as to effect the purposes they have in view. The ponds which are formed by these dams, are of all dimensions; from four or five, to five or six hundred acres. They are generally spread over lands abound. ing with trees, and bushes, of the softest wood: Maple, birch, alder, poplar, willow, \&c. The better to preserve their dains, the beavers always leave sluices, or passages near the middle, for the redundant waters to pass off. These sluices are generally about eighteen inches in width, and depth ; and as many in number, as the waters of the stream generally require.

$$
\text { YOL. I. } \mathbf{P}
$$


$W_{\text {HE N }}$ the public works are completed, their domestic concerns and affairs next engage their attention. The dam is no sooner completed, than the beavers separate into small bodies, to build cabins, or houses for themselves. These houses are built upon piles, alnng the borders of the pond. They are of an oval form, resem. bling the construction of an haycock ; and they vary in their dimensions, from four to ten feet in diameter, according to the number of families they are designed to accommodate. They are always of two stories, generally of three, and sometimes they contair four. Their walls are from two to three feet in thickness, at the bottom ; and are formed of the same materials as their dams. They rise perpendicularly a few feet, then assume a curved form, and terminate in a dome or vault, which answers the pur. pose of a roof. These edifices are built with much solidity, and neatness : On the inward side, they are smooth, but rough on the outside ; always impenetrable to the rain, and of sufficient strength to resist the most impetuous winds. The lower story is about two feet high : the second story has a floor of sticks, covered with mud : the third story is divided from the second, in the same manner, and ter. minated by the roof raised in the form of an arch. Through each floor, there is a communication; and the upper floor is always above the level of the water, when it is raised to its greatest height. Each of these huts have two doors ; one, on the land side, to enable them to go out and procure provisions by land; another under the water, and below where it freezes, to 
preserve their communication with the pond. If this, at any time begins to be covered with ice, the ice is immediately broken, that the communication may not be cut off with the air.

IN these huts, the families of the beavers have their residence. The smallest of their cabins, contain one family, consisting generally of five or six beavers; and the largest of the buildings will contain from twenty to thirty. No society of animals, can ever appear better regulated, or more happy, than the family of beavers. The male and the female, always pair. Their selection is not a matter of chance, or accident ; but appears to be derived from taste, and mutual affection. In September, the happy couple lay up their store of provisions, for winter. This consists of bark, the tender twigs of trees, and various kinds of soft wood. When their provisions are prepared, the season of love and repose commences : And during the winter they remain in their cabins, enjoying the fruits of their labours, and partaking in the sweets of domestic happiness. Towards the end of winter, the females bring forth their young, to the number of three or four. Soon after, the male retires to gather fish, and vegetables, as the spring opens ; but the mother remains at home, to nurse, and rear up the offspring, until they are able to follow their dams. The male occasionally returns, but not to tarry, until the fall of the year. But if any injury is done to their public works, the whole society are soon collected, and join all their forces to repair the injury, which affects their common. wealth, 
Nотн $\mathrm{I}, \mathrm{c}$ can exceed the peace and regularity, which prevails in the families, and through the whole commonweaith of these animals. No discord or contention ever appears in any of their families. Every beaver knows his own apartment, and store house ; and there is no pilfering or robbing from one another. The male and the female are mutually attached to, never prove unfricndly, or desert one another. Their provisions are collected, and expended, without any dissention. Ear.a knows its own fumily, business, and property ; and they are never scen to injure, oppose, or interfere with one another, The same order and tranquility prevail, through the commonwealth. Different societies of beavers, never make war upon one another, or upon any other animals. When they are attacked by their enemies, they instantly plunge into the water, to escape their pursuit : And when they cannot escape, they fall an easy sacrifice.

In the arts necessary for their safety, the beavers rise to great eminence. The situation, direction, form, solidity, beauty, and durability of their dams, are equal to any thing of the kind, which has ever been performed by man. They always form a right judgment, which way the tree will fall : And when it is nearly cut down, they appoint one of their number, to give notice by a stroke of his tail, when it begins to fall. With their tails, they measure the lengths of their dams, of the stakes they are to use, of a breach that is made in their works, and of the length of the timber that is necessary to repair it. When an enemy approaches their domin-

ions, the striking to the w and all And wh country centinel Tне ding to habit. general and the towards all ove is gene it some shorten part is part of down, so soft is used use in the be: lower

$\mathrm{TH}_{\mathrm{H}}$ any $c$ pound tion $r$ quent greate of so south found ted $\mathrm{p}$ 


\section{HISTORY OF VERMONT. 121}

ions, the beaver which makes the discovery, by striking on the water with his tail, gives notice to the whole village of the approaching danger ; and all of them instantly plunge into the water. And when the hunters are passing through their country, some of their number appear to be centinels, to give notice of their approach.

Tн $\mathrm{E}$ colour of the beaver is different, according to the different climates, which they inhabit. In the most northern parts, they are generally black; in Vermont they are brown ; and their colour becomes lighter as we approach towards the south. Their fur is of two sorts, all over their bodies. That which is longest, is generally about an inch long, but on the back, it sometimes extends to two inches, gradually shortening towards the head, and tail. This part is coarse, and of little use. The other part of the fur consists of a very fine and thick down, about three quarters of an inch long, so soft that it feels like silk, and is that, whirh is used in manufactories. Castor, of so much use in redicine, is produced from the body of the beaver. It is contained in four bags, in the lower belly.

THE largest of these animals, of which I have any certain information, weighed sixty three pounds and an half : But it is only in a situation remote from, and undisturbed by the frequent appearances of men, that they attain their greatest magnitude, or their highest perfection of society. The beaver has deserted all the southern parts of Vermont, and is now to be found only in the most northern, and uncultivated parts of the state. 
The MUSkrat seems to be a smaller kind of beaver, resembling it in every thing but its tail. This is also an amphibious animal, and forms a cabin of sticks and mud, in some stag. nant water ; but is less fearful of the approach. es of men, and affords a very strong musk. 'These animals are to be found, in very consid. erable numbers, in our creeks, and lakes ; but are much less numerous, than they were for. merly. The muskrat, in this part of America, is about fifteen inches in length; the greatest magnitude I have known is five pounds and thrce quarters of a pound. A litter of these muskrats, will frequently amount to four, five, and sometimes six.

AN OTHER of our amphibious animals, is the MxNk. It always resides in the neighborhood of rivers, ponds, or lakes ; and provides a place of residence, by burrowing into the earth. The mink is about twenty inches in length; his legs are short, his colour brown, and his fur is more valuable than that of the muskrat. One of the largest which I have known, weigled four pounds and one quarter of a pound. The female produces two or three, at a birth.

THE OTTER is a voracious animal, of great activity and fierceness. When it is fully grown, it is five or six feet long; with sharp and strong teeth; short legs, and membranes in all his feet ; and fitted either for running or swimming. The otter explores the rivers and ponds in search of fish, frogs, water rats, and other small animals : And when these are not to be had, he lives on the boughs and bark of young, or aquatic trees. He has generally been ranked fiercene: that the when th hunter $\mathrm{mal}$ is The ott creeks, which plain : the nam become have a I pounds

To $t$ mont, I general The counts part of perfect tled als trated rivers. littlek in $\mathrm{N}$. the $w$ is no gions: 
er kind but its hal, and pe stag. proach. musk. consid. ; but re for. merica, reatest is and these , five,

is the orhood i place The is legs more of the four le fe.

great

own, rong his ling. arch ani. , he or ked among the amphibious animals, which can live either in the air, or water; but he is not properly an amphibious animal, for he cannot live without respiration, any more than the land animals. The female is in heat in the winter, and bears her young in the :. unth of March; the litter generally consists of three or four. The fierceness and strength of the old otters, is such, that the dog can scldom overcome them : And when they cannot escape, they will attack the hunter with great rage. The colour of this animal is black, and its fur is much esteemed. The otter formerly abounded very much in our creeks, and rivers ; and especially in those, which empty themselves into Lake Champlain : On this account, one of them still bears the name of Ottercreek; but the animal is now become scarce. The largest otter, of which I have a particular account, weighed twenty nine pounds and an half.

To this account of the quadrupeds of Vermont, I shall subjoin some reflections on the general state of these animals in America.

The enumeration very imperfect. Our accounts of the quadrupeds in this, and in every part of America, must be viewed as greatly imperfect. The descendants of Europe have settled along the sea coasts, and they have penetrated to the lakes, and most of the navigable rivers. But the internal parts of S. America, are but littleknown: Andall that immense tract of country in N. America, which lies to the north, and to the west of the lakes, is wholly unexplored. It is not to be doubted, but these extensive regions, abound with quadrupeds: Of what spe- 
cies, and how numerous, we cannot so much as conjecture. When the country shall be fully explored, and when able naturalists shall have visited and examined the internal parts, the his. tory of the animals of America, may be brought to some perfection ; but it is far from it, at present. All the animals which have been enlu. merated; are only those which are frequently found, in a small part of the continent. 'That an animal of grcat and uncommon magnitude, has existed in North America, and in Siberia, is certain from the bones of the animal which yet remain. On the banks of the Ohio, and in many places further north, tusks, grinders, and skeletons, of an enormous size, are to be found in great numbers. Some of them lie upon the surface of the ground, and others are five or six feet below it. Some of the tusks are near seven feet long, one foot and nine inches at the base, and one foot near the point; the cavity at the base, nimeteen inches deep. From the size and thickness of these bones, it is certain that they could not belong to the elephant; but denote an animal five or six times as large, and of the carnivorous kind. We have the testimony of the Indians that such an animal still exists in the western parts of America. And it would be contrary to the whole economy of nature, to suppose that any species of her animals, is be. corme extinct. This animal must formerly have been numerous, at those places, where their bones are found in such numbers. The prota. bility is, as the means of subsistence were de. stroyed, they rel.loved further to the westward. But until those parts of America shall be ex.

plored cernin And $\mathrm{n}$ any otl 1 is bc and $\mathrm{fr}$ that th peds,

Or over $t$ for the No an dapted but wl the eal est pet the bu will flo and th the $\mathrm{m}$ : ferent mates, their anima are ne This Puma anima of the ed inc $\Lambda$ mer mals The of $\mathrm{As}$ in $\mathrm{Al}$ vo 


\section{HISTORY OF VERMONT. 125}

unch as

c fully

Il have he his. rought it, at n enl. quently

That nitude, eria, is ch yet and in $s$, and found on the or six seven base, at the ee and they lenote of the min of sts in ald be re, to is be. have their rola. e de. ward. e ex.

plored, little information is to be expected con. cerning this animal of the most enormous bulk : And we niay as well call it the Mammoth, as by any other name ; or the Pseudo Elephant, as it I ds been numed by Dr. Hunter. From this, and from many other considerations, it appears that the cnumeration of the American quadrupeds, is extremely imperfect.

Oricin. The animals which are spread over the fice of the earth, are fitted by nature, for the climate and country, where they reside. No animal, or vegetable, has a constitution adapted to every country : And there are none, but what are suited to some particular part of the earth, where they will arrive to their greatest perfection: A camcl is peculiarly fitted, for the burning san's of Arabia : And the reindeer will flourish the best in Lapland, Hudson's Bay, and those northern countries, where the cold is the most intense. The origin therefore of different quadrupeds, is to be sought in those climates, that appear to be the best adipted to their growth and multiplication. There are animals in the torrid zone in America; which are never found in any other part of the earth. This is the case with the Tapyr of Brasil, the Puma and Jugar, the Lama and Paco: These animals have never wandered into any other part of the globe : "They are therefore to be esteemed indigenous, or natural to the hot climates of America. The same is the case with the animals of the torrid zone in Asia, and Africa: The elepliant, and rhinoceros, are productions of Asia. The deserts of Zaara and Biledulgerid in Africa, may be termed the native country of vol. I. $Q$ 
lions, tygers, and panthers. No part of the climate of America is so inteusely hot, or sandy, as to render it the proper country fur the pro. duction or increase of animals, so fierce and noxious. 'These qualrupeds of hot climates, have never wandered from the onc country, to the other : Not because they could not find a pasage, but because they must have passed through a ciimate, the cold of which, being stich at they could not curiure, was an effectual bar to their passage. There alre other quadru. peds which are common to America, to the worth of Asial, and to Europe. Of this kind are the bufials, white bear, carabou, black bear, clk, moosie, red decr, fallow dece, wolf, roe, ghlutton, lynx, wild cat, beaver, badger, red fox, grey fox, black fox, otter, monax, vison, por. cupine, martin, water rat, weasel, crmine, flying squirrel, mole, and mouse. If we add the un. known animal, which we have called the mam. moth, the number of those quadrupeds which are common to both hemispheres, will amount to thirty... All of them, are the quadrupeds of cold countries ; fitted by nature to that climate, through which the passage inust have been, from the one country to the otlicr. The origin. al situation thereforc of these quadiupeds, must have bcen a cold country. But whether they passed from the northeastern parts of Asia, into America; or whether they issued from the northwest parts of America, into Asia; we have no way to detcrmine. The probability is equal, upon either supposition. All that we can de. termine is, that they were originally the quadrupeds of a cold climate. situlatic other. untary modat food, : the ha to a w not lea suited to acq food, gratior from. they fo ed, a equall. left. in the ture, could for al both. or $\mathrm{m}$ opera first i peds meric ture, creas and $A$ vigor woul 


\section{HISTORY OF VERMONT. 12T}

the

ndy, pro. and ates, $r$, to und a ssed cing tual diru. the kind ecar, roe, fox, porying

un.

ambich unt s of ate, een, rin.

iust

hey

nto

the ave sal, de. ad-

Migratron. Animals of every kind when oppressed by hunger, harassed by their cne. mies, or when they can find a more comfortable situation, will migrate from one cesuntry to an. other. Their migration wlicn chosen and voluntary, is always with a vicw to better accom. modatious ; to a situation more frourable for food, growth, and multiplicution. Directed by the hand of neture, their natural progress is not to a worse, but to a better situition. 'They do not leave their own country, to scttle in one less suited to thcir sabsistence, and increase; but to acquire greater advantages ; an increase of food, numbers, and vigour. Whetler the migration of quadrupeds then was from Asia, or from Ancrica, there can be no doulst, but that they found in the country to which they repaired, a climate, soil, and moans of subsistence, equally favourable to them, as those which they left. Had there been any very great difference in the provisions, and accommodations of nature, in cither country, the quadrupeds that could easily migrate, would not have remained, for any considcrable timc, common to them both. Nothing therefore can be less probable, or more contrary to the laws, tenciencies, and operations of nature, than the European idea first introduced by M. Buffon, that the quadrupeds of Europe migrated into a country in America, where every thing was adapted by nature, to their diminution, clegradation, and decrease. Had not the northern parts of Asia, and America, been well suited to the subsistence, vigour, and increase of these quadrupeds, there would not have been any voluntiny migration, 
from the one to the other; nor would these animals have remained, for so long a time, conl. mon to them both.

Species. How far nature has proceeded in the production of quadrupeds, we have not as yet, sufficient information to determine. There may be many species, yet unknown, in those parts of the earth which have not been explor. ed : Nor is the enumeration complete, in those countries which are known. The most that has been done in this branch of natural history, is to be found in the celebrated work of $M$. Buffon. As the result of his inquiries and information, this able philosopher concludes that the whole number of quadrupeds, which are spread over the face of the earth, will form a. bout two hundred different species or kinds.** Of these, onc hundred are found in America, and about seventy five are peculiar to it. If the power, the force, or the vigour of animated nature, is to be estimated by the species of quadrupeds, which different countrics contain, the conclusion will be, that nature has acted with the greatest vigour and energy in America. In the different climates in America, na. ture has produced seventy five species of quadrupeds : the number of those which are peculiar to the other parts of the globe are one hundred. The dimensions of America, compared with the dimensions of Asia; Africa, and Europe, by the computation of the modern geographers, are as one hundred and forty one to two hundred and forty nine.t The ratio of onc

- Vol. IX, 4 T.

+ Guthrie's Geography, p. 25.

hundre

ty ning dred : should to pres more, then to we are yet be nature

MA anima its ori nouris each lished tion, e nitude nature ginal no inc With place, the a stance the $d$ their the 0 : size quad ginal

afford latest c specics tuins ab 
hundred and forty one to two hundred and forty nine is the same as seventy five to one hunclred and thirty two. And so many species should be found, in the other parts of the globe, to preserve an equality: But this is thirty two more, than nature has produced. In respect then to the different specics of quadrupeds, if we are to judge by any enumeration which has yet been made, the greatest force and vigour of nature is found in America.*

Magnitude. The magnitude which any animal will attain, seems to dcpend much upon its original constitution, the clinate, and proper nourishment. In the original constitution of each animal, the Creator scems to have established certain laws, respecting its form, generation, expansion, and support. The proper magnitude of the animal, is therefore assigned by nature, to each species: In this way, the original limits are fixed; above, or below which, no individual of that species shall rise, or fall. Within these limits, those variations may take place, which we mean to express, when we call the animal great, or small. But no circumstance will reverse the laws of nature, enable the different species of animals to exchange their proper form, and magnitude ; to debase the ox into a mole, or to exalt the mole to the size of the ox. Nature has also fitted each quadruped for the climate, in which it was originally placed; and in that climate cnly, will it

* THF enumeration of quadrupeds secms to be too imperfect to afford an'; accurate calculations of this kind. According to $M$. Buffon's latest conclusions, in his Enoques de la Nature, there are three hundred specics of quadrupeds: America aceording to the Abbe Clavigero, contoins about one half of these. 
attain its proper perfection. The lion would lose its fierceness, and perish, if it was removed to Lapland ; and the reindeer would diminish, and die, if it was carried to the sandy deserts of Africa. In those climates only, to which nature has adapted each animal, will it attain its greatest magnitude, and most perfect form. Ine animal, to which nature has thus assigned its proper constitution, and climate, must be preserved and supported by proper food, or nourishment. A deficiency here, will bring on leanness, impotency, a diminution of size, and a gradual waste and consumption of the whole species. But when the climate, and the food, are both suited to the natural constitution of the animal, their joint influence will produce the greatest size or magnitude, that species will ad. mit.

By comparing the magnitudes of such quad. rupeds in Furope, and in America, as arc common to both, and derive their support from the hand of nature, we shall of consequence have another comparative view of the vigour and force, to which animated nature arrives, in each country. Several of those quadrupeds, whose weight has been ascertaincd in Vermont, $M$. Buffon has given us the weight of in Europe. They are these,

The Bear
Wolf
Deer
Fox, red
Porcupine
Martin

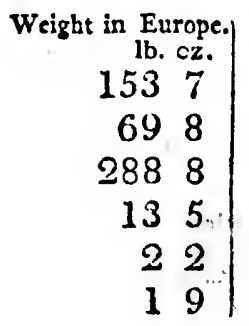

Weight in Vermont. Ib. oz. 4.56 92 308 20 16

Polecat Hare

Rabbit

Wease

Frmine

Flying

Beaver

Otter

Fro one of it is in decisiv that the their $\mathrm{gl}$ $\mathrm{r}, \mathrm{tl}$ the will $\cdot x$ the rhil the qua is, Arn duction climate produc a hot c the $\mathrm{M}$ : but of ductio: merica 'TE mals $\mathrm{h}$ assign which some 


\section{HISTORY OF VERMONT.}

ould ved ish, s of n?. its rm. ned be or on and role od, the the ad.

Polecat

Hare

Rabbit

Weasel

Frmine

Flying Squirrel

Beaver

Otter

$-$

We

Weight in Vermont.

$\begin{array}{cr}\text { Ib. oz. } \\ 7 & 8 \\ 8 & \\ 7 & \\ 12 \\ \\ 14 \\ \\ & 10 \\ 63 & 8 \\ 29 & 8\end{array}$

From this comparison it appears, that every one of these animals, is larger in America, than it is in Europe. The inference is clear, and decisive : It is in America, and not in Europe, that these quadrupeds of a cold climate, attain their grcatest magnitude, and highest perfection.

I. the comparison should be made, between the : irupeds of the torrid zone, the reverse will or sund to be the case. The elephant, the rhinoceros of Asia, are much larger than the quadrupeds of Peru and Brasil. The truth is, America is the most favourable to the productions, and growth, of the quadrupeds of cold climates: Asia is the most favourable to the productions, and growth of the quadrupeds of a hot climate. But the greatest of all animals, the Mammoth, was not an animal of the torrid, but of the temperate zone; and was the pro. duction of both countries, of Asia, and of $A$. merica.

Temper and Disposition. Most animals have a particular disposition and character assigned to them by nature, indelibly fixed, and. which distinguishes the whole species. Thus some are naturally fierce, sanguinary, and car. 
nivorous; while others are mild, temperate, and gentle : And sll of them, are not a little influenced, by the climate they inhabit. In the, hottest climate, and in the burning sands of $\mathrm{Af}$. rica, the most ravenous, and the fiercest animals abound : 'The lion, the tyger, and the panther, are there; in their greatest size, their largest numbers, and most extreme fierceness. In such places, the vegetables also contain their strongest qualities; the-drugs; perfumes, and poisons, are the most active, subtle, and power. ful. In America every thing in her vegetables, fruits, and animals, is more mild and temperate. The quadrupeds that most abound, are the lama, paco, buffalo, elk, deer, fox; beaver, 'hares, rabbits, and squirrels ; animals, marked with a mildness, and gentleness of character. Those that are the most fierce, the bear, the wolf, the wild cat, the otter, the congar; or tapyr, are sel. dom known to inake their attacks upon men, unless they are impelled to it by extreme hun. ger, provocation, or self defence. It was not therefore with the most fierce and ravenous ani. mals, that America abounded : Her quadrupeds were of a more mild; and temperate disposition. To these, her climate gives the greatest size, the highest perfection, and the largest increase.

Increase and Multiplying Powero The increase and multiplying power of animals, is derived partly from nature, and partly from situation, and other circumstances. Nature has made those animals which are the most large, fierce, and noxious, the least apt to mul. tiply. The smaller and more useful any quad. ruped is, the more rapid is its increase. All of

them the ye ble. an suppo greate lested plying time, of nun check natura fore th had do first di of the and $\mathrm{g}$ nature greate: tivated have 1 seems taken numbe phenos crease of the that th in any period in An But if she ac power try ha ty th: rol 


\section{HISTORY OF VERMONT.}

arate, little n the Af: mals ther, rgest In their and wer. bles, rate. e laares, ith a hose the sel:

nen, uun. not ani. peds ion. ize, asc. ER。 als, rom ure host hul. ad. lof

them bring forth their young, at that season of the year, when nature has made the most suitable and ample provision, for their food and support. And then they multiply with the greatest rapidity, when they are the least molested by man. But whatever be their multiplying power, it would require a long period of time, before they would arrive at that increase of number's, in which their progress would be checked, by the want of food. They would naturally spread over the whole continent, before they arrived to such a state. This they had done in every part of America, when it was first discovered by the Europeans : Every part of the continent, fitted for their nourishment and growth, abounded with them. How far nature may proceed this way, or what is the greatest number of quadrupeds, that the uncultivated state of any country will support, we have no observations to determine. But it seems probable, that the maximum had already taken place; that America contained her full number of quadrupeds. No observations or phenomena, denote that there has been any increase of these animals, in the uncultivated parts of the continent, since its first discovery; or that they ever were more thick and numerous, in any other part of the globe. How long a period nature required to advance to this state in America, we have no data to determine. But if we may judge of the energy with which she acts, from the effects of her multiplying power, the conclusion will be, that in no country has she displayed greater powers of fecundity than in America. These circumstances

$$
\text { rol. I. } \mathbf{R}
$$


denote an high antiquity, in the origin of the American quadrupeds; and a great fertility in that climate and country, in which they have attained their greatest numbers, their greatest magnitude, and tieir greatest fecundity.

\section{B I R D S.}

THE Birds - which abound in every part of America, make a curious and beautiful part of her natural history. C'atesby has given an elegant description of the birds of Carolina. Belk. nap has furnished a good catalogue of those of Newhampshire. Most of the birds which have been mentioned by these authors are to be found in all the northern states. As we approach further towards the north, a great number and variety of water for 1 are to be found, in the lakes, rivers, and harbours, which have never been described, or classed.

In Vermont we have most of the birds, which are known in the inland parts, and lakes of the northern climates. Some of them seem to be fitted by nature, to endure all the severity of our climate, and are to be seen in the coldest weather of o:m winters. Of this kind, are The Crow. Corrus Cornix. Hawk, forked tail. Falco Furcatus. Owl. Strix Asio.

Blue Jay. Corvus Cristatus.

Snowbird. Emberiza Hyemalis.

Partridge. Pcrdix Sylvestris.

Woodpecker, redheaded. Picus Capitc toto rubro,

THERE are several other birds, the robbin, blackbird, lark, snipe, bluebird, \&c. which are

seen as They found ly app them 1

'TiI' with $\mathrm{t}$ depart

TheS Wild

Wild

House

Barn

Grou

Black

$\mathrm{T}_{\mathrm{H}}$ ly, lit colou them in an: day 0 of ve and grouı these lively and a are to The white as th

$\mathrm{T}$ Apri 
seen as soon as the snow goes off, in the spring. 'They are not seen in the winter, but they are found late in the fall. From their late and ear. ly appearance, it is not improbable that some of them may tarry here through the winter.

'Гиов Е which are esteemed birds of passage, with the usual times of their appearance, and departure, are

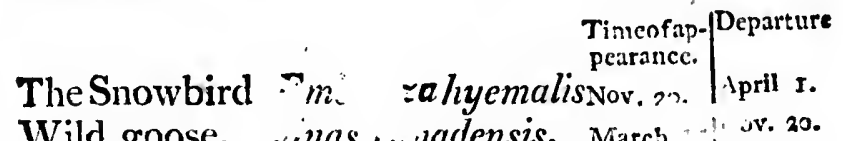
Wild goose. vinas walensis. March ov. 20. Wild Pigeon. Columba migratoria March 20. Ooct. so. House Swallow. Hirundocaudaacculeata $\left.\begin{array}{l}\text { Barn Swallow. Hirundo Rustica. } \\ \text { Ground Swallow: Hirundo Riparia. }\end{array}\right\}$ Ap.20Sp.20 Black Martin. Mirundo Perpurea,

$\mathrm{T}_{\text {H }} \mathrm{S}_{\mathrm{N}}$ OW B IR $\mathrm{D}$ is a beautiful, active, sprightly, little animal. They are generally of a grey colour, and less than a sparrow. Flocks of them appear, as soon as the snow begins to fall in any considerable quantity ; and generally a day or two before. They perch on the spires of vegetables above the snow, on the bushes, and trees; and collect on the spots of bare ground. In the most severe storms of snow, these birds appear to be the most active and lively. They feed on the seeds of vegetables, and are extremely fat, and delicious; but they are too smail to be molested on this account. They seem to be of different colours, black, white, and grey ; but they all disappear as soon as the snow goes off.

The WILD Goose, from the beginning of April, to the middle of November, resides 
chicfly in the more northern, and northeasterly parts of America. In those parts they produce their young, and are to be found in the rivers and harbours, in immense numbers. In November they come in large flocks from the north, and northeast, and pass off to the southwest. In March and April, they return fiom the southwest in a contrary direction, and go back to their summer habitation. These flocks frequently consist of lify or sixty : They fly at a great height, and appear.to observe great regularity in their passage. They sometines follow one another in a straight line, but are more generally diawn up in the form of a wedge ; and appear to be led by one of the strongest, and most active. While they keep together, they seem to understand their course perfectly well ; but if by any means their order is bro$\mathrm{ken}$, and the flock dispersed, several of them wander out of their course, appear to be per. plexed, descend to the earth, and are often kil. led or taken. When tamed, they will join with a flock of domestic geese ; but at the ustal times of migration, are very apt to join any flock, which approaches near to them, in their passage.

IN the WILD PIGron, the multiplying power of nature acts with great force and vigour. The male and female always pair: they sit alternately upon the eggs, and generally liatch but two at a time ; but this is repeated several times in a season. The accounts which are given of the number of pigeons in the uncultivated parts of the country will appear almost in. credible to those who have never seen their

nests. the line mont, it ances, $y$ Connec the pige dred $m$. one tim the hen sand at the first accoun by one "the n ty five one tr these $b$ ed with acres $t$ their $d$ noise $i$ and so slcep, hour a as to $\mathrm{d}$ were they $\mathrm{c}$ settler load is appeal servec much state (

:Bell 


\section{HISTORY OF VERMONT. 137}

nests. The surveyer, Richard Hazen, who ran the line which divides Massachusetts from Vermont, in 1741, gave this account of the appearances, which he met with to the westward of Connecticut river. "For three miles together the pigeons' nests were so thick, that five hundred might have been told on the beech-trees at one time; and could they have bcen counted on the hemlocks, as well, I doubt not but five thousand at one turn round."* The remarks of the first settlers of Vermont, fully confirm this account. The following relation was given me, by one of the earliest settlers at Cendon: "the number of pigeons was immense. T'wenty five nests were frequently to be found on one tree. The earth was covered with these beech trees, and with hemlocks, thus lor $i$. ed with the nests of pigeons. For an hundred acres together, the grcund was covered with their dung, to the depth of two inches. Their noise in the evening was extremely troublesome, and so great that the traveller could not get any slcep, where their nests were thick. About an hour after sunrise, they rose in such numbers as to darken the air. When the young pigeons were grown to a considerable bigness, before they could readily $\mathrm{fy}$, it was common for the settlers to cut down the trees, and gather a horse load in a few minutes." "This account may appear improbable to those who have not observed the fecundity of nature. But it falls much short of what has been observed in the state of Ohio. The following is from Harris's

- Belkoap's history of Nephampahire, Vol. III. p. I7I. 
account of that state p. $179,180 . \quad$ "The rast "flights of pigeons in this country scem incred. "ible. But there is a large forest in IVater"ford, containing several huncired acres, which " has been killed in conscquence of their light" ing upon it cluring the autumn of 1801. "Such numbers lodged upon the trees that " they broke off large limbs; and the ground be"low is covered, and in some places a foot " thick, with their dung, which has not only "killed all the undergrowth, but all the trees " are dead as if they had been girdled."

THE above, he arlds is confirmed by a letter from the Rev. Mr. Story, datcd Marietta, June 3, 1203. "I have visited two pigeon-roosts, " and have hard of a third. 'Those I have seen " are astonishing. One is supposed to cover " one thousand acres; the other is still larger. "The destruction of timber and brush on such " large tracts of land by these small auimals is " almost incredible. How nrany millions of " them must have assembled to effect it ! espe" cially as it was done in the course of a fer " weeks." The settlement of the country has since set bounds to this luxuriancy of animal life ; diminished the number of these birds, and drove them further to the northward.

WE have four species of SW a L Low 3 in this part of America. 1. The house swallow. This may be readily distinguished from the rest, by the greater forkedness of its tail. It has also a red spot upon its forehead ; and under its chin. This species build their nests in chimneys. Their nests are made of small sticks, ccmented together, with a kind of gum, and

mud ; and the lows ap And a $t$ fall, the trees, a panies. this, is the tail build tl they ar Their c white. place i The gr whole on sand eightes Their holes, loose : perfec laid, a the sv winte gest c nests or ret ings. crs. soone

$\mathrm{T}$ peara perat as an 
vas: cred. aterwhich light. 1801. that d be. foot only trees

letter June posts, seen cover trger. such als is is of espe. few has iimal , and

this

This

by also its him• cks, and

mud ; they are covered or arched over the tops, anl the aperture is on one side. 'These swallows appear the earliest of any, in the spring : And a few days belore their departme in the fall, they associate on the tops of buildings, dry trees, and bushes, as if about to depart in companies. 2. The barn swallow. The size of this, is rather less than that of the other; and the tail is not lorked so much. These swallows build their nests in barns and out houses ; and they are formed of grass straw, and feathers. Their eggs are speckled, of a dark brown and white. It is called the barn swallow from the place in which it generally builds its nest. 3. The ground swallow. 'This is the smallest of the whole species. 'These swallows form a hole in sandy banks, and on the sides of rivers, of eighteen or twenty four inches in length. Their nests are made at the extremity of these holes, of straw and feathers, laid together in a loose and careless manner. Their eggs are perfectly white. The holes in which they are laid, are designed only for their nests : None of the swallows ever remain in them, during the winter. 4. The black martin. This is the largest of all our swallows. They build their nests under the eaves of houses, in the secret or retired places of out houses, and old build. ings. Their nests are made of straw and feathers. They arrive the latest, and disappear the soonest of any of the swallows, which visit us.

TH E usual times of the appearance and disappearance of these birds, serve to mark the temperature of the climate, with as much precision, as any of the phenomena of naturc. But they 
do not seem to be properly birds of passage. At Danby in this state, the inhabitants report, that some of them were taken out of a pond in that town, some years ago. A man was em. ployed in the winter, to procure the roots of the pond lily, for medicinal purposes. Among the mud and roots which he threw out, several swal. lows were found inclosed in the mud; alive, but in a torpid state. The account is not doubted among the inhabitants; but I have not the testimony of any persons who sair these swallows. It has been doubted by some able naturalists, whether it is possible for the swaiiow to live in such a situation. I saw an instance, which puts the possibility of the fact beyond all room for doubt. About the year 1760, two men were digging in the salt marsh at Cambridge, in Massachusetts : On the bank of Charles' river about two feet below the surface of the ground, they dug up a swallow, wholly surrounded and covered with mud. The swallow was in a torpid state, but being held in their hands, it revived in about half an hour. The place where this swallow was dug up, was every day covered with the salt water; which at every high tide, was four or five feet deep. The time when this swallow was found, was the latter part of the month of February : but the men assured me, they had never found any other swallows in such a situation. The species called the house or chimney swallow, has been found during the winter, in hollow trees. At Middlebury in this state, there was a large hollow elm, called by the people in the ricinity the swallow tree. From a man who,

for sevd it, I pr thought the win :iccount ciune o micldie weather nornin si) on di cown, t or thres riing lik from th in the motions listurbe ly again would 1 noise. wis bl the sw appeara cutting tity of found ; nests.

ANo port.

this ace red to bout th pear or came 0

yox. 


\section{IISTORY OF VERMONT. $14 I$}

for several years, lived within twenty rocls of it, I procured this information : He always thought the swallows tarried in the tree through the ivinter, and avoided cutting it down, on that :iccount. About the first of May, the swallows cime out of it, in large numbers, about the middle of the day; and soon returned. As the weather grew warmer, they came out in the morning with a loud noise, or roar, and were s)on dispersed : About half an hour before sun down, they returned in millions, circulating two or three timcs round the tree, and then descending like a strean, into a hole about sinty feet from the ground. It was custornary for persons in the vicinity, to visit this tree, to observe the motions of these bircls : And when any persons elisturbed their operations, by striking violentIy against the tree, with their axes, the swallows irould rush out in millions, and with a great noise. In November, 1791, the top of this tree, was blown down, twenty fect below where the swallows entered. There has been no appearance of the swallows since. Upon cutting down the remainder, an immense quantity of excrements, quills and feathers were found; but no appearance or relicks of any. nests.

Another of these swallow trees, was at Bridport. The man who lived nearest to it, gave this account: The swallows were first obserred to come out of the tree, in the spring ; about the time, that the leaves first began to appear on the trees. From that season; they came out in the morning, about half an hour af

YOL. $x$. S 
ter sunrise : They rushed out like a stream, as big as the hole in the tree would admit, and ascended in a perpendicular line, until they were above the height of the adjacent trees ; then assumed a circular motion, performing their revolutions two or three times, but alway's in a larger circle, and then dispersed in every direc. tion. A little before sundown, they returned in immense numbers, forming several circular motions, and then descended like a stream into the hole, from whence they came out in the morning. About the middle of September, they were secn entering the trec, for the last time. These birds were all of the specics called the house or chimney swallow. The tree was a large hollow elm, the hole at which they entered was about forty fect above the ground, and about nine inches diameter. The swallows made their first appearance in the spring, and their last appearance in the fall, in the vicinity of this tree; and the neighboring inhabitants had no doubt, but that the swallows continued in it during the winter. A few years ago, a hole was cut at the bottom of the tree : From that time, the swallows have been gradually forsaking the tree, and have now almost deserted it. The following account from

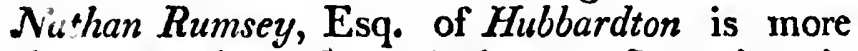
circumstantial and conclusive. "Sometime in the month of March, A. D. 1786, when the snow was deep on the ground, I was making sugar in the town of Hubbardton, with the assistance of some boys. The boys informed me that they had discovered a large number of birds flying out from a tree. I went myself to

the tr of the a larg the $\mathrm{g}$ vicini of the the di ped a throu and $f$ feet i) appea they c2rit consi torpic $\mathrm{Fr}$ the $\mathrm{l}$ gener of tre secur river

Of the $\mathrm{n}$ their The

Skyl:

Thr

Thra

Bobl

Yell

Blue

Wre Red 


\section{HISTORY OF VERMONT. 143}

the tree, and found that the birds were swallows of the chimney kind. The tree was an elm of a large size, and hollow fifty or sixty feet from the ground. Kemaining for several days in the vicinity I obscrved the swallows in the fore part of the day going out, and in the latter part of the day going in at the same place. I chopped a hole in the tree from whence I could see through it to the place where they went out, and found that they extended from fifty or sixty feet in height near down to the ground ; and appeared to be sticking to the tree as thick as they could be placed, and that the sides of the carity were cvery where lined with them; a considerable part of them seemed to lic in a torpid state."

From these accounts I am led to believe that the house swallow, in this part of America, generally resides during the winter, in the hollow of trees; and that the ground swallows, find security in the mud, at the bottom of lakes, rivers, and ponds.

Of the SIngInc BIRDS, the following are the most distinguished, either by the variety of their notes, or by the melody of their sound : The Robin. Turdus Migratorious.

Skylark. Alauda Alpestris.

Thrush. Turdhis Rufius.

Thrasher, or Mockbird, Turdus Polyglottos.

Boblincoln. Emberiza Oryzivora.

Yellowbird. Fringilla Aurea.

Bluebird. Motacilla Coerulia.

Wren. Motacilla Regulus.

Red winged Blackbird. Turdus Niger Alit Su; perne Rubentibus. 


\section{NATURAL AND CIVIL.}

Catbird. Muscicapa Vertice Nigro.

Golden Robin, or Goldfinch. Oriolus Aureus. Springbird. Fringilla, Hangbird. Oriolus Icterus.

THE only natural music, is that of birds. In the uncultivated state, and parts of the coun. try, this delightful sound is not to be heard. Either disgusted with so sloomy a scene, or disliking the food in the uncultivated lands, the musical birds do not deign to dwell in such pla. ces ; or to put forth their melody to the rocks, and to the trees. But no sooner has man discharged his cluty, cut down the trees, and opened the fields to the enlivening influence of the air and the sum, than the birds of harmony repair to the spot, and give it new charms by the animating accents of their music. From break of day till about nineo'clock, the lovely harmony is heard from crery cuarter. About that time of clay, the music ceases. The nusicians retire to other employments ; and there is no further concert, until next morning. This is one of the most delightful sccnes, which nature affords : But like most of our delicate pleasures, it is not to be enjoyed, but in the cultivated state.

A great variety of birds generally resort to the ponds, rivers, and lakes ; which on that ac. count, are commonly distinguished by the name of Water Fowl. Among these aquatic birds, the most common are

The Goose, three species. Anser Canadensis.

Duck, eight or ten. Anas

Teal, two. Anas.

Heron, two. Arclea.

Gull, ts

Shelldr:

Cranc.

Stork.

J.oon.

Waterh

The

fall und

this kin

and num

The E:

Hawk,

Owl, th

Woodp

Kingbin

Crow B

Cuckor

Kingfis

Woodc

Woods

Quail.

Curlew

Plover,

Wild 'I

Turtle

Whip

Nighth

Hedgel

Crossb

Humm

IN a ped, th variety never

We m 
Gull, two. Larus.

Shelldrake, three. Mergus.

Crane. Ardea Canadensis.

Stork. Ardea Ciconia.

J.oon. Colymbis Immer.

Waterhen. Alea Artica

THERE are many other birds, which do not fall under either of the above descriptions. Of this kind, the following are the most common and numerous.

The Eagle, two species. Falco.

Hawk, four. Falco.

Owl, three. Strix.

Woodpecker, seven or eight. Picus.

Kingbird. Lanius Tyramus.

Crow Blackbird. Gracula Quiscula.

Cuckow. Cuculus Amcricanus.

Kingfisher. Alcedo Alcyon.

Woodcock. Scolopax Rustica.

Woodsnipe. Scolopax Fedoa.

Quail. Perdix Minor.

Curlew, two. Scolopex

Plover, four. Charadrius.

Wild Turkey. Maleagris Gallopavo.

Turtle Dove. Columba Carolinensis.

Whip poor Will. Caprimulgus Europaus, $\boldsymbol{B}$.

Nighthawk. Caprimulgus Americanus.

Hedgebird. Muscicapa Canadensis.

Crossbill. Loxia Curvirostra.

Hummingbird. Trochilus Colubris.

$I_{N}$ addition to these, there is a mamillary biped, the Bat (vespertilio murinus :) And a great variety and number of small birds, which have never been enumerated, described, or classed. We meet with them every day in the fields, but 
they are not distinguished by any proper names.

IT is worthy of remark that in the birds of America, nature procecds from her most minute and curious, to the most sublime and magnifi. cent productions. The Hummingbird is the least of all birds. The Condor, a bird of South America, in bulk, strength, and courage, ir the greatest. Both of these are peculiar to America. The gradation from the least to the great. est, through all the intermediate steps and de. grces, is nicely and beautifully filled up with an infinite variety of others.

\section{F I S H E S.}

Of the great variety of fish, which nature has produced in the waters of America, but a sinall part are found in the internal parts of the continent. The largest collection of waters which we have in Vermont, are the lakes Champlain, Mempliremagog, Connecticut river, with the ponds and streams connected with them. In these waters we have The Sturgeon. Acipenser Sturio.

Salmon. Salmo.

Salmion trout. Salmo Salar.

Bass. Perca Ocelata.

Pickerel, or Pike. Essax Lucius.

Shad. Clupea Alosa.

Alcwife. Clupea.

Eel. Murena Anguilla.

Trout. Tranta.

Red Perch. Perca Fluriatalis.

White Perch. Perca Luciopersa.

Pout. Silturus Felis.

Shiner.

Chub.

Bream.

Bret.

Menow

Sucker

Dace.

Mic

Several of appr sage.

the spr begin $t$ to the or a lit plain, : So strc salmon thcir $\mathrm{p}$ height, rents. or seve ascend in the cellent in $\mathrm{Ma}$ taken the ur spawn seasol Towa turn they these five $c$ 


\section{HISTORY OF VERMONT. 147}

Shiner. Perca Nobilis.

Chub. Perca Philadelphica.

imes. ds of inute gnifi. the South $\therefore$ the neri. reat. de. th an

\section{Bream. Perca Chrysoptera.}

Bret. Clupea Minima.

Menow.

Sucker.

Dace.

Migration is not peculiar to the birds: Several kinds of fishes, have as regular periods of approach, and departure, as the birds of passage. This is the casic with the salmon. In the spring, about the 25th of April, these fish begin to pass up Connecticut river, and proceed to the highest branches. About the same time, or a little later, they are found in Lake Champlain, and the large streams which fall into it. So strong is this instinct of migration in the salmon, that in passing up the rivers, they force their passage over cataracts of several feet in height, and in opposition to the most rapid currents. They are sometimes seen to make six or seven attempts, before they can succeed to ascend the falls. When they are thus going up in the spring, they are round and fat, of an cxcellent taste, and flavour. From the first weck in May, to the second week in June, they are taken in great numbers. When thev arrive at the upper parts of the rivers, they deposit their spawn, and remain there during the summer season; but become very lean, and flaccid. Towards the latter end of September, they return to the ocean; but so much emaciated, that they are not taken, or used for food. Some of these salmon in the spring, will weigh thirty five or forty pounds. They migrate only to 
cold waters. None of them are ever found to the south, or west, of Connecticut river. Those that go further to the northward, and pass up the river St. Lawrence, are generally more large and rich, than those which come from the south. ward.

'Tin Salmon Trout, in its form, dimensions, and appearance, very much resembles the sal. mon ; but the meat is of a finer grain, and of a more delicate taste, and flavour. 'This trout is found in Lake Champlain, and in the rivers and ponds, which are connected with it. Thesc fish are taken with the hook and line, like the cod and haddock. Trouts from seven to ton pounds are common. In a pond at Leicester in this state, some have been taken which weighed twenty five pounds: Others much larger have been secn leaping out of the water, which the fishorman supposed would weigh from thirty five to forty pounds.

Tue Pike or Pickercl abounds much in Lake Champlain. It is there called by the name of Muschilongoe, and grows to a great size. They are easily taken with a spear, and some of them have weighed forty pcunds, and were six feet in length.

OF the small fish, which reside in the brooks and small streams, the most numerous and use. ful, are the trout, perch, and sucker. The trout, in its colour, form, and taste, resembles the salmon trout, but is of much smaller dimensions. 'The largest of them, will not weigh more than two pounds and an half, or three pounds. This fish is found in all the streams, which have their origin in the mountains; and

gencrall

lands.

numero

dimensi which I er of $n$ At 'Tin ty feet the tro commo across water $f$ which acres, had ne years, numbe that at brook rumnin their o any att arc ta swine net, $\mathrm{t}$ draug succe: a time when tomar shilli incre: than incre other 


\section{HISTORY OF VERMONT. 149}

hd to

hose uाp $\operatorname{arge}$ $\mathrm{utl}_{1}$.

ons, sal. of a it is and inse the ton ster ich uch

gencrally very near their sources, in the high lands. The perch and the sucker are also very numerous, and uscful, and of nearly the same dimensions. The most uncommon instance, which I have ever seen, of the multiplying power of nature, was in the increase of these fish. At Timmouth, is a brook about twenty or thirty feet wide, and two or three deep ; in which the trout and sucker were to be found of the common size, and number. A dam was built across this stream, for the purpose of supplyiris water for a sawmill. This dam formed a pond, which covered by estimation, about a thousand acres, where the trees were thick, and the soil had never been cultivated. In two or three years, the fish were multiplied to an incredible number. They were become so numerous, that at the upper end of the pond, where the brook fell into it, in the spring the fish are seen running one over another; embarrassed with their own numbers, and unable to escape from any attempt that is made to take them. They are taken by the hands, at pleasure; and the swine catch them without difficulty. With a net, the fishermen often take a bushcl at a draught, and repeat their labour with the same success. Carts are loaded with them, in as short a time, as the people could gather them up, when thrown upon the banks; and it is customary to sell them in the fishing season, for a shilling by the bushel. While they have thus increased in numbers, they are become more than double to their former size. This cxtreme increase does not secm to be derived from any other cause, than that of collecting the waters voL. I. T 
in such a quantity, as to form the pond; and thus increase the means of subsistence, by carrying the water over a large tract of rich, and uncultivated land. Events of a similar nature generally take place, when an artificial pond is made in any part of the country, not before cul. tivated ; and probably from the same cause.*

Is the production of fish, nature secms to have been extremely prolific, in every part of America. Their species, their multiplying power, and the age at which they become prolific, are beyond our knowledge, and computation. The brooks, rivers, ponds, and lakes, are every where, stored with them. The sea coasts are one continued range of fishing banks, covered with cod, haddock, and other animals of the ocean. The ruluale is generally esteemed the greatest animal, which nature has produced in the water : In the seas of America, this is to be found in its greatest perfection of magnitude and numbers.

Fossil shells are frequently found at some distance from the banks of our lakes, rivers, brooks, and meadows. Some have been found on the sides, or rather in the gullies of the mountains. Such productions require a collection of water for their formation. Naturalists have proposed many theories and speculations,

- THE number of fish in the rivers of South America, is fully equal 20 any thing that takes place, in the northcrn parts of the continent. "In the Maragnon," says P. Acugna, "Fish are so plentiful, that, without any art, they may take them with their hands."

"IN the Orinoco," says P. Gunilla, "besides an infinite variety of other fish, tortolses or turtle abound in such numbers, that I cannot find words to express it. I doubt not but that such as read my account will accusc me of exaggeration: But I can affirm, that it is as difficult to count them, as to count the sands on the bank of that river." Hist. del. Oreagque, ü. c. 22, P.59- M. de la Condamine confiruns their accounta cd.

sides what of the water: which In st they those scend into draw the $v$ ed $\mathrm{m}$ 


\section{HISTORY OF VERMONT. 151}

and

car-

and

ature nd is

cul. e. $*$

ns to irt of ying proputa, are oasts covis of med uced is to tude

ome crs, und the lec. ists nis, qual
cIn
out
th-
find
will
to
el.
sen

to account for the collection of water in such places, where there are now no appearances of the kind.

Is their descent from the mountains, the brooks and rivers must every where have formed themselves into lakes, ponds, and small collections of water : And it was not until after long periods of time, that they could form for themselves channels of such depth, as to discharge the waters which had been thus collectcd. Some of these ponds were formed on the sides of the mountains, and others overflowed what are now called the meadows; and many of their ancient phenomena yet remain. The waters have long sincc formed the channels, by which they are now discharged into the ocean. In such places, fossil shells are yet found : they are the productions of former times, when those places were covered by the waters de. scending from the mountains; then collected into quantities for want of natural channels, now drawn off by the depth of the channels which the watcrs have formed, and constantly rendered more and more deep.

\section{REPTILES AND INSECTS.}

THAT class of animals, which are distin. guished by the names of reptiles, and insects, are numerous in every part of America. They abound the most, and are of the largest size, in the hottest parts of the continent. In a climate so cold as that of Vermont, they are comparatively of but a few species, and small in their size; but they exist in great numbers. The following are our 


\section{AMPIIBIOUS REPTILES.}

The Turtle, two species. Testudo.

Toad. Rana.

Frog, five. Rana.

Lizard. Lacerta punctata.

Swilt. Lacerta fisciata.

THe R are several accounts in natural histo. ry, of toads being found in the hearts of trees, and in solid rocks, wholly inclosed, and shut up from the air, and all appearance of food ; and being taken alive, out of such situations. In the Memoirs of the Academy of Sciences, there is an account that in the ycir 1731, a toar was found in the heart of an old rals near Nantz, without any visible entrance io its habitation. From the size of the tree, it was concluded, that the toad must have been confincd in that situation, at least eighty or an hun. dred years.* We have several instances in Vermont, equally cxtraordinary. At Windsor, a town joining to Connecticut river, in Scptem. ber, 1790, a living frog was dug up at the depth: of nine feet, from the surface of the earth. Stephen Jacobs, Est?. from whom I have this account, inform me, that the place where this frog was found, was about haif a milc from the river, on the intcrvale lands, which are annually overtlowed by its waters. At Castleton, in the ycar 1779 , the inhabitants were engaged in building a fort, near the centre of the town. Digging into the earth five or six fect below the surface, they found many fiogs, apparently inactive, and supposcd to be dead. Being ex-

- Smellic's Philosophy of Natural History, p. 122.

poscd

they II have tl Mir. A firgs dicl $n$ orcertlo sprilig Burlin 1788 , ncar h thirty labour thing or stor these to whi exami well, ber of and se in pie ing $\mathrm{e}$. tive ; the s coun one wher of ea it ca been or 1 cent far $\mathrm{f}$ circ 


\section{HISTORY OF VERMONT. 153}

isto. rees, shut and In hicre toind oals o its wats ifin. lun. $\mathrm{s}$ in sor, cminth Ste. in

in. ow tly

posed to the air, animation soon appeared, and they were found to be alive, and healthy. I have this account from General Clurtice, and a Mr. Moulton, who were present when these firgs were dug up. Upon viewing the spot, it dicl not appear to me, that it had crer been orerflowed with water, but it abounded with springs. A more remarkable instance was at Bumlington, upon Onion river. In the year 1788, Samucl Lane, Esq. was digging a well stear his house. At the depth of twenty five or thirty feet, from the surface of the carth, the labourers threw out with their shovels, something which they suspected to be groundnuts, or stones covered with earth. Upon examining these appearances, they were found to be frogs; to which, the earth every where adhered. The examination was then made of the earth, in the well, where they were digging. A large number of frogs werc found covered with the earth, and so numerous, that scveral of them were cut in pieces by the spades of the workmen. Being exposed to the air, they soon became active; but unable to endure the direct rays of the sun, the most of them perished. This account is fiom Mr. Lane, and Mr. Lawrence, one of the workmen, who were both present when the frogs were lug up. From the depth of earth, with which these frogs were covered, it cannot be doubted but that they nuust have been covered orer in the earth, for many ages, or rather centuries. The timber on the adjacont land had grown very large; a pine trec not far from the well, was more than twelve feet in circumference. The appearances denote that 
the place from whence these frogs wert taken, was once the bottom of a channel or lak , form. ed by the waters of Onion river. In digging the same well, at the depth of forty one feet and an half from the surfice, the workmen found the body of a tree eighteen or twenty inches in diameter; partly rotten, but the biggest part sound. The probability is, that both the tree, and the frogs were once at the bottom of the channel of a river, or lake; that the waters of Onion river, constantly bringing down large quantities of carth, gradually raised the bottom : that by the constant incrcase of earth and water, the water was forced over its bounds, and form. ed for itself a new channel or passage, in its descent into Lake Champlain. How vigorous and permanent must the principle of life be, in this animal! Frogs placed in a situation, in which they are perpetually supplied with moisture, and all waste and perspiration from the body prevented, preserve the powers of life fiom age to age ! Centuries may have passed since they began to live, in such a situation; and had that situation continued, nothing appcars, but that they would have lived for many centuries yet to come!*

\section{SERPEN'TS.}

The Rattle Snake. Crotalus horridus. Black Snake. Coluber constrictor. Green Snake. Coluber saurita. Striped Snake. Anguis cryx. Water Adder. Coluber fasciatus. there a nont.

'TH two of further sons $w$ and in believe cr of $f$ sed, of The a the sn: some inches their $\mathrm{g}$ uncom ly fixc scenc, tress ; mouri formir and at snake repeat escap jaws But i durin anoth bird . I hav cinat ly si

\footnotetext{
- Appendix No. Ill.
} 


\section{HIS'TORY OF VERMONT. 155}

aken, form. rging $t$ and ound cs in part tree, the ins of large on : atcer, orm.

s de. and this hich iure, ody age they that that yet

Turse are all the speries of this kind of anumals, of which l lave any acessunt ; and these are but selourn to be met with in Vermoni.

' $\mathrm{TH} R \mathrm{R}$ is a curious pheroincnon respecting two of these species, which scems to descrve furthar inquiries. The farmers, and other persons who frequently mect with the rattle snake, and with the black snake, seem universally to believe that each of these animals, have a powcr of fascinution; or as it is commonly expressed, of charming birds, and other small animals. The account which is generally given, is this : the snake lies stretched out his full length, in some open place; his head raised eight or ten inches from the ground; his colours glow with their greatest brightness ; his eyes play with an uncommon brilliancy, and fire ; and are steadily fixed on the enchanted animal. During this scene, the bird appears to be in the greatest distress ; is constantly putting forth the most mournful accents; at the same time, is performing a number of irregular circular motions ; and at the end of each, approaches nearer to the snake : this scene continues, and is incessantly repeated, until the bird, without any power to escape, comes within the reach of the voracious jaws of the serpent, when it is instantly scized : But if the snake is attacked, or so disturbed during the operation, that his attention is turned another way, the charm is broken; and the bird recovering his liberty, immediately flies off. I have never myself seen any thing like this fascinating scene ; but I have had accounts exactly similar from more than a dozen persons, 
whose incerrity I cannot in the smallest degree call in ques:ion. There is room, however, for mistakes in such kind of observations ; and in most of them, the snake was disturbed, before the scene was finished. That there is something curious in these appearances, cannot be doubted. But whether these snakes have such powers, or by what causes such events are pro. duced, seems to require more accurate obser. vations, and a more philosophical investigation.**

\section{INSECTS.}

Tf́r insects are too minute, and numerous, to be particularly described. The most common are the beetle, grasshopper, cricket, butterfly, firefly, blackly, moth, flea, ant, musqueto, spider, hornet, wasp, bumble bee, honey bee, various kinds of bugs, and several species of worms. Of these the musqueto is the most troublesome. 'The weavil, the Hessian fly, and the locust, are not known in this part of the continent.

$\mathrm{O}_{\mathrm{F}}$ the bee, there is a species which is generally called with us, the bumble bee. This is indigenous to the country, and much larger than the common bee. It forms a nest upon the ground ; arid produces a species of hoiley, in transparency, beauty, and sivectness, fully equal to that of the honcy bee; but much less in quantity. Whether the honey bee is a native of the country, scems to be ricwed by some as uncertain. I do not find much reason to dubt, but that it was in America, before the Europc.

- Appendix No. IV.

ans $\mathrm{m}$

From jcans, and th which rival of $\mathrm{NIC}$ ions two 0 agrees cies o found cordi 1540 Flori by So loub and 'Tot And of $\mathrm{B}$ hone was the nort the are oror they in $\mathrm{t}$ arti Rus that the $\mathrm{COU}$ 


\section{IHSTORY OF VERMONT. 157}

egree $r$, for nind in efore some. to be such pro. bser. ion.*

rous, com. itter. ueto, bec, is of most and the

genis is than the , in jual in tive as libt, pc.

ans made their first sett'ements in the country. From the pictures and tribute rolls of the Mexicans, it appears that the honey bee was known, and that honey was one part of the annual tribute which was paid to their empcrors before the ar. rival of the Spaniards. Claviscro, in his history of Mexico, confirms these accounts ; and mentions six kinds of becs which make honey; two of which have stings, and one in all respects agrees with the honey bee of Furope. A species of the honey bee, but without stings, was found in Chiapa, and Yucatan. The same according to Margrave, was tound in Brasil. In 1540 , among the provisions of the natives of Florida, " a pot full of honie of bees," was found by Soto. From these accounts, it is not to be cloubted, but that the honey bee was indigenous, and had spread over the empire of Mexico. 'To the east, it had advanced as far as Florida ; And to the south, to Yucatan, and the country of Brasil. 'To an immense country, then, the honey bee was indigenous, and common. 'There was no cause in the nature of the animal, or of the elimate, to prevent their spreading to the northward. They live in the hollow trees in the woods of Vermont, from year to year ; and arc always found of their full dimensions, vigorous, and plentifully supplied with honcy ; and they bear the eold of our winters, much better in the hollow of a large tree, than in any of our artificial bee hives. They live and abound in Russia, where the climate is much more severe, than it is in this part of America : They would therefore naturally extend, and spread along the country, where they could find the means of vol. I. U 
subsistence, and a climatc not unsuited to their support. It has always been found far beyond the English settlements. From our earliest acquaintance with Lake Champlain, it was to be found in the open lands, along those shores, at the distance of an hundred miles from the Eng. lish or French scttlenents; and long before those settlements had begun to attend to the cultivation of this animal : And from the first settlement of New England, hunting for theif nests has been a lavourite and profitable amuse. ment. But as the chicf food of the bee is from the blossoms and flowers of plants, it does not multiply so fast in the uncultivated parts of the country, as where the improvements of agriculture and gardening, are constantly producing a greater variety, and number of vegetables.

To the tribes of reptiles and insects, we have affixed the idea of something, unpleasant, diminu. tive, or odious. The designs, the wisdom, and the power of the Creator, are not to be estimated by such feelings, fears, and prejudices. The reptile, the insect, the fish, the bird, and the quadruped, one as much as the other, denote wisdoin, power, and design, in the author of nature: And they are alike evidences, and instances, of the power of animated nature, in the different parts of the carth. We may therefore as justly and clearly cleduce the energy, and force of animated nature in any country, from the number and magnitude of the insects, as from the species and dimensions of any other animals. The European philosophers have dwelt with wonder and astonishment, on the numbers and size of these animals in America. 
The facts are justly stated, in several of their accounts; and they ought to have concluded from them, that the suil was uncommonly rich, fertile, and luxuriant. Anxious to find marks of degradation in America, they have almost universally advanced a contrary conclusion : that this prolific power of nature, denoted an uncommon corruption, and degradation of climate. No conclusion was ever further from the truth, or more remote from probability. It is only a rich soil, and a temperate climate, which can produce what they call a rank vegetation, or numerous reptiles and insects, of the largest size.

$\mathrm{F}_{\mathrm{ROM}}$ this imperfect view of our quadrupeds, birds, fishes, and insects, instead of finding nature but weak and fecble in America, as M. de Buffon has supposed ; $*$ her animals appear to be marked with an energy, and a magnitude, superior to what is found in Europe ; and equalled only, by the magnificent and vigorous productions of Asia.

* "La nature vivante est heaucoup moins agissante veaucous moing forte." Hist. Nat, xviri. I22. edit. Paris, I;64. 


\section{CIHAP'TER VII.}

Originat. In habiants. The Employments, Cizil Government, System of W'ar, Ediucation, ALuncrs, and C'ustoms of the Indians; the Adrantages, and Disadiantages of the Sazage State.

IN the formation of the mountains, riv. crs, vegretables, and animals, the pourers of nat ture appear to rise in a steady and bcautiful progress. This progress scems to be completed in the production of a rational, moral, and accountable animal. This animal is $M_{A N}$ : And he evidently appears in every part of the globe, to be at the heald of all the productions of nature : But the men of dificrent countrics and nations, appear to be very different from one another.

THE original inhabitants of this country were the Intiens: : These were the only species or kind of men, that had spread over Anierica. It will be more difficult to give a just account of the man of America, than to dascribe its vegetables, and animals. The latter are subject to stated, and invariable lawes ; they pass through but few changes and variations, and are alwalys to be found in that state, in which nature placed them. Man is sulject to a great variety of al. teration, and improvencnt. In his rudicst and most simple state, he appears but little supcrior to the brute; in his highest improrement and polish of manners, he alppears at an infinite remore from the bare animal; and in all the

stages

other, 1 situatio stantly powers. natural ficult, 1 tant sis ing the shall $f$ unimpr placed, $A \mathrm{PP}$ appear ninder The ed nearly rathe: appear: ry acti black, they $\mathrm{g}$ men corpul strong are re tenanc sullen tilated sense: but $\mathrm{s}$

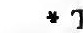

thérn $\mathrm{p}$ tings of the aced bave liv 
stages of his progress from the one state to the other, he passes through an endless varicty of situations and circumstances, which are constantly giving a new appearance to his capacity, powers, passions, mamners, and pursuits. The natural history of man is therefore the most difficult, but it is also the most useful and important subject we can contemplate. In examinjing the history of the Indian of America, we sliall find man in the most simple, rude, and unimproved state, in which he has cver been placed, or viewed.*

Appearance and Countenance. The appcarance of the Indians was different from any, lunker which man had ever been vicwed before. The colour of their skin is of a reddish brown, nearly resembling the colour of copper, but rathe darker. Their faces are broad, the nose appears flattish, their cyes black, small, and very active. The hair of their lueads is always liack, coarse, long, and perfectly straight ; and they generally appear without any beard. The men are taller than the Europeans, but rarely corpulent; and their bodies appear to be firm, strong, and well proportioned. 'Their features are regular and well adjusted, but their countenance discovers something wild, fierce, and sullen. ivone of them are seen crooked, mutilated, or deformed; defective in any of their senses, or deficient in any of their bodily organs ; but straight, well built, and robust. In the ap-

* THE following account relates chiefly to the Indians in the northern parts of Amcrica. I have reccived much assistance from the wri. tings of Or. Robertson, and other authors. But the authorities on which the accounts are founded, are chicfly the relations of those persons who have lived amoug tbe Indians, and been intituate!y acquainted with them. 
pearance, aspect, and countenance of the Indi. ans, there is an uncommon uniformity, and re. semblance. It is the same in all climates, and in all the tribes of America. It does not vary with heat, cold, situation, employment, or other circumstances ; but the Indian countenance has the same combination of features, and peculiari. ty of aspect, in evcry part of America.

Employment, and Method of Pro. curivg Subsistence. The food proper for man, is to be found in every part of the earth. But the means and the method of procuring it, are difierent among different nations, and in different stages of society. The saviges of North America had discovered the properties and of fects of those sceds, berries, and roots, which the earth spontaneously produces; and one part of their food was derived from this source. Fishing was another method which they used to procure subsistence. 'The great plenty and variety of fish, with which the rivers of Amcri. ca abounded, rendered this kind of provision casy to be procured, and of great use. The Indian had acquired much skill and address, in his method of catching the fish; and he was accustoned to dry, and smoke them, in order to prescrve them. The falls of rivers were the places, to which they most resorted for this purpose : And most of these falls were the places, where some of their tribes or small companies resided: And they were generally distin. guished by some particular Indian name. $A$ more general and effectual method of support, was hunting. The fruits which the earth spontancously produced, werc but few, and of short

continua commoc of a riv found. and oth in every these, plentifu ing fooc activity swiftne: the wes which $t$ the bus cult ; a the sar greatest cious is accurat and $\mathrm{pe}$ ment "I tion, ec urally $\mathrm{b}$ And $t$ most these some corn, only these

Withe domes prope were deriv 
Indi. d re. and vary ther thas iari.

PRO. for arth. it, dif. orth 1 ef. hich onc rec. ised and eri. ion The in ras der the his la. Dilin. $\Lambda$ $\mathrm{rt}$ n. rt

continuance. A few tribes only could be ac. commodated, by the vicinity and convenence of a river: But gane was every where to be found. The bear, the deer, the bearer, the fox, and other animals, were in great numbers, and in every part of the northern continent. From these, the Indian derived his most sure, and plentiful support. But this method of procuring food, required grealt efforts of invention, and activity. The strength, the fierceness, and the swiftness of the wild animals, the feebleness of the weapons, the bow, arrow, and club, with which the sarage attacked them, joined to make the business of the hunter laborious and difiicult ; and called forth all the active powers of the savage. And here, he appeared to the greatest advantage ; fertile in invention, sagacious in distinguishing and observing, nice and accurate in tracing the animal; indefatigable, and persevering in the pursuit. An employment which thus gave excrtion to all the invention, courage, force, and vigor of the man, naturally became the most honourable employment ; And the most dexterous hunter becaine the most distinguished savare of the tribe. To these methods of procuring food, were added some feeble attempts in agriculture. Indian corn, beans, pompions, and squashes, were the only plants they cultivated. The culture of these was wholly in the hands of the women. Without the use and knowlerge of any of the domestic animals, altogcther destitute of the proper instruments of husbandry, their efforts were weak and languid; and the supplies thev derived this way, were but small. 
THEse were all the methods of procuring food, with which the Indians were acquainted. They afforded them but a scanty and precarious support. When the game was plenty, and the hunter successful, they had an abundance of food. When the season of the ycar was unfavourable, and their success but small, they were reduced to scarcity and want. Their sufferings this way, were sometimes cxtremely se. vere. And there was no year, in which they were not subject to these extremes, of great plenty, and severe famine.

TH z appetite of the Indian conformed to this state of things. In the seasoins of plenty, the savage indulged himsulf to great excess : In the time of faminc, the Indian bore his hunger with astonishing patience, and firmness. So accus. tomed was he to this irregular method of living, that excess and famine were equally faniliar to him ; and his constitution and health remained firm and vigorous, under the cxtremes of both.

$F_{\text {rom }}$ this situation and employment of the Indian, all the regulations, customs, advantuges, and disadvantages of the savage state, were de. rived.

Societr. When any considerable number of the human race subsist near each other, they will always combine in some form of societr. Mutual wants, dangers, dependencies, interests, and benefits, operating with the appetitc man has for society, will not fail to produce this cffect. The situation and employment of the $\mathrm{In}$ dians, determined what the nature and extent of this society must be, among them. The chief source of subsistence among them, was

From

form

The savag duct safety sugge and $\mathrm{j}$ fish i were he hi than

were er sa his river ken, they elair 


\section{HISTORY OF VERMONT. 165}

uring inted. rious al the ce of unfa. they suf. $y$ sethey great

o this , the in the with ccus. ving, ar to ained both. f the uges, c de-

mber they ietr. ests, man $s$ efe Instent 'The was

hunting. On this account, a large territory became necessary for the support of a small num. ber of people. Like the game on which they subsist, they must be dispersed over a large tract of country, or they cannot procure food. In this stage of society, the extent of it is derived from its situation. Its territory must be large, the number of people will be small, and all hostile tribes must be kept at such a distance, as not to encroach upon the territory or the game. This was the state, in which the savages were found. Divided into a number of tribes, small in the number of pcople, large in the extent of territory, and generally unfriendly and hostile to each other.

Nature of their Civil Government. From this state of society, arose a species and form of governmont peculiar to the Indians. The design and object of government among the savagos, was not the property, security, or conduct of the individual ; but the property and safety of the tribe. The idea of property is surgested by nature ; and was clear, distinct, and just, in the mind of the rudest Indian. The fish in the river, and the game in the forest, were not the product oi" his care or labour; and he had no idea that they belonged to him, more than to any other individual. But when they were acquired by his personal exertion, no other savage doubted but that they were become his particular and exclusive property. The river, or the forest, from which they were ta. ken, were not personal but public property : they belonged to the tribe. No individual elaimed a right to them, in preference to, or rox. $x$. 
exclusive of others. These were the property of the tribe, belonging equally to all, and to which all had a right to repair in quest of sub. sistence, and hadan equal and common privilege. When the Indian builded his house, or planted lhis corn, no one had a right to molest him; the house and the corn became his. When he relinquished his possession, any other of the tribe had a right to take possession, and pursu? the same employment that he had done. The fruits of their own labour and industry, was always the property of the individual: The riv. er, the forest, the hunting ground, the land or the territory, was the property of the tribe. The former was of so simple a nature, so well understood, and so universally agreed to, that few controversies could ever arise about it; common custom and consent was sufficient to adjust and regulate every thing of this nature. The latter contained all the property, the mean of subsistence, and that on which the whole tribe depended for their existence. This was the great object and aim of their government; to protect and defend that, on which the whole tribe subsisted. In such a state of society, the injuries that would be done to individuals would not be many in their number, or often of such a kind, as to endanger the existence or sovereignty of the tribe. The iright of redressing them, was therefore left in private hands. This has always been the casc, in the infancy of society and government. If injuries were done, if blood was shed, it belonged to the friends and family of the injured person to seek redress. If the chiefs interposed, it was only by way of 


\section{HISTORY OF VERMONT. 107}

counsel and advice. The friends of the injured person might accept of their advice, or of the reparation offered by the aggressor, or they might rcject it : If it was accepted, all was settled in a quiet and friendly manner : If rejected, nothing remained but to pursue the aggressor with a revenge and rage, that aimed at nothing less than destruction and death.

'T $\mathrm{E}$ form and manner of the Indian government, wis the most simple that can be contrived, or imagined. 'There was no king, nobility, lords, or house of representatives, mong them. The whole tribe assembled tog $c$ in their puisic councils. Destitute of writugs, records, and history, to preserve the memory of their public transactions ; their most aged men became the depositories, of what had been gathered from experience, observation, and a knowledge of their former transactions. It is by them that the debates and consultations are chiefly carriced on. Their councils are slow, solemn, and deliberate. Evcry circumstance that they can foresec, is taken into consideration. The prob. able advantages and disadvantages of every measure, are examined and weighed. All the prospects of success and disappointment, are revolved in their debates; and nothing is omitted, which occurs to their views or expectations. The whole business is a scene of consultation, and advice. And the advice has no other force or authority, than what is derived from its supposed wisdom, fitness, and propriety.

THE strength and power of the government, is placed wholly in the public sentiment. The clief has no authority to enforce his counsels, 


$$
\rightarrow
$$




\section{IMAGE EVALUATION TEST TARGET (MT-3)}
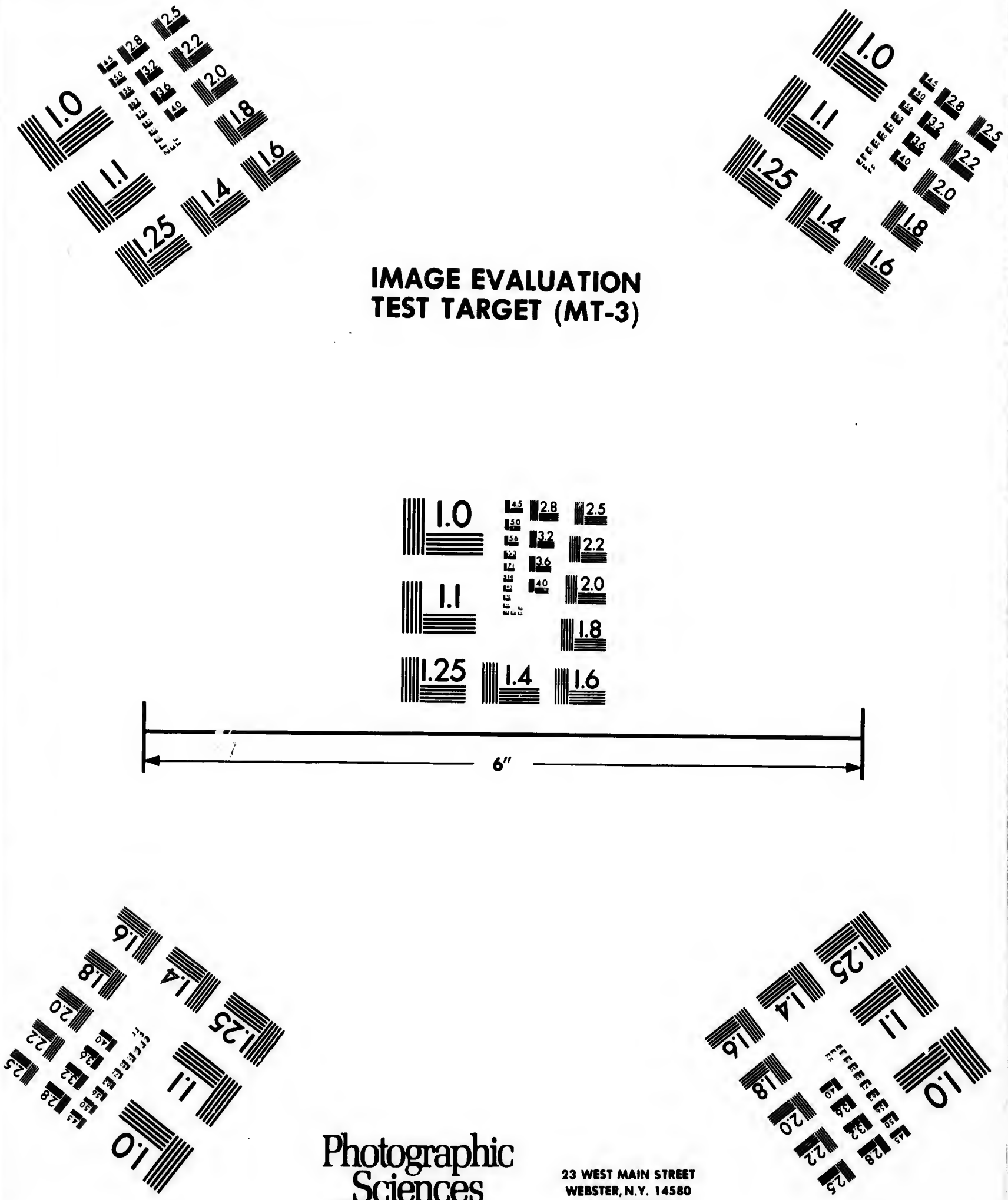

Photographic Sciences

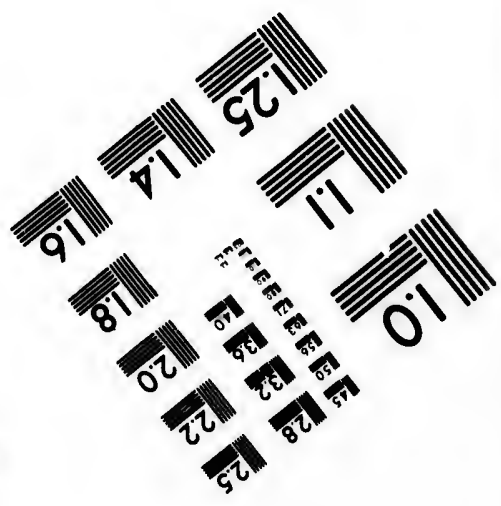
Corporation 


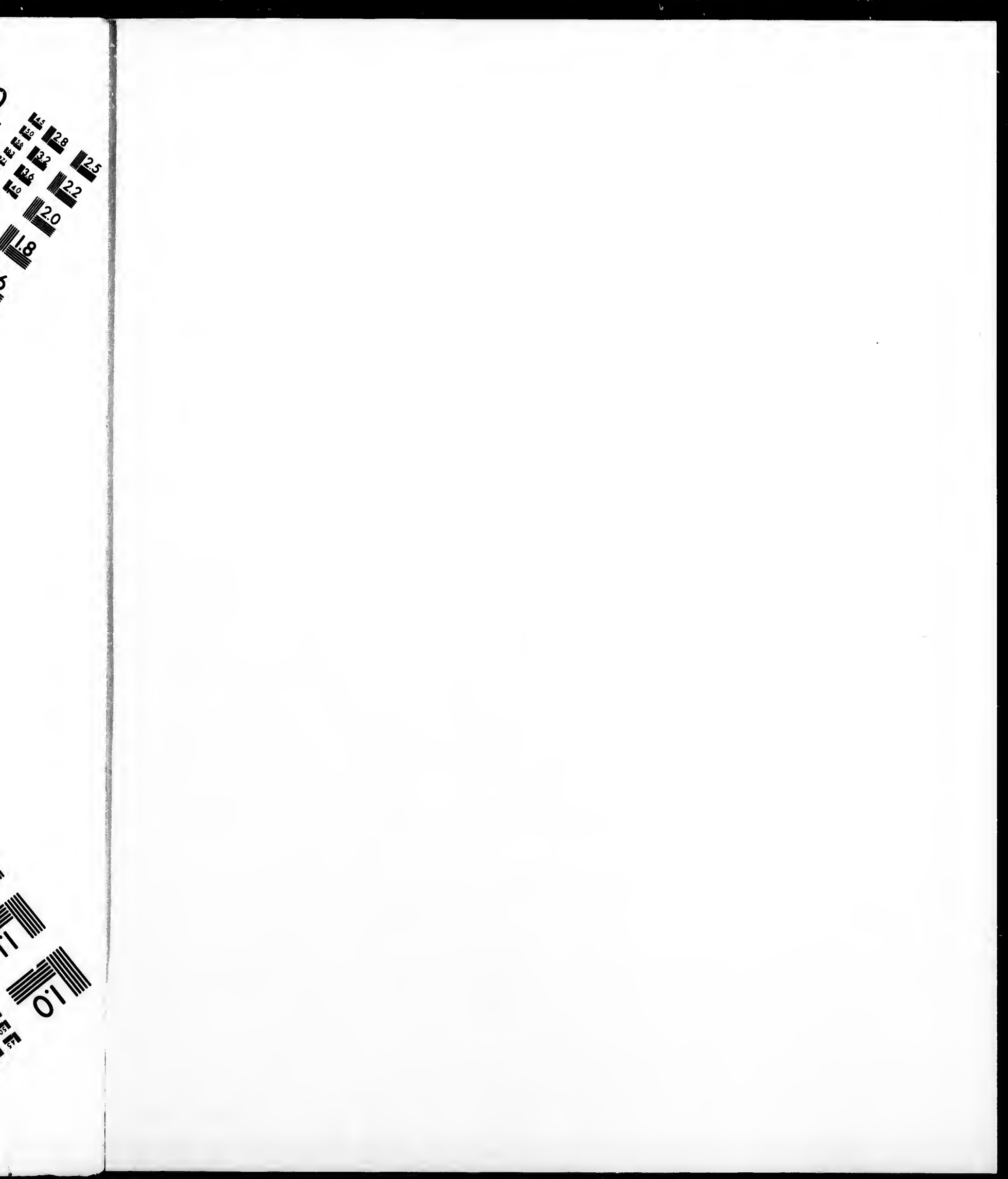


or compel to his measures. $\mathrm{He}$ is fed and clothed like the rest of the tribe. His house and furniture are the same as those of others. There is no appearance, or mark of distinction: No ceremony, or form of induction into office : No ensigns or tokens of superiority, or power. In every external circumstance, thie chiefs are upon a level with the rest of the tribe: And that only which gives weight and authority to their advice, is the public opinion of their superior wisclom and experience. Their laws stand on the same foundation. There was no written law, record, or rule of condact. No public precedent, established courts, forms or modes of proceeding. The causes and occasions of contention were so few, that they did not much affect the tribe. And when the chiefs interposed in the conccrns of inrlividuals, it was not to compel, but only to commsel and advise them. The public opinion pointed out what was riglth, fit, and proper to be estcemed law's and rules of conduct. These rules or laws rle. rived from nature, were seldom wrong, obscure, or inconsistent ; but generally plain, clear, and useful. Their penalties and punishments were derived from the same source. Loss of char. acter, and reputation, disgrace, exclusion froin the tribe, and death, were the punishments to which offenders were exposed, according to the nature und aggravation of their crimes. These punishments were not described, 'snd assigned to a particular crime by a written law ; but they rested upon the public opinion of the tribe, and derived great force and power from it. An offender who lad been greatly and dẹply guilty, 
fled from the tribe, as the only way to safety, peace, and rest.

'THERE was a fitness and propriety in this govermment, or rather, it was fuily adequate to is chd and design, and to the situation and state of the savage. A modern statesman would sniic at this idea of Indian government : And because he could find no written constitution, or biil of rights, no mutual checks, and balanccs, accountability and responsibility, pronounce it weak, foolish, and contemptible. But it was evidently derived from the dictates of nature, and weil adapted to the state and situation of the savage. The idea of property was so plain and clear, and the objects to which it related were so few and simple, that there was no need of a code of laws to describe and define it. The rights of the individual, his freedom and libcrty, were so strongly felt, and so universally acknowledged, that no person dared to invade them. The crimes of the vicious received a just and a full punishment, in the disgrace, contempt, and danger, they brought upon the guilty. The individual had all the security, in the public sentiment, custom, and habit, that government can any where afford him. All that was to be defended was the territory ; the interest, the independence, and sovereignty of the tribe; and every part of the government was aciapted and designed to form, to animate, and to inflime, a national spinit of vigour anci independence.

AgREABLY to its nature and design, the tenciency and effect of the savage government, yas equality, ifectom, and independence, among 
all the members of the tribe. In respect to rights and privileges, the savage knew no supc. rior. Of abasemcnt, humiliation, dependence, or servitude, he had no idea. Depending on his own exertions for food and raiment, he had never looked to another for assistance, promo. tion, or wealth. When the interest of the tribe was in question, or in danger, the wisdom and experience of years was consulted, to advise and determine : And their counsels became matters of great respect. But constraint, compulsion, and force, was the object of the highest detesta. tion and horror. Every measure of the govcrnment tended to confirm and increase the spirit of freedom, equality, and independence, and to render it strong, fieree, and permanent, through the whole tribe.

System of War among the Indians. The civil regulations of the savages were all designed to qualify and prepare them for war. Among the causes that lead to this, an opposition of interests, was the most common and powerful. No people ever had more clear, or more just ideas of their own rights and property, than the Indians. They not only understood their own personal rights, but they were perfectly well acquainted with the rights and pro. perty, that were vested in the tribe. Each tribe claimcd the soil in their own domains. This right was viewed as complete, perfect, and $\mathrm{ex}$ clusive : Such as cntitled them to the full and entice possession; and to oppose by force and violence, all encroachments upon the soil, or game, in any part of their territories. The bounds of thesc territories were cxtensive, and

ill defi and i Hence and $c$ fiercen mutu? l: $\mathrm{iti}$ siond. cosd, this $c$ perpet $\mathrm{TH}$ thintir zed $n$ enemy irregu tle or bastio. was et ber of asylui childr out to club Thu: bag cam such ply. in $\mathrm{s} 1$ sup? app troc stra em 
ill defined. Real or supposed encroachments and injuries, were constantly taking place. Hence arose innumerable subjects of dispute and controversy, which easily inflamed the fiercencss of the savage temper, and brought on mutul injuries, reproaches, hostilities, and war. I: his stite, most of the Indian tribes were iju:id. Interest had become a source of discyrd, anong the neighbouring tribes. From this cause, arose most of their inveterate and perpetual wars.

' their wars, is very different from that of civilized nations. To defend themselves against an enemy, they have no other fortification but an irregular kind of fortress, which they call a cas tle or fort. It consisted of a square without bastions, surrounded with pallasadoes. This was erected where the most considerable number of the tribe resided, and was designed as an asylum for their old men, their women, and children, while the rest of the tribe were gone out to war. The weapons of the Indian were a club made of hard wood, a bow and arrow. Thus armed, the Indian takes with him a small bag of corn, and is completely equipped for a campaign. When he takes the ficld, it is with such a number of warriors as the tribe can supply. During their march, they are dispersed in straggling companies, that they may better supply themselves by hunting. When they approach near to the enemies' frontiers, their troops are more collected : All is then caution, stratagem, secrecy, and ambuscade. Their employment as hunters has taught them great 
address and vigilance, in following and surpri. sing the game. Their mode of war is the same, as that of hunting. With great ingenui. ty, they will find and follow the track of their enemies : With a surprising patience and per. severance, they will wait for the moment, whon they find him the least able to dofend himself. And when they can find an enemy unprepared, they make their attack with great fury, and with pretty sure success. In their battles thcy aiways endedvour to secure themselves behind the trees or rocks, and never meet their enemy in the open field, or upon equal tcrims, if the $y$ can avoid it. The method of the Europeans, of deciding a battle in the open field, they rcgard as extreme folly and want of prudcnce. Their established maxims are to obtain a superiority in situation, numbers, concealment, or some other circumstance before the battlc: In this way, to preserve the lives of their own party, and destroy their enemies, with as little loss as possible to themselves. A victory obtained with the loss of many of their own party, is a matter of grief and disgrace, rather than of exul. tation: And it is no honour to fall in the field of battle, but viewed rather as an evidence of want of wisdom, discernment, and circumspec. tion. When the attack is to be made, nothing can exceed the courage and impetuosity of the savage. The onset begins with a general out. cry, terminating in a universal yell. Of all the sounds that discord has produced, the Indian warwhoop is the most awful and horric. It is designed and adapted to increase the ardor of those who make the attack, and to carry terror

and

the com and osity the subo entir orde aims ditan strin thei gled mak thei sent is $\mathrm{c}$ try stre are val ge: the an ge sit trc bu

es

$\mathrm{d} \epsilon$

of

lis 
and horror inte the feelings of those, on whom the attack is made. The Indians immediately come forward, and begin the scene of outrage and death. All is then a scene of fury, impetuosity, and vengeance. So great is the rage of the sarage, that he has no regard to discipline, subordination, and order. Revenge, takes an entire possession of his soul : Forgetful of all order, regardless of discipline and danger, he aims only to butcher and destroy. If the In. dituns remain masters of the ficld, they always strip and scaly the dead. Leaving the bodies of their enemies, naked, unburied, and often mangled, they carry off the plunder and scalps; and make a very swift and sudden retreat. Upon their approach to their own tribe, a herald is sent forward to announce the event : the tribe is collected, and the conquerors make their en. try with their ensigns of triumph : the scalps stretched upon a bow, and clevated upon a pole, are carried before them, as the tokens of their valour and success, and monuments of the vengeance they have inflicted upon the enemies of their country.

$T_{\text {H }}$ e prisoners which they have taken, make an important part of their triumph. The savages are anxious to take as many of these as possible. During their march, they are generally treated with a degree of humanity and kindness; but the greatest care is taken to prevent their escape. When they arrive at the place of their destination, the old men, women, and children of the Indian tribe, form themselves into two lines, through which the prisoners must run the gantlet to the village. If the prisoner is young, ror. $x . \mathrm{X}$ 
active, and a good runner, he makes his way through the lines without receiving much inju. ry. It he is weak, old, and infirm, he receives much damage by the blows, stripes, and bruises, he receives. When this scene is finished, the prisoners arc conducted to the village, treated with apparent good humour, and fed as well as the Indians' fare admits.

To the village thus assembled, the head war. rior of the party relates every particular of the expedition. When he mentions their losses, a bitter grief and sorrow appears in the whole as. sembly. When he pronounces the names of the dead, their wives, relations, and friends, put forth the most bitter shrieks, and cries. But no one asks any question, or interrupts the speaker with any inquiry. The last ceremony is to proclaim the victory. Every individual forgets his own loss and misfortune, and joins in the triumph of his nation. Their tears cease, and with one of the most unaccountable transi. tions in human nature, they pass at once from the bitterness of sorrow to all the extravagance of joy. The whole concludes with a savage fcast, songs, and dance.

Tin $\mathrm{E}$ fute of the prisoners is next to be deci-

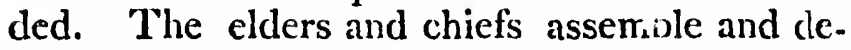
liberate concerning their destiny. The women and children are disposed of, according to the pleasure of their captors ; but they are seldom or never put to torture, or death. Of the men some are appointed to supply the places of such Indians as have fallen in battle. These are delivered to their friends and relations, and if they are received by them, they have no suf-

ferin

ly, ar cease and 1 and tined horri the leave the s to be ensu tied he $\mathrm{m}$ the $y$ unha way. to bc tator striv and red kniv ers and of $c$ inve suff par torr hor ints $\mathrm{He}$ wa 


\section{HISTORY OF VERMONT. 175}

ferings to fear : they are adopted into the fami15 , and succeed to all the privileges of the deceased ; and are esteemed as friends, brothers, and near relations. But if they are not received and admitted into the family, or if they are des. tined to be put to death, a most distressing and horrid scene ensues.

A stake is fixed firmly in the ground. At the distance of eight or ten feet, dry wood, leaves, and faggots, are placed in a circle round the stake : And the whole village is collected, to bear their part in the tragedy, which is to ensue. The prisoner is led to the stake, and tied to it by his hands, in such a manner that he may move freely round it. Fire is set to the wood, that as it runs round the circle, the unhappy victim may be forced to run the same way. As the sufferings of the prisoner begin to become severe, the acclamations of the spec. tators begin. The men, women, and children, strive to exceed each other, in finding out new and keener methods of torment. Some apply red hot irons, others stab and cut with their knives, others mangle and tear off the flesh, others again bite off the nails and joints, or twist and tear the sinews. Evcr, species and degree of cruelty, that savage rancour' and revenge can invent and apply, is tried upon the wretched sufferer. But great care is taken that the vital pirts may not be so injured, as to bring the torments of the victim to a speedy end. In this horrid situation, the sufferer is undaunted and intrepid. He reviles and insults his tormentors. He accuses them of cowarciice, meanness, and want of spirit ; as ignorant, unskilful, and des. 
titute of ingenuity and invention in the art of tormenting. Not a groan, a sigh, a tear, or a sorrowful look, is suffered to cscape him. To insult his tormentors, to display nindaunted and unalterable fortitude in this dreadful situation is the most noble of all the triumphs of the warrior. With an unaltered countenance, and with the decisive tone of dignity and superior im. portance, the hcro proceeds with great calmness to sing the song of his death-" Intrepid and brave, I feel no pain, and I fear no torture. I have slain, I have concuered, I lave burnt mine enemies; and my countrymen will avenge ny blood. Ye are a nation of dogs, of cowacis, and women. Ye know not how to conquer, to suffer, or to torturc. Prolong and increase niy torments, that ye may learn from $\mathrm{my}$ example liow to suffer and behave like men !" With such unconquerable magnanimity and fortitude, the sufferer perseveres under evcry method of torment and torture. Wearied with cruelty, and tired with tormenting a man whose fortitude they camnot move, one of the chicfs in a rage concludes the scene, by knocking the prisoner on the head, or stabbing him to the heart.

THESE scenes however were not common. They seem to have been kind of honours, reserved for the warriors; and were the trials of their courage and fortitude. And nothing wai: estecmed more base and ignominious, than to shrink from them, or to shew any sense of fear or pain under them.

WIIEN the prisoners were adopted into the tribe of the conquerors, nothing could exceed 
the kindness and affection, with which they were treatted. All distinction of tribes was forgottcn ; they held the same rank as the deceased person, whose place they filled; and were treated with ati the tenderness duc to the husband, the b: ther, the child, or friend. And it was gencrally the case, that the savages avoiled abusc and cruelty to the women and children, that fell into their hands.

'l'H $\mathrm{E}$. Indian method of carrying on a war, was so contrary to the maxims and customs of all civilized nations, that some of the European writers, judging from their own customs, have concluded it was founded on cowardice, and arose from an ignoble and timid spirit, afraicl to meet its opposers on equal ground, and depending wholly on craft, and not at all on courage and firmness of mind. No conclusion was ever further from the truth. When placed in a criticul and dangerous situation, no people cver discovered more valour, firmness, and intrepidity. When subdued, an Indian was never known to ask for his life. When compelled to sufficr, the Indian bore it with a steadiness, a fortitude, and a magnanimity, unknown to all other nations; and of which, there are no $\mathrm{cx}$ amples in the history of war. His method of war did not arise from a sense and fear of dangrer; he was well acquainted, and always in the midst of this ; but it arose from his situation and employment, and was perfectly well adapted to it. From his situation and employment as an hunter, he acquired the art of ambuscade and surprise; and the method with which he could best succeed in taking his game, he found to be 
the most successful to ensnare and overcome his chemy. The situation and state of the country, overspread with thick forcsts, lcal to the same method. The situation of the tribe, scittered and dispersed in the roods, suggested the same idea. The method of fightings could not be in the open fields, but among the trees. And he wiscly placed the point of honom, in the public good; where the prospect and the probability of his success lay. Had the honom of the Indian warrior been placed, in courting fame and victory in the open field, the wholc tribe would have been destroyed by the effusion of blood that must have succeeted. His max. ims therefore were bettcr chosen, and they were such as evcry circumstance in his situation and employment naturally led him to: Not in an useles. estentation of daring courage and boldness, but in the public utility and advantage. So fir as an enterprize depended on secrecy, subtlety, surprize, and impetuosity, the Indian method of war scems to have becn fully cqual to the European. 'The Spaniards, the French, the Finglish, and the States of America, have had many and painful proofs of their address and prowess in this method. But when a fort was erected, or a small fortification to be carried, the Indian method of war wholly failed. Neither their arms, their arts, or their customs, were of any avail here. Tholly unacquainted with the art of fortification, they could neither crect, or take a fort of any strength. When the Europeans had once got possession of any part of their country, and erected a small fortification in their territories, they held it by a

- Hre po able to and $\mathrm{n}$ further lish, an ces int forded rent 0 foilow streng tatere, ed the lin of the and $w$ nust sions. men 1 inost 10) $\mathrm{Wa}$ susece sions tincti basis tion, yout mak and in $d$ and no pise crni cult und 


\section{HISTORY OF VERMONI. 173}

sure possession. The savages were wholly unable to dispossess them by their method of war, and nothing was left for them but to retreat further into the forests. In this way the Eng. lish, and French were making constant advallces into their country ; and their art of war af. forded them no sufficient means, either to preient or to redress it. But when the Europeans followed them into the woods, where their strength and art might be employed to advan. tare, the Indians genurally surprised and defeat. ed their armies, with great havoc and slaughter.

Enicatrox. The subsistence and safety of the tribe depended $:$, much upon the hunter, and warrior, that these becume of course the most necessary, useful, and honourable profes. sions. When in pursuit of food, the young men put themselves under the direction of the most noted and successful hunter. Going forth 10 wirl, they followed the most renowned and successful warrior. Eminence in these profes. sions was the surest way to subsistence, to dis. tinction, to honour, and renown. This wats the basis, and formed the whole business of educa. tion, among the savages. 'Po train up the youth to address and dexterity in hunting ; to make him paticnt, firm, persevering, in hardship and suffering; inveterate, fierce, and intrepid in destroying his enemies ; was the chief aim and design of the parent. Every thing that had no connexion with this, was neglected and des. pised. The arts of acquiring knowledge, governing the passions, refining the manners, and cultivating improvements, were unknown and undesired by the savage. ILe nerer corrected 
or restrnined his child, taught him to moderate his appetites and passions, to submit to parent. al, or any other authority : On the contrary he was trained up to take care of himself, to grati. fy every inclination and appetite, and to look fo: food and honour in his own exertions, independence, and superiority. The parent wished and aimed to form his son to hardship and dauger, to bear fatiguc, famine, and torture, to ensnare and take the rame, and to carry destruction and vengeance upon lis enemies. To this plan of education, the whole aim and conduct, the instruction, the mamners, and the examplic of the pirent, was directed : the only aim and design, was to make the youth an able and ac. complished hunter, and warrior. Neither the views of the parcnt, or the wishes and aims of the child, ever rose any higher, or extended any further than this.

$\mathrm{N}_{\mathrm{X} \mathrm{x}}$ to the civil and military regulations,

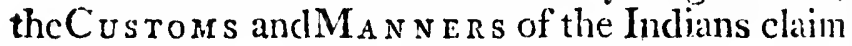
our attention. The customs and mamners of a nation, always constitute a distinguishing part of the national character ; and as they vary with the progress of society, they serve to asccrtain, and mark the different stages of it. In several respects, the manners and customs of the Indians were difierent from those of other people, and are marked with a singularity peculiar to the savage state.

Gravity of Appearance. A gravity of appearance and countenance always engages our attention, when we are in the company of the Indians. Placed in a situation of constant difficulty and clanger, depending altogether upon 


\section{HISTORY OF VERMONT. 181}

lcrato arent. ry lie crati. look indc. ished daui. o entruc. o this duct, milic $h$ and d ac. the ms of d any

ions, claim of a part with tain, reral In. ple, ar to y of our the dif:

himself, and having ever before him pursuits, which to him are of the highest importance, the savage becomes extremely grave and serious. Every thing in his appearance and behaviour, is marked with this gravity of aspect. His behaviour to those around him, is decent and modest. His words are few and significant, and generally upon some matter of business ; scarcely ever for merriment or diversion. So great is their habit of gravity, seriousness, and silence, that it rather bears the appearance of melancholy and sadness.

Treatment of Women. A promiscuous intercourse between the sexes, scarcely ever took place among the human race. The relation of husband and wife, has been everv where understood, adopted, and acknowledge $\mathrm{u}$; and this was universally the case among all the tribes of the American Indians. Where the difficulty of procuring subsistence was not easily to be removed, the man had generally but one wife. Where the means of subsistence were in great plenty, and easily to be attained, the savage had often a plurality of wives. But in general, the Indian family consisted of one man and woman, and their children. This union generally subsisted during the lives of the parties ; but if it became a matter of choice to separate, the marriage union was dissolved, and no cause or ceremony was necessary, but choice and consent. It is not until the refinements of society have taken place, that women acquire the rank, consequence, and importance, to which they are so justly entitled. To despise, to degrade, and to abuse them, has been the vol. I. $\mathbf{Y}$ 
practice of every nation while it remained in the savage state. 'Without tenderness, without delicacy, without refinement, the heart of the savage does not look for pleasure in the beauty, chastity, and modesty ; in the tenderness, deli. cacy, and affection ; or in the attachment, conversation, and retined manners of the female ; but in the labours and menial services she is able to perform. In this stagre of society; marriage is not a tender attachment, or a union of refined and delicate aflections between the sex. es; but altogether an animal inclination, the bare instinct of nature. Placing all excellency in strength and courage, the male views the female as every way inferior to himself ; not fitted for; honourable employments, but ciestined to inferior purposes and services. Of consequence, the condition of women in the savage state becomes degraded, mortifying, and subject to servitude. The savage assigns to his wife the care of the children, the business of labouring in the field, and all the services of domestic care and difficulty. Among the Indians, this degradation of the female was carried to its greatest extreme. Every thing most valuable in food, dress, and ornament, was reserved for the man : the most laborious, fatiguing, and disagreeable services, were assigned to the women. Doomed to incessant toil and slavery, the women perform their perpetual tasks without pity, without compassion, without praise, and without the gratitude of their husbands. To this degraded, unhappy state, were the women reduced among all the Indian tribes. 
Dress. The same pursuit that supplied the Incian with food, provided also his clothing. This was made of the skins and furs of the animals they took in hunting : these scrved the puiposes of covering, and modesty, none of the northern Indians ever appearing naked. In thuse pations where opulence and luxury pre. viil, dress becomes a complicated, a profitable, and a curious art : And beauty acquires new force asd power, from ornament and fashion. licine it becomes a most lucrative business in poiislice socicties, to invent and supply the modes, fasilions, materials, and ornanients for dress. 'The savage rias not without his taste fur ornament, and fashion. His hair was dres. scd in many, and in very singular forms. His nose and ears had pieces of goid, shells, or shining stoncs, affixed to them. His face and skin were painted, with different colours and figures. And, much time was spent to give his countenance the aspect he aimed at. The design of his dress and ornament was not gallantry to recommend himself to the female, but ra. ther war ; to appear the object of dignity, majesty, and fear. And what was extremely singular, all the finery and decoration of dress, was reserved for the man. The share that fell to the woman, was only that which remained, when her husband was completely decked. When he was about to $j \mathrm{r}$.in the council of his nation, or was going forth to war, he was most of all solicitous to appear in his richest ornaments, and finest decorations. A custom prevailed among the Indians, of rubbing and anointing their bodies with grease, oil, and different kinds 
of gums. These were often mixed with differ. ent colours, and formed a very durable paint, or kind of varnish. This may properly be esti. mated as a part of the Indian dress. And it was well adapted to defend the body, against the extreme moisture and cold of the forest and lake, to protect them against the "numerous tribes of insects to which they were exposed, and to check the profuse perspiration to which they were subject, at different times and places.

IDLENESS. When engaged in hunting and war, the savage appears active, enterprising, and indefatigable. But when these favorite occupations are ended, an universal inactivity, and indolence, take place. The time of the Indian is sperit in eating, sleeping, and sitting still. When he applies to any kind of labour, it is with little activity, and with a great aversion. They will spend whole years in making a pipe, forming a canoe, or building a hut. The labours of agriculture, are wholly assigned to the women : Inactive and slothful, the man cannot be roused up to any kind of labour and fatigue. His time is of no value to him : Every thing but hunting and war, is esteemed below his dignity and attention. And of all employments, the lowest and most base, in his view, is digging, toiling, and labouring in the earth. The most indolent, slothful, and contemptible, in civilized nations, have the same idea of honor and industry ; that labour, especially agriculture, is beneath their dignity and honor.

Dirtiness. Cleanliness seems to be inseperably connected with industry, and some degree of refinement. Destitute of both, the sar sels in are ne huts, : garme wear cleanl minds comm are al which rally and $v$ many for th to $\mathrm{m}$ by th falls ment of lal ous, ses, his But tion fran and the 'lo mu 
ages of North America were sunk into the lowest estate of filth and dirtiness. Nothing can exceed the nastiness that appears in their food, in their cabins, and in their garments. The vessels in which they cook and eat their victuals, are never washed. The dirt and grease in their huts, are never removed or swept away. 'Thicir garments are never changed or washed,until they wear to rags, and waste away. No idea of cleanliness seems to have entered inco their minds. 'This seems to be one of the customs, common to all savages : Inactive and lazy, they are all extremely filthy and dirty.

Gaming. Gaming is an amusement, to which indolence and want of employment naturally lead. Above the occupations of labcur, and without a taste for useful employments, many in civilized life seek a relief in gaming, for the pains of indolence; and for a method, to move and agitate a languid mind. Moved by the same cause and motive, the savage also falls to gaming, as the most favorite amusement ; indolent and lifeless in all the exertions of labour, he becomes deeply engaged, impetuous, and noisy in play. Every thing he possesses, is staked at these diversions; and he looses his peace, his senses, and all that he is worth. But these amusements do not issue in contention and quarrels : Though carried on with a frantic eagerness, they are generally managcd, and terminate in good humor and peace.

So ngs. Averse to all abstruse meditations, the Indians are much delighted with songs. To an European ear, their songs do not afford much entertainment nor can such discern har. 
mony, melocly or any variety in their tunes. However this may be, the savages are alwalys delighted with music. 'Their song's are of a grave and serious turn. They never relate to the concerns of gallantry and love, but to their nost serious employmenis. 'They have songs for war, songs for victory and songs for death. Each of them is designed to excite and call forth the sentiments, feelings, and passions, that such occa. sions require; and they have a great influence on their feelings, and actions. Amidst the scverest sufferings of death, this is the resort of the savage; and when burning at the stike, the last conso. lation, is to sing the song of triumph and cleath.

Da N ING. Dancing has been one of tie favorite amusements of all nations. In civilized societies this amusement is dcsigned to $\mathrm{po}$ omote a refinement of manners; aid serves to excite the sensibility, and delicacy, which attaches and refines the sexes. Dancing is also the favorite employment of the savage, in every part of the globe. It calls forth his active pow. ers, which, when unemployed, languish and de. cay for want of cxercisc. And in no employ. ment, does he become more animated, vigorous, and eager. Instead of being an amuscment, an affair of gallantry, love, or refinement, dancing;, among the savages, is a ceremony of great importance and seriousness. With this ceremony war is dcclarcd, an embassador is received, and peace is concluded. It is by a dance, that every important transaction in public or private life, is celebrated. Theirequnces are generally carricd on by the men, eftid it is but seldom that the women are permitted to join in them.

All th are $\mathrm{ex}$ or tral is to 1 the res mies, mean agains perfo: whole warric count1 and $\mathrm{c}$ scaipil the ap appea1 sions these fiercel sented whole feeling repres is the tator groun slaugh also and $\mathrm{tl}$ join $\mathrm{t}$ adapt that ghost and $t$ friend 
unes.

walys

of a

to the

most

war,

ch of

esen-

occa.

ce on

crest

age;

biso.

leath.

e fa.

ilized

p o-

es to

h at.

c.lso

every

polv.

d de.

ploy.

rous,

it, an

cing;

im.

nony

and

ev.

ivate

rally

Idom

hem.

All the steps, figures, and motions of the dance, are expressive ; and significant of the business or transaction, it is designed to denote. If war is to be proclaimed, the dance is expressive of the resentment and rage thcy bear to their ene. mies, and of the hostile manner, in which they mean to treat them. If a party are going forth against their enemies, the dance of war is to be performed. In this, the transactions of the whole campaign are to be expresscd. The warriors are represented as departing from their country, entering that of the enemy, surprising and conquering their foes, seizing prisoners, scaiping the dead, and returning in triumph to the applause of their country. The performers appear to be agitated with all the natural passions and feelings, that take place in any of these scenes. The caution, the secrecy, the fiercencss and cruelty of the warriors, is represented in a natural and animated manner. The whole is designed to excite those passions and feelings in the warrior, which it is designed to represent. And so quick, cxact, and dreadful, is the representation, that the uninformed spectator is struck with horror, and looks to see the ground covered with mangled limbs, and slaughtered bodies. If peace is made, this is also celebrated by a dance. The ambassadors and the warriors smoke in the same pipe, and join together in the same dance. The dance is adapted to signify that the hatchet is buried, that the blood is all washed away, and that the ghosts of the slain are appeased, and at rest ; and that both nations are now to live, in all the friendship and familiarity of brotherhood. 
'Thus instead of being bareiy an amusement aid diversion, dancing among the Indians, is a very important and significant ceremony ; designedto represent some important transaction, and to inspire those feelings and passions, which it should naturally produce. Is it not remarkable, that among the savages in the first stage of so. ciety, dancing should be adapted to public and national purposes; that all the steps, figures, and motions of it, should be arts of imitation; and that among civilized nations, all the steps and motions should be without design, insignifi. cant, and without any meaning at all ?

BEARD. The customs and methods of different nations, have been various and different, respecting their beards. Some have carefully preserved them as the tokens of manhood, gravi. ty, and majesty. Others have curled, twisted, and braided them, to give the appearance of elegance and beauty : Others have entirely cut them off, as an useless encumbrance ; and to acquire greater softness, mildness, and amiable. ness of appearance. These different customs and fashions, do not appear to be derived from any permanent cause, or instinct founded in na. ture ; but to be matters of fancy, supesstition, convenience, or vanity. In this respect the Indians had a custom different from those of other nations. It is their universal and constant practice, to pluck them out by the roots; and to destroy, as far as possible, the appearance of any beard at all. Every man has an instrument made for this purposc : It consists of a wire, twisted round a stick, in such a manner as to draw the hair out of the flesh, and extract the

pont. with stant to ex they can 0 to ex zer, They their beau whic Sc bear not Indi of $\mathrm{l}$ Tha and wea The

Nat

Eu it $h$ oth hav I he hav all anc is civ fic 


\section{HISTORY OF VERMONT.}

root. The Indian carries such an instrument with him : And it makes a regular and con. stant part, of what he esteems his dress, to extract and destroy his beard. So fond are they of this custom, that whenever the Indian can obtain a looking-glass, his first business is to examine his face, and with this kind of twee. zer, pluck out all the hairs he can discover. They generally recommend this custom to their captives, as what would increase their beauty, and destroy their hairy appearance, which the savage greatly dislikes.

Some philosophers have supposed, that the beardless countenance of the Indian, is derived not from custom, but from nature : 'That the Indian is without any beard, or hair on any part of his body, except the eyebrows and head : That this arises from a defect in the powers and vigour of nature; and is an evidence of weakness, impotency, and want of manhood.* The fact and the conclusion, are both mistakes. Nature is the same in the Indian, as it is in the European : And on whatever part of the body it has assigned hair to the one, it has given it to the other. I am assured of this from those who have slain, stripped, and buried their warriors : I have the same information from those, who have been their captives ; and who have seen all the members of an Indian family, dressed and undressed, and in all situations. The same is asserted by those, who have lived among the civilized tribes, and been called to perform offices of humanity, to the Indians of each sex.

* Buffon, Kaims, Robertson, \&c.

VOL. I. 
'The beardless countcnance of the Indian then, is not to be ranked among the curious and ex. traordineiy phenomena of nature, but is to be placed among the customs peculiar to the In. dian tribes.

DRUNKENNESS. Drunkenness is one of those vices, which prevail among a rude and uncultivated people. The savages of North America, are universally addicted to it. Before they were acquainted with the Europeans, they had cliscovercd a composition, or liquor, of an incbriating nature, macle cut of maize or Indian corn. But the difliculty of procuring a large quantity of this liquor, prevented any general intemperance, or cxcess.

No sooner had they tasted of the spirituous liquors brought by the Europeans, than they contracted a new appetite, which they were wholly unable to govern. The Europeans found it the most lucrative branch of the Indian trade, to gratify this inclination. With an avidity of desire altogether uncontroulable, the Indians fell into the snare. 'The first object of inquiry with them, was, whether the trader had brought any brandy or rum; and no considerations could restrain them in the use of it. The old and the young, the sachem, the warrior, and the women, whenever they can obtain strong liquors, indulge themselves without moderation, and without decency, until unircrsal drunkenness takes place. All the tribes whether placed in a temperate, or in a scrcre climate, appear to be under the dominion, and unable to govern this appetite. An effect so unircrsal and similar, must haveasgencral \& universal a causc. The cause 
wi!l be found to have a decp and a strong foumdation, in their manner, custom, and habit of living. Their constant method of living, was on raw or boiled meat, and fresh water. 'This did not satisfy the desires of nature ; and naturally produced an appetite for every thing, which was astringent, stimulating, and inflammitory. When they met with ardent spirit, they found that, which is the most highly gratifying to stich an appetite. The hardships and sufferings to which the Indian was cxposed, their want of comfortable refreshments and support, and the extremes of heat, cold, and moisture, to which they were subject, were constantly adding new force, to an appetite already cxcessive. Few of the white people, who have been reduced to such a situation for a few months, have becn able to preserve their temperance. 'The Indian proved wholly inadequate to the trial. Unaccustomed to lay any restraint on his appetites and passions, and unable to bear but a small quantity of the liquor, to which he had been unused, he is overcome up. on the first trial: His appetite, the more inflaned by irregular enjoyment, becomes more keen and raging, until cxtreme excess puts it out of his powcr to indulge himself any longer. Nothing but a total changc of the whole method of his living, will enable him to preserve that temperance and regrularity, which to a person surrounded with all the comforts of life, is an casy and a common attainment.

CRUELTY. There are no passions in the humanmind, whichoperate with so much forceand ferceness, as those of anger and revenge. The 
customs and maxims of polished societies, with all the aid of their laws and religion, have not as yet been able to give a due regulation or restraint to these passions. In many cases, an offended individual camnot be made to believe, but what it is right and best for hin, to be the judge and the avenger of his own injuries ; and that it is the mark of meanness, to leave it to the laws of society, to make a proper retaliation for the wrongs he has received. Higher attainments must yet be made in the state of so. ciety, before an adequate restraint and regulation will be found for these passions. In the breast of a savage, they rage without any controul : Instead of being taught any restraint, the ycung savage is taught in early lifc, to gratify and indulge them. The whole force of educa. tion, example, custom, habit and manner of living, operate with a decisive influence, to give them new force and vigour. By the government of the tribe, the revenge of injuries is left in the hands of every individual ; and to be patient and moderate, is the highhest mark of meanness and want of spirit. To give further force to the spirit of vengeance, all the maxims and customs of war, have placed the point of honour, in rendering the spirit of revenge, im. placable, unabating, and such as never can be satisfied, subdued or lost. Aided by all these motives and considerations, anger and revenge, become fierce, brutal, horrid, bloody, and implacable passions, in the breast of the savage: More like the destructive rage of a beast of prey, than like a passion in thic heart of a human being. The effect, is a barbarous and unre. 
lenting cruelty : Far from pitying, sparing, or forgiving, the savage aims at the ruin, destruc. tion, and utter extermination of his enemics. Hence the method of carrying on his war, was to destroy men, women, and children. To plunder and burn their towns, and villages : To torture and torment their prisoners : And to swcep off whole tribes, with an universal and un. distinguished carnage. This seems to have been the wish and aim of every tribe, when they engaged in war. A barbarous, unrelenting cruclty, distinguished and marked all their steps.

ThE cruelty of the Indian seems to have arisen from the passions of anger and revenge. It is not to be clenied but that there are other pas. sions, which have carried civilized nations, to the same dreadful extremes in cruelty. Avarice led the Spaniards to perpetrate more cnormous crimes and cruelty upon the Indians, than the Indians were ever capable of returning. The sccne of promiscuous calamity, destruction, murder, and butchery, which the Spania. ds carried through all parts of South America, in the number, design, degree, duration, variety, and enormity of its cruelties, far cxceeded any thing that was ever perpetrated by the Indians. If we are to believe the declarations of a celebrated modern Statesman,* the avarice of a company of merchants, has murdered millions and millions of mankind, by starving them to death in Bengal. The spirit of superstition and bigotry, is equally cruel and unrelenting. The

- Ms. Burke. 
murders of the inquisiiion subsisted for centurics : they were sanctioned by law, and are not yet done away. Imprisonment, confiscation, and death in its most awful forms, were the punishments which bigots, whenever they had power, never failed to inflict with great plcas. ure, upon those who were wise and virtuous enough to oppose them. The massacre on St. Bartholomew's day, in 1572, was one of the most barbarous and hon id of all human trans. actions. In the midst of the most polite city in Europe, the king, princes, nobility, and priests, turned monsters, assassins, and hutcicrs ; and murdered thirty thousand of their fellow men, on account of their religion. "Their rage was attended with circumstances of inhuman cruelty and barbarity, far excecding the fierce and bloody passions of the savages of $A$. merica. Our own countrymen ought not to forget, that revenge has also transported them into a conduct, equally inhuman and barbarous as that of the Indians. At the conclusion of the Indian war, in 1676, the government tried several of their captives, by the English laws: Some were condemned, and executed upon the. gallows ; and others were scnt to consume their days, in the slavery of the West India Islands : A punishment, to them more severe than death. Is the cruelty and barbarity of the Indian, man appears in a situation but little removed from the brutal ferocity of the beast of prey. But when avarice, bigotry, and revenge, produce the same infermal spirit among civilized nations, crucliy appears with a more diabolical aspect; not like the rage of wild beasts, but

like of apo: huma: effecti

Su mann meric phers, Some the in nent sea, a degra men phere ed th man noble alwa socie ness is al finer in it pare mar of $i$ I $\mathrm{HE}$ Bo: nec est tha 


\section{HISTORY OF VERMONT. 195}

like the fury and vengeance of a combiration of apostate spirits. The proyress of knowledge, huminity, and refinement, will afford the only effectual remedy for this evil.

SUCH were the regulations, customs, and manners of the Indians, the original men of $\mathbf{A}$ merica. They have been vicwed by philoso. phers, in the most opposite and contrary lights. Some have supposed that the Indians were in the infuncy of existence, that the whole continent of America was but lately raised out of the sea, and that her inhabitants were in a state of degradation, unworthy to be compared with the men of the more ancient and improved hemisphere.* On the contrary, others have contended that in the rudest and most simple state, man attains an independence, a dignity, and a nobleness of mind, which is never found, but is always lost, amidst the refinements of polished societies : that the highest dignity and nobleness of man, is derived solely from nature, and is always debased and corrupted by polish, refinement, and the arts. $t$ To view this subject in its proper light, it will be necessary to compare the savage with the civilized state, and to mark the various Adrantages and Disadvantages of it.

The Savage Statefavourabie to the Health, Activity, and Vigour of the BoDr. Among the advantages that were con. nected with the savage state, it may justly be estecmed one, and a matter of much importance, that it was favourable to the vigour, antivitr, 
and health of the body. It is by exertion and exercise, that the body acquires its most improved state of activity, firmness, vigour, and health. Accustomed to range the forests in quest of game, the Indian acquired an habit and activity in travelling, that exceeded that of any other people. In the expedition, swiftness and perseverance of his course, he much exceeds the European. No people bear hardship, suffering, and fatigue so well : The extremities of heat and cold, of hunger and thirst, of bad weather, and of bad accommoda . tions, are perfectly familiar to the Indian : And he bears them with a much less effect upon his constitution, than themen who have been used to better accommodations. Unaccustomed to the steady and regular employments of agriculture, his body does not acquire the strength that the Europeanshave. And when the exertion, is anex. ertion of strength, and steady labour, the white man is found to be the strongest. 'Those only of the Indians, who have becn educated and trained up to steady and hard work, are equal to the white men in bodily strength. In running the race, and in bearing hardship, the Indian exceeds; but in strength of body, and bearing hard and stead labour, he is generally unequal to the European.

In respect to health, the savage state seems fully equal to the civilized. Used to all the variations of the weather and climate, he suffered but little from such changes. The diseases to which the Indians were subject, were chiefly those which arose from excrcise, hardships, and fatigues. Fevers, the asthma, and paralytic

disord ry of and $\mathrm{fe}$ luxur cise, Indiat be a solis, equal had 1 no $\mathrm{c}$ age. appes pit at and ty to er se and in th men the firm suffe sava coul lecte And fear. was stall and in h pur 
rtion its ness, the ed an eded tion, \&, he bear The and oda. And h his ed to 5 the ture, t the nex. man f the ined the the exring qual

disorders, made the capital articles in the history of the Indian diseases. But that numerous and fearful train of maladies, which arise from luxury, sioth, intemperance, and want of exercise, were unnamed, and unknown among the lndian tribes. In their villages there seemed to be a greater number of decayed and aged persous, than are generally to be found among an equal number of white people. But as they had not the art of numbers and computation, no exact accounts could be procured of their age. 'This article rests thercfore rather upon appearance, and indication derived from decrepit and shrivelled bodies, than fiom any proper and authentic accounts of the years and longevi. ty to which they attain. All appearances howerer secm to indicate, that activity, vigour, health, and age, were to be found to great -advantage in the savage state.

Favourable to Firmess and Forti. TUDE OF MIND. The situation and cmployment that promoted the vigour and health of the body, tended to produce independence, firmness, and fortitude in the mind. lnured to suffering, hardship, and danger, the mind of the savage was formed to an habitual firmness and courage. His mind became composed and collected in critical and dangerous situations: And he suffered but little from apprehensions of fear. The spirit of freedom and independence was cultivated and confirmed by every circumstance attending his education, employment, and reputation. Neither corrected nor checked in his early years, retarded or stopped in any pursuit, le knew of no controul or restraint.... VOL. I. $\Lambda 2$ 
Master of his own actions, and never wishing to moderate his passions, the spirit of freeclom and independence took the entire possession of his soul. Moved by and perpetually conscious of this independent spirit, he acted in circum. stances of distress and danger, with amazing force and magnanimity of mind. But that which the savage esteemed his greatest glory and highest dignity, was his fortitude and bravery. 'To bear hardship, to enclure suffering, to be unmored in the midst of torment, and to rise superior to any thing that could be laid upon him ; this, was the highest honour, and the noblest attainment of the warrior. And in this, it is not to be denied, that the human nind attained in the savage state, a fortitude and a magnanimity that it does not attain, amidst the refinements, cusioms, and maxims of polished na. tions.

AMAZED at the firmness and fortitude, which the savage displays in the most dreadful of all situations, several philosophers have aimed to discover some apathy, some natural defect, or want of sensibility in his frame, which qualified him to bear pain with less feeling, and with more fortitude, than other men. There is no such defect in his constitution. His magna. nimity arises from a sense and principle of honour. This is the first principle he is taught; the sole object of his education, profession, and pursuit. Amidst the rudeness and hardihood of the savage state, this principle acts with more force and vigour upon the human mind, than it ever acquires amidst the refinements and softness of a more polished state of society. 
Refincment, and the arts, soften and relax the mind ; philosophy debilitates the body, while it aims to correct all rudeness and cxcess in the mind, and to grive it a just habit and tone of thinking and acting : But in the rudeness of the silvalge state, every thing concurs to give an unaltered firmness to the body, and to the mind ; the principle of honour has nothing to opjose or relax it : And it will be in the most hardy body and mind, that nature and honour will act with the greatest force and vigour. The principles of religion only, have ever produced a simailar phenomenon. The heroic spir. it of the martyr, undaunted and triumphant in the torture, and in the flame, has alone exceeded or equaliced the fortitude and magnanimity of the man of nature.

Favourable to Political talents, and Virturs. The savage state was also friendly to some of the political talents and virtues. The love of his country, derived from nature, cherished by education, ambition, precept, and example, became a very powerful principle in the breast of a savage. His affections were confined to the limits of his own tribe, and his views never extencled any further. His giory terminated in the services he could render to it : And the greatest of all attainments was to expand the national fame, reputation, and conquests. 'To this he becane attached by birth, education, and interest ; by ambition, honour, and a thirst for glory. Every passion that glowed in the breast of the savage, served to increase and add strength to the love of his country. No motives of ambition, gain, re- 
venge, or policy, cver lead him to betray its in. tcrests or councils, to desert to the enemy, or to prove a traitor to the country and tribe, that gave him birth. This principle connected to. grether the member's of the same tribe : It seems to have taken the deepest root, to have acted with the greatest force, and to have been the least corrupted, in the savage state.

WH $\mathrm{N}$ the interests of their country were to be considered, much prudence and wiselom were displayed in thcir councils. The chicfs and clders consulted with great deliberation, seriousness, and calmness ; and without any appearance of provocation, resentment, or impatience at contradiction and opposition. Every proposal was considered; the probabie effects and consequences, advantages and disadvantages, were examined and woighed. $\nu^{\top}$ o heat, anger, ill nature, or reflections upon one another, but perfect calmness prevailed : And that conclu. sion was embraced, which appeared to be most bencficial to the tribe. Those of the Europeans who have attended these councils of the savages, have compared them to the accounts, historians have griven us, of the proccedings of the senates in the ancient republics, * They bore the appearance of solemnity, gravity, and deliberation. In these councils, integrity and public virtue was always preserved. 'The ob. jects they had to determine, were not of a trivial or insignilicant nature : they were those, which involve all that is the most dear, valuable, and important to man, in any stage of society : The

* Charlevoix iii. 26. Smitd's Fliat, Newyork, f.5g. Phil. Edit.

'Ther

dissir

that the $g$ was was play rirts 


\section{HISTORY OF VERMONT. 201}

prcservation and protection of their property; the safety and the lives of their wives, chilclren, and fathers; the existence, the independence, and the freedom of their country. The coun. cils of civilized nations may be employed upon objects of a much greater extent; but they never can contemplate objects of more importance, of greater value, or of a higher nature. In attencing to them the mind of the savage became composed, sedate, grave, and serious. He liad no private interest to corrupt him; no broken fortune to be repaired; nothing to be cxpected from the misfortunes of his country; from lucrative jobs, posis of honour and profit; from the management of the public wealth ; or from the weakness, prejudice, and favourite passions of a prince. No emoluments or ad. vantages could accrue to him, but those of the public good. In such a situation, corruption would not enter into the councils of the savages. There was nothing to be gained by intrigue, dissimulation, or knavery. All the advantages that could arise to individuals, must arisc from. the general good of the tribe. And where there was nothing to be gained by corruption, there was nothing left for their counscllors, but to dis. play thcir greatest wisdom, integrity, and public rirtuc.

'T In E nature of their government and councils was also favourable to eloquence, and the art of fuiblic speaking. This seems to have been the only art, in which the Indian rose to any eminence. Unable to remember an irrcgular unconnected discourse, the Indian was extremely fond of regularity and method. When he spoke, 
his specch was shoit and laconic; and the ments. ing irus conveyed in bold and strong metsy lon"s. when ther retum an answer, they repeat hive rlooic that has been said to thom, and reduce it into a striet and reguhar order. The ir woods are but feiv; the binguage strong, and figuritive ; the figures expressive, vigorous, and bold ; the ir mance, grave snd mimating; the tone, determined and decisive; and the sentimert they moan to convey, so elcarly cxpressed, that they are never misinderstood. An listorian who was present at several of their conferences wih the English, gives this account of the aprearaiace and nuaners of their orators, "Tletr: speakers dcliver thensclves with suprising force, and great propricty of gesture. The fiercencss of their countenances, the flowing blanket, dievilied tone, naleed arm, and erect stature, with a helf circle of auditors scited on the ground, and in the open air, cannot but inpress upon the mind, a lively idea of the ancient omitors of Creece and Rome." Some of their specele": in manliness of sentiment, in the force of expression, and in the elegunce of the armonemen, have been fully counal to the productions of the Grecin, Roman, or British clocuence. And in no case docs language acpuire such force and vigrour, as when it is the dictate of the puscions and feelings of nature, in her rude and unculti. vitted state.

It was by the combination of these virtucs and abilities, that the savage rose to public honouis, cmpleyncint, and distinction. The bri:

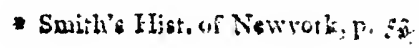

cistind secheir !ic cosic exploit $\operatorname{rocod} 1$ cations this id distins: misn $n$ in unl lust al in state, to the virtuc corrs relate is in amor tues, was anci port 


\section{HISTORY OF VERMON'T. 203}

cond the wisest became the leader, and tile sachem. No other arts could secure the pub. lic esicem and farour, but superior 'silities and a:ploits. The ancients generally numbered good lontme, among the most necessary qualifications of their heroes. The Indians adopted this idea in its lull force, and extent. Without distinguished bravery and suceess, the privite man wats never promoted at all : If he proved an unfortunate and unsuccessful leader, he soon lost all his infuence and repatution.

in these maxims and customs of the savage state, there were constant and powerful motives, to the exertion of all their political talents and virtues : And there was much less intrigue and corruption in those public procecdings, which related to thei: own tilbe, than there gencrally is in the transacticus of civilized societic's.

Eavourabie to the Exercise of SOME Vintés. Several of the vices that prevail among polished nations, were seldom to be found among the Indians; and there were some virtues, to the excreise of which, the savage state was not anfriendly. The hospitality which the ancients celebrated so much, was of great imporrance and use in the early stages of socicty. When the stranger and traveller could find no accommodation or protection, but in the kindness of those on whom he called for relief, hospitulity became a virtue of the highest use and excellency : the business and convenience of life, could not have been easily carried on without it. As society bccame improved, the stranger found in the protection of laws, and in the use of money, that relief, which he before de. 
rived from the hospitality of the ag;a. In poi. ished nations, the necessity and the existence of this virtue, have in a great measure ceascd. Among the savayes it prevailed to an high de. gree, and acted with its full force. The liuro. peans every where found the most fricndly and cordial reception, when they first came among the savages; and from their hospitality, they derived all the assistance the savages could at. ford them. It was not until clisputes and clif: ferences had taken place, that the Indians be. came unfriendly. Liven now, an unarmed defenccless stranger, that repairs to them for re. lief and protection, is su ce to find safety and assistance in their hospitality. The firendship of the Indian, is always a very strong and vigorous affection. His passions unsubdued, undisciplined, and ungovemed, always act with great force and vigour : Whatever ic the object of them, the passion itself is alwas impetuous and strong. No Lounds are set to his resentment and revenge, when injured; and no length of time, will obliterate the memory of a favour. The same impctuosity and perseverance, with which he pursues his enemy, is employed to as. sist and preserve his friend. In this respect, the Indian attachments have fully cqualled any thing that is to be found, in the history of man. Several of their best concerted expeditions have failed, through the anxicty of an individual to preserve a friend from the common vengeance and destruction.

TRAINED up to the most refined cunning and dissimulation in war, the Indian carries nothing of this into the affairs of commerce; 


\section{HISTORY OF VET \IONT. 205}

but is fiir, open, and honest in his trade. was accustoned to no falsehood or deception in the management of his barter. And he was astonished at the deceit, knavery, and fraud of the European traders. He had no bolts or locks to guard against stealing, nor did he ever conceirc his property was in any danger of being stolen, by any of his tribe. All that train of infaunous and unmanly vices, which arise from avarice, were almost unknown to the savage state. Lying and falschood were viewci with horror, and detestation. When they found these vices common among some of the Europeans, the Indians viewed them as a corrupt and odious race; in whose truth, justice, and cieclarations, no faith could be placed. 'They had no name for adultery, or rape. Quarrelling, contention, and discord, with their numerous ill cffects, were but little known among the members of the same tribe.

'Tieir morality, confined to a few objects, admitted of fewer vices than the civilized state. Where no wants are known but those of nature, and the way to supply those wants is the same, and open to all ; the individuals of the same socicty, will live in a friendly and cordial manner tosether; without many grounds of strife, and without much temptation to injure each other. In the language of the Indians, this is denominated a state of brotherliood : In this state, the moral sense will join its influence with the social affections, to prevent injuries, evils, and viccs; and to restrain the members of the tribc, from violating the rules of morality. As such a state does not adnit of many of the virtues of

$$
\text { VOL. I. B ? }
$$


civilized nations, it is also in a great measure free, from many of their nost dangerous vices.

In such respects, the savage state seems to have had advantages peculiur to itself ; and to have produced etficts, which are not to be ex. pected anong civilized nations. But before we decide on its opcration and tendency, it will be necessary to cxamine the disationtages, to which it is subject; with their influence, and effect on society.

The Savage state unfavorable to

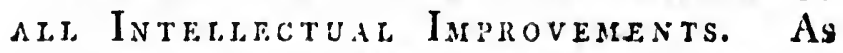
one disadvantage of the sarage state, it has constantly proved unfivourable to all intellectual improvements and excrtions. Occupied solely with hunting and war, the sarrige had no idea or wish for any intellectual attainment, which was not immediately connected with his favour. ite professions. Neither his reason, nor his invention, appear to have been much exercised upon any objert, not suggested by his necessi. ties. 'laking; the game, and subduing his enemy, did not depend on the knowledge of letters. The transactions of his ancestors, were not of much importance to him : He had no code of laws, no evidences of property, or any public transactions to be recorded. With these arts, of so much importance to civilized nations, but of little consequence to the Indians, they were wholly unacquainted; and had not made any advance towards the ciiscovely of letters. The only thing which they appcared anxious to record, was the exploits of their warriors. When a party of these had met with uncommon success, it was often the case that they made some 
very rough figures or inscriptions upon the trees, to represent the direction of thcir march, the number of enemies which they had slain, and taken captive.* These lind of inscriptions were sometimes made upon the rocks; but they were not confined to the affiurs of war. At West river in this state, ncar its entrance into Connecticut river, several of these inscriptions yet remain. 'They are irregularly placed, and rudely scratched upon a rock, and but little sunk below its surface. Four of them seem designed to represent the wild duck, and the fifth was probably designed for a fox or wolf. At Bellow's falls in Rockinghan there ale several figures of a superior work. They amount to ten or twelve in number, and are wrought into the surface of the rock. 'These inscriptions represent a number of heads; some of $\mathrm{men}$, some of women, some of children, and some of other animals. 'The outlines of these figures are aukward and ill executed, but they are sunk into the rock at least one third of an inch in depth. How long they have been there, or what transactions they were intended to repre. sent, no tradition gives us any account; but their rudeness and awk wardness denote that the formers of them were at a great remove from the knowledge of any alphabet. The art of mumbering and computation, is an elementary and essential art in every nation where business is transacted, or any considerable intercourse and commerce is carried on. But the savage had nothing to number, that was of much im

- Sir W. Johnson'u acesupt: Phil. T:ans. Vol. L.X.111. page 343. 
portance to him. He had no treasures to count : no property, the value of which, was to be com. puted; nor any variety of objects, the number and value of which, must be expressed by fig. ures. Arithmetic would thercfore have been an useless art to the Indian; and he had not macle any attempt to attain it. They couli count as fạr as ten or twenty ; all beyond this, was compared to the number of the trees, or the hair on their heads. "The only objects, on which the Indian had employed his reason, were those of external sense ; such as are material or corporal, the idca of which is received by the senses. 'They had no name for any of the sciences, or for abstract and minersal icleas. 'Time, space, cluration, substance, and all thoso terms, which are used to represent abstract and universal ideas, appcar to have been unknown ; and probably never werc the objects of their in. quiry, contemplation, or thought.

THe ideas of religion, were extremcly weak and obscure in the savage. Our Muker has not left us to a course of metaphysical rcasoning upon the connexion between cause and effect, to come to the knowiedge of his existence. Long before men become capille of such exercises of the reasoning powcrs, they believe in the existence of a Deity. A scinsc of his being, seems to be inscribed upon the human mind. And probably no tribe has ever been found, that had not the idea of some superior powerful being. Whether this was the object of fear, or of love, or however it was represented, the idea of a superior being seems to have been common and general among all nations. It takes plaçe 


\section{HISTORY OF VERMONT. 209}

in the mind, before we are capable of reasoning about cause and effect: And it secms to be derived from a revelation, which the Dcity hath made of himself to man. In the constitution of the human mind, in its feclings, passions and motions, a sense of the I)eity scems to be interwoven, instamped, and inscribed. And this revelation bccomes more clear, plain, aud intelligible, according to the manner and degree in which it is improved. Among the Indians, it appeared in its weakest and most obscure state. "They denominated the Deity, the Great Spirit, the Great M/un above; and scemed to have some gencral, but very obscure ideas of his government, providenee, universal power, and dominion.

THE immortality of the soul, was every where admitted among the Indian tribes. The sentiment itself results from our fears, hopes, and feelings. Man is scarcely ever degraded and sunk so low, but that he hopes and believes that death will not prove the extinction of his being. 'This sentiment prevailed in every part of America. The Indians so firmly believed it, that it was their gencral custom to bury with the clead, their bows, their arrows, their spears, and some venison, that they might not be wholiy unprepared to begin their course with advantage, in another state. There might be a few exceptions, but the general sentiment was nearly the same in every part of the continent.

But both these sentiments, the existence of a God, and the immortality of the soul, were nothing more in the savage, than the dictate and vice of nature. They were not the object of 
his inquiry, discourse, reasoning, or contempla. tion. The Indians had made no improvements, no cultivation of the grifts of nature and provi. dence ; and they had very little influence on any part of his conduct. They had not produced any domestic, or public devotion; any form, rite, or mode of worship; or any system of manncrs and customs, favourable to national virtue and religion. Without a priest, without a temple, sacrifice, or altar, the Indian was sunk under the thickest gloom of ignorance, superstition, and stupidity.

His reason, never employed on any intellec. tual attainment or exertion, he remained in a state of nature; wholly unacquainted with eve. ry thing derived from the exercise, improve. ment, and cultivation of the powers of the mind. Neither his reason, or his desires, ever moved or tended towards any such improvements : And so long as hunting should have continued to be the mode of his subsistence, so long it is probable, he would have remained at a distance from every intellcctual attainment.

Anmits of but few Virtues. It was another disadvantage of the savage state, that it did not admit of but few virtues. The moral sense, or conscience; makes part of our natural constitution ; and is as essential to man, as his appetites and passions, as his countenance and form. When this is not corrupted or perverted, its dictates are clear and right, and do not tend to mislead us : And its dictates are never more clear and certain, than when they are the genuine and simple voice of nature. There were fewer temptitions and there were fewer vices in

the sa

ral sen ciety casion ence : or effe There those soften life, $\mathrm{i}$ indep heart for to Depe savag rougl ions. other the d the d cd, affec and man few tion. $\mathrm{N}$ mer kno erin mo hav the apt 
empla. ments, provi. on any duced form, em of tionat ithout sunk persti.

cllec. in $a$ eve. rove. nind. coved ints : nued it is ance

the savage state, to corrupt and pervert the mo. ral sense, than there are in a polished state of society : But there were also fewer motives, oc:casions, and opportunities for virtue. Reverence and respect to the Deity, had little place or effect on the uncultivated mind of the savage. There was nothing in his situation to produce those offices of kindness, and tenderness, which soften the heart, and sweeten the intercourse of life, in the civilized state. The sullen pride of independence, was the strongest passion in the heart of the Indian; and it left but little room for tender and generous affections to others. Depending solely upon himself, the heart of the savage contracts an insensibility, an hardness, a roughness, very unfavorable to social connexions. Expecting no ofices of kindncss from others, he was very little employed in relieving the distresses, supplying the wants, or gratifying the desires of others. In a heart thus contractcd, but few virtues will reside. The natural affections will remain, and may become strong and vigorous: But the divine, social, and human virtues, find an unfriendly soil ; become few in their number, and weak in their operation.

No Atrainuent in the Arts. Those arts, which are the most necessary and useful to men in the civil state, were almost wholly unknown among the savages. To provide a covering to defend the body against heat, cold, and moisture, is one of the first arts that mam must have attended to. The Indian had gone no further in this primary and essential art, than to apply the skins and furs of animals to this pur- 


\section{2}

\section{NITURAL AND CIVIL}

pose. The art of spinning, knitting, and wcilin ing, were wholly unknown to the northern it. dians. They hicd no other matcrials to cover and clothe their bodies, than what were derived from hunting. " rchitecture of! sone kind and form, must univoidably engage the attention of men, in every climate and conntry. The attainments of the Indians in this art, were the lowest that can be conccived. Their buildings were nothing more than a few temporary and wretehed huts, put together without orcler, strength, or convenience. Some crotched stakes were thrust into the ground: these were counected by poles, laid from the one to the oth. er ; and the whole was covered with the bark, limbs, and leaves of the trecs. An aperturs was left at the top, for the conveyance of smoke; and the fire was kindled in the middle. This was called a cabin or wigum, and was without windows, doors, or any division of apartments. 'This was the highest clegance and convenience, the house of the Indian had attained.

The progress of the arts, depends very much on the instruments and tools, with which the artificers are furnished. Most of these among civilized nations ate derived from the application, and use of the metals ; particularly that of iron. From this metal is formed almost every instrument, that is employed in peace or in war. Civilized nations have availed themselves of the discovery and use of this metal, in every kind of art that they pursuc. The Indian was in no capacity to arrive to such an improvenient. Copper, silver, and gold, have been found in their perfect state, in the rocks, mountains, and 


\section{HIISTORY OF VERMONT.}

rivers; and were the metals, which were first known and used. But nature never completes the formation of iron. It must pass through two or three tedious operations by fire, before it appears in its perfect and useful form. With the former metals, the Indians in some parts of America, were well acquainted: But of the nature and use of iron, all of them were wholly ignorant. Destitute of this capital advantage, all their tools and instruments to an European; would have been wholly useless. Their axe was made of a sharpened stone. Their knife was formed out of a shell, or bone. Every other instrument was equally impotent, and ill contrived. The arms they had contrived for defence or attack, were equally feeble and awkward : A club made of hard wood, a stake hardened in the fire, a lance armed with a flint or a bone, a bow and an arrow, constituted the whole artillery of an Indian war. Of domestic utensils and household furniture, they had nothing that deserved the name. A bed, a chair, a table, a pot, a kettle, or an oven, were wholly unknown. Their bread was baked on the coals. Their meat was broiled in the same manner. Their greatest art in cookery, was their method of boiling their food. A piece' of wood, or a stone, with extreme labour, was formed into a hollow, and filled with water; and this water was made to boil, by throwing into it stones heated res. hot.

'T $\mathrm{E}$ greatest performance of the Indian gen.' ius, was the construction of his canoe. With infinite labour, they sometimes hollowed out a tree, and gave it a form adapted to the purpose vot. $x_{0}$ C 2 
of navigation. In a canoe thus formed, four of five indians would pass a river, a large lake, or a dang arous rapid, with much safety, and dex. terity. Another kind of canoe, was formed out of the bark of the clm, or birch. This was the work of but a few days, and was cxtremcly light and convenicnt. It was of sufficient dimensions, to carry four or five Indians; and so light, that cae of them could casily carry it on his back. The dexterity of his management, the swifmess of $1 . i$ voyagre, and the safety with which the Indians pass the falls, rapids, and waves in this kind of boat, has appeared surpri. sing to those persons, who were best acquainted with the arts of navigation. And it seems to have been the lighest attainment, to which the genius or invention of the Indian, had ever arisen.

IN the application an 1 use of particular vegetable, animal, and mincral substances, the Indians seem to have had some information, which ought to have been more attended to, and better ascertained. They certainly knew of some substances, which gave the most vivid and permanent colours ; and of others which contained the most subtle, active, and powerful poisons. In several cases of poisons, wounds, and some other disorders, the Indians had the knowl. edge of very valuable medicines : And they derived support, refreshment, and medicine, from several plants and vegetables, in which the English had not discovered any such virtues or qualities. The knowledge of such facts, was the result of such observations, as experience maturally produced. But as the Indian never 
attempted to improve any information which he had, and knew of no method to preserve it but tradition, he made snall advances in this kind of knowledge; and it was rather a inatter of secrecy, than of investigation. Nor was there any thing in his situation, or employment, adapted to call fortl the latent powers of his mind, and to produce the spirit of inquiry and improvement.

Very Unfavourabie to Population. $A$ disadvantage still more unfavourable attended the savage state, it tended much to retard population. From the earliest histories of Virginia, it has been computed that the number of Indians in that part of the continent, did not amount to more than one for every square mile.* I do not find any account, which will lead us to estimate the number of Indians in New England, at a higher ratio than this. In those parts of the United States where the farms are well maniged, a farm of onc hundred acres will well support a family of ten persons. This amounts to sixty four persons, on one square mule. 'The Indian population then, compared to what has alieady taken place in those parts of the United States, which are well settled and cultivated, was in no higher a proportion than one to sixty four. A difference so unfavourable to the production ol life, denotes some esscntial defect in the savage state.

Poputation depends upon a variety of circumstances, all of which are ncver found to concur, in favour of any people. In the state

- Jeffercon's Notec on Virginia, p. $>=0$. 
and situation of the Indians, there were fewei circumstances favourable to population, than in any other state of society. In the constitution, form, and vigour of his body, nature was bountiful to the Indian, In the dimensions and size of his body, in the proportion and perfection of all his limbs, members, and organs, he rather excceded than fell short of the European. All that have been acquainted with the savages, have been struck with this circumstance. In no race of men, has the human body appeared to be better formed, morc nicely adjusted, or to be more perfectly proportioned in all its mem. bers and parts. No deficiency therefore arose from any impotency, or want of vigour, in any of the powers of nature.

Bu $\mathrm{T}$ whatever may be the original powers of nature, they are weakened and impaired without proper food, and nourishment : And it is only, where suitable and nutritive food is to be obtained in regular and sufficient quantities, that animals will become the most prolific. In this respect, the situation and state of the savage, was greatly unfavourable to increase and popu lation. Destitute of any certain or regular food and nourishment, the Indians suffered severely this way. At one period, all was gluttony and excess ; at another, famine and hunger became extrenie and distressing. The heaviest part of this distress fell upon the women, who were the least able to bear it : And at no time did they enjoy that regular and steady supply of food, which nature required. In the male, this tended to impair the animal passion : In the female, it tended not only to weaken it, but to render it 
greatly dangerous to indulge it. Its effects were still worse upon the pregnant; and often destroycd the increase and fruit of nature, before the birth

TH E manner in which the Indians procured their food, was equally unfavourable to population, as the uncertainty and irregularity of it. Destitute of a fixed scttlement and abode, the savage spent the hunting season in wandering through the forests in quest of game, and generally carried his family with him. Their women must climb the mountains, wade through the rivers, force their way in the thickets of the forest, sleep upon the wet ground in the open air, and carry their children with them ; and amidst all these fatigues and distresses, were often without food for several days, and always without comfortable refreshment. Instead of being in any degree prolific, the white women would have all perished in such a situation. The wonder is, not why population should have been so small, but how it should subsist at all, in such a situation. If the constitution of the savage had not been uncommonly strong and vigorous, not only the animal passion, but all the powers of nature would have ceased and become extinct, by such continued scenes of fatigue and distress.

THE constancy and perpetuity of their wars, had also a fatal influence on population. The irruption of an enemy desolated their cultivated lands, disturbed them in their hunting exertions, and destroyed all the little stock of provi. sions they had saved. The women and children had no place of refuge, but to conceal 
themscives in the woods, and mountains; where matiy of them must perish for want of food, and all o! them nust be in a sufering and distressed condition. In the whole catiloguce of human wocs, it is not possible to conceive of any state more distressing, than that of a pregnant lloman, in a situation so horrit? and awful. Bimy of them lived, and brought fortl the firuit of nature, anidst this complication of miseries. But the prescrvation of the mother and child approached newrer to the nature of a miracle, than to what is estcemed the cficet of the cistab. lished and regular laws of nature, in the cirilized state. While their wars had this fatal tendency to prevent the increase, they operated with a force equaliy fital, to destroy and sweep off those that were the most vigorous and active. Revenge, destruction, the utter extermination of an enemy, was the object aimed at in an Indian war : And while it was carried on, it operated and raged with a fatal and a cortain tondency, to effect its design, aim, and cncl.

Other causes night be found, in the cuszoms, manners, and maxims of the savages, which were also unfavourable to increase and multiplication; but it is not necessary to enumerate every particular, that would apply to this subject. The circumstances which have been mentioned, are sufficient to account for all that has been uncommon, in the defect of Indian population. 'That these circumstances, do in fact contain the causes, which rendered the popu.ation so small among the savages, is collfirned from this additional evidence. Wherever the Indians have been placed in a situation ral of marric rome able $f$ licred salliag nume of the witen $\mathrm{er}: \mathrm{ab}$ gime eil by creasc estues force Is adval some statc. numl amor the $\mathrm{s}$ finen wom their tach empi mad And rapic ance boul fami 


\section{HISTORY OF VERMONT. 213}

hacr:

furcurable to increase, they have become equally prolific as the descendants of Europe. Several of the traders annong the Indian tribes, have marricd with their women: When the Indian women have been thus provided with comfortable food, raiment, and places of abode, and relicred from the firtigues and distresses of the sarage sialie, they have raised up as large and numerous familien, as are found in the houses of the whice people. And among themselves, when a tribe was situated on the baik of a rivcr abounding with fish, or in a spot where the gane wats plenty, and they romained undisturbell by their cnemies; their numbers soon increased, their women became more valucel and esicemed, and population assumed a greater force and vigour.

Is some parts of America, the Indians had advanced berond the savage state, and acquircd some of the arts and conveniences of the civil statc. In such places, the same increase of numbers took place among them, that is scen among other nations. The intercourse between the sexes approached nearer to delicacy and refinement. Greater attention was paid to the women. The men became sensible, how much their happiness might be promoted, by the attachment and tenderness of the female. In the empires of Peru and Mcxico, the Indians had made considerable advances to such a state : And their population had become vigrorous and rapid. 'Their numbers resembled the appearance of things in Europe ; and thcir cities abounded with inhabitants. Sixty thousand families, were said by Cortez, to be contained 
in the city of Mexico, when he led his band of ruffians against it. From these effects we may determine with certainty, that the defect in the Indian population, was not derived from any weakness, impotency, degradation, or defect of mature ; but arose from a situation, in which every circumstance was unfriendly to increase, and multiplication.

From $_{\text {R }}$ the beardless countenance, and inattention of the Indian to the female, some philosophers of great eminence and abilities, have formed the most extravagant systems and theories. One has asserted that the Indian of A. merica has an inferior constitution to the Europcan ; that he is weak, and deficient in the or. gans of generation ; without ardour, and impo. tent with the female; and destitute of natural affections to his wife and children.* Another is positive that he is not descended from the common parents of the whites, but is a distinct, separate, and inferior order of men to them ; of a different original, and species. $t$ And it scems to be gencrally asserted and believed, by the historians who have quoted these accounts, that the man of America was of less force, energy, and vigour, than the man of Europe; and laboured under some physical defect, or degradation.

$T_{H E}$ clearest proof, and the most unexceptionable evidence, ought to have been produced, before a philosopher admitted as facts, things so repugnant to the general principles and laws of nature. Had this been attempted, it would

M. de Buffon, xviti. 146 .

Kaimb' Sketohes Hist. of Man, Vol. I. Skotoh I. Vol. III. Sketeh 12e 


\section{HISTORY OF VERMONT.}

have corrected the error; for the facts are all in opposition, to what has been so often asserted, and quoted. No such animal was ever scen in America, as the Indian M. de Buffon described in Paris. If the facts had been true, the conclusions which have been drawn from them; *ould have been wholly uncertain. The want of a beard would have been no proof, that the Indians werc incapable of population : And tie want of that excessive licentious ardour, with which the nogro and the libertine glows, is in no degrce unfriendly to population. Every passion carried to excess, tends to weaken and enervate the whole animal frame. In obedience to that temperance, purity, and regularity, which nature enjoins and requires, are we to look for the effects, which nature designs. But the ardour produced by luxury; intemperance, and excess, weakens its own powers, defeats its end, and destroys its purpose : Instead of proving fivourable to population, it tends to weakness, impotency, and the loss of manhood. Is it not surprising, that philosophers who had seen the debilitating and degrading effects, which luxury, intemperance, and exceşs, are constantly producing in the populous cities of Europe; should view the unnatural ardour they create, in any other, than an unfavourable light? Or suspect the Indian was inferior by nature to the European, because he did not appear to be governed by that unnatural ardour, which never fails to debilitate all the powers of nature: And which often ends, in the most emaciated and degraded siate, to which man can be reduced ? Happily for himself, the Indian was without this unnatu.

vGL. $x$. D 2 
ral ardour. Had it been added to the other unfortunate circumstances attending his situation, it would have gone far to have destroyed the whole race.

Averse to all Improvements. The most fatal circumstance of all, was, the savage state was extremely averse and opposed to all improvements. It is with a benevolent design, that nature reconciles and conciliates the mind of man, to that state in which it is placed. At the same time, it has made us capable of continual advance and progression, to greater im. provements and perfection. So attached was the savage to the former, that he had no wish or desire of the latter. Content and satisfied with his own state, he had no wish, hope, or conception, that it could be changed for a better. Accustomed to the most perfect freedom and independence, he beheld with detestation, the inequality of rank, and the subordination established among the Europeans. Free from all care, and without foresight, he was amazed at the anxiety, the care, and perpetual industry of the white people : And could not conceive why they should be thus perpetually adding hard labour, to the other calamities of life. The constant scenes of hurry, care, and business, in which they were employed, werc objects averse to all their feelings and wishes : And what they viewed as the most degraded condition, to which man could be reduced, was the business of agriculture, digging and labouring in the earth. The weapons of the Europeans appeared usefiul to them, and these they were at much pains to acquire. But most of their arts, customs, and 
manners, were greatly disagreeable to men, accustomed only to the business of hunting and fighting. Men thus satisfied with their own condition, and averse to that of others, could not be brought, but with great difficulty, to ad. mit the improvements of the civilized life; or to give up that independence, which they esteemed the highest distinction, and the greatest glory of man.

THE appetite for the hunter's state, is one of the most general and powerful, that prevails in any period of society. Men never quit this state, until it becomes inadequate to their subsistence and support. It is in hunting and in fishing, not in agriculture and the arts, that the indolent and wealthy in the most polished nations, find their favourite amusement and exercise. The children of the white people, when carried among the savages in early life, have often contracted such an attachment to that state, that they could not be persuaded to return, and reside among their friends. But nothing can reconcile the children of the Indians, to the customs, manners, and methods of living among the Europeans : However caresscd and indulged, they droop and languish, until they return to the freedom and wildness of the forest.

Nor was there any thing in the savage state, that could refine or improve itself. While the game continued, the same method of living would have remained : And this would naturally have continued all the disadvantages, and habits of the savage state. The same method of support, would have perpetuated the same manners, maxims, and customs. Nothing: 
would have led a people in such a situation, to any improvements, until necessity should have introduced agriculture ; and forced them to be. come husbandmen, instead of remaining hun. ters.

Sucr. were the disadvantages attending the savage state. They appear to have been inseparably connected with it : And of such a nature, as to prevent the improvement, progress, or increase of society. We need not hesitate to pronounce, that these disadvantages far exceeded any advantages that could attend it; and operated with a certain and fatal tendency, to continue man in a state of infancy, weakness, and the greatest imperfection. The freedom to which it lecd, was its greatest blessing ; but the independence of which the savage was so fond, was nevẹr designed for man : And it is only in the improvements of civil society, that the human race can find the greatest increase of their num. bers, knowledge, safety, and happiness. 


\section{CHAPTER VIII,}

OrIGINAL InHaBtants. Observations on the Origin of the Indians, their Antiquity, Progress of Sooiety, and Tendency to Dissolution.

THE Man of America differed in so many respects from the men of other countries, that it has been made a question among some of the modern philosophers, whether he was originally derived from the same parents as the white men ; or ought to be considered as a different race, from the men of other countrics. No inquiries have the appearance of greater difficulties than those, which rclate to the origin, and antiquity of the American Indians. With. out attempting to resolve all the questions that have been proposed upon these subjects, it may be of use to collect some of the facts that secm to relate to them, and to note the conclusions to which they lead,

ORIGIN. In whatever manner- this part of the earth was peopled, the Indian or the Red Man, seems to have been the most ancient, or the original man of America. This race were by far the most numerous; and they had spread over the whole continent, from about the fiftieth degree of north latitude to the southern cxtremity of Cape Horn. This vast extent of comtry, including all the variety of climates, with the red men : And these me. appeared to be the same race, or ] In every part of the continent, the 
marked with a similarity of colour, features, and every circumstance of external appearance. Pedro de Cieca de Leon, who was one of the conquerors of Peru, and had travelled through many provinces of America, gives this account of the inhabitants : "The people, men and women, although there is such a multitude of tribes or nations as to be almost innumerable, and such diversity of climates, appear never neless like the children of one father and mother."* Ulloa, an able philosopher, and an accurate ob. server, visited and observed many of the Inciian tribes and nations, of South America : He observed also the Indians at Cape Breton, in North America ; and saith of the latter, that they were the same people with the Indians of Peru, resembling them in complexion, in manners, and in customs ; the only visible difference, being, that the Indians at Cape Breton, were of a larger stature than those at Peru. "If we have seen one American," saith he, "we may be said to have secn them all, their colour and make are so nearly the same." $\dagger$ And it is worthy of remark, that no nation or people upon the earth, ever have spread over so large a tract of coun. try, as these red men of Americal.

WERE these men the same people with the inhabitants of the other parts of the globe? Or did they radically differ from the men of all other countries? 1. They were of the same complexion, with the most ancient nation in Asia. From authentic documents, we are able to trace the existence, and national transactions of the

* Ruberrson's Hist. America, Vol. I1. p. 462. note 45.

; Ulloa, Notie. Amerieanus, p. 308. 
Hindoos, to an higher antiquity, than we can find with certainty in any other nation. These were the Indians, or red men of Asia. And the Indians of both continents, are marked with the same peculiarity of colour. The distinguishing colour of the Indian, is red, or rather a reddish brown; resembling, but more dark than a copper colour. From this similarity of complexion, it is natural to conjecture, that the Indian of Asia and of America belonged to the same family. 2. The features and countenance of the American Indians, very much resemble those of another of the nations of Asia, the Tartars. The Tartars join upon India, are spread over the northern parts of Asia, and extend to the eastern coasts of the Pacific ocean. Of their appearance and countenance, geographers give us this account : "They are in general strong made, stout men : 'Their faces broad, their noses flattish, their eyes small and black, but very quick."* The Indians of America are thus described, by those who had lived long among them : "The limbs are well turned, the body of just proportion, the countenance broad, their nose flat, their eyes black, small, but capable of discerning objects at a great distance." $f$ If these descriptions had been taken from the same individual, there could not have been a greater agreement, in every circumstance of as. pect and countenance.

3. Some information respecting the descent of nations, may also be derived from their customs. Those customs and manners which arise

- Guthrie's Geog. p. 660.

+ Ulioa's and Pinto's account. Robertson's Hiat. Amer. I, 460. 
from the wants, desires, and inclinations, pecu. liar to situation and employment, will be the same in the same state of society. A hunter in Asia, and a hunter in America, will have near. ly the same character, the same occupations, pursuits, and manners. But those customs which do not arise from situation, or from any natural want or desire, may be termed arbitrary: And the probability is, that two nations would not agree in these, unless they were derired from the one to the other. Several of these arbitrary customs, were common to the men of Asia and Amcrica.

$\mathrm{O}_{\mathrm{N}} \mathrm{E}$ of these customs, was that of extracting their beards with the roots. The Tartars and the Americans, had both adopted this practice. Both of them appeared either wholly without a beard, or only with a few scattered hairs : And both of them made it their practice to extract or pluck them out with the roots. Something of the same kind is practised by the Chinese. The Tartar and the American had both contracted the same wandering or roving disposition, contrary to the customs and dispositions. of most nations ; who scldom have any disposition to desert their connexions and country, until they are compelied to it by necessity or force. They had both adopted the same method of war ; wasting, destroying, and burning a country. 'The custom of scalping the dead, was one of the barbarous habity the Scythians practised. 'They cut a circle round the necks of those which they had slain, stripped off the skin, and carried it with them in triumph. In their marches, the Kamitschatkans never went 


\section{HISTORY OF VERMONT.}

pecu. pe thie iter in near. htions, stoms n any rary: vould rived these en of

cting and tice. sut a And ct or ig of tese. con. osiions. ositry, or th. g a ad, ans cks the In ent

abreast, but followed one another in the form of the In lian file. 'The Tongusi, the most nu. $m$ trous nation resident in Siberia, use canoes mide of birch bark, distended over ribs of wool, and nicely sewed together. In these customs they are exactly imitated by the Indians of $A$. merica. In burying the dead, many of the $A$. merican nations place the corps ai full length, others place it in a sitting posture, and lay by - t.. most valuable rinthing, provision, and arms. The Tartars people agreed in covering the whole with earth, so as to form a tumulus or barrow. The method, in which both people treated their neares: friends and relations, was still more extraordinary and uncommon. When their fathers and nearest friends were become extremely old and infirm, or were seized with a distemper deemed incurable, it was the custom of the Tartars to make a small hut for the patient, near some river, and to supply it with a small quan. tity of provisions: Removing the sufferer to such a situation, they left him to end his days, without visiting or affording him any further relief. The rudest tribes of the Americans, in several parts of the continent, had the same cus. tom ; and sometimes they made use of force to extinguish the remains of life, in their diseased and aged friends. Both people adopted this custom, opposite to the practice of all other na. tions : And they both viewed it in the same light, not as an act of cruelty, or of any disres. pect ; but as a deed of duty, and mercy : And thev both assigned the same reason $f . i$ it: " They were kindly relieving their friends from rol. I. E 2 
the increasing and unavoidable miseries of life; and they were assisting them in their journey to the other country." Nor is it to be doubted but that they assigned the true reason and motive, upon which they acted ; for no people were ever known to pay a greater reverence to the aged, or were inore enthusiastic in the veneration they paid to the tombs and memories of their ancestors.

Suc н customis are not derived from any natural appetite, or from any thing peculiar to the state of the hunter, or the savage ; but must be deemed extraordinary, uncommon, and arbitrary. Being found only among the men of Asia and America, the presumption is, that they were derived from the one to the other ; or that the latter had taken them from the former.

4. In the empire of Peru, there were several appearances of Chinese customs and manners. The appearance, the dress, and the superior knowledge, of Manco Capac and Mama Ocollo; the knowledge of agriculture and the arts, in which the one instructed the men : the knowledge of spinning, knitting, weaving, and making garments of cotton, which the other diffused among the women; the high estimation which the children of the sun assigned to agriculture, above all other arts and professions; their custom of tilling a field with their oivn hands; the ceremony with which the Inca began the busi. ness in the spring; the festivals which attended it ; the unlimited authority of the emperor, with the patriarchal aspect of the government; the benevolent tendency of their laws, and wars ; and their public regulations respecting roads, 


\section{HISTORY OF VERMONT.}

231

ife ;

$y$ to

bted

mo.

vere

the

era.

of

bridges, canals, industry, provision for the poor and aged, and the responsibility of parents for the conduct of their children ; all, or most of these articles, bore a greater rescmblance to Chinese nuaxims, manners, and customs, than could have been acquired in America, during the iffe of one man and woman, from their own observations and reasonings. They were ad. vances towards a state of civilizatiun, that nothing in the degraded state of the Peruvians, conid have sugresestcd, or produced, but in a long period of time.

MUC H pains has been taken by many learned and ingenious men, to compare the languages of the Americans, with those of other nations. But while these inquiries he : been carried on with great assiduity, the most ancient language which prevailed in the east, the Sanskreet, "the parent of almost every dialect from the Persian galf to the China seas," * was itself wholly unknown : And no information has bcen derived from these inquiries.

IVE must reason then from such circumstances as we can find: And if a judginent can be formed from a similarity of complexion, features, and customs, we shall be led to conclude that the men of America were the same people with the men of Asia ; but that thcir descent, was not from any particular one, but from seve. ral nations on the eastern continent.

No difficulty could ever have attended such emigrations. The continents of $A$ sia and America approach so near to each othęr, that the

- Preface to the Grammar of the Bengal I.anguage, p. 3. The first translatioa from the Sanskreet language was published in 1785 . 
Inhabitants are frequently passing from the on to the other. The discoreries of thic Russians, and the greater discoveries of the most celebra. ted modern navigator, Captain Cook, hale made it certain that if the two continents are st.erdted at all, it is only by a strait, not more than eighteen niles in width. At no time within the period of history, was the navigation of the ruclest tribes unequal to the passage of such a strait. And probably there never has been any difficulty, in passing from the one contiuent to the other.

Ir is not improbable that the red men of Asia, might find a passage into Anerica alto. gether by navigation. "It has been long known that the Asiatic nation called the Mialayans, possessed in former timcs, much the large'st part of the trade of the Indies; and that their ships frequented, not only all the consts of Asia, but even those of Atrica, and particularly the large island of Madagascar. It has been more lately discovered, that the same nation had extcnded their voyages and migrations from Madagascar, to the Marquesas, ard Easter Island ; that is nearly from the east side of Africa, until we approach the west coast of Amcrica. This space inciudes almost one hatif of the circumfercnce of the globe. 'Thro' this immense space the Maluyans had spread, made settlements, and founded colonies in the islar:ds at all the intermediate stages, at an ins. mense distance from the parent continent. The voyages of Captain Cook have afforcled the 1?col of these historical facts: Ard they huve been ascertaincd not oaly by a similarity of 
manners and customs, but by the affini $y$ of Language, and a coliection of similar words, made from all the widcly diffiused islands and countries visied hy this celebrated navigator:"

A PEOPLE who had thus spreid over one half of the globe, from the coast of Alrica to. wards America, and who had settled all the islands that lay between them, could scarcely have avoided arriving upon the western co.st of America, and leaving some of her people there. Several of the islands that were scttled, were near the American coast ; and it must have been much easier to have discovered the continent along the western coast of Americi, than to have found so many small and scattercd islands. It is therefore highly probable, that the same people who spread over the islands in the Pacific ocean, should at times arrive also on the western shores of the continent. In both these ways might people from different nitions in Asia, find a passage into Amorica, and at very different periods of time.

I'he Inciians however, were not the only men which appeared in America. Another race or kind of men were settled in the noitl:ern parts of the continent. These have been called Es. quimaux. In their colour, dimensions, feitures, and customs, they differed much from the red men. They were of a fallow or brownish ccm. plexion: Their size about four feet in leiglit; their fuces long and wrinkled; the ir roses thick and compressed; their eyes small and surik; their cheeks much raised; their ryebiows and cyclids thick; with smiull legs and hands. This nation had spread over the most novidican 
parts of America. 'They are found in Green. land, on the coast of Labradore, in Hudson's bay, and in all the coasts and islands on the west side of America, opposite to Kamtschatka. Their migrations had extended to Norton's sound, Onolashka, and prince William's sound; one thousind five hundred leagues from their stations, in Greenland and Labradore. The sameness of the people in these different places, has been ascertained by thcir manners, customs, features, and complexion ; but more decidedly by such an affinity and similarity of langruage, as leaves no room for cloubt. It will be e:sy to determine from whence this nation of the Esyuimause procecded. Every thing in the appearance of this people, denotes them to be the same with the Laplanders, the Zcmblans, the Sanojeds, and the Tartars in the east.... Like them they are a mation of dwarfs; largest towards the south, but decreasing towards the north. 'They have all the same fallow complex. ion, deformed features, ugly appearance, and singular customs. Whether the inhabitants, could pass from the northern parts of Europe into Ameriea by lind is as yet unknown. But the passige by water, was at all times casy; and certainly at a very early period. In the voyage from Norway to Icelind, and from Iceland to Grcenland, or the coast of Labradore, the first pirt of the voyage was nuch the largest: And this was practised from the earliest times, of which we have any account. For the ninth century, when navigation was extremely imperfect, the passage fiom Europe to America was so well understood, thit the Norwegians planted 


\section{HISTORY OF VERMONT. 235}

Green. clson's in the hatka. prton's ound ; their The ferent iners, more ty of It will pation ng. in to be blans, ist.... rgest the plex. and ants, into the and age to irst and of ath

er-

and settled their colonies in Grecnland. There is but little room then to doubt but that the na. tion of the Esquimaux was deriyed fiom the same people in the northwest parts of Finrope. Their descent therefore must have been from the Tartars of Asia, for it was fiom them, that the Laplanders, who are spread over the northwestern parts of Europe, 1 ere derived. In the year 1769 , Pere Hall, an astronomer of Hungary, iras sent into Lapland to observe the transit of Venus. 'This able philosopher had a good opportunity to become acquainted with the manners, customs, features, and linguage of the inhabitants in that part of the globe : $\mathrm{B}_{\mathrm{y}}$ his account, " it appears that the Laplanders are only degenerate 'Tartars; and that they, and the Iungarians, originally sprung from the same /reed of men, and from the same country."*

The two kinds of men then that were in America were derived from the sime source. The Indians and the Esquimaux, were both descended from the man of Asia ; and probably the most of them, from the same nation, the 'I'artars. In America then nature had not made different races of men, fitted for, and originally placed in different climates. 'The men of America were the same with the men of Asia : And both of them migrated ficsin one place to another, and spread through ali the various climates of the carth. They were distinguished by the differences of complexion, dimension, features, arbitrary custcms, and peculiarities of manners, as much as the inhabitants are in other parts of the

- Kaim's Sketches of tbe Hist. of Man, I. p. I1. 
globe. But these differences must have been derived fron alinate, fool, manner of living, or some other circumstance ; for they certainly were not darived from a different origin, or any particular local creation.

The constitution of man appears to be the sime, in every part of the globe. Nature has given to him the same physical and moral pow. crs, capable of different degrees of improvement according to the state of society in which he silall be placed. But in no country, or part of the globe, does m.n appear to be au animal of climite. Among animuls nothing is more apparent, than that some are animals of climate that is, they are fitted by nature and constitution to some particular part of the globe ; where alone they can subsist, multiply, and obtain their proper perfection. 'Thus the animals peculiar to the torrid and frigid zone, never leave their particular climates out of choice; and when a change of climite is forced upon them, they de. generate, and waste away. It is evident that min is sot such an animal. He can multiply. and attain his proper perfection in all the various climates of the eaith. Nature has not furnished him with any kind of coveriug, fitted to a hot, to a temperate, or to a cold climate : This is left to his o:vn reason and industry, according as his situation may require. Nor has nature assigned to him any particular, invariable colour. Black is the absence or want, and white is the mixture of all colours : And these are the extremes between which, all the various complexions fali. Nature therefore has not as. oigned to man any covering, or any invariable 
been living, tainly ar any

e the re has pow. ement ch he irt of nal of re apnate s ution ere a. their culiar their len a $y$ de. that iply. varifur. d to dte : ac. has riaand ese ous as. ble

ectour, or any thing in his constitution, that has fited him particularly for the torrid, temperate, o: firigid zone : But has given him a nature and constitution, adipted to every climate. And in every climate which produces his proper food, the white, the red, and the black men, will sub. sist, multiply, and attain their proper perfection.* If nature his thus made man the alimal of all climates, would it not be altogether unphilosophical, to look out for local creations ; or to introduce miraculous interpositions of the Deity, to explain those differences among men in other places, which in America, we are certain were derived from natural causes ?

ANTIQUITY. In attempting to estimate the antifuity of the most polished nations, we can derive but little information from history. No records, no monuments, no writings can be. found, that reach back to so ancient a period. Least of all is this to be expected from a race of savages, which had not the knowledge of let. ters. All the information we can obtain, must be derived from such circumstances and events, as imply or denote certain periods of years; and of these there are but $\mathrm{few}$, in the transactions of the savage state.

Some information may be collected from the extent of the country they had settled. The continent of America, in its dimensions, anounts to one third part of the habitable globe. Ovar the whole of this continent had the savages ex. tended, when it. was first discovered by Colum. bus, in the year 1492. Their population had

- Appendix No. V.

DOL. I. F 2 
then attained its greatest perfection. No ini crease of their numbers has any where appeared to take place, since that time. No circumstance or event has taken place during the three hun. dred years, that the Europeans have been ac. quainted with the Indians, which can lead us to suspect that the savage state either has, or can admit of a greater population, thin what it had already attained. Nor is it probable, that any increase of numbers, and population, could have taken place, while hunting continued to be the method of procuring subsistence. From the observations that were made in Virginia, and Massachusetts, it has been computed that the population of the Indians upon the sea coasts, could not be estimated higher than one for every square mile. In the inland parts of the coun. try, the Indian population certainly did not exceed this. Geographers have computed the number of square miles in America, to amount to fourteen millions, one hundred and ten thousand, eight hundred and seventy four. We cannot make a nearer computation, than to suppose this was about the number of Indians it required in the hunter's state, to spread over the whole continent. How long a period would it require, for the savages to increase to such a number? There has been no instance of a more sapid increase, than that of the British colonies in America. They were aided by new emigrations from Europe : But so much were they retarded and broke up in their settlements by war, before the American revolution, that they did not in fact double their numbers in thirty years. The families of the Indians did not 
contain more than half so many members, as those of the white people. The Indian population then will be highly estimated, if we com. pute it to be one half of that of the white inhabi. itants; and instead of thirty, admit sixty years as the period of doubling. Assuming the population to have proceeded from one male and female, this would require thirteen centuries and an half to have spread over the whole continent, and produced one inhabitant to every square mile. The period of population could not have been less than this. But probably this period was coinpleted long before Columbus came into America. The Indians in several places, had gone out of thc hunter's state. On the sea codst: they were advancing into something like monurchy. In Mexico and Peru they were be. come extremely numerous, and had established extensive and powerful empires; the duration of which, could be traced back four or five hundred years. From their extent and population then, we deduce with some degree of probability, that the Indians must have been settled in America eighteen centuries when Columbus first discovered the continent. This will carry us back three centuries before the christian era.

TH $\mathrm{F}$ number and variety of their languages implies and requires a much longer duration, and an higher antiquity. The Indians of $\mathbf{A}$. merica had not only spread over the continent, but they had every where formed themselves into a number of small tribes. If we may judge of the number of these tribes from what took place in New England, and Virginia, they must have amounted to thousands. Several of these 
tribes had subsisted so long in a national form, and as a distinct pcople, that they had formed a particular language for themselves. There were three original languages spoken in $\mathrm{C}$ anada ; the Sioux, the Huron, and the Algonquin.* In New England, there wcre one or two others. $f$ In Virginia there were three, different from ci. ther of these. In Mexice thi ty five: were discovered. In South America there wcre still more. In Maraguon, the Portuguese countcd fifty. In each of these places, the clialecis were nearly as many as their tribes. And yet thicse places ma e but a small part of ti:e continent. What an immense period of time does this require? A language may be separated into different dialects in a fow generations : Eut for these dialects to recede so far from one anotlect, as to lose all resemblance ard iffinity ; and several new languages to be formed, radically difforing from one another; such an ercut could not take place, or be eflected, unit the tribes had sub. sisted for many centuries, as distinct and separate nations. We cannot estimate this process by fixed periods of timc, because we have no facts from which a computation can be made. But it may be comparcd to the state ar d progress of things, in the other hemisphere : and we shall find the number of languages ratically differis: $g$ ficm one another, more numerous among the Americans, than they were in Asia and Europe. Is not this an indication, that the red $n$ chi of America are as ancicnt as the other natiolis of the eund ?

- Abbe Raynal, V. Ioz.

4 Hutchinsin, 1.4.57, 479.

\$ Jefierson's Notcs on Virginia, p. 9a 
Learning and science ther had none : But nature, situation, and necessity, would operate as cortiilily, and as regularly upon them, as upon any other people. And would it not require as long a periorl of time to produce, and to form a lituguage among the savages, as among any oiher prople ? 'This circumstance seems to denote an antiyuity, fully equal to that, which is claim. ed by any of the nations of the other hemis. phere.

I'нег antiquity may also lic traced back to the time, when the most useful arts were unfrowin; and when the red micn of Asia had not the use of the mctals, or of domestic anima's. Some of the aris must have been nearly cosval with the human race ; for neither food, raiment, or halitations, could be procured without sometiving of them. Cther of the arts have been \$.llully advancins, without owing much to ans origina? inventor. And many of tlem are of such antiquity, that their origin and inventor are beyond the reach of history. 'I"his is the case with the noost necessary and uscful arts of life. The origin of spinning, and kniting, of the plough, the loom, and the forge, were more ancient than any of our historical monuments, rccords, or traditions. But when those arts were invented, they never could be lost. A. midst the wars, changes, and revolutions, to which nations are exposted, what are called the fine arts may perish and be lost. But no vicis. situdes of human affuirs tend to destroy those arts, by which all men derive their subsistence; and which are equally necessary to the conqueror and to the captive, to the oppressor and to 
the oppressed. The same observation may be made with respect to the use of domestic animals. A people that have experienced the ad. vantages derived from the food they afford, and from the labnur they perform, would never lose this kind of knowledge; but cndearour to apply it to such kind of animals, as the found in the country to which they repaired. Of all these, the Indians of America were igno. rant. They knew not the use of the metals, spinning, weaving, or the domestic animals : They had derived no such knowledge from thicir ancestors, nor had they acquired it them. selves. At what period then, must they have settled in America? Before these arts were known in Asia. Before the Scythians became husbandmen, and before the most necessary and useful arts were known in the midst of Asia. Without attempting therefore to go back to the beginning of the creation of God, we can find circumstances that will carry us as far back into antiquity, as any other nation can pretend. The history and pretensions of the Chinese, do not imply or suppose any circumstances of greater antiquity, than those which have been mentioned. And it must be from circumstances and facts, not from tradition, that we must trace the antiquity and origin of ancient nations.

Progress of Society. The progress of society among the Indians, would make a curious, and most useful part of their history. The rudest and most simple state that took place among them, was that which $I$ have bcen describing. Wheresoever the savages continued to derive their support from hunting, they con- 
tinued from age to age in the same condition, and made no improvements. Where the means of subsistence were plentiful, and easy to be procured, the Indians had advanced beyond the state of an hunter, and began to increase their numbers, and their agriculture. In such pla. ces, society began to assume a different form, from what it bore in their rudest and most simple state. And the tendency of it was every where to monarchy. In the southern parts of New England, and Virginia, some of the tribes were advancing fast to the form of hereditary monarchy. In the hotter climates it was already established. This was the case in Florida, among the Natchez on the Missisippi, in Cuba, Hispaniola, and all the large islands. In Bagota, Mexico, and Peru, monarchy had acquired its perfect form, its full powers, and a complete establishment. In each of these places, the progress of government had been from perfect freedom and independence, to almost absolute and unlimited monarchy. In the course of this progress, two remarkable phenomena appeared ; In one part of America, an empire and a monarchy was established, in most respects resembling those which had arisen in the other hemisphere. In another part of America, an enpire and a monarchy was produced, far superior to those which were produced in the other parts of the globe.

IN the empire of Mexico, almost every thing had taken the Asiatic, and European course. The great body of the people were reduced to a degraded and humiliating state ; and held their lives, and performed their labours, under various 
names and deprees of degradation and ainitse. ment. A body of nobility were possessed of ample territorics, of great privileges, powers, and honours, under different names and degices. Above, and over all, was the monarch, cnjoying suprence power and clignity. After being eicetive during the reign of cleven of theil sover. eigns, the monarchy was become almost abso. lute and hercditary, in Montezuna. The system of religion agreed perfectly well to the na. ture of the government : It was scvere, crucl, and barbarous ; and delighted in the sprinkling and shedding of biond : Human sacrifices of all others were esteemed the most acceptable, and availing; and the priests had the privilege, the honour, and the profit, of announcing or remov. ing the vengeance of the gods. This system of monarchy had acquired a stability, a regularity, and a vigcur, equal to any monarchy that was then upon the earth. Upon comparing the spirit of monarchy, untempered by representation, in America, in Asia, and in Europe; the spirit and the principles of it, will be found eve. ry where to have operated alike. It degrades the bocly of the people bclow the condition and nature of man. It exalts the nobles and the sovereign above the condition and state, which nature designs or admits. In oine form or another it has always been atiended with a perse. cuting, cruel, and bloody religion, put into the hands of a wealthy, and powerful priesthood. It has constantly produced the spirit of war and destruction ; and generally derived to itself security, wealth, and power, from the misery, destruction, and slaughter, it has entailed on the 


\section{HISTORY OF VERMONT. $\quad 245$}

ai)isesecl of power's, cgicis. joying ig eicesover. it abso. 1e systhie nacrucl, inklingr es of all ble, and ige, the renovstem of ularity, hat was ing the resentaxe ; the nd eve. egrades jon and and the , which or ana perse. into the sthood. war and tself se. ery, de. 1 on the human race: By placing the rulers in a situa. tion altogether unnatural; that is, above all sense of accountability to their fellow men, it has pro. duced that constant, steady, and universal abuse of power, which, in every part of the globe, has been the distinguishing and certain effect of this form of government. Its spirit and principle have every where been the same; not the honour which the great Montesquieu wished to ascribe to it, and wanted to find in $i t_{i}$ but that total want of regard and accountability to man, which, with great accuracy and propriety, has been lately named $a$ contempt of the people.

TH $\mathrm{E}$ empire of Peru was formed and govern. ed by a species of monarchy, different from what has ever taken place among any other people. Twelve successive monarchs, for a period of more than four hundred years, had been invested with hereditary and absolute power. They claimed this authority, not as derived to them in any manner or degree from the people, but as the absolute and exclusive donation of heaven. 'They announced themselves to be the children of the sun, and clothed with divine and unlimited power to direct all the civil and religious affairs of the people. The sovereign was named Inca; and so sacred and pure were the family of the Inca's, in the minds of the people, that they were universally esteem: ed incapable of committing a crime, or falling into an errour: No other family might marry or mingle with it, for fear of polluting the heavenly blood. The people looked up to them, as to beings of a superior and heavenly race : And all disobedience to them, was viewed not barely VOL. I. G 2 
as a crime committed against men, but as an act of rebellion asgainst Crod. The nobility of course was nothing more than families of office. Though a difference of rank had taken place throughout the empire, all but the children of the suil, were supposed to belong to the cornmon race of men.' The peopic were well cloth. ed, and fed; every where distinguished for their industry, economy, moderation, contentment; and happincss. Over this people, the Incas, though absolute in power, established a government the most mild and gentle, that has ever taken place in any part of the earth. The morals of the people were so pure, that few crimes were ever committed : The genius of the government, was so mild, that few punishments were ever exccuted: And when they werc, they were viewed as the necessary acts of God; and not of men. Their government, the dominion of prosperity and virtue, was esteem. ed by the people the dominion of God and his Inca:. . Their system of religion, like their gov.ernment, was mild, gentle, and pacific. The sun, the emblem of light, serenity, fertility, beneficence, joy, and life, was the object of neir adoration. They oflered to him a part of those productions, which they derived from cultivating the earth, enriched by his genial warmth. They presented to him specimens of those works of ingenuity, which they had performed by his light. And they brought to him some of those animals, which tvere nourished by his influence. But the Inca never stained their altars with human blood ; or admitted the sevage idea, that the source of beneficence could 
be pleased with the persecution, cruelty, and destruction of men. Their system of war par. took of the same spirit of mildness, and wisdorn. They fought not to exterminate, but to conquer : they conquered not to enslave, but to improve, to civilize, and refine. No cruel torture awaited the captive. No barbarous marks of degradation, disgrace, triumph, or slavery, were reserved for the prisoners. They were taught the same system of government and religion, as the rest of the people : they were admitted to the same privileges; and treated with the same lenity and mildness. Of all the triumphs of the Inca, the noblest and the greatest, was to diffuse the manifold blessings of peace and happiness, to the people whom they had subdued.

Sucr was the genius, the spirit, and the effect, of the system of monarchy that was estab. lished in Peru. We need not hesitate to pronounce it superior to any, that was then to be found upon the fice of the earth. The genius and the spirit of it, were above all others, mild and gentle : the object and the aim of it, were in fact, the improvement and the happiness of the people. And if any government ever produced this effect, that government was the monarchy of Pern: Not the attainment of the most polished nations of Asia, and Europe, of their arts, science, and improvement ; but of the greater wisdom and simplicity of the Indians, and Incas of America.

$W_{E}$ have here a phenomenon, new, and almost incredible in the political world. Abso. lute, unlimited, and hereditary monarchy, which 
has never failed before or since to prove one of the heaviest curses, which has fallen upon mankind ; in Peru became mild, gentle, and benefcent : And was constantly employed during the reign of twelve successive monarchs, to refine, civilize, and improve the people ; and to do the greatest good to mankind. And yet this was a system not founded in truth, or in nature ; but in delusion and superstition. What could give it a direction so steady, uniform, and benevolent? Not the form, but the principle of it. It contained the best and the purest principle, that can enter into the nature of human government. Its origin, duration, and power, depended wholly upon the public sentiment. The Inca claimed immediate descent, and relation to the sun. The sun was the emblem of peace, and benevolence. Had the monarch stained his character by enormity in crimes and vices, or by a coll. stant abuse of power, nature would have taught the Peruvians that monsters in corruption, vice, and cruelty, could not have been the favourite children of the Deity. If the Inca had been viewed in this light, all his divinity, and his power would have ended. His power was founded altogether in the opinion the pcople had formed of his divine descent, qualifications, character, and virtues. So solicitous had the Incas been to preserve this opinion, that through the whole period of their successions, they had taken the most scrupulous care not to endanger or oppose it, by any base and unworthy conduct. And while they thus proved the constant fricnds and benefactors of the people, the public esteem and veneration increased. In the benevolenec 
and uscfulness of the Inca, the people believed they saw the children of the sun : And in the affections and opinions of the people, the Inca found an absolute and unlimited power. But if his conduct had plainly discovered that instead of being the child of the sun, he was the child of folly, of vice, and abominable iniquity, his divinity, his power, and his empire would have. ceased with the public opinion.

INSTEAD then of being founded in a contempt of the people like the empire of Mexico, the monarchy of Peru had the singular good fortune of being founded in the pullic sentiment. This rendered the Inca accountable to the pcople for every part of his conduct : And this sense of accountability would kecp a constant sense of duty and character upon his mind. Thus under the form of absolute hereditary monarchy, the government of Peru had the uncommon advantage of excluding nobility with all its odious distinctions and clains ; and of embracing the best and purest principles, upon which civil government can ever be founded. The Indians seem to have been the only people, among whom, a regard to the public sentiment and benefit, clid in fact constitute the spirit and principle of hereditary and absolute monarchy.

Tendency to Dissolution. However beautiful and promising tice progress of society once was among the Indic.ns of America, it is now every where tendieg to dicay and clissolution; and this has bien its tudency, ever since the first arrival of the Europeciass. in the destruction of the empines of ivicadio, and Peru, 
Cortez and Pizarro performed the most accurs. ed transactions that ever were done by man. And wherever the Europeans have settled, miscry, calamity, and destruction, have been entailed on that unhappy race of men. The vices we havc taught them, the diseases we have spread among them, the intempcrance they have learnt of us, and the destruction of their game, are evils for which the savage is unable to find a remedy. A centempt of our morals, a horrour at the knavery that has attended our commerce with them, and the constant advances we have made into their country, have filled their minds with prejurlices against our arts and improve. ments. This, added to the frequency and bit. terness of their wars, to their constant hardships and sufierings, and to a defective population, but too plainly denote the event. The constant waste and decay of this people, must end in their total destruction : According to the present course and tendency of things, in two or three centuries, the whole raee must become extinct. Instead of wishing for such an event, it would add to the giory of the United States to make a serious attempt to prevent it. It has been the practice of arbitrary governments to sport with the liberties, and lives of men. A govcrnment of reason and nature ought to at. tempt to conciliate the affections of a free, brave, independent, and generous people. It would be a greater glory than we have ever yet attained, if we conld find out a way to impart the blessings of the civil state, to a people whose great. est miseries and misfortunes have been derived from the superior arts, the policy, and the porw. er of civilized nations. 
accurs. y man. settled, ecn en. ac vices e have ey have ganie, to find horrour nmerce ve have minds aprove. nd bit. rdships ulation, onstant end in le pretwo or recome event, States It has ents to n. A to at. brave, uld be ained, bles. great. rived pow.

\section{CHAPTER IX.}

First Settienents and Wars with the IN DIANS. Earliest accounts of the Northern Indians. Discoveries and settlements in their country by the French. Origin and prugress of War between the natives and the Europeans. Influence of the Priests. French \&ixpeditions. Proceedings of the Governor of Newyork: Destruction of Montreal by the Iroquoise. From the year 1535 to 1689.

SUCH were the men who were spread over the northern parts of America in the tifteenth century. It does not appear that any other men but the Indians had ever been in the country, previous to that time. On October the 12th, 1492, by astonishing efforts of genius and perseverance, Coxumbus discovered the western hemisphere, at the island of Guanahana. Among all his discoveries the most important, was that of a new race of men ; of men in their appearance, manners, habits, and customs, very different from the inhabitants of the eastern hemisphere. Influenced by the spirit of curiosity, enterprize, avarice, and ambition, the subjects of the Spanish monarchy embarked in great numbers to the southern parts of America ; visited the natives, subdued the accessable parts of their country, and planted them with the men of Europe. These attempts and measures every: where produced the same effects, bloody and barbarous wars, between the men of the two continents; now for the first time, in- 
termixing and ming!ing togcther.

WHIL the court of Spain was carrying its conquests, and advancing its interest in the southern parts of America, the courts of France and England turned their attention to the nor. thern parts of the continent ; and endeavored in those regions to find atcnues equally favorable to comnerce, conquest, wealth, and power. Francis the first, at that time king of France, was one of the most active princes of the age; and though constantly involved in wars and misfortunes he did not intend that the kings of Spain and England should divide the wholc continent of Americil between themselves. With a view to explore the northern latitudes, and to find a place for a French colony, he fitted out James Curtier on a voyage of discovery. Cartier sailed from St. Malo, on the 20th of April 1534; and in the course of the summer entered the mouth of Canada river, visited the bay of Chaleur, and that of Gaspe ; and from thence sailed to the northward, till he discovered the land on the opposite side of the river. Having made these discoveries he returned to France, and arrived at St. Malo on the fifth of September.

THE next year he was fitted out with three ships, and arrived at the isle of Orleans, in the beginning of September, and came to anchor between the island and the north shore: To the river he gave the name of St. Lawrence; and leaving his ships at anchor on September the 19th, he set out with his pinnace and two boats upon a voyage up the river to Hochelaga; where he arrived October the second, and gave to the 
lying its in the f France the nor. ivored in avorable power. France, he age; yars and kings of e whole mselves. atitudes, he fitted scovery. 20th of summer ited the d from scover:e river. rned to fifth of

three in the anchor To the ; and or the boats where to the place the name of Montreal, by which it has ever sirce been denoted.

INSTEAD of meeting with hostilities at either place, Cartier was received by the natives with all the demonstrations of joy, which they were able to exhibit. At Hochelaga the Indians had intelligence of his approach, and made preparations to give him the most friendly reception. The savages, to the number of about a thousand, came forward in a body to bid him welcome to their country. The men were on one side, the women on the other, and the children in a body by themselves; and the whole came forward singing and dancing, with every appearance of the highest confidence and joy. To their new guests, the Indians made presents of corn, fish, and such other kind of provisions as they had; in return, the Frenchmen gave knives, beads, and other trinkets. The first night the Europeans lodged in their boats, and the natives watched on the shore, dancing all night round their fires.

'THE next day Cartier with twenty five of his company set out on a visit to the Indian town. He was met on his way by a man, who appear. ed to be one of thair chise fs ; and whose business it was, to introduce him to the capital of their country. Cartier uresented to the Indian chief two hatchets, two knives, and a cross, which he hung over the Indians neck, and taught him to kiss. Passing from the river towards the town, the French went through groves of oak, the acorns of which were fallen, and were so nume. rous as to cover the yround. They passed also through fields of corn, some of it gathered,

vol. $x$. $\mathrm{H}_{2}$ 
and all ripe. In the midst of these fields of corri; and surrounded by them, was the Indian capir tal, Hochejaga.

$T_{H E}$ construction and state of the town dis:covered a degree of improvement, of which Cartier had before met with no specimen in the Indian courtry, and had no expectation to find from the Indian genius. It was laid out in a circular form, and was surrounded with three lines of palisadoes; through these palisades there was but one passage or place of entrance, and that was weil secured both with stakes and bars. On the inside, the fortification consisted of what in the European language was called a rampart of timber, to which the ascent was by ladders; heaps of stones were also collected, and placcd in such situations as would best serve the purposes of strength or defence. Within these fortifications there were about fifty Indian houses : these houses were a kind of long huts, built with stakes, and covered with the bark of trees. In the middle of each Indian house there was a fire place; and around the sides were the lodging or sleeping places, the floors of which were bark, and the covering made of skins. In the upper parts of the houses were scaffolds, on which they placed and dried their corn. Their provisions were corn, beans, squashes, pump. kins, and fish. 'Their corn they pounded in a kind of wooden mortars, and when beat mixed with water, and baked on hot stones. Their fish was dried in the sun, or in their houses, and preserved in troughs. Their squashes and pumpkins were generally consumed while they remained green. At Hochelaga the people ap- 


\section{HISTORY OF VERMONT. 255}

corri; capis

dis:artier ndian from cular es of was that bars. what ppart ers ; aced purhese sus. iuts, $\mathrm{k}$ of here the aich In on heir $\mathrm{np}$. in a red leir es, ind ey ap-

peared to derive their chief subsistence from fishing and tillage, but in the lower parts of the river, hunting seemed to be the chief cmployment : But at both places, the sachem, or chief man of Hochelaga was considered as the sovereign, to whom the people were in subjection, and paid tribute.

IN the centre of the town there was a large open square : to that place Cartier and his company was conducted, and mats were spread on the ground for the new guests to sit on. The Indian men seated themselves in a large circle round them ; but the women came weeping, with joy, rubbing their hands and faces, and bringing their children to be touched by their new visitors. At length the sovereign, the Indian King, was brought on the shoulders of ten men, and placed on a mat next to Carticr. The monarch of the savages had a covering made of the quills of the porcupine, died red; this he took off and gave to the French captain, requesting him at the same time to rub his arms and legs, which were much affected with a palsy. Several other persons declining with age or sickness, were also brought to be touched and healed by the sirangers. Cartier saw at once that the Indians viewed him and his company as gods ; or at least as a race of beings far superior to themselves; and resolved to avail himself of their weakness and superstition. He laid his hands on them, cast his eyes to hcaven, repeated some devotional passages from his ser.. vice book, and assumed such features and gestures as he supposed would most cngage and affect a savage mind and tribe. The Indians. 


\section{NATURAL AND CIVIL}

attentively observed all his motions and ges. turcs, and endeavored to imitate and repcat them.

Tнгs farce being finished, Cartier proceeded to exhibit more substantial proofs of his benevo. lence and power. He signified to the multitude that he wished the men, women, and chil. dren, would divide themselves into separate companies. The natives immediately made such an arrangement. To the men Cartitr then made a present of hatchets, to the women he presented a quantity of beads, and to the children he gave a multitude of rings. The moment these donations wẹre ended, he ordered his drums to beat, and the trumpets to sound. As. tonished but delighted with the scene the savages shouted, and the whole company fell to dancing. What could be wanting to convince the multitude that their new guests were gods, full of benevolence and power?

Cartier next proposed to ascend the hill, under which the town was built. The Indians sonducted him to the summit, and pointed out to him the course of the river above their town; and informed him that he might sail on it for three moons without coming to an end : that it ran through two or three lakes ; that beyond them there was a sea of fresh water, to which they knew of no limits; that on the other side of the mountains there was another river which rain to the southwest, through a country in. which there was no ice or snow; and that there. were such metals as silver, gold, and copper, to be found in the country. Having obtained all the information which he expected, Cartier pre: 


\section{HISTORY OF VERMONT. 257}

pared to depart, and left Hochelaga October the fourth. T'he natives accompanied the French to their boats, carried such of them as were sick upon their shoulders, and followed them along the banks of the river to a considerable distance; discovering the marks of sorrow and distress at their departure. On October the cleventh Cartier and his company arrived safe at the isle of Orleans, where he tarried that winter, and attempted to found a colony, but which was soon broke up.

$F_{R O M}$ this voyage, the first that had ever been made into the interior parts of North $\mathrm{A}$ merica, the manners and dispositions of the natives became in some measure known. It was found that the Indians were divided into many distinct tribes or nations ; which, instead of being in a state of union or confecleration among themse!ves, were generally in a state of hostility and wit. Among other proofs of their hostility to each other, Cartier found at the isle of Orleans the scalps of five men, spread out, and dricd like parchment. These, he was told were taken from some of the southern Indians, with whom they were constantly at variance; and that the scalps of their enemies were considered as the most honorable evidence of their own prowess and exploits in war. But with respect to their new visitors, instead of any appearances of suspicion, fear, or hostility, they were every where received with the tokens of friendship. confidence, and the highest expectations of uncommon benefit and advantage from their visit. ations. Instead of making any preparations to oppose, the natives reccived them with the high. 
est marks and effusions of joy, as beings of a superior order, from whose benevolence and power they expected to receive uncommon benefits and advantages. Nor was it till the Europeans began their enterprizes of injustice and violence that the natives had any fear or suspicion, or made any preparations either for defence or hostility.*

THE colony attempted by Cartier having failed, no further attempt was made either to explore, or to make any settlements in the in. terior parts of Canada, till the year 1603. 'That year a voyage was undertaken by $S_{A M U E I}$. CHAMPLAIN, a man of a noble family in France. He sailed up the river St. Lawrence as far as Cartier had proceeded in 1535, and visited the places which that celebrated navigator had described. Passing the isle of Orleans he came to anchor at a place called Quebce, which in the language of the natives denoted a strait. Cham. plain remarked that this place might be ap. proached by the largest vessels, that it was surrounded by water on three of its sides, had a situation elevated and commanding; and that with a little labor it might be made a place of great strength, and was in every view a fit place to erect a fort, and begin a settlement. He then proceeded up the river to Hochelaga or Montreal, and made many inquiries of the natives respecting their country, its rivers, lakes, productions, and inhabitants. Without fear or suspicion, and with the most artless simplicity, the Indians informed him that there was a com-

* Hakluyt Vol. 3, p. 20I-209. American Biography Vol, 1, page 258-184. 
of a and moll the tice $r$ or for ing to in. hat E r. ce. as the de. me the m. p. sr.

munication to the south, by means of the lakes with a fertile country, which belonged to a powerful and warlike nation called the Iroquoise ; that there were several and large lakes to the west, to one of which they knew of no bounds : and that to the north there was a large inland sea of salt water, the limits of which were also unknown. Having obtained this information, Champlain returned to France to communicate his discoveries to the government ; and to procure assistance and supplies, to effect a settlement in the country.

Is 1607 the establishment of a colony on the river St. Lawrence, became an object of serious attention to the court and merchants of France. It was concluded that such a colony would extend the fur trade, and open a communication to China through the western lakes; and thus serve to benefit the kingdom, and to enrich the adventurers. Encouraged by these expectations, several vessels were fitted out in the year 1608, to begin a colony. Champlain had the command. He arrived at the place called Quebec, in the beginning of July. In his former voyage he had fixed upon this, as the most eligible place for a settlement, and upon his arrival he immediately began to cut down the trees, to clear up the land, to erect buildings, and prepare the soil for gardens and fields. At that place he spent the winter with his company, in the course of which they suffered much from the severity of the climate, and the prevalency of the scurvy.

HAVINC began his colony at Quebec, in the spring of the year 1609 Champlain set out to 
explore the southern lake, which the Indians informed him opened a communication with the warlike nation of the Iroquoise. 'Taking with him a party of the natives, and two Frenchmen, he went up the river now called Sorel, and ex. plored both the southern lakes. To the largest of these he gave his own name, Champlain, by which it is still known. To the other he gave the name St. Sacrament, but which his since been called Lake Giorge. On the shcre of the latter, Champlain with his company was dis. covered by a party of the Iroquoise. Between these Indians and those at Hochelaga, a war had long subsisted, and a skirmish now took place. The Frenchmen were armed with musquets, and Champlain killed two of the Iroquoise him. self, with that weapon. This was probalily the first time the Iroquoise had ever scen the effect of the European arms, and the victory over them secms to have been compleat. The whole party were put to flight, and the scalps of fifty of them were taken and carried in triumph to Quebec.

Is the fall Champlain returned to France, and came again to Quebec in 1610 ; but io slow was the progress of his colony that it was not till 1626 that Quebec began to assume the appearance of a city, or had any other fortifications than those of wood. That year the fortress was rebuilt of stone; and preparations were made to defend the place not only against the natives, but lest some of the European ves. sels should approach, and attempt to carry the works. Nor were the preparations needless : A war had broken out between Charies I. king of 


\section{HES'TORY OF VERMONT.}

Indians vith the $g$ with chmen; ind $\mathrm{ex}$. largest ain, by egave since of the is clis. etween ar had place. pquets, e him. iy the effict over whole fifty iph to

rance, ut so $t$ was e the ificafortions ;ainst ves. $y$ the $\because \mathrm{A}$ ig of

England, and Lewis XIII. king of France ; and as the English were carrying on their settlements with grcat appearance of success in Virginia and Massachusetts, it was proposed in the Iinglish cabinet, to attack the French settlements in North America. In 1629 an armument was fitted out in Eingliand for this purpose, and the command given to Sir David Kirk. He sailed up the river St. Lawrence and appeared with his ships before Quebec. The city was in no condition to resist his force, and Champlain was obliged to capitulatc. Agreeably to the articles of capitulation, 'umplain was sent to France in an Finglish ...sscl. If he was mortified by the capitulation, he was more mortified by finding that his new colony was an object of but little consideration in France ; and that the loss of it was scarcely regretted.

MANY thought it was not worth retaining, that it had already been attencled with an expence far above its value, and probably the case would be the same in future. Others were of opinion that the fur trade and fishery were national objects of real consequence, and that the settlement of Canada was the sure method of increasing their importance, and would serve as a mursery for seamen, and thus eventually prove highly beneficial to navigation and commerce. The councils of Lewis XIII. were so little ac. quainted with the advantages arising from colonies, or with the value of their settlements in Canada, that they did not think it an object of any consequence to demand the restitution; and it was more a scnse of honor than a regard to interest that led them to wish for the restora. vol. I. I 2 


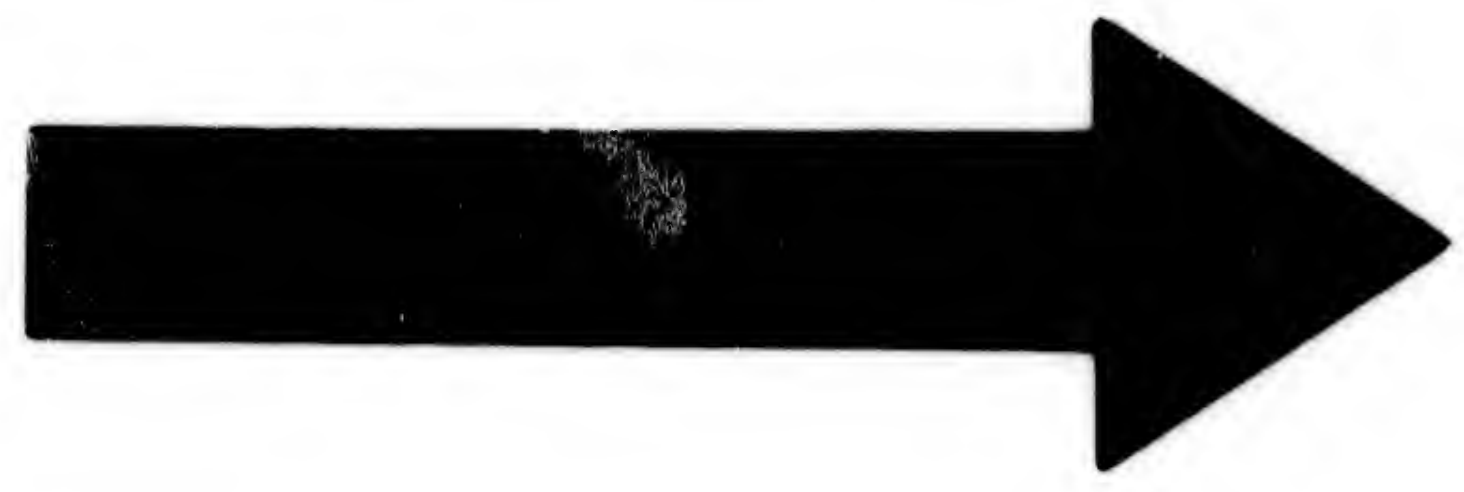




\section{IMAGE EVALUATION TEST TARGET (MT-3)}
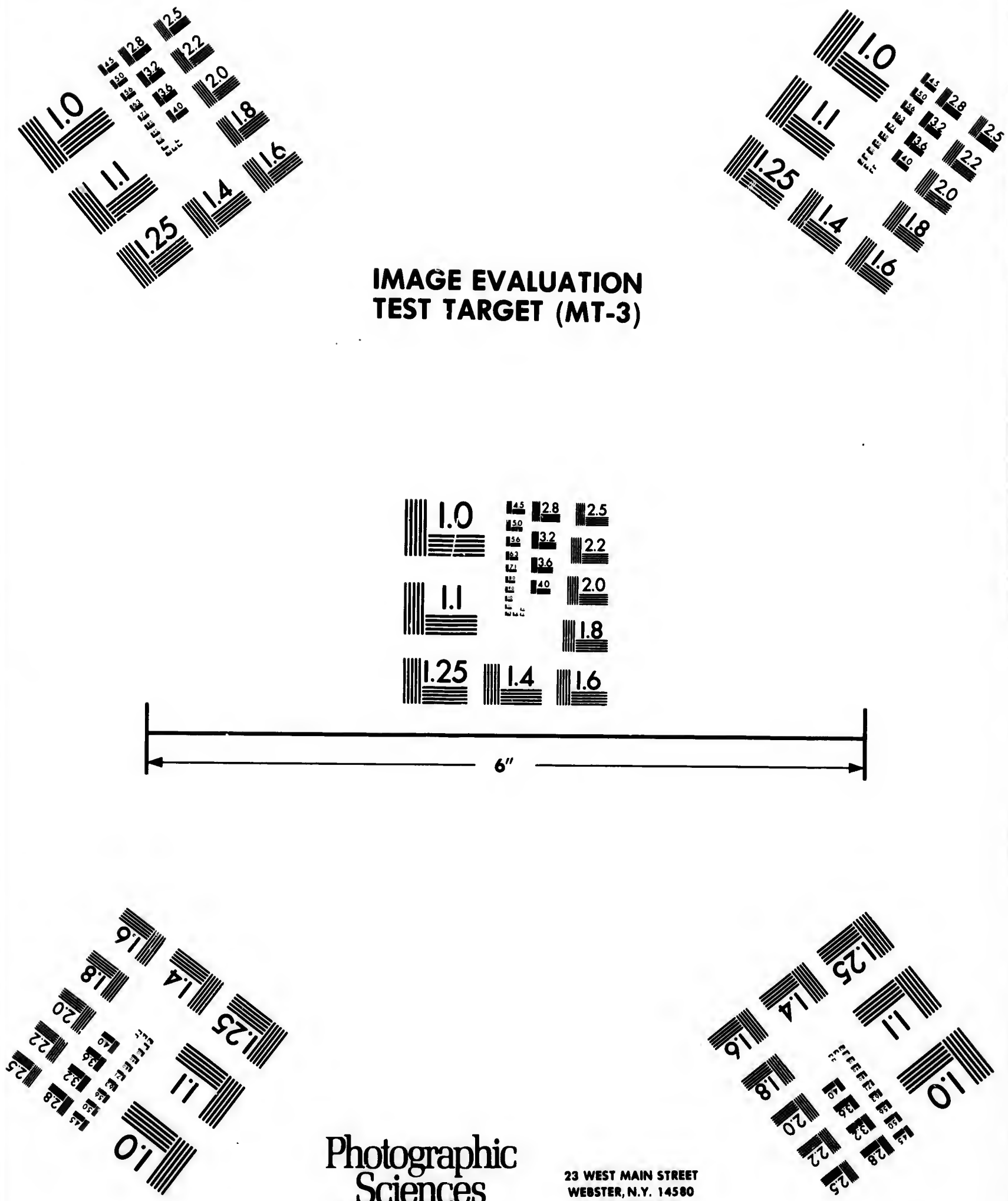

Photographic Sciences

23 WEST MAIN STREET WEESTER, N.Y. 14580

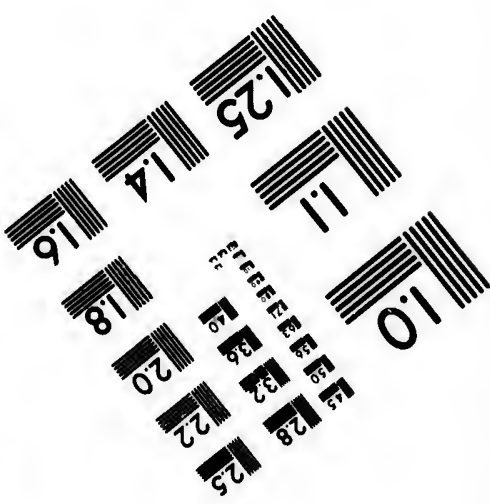
Corporation 
tion of the country ; having lost it by what they estcemed an English cncroachment on their claims, pride and honor urged the French court to effect the recovery of a country, which yct they believed was of little or no value. Cham. plain availed himself of these sentiments and feelings, and as the English monarch did not concern himself much about the matter, the so. licitations of Champlain prevailed ; and by the treaty of St. Germain's, Canada, Acadia, and Cape Breton, were restored to France in the year 1632 .

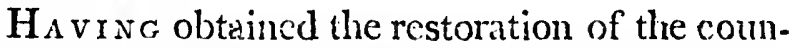
try, Champlain resumed his favorite government and enployment, and continued zealously cugaged in the aftiirs of the colony till the month of December 1635; at which time he dicd governor of the colony, of which twenty seven years before he had been the founder. Clamplain is represented by the writers of that time, as a man of much penetration, integrity and activity. $\mathrm{He}$ could not have succeeded in founding his new colony, if he had not been active, enterprizing, firm and brave. 'The Eeclesiastical writers represent him as a man of great piety, and remarkably zealcus for the propagation of the catholic religion ; and they record with great pleasure, one of his speeches, that " the salvation of one soul was of more value than the conquest of an empire." The work in which he was engaged, required great abilities, and great virtues; without these he could not. have succeeded in establishing a new city and colony in the midst of numerous, warlike, and savage nations.*

- Charlevoix Hist. Nouv. Franee, Tom. t. p. I97. Abbe Raynal, Yol. s. p. I3O. Amer. Eiozraphy, Vol. I. p. 34 I. 


\section{HISTORY OF VERMONT. 263}

they

their

court

li yet

hain.

and

not

e so.

the

and

the

boun.

incut

c11-

honth

gov-

years

in is

as a

vity.

his

rpri-

wri-

and

the

reat

ation

uest

en.

les ;

in

idst

aynal,

Is all countries, the succeeding state of society seems naturally to result from the measures and pursuits of an earlier policy. While zealously engaged in promoting the welfare of his new colony, it was the misfortune of Champlain to entail upon it the miseries and curses of war. Three of the most powerful of the savage nations, the Iroquoise, the Algonquins, and the Hurons, were engaged in a fierce and bloody war when Champlain was laying the foundations of Qucbec.

$\mathrm{T}_{H \mathrm{E}}$ Iroquoise were spread over an extent of country, nearly eighty leagues in length, and more than forty in breadth. Their country reached to lake Erie, lake Ontario, the river St. Lawrence, and the countries which now belong to the States of Pennsylvania and Newyork. To the eastward it took in lake Champlain, and the western parts of Vermont, and the Indians on the banks of Susquehanna, Delaware, Hudson, and Connecticut rivers, were in a kind of subjection to them. The land between these extensive limits was fertile, abounded with game, and was watered by a number of fine rivers, rich in the plenty and variety of their fish. The inhabitants consisted of five nations, and contained many thousand warriors. Their five nations were formed into an united or confederate body, which bore the appearance of a number of confederate republics. In the grand council of the whole all the affairs of peace and war, and other general concerns were determined. These confederate tribes or five nations, formed a more powerful body than any of the adjacent nations. They were generally at war 
with the neighboring tribes, and on account of their numbers, power, and conquests, were become the objects of fear, dread, and aversion, to the other nations. At the time when the French were forming their colony in Canada, the five nations of the Iroquoise were engagyed in a war with the Algonquins and Hurons. The Algonquins lived allong the banks of the river from Quebec to Montreal. 'The Hurons were dispersed about the lake that bears their name. 'These, with some other tribes of less consequence, had suffered severely from the inroacis of the Iroquoise; and were unable to make effectual opposition to their arms.

IN S T E A D of attempting to introduce a reconciliation among these hostile nations, Champlain meaning to avail himself of their quarrels, soon engaged in their wars. He took a decided part with the Algonquins, and went himself with the Hurons in their expeditions against the Iroquoise : He instructed them ho $N$ to carry on their wars, was personally engaged in several of their battles, and in one of them recieived a wound not a little dangerous to his life.

$T_{\text {н }}$ E Indians saw with wonder and surprise the effect of the European arms, in the attacks which Champlain had made upon the Iroquoise at lake Sacrament, and other places. "The $\mathrm{Al}$. gonquins and Hurons soon gave a friendly at. tention to the new settlers, and meant by their assistance to gain the superiority over their an. cient and haughty foes. Of course they favored the settlement of the French, gave them lands, courted their frierdship, and invited them to settle in every' part of their country; and by 
their assistance they obtained many and repeated advantages over the Iroquoisc. Nor was it until the five nations became accustomed to the effect of the European arms, that they could make any effectual opposition to an enemy, whom they had before defeated and despised. But instead of being subdued or disheartened by the new method of war, it served rather to inflame the haughty Iroquoise with the fiercest resentment against the French. They viewed the strangers who were settling in the country, as the most dangerous of all their enemies; and it became the first and most important of all objects to carry on a destructive, unceasing, and exterminating war with them.

'T н French were gradually extending their settlements upon the river St. Lawrence, and advancing further and further into the Indian country. In about ten years from the settlement of Quebec, they began the foundations of a fort and village at 'Trois Rivieres ; and in 1640 they begain a fortress and town at Montreal. Wherever they went, they assisted and encouraged the Algonquins; and they met with a steady and bitter enemy in the Iroquoise. The hostile Indian nations were an enemy, which the five nations wished to subdue; but the French were every where ithe chosen victims, and the objects of their invetcrate hatred. To have taught a despised enemy how to conquer, to have introduced among them weapons every way superior to their own, were crimes which the fierce and savage temper of the haughtiest of all the Indian nations, could not forgive or endure. Thus by interfering in the 
quarrels of the natives, the French had brought upon themselves a fierce and bloody war, with the most powerful of all the Indian nations; and produced an enmity, which appeared to be fixed, permanent, and obdurate; and such as the revenging spirit would endeavor to transmit from one gencration to another.

Is the destruction occasioned by these wars, in the coldness of the climate, in the immense quantity of labor necessary to effect the settlement of the country, and in the fewness and poverty of the Europeans, there were caus. es which rendererl the French settlements ex. tremely slow in their growth, and very precarious as to their duration. In addition to these difficulties, the five nations were now becone accustomed to the effect of the European arms, had procured some of them, and regained their customary superiority cver their ancient enc. mies. Surrounded with so many dificulties, the French were full of apprehensions that the time was not far distant, when they should be forced to abandon the country. Their Indian allies whom they had once taught to conquer, were now continually flying before their ancient enemies, whom they had been accustomed to dread. And the Iroquoise, feeling the animation of their regained superiority, were become more fierce and insolent than ever : and were loudly boasting that they would not only sub. due their former enemies, but that they would soon force the Frerich to leave their country, or put them all to death.

In this clistress the court of France interfer. ed to save the colony. A body of four hun. 


\section{HISTORY OF VERMONT. 267}

dred good troops were sent from France, in the year 1662; and these, in two years more, were re. inforced with the regiment of Carignan. With this force, the courage and hopes of the colony revived. M. Courcelles, the governor of Canada, supposed it would have a good eflect, to carry the war into the country of their enemies : With this view in 1665 he sent out a large party against the Mohawks, one of the five nations. The expedition was undertaken in the ivinter : 'Through ignorance of tive country, and the want of proper snow-shoes, the whole army were near perishing; when they accidentally fell in with Schenectady, a Dutch scttlement oil the Mohawk river. At Schenectaly, the whole party were in the utmost danger of being destroyed by the Moha:vks. What prevented, was the interposition of one Corlear, a Dlitchman. And such an impression was made on the minds of the Indians, by the prescrvation which this man had afforded them, that they never forgot either his friendship, or his name. In all their trea. tics ever after, with the governors of Newyork, they al:-:ays addressed them by the name of Corlear ; an expression, in their view, significant of kindness, friendship, and confidence.

To retrieve the misfortunes of their winter expedition, in the spring of 1666 , twenty light companies of foot, with all the militia of Canada, marched into the Mohawk country. 'Their march was attended with great expence, and fatigue; and continued for more than seven hundred miles, through an uncultivated and hostile country; but did not prove destructive of many of their enemies. At the approach of 
the French, the Inclians easily found places of safety, by retiring into the woods and swamps, where the French army could not follow them. Nothing was to be found but a few of their old sachenis, who were super-anmuated and weary of their lives, to gratify the fury of their enemies. 'The resuit however was faworable to both parties. The French, exhausted with the expence and fatigue of the campaign, and mortified by the want of success, did not wish to repeat the experiment of anoiher expeclition in the Inclian country. The Indians were not pleased to see the war brought into the heart of their own country, nor could they yet oppose a large body of men arned and disciplined in the European manner, with much prospect of success. While both parties thus wished to put an end to hostilities, it would not be difficult to find reasons, ways, and means, to effect a reconciliation. In this disposition of their minds, they agreed to put an end to their wars ; and in the year 1667, concluded a treaty of peace, which continued for several years.

' $\Gamma_{H I}$ Is was the first time that the French colony had ever enjoyed a compleat peace. Both the English and the French immediately embraced the opportunity to conciliate the affec. tions, and to cultivate a trade among the natives; and their interest lead them to urge it, with much zeal and address. At that time the tracle with the natives was attended with much profit and advantage to all parties. The French in Canada, and the English at Albany and Schenectady, were as yet too remote from each othcr, and too few in numbers, to occasion any 


\section{HISTORY OF VERMONT. 260}

laces of wamps, then. heir old weary: eir ene. able to iith the d mor. vish to ition in re not cart of ppose a in the of sucput an cult to reconminds, and in peace,

ch co. Both em. affec. le nage it, e the nuch ench iche. othany

considerable differences, or interference in the indian trade. Ind the Indians who lived betwien the civo countries, availed theinselves of the iest markets and terms which lify could find ; asserting in a wise and pactical manner the doctrine of their independence, liverty, and equality with any of the European colonies. M. Courcelles liowever was not inactive during this season of peace. He easily foresaw that a peave with the savages, corld be of but a short cluration; and he was extremely active in ma$\mathrm{king}$ preparations for the future defence of Canatla. To prevent the irruptions of the Iroquoise into Camada, by the way of lake Champlain, in 1665 he built the forts of Chambly and Sorel; both on the waters by which the comnunication is kept up between the lake, and the river St. Lawrence. In 1672, under pretence of a treaty of commerce, but with a design to effect an establishment, which should scrve to restrain or subdue the Algonquins and Hurons, he obtained their leave to build a fort at Cadaraqui ou lake Ontario. His successor, Count Frontenac, compleated the works the next spring; and in 1679,M. de Salle inclosed with pallisadoes a spot of ground at iagara, upon the strait which forms the communication between the lakes Ontario and Erie. Such was the origin of those fortresses, which have since occaisuned so much expence of blood and treasure.

'To this perrod, the wars in Canada had been confined to the French and the natives; neither the Datch or the English colonies had been en: saged or concerned in them. Albany, and all voL. I. K 2 
the northern settlements on Hudson's river, had bcen conducted by the Dutch. 'That people, inclined nost of all to commerce, had so mana. ged the Indians as to secure their fricndship, derive much profit from their trade, and had al. ways avoided any contests, or at least any open hostilities with them. In 1664, the whole coun. try, called at that time New Netherlands, was surrendered to the crown of England. The country assumed the name of New York, and was governed by authority derived from the king of England. The Indians who lived bctween the settlements in New York and Canada, traded with either as best suited their convenience or interest. But from this intercourse they soon found that the English and French were far from being friends; that they were often at war with each other, and were always rivals in trade. With the spirit of sound policy they endeavored to avail themselves of this state of things, and to procure from the English a plentiful supply of that kind of arms and ammunition, which had been so successfully employed against them; and which could alone be applied to the greatest advantage in all the purposes of war and hunting. At the same time they resolved to preserve their own independence and importance, by trading with, or favoring either, as their own interest might dictate.

THE English and the French colonies were both aware of the Indian temper and policy, and they were anxious to secure the Indian friendship and trade. It became of course their interest and endeavour to impart their orwa 
er, had pcople, mana. dship, had al. open coun. s, was The $k$, and in the ed be. anadi, pnvencourse rench were llways policy state lish a am. y em. alone 1l the same indeth, or dic-

were licy, idian Jurse orka

maxims and prejudices, to the savages ; and to attach them as much as possible to their own nation, views, and party. As war had now ceased, this was the time to try what could be done by the councils, measures and arts of policy and insinuation. In this kind of manœuvering, or Indian courtship, the French had the most address and success. They not only sent their traders, but they sent their Priests to reside among the Indian tribes. The missionaries, educated in all the knowledge of Europe, studied the Indian temper and character ; and soon became well acquainted with their business. Their superior knowledge and address gave a direction to the councils and measures of the savages ; their acquaintance with medical and chirurgical subjects, qualified them to become their physicians and surgeons ; from their knowledge in the arts of life, the Indians were daily instructed in their rude attainments of fishing, agriculture, and making their cabins and weapons. To gain their affections, the fathers were distinguished by their attention to all the offices of humanity; and to these were added the arts and influence of superstition, as a still more effectual means of gaining an ascendency over the savage mind. In this kind of management the Jesuits were most of all distin-. guished : And it does not appear that in any nther order of clergy, so mucli knowledge of science, of business, of men, of human life and conduct, were ever so well united. Wherever they were sent they met with great success; and when their manners and conduct were compared with the aukward and disgusting manners of. 
the Erglish missionarics, the natives concluded that the Jesuits were the men who were the fa. vorites of the Great Spirit above; and that he neitier dicl or would work much by the other missionaries ; estecially by the formal, unaccomnoduting, nietaplyysical English Pricsis.

To this influence and instigation of the French priests, the English ascribed the commence. ment of hostilities which took place in the year 1683, on the back parts of Yirginia and Mirrland, by some of the five nations. This wis the first time that any of those nations had $\mathrm{cr}$. er bcen engaged against the English ; and the prospect of a war with the Iroquoise, occasioned a most serious alarm to the country. If they had proved so formidable to the Ficnch, when they had only their bows, arrow's, and clubs, it was coriciuded they must prove a most formidable cnemy now, when they were generally armed with guns and hatcliets, and kncw how to use them. To ruard against so chan. gcrous an event, a general convention of the English colonies was held at Albany in the year 1684. Lord Howard, governor of Virginia, was present. Col. Dongan, governor of $\mathrm{New}$ York, and other infiuential characters atterdicd. The convention succeeded in arerting the 0 or m. Howard, as Presiclent, made a treaty with the five nations, and entered into a plan of peace, trade, and alliance. 'This covenant was again confirmed in 1685, and has been renewed at several other times, since thiat jeriod.

WHiLE the convention of the English colonies were engaged in this treaty with the five nattons, an event took place, which tended to 


\section{HISTORY OF VIRMONT. 273}

cluded he fa. hiat he other unacsis. french nence. e ronir Marris Wis ad $\mathrm{er}$. id the asion$\therefore$ If ench, i, and 1 most gener. kncw dan. of tire n thec vini:l, New ricd. oi m. the cace, again at

colofive do

Glve it suceess and cficacy. I messenger arrived from $\mathrm{H}$. de Barre, goverror of Canadin, complaining that the Indians of the Suseca tribe hat interrupted the Frencis, in their track with the more distant nations. The Senceas admitted the charge, bat complained in their turn that the Fiench had supplice some of the Indian tribes with whom they were at wat, with arms anci :m:nunition. And it became known that whice De Bare was amusing the governor of Ne: Yoik, and the Iroguoise with these complaints, he was making large preparations for the cntire clestruction of the five nations. That nothing might ve wanting to sccure success to his measures, he had procured fiesli troops from France ; and a letter of instructions from the Siluc of York, proprictor of the province, to Col. Longan his govcrnor, cnjoining him not to oprese ine Prench procecdings. Thus preperied, De Burre procecded with an army of seventecn hundred men to lake Ontario; and sent to all the officers in the western posts, to coilect all the Indians they could in the upper puits of the country, and rerickzvois at Niagara.

'Г⿴囗 $\mathrm{E}$ interference betwen the English and French colonics in the aftairs of the Indizins, though not avowed, had resolved itself into a steady opposition for several years ; and was now assuming the aspect of a regular national policy. Dongan had been appointed governor of New York in the year 1682; and was the first English governor'that saw the advantages. which might arise from the Indian commerce and alliance. Aware of De Barre's mcasures, and designs, he dişregarded the orders which 
he had received from the Duke of York ; an. nounced to the Indians the designs and preparations of the French, and promised to afford them his assistance. Encouraged by these advances from the governor of New York, the five nations became more and more attached to. the English, and prepared to make a vigorous defence.

A $\mathrm{T}$ fort Frontenac, De Barre was detained six weeks in want of provisions and recruits. During this delay, a distressing sickness broke out in his camp, occasioncd chiefly by the badness of his provisions. Incapable of carrying. on war in an enemy's country with a diseased army, he now wished to adjust his operations to the purpose of concluding a treaty of peace. With this view he, crossed lake Ontario, and came to a place, which on account of the distress of his army was called la Famine. Dongan received intelligence of all his movements, and labored to prevent the Indians from attending his proposed treaty. Two of the five nations, the Mohawks \& Senecas were dissuaded, and refused to join. The other three, the Oneydoes, the Onondagoes, and the Cayugas, were influenced by the French missionaries; but were unwilling to hear the French interpreter, unless it should be in the presence of the priests, to whom they had been much attached, Matters were at length partially adjusted, and the sachems of three of the tribes agreed to meet the French governor.... Twodays after their arrival in the French camp. the council was opened. De Barre attended by: a circle of French officers andIndians, addressed 
a specch to Garrangula, an Onondago chief: In his speech he told the Indians that he did not come into their country for the purposes of war, that his aims were altogether pacific, and that he had no other wishes or desigus, but to conclude with them a treaty of peace and perpciual friendship. Garrangula replied, that he had heard and considered his tilk, and did not believe it; that he knew that he came into their country to destroy them all ; that the great Spirit had put it out of his power, and that the Indians perfectly well knew the distresses of the French army ; that notwithistanding all their boasting, they were the objects of compassion, rather than fear ; but notwithstanding they would go so far as to make a treaty with them. Mortified and provoked at the bold and sensible answer of a savage, whom he meant to have despised and destroyed, De Barre was obliged to conceal his resentment, and his fear. No. thing remained but to conclude the best treaty the savages would admit; and he retired to Montreal, mortified with the expence, the want of success, and the disappointment that had attended every part of the expedition; and not at all pleased with the terms or extent of the treaty which he had obtained.

M. de Barre returned to France; and the marquis De Nonvillu being appointed to succeed him in the government of Canada, arrived at Quebec in 1685 . The marquis was colonel of a regiment of dragoons, of an active and enterprizing turn of mind; and was appointed

- Appendir No. Vr. 
for the rarpose of removing the disasters and asp...es, which came upon the colony in the time of its former goveruor. As soon as $\mathrm{s}$ c Nonville was become acquainted with the aflairs of the col. ony, he wrote to cardina! Rivilicu, the French minister, urging a plan to enkme and strengthen the works at Ningar:, to exclude the En. gii-h altogether from the lakes, to engross the whote of the furr trade, and to sublue the five nations ; and immediately beran his operations by throwing lare supplies of troops and provisions into fort frontenac.

The governor of Ncw-York watched all his procecdings, and was very suspicious of his designs. He wrote to him that the five nations were his friends and allies, and that an attack upon them would be considered as a breach of the peace which subsisted between the Engiish and the French crowns. He objected to his sending so powcrful a force to fort Frontenac, and protested against his building a fort at Niagara ; claiming that part of the country, as a part of the province of New-York. In his answer, De Nonville denied any intention. of invading the five nations, but claimed the country at Niagara, as belonging to the French crown. Dongan placed no confidence in the declaiations of the marquis : Aware of his pres parations and clesigns, and of the importance of the Indian alliance and commerce, he exerted his influence to encourage and prepare the confederate tribes for war ; and was constantly at work to make all the opposition in his power, short of actual hostilities, to the plans and procecdings of the French governor. 


\section{HISTORY OF VERMONT. 277}

THE five nations, at that time, had been fortunate in their yictories over some of the Indian tribes with which they were at war; and with whom, the French had carried on a lucrative trade. To put an end to their triumphs, and to the obstruction which they gave to the French trade, De Nonville determined to carry war into their own country. To effect these purposes, in 1687, he assembled a body of two thousand French troops, and six hundred Indians at Montreal ; and directed all the officers in the upper parts of the country to meet him at Niagara, with all the force that they could collect. While these preparations were taking place, hostilities were commenced. 'Two parties of the English, who were trading on the lakes were seized by the French, their effects were confiscated, and their persons imprisoned. A French officer with two or three hundred men, had surprized two villages of the confederates, whom they had invited to settle in their country: And so anxious were the French to prevent any of these Indians from escaping, and carrying the intelligence to their countrymen, that they were all conveyed to fort Frontenac. In the treatment of these captives, the French exceeded the barbarities of the savage tribes : All the captives, thiteen excepted, were burnt at the stake ; and spent their last moments in singing with an heroic and undaunted spirit, the baseness and perfidy of the French. The rest, by the particular order of Lewis XIV. were put in irons, sent to Quebec; embarked from thence to France, and there put on board the gallies.

$$
\text { YOL. I Li } 2
$$


Hostruties being commenced, the interests of the Fiench colony now repliired vigorous \& animated cxertions. De Nonville was not de. ficient in courage or enterprise. On the twen. ty third of June he embarked his whole army in canoes, and set ont from fort Cadaraqui ; one half procecded on the morth, and the other half marched on the south side of the Oneida lake. They met the same clay, at the place appointed for their rendezrous, seven leagues from the chief village of the Senecas. The Iridi:ns were placed in the front, and rear; the main body, consisting of the regulars and militia, were kept together in a regular form. On the sccond day of their march the scouts arrived at the com. fields of the Senecas, and within pistol shot of five hundred of the warriors' of that nation, who lay on their bellies undiscovered. The French concluded that the Senecas were all fled, and were in full march to overtake the old men, the women, and children. In this state of rapid movement, and high expectation, they arrived at the bottom of an hill, within one mile of the Seneca village. In a moment the war-shout and yell of the Senecas, was heard from every side ; and the French army was attacked from every quarter. The whole army was struck with surprise and horror, and universal confusion ensued. The regulars and militia seized with the panic, could neither preserve their order or exert their force to any advantage. One battallion fired upon another, and all endeavored to fly into the woods. Expecting such a scene, the Senecas rushed on with impetuosity to increase the confusion; and would have compleated the 
intergorotis not de. twon. army ; one er half a lake. ointed $m$ the $s$ were body, kept al day corn. hot of , who rench were. wo. 1ove. $t$ the ieneand ide ; very surnsupaxert lion fly the ase the

defeat of the whole army had it not been prevented by the superior prowess of the French Indians. Accustomed to such scancs, they understood the business, and the outrage of an Indian attack ; rallied their forces, rushed on to the attack, repulsed the Senecas, and saved the army of the French.

So dispirited was the French general by this unexpected and alarming onset, that he could not be pursuaded to make any further attempts that

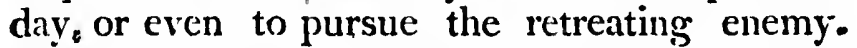
While he was collecting his spirits and his troops, the Senecas burnt their town and marched off with safety into the woods; leaving nothing but two of their oldest men, for the French to kill and torture. All the exploits that remained for De Nonville, was to burn the cornfields belonging to the Indian village, and make captives of the two old men. Having compleated this business he marched his army back.to lake Ontario; and erected a fort on the strait at Niagara. 'To preserve this fort, he left a garrison of one hundred men; all of which, except seven or eight who escaped, being closely blocked up by the Senecas, perishcd in a fer months by famine.

RECEIVING intelligence of the event of De Nonville's expedition, the governor of NewYork concerted measures to avail himself of the power and friendship of the Indians. For this purpose he repaired to Albany, and had a conference with the five nations in the month of August. His speech on that occasion was well adapted to secure their confidence and dependance. He rejoiced, he told them; that they 
had not suffered a greater loss by the French, whose designs undabtedly were to destroy them all ; and that he would provide them with such necessaries as they wanted. He advised them not to destroy their captives, but to kcep them as prisoners, for the redeription of their own countrymen whom the French had taken: To keep up a correspondence with him as to all their designs and measures; to send away the French priests from their country; to point out a place on Lake Ontario, where he might build a fort to supply them with stores and provisions; and above all not to pretend to make any treaties with the French, but by his advice and consent.* These measures and speeches of Dongan served to encourage and animate the Indians. Soon after a considerable party of them beset the French fort at Chambly, burned several of the houses, and returned to Alba. ny with a considerable number of captives. A. bout the same time forty of the Onondagoes sur. prised some of the French soldiers at fort Frontinac, whom they confined and reserved for the redemption of their countrymen, who had been sent to the gallies. Great pains were taken to recover these Frenchmen out of the hands of the Irdians. 'The French priests interposed to persuade the savages to treat them with kind. ness, and return them to their countrymen; and a message was sent to the governor of New York, to engage his influence in the affarr. Dongan informed the governor of Canada that no peace could be made with the five nations;

Smith's Hist. New-York, p. 69. 


\section{HISTORY OF VERMONT. 281}

rench, estroy n with dvised 0 kecp their aken : $\$$ to all y the point might d promake advice eches aimate irty of bur. Alba. A. s sur. Fron. d for o had e tarands sed to kind nen ; New iffair. that ions; unless the Irdians which had been sent to the gallies were returned, the forts at Frontenac and Niagara demolished, and satisfaction given for the damages which had been done to the Sene. cas.

In this situation of the French affairs, Dongan hopetl to compleat his favorite plan of policy; to compel both the French and the Indians to apply to him, in all their affairs of peace and war. He had nearly effected his plan with the Indians ; but the French governors were jealous of his designs, and wished to treat with the Indians, as a nation independent of the English crown or colonies. It was however. in Don. gan's power from the situation of the French colony at that time, to force it into such kind of concessions; and he was steadily following measures to effect the purpose, when he was ordered by James II. one of the most obstinate and infatuated of all the English kings, to give up the point to the grovernor of Canada; and to use his influence with the five nations, to make peace with the French.

DEPRIVED of the assistance and councils of Dongan, the five nations began to hearken to the French invitations, and a general meeting of the hostile parties was proposed at Montreal. Twelve hundred Indians of the five nations attended at this conference, and insisted with much carnestness, on the terms which Dongan had recommended. De Nonville declared himself ready to put an end to the war, if the Mohawks and Senecas as well as the other tribes would agree that the French should not be hindered in supplying fort Frontenac with provisions. Ac. 
eording to the French accounts the conditions were acceded to, and a treaty was agreed upon by both parties.

It proved however of no avail. The policy of one Inclian was sufficient to destroy every idea of confidence between the parties, and to inflame both still more with the spirit of bitterness and revenge. Amorg the tribes which lived on the shores of the western lakes, there was one called by the name of the Dinondodics; a party, or appendage to the Hurons. 'This tribe had found it profitable to trade with the English, at Michilimacinac. On that account it was suspected by the French, as being inclined to withdraw from their alliance; but it was still at war with the confederates. Adario, called by the French Le Rat, was their chief. With a poiicy perfectly. similar to that of Europe, he wished to derive advantages to his own tribe, from the follies; jealousies, and wars of the belligerent powers. His wish and view was to prevent the peace between the French and the five nations. If he could effect this purpose, it would secure his own tribe from the attacks of the Fiench, or Iroquoise ; render their friend. ship of much importance to both; and at the same time secure his own influence, popularity, and power with his own tribe. To effect these purposes, he put himself at the head of one hun. dred men, and marched to intercept the ambas. sadors of the five nations, who were going to compleat the business of peace with the French governor. At one of the falls of Cadaraqui river he met the Iroquoise ambassadors; killed some, took others prisoners, and informed them 


\section{HISTORY OF VERMONT. • 283}

nditions: d upon

policy every and to bittciwhich there dodics ; This ith the iccuunt inclinit was io, calchief. of Euis own vars of ew was and the ose, it icks of friend. at the larity, these e hun. imbas. ing to French ui rivkilled them that it was the French governor that had given him intelligence that fifty warriors of the fivo mations were coming that way.

To be letrayed by the person with whom they had agreed upon a treaty, and were now going to confirm it; and at the same time to bo delivered into the hands of a party with whom. they were at war, exceeded all the conceptions the savages had been able to form of citiplicity, perfidy, and baseness ; and in their rage against De Nonville, they dectared to Adario the nature of their business, and the design of their journcy. Adario instantly put on all the appearan. ces of anger, shamc, and distress, at being made the executioner of De Nonville's baseness and treachery. He flew to the principal of the am. bassadors, cut his bands, and set him at liberty. "Go, says he, my brother, return to your' nas tion, and tell them it was the French who led me to commit so base and vile an action, as to make an attack upon the messengers of peace. Though our nations are at war, you are at liberty ; and I shall never be at rest, till you have revenged upon the French, the base and perfidious conduct into which they have betrayed me." By these arts, similar to those of more polished nations, Adario secured peace for his own tribe, and left the contending powers more exaspera ted against each other than they had ever bcen before.

$T_{H E}$ intelligence soon reached the five nations that their ambassadors had been intercept. ed, and assaulted by the contrivance of the French governor; and they did not doubt of the truth of the information. The whole nation 
vowed revenge, and agreed to make retaliation. Twclve hundred of their warriors, animated with the fiercest feelings of the savage heart, set out on a march to Montreal. The inhabitants, unacquainted with the attack upon the ambassadors, and believing that peace was made with the five nations, were in perfect tranquility, without any preparation for, or any apprehension of danger. While the city was thus serene, and without fear, the storm of vengeance gathered and burst. On the 26th of Ju'y 1688, the Indian warriors landed on the south side of the island of Montreal, and immediately began their assauit upon every part of the city. Nothing could exceed the destruction which the savages carried with them. They burnt the houses, sacked the plantations, and put to death every man, woman and child, which they could find without the fortifications. One thousand of the French were slain in this massacre ; and twenty six were carried into captivity, and burnt at the

- stake. And so great was the consternation of the French, that the Indians lost but three of their number, while they carried destruction and carnage through the whole island. Not satisfied with the calamities they had already occasioned, in October the Indians made another descent upon the island; again destroyed the lower part of it, killed several of the inhabitants, and took many prisoners.

A $\mathrm{T}$ no time had Canada ever before, met with so heavy' a misfortune. The very news carried defeat as well as alarm along with it. On receiving the tidings, the garrison at Lake Ontario set fire to two barks which they had 


\section{HISTORY OF VERMONT. 285}

liation. imated heart, inlabi. on the $s$ inade quility, iension he, and athered the Inof the in their othing avages louses, every ld find lof the twenty at the tion of iree of uction

Not Iready anothtroyed nhabi-

met news ith it. Lake y had just compleated, and abandoned the fort ; leav. ing a match to twenty eight barrels of powder, disposed with a design to blow up the works. The troops went down the river with such rapidity and fear, that one of their battoes, with her crew, was swallowed up in one of the falls. The confeclerates were in all the animation and insolence of victory : 'They seized the fort at Cadaraqui, with all the powder and stores; they sent their scouts every where, to invade the frontiers, and break up the settlements in Canada. The French were involved in every kind of difficulty and danger; their borders were invested, inroads made on their oldest plantations, their new settlements breaking up ; it became difficult and dangerous to cultivate the lands, or to gather in the harvest : And to all the miseries and calamities of war, were now added the distresses of famine, to compleat their catalogue of woes. Their Indian friends and allies forsook them, and made peace with the Iroquoise and English. Two only of the Indian tribes adherec to the French in their ca. lamity ; and these were too much dispirited, to attempt any thing in their favor; and it was only in the cities of Quebec, Trois Rivieres and Montreal; that the inhabitants of the colony found any safety. The savages knew not how to approach, or to carry any fortified works ; and the French availed themselves of this cir. cumstance, till the affairs of the colony took a different turn.

$W_{\text {IIL }}$ the Iroquoise had been carrying on these measures against the French, a war had broke out between the Abenaquies and the vol. I M 2 
English colonies at the eastward, which hore a threatening aspect. It was understood by the English, that there was not any alliance between the Iroquoise and the eastern Indians; but rather, some remains of former hostilities and jealousies : And it was hoped that the licrceness of the savage temper and passions, might be managed so as to (lraw them into a war with the eastern tribes. To effect this purpose, commissioners from the colonies of Massachusetts, Plymouth and Connecticut, hald a conference with the five nations at Albiny, in Scptember 1689. When urged to engage in the eastern war, the Indians replied that it was not. their custom to go to war with any people, fronı whom they lad not received any injury or insult ; that they were engaged alleady in a war with the Irench, the common enemy ; and that they believed the best policy would be for the English colonies first to assist then in subduing the enemy, that was aiways reacly to make war against them both. The speech which their orator made on this occasion, is an amusing specimen of the Indian genius, policy and eloquence. The English commissioners learnt from it, but with surprise, that the Indians well understood their own interest and affairs; and were as much disposed and qualified to avail themselves of policy in the management of war, as the Europeans who had got possession of their country. 
hore a by the between ; ; but tics and rrceness hight be ar with purpose, ssachu. conferin Sep. in the was not. le, front $y$ or in. n a war ind that for the ibduing ake war h their musing nd elo. learnt ns well $s$; and o avail of war, sion of

\section{CHAPTER X.}

$\mathrm{W}_{\Lambda \mathrm{R}}$. The first war's between the English and French colonies, assisted by the Indians; frome the year 1689 ta 1750 . Effect of the revolution in favor of William and Mary. Plans of the French. Destruction in Niew Hampshire and Schenectady. First attempt to reduce Canada. Sentiments of the Indians on that occasion. French expedition agrainst the Mohazwlis. Destruction of Deerfield. Second expedition against Canada. Proccedings of Schuyler. Third attempt to reduce Canada. Procceding's at Oswego and Lake Ontario. Buildings and seitlement at fort St. Frederick at Crown Point. Capture of fort Massachusetts. Proposed expedition against Crown. Pcint. Attcmpt upon the fort at C'/arlestown.

THE wars which had litherto taken plice in the northern parts of the country, had been chicfly between the natives and the European colonies. The English and the French colonies had made it their practice to assist the Indians with arms, ammunition, cloathing and provisions, when they were going to war, either against each other, or against the opposite colony ; but neither of them had as yct adopted the custom, of joining their own troons to the Indians, or sending out parties to aid or assist them in their expeditions.

Col. Dongan, who was governor of Newyork under. James II. was expressly commanded by his sovereign, to avoid giving the Indians any. 
assistance, or the French any molestation. A dupe to his bigotry and to his priests, it seemed to be the grcat object of the English king, to have the French missionaries succeed in converting the American Indians to the faith and ceremonies of the church of Rome; and that every political movement in the province of Newyork might be directed to favor that event. Dongan was an avowed roman catholic, but had more understanding than to sacrifice the political interests of his colony, to the dangerous design of making the Indians a new sect of believers in the eatholic priests. He foresaw the politieal consequenee and effect, avoided the civil politics of his master, opposed the views and measures of the governor of Canada, and gave much assistance to the Indians in their opposition to the French; and the governor of Canada was full of his complaints, that all his measures were opposed and defeated by the govemor of Newyork. But this strong and mutual jealousy and opposition between the governors of Newyork and Canada, was much restrained, and kept from any open and avowed hostilities, by the friendship and good under. standing, which at that time prevailed, between the kings of England and France.

HAPPILY for the English nation, the folly, bigotry, and arbitrary measures of James II. were carried to such an excess, as to alarm all orders and degrees of men. In the event, they prepared the mind of the nation for a revolution; which ter minated in the abdication of James, and in the elevation of William and Mary to the English throne. In his perplexity and dis- 
tion: A it seemed king, to in confaith and and that vince of at event. olic, but rifice the danger$w$ sect of e foresaw oided the the views hada, and their opvernor of at all his d by the ong and veen the as much 1 avowed d under. between

the folly, ames II. alarm all ent, they revoluof James, Miary to and dis. tress, James fled into France for protection. Lewis XIV. avowed his cause, and aftorded him assistance in his endeavors to recover his throne. These events, according to all the European customs and maxims, could not fail of producing hostility and war betwcen England and France.

IT was the fate of the colonies at that time, not to partake much in the prosperities, but to be involved in all the misfortunes and quarrels of their parent states. No sooner had England and France plunged themselves into all the calamities and distresses of war, by the vices and follies of one of their worthless kings, than all the people in their colonies must share the same fate, and be involved in the same pursuits and sufferings. And the time was now come in which both the French and the English colonies were destined, not only to carry on a war with nations of barbarous natives; but to become parties and sufferers in all the quarrels of more cautious, but equally capricious European sovereigns.

M. De Callieres, seems at that time to have had the management of their military affairs, in Canade. Of an active disposition, and sound judgment, he concluded that the surest way to subdure the five nations would be, to effect the conquest of the province of Newyork. The plan that he proposed was to attack the city of Newyork by sea, and that a large body of Canaclians and Indians should march by the way of Sorel and lake Champlain, to take Albany. In pursuance of this plan he went to France in 1688, and presented a memorial to the French 
king on the subject. The force which he requested for these purposes, was thirteen hundred regulars, and three hunared Canadians. Albany was said to be fortified only by an inclosure of stockadoes, and a little fort, with only four bastions; and that it contained but one hundred and fifty soldiers, ard thrce hundred inhabitants. The capital of the province, Newyork, was described as defended only by a stone fort, with four bastions ; and containing four hundred inhabitants, divided into eight companies. The Court of France acceded to the proposals and solicitations of M. De Callieres. A French fleet and troops were sent to Chebucta, in September 1689, to proceed to Newyork, as soon as the troops should have marched towards Albany. The Count De Frontenac proceeded to Qucbcc, to put himself at the head of the Canadians and Indians, in their march to Albany. On his arrival at Quebec, he found the affiirs of Canada in great confusion. He learnt with astonishment that the Iroquoise had plundered and burnt the city of Montreal, and killed most of the inhabitants ; that the frontier settlements were broken up, and the inhabitants of Canada in such a state of weakness and poverty, that they could not undertake any expedition against Albany. It was in vain for Frontenac to attempt a conquest of Newyork, while the French colony was in such a situation ; and he was obliged to give up an expedition, on which his heart had been much engaged.* Thus eariy did it occur to the

- Charlevoix. Smith's Hịt. Newyork. 


\section{HISTORY OF VERMONT. 291}

h he re. ecn hun. anadicins. y an in. ort, with ined but rce hunprovince, nly by a ontaining to eight ceded to e Calliesent to ceed to ld have unt De himself at Que. at con. hat the city of itants ; en up, state of lot unIt was uest of a such up an much o the minds of military men, that whether Newyork or Canada were to be conquered, the passage of the army must be through lake Champlain.

MoRTIFIED by the failure of the proposed expedition against Newyork, and alarmed by the distressed state of Canada, the count found it to be absolutely necessary to revive the hopes of the Canadians and Indians, by some attempt against the English colonies. With this view he projected two incursions; one against the eastern frontiers of Massachusetts and NewHampshire, and the other against the northerly settlements in the province of Newyork. The former was put under the command of Sieur Hertel, who set out frcm Trois Rivieres, and succeeded in the destruction of the fort at Salmon Falls in New. Hampshire, on March 18th, 1690. Thirty of the English were killed, and fifty four, chiefly women and children, were carried into captivity.*

Tнг other party designed against NewYork, was put under the direction of D'Aillebout, assisted by De Montel, and Le Moyn. Under their command, a detachment of about two hundred Frenchmen, and fifty Indians who were well acquainted with the country, set out from Montreal, in the beginning of January, and proceeded by the way of lake Champlain. By the advice of the Indians, instead of proceeding to Albany, they directed their march towards Schenectady, a village about seventegn miles northwest of Albany. After a march of twenty two days, they arrived in the vicinity of the

- Belknap's Hist. New-Hampsbire, Vol, I.p. 250.' 
village; but were reduced to such wants and distress, that they apprehended they must surrender themselves prisoners of war, as the only alternative to prevent perishing by hunger and cold. 'To ascertain whether there was any prospect of success, they had sent forward their scouts to gain intelligence. The spies were one or two days in the village, without being discovered or suspected. On their return to the French army, they informed the commander that the village was in a state of the greatest inattention; that the troops were few, and under no discipline; that the gates were not shut even in the night ; that no preparation of any kind was made for war ; nor did the inhabitants ap. pear to be in any degree apprehensive of dan. ger. Encouraged by this intelligence, the French officers determined to move forward, and make a vigorous assault upon the place. On February the eighth, 1690, at eleven o'clock at night, they entered the city by the gates, which they found open; and that every house might be invested at the same time, they divided themselves into small parties of six or seven to a division. Never was there a place, that was more compleatly surprized. The inhabitants were in their beds without fear, and with. out any suspicion of danger ; the noise and vio. lence of the onset, awakened them from their slumbers; but before they had risen from their beds, the French and Indians had entered their houses, and began the work of destruction and slaughter. Col. Schuyler, commander of the military force in that part of Newyork, has giv. en the most accurate account of this tragedy: 


\section{HISTORY OF VERMONT. 293}

ants and ust surthe only ger and hy prosd their vere one ing dis1 to the mander atest in. d under hut even ny kind ants ap. of dan. ce, the orward, place. o'clock

gates, - house divior seve, that inhabiI with. ad vio. their their their $n$ and of the $s$ giv. redy:
"Notongue," says he, "can express the cruelties that were committed. The whole village was instantly in a blaze. Women with ohild ripped open, and their infants cast into the flames, or dashed against the posts of the doors. Sixty persons perished in the massacre, and twenty seven were carried into captivity. The rest fled naked towards Albany, through a deep snow, which fell that very night in a terrible storm ; and twenty five of these fugitives, lost their limbs in the flight, through the severity of the frost."

$\mathrm{T}_{\mathrm{E}}$ e news of this awful tragedy reached $\mathrm{Al}$. bany, about break of day. An universal dread and consternation seized the inhabitants; the enemy were reported to be fourteen hundred in number; and many of the citizens of Albany entertained the idea, that the best method was to destroy the city, and abandon that part of the country. But Schuyler and others roused and rallied the inhabitants. A party of horse was soon sent off to Schenectady, but they were not strong enough to venture a battle. The enemy kept possession of the place till the next day at noon; and having plundered the whole village, they went off with forty of the best horses load. ed with the spoil ; the rest, with all the cattle they could find, lay slaughtered in the streets.

THE policy of the French was apparent in the midst of these horrid transactions. They not only spared the Mohawks whom they found in the place, but several other persons were released at the request of these Indians, with whom

\footnotetext{
"Smith's Hist. Newyorik, p. 82:

tor. I. $\mathrm{N} 2$
} 
they wished to be at peace. Captain Glen was a citizen of note in the village : His wife, in the time of Col. Dongan, had shewn many civilities to some French captives. The enemy. offered no violence to this man, and released several women and children at his request ; de. claring they had strict orders not to do. him any injury on account of the former conduct of his wife. The people of Scienectady had been inormed of the design of the enemy, and that an cxpedition was undertaken against that part of the country ; but they judged it to be impos. sible for any body of men, in the severest season of the year, to march several hindred miles, through the dcepest snows, with their provisions on their backs. The civil government of the province, at that time, was incapable of affording them any intelligence, or protection ; universal weakness and disorder were sprend through the whole province, by a revolution at at New York, under the direction of a captain Lester.

TH in success that attended these expeditions; was greatly favorable to the views of Frontenac, and served to revive the spirits of the French colony: At the same time they occusioned an alarm in every part of the English plantations ; and it was apparent, that unless they could be checked, New Eingland and New York would receive much greater injuries and insults. It was proposed that there should be a meeting of commissioners from ail the New England colonies, and from the province of New York, to consult, and agree upon measures for the common defence and saiety. Commissionery for 
ald be

vould

. It

ng of

colo-

$\mathrm{k}$, to

zom.

that purpose asscmbled at the city of New York, Miay 1, 1690; it was their unanimous opinion that thers would be no permanent peace in the Engiish colonies, till the French in Canada were suvdued; and that the only effectual measures would be, to engage upon an expedition for that purpose. To effect the conquest of Canada, they agreed upon this plan of operations ; that eight or nine hundred Englislimen, with five or six hundred Indians, should proceed by way of lake Champlain, and make an assault upon Miontreal ; while a fleet and army of eighteen hundred or two thousand men, should go up the river St. Latwrence, and make an attack upon Quebec, at the same time. By thus penetrating into the heart of the country, and carrying: the operations and ravages of war to their two capital cities, it was supposed that the forces of the enemy would be so divided, and their councils so perplexed, as to afford a fair prospect of success to the English armaments ; and might probably terminate in the conquest, or at least in preventing any further insults from Canada.

A small vessel had bcen sent express to England in the beginning of April, with a representation of the exposed state of the English colo. nies, and the necessity of reducing Canada ; earnestly requesting a supply of arms and ammunition ; and that a number of the kings frigates might be sent to make the attack by sea, while the colony forces should invade the country by land. The English nation, involved in a war with France, was in no situation at thit time to afford any assistance to the expedition; 
and having waited till August in hopes of stores and aid from England, the colonies determined to proceed. Massachusetts agreed to fit out the force that was to procecd to Quebec ; New York and Connecticut were to furnish the army that was to advance against Montreal.

'THE Connecticut and New York troops were put under the command of John Winthrop, Esq. of Connecticut ; who was appointed major general and commander in chief. Early in the month of August he arrived with the troops under his command, near the falls at the head of wood Creek. This was the place appointed for the rendezvous of the Indians of the five nations. But instead of finding a numerous force as he expected, there were not more than seventy warriors of the Mohawks and Oncydces. A messenger was sent to the other nations to persuade them to send on their warriors, but they did not come forward to join the army. When the general had advanced atout one hundred miles, he found that there were not batteaux or canocs provided, sufficient to transport one half of the English army ; and that the commissary had not made preparation to supply the army with provisions. The Indians told them it was too late in the year to make canoes; and that it would be best for them not to attempt Montreal, but to direct their attacks against Chambly, and the French settlements on this side of the river St. Lawrence. Liscouraged with the difficulties and prospects before him, Winthrop called a council of war ; in which it was determined that the army must return to Albany for subsistẹce, and to send on about an hundred 


\section{HISTORY OF VERMONT.}

ff stores rmined out the ; New he army

ps were inthrop, ed ma. Early in troops he head pointed five nais force sevenes. A to perut they When undred aux or ne half nissary army it was ! that it intreal, ly, and e river ifficul. p calermin. ny for indred and forty of their active young men, English and Indians, to make a diversion in favor of the fleet. Aвоuт the same time, August the ninth, that Winthrop set out for Albany, the fleet sailed from Boston, for Quebec. It consisted of between thirty and forty vessels; the largest of forty four guns, and the whole number of men about two thousand. Sir William Phips, governor of Massachusetts, had the chief commiand. The fleet had a long passage from Boston, and did not arrive before Quebec till the fifth of October. From the lateness of the season, and the retreat of Winthrop's army, Sir William Phips could have had but little prospect of success, Count Frontenac had advanced with all his forces to Montreal, to defend that part of the country against the army, which was advancing by way of lake Champlain. No sooner had he received advice by his scouts that the English army had retired to Albany, than he set off with the greatest dispatch for Quebec, and arrived in the city before the English fleet had come to anchor. The baron Le Hontan, a French officer who was then in Quebec, gives this account of the proceedings; that count Frontenac was at Montreal when he heard that the English fleet was in the river; and lad the English made their descent before his arrival at Quebec, or two days after, thcy would have carried the place without any contest ; as there were not two hundred French in the city, and it was open and exposed in every part; but that they lost the opportunity, by spending three days in consultation, before they came to any determination how to act. 
$\mathrm{O}_{N}$ the eighth of October, the troops were Janded, amounting to between twelve and thirteen hundred men, and advanced towards the town. 'The next day the ships were drawn up before it, and cannonaded with all their force. They did but little damage to the enemy, but wcre much shattered by the cannon from their batteries. On the eleventh, the troops were re. embarked. They had advanced, and maintained their ground with spirit, but they received such an account of the strength of the French from a deserter, as discouraged them from any further attempt. Nor was there cuy prospect that they could succeed, when they had to oppose the whole force of Canada, under so able a commander as Frontenac. In a few days tem. pestuous weather came on, which drove some of the vessels from anchor, and scattered the whole flect; and they made the best of their way to Boston, where Sin William Phips arrived on the ninetcenth of November.*

$\mathrm{Suc}$ i was the fiate of the first attempt of our ancestors for the conquest of Canada. From the ill success which attended it, it has been customary for the English and French writers to speak of it in the language of derision and contempt. With the multitude, success generally passes for wisdom, and misfortune is esteemed to be folly. The plan of the expedition was the same, that was trice afterwards adopted by the statesmen and gencrals of the British nation: Its success depended on the joint operation of the forces under the command of Winthrop and

* Hutchinson's Hist. of Masachusetts, Vol. I. p. 100. Trumbuli's Hist. of Conascticuts, P. 402. 
Phips. Unfortunately the colonies wasted the summer in a fruitless expectation of succours from England. When Winthrop proceceded to the lake, the Indians saw that it was too late to make the necessary preparations to embark his army ; and they would not venture to join him in any considerable numbers. Unable to pro. ceed he was obliged to return to Albany. This retreat proved fatal to the attempts at Quebec. When opposed by the whole force of Canada, Phips could not succeed either in taking, or in holding the capital of the country.

$T_{\text {H }}$ fruitless attempts of the English colo. nies to subdue Canada, left very unftivorable impressions on the minds of the Indians of the five nations. They saw a precarious dependency of the colonics on a distant and unknown nation, which they could not comprehend; a waste of time, which appeared to them to be unnecessary ; and d want of that unanimity, secrecy, energy, and perseverance, which were generally to be found in their own councils, and in those of the French ; of course they became apprehensive that thcir new allies had not the necessary information, or power, to subdue their enemies. Major Schuyler, of Albany, was acquainted with the Indian character, and discerned the depression of their minds. To keep alive, and to animate their enmity and hostiiity against the French, in the summer of the year 1691, he put himself at the head of a party of Mohawks ; and passing through lake Champlain, made a vigorous irruption upon the French settlements on the river Sorel. He was opposed by M. De Callieres, the governor of 
Montreal, who with an army of eight hundred men, was enramped at La Prairie. Several en. gargements took place between the hostile par. ties, and in these encounters Schuyler slew a. bout three hundred of the enemy; a number which exceeded that of his own force. While the French kept thei: troops together in the European form, Schuylcr adopted the Indiun method of placing his men under cover of trees and swamps ; and derived great advantagc, from this method of carrying on his assaults.*

$\Lambda_{\text {MIDST }}$ these invasions of Canada, Fronten. ac, though far advanced in age, being above seventy, preserved his vigor and activity ; and was perpetually planning some enterprize for the benefit of the" colony, and animating every body around him. Having failed in his attempts to make peace with the five nations, he was now meditating a blow upon the Mohawks. The force he collected for this purpose, amounted to six or seven hundred French and Indians. Well supplied with every thing necessary for a winter campaign, the army set out from Montreal, January 15th, 1695, and marched by the way of lake Champlain. Persevering through incredible hardships, they passed by Schenecta. dy on February the sixth, and that night cap. tured five men and some women and children,

- at the first castle of the Mohawks. They met with the same success at the second castle; the Indians being in perfect security, and many of them gone to Schenectady. At the third, they found about forty Indians engaged in 2

- Smith's Hist. New York, p. 92 . 
ht hundred Sevcral en. hostile par. ler slew a. a number c. While her in the the Indiun ver of trees ntagc, from Its. *

, Fronten. eing above ivity ; and erprize for ting every in his at. nations, he Mohawks. ie, amountad Indians. ssary for a rom Monhed by the ig through Schenecta. night cap. 1 children, They met id castle ; and many the third, aged in 2 war dance, and prepared to go out the next day upon some warlike expedition. Entering the mohawk castle, a warm conflict ensued, in which the French lost thirty of their men ; but they carried the Indian fortress, and captured nearly threc hundred of the Mohawks, but mostly women and children.

Tив misfortunes of the Mohaivks were no sooner known at Albany, than Schuyler put himself at the head of two hundred volunteers, and marched in pursuit of the enemy. On the fifteenth of February he was joined by three hundred Indians, ill armed, and many of them boys. With this force he fell in with the enemy, who had made some attempts to fortify their camp. Having still the advantage in the number and discipline of their troops, the ene. my made three successive sallics upon Schuyler, but in every one met with a repulse; and Schuyler firmly maintained his ground, every moment expecting a reinforcement and provisions from Albany. Fearful of that event, the French on the eighteenth, embraced the opportunity of a heavy snow storm, and marched off for Canada. The next day eighty regular troops arrived, with provisions from Albany. Schuyler resumed the pursuit, and it was by means of a floating cake of ice, that the French army were able to escape over the north branch of Hud. son's river. But so pressed were they by Schyyler's pursuit, that they sufiered most of their prisoners to escape. In these engage. ments Schuyler lost eight of his men, and four. teen wounded; the loss of the French was cighty killed and thirty wounded. Both parties

$$
\text { VOL. I. O } 2
$$


suffered scverely by the severity of the weather, and the want of provisions. 'The Mohawks found about thirty of the French, which had been slain; such was their hunger and rage, that they roasted their bodies, and eat them for provisions. The French, in their turn, werc so reduced that they cat up theit shoes before they arrived in Canadia.*

For several years after this period, the war was continued with much activity and animosity. Scouting and ravaging parties of Indians were frequently making inroads upon the English and French settlements, many were slain on both sides, and much injury was clone to the advan. ced settlements of both countries. Frontenac was also much engaged in erecting forts, and making excursions in the Indian country, to restrain and bridle the five nations. But as these expeditions were at a distance from lake Champlain, they do not come within the proposed limits of this narration. Nor did the war cease on the frontiers of Canada, New York, or New England, till the peace of Ryswick, September 20, 1697. The treaty between the two crowns of England and France, by putting an end to the European wars, restored tranquility to the Indians, and to the American provinces.

THE tranquility of the provinees, however was to be of but a short duration. Upon the death of James 11. the king of France did not admit the prince who was in possession of the Fnglish throne, and acknowledged by the Eng. lish nation, to be their rightful sovereign ; and

* Smith's Hiat of New York, P. 95. 


\section{HISTORY OF VERMONT. 308}

eather, ohawks ich had 1 rage, lem for werc so re they

he war mosity. $s$ were ish and n both advan. pntenac $s$, and try, to But as m lake ropos. he war ork, or Sephe two ing an quility nces.

wever n the id not of the Eng; and

proclaimed another person to be king of Jingland. This affront could not fail to engage those mighty kingdoms in war, and to involve their American colonies in all its effects and sufferings. On May 4, 1702, war was proclaimed between England and France ; a signal to the people that mutual hatred, hostility, and destruction were to begin. At first the war did not prove distressing to New York. Count Frontenac, the able and vigilant governor of Canada, died in the ycar 1698 ; and his suc. cessor, M. De Callieres, had succeeded in compleating a treaty of peace and neutrality with the five nations. This agreement was allowed to be in force by the governors of New York and Canada, notwithstanding the war between the two crowns. And instead of being harrassed by the inroads of the French and Indians, the province of New York continued for some time in a state of grcat tranquility, and carried on a lucrative tracle with the French and Indians in Canada, at the very time they were carrying destruction into the other English colonies.

Whil : New York was thus enjoying peace, the French and Indians were carrying uncommon destruction and calamities into the eastern provinces. In August 1703, a body of French and Indians, five hundred in number, divided themselves into several small parties, and assaulted all the settlements from. Casco bay to Wells. They killed, and captured, one hundred and thirty of the English; burning and destroying the houses and settlements. 'The whole eastern country was in terror, and con: 
fusion ; alarms were every where taking place ; and the whole frontier from Deerfield on Connecticut river, to Casco bay on the sea const, was kept in one continual terror by small par. ties of the enemy.*

The neutrality which New York maintained with the French and Indians, and the supplies which they afforded them in their descents upon the eastern colonies, was cxtremely blamed and censured in all the New England colonies. It was however attended with one gcod cfiect; the Indians, in their trading visits to Albany, frequently gave accounts of the expeditions the French were preparing against the eastern colonies : and Col. Schuyler never failed to give the most faithful and early intelligence of such designs. Deriving his information from this source, lord Cornbury, governor of New York, advised Mr. Dudley, governor of Massachusetts, so cariy as the month of May, that the French and Indians intended to make a descent upon Deerficld. The design not being carricd into execution in the course of the sunmer, the intelligence was not enough regarded. But the next winter, 1704, M. Vaudrieul, governor of Canada, resumed the project with much attention.

DEERFIELD, at that time, was the most northerly settlement on Connecticut river, a few families at Northfield excepted. Against this place M. Vaudrieul sent out a party of about three hundred French and Indians. "They were put under the command of Hertel de Rouville,

- Belksap's Hist. New Hampshire, Vol. J.p. 331-33e. 
place :

n Con-

coast, all par.

tained upplies

s upon

ed and

es. It

efiect ;

lbany,

ins the

an col.

o give

f such

1 this

York, jachu-

at the

escent

arricd

r, the

ut the

or of

atten.

nor-

a few

this

ibout

were

ville,

assisted by four of his brothers ; all of which had been trained up to the business by their father, who had been a famous partizan in their former wars. The route they took was by the way of lake Champlain, till they came to the French river, now called Onion river. Advancing up that stream, they passed over to Connecticut river, and travelled on the ice till they came near to Deerfield. Mr. Williams, their minister, had been much apprehensive of dan$\mathrm{ger}$, and attempted to make the same impression on the minds of his people, but not with sufficient success ; but upon his application the government of the province had sent a guard of twenty soldiers for their assistance. The fortifications were some slight works thrown round two or three garrison houses, but were nearly covered in some places by drifts of snow. To this place, Rouville with his party, approached on February the twenty ninth. Hovering round the place, he sent out his spies for intelligence. The watch kept the streets of the town till about two hours before day, and then unfortunately all of them went to sleep. Perceiving all to be quiet, the enemy embraccd the opportunity and rushed on to the attack. The snow was so high, that they had no difficulty in jumping over the walls of the fortification ; and immediately separated into small parties, to appear before every house at the same time. The place was compleatly surprized, and the enemy were entering the houses at the moment the inhabitants had the first suspicion of their approach. The whole village was carried in a few hours, and with very little resistance ; one of the garrison 
houses only, being able to hold out against the cuemy.

H IVING carried the place, slain forty seven of the inhabitants, captured the rest, and plun. dered the village, the enemv set it on fire; and an hour after sun rise on the same day, retreated in great haste. A sinall party of the Eng. lish pursued them, and a skirmish ensued the same day, in which a few were lost on both sides. The enemy however compleatly suc. ceeded in their enterprize, and returned to Can. ada on the same route, earrying with them one hundred and twclve of the inhabitants of Decr. field as prisoners of war. They were twenty five days on their march from Deerfield to Chambiy ; and like their masters, the savages, depended on hunting for their support. On their arrival in Canada they found much hu. manity aud kindness from the French, aad from M. Vaudrieul their governor; but complained much of the intolerance, bigotry, and duplicity of the priests.*

- WITH a profound respect tothe memory of his worthy grand sire, the writer of these sheets calnot omit this opportunity of mentioning with pleasure his descent, as beiner the grand son of the Rev. John Williams, at that time the minister of Dectfield. This worthy nian was born at Roxbury, in Massachusetts, in the year 1664. He was educated at Harvard Collcge, and took his degree in 1683 , and was the first settled minister at Deerficld. $\Delta t$ that time, when the people were forming a new plantation it was customary to engage some respectable preacher of the gospel, to begin the settlement with them. Having the best educa. tion which the country eould give, and being men of sober morals, $t$ t. clergy had of eonsequence great intluence in the civil, as well as in the religious concerns of the country : And the people generally found in their ministcr, not a useless dupe to metaphysical chimeras, but an able, a moral, and judicious friend; capable of directing their devotions, and assisting them in the difficulties and hardships, inseparable from their situation, when first commencinz their settlement.

Sucr a one was the minister of Deerfield. : Learned, moral, judicious, and of exemplary piety and gravity, he was greatly amiable, and active. In 1697 , the village was attacked by a party of the enemy; the minister put himself at kire bead of his people; and with much prodenos and 
For several years after this period, a continu. ed scene of devastation and destruction was kept up. 'The New-England colonies formed several expeditions against the French and Indians, in the eastern parts ; and they, in their turn, were constantly making inroads on the exposed settlements of the English. Success often attended both parties ; but the exertions of the English colonies proved extremely distressing to the inhabitants, as well as their losses. They were too few in nnmber, to bear the loss of men; and so low in their circumstances that

bravery they repulsed the enemy. On the breaking out of a new war, his anxiecy and his activity increased : Upon his application, the governmene scnt a guard of 20 soldiers to Deerfield ; \& during the whole winter be was incessant in his religious and civil conduct, to impress the minds of the pcople with a sense of their danger, and with a spirit of vigilance and activity. When the enemy broke in upon the town, they went to his bouse in the beginning of the onset; and about twenty of the Indians entercd his house, as he was rising from his bed. Such was the firmness of his mind, that he took a pistol from the head of his bed, and presented It to the breast of the first Indian that came up. The pistol missed fire, and the lndians immediately disarmed and bound him. Tivo of his children, and a negro woman, were butehered, and his housc pillaged. The Indians then suffered him, his wife, and the five surviving children to pue on their cloaths, and prepare for their dreadiul march.

Wues the sun was about an hour high, they led hin out with his wife and children, and set fire to his house and barn. On the second day of the jurney, his wife scarcely recovered from lying in, informed him that her strcigth hegan to fail. He knew the consequenec; her savage master clove her head, and put an end to her life, by oule stroke of his hatchet. Af: Williams himself was carried to Canada with his chlldren. At times, they all recived favors from their Indian masters, and many acts of kindness from the French. During his captivity, by his learning, firmncss, oteadiness, and resolution, he proved of much serviee in supporting the spirits of bis people, and preserving their attachment to the religion and government of their country. In 1706 he was cxchanged, and sent to Boston, with a number of the Euglish captives. Some of the best parishe near Boston, urged him to settle with then, as a mitister. Declining every offer and prospect of this nature, in conformity to a vow made in his captivity, he returned to Deerfield; collected his flock, and began agaip with them the labors and hardships of another settlement: and remained their worthy and faithful minister till the year $\times 728$; dying in peace, beloved by his people, and lamented by hiscountry. The account that he wrote of his captivity, is in the plitin serious style of that day; an instructive and entertaining relation, and has gone through seven editlons.-" The memorial of virtue is immortal. It is known with God and $n$ ith men. When it is present, men take example at it; and when it is gone, shey dro ine js." jiable, and active. my; the minister ach prodeneo anl? 
they could scarcely procure the necessarics of life, much less bear the expences of war. 'The whole country was in a state of constant terror and alarm ; and in the frontier towns, the wo. men and children found no refuge, but in the garrisons. The men went armed to their work, centinels were posted in the fields, attacks were made almost every weck, reports of French and Indian armics and incursions were incessint, and every month some of the inhabitants were cut off by the enemy. And what was more humiliating, a favoritc but ill managed expedition against the French at Port Royal in Acadia, in 1707, had failed.*

To put an end to this horrid scene of depre. dation and slaughter, there was no way but to carry the war to the head quarters of the enemy, and make another attempt for the conquest of Canada. Solicitations for this purpose had been made to the court of England by the assembly of Massachusettis; by Francis Nicholson, who had been lieutenant governor of New York and Virginia ; and by captain Samuel Vetch, who had been several years before at Quebec, for the redemption of prisoners, and was well acquaint. ed with the river St. Lawrence, and the French settlements. Vetch made a full representation to the British ministry, of the state of things in America ; and of the necessity of carrying the war into Canada. The British ministry ap. proved of the plan; and early in the spring, [1709] Vetch came to Boston with letters from the carl of Sunderland, the British secretary of state,

* Hutchinson's Hist. Massachusetts, Vol. 2. j. I27-I59. Belknap's IIbt. New-Hampshire, Vol. I. p. 329-.-347. 


\section{HISTORY OF VERMONT. 309}

essarics of war. 'The stant terror is, the wo. but in the their work, ttacks were French and incessint, tants were was more ed expediin Acadili,

he of depre. way but to the enemy, conquest of se had been e assemibly olson, who $\checkmark$ York and Tetch, who ec, for the Il acquaint. the French resentation f things in urrying the inistry ap. $n g,[1709]$ from the $y$ of state,

59. Belknap's to the governors of the English colonics to engage thicir assistance.

The plan announced by these letters, was, that her Majesty would dispatch a squadron of ships to Boston, by the middle of May, with five regiments of regular troops. The colony govemments eastward of Connecticut, were required to raise twelve hundred men; and to furnish them with transports, flat bottomed boats, pilots, and provisions, for threc inonths. With this force it was designed to make an attempt upon Quebec. $A_{i}$ the same time fiftecn hundred men were to be raised in Connecticut, New York, New Jersey, and the southern colo. nies. This corps was to proceed by way o! liake Champlain, and make a descent on the Is!: and of Montreil. Vetch was appointed a colonel, and Nicholson, by the nomination of the governor of New York, and the consent of the governors of Connecticut and Pennsylvania, was appointed commander in chief.

Ar L the colonies, except Pennsylvania, furnished their quotas of troops. The provincial army from the eastern colonies, was ready to mail for Qucbec by the twentieth of May. Nicholson with his troops marched early in the summer to Wood cre:k, where he wals directed to wait till the flect should arrive at Boston. Besides the quotas of troops which were to be raised, several independent companies vere formed, and sent on to the arny. Six hundred Indians were also collected, and a thousand of their wives and children were main. tained at Albany during the campaign. Provisions and stores for the army were collected roL. I. $P_{2}$ 
and transported ; and more than one hundred battoes, and as many birch canoes were con. structed for crossing the lakes. Three forts were built at Woud creek, b_sides many blockhouses and stores for the provisions, which had been provided and transported with great dispatch.

EVERY thing now bore the appearance of success. The public affairs of Great Britain were conducted by a wise and able ministry. Their arms had been attended with uncommon success in Flanders, under the celebrated duke of Marlborough ; and France was so weakened by her repeated defeats in that country, that she was not in a condition to give assistance to so remote a colony as Canada. The Indians of the five nations, through the address and soli. citations of Schuyler, afpeared to be heartily engaged in the business. Joy seemed to sparkle in crery eye, and the expectation ap. peared to be universal, that the time was now come, when Camada was to be reduced; and an end put to those horrid scenes of destruc. tion and slaughter, which had so long distressed and wasted the country.

Tur scene of joy and expectation was not however of a long duration. The armament expected from England did not arrive; nor any intelligence that it was ready to sail. A great mortality began to prevail amcng the troops at Wood-creek. With the sickness and disappointment, the public humour and expectation began to change; and the spirit of discontent and suspicion became apparent, and increasing. 'The delay of the fleet spread 2 
hundred ere con. ree forts ny block. s, which ith great

arance of at Britain ministry. icommon ted duke weakened try, that stance to Indians of and soli. heartily to spar. tion ap. was now ed ; and clestruc. istressed

was not mament e ; nor sail. A cing the sickness and $e x$ pirit of nt, and read 2 general discontent through the country; and early in the fall, the assembly of New York ad. dressed their commander in chief, to recall their forces from the carnp. Nicholson and Vetch put an end to the campaign; and repaired to New Port in :...sode Island, to join in a congress of colony governors, to consult what further attempts they should make against the enemy. Two or three diys before this con. gress met, on October the cleventh, intelligence was received from England that the British ministry had been obliged to give up the prospect of the Canada expedition : That when the troops were ready to embark, news arrived of the defeat of their allies in Portugal, and that the British ministry had no way to afford thein. relief, but to order to their assistance the troops. designed for Canada; and that their attention was now wholly diverted from that expeciition. Upon the receipt of this news the assembly of Massachusetts desired their governor to disband: their men, and dismiss their transports.

THus ended the second attempt to reduce Canada. The plan of the expedition seems to have been well concerted, but it was not known how many difficulties would unavoidably attend the progress of an army through Lake Champlain ; and how much time it would require. While Nicholson lay at Wood creek, the governor of Canada had intelligence of all his motions ; and sent out an army from Montreal of fifteen hundred French and Indians, to oppose him. The French army set out on the twenty eighth of July, and in three days advanced forty leagues towards Nicholson's camp. The intelligence 
they received, was, that the English ariny aniounted to five thousand; and they concluded it would be the safest to return to thcir advan. ced posts, and receive them there. If Charle. voix, the French historian, is to be credited, the Indians of the five nations were doubtful whether the completc success of the English army would be best for them. Upon the au. thority of fither Marcuil, who had been a prisoner at Albany, he relates that a grand council of Indians was held at Onondago, that one of their old men made a speech in the council, and aslied them whether they were not sensible that they were situated between two powerful artions, either of which were able to extirpate their tribe's ; and would not fail to do it, when either of them had fully subdued the other. IS e then advised them not to adopt any measures that would tend to destroy their own importance and inclependence; but to pursue their former policy, and to be at peace or war with either nation, as should best tend to keep up the contest between them. The speech and policy of the aged Sachen madc a gieat impression on the assembly ; and according to Mareuil, the Inciians were not active in assisting Nicholson, but rather wished to pollute the water from which his army drank, and to impede their progress. But whatever might be the circumstances, an event in Portugal put an end to the whole expedition. And the plan concerted and urged by the British ministry scrved no other purpose than to produce the loss of a great part of Nicholson's army, to eniail a heavy debt on the English colonies, to dishonour them in the view 
ish army concluded ir advan. Charle. credited, doubtful English the au. en a priscouncil it one of council, t sensible powerful extirpatc it, when he other. measures iportance ormerpoer nation, itest beof the $n$ on the the InciiIson, but m which rogress. aces, an hole ex1 urged purpose ff Nich. the Enle view

of the French and Inclians, and to spread a general discontent and suspicion through the country.**

The attempt upon Canada having failed, the frontiers were again involved in blood and destruction. While the preparations were making to invade Canada, the French cmployed all their arts in managing the Inditus who were attached to them, and engaging tisem in a vigorous opposition ; but as soon as the danger wias over, numerous parties were sent out to harrass the English frontiers. These irruptions were chiefly made on the northern and eastcrn parts of New England. Among others, one of their. celebrated partizans, Rouville, with one hundred: and eighty French and Indians, made another. attempt upon Deerfield. The inhabitants had. but lately returned from their captivity, and had. not forgot their sufferings. 'The enemy' was, discovered at a distance, the inhabitants rallied, bravely defended themselves, and repulscd their. assailants.

New York had as yet escaped the Indian: desolation and carnage, being covered by the. Indians of the five nations ; between uhom, and, the French and India's of Canada, there was. yet subsisting a treaty of friendship and neutral. ity. Mr. Hunter, the governor of New York, was so apprehensive of danger from some of the. confederates, that he made a voyage to Albany. to renew the treaty that subsisted with those nations. While engaged in this business, he was, strongly solicited by the New England governm-

\footnotetext{
"smith's Hist. New-York, p. I76. Trumbull's Hist. Connecticat, P.458: Hutchinson. Vol. 2. p. I62. V.OL. I. P. 3.
} 
ments to engage the five nations in a war with the Abenaquies, who were daily ravaging their borders. Attentive chiefly to the interest of the province of which he was governor, he declined the measure, lest it should bring hostilities upon that province. New York commended this policy as wise, prudent, and salutary to that province. The New England governments condemned it as narrow, partial, and selfish ; and tending to create distrust, danger, and disunion, in the English provinces; and were loud in their complaints, that their enemies found at Albany, alrms and ammunition to carry on the war angainst them, and a good market for all the spoil and plunder that was taken from them.

Suc 4 however was the importance of vigorous measures to preserve the attachment of the live nations, and to defend their own frontiers, that the English colonies still retained the idea of driving the French out of Canada. The congress of governors which met at Rhode Island, were agreed in the necessity of this measure; and Nicholson and Vetch who had met with them, were fully in the same sentiment. It was agreed that an address should be made to quecn Anne, representing the great harmony and exertions of the colonies in her service, the necessity of reducing the French in North $A$. merica to her government; and praying her majesty to giant to the colonies an armament, which with their assistance, should be adequate to the clesign ; and that agents should be sent to Great Britain, to join with Nicliolson in representing the state of the country, and soliciting assistance against Canadiu. 


\section{HISTORY OF VERMONT. 315}

ar with ng their st of the: leclined es upon ed this to that rnments selfish ; and dis: ere loud ound at on the for all in them. f vigo. t of the ontiers, the idea The ode Isl. $s$ measad met itiment. made to armony. ice, the rth $A$. ng her tament, lequate xe sent in repliciting

No man at that time had a more extensive asquaintance with the affiairs of the English colonies than colonel Schuyler of Albany. He filly comprehended the importance of the Indian alliance and trade, the necessity of expel. ling the French from the northern continent, and the danger that arose to the English colo. nies from the diversity of their interests and governments. His influence among the Indians was much greater than that of any other man : By his liberality and generosity to their chiefs, he had impaired his own fortune, but acquired an ascendency that was of much use to his country. Dissatisfied with the management and failure of the expedition, impressed with the necessity of vigorous exertions against the French, he resolved to make a voyige to Eng. land at his own expence; and to carry with hin five of the Indian sachems, to give a more sensible impression to his solicitations at the British court. 'The assembly of New York had determined to address the queen on the subject of a Canadia expedition; and they a. vailed themselves of Schuyler's intentions, to express the sense they had of his merits, and to have their address presented by him.

Sc nUyzer. soon embarked from New York with the five Inclian chief's, and had a prosper. ous voyage to England. The manner of his reception, served to display the knowledgre and prudence, with which he had concerted his plan. His five Indian lings engaged the attention, and gave him admission to all orders, companies, and socicties of men in the kingdom. The lords and commons, the nobility and gentry, 
the clergy, the philosophers, and citizens, all wanted to see the American Mohawks. The mob followed them, wherever they went; and small portraits of them were every where soid in the streets. 'The British court was then in mourning, on account of the death of the prince of Denmark; and it was determined in the cabinet, that the Mohawk kings should appear to mourn as.well, as the rest. The managers of the play house were to determine upon the forms, and adjust the ceremonies of their dress ; and the queen was to be at the expence. The result was, the five Mohawks came forth array. ed " in black under cloths, after the English manner ; but, instead. of a blanket, they had each a scarlet ingrain cloth mantle, edged with gold, thrown over all their other garments." The next part of the business was to adjust the etiquette of the public audience they were to have of her most sacred majesty; and it was concluded that profound reasons of state requir. ed that an extraordinary solemnity should at. tend this transaction. Sir Charles Cotterel, master of the ceremonies, conducted them in two coaches to St. James's ; and the lord cham. berlain introduced them to the royal presence. Amidst this scene of parade and ceremony, the Indians made a speech to the queen, April the nineteenth, 1710; the whole object of which was to persuade her majesty to make another attempt for the conquest of Canada ; but th: speech itself, whether owing to the customs of the British court, to an English composition or correction, to an adjustment to a royal Euro. pean ear and importance, or to any other cause, 
citizens, all wks. The went ; and where sold was then in $f$ the prince ned in the ould appear managers e upon the their dress ; ence. The forth array. he English , they had edged with garments." is to adjust they were and it was tate requir. should at. is Cotterel, d them in lord cham. al presence. emony, the April the which was mother at; but th: zustoms of position or yal Euro. ther cause, the specch itself was destitute of the spirit, dignity, energy, and independence, with which the Mohawks always spoke in their own country.*

'Гн speech however had the effect, which wis intended ; it proved acceptable to her most gracious majesty ; and Schuyler had the pleas. ure to see his plan succeed, and the address to make his five Indians of more consequence at the court of London, than the whole royal fami. ly would have been in the Mohawk country.

Applications were now before the queen from New H:ımpshire, Massichusetts, Khode Islind, Connecticut, New York, and the five nations, seconded by Nicholson and Vetch, and many other respectable characters, soliciting for another expedition against Canada. The Brit. ish ministry at first seemed inclined to favor the business, and encourarement was given that

* According to Oldmizon s account, the following is a translation of the lindian address.

"Great Queen,

"Ws luave undertaken a long vopage, $\because$ hich $n$ one of olx prectecessors could be prevailed upon to mulertite, to sec our great queen, and relate to hir those things, which we thought absolutcly nccessary for the good of her, aud us hir allies, on the other side of the water.

"Wr desubt not bat our great queen has been acquainted with our long and tedious war, in conjunction with her children, aga nst her enemies the French; and that we bive been as a strong ivall for their stenrity, even to theloss of our isest inen. We were inighti!y rijoiced, when ws heard ourgreat queen hat resolved to send an army to roduce Canada, and im-

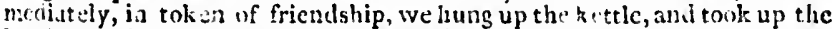
bich at, and, with one consent, assisted colonill Nicholson in making preparations on this sice the lake; bat, at leugth, we were told our great queen, by some important affairs, was prevented in her lesign at present, which :made as sorrowful, lest the Prench, who had hitherto drcalled us, should now ihiak tig ulluble to mike waraguinse tinem. 'l'he reluction of Carada is of great wcight to our free hunting; so that if our great queen sirould not be ini:adiful of us, we must, with our families, forsalse the country, and s.ek other habitations, or stand neutcr, cilher of which will be much against uur inciiantions.

"IN tokel of the sinzerity of these uatinns, we do, in their names, preseit: our great queen with these belts of Wa!ilnum, and in hopes of our great iue rn's favor, leave it to her most gracious cullsideration." "Smith's Hist. Ncwyork, p. Izo. 
it would be taken up the next spring. Nichol. son came over in July with that expectation, accompanied by a fleet of five or six frigates, with orders to raise recruits in the colonies. They were designed however, not to make an attempt upon Canada, but to effect the reduc. tion of Port Royal, and Nova Scotia. The chief command was given to Nicholson, and he made an easy conquest of the place on the fifth of October. In honor to queen Anne the place was now named Annapolis, and Vetch, who was adjutant general, was appointed by Nichol. son to be the governor of the place.

Encouraged by this success, Nicholson in the fall made another voyage to England to urge again the Canada expedition. The expectation of the country had been so much disappointed by the measures of the British court, that it was not expected that any assistance would be afforded. The business however was resumed, and the ministry fell in with the proposals. On June the eighth, 1711, Nicholson arrived at Boston, with the intelligence that a fleet might soon be expected from England; and with orders that New England, New York, New Jer. sey, and Pennsylvania, should have the quotas assigned to them in readiness to join the expedition. A general meeting of the governors of the colonies was immediately appointed at New London ; and while they were holding a council upon the subject of their orders, the fleet arrived at Boston but sixteen days after the first intelligence of the expedition by Nicholson.

$T_{\text {H }}$ Geet was not furnished either with pilots or provisions; and in addition to the troops 
Nichol. xpectation, $x$ frigates, colonies. o make an the reduc. otia. The on, and he on the fifth e the place etch, who by Nichol.

icholson in and to urge expectation sappointed that it was uld be af. resumed, osals. On arrived at leet might id with or. New Jer. the quotas the expevernors of ed at New $g$ a counhe fleet arer the first holson.

$r$ with pithe troops and stores required of the colonies, they were called upon to find provisions for the English fleet and army for ten weeks. It must have been known to the British ministry that a compliance with these requisitions was impracticable. The colonies, from the nature and circumstances of the ministerial management, were suspicious that nothing would be effected ; and that in such an event, the policy of the British cabinet would be, to lay the blame upon them. Zealous for the expedition, and determined that no fault or blame should attach to them, they made the most vigorous exertions to comply with the requisitions. Troops were raised with the greatest expedition, provisions were procured wherever they could be found. In some of the colonies, a price was fixed for them by the arts $f$ the assemblies ; and in others, the own. ers compelled to part with them, or to hav - inem seized by the civil authority. The whole country was in niotion, to provide for the expedition; and no other business was much attended to, but the raising of troops, and procuring military stores.

So general and spiritcd had been the exertion of the colonies, that in little more than a month from the arrival of the fleet, the levies and provisions for the colony army, and for the fleet, were compleated ; and on the thirtieth of July, the whole armament sailed from Boston The fleet consistcd of fifteen ships of war, from eighty to thirty six guns, with forty transports, and six store ships; under the command of Sir Hovenden Walker. 'The army on board contained seven regiments from the duke of 
Marlborough's troops, and a battalion of $\mathrm{mi}$ rines : two regiments raised in New Hampshire, Massachusetts, and Rhode Island, were also embirked. 'The whole anounted to near seven thousind men, with a fine train of artillery, and amply provided with the necessary warlike stores, under the command of brigadier general Hill. This force was fully competent to the reduction of Quebec ; which at that time wis not strcngly fortificd, or in any preparation to withstand a regular siege by a veteran army.

$O_{N}$ the same day in which the fleet sailed from Boston, Nicholson set out on his journcy to Albany ; and in a few days appeared at the head of four thousand men. This army was raised in Connecticut, New York, and New Jersey. The Connecticut troops were commanded by colonel Whiting, an experienced officer, who had conmanded them the year before at Port Royal. The New York and New Jersey troops were commanded by coloncls Schuyler, and Ingoldsby ; and Schuyler, with his usual spirit of activity and enterprize, had procured six hundred Indians of the five nations, to join the colony troops.

TH E enemy in Canada were not unacquainted with these preparations. Vaudrieui, the governor general, sent his orders from Mlontreal to Sieur Beaucourt, to hasten and strengthen the works at Quclec ; and commanded all the regular troops and militia to hoid themselves in readiness, to march on the first alarm or notice. Four or five hundred Indians of the distant na. tions, wcre collected at Montreal. Several In. dians, and two missionaries, were sent anong 


\section{HISTORY OF VERMONT. S21}

$n$ of $\mathrm{ma}$ v Hampnd, were d to near of artille. sary warbrigadier competent that time reparation ran army. eet sailed s journcy red at the army was and New commaned officer, before at cw Jersey Schuyler, his usual procured is, to join

acquaint. ievi, the Montreal trengthen ed all the uselves in or notice. istant naveral In$t$ ausong the five nations, to detach them from the Finglish interest. Quebec was fortified, and put in. to the best situation that the time would admit, to sustain a siege ; and all the principal posts below the city, and on both sides of tive river, were prepared to oppose the landing of the British troops.

W ILKER arrived with the ficet in the mouth of the river St. Lawrence, on the fourteenth of August. Fearful of losing sight of his transports, and the wind fresh at the north west, he put into Gaspe bay ; and continued there till the twentieth. On the twenty second, two vlays after he left the bay, the fleet appeared to be in great danger; without soundings, without sight of land, surrounded with a thick fog, and the wind high at the south east. In this situation the ships were brought to, with their heads to the southward, in expectation of bcing driven by the cu:rent, into the midst of the channcl. Instead of this, about midnight, August the twenty third, the seamen found that they were driven on the north shore, among the rocks and islands, and in extreme danger of being lost. The men of war escaped, but eight transports were wrecked on Egg Island, near the north shore; one thousand of the men perished, and six or seven hundred were saved by the other ships. In this distress but one of the colong vessels was lost, and the men of that were sav. ed; the admiral and general were in greit danger, but escaped by the vessel's coming to anchor. The next morning the wind came round to W. S. W. the admiral bore away for Span. ish river, and the men of war and transports voL. I. $Q 2$ 
followed. The wind carse round again to the east, and would have carried them to Quebec in two days ; but instead of making another attempt, thcy were eight days beating down the river, against an easterly wind, before they arrived at Spanish river in the island of cape Bre. ton. At that place a council of war was held, and after some fruitless consultations it was unanimously resolved, not to make any further trial to go up the river St. Lawrence, and not to make any attempt against the French at Pla. centia in Newfoundland ; but to return, as soon as they could, to England. On September the sixteenth, the fleet sailed fir England, and the American troops and ressels departed for their respective colonies; October the ninth, Walk. er arrived at Portsmouth. Here the scene was closed; in addition to the other misfortunes, on the fifteenth, the admiral's ship the Edgar, of screnty guns, was blown up ; having on board above four hundred men, many other persons who came on board to visit their friends, and most of the admiral's papers.

TuE army designed to invade Canada by way of lake Champlain, had not advanced far from Albanr, before they received intcligence of the disaster which had attended the flect. Nothing remained for Nicholson, but to disband his antny and return. The marquis de Vaudrieul had been at Qucbec, waiting for the arrival of the English flect. He received intelli. gence by the fishermen, and other vessels, that many ships had bcen stove, that much military: apparatus, and many dead bodies with red coats had been driven on shore, and that the river was 
in to the Qucbee other at. own the they arape Bre. as held, it was further id not to at Pla. as soon nber the and the or their Walk.

ene was ines, on dgar, of $n$ board persons ds, and ada by sed far iigence fleet. lisiband Valute arri. intelli. s, that ilitary: coats was clear of ships ; and he justly concluded that the English fleet had suffered so much, that they had given up the idea of making any attempt upon Quebec. Immediately he ordered the whole force of Camada towards Montreal, and lake Champlain ; and formed a camp at Cham. bly of three thousind men, to oppose Nicholson's army, should they attempt to penetrate Canada in that quarter. But he was soon in. formed that he 1 nothing to fear from the colony army, that 'cholson had $r$ 'LL.: $:$ ed with his troops, upon the news of the disaster which had attended the fleet; and that the pcople of Albany, instead of bcing engaged in any hostile attempts against Montreal, were in much anxiety and fear for their own safety.

Sucn was the issue of the third attempt to effect the reduction of Canad. 'The two former had served to bring heavy debts upon thro colonies, to destroy a numiser of their yo.:? men, to discourage the public confuience in.t exprctation, and to abate the attachment of the ir Indian allies. 'This, hul not only produced thr: same effects, but it served to fill the country. with jealousy and suspicion of the Bitish min. istry ; with severe charges, and loud complaints against their conduct. The want of seasonable intelligence and orders, the late arrival of the flect at Boston, the known impossibility of pro. curing the provisions required without previous notice, the complaints and obstinacy of the ad. miral, the ignorance of the pilots, the secret intentions of the tory ministry, were subjects of angry debate and altercation. The remarks of the whigs in England were still more severe. 
Lord Harley went so far as to eay, in his ac. count of this expedition, that the whole was a contrivance of Bolinbroke, More, and the lord chancellor Harcourt, to cheat the public out of twenty thousand pounds. N.o public enquivy seems to have been made into the matter. It is more candid to assign the misfortunes of the fleet to error, than ta design. But when every allowance is made that candor can admit, it will. be extremely difficult to believe that the British ministry at that time were seriously in carnest, in wishing to carry their conquests. any, further against France.*

THE. ill success attending this expedition, gave to the five nations unfayorable sentiments, of the power and policy of the English colonies. finissarics were among them from the governor of Canada, to seduce them from the English, ated attach them to the French, the better man. aresed and more successful cause. And yery serious apprelicusions were entertained, that they were inclining to the French intelest. The enstern Indians were encouraged by the failure of the expedition, to harrass the frontiers of Massachusetts and New Hampsnire; and much damage was done the next summer in that part of the country. Dudley, Salstontal and Cran. ston, the governors of the eastern colonies form. ed a design. to engage the five nations in a rupture with the French, to afford some relief to their frontiers. But neither, the governor, the assembly of New York, or the Indians, appearing: to fivor the plan, the scheme was dropped;

- Smith's Hist. New York, p. I.j6. Hutehinson's Hivt. Massachusetta. Vol, 2, p. 180 . Trumbull's Hist. Connecticut, p. 465 . 


\section{HISTORY OF VERMONT'. 325}

his. ac. e was a the lord c out of enquivy tter. It s of the n every t, it will: British carnest, further

pedition, timents, colonies. governor inglish, er man. very sc. hat they t. The e failure. atiers of ud much hat part d Cran. is form. 1 a rup. elief to or, the appearopped ; esackusetıa

and the eastern colonies defended themse: with good succes;, against the inroad's of savages.

THe European powcrs had now inecone ed of the war. The real interests of the $6: \ldots$ ? court, and the fuctions of the Britih, incones them to terms of peace; and o: Mrere': thirty first, the treaty of Utrecht wis by the plenipotentiaries of Gresti linitin: France. The fifteenth article of this; tren: designed to prevent any further inte: fyne : eicher power to molest, or to influenes the dians to war. The plenipotentiaries seem have scarcely known whether to call the India." allies, friends, or subjects ; but the Indinss themselves perfectly well knew, that they did! not mean to be in subjection to cithr. of the European powcrs, or to their cotonic:s ; but to preserve their independence, and make the most that they could of their tracle, and of their ciarrels.

WIIEN the news of this treaty. became known in America, the Indians every where apeared to be disposed ta. peace. On the cleventh of July, 1713, the eastern Indians had a treaty with the governors of Massachusetts and Neiv. Hampshire, at Casco bay; they renewed their professions of allegiance, engaged to be at peace with the English, and to prevent all hostilities for the future. 'Though little conficience couid! be placed in such treaties, sich had been the sufferings occasioned by the war, that this agreement with the Indians was considered as a matter of great benefit and joy to all partics; and the country had the prospect of that trou-.

roc: 1 . Q 3 
quility, which the people so much needed and jesired.

$P_{E, I C E}$ with the savages however could not. be of long duration. The English were constantly extending their settlements to the east. ward. The Indians claimed the lands, and an opposition of interests was constantly producing jealousies and complaints on both sides: the governor of Canadu availed himself of so favorable an opportunity to encourage and assist the indian animosity, without appearing to take any. avowed part in the business. Insults and ravages soon succeeded, which termmated in burning the property, and captivating the inhabitants in the advanced settlements : And from 1720 . to 1725 , a war was carried on with great violence between the Inclians in the eastern parts of Canada, and the provinces of Massachusetts and New Hampshire. Few wars have, ever been miore bloody or destructive. But as the crowns of Great Britain and France were then at peace, this war could not be carried on with the open assistance of the French government, and of course did not become general among the Indian tribes. To prevent such a calamity there was a congress of the English governors and commissioners, to renew the ancient friendship with the Indians at Albany; and Mr. Burnet, governor of New York, prevailed upan them to send a message to the eastern Indians, threatening them with war, unless they concluded a peace with the English. 'The Indian war became of course confined to the eastern parts, and did not extend to the province of Newyork, or to any of the settlements in the vicinity of 
puld not. re con. he east. and an oducing. es : the $p$ favor. sist the ake any. d ravan burnebitants n 1720 . at vioparts of etts and $r$ been crowns peace, open and of he In. there rs and ndship iurnet, lem to eatended a $r$ be. parts, york, ity of

lake Champlain ; and was concluded by a treaty with the Indians at Falmouth, in the year 1725. At this period both the English and French were extremely cautious to preserve the friendship of the five nations, as they had lately received a very considerable addition to their strength. Above eighty Nicariagas, with their women and children, had repaired to their territories, from the country north of Missilimakinac ; and the whole tribe of Tuscaroras, who possessed a large tract of country near the sources of James' river in Virgivia, had also removed and settled near the south east end of the lake Oneida. This event had augmented the Indian importance; and instead of calling themselves the five, they now assumed the name of the six nations; and like the European powers, felt the comfort and pride of increased territory, popu. lation and power.

From the treaty of Utrecht, a long period succeeded, in which there was peace between the British and French courts. 'I'heir colonies in America, were now enjoying the benefits of it ; but neither of them were inattentive to their future prospects or interests. Aware of the increasing power of the English colonies, and the threatening aspect which it had on the growth and safety of their own, the court of France had adopted a regular and systematic plan of conduct and policy. 'Their aim was to seize all the important posts and passes from Canada to Louisiana, to fortify the commanding situations, and thus to command the Indians, secure their trade and dependence, and confine the English to a narrow limit along the sea coast, and pre. 
vent their extending any further into the Indiad or inland countries. Mr. Burnet, the intelli. gent and vigilant governor of New York, well acquainted with the geography of the country, very justly concluded that the most effectual method of counteracting the French pursuits, would be to get the command of lake Ontario. For this purpose, in the year 1722, he began to erect a trading housc at Oswego, in the country of the Senecas : and to make it a place of in. creasing strength, trade, and general resort. Nothing could more naturally excite the jeal. ousy, and alarm the fears of the French, than this proceeding of governor. Burnet. An English trading house and fart at the mouth of $O$. nondago river, could not fail to injure their wade, to introduce the English into the heart of the Indian country, and without a considerable naval force on their part, would give them the command of lake Ontario, and divert the Indians from their customary route and iesort to fort Frontenac. Determined at all events to preserve the Indian trade, and the command of lake Ontario, in the year 1726, they launched two vessels in the lake ; and transported mate. rials to build a large store house and to repair the fort at Niagara. The French already com. manded the entrance into the lake at the east end, by fort Frontenac; if they could now secure the navigation by their vessels, and the en. trance into the west end of the lake by the fort and trade at Niagara, they would effect their purpose and render Oswego useless to the English, by carrying the Indian trade two hundred miles further to the west. The English and 


\section{HISTORY OF VERMONT. 32\&}

the Indian: the intelli. York, irell te country, st effectual h pursuits, se Ontario. he began to he country lace of in. ral resort. $c$ the jeal. ench, than An Eng. outh of $O$. hjure their the heart of onsiderable e them the ert the In. d iesort to events to ommand of y launched rted mate. 1 to repair eady com. $t$ the east d now send the en. $y$ the fort fect their the Enghundred glish and
French governors exerted themselves on these occasions ; wrote, complained, and sent mes. sengers to each other; tried to engage their European sovereigus to interfere ; flattered, deceived, and made speecizes to the Indians, to convince them that all they meant was to promote their sufety, by taking possession of their country : thus murmuring and wondering at the injustice and fraudulence of each cther's pro. ccedings, they agreed in the event, to keep firm. possession of all the posts they had established in the Indian territory.

IN this kind of enterprise and nanceuvre, the French generally discovered the most activity and address : and while the attention of New York was taken up with the afficirs of the western lakes, the French determined to make nearer approaches to the vicinity of Albany. In pursuance of this plan, in the year 175? they eame up lake Champlain with a con:idciable lorce ; and immediately began to erect a fort at Crown Point. No measure could have been bitter adapted to promote their own interest. It was through lake Champlain that the troops had marched in their expeditions against Schenectady, the Mohawk's castles, and Deerfield. It was through this lake that their scouting parties found the most easy, and the safest passage, in their excursions against thinglish culonies. In all the attempts of the English to effect the conquest of Canada, the attacks upon Montreal were always contemplate $i$ to have been effected. by the waters of lake Champlain. To erect a fortress at the south end of this lake, was to secure the whole navigation of it; and the com- 
mand of a large portion of the English and In. dian frontier. From this commanding situation the French could not only prevent the attempts of the English to penetrate into their own coun. try, but would always have a magazine of arms and ammunition, to supply their own troops and scoutinf parties; and an asylum, to which the Indians might readily retreat, from their plun. dering and scalping expeditions against the English frontiers. And by means of the river Sorel, and the lake, it might always be reinforced in three or four days ; or receive any supplies, without difficulty or danger.

$T_{\text {H E }}$ French garrison was at first placed on the east side of the lake, and the settlement was begun, in what is now the town of Addison. On the western side, a more convenient and safe situation was found; in which the harbour was good, and the fortress would be surrounded by water on three of its sides. On this spot, now called Crown Point, the French erected a fort sufficiently strong to resist any force, that could be suddenly, or easily brought against it ; and gave it the name of St. Frederick. 'The lapd on which it was erected, properly belonged to the six nations; but was claimed by the go. vernment of New York, and liad been granted by one of their governors, so early as 1696 , to Dellius, the Dutch minister of Albany. The designs of the French, and the dangerous consequences attending the erection of their new fort, were well understood in the English colonies. The Massachusetts government was not a little alarmed. Mr. Belcher, their governor, gave the first information to the government of 
sh and In. g situation attempts Jwn counhe of arms troops and which the heir plun. ainst the $f$ the river re reinfor. any sup.

placed on ment was Addison. nient and e' harbour urrounded this spot, crected a orce, that gainst it ; ck. 'The belonged y the go. a granted 1696 , to ny. 'The rous contheir new lish colo$t$ was not governor, inment of
New York, of the French proceedings. He wrote to Mr. Van Dam, president of their council, on the subject ; informed him that the Massachusetts assembly had voted to bear their proportion of the expence of a messenger to Canada, to forbid the works, and urged him to engage the opposition of the six nations. New York, at that time agitated with internal controversies, paid very little attention to the business. On February the fourth, 1732, Van Dam laid Belcher's letter before his council : With a singular weakness and want of spirit, they advised him to write to the commissioners of Indian affairs at Albany, and make inquiry whether the land belonged to the confederates or to the river Indians. Their passiveness on this occasion was the more unaccountable, as the British crown at that time supported four independent companies at an anuual expence of 7500l. sterling, for the protection of that province. Thus were the French suffered to advance nearly two hundred miles towards Albany ; and to erect a fortress, which would enable them in any future war, to make their assaults with safety and success, on the frontiers of New York, Massachusetts, and New Hamp. shire. *

Wurte the English and French colonies appeared thus suspicious, and preparing for each other, both of them enjoyed the substantial and uninterrupted blessings of peace. The pacific disposition of the European courts that timc, and the mutual interests of the colonies, made

- Smith's Hist. New Yotis 
all parties carefully aroid the appearance of hos. tilities. They were enjoying the benefits of mutual trade and commerce, and the Indians were unusually pacific ; every whcre appearing more disposed to trade and friendship, than to hostility and war. To the English, this state of peace was peculiarly beneficial ; for although the French generally excceded them in the management and activity of a predatory war, the English colonies were far superior in the affairs of agriculture, commerce, forming new settlements, improving the fisheries, and other arts of peace : And they could not but wisin for a continuance of that state, which not only contributed to increasing extent, population, wealth, and safety ; but was every year giving them the superiority over the French colonies. Some persons began to flatter themselves that the Indians had in fact changed their habits; and had no hostile events taken place in Europe, it is not improbable that peace would have con. tinued for many years longer in the American colonies.

Is the year 1740 , the affairs of commerce had involved the crowns of Great Britain and Spain in mutual hostilities. Declarations of war ensued ; and in conformity to the Europe. an custom and policy, the war spread over a great part of Europe. France soon became cn. gaged in it, and a declaration of war ensued be. tween Great Britain and France, March 31, 1744; of course, their colonies and Inclian allies vere again to be involved in destructive and bloody contests. The scene of both was opened in Nova Scotia; and the French, with

$F_{1}$

fel

da

ne

$F_{1}$

ca 


\section{HISTORY OF VERMONT. 333}

ance of hos. benefits of the Indians e. appearing hip, than to this state of or although iem in the datory war, erior in the orming new $s$, and other ot but wisil ch not only population, year giving ich colonies. mselves that heir habits ; $e$ in Europe, ld have con. he American

if commerce Britain and clarations of the Europe. pread over a i became cn. $r$ ensued be. March 31, d Inclian al. destructive of both was French, with their usual activity and impetuosity, began the business by invading the island of Canseau ; they took the island, burned the houses, destroyed the fishery, and made the garrison and inhabitants, their prisoners.

To savages, the horrors and plunder of war are so agreeable, that when the flame is once kindled, they delight to increase and expand it ; and notwithstanding the long period of peace and friendship, they very readily embraced the opportunity to fall upon the English frontiers. In these incursions, the advantages which the fort and settlement at Crown Point gave to the French and Inclians, were soon and severely felt. In the first year of the war, but little damage was done; but in the course of the next year, scouting and ravaging parties of French and Indians every where appeared, and carried destruction and slaughter around the frontiers of the English colonies. Mr. Shirley, governor of Massachusetts, was at that time the most active and enterprising of any governor in the English colonies. His attention was chiefly taken up in the year 174.5, in planning and executing the important and successful expedition against the French settlements in the island of Cape Breton. During that summer, and the next, the Indians in small parties were killing, scalping, and plundering, wherever they could find a defenceless party or family.

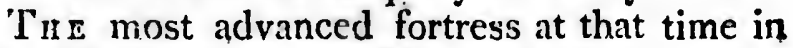
Massachusetts, was a fort at Hoosick, since Williamstown. This fort was erected at the breaking out of the war, to cover the western "parts of the province from the Indian depreda.

$$
\text { vol. I. R } 2
$$


tions, and bore the name of the province. In August 1746, an army of about nine hundred French and Indians set out from Crown Point, under the command of $\mathbf{M}$. de Vaudrieul, to attack this place. They came before it, $\mathrm{Au}$. gust the twentieth. The fort-was commanded by colonel Hawks; but thirty three persons were in the garrison, including women and children ; and the fort was not properly provided with ammunition. Hawks defended the place with much fortitude and spirit, but at the end of twenty eight hours, he had expended his powder, and was obliged to propose terms of capitulation. It was agreed that the garrison shculd be prisoners of war, but that none of them should be delivered to the Indians. The day after the capitulation was compleated, Vaudrieul divided the prisoners, and delivered the one half of them to the Indians; one of the prisoners being unable to travel, was immediately killed. The French general, when accused of an open violation of the capitulation, assigned as the reason for his conduct, the state of his army; that they were in danger of a mutiny, the Indians being highly irritated that they were by the capitulation deprived of their part of the plunder and prisoners. Hawks lost but one man in the siege; and supposed he could have preserved the fort, had he been supplicd with ammunition and provisions. From the best accounts that he could procure, the enemy, in those that were slain or died of their wounds, lost forty five of their men in this enterprise.

Mr. Shirfey, to the astonishment of all 
vince. $I_{11}$ e hundred m Crown audrieul, ore it, $\mathrm{Au}$. ommanded ee persons omen and erly proviended the but at the expended pose terms e garrison $t$ none of ins. The ated, Vauivered the ne of the s immedi. when ac. jitulation, , the state nger of a tated that d of their awks lost posed he he been rovisions. procure, $r$ died of en in this nt of alt
Europe, having succeeded in effecting the conquest of Louisbourg by the New-England troops, was deeply engaged in a plan for the re. duction of the French dominions in the northern parts of America. For this purpose in the fall of 1745, he had written to the British Ministry, soliciting the aid of a fleet and army to attempt the conquest of Quebec, while the colony forces should be engaged in an expedition aggainst Crown Point, 'I'he British Ministry agreed to the proposals, and Shirley with his usual spirit of energy and enterprise, engaged all the New. England provinces, and Ncw-York in the pro. posed expedition. The provinces, animated by the success at Louisbourg, pursued the bu. siness with great eagerness ; their troops were raised early in the season, and they waited all summer, impatient for intelligence and orders from England. In this state of impatience and expectation, the news came that a large flcet and army from France, had arrived at NovaScotia, commanded by the duke D'Anville; that it was designed, and powerful enough to recover Louisbourg, take Annapolis, to break up the settlements on the eastern const of Massachusetts, and effect the conq'iest of Boston, and perhaps of New-York. England was not more alarmed by the approach of the Spanish armada in 1588, than was Boston, and the other sea ports, on this occasion. Alarm and terror ran through the country, and nothing was to be seen or heard, but preparations to defend the maritime towns, and seal coasts. An uncommon series of misfortunes, losses, storms and shipwrecks, destroyed the power, and defeated 
the designs of the French armada ; and those of their ships, that escaped destruction by the storms and seas, returned singly to France, without having made any attempts upon the English colonies. When the alarm occasioned by the French fleet had subsided, and it became known that it was nearly destroyed, and was attempting to return to France, Mr. Shirley's hopes revived that he might still effect something against the enemy. So much was he engaged in the business, that he proposed to. make the attacks upon the enemy in the midst of winter; that the New-Hampshire troops should proceed by the way of Connecticut riv. er, to the Indian village of St. Francis, and lay it waste ; and that the Massachusetts, Connec. ticut, and New-York troops, at the same time should move on through lake George, and attempt the conquest of Crown Point. Such was Mr. Shirley's influence at that time, that all the provinces which had raised troops for the expedition, agreed to his proposal of a winter campaign, except Connecticut. To that colony, such an experiment appeared too dan. gerous and uncertain; and it was owing to their refusal to join in it, that the winter expedition was given up.*

$\mathrm{O}_{\mathrm{N}}$ Connecticut river, the most advanced settlement at that time, was at a place called Number Four, now Charlestown in NewHampshire. A fort had been built there some years before, which was designed to protect the settlements and forts in the vicinity. From the

- Belknap's Hist. Nęw Hampshire, Vol, 2, p. $2,34$. 
and those tion by the to France, upon the occasioned it became and was at. - Shirley's fect some. ch was he roposed to the midst hire troops ecticut riv. is, and lay s, Connec. same time ge, and atint. Such time, that troops for ll of a win. To that d too dan. orving to nter expe-

advanced ace called in New. here some protect the From the commencement of the war several parties of Indians had appeared at that place; and at different times had killed, and captivated some of the inlabitants, and frequently destroyed their. cattle. In the spring of the year 1747 , the enemy made an attempt to take the fort, and destroy the settlement. On the fourth of April, M. Debeline came before it with a large party of French and Indians. It was defended by captain Stevens, an able and judicious officer. The enemy commenced their attack by firing at the fort, on all sides, with their muskets. These making little or no impression, they next attempted to burn the fort by setting fire to the fences, log houses, and other buildings ; and by discharging.against it flaming arrows. Having tried these methods for two days without success, they next prepared a wheel carriage, loaded with dry faggats. This machine they pushed before them to set fire to the fort, while it served to protect them from the fire of the garrison. 'These attempts were defeated by the bravery and prudence of Stevens and his men. Debeline then urged Stcvens to surrender the garrison, and be conducted to Montreal as prisoners of war ; threatcring to storm the fort and put all to the swurd, if this was refused. In answer he was told that the garrison had determined to defend the fort to the last extremity. On the morning of the third day it was proposed, if Stevens would sell them provisions they would depart. This also was refused; but Stevens informed them he wculd give five bushels of corn for any captive, for whom they would give an hostage, till they 
could be brought from Canada. On receiving this ansiver a few guns were fired, and Debeline with his troops withdrew to Crown Point. Sir Charles Knowles, a commodore in the British navy, was then in Boston harbor; and so much did he admire the bravery, and soldier like conduct of Stevens in defending his fort, that he presented him with a valuable and ele. gaut sword, as a testimony of respect. From this circumstance it was that the town when incorporated by the government received the name of Charlestown.*

DURINe the remainder of this war the Indians were scattered around the frontiers in small parties, and did much damage to the in. habitants ; burning their houses, destroying their cattle, pillaging their property, killing some of the inhabitants, and making captives of others; but there was not any regular expedition undertaken by the French till the treaty of peace at Aix la Chapelle of October the seventh, 1748, put an end to the war, between the English and French colonies. But it was not till the next year, that the Indians ceased from their hostilities.

- Ecilerap's Hiju Nen Hampshire, Vol. 2. p. 2gx. 


\section{HISTORY OF VERMONT.}

receiving ind Debe: wn Point. the Brit. ; and so d soldier his fort, e and cle. t. From when in. eived the

hr the In. pntiers in to the inestroying , killing aptives of $r$ expeditreaty of seventh, the Eng$S$ not till rom their:

\section{CHAPTER XI.}

WA . From the year 1750 to 1757. Conferences at Paris. Measures of the Firench. Embassy and defeat of Washington. Views of the English and French colonies. Congress; and plan of union at Albany. Council of senerals and governors at Alexandria. Expedition and defeat of Bradklock. Success or Monckton and Winslorv in Nova Scotia. Proposed expeclition to Niagara. Proceedings of baron Dieskau at lake Champlain. Victory of Johnson at lake George. Termina: tion of the campaigns of 1755: Military arrangements of the British ministry in 1756. Capture of Oswego by Montcalm. Inactivity of the earl af London.

1752. BY the treaty of Aix la Chapjelle, the controversy between the British and French crowns relative to their claims in A. merica was referred to commissioners to be appointed by the two sovereigns for that puipose. These commissioners met at Paris in the year 1752, of which Mr. Shirley, governor of Massachusetts, was one. They laboured much to establish the claims of their respective sovereigus by virtue of ancient grants, maps, treaties, priority of discovery, ceremonies of taking possession, concessions, and such other grounds of claim, as were then customary among sovereigns ; and were supposed to be matters of real weight and importance. The commissioners were not able to come to any agreement; and 


\section{NATURAE AND CFVHL}

ho other advantage resultcd from their labors and controversies, than a well written account of their conferences, containing much historical and geographical information.

1753. In the mean time the settlers in the English and French colonies, vere making nearer approaches to each other ; and their rulers were anxious on both sides to seize the most favorable siturations and passes for new forts and trading houses. These interferences of the colonists took place the most in the provinces of Nova.Scotia, New-York, and Virgimia. In these encroachments the French generally discovered the most foresight, vigilance; and activity. They surprised Logstown, which the Virginians had built upon the Ohio; made themsclves masters of the block-house, and truck-house, with the stores of twenty thousand pounds value, and destroyed the British traders : An officer, with a large force came down the Ohio, and reduced a fort, which the Virginians had built on the forks of the Monongehala. The marquis Du Quesne ivas at that time invested with the chief command in New-France. Of an active and enterprising genius, in the year 1753, he began a fort and settlement on the banks of the Ohio, at the place from whence he had driven the English, now called Pitts. burgh ; designed to secure a station on that beautiful and extensive river, which should engross the trade, and command the Indians in the adjacent parts of the country. The governor of Virginia, Mr. Dinwiddie, was alarmed at so near approach of the French to the settlements in that province. On October the thirty first 


\section{HISTORY OF VERMONT. SAI}

he wrote to the commander of the French troops, complaining of sundry acts of hostility ; and desiring to be informed, by what authority, the French troop 3 had taken possession of a territory belonging to his master, the king of Great Britain.

Ir was on this occasion that the name of George Washington was first announced to the world. Governor Dinwiddie gave him a major's commission, and appointed him to be the bearer of his letter to the commander of the Frenoh troops. In the winter, and through a scene of much suftering and danger, major Washington executed the business of his commission with that intrepid, determined, perse. vering spirit, which, since that period, has so much engaged the attention and applause of his country, and of the world. M. Legardcur de St. Pies re, commander of the French troops on the Ohio, returned an answer, December the fifth, full of spirit and resolution, declaring the country to belong to the French king; and announcing his determination to obey his orders, preserve his post, and retain a situation so favorable to defence and strength.

1754. Convinced by the spirited and resolute answer of the French commander that further encroachments were to be expected, the governor and general assembly of Virginia determined to make a serious opposition to the French establishments on the Ohio. In February 1754, the assembly voted to raise three hundred men, for the protection of their fron. tiers. Washington at that time was a young gentleman of twenty two years of age. His

$$
\text { vol. I. S } 2
$$


conduct, in the embassy to French eorm. mander, had proved highly sactory to the governor and council ; and hi was now appointed lieutenant colonel, and the command of the troops was assigned to him. In addition to the men raised in Virginia, two independent companies of foot were ordered by the king to march from New.York to the frontiers of Vir. ginia and Pennsylvania.

ON April the third, Washington set out from Alexandria at the head of a little army of one hundred and sixty seven men. On May the twenty eightl, they had a skirmish with an advanced party of the French; of which nine were killed, with M. de Jumonville their com. mander, and tiventy one were taken prisoners. A reverse of fortune soon took place : While Washington was waiting with about three hundred rnen for a reinforcement, he received intelligence that the French were advancing with a body of nine hundred men, and two hundred Indians: On July the third he was attacked by a force greatly superior to his own, under the command of De Villier ; and after a resistance of three hours, found it necessary to sub. mit to the superior force of the enemy. The terms that were offered to him were of an humiliating nature, but he was no longer in a situ. ation to refuso the demands of the enemy, and was obliged to capitulate. In this engagement the English had thirty killed, and fifty wounded. De Villier reported his loss to be but two Frenchmen, and one Indian killcd, and seventeen wounded; and boasted that by making use of the Erench language, the terms of the 
ch eom. y to the now ap. mand of Idition to ependent king to of Vir.

but from of one May the $h$ an ad. ch nine eir com. risoners.

While ree huned intel. with a uirndred tttacked: under resist. to' sub-

The an hu. a situ. $y$, and jement unded. it two seven. naking of the

\section{HISTORY OF VERMONT.}

oapitulation were so expressed, as to make the English acknowledge that they had committed murder in the case and camp of his brother Jumonville ; and that the favors manifested to them in the capitulation, were designed to show how much they desired to treat them as friends. Hostilities being thus commenced, and some of the Indians slain, it was known that in conformity to what had always been the maxims and customs of the savages, the other tribes would immediately engage, and an Indian war would commence from one end of the British colonies to the other. And before the summer was ended, the Indians all round the frontiers from Virginia to the province of Maine, appeared to be in arms, and began their attacks upon the English.

Sucr was the commencement of war in 1754; a war, in which all Europe was soon to be involved; and by which, the empire and destinies of North America were to be decided. The French, with a policy superior to the English, had for several years been pursuing an uniform and systematic plan of colonization. Their settlements in Canada and Louisiana were at a great distance from each other. By means of the lakes, and the rivers St. Lawrence and Mississippi, they had found situations by which these settlements might be connected by a chain of posts and forts. The plan they were execu. ting, was to take possession of all the comman. ding situations from one colony to the other; to erect forts and trading houses, not far from each other; and thus to command the trade, exclude the English from the Indian country, 


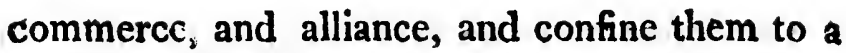
narrow limit along the sea coast, and prevent their extending any further to the westward. The English colonies saw their policy, and were alarmed with the measures they were so inces. santly and zealously pursuing ; and determined to employ their superior numbers and power, to oppose the French proceedings; and to effect some plan to produce a greater uniformity in their councils and measures. Both partieshad long been in the habit of trying to engage the Indian tribes in their quarrels, and to inflame the savage vengeance against their opposers. 'They had now approached so near to each other in their settlements, that a constant interference of views, interests and situations, could not fail to make their commerce precarious, and their neighborhood ful! of animosity and danger. As peace could no longer be expected between the English and French colonies, the period scemed to be now come in which the grand contest must take place, which of the countries should be subdued; and whether France or England for the future, should have the empire of North America. And all parties now set thcmsclves very seriously to prepare for the exertion of all their powers and strength.

$T_{н}$ E first step necessary for the English colonies, was to agree upon some plan of Union, for their mutual protection and operations. The British secretary of state wrote to the governors of the colonies, urging such a measure, and a favorable opportunity now presented to make the attempt. A Congress of Commissioncrs from the colonics had been appointed at Albany, 


\section{HISTORY OF VERMONT. S45:}

hem to a i prevent vestward. and were so inces. termined d power, nd to efniformity h partiesto engagt nd to ineir oppo. near to constant ituations, precariinimosity er be ex. ich colocome in :e, which I whether uld have Il parties prepare strength. rlish col. U Union, ns. The overnors e, and a to make issioncre Albany, for the purpose of holding a conference with the six nations, and to consult on measures for the general interest and welfare. Governor Shirley proposed to the several governors, that their commissioners should be instructed on the sub. ject of an Union among the colonies.

$\mathrm{O}_{N}$ the fourteenth of June, the commissioners assembled, and on the eighteenth, the Congress was opened. It consisted of delegates from New-Hampshire, Massarihusetts, Rhode-Island, Connecticut, New-York, Pennsy!rania, and Maryland. They agreed to take their places in geographical order, beginning at the north ; and having adjusted their ceremonies and rules of proceeding, on the twenty ninth they were ready to treat with the Indians, who had been assem. bled for that purpose. The cercmonies and formality that generally attend an Indian treaty, render it a matter both of curiosity and instruction. The arrangement that was adopted on this occasion, 'was designed to give importance to the transaction. Mr. De Lancey, lieutenant governor, and at that time commander in chief of New-York, within whose territory the lands of the six nations chiefly lay, was appointed speaker to address the Indians. On his right hand were the commissioners from the colonies ; on his left hand, were the council of New-York, officers, and citizens of rank and respectability. In the front were the Sachems and chiefs of the six nations, attended by many of their tribes; arranged in a circular form, and preserving a solemn silence. The speech turned on the customary topics, how much the French injured and abused, and how much the English loved 


\section{NATURAL AND CIVIL}

and benefitted them; and that they now valued their friendship in the highest degree, and should probably soon want their assistance to conquer and extirpate the French. To give weight to their eloquence, and to make more effectual impressions on the savage mind, a val. uable present was made to the Indians by order of the British king; and several of the colony governments, on this occasion followed the example of their sovereign, and endeavored by their donations to secure the Indian friendship and forbearance to their particular provinces. At no time had the presents made to the Indians amounted to so large a sum, and no art or address was spared to secure their friendship. The Indians perfectly well understood the business, and were well pleased with the presents, and with the attention that the British king and colonies had paid to them. Their answer was expressive of gratitude, and of a sense of their own importance ; and they very plainly told the commissioners, that the English were not enough attentive to their business and interest : That in the last war they had deserted some of their own forts ; that their frontier city, Albany, was almost in a defenceless state; and that the French managed the business of fortifying and maintaining their garrisons, much better than the English had done,

$T_{H E}$ treaty with the Indians being finished, the next business of the commissioners was to form some plan of general union, and defence for all the colonies. The commissioners were a. mong the first men in the colonies for rank, a. biiities, fortune, and infuence. Instead of 


\section{HISTORY OF VERMONT. SAT}

contemplating any such events as a contest with Great Britain, or an American Independence, the question was how to establish such an union and government among the colonies, as should prevent their destruction and conquest by the French. One member from each colony was appointed for this purpose; Atkinson of New-Hampshire, Hutchinson of Massachusetts, Hopkins of Rhode-Island, Pitkin of Connecticut, Smith of New-York, Franklin of Pennsylvania, and Tasker of Maryland. In adjusting a plan of union and defence, different political sentiments were found to prevail. Some were fearful of throwing too much power into the hands of the king, and others were as much afraid of giving too much power to the colonies. Alamed however on all sides with the increasing power and policy of France, they were extremely cautious not to break on these points, and in a few days agreed upon a result. Their plan was, that application should be made to the parliament of Great Britain for an act, to constitute a Grand Legislative Council in the colonies. This council was to consist of delegates from the several Legislative assemblies, subject to the controul of a president general, to be appointed by the crown, and to lave a negative voice. 'This council were to enact general laws ; apportion the quotas of men and money, to be raised by each colony ; determine the building of forts; regulate the operation of armies ; and concert all measures for the common protection and interest. 'The delegates of Connecticut alone entered their disscnt, and their objection was against the negative voice assignied to the crown. 
Wirr the plan of union and defence, a very just representation was made to the king, of the state and danger of the American colonies ; and copies of both were laid before the several as. semblies. But the plan of American union and defence had the singular fortune of being rejected, both by the mother country, and by the colonies : By Great Britain, because it assigned too many, and too important powers to the provincial assemblies ; and by the assemblies, be. cause it assigned such extensive and important powers to the sovereign, and his ministers. Thus at the very time when the fears and ap. prehensions of Grcat Britain, and her American colonies, were at an unusual height, both were fearful of the consequences of new arrange. ments; and endeavored with singular caution to guard against any questions, thit might arise respecting the prerogatives of the king, or the liberties of the colonies. The plan of American union was agreed to on the fourth day of July 1754 ; but not a single member of the congress that drew it up, had an idea that they were en. gaged in a plan, which it was in the destinies of nature and providence to complea, in the course. of twenty two years from that day.*

WHILE these measures were going on at Albany, Mr. Shirley was employed in securing the eastern parts of Massachusetts ; and built the forts of Richmond and Western, to protect the inhabitants, and check the Indians, in that part of the country. Nor was the court of Great Britain inattentive to American matters :

- Belknap'6 Hist New Hzappshixe, Vol. 2. P. 286. 
ce, a very ing, of the onies ; and several asunion and being rend by the it assigned to the pronblies, be. important. ministers. $s$ and ap. American both were $v$ arrange. ar caution night arise ng, or the American lay of July e congress. were en. lestinies of the course.

ing on at n securing and built to protect ns, in that court of matters :

On November the twenty fifth, major general Braddock was appointed general and commander in chief of all the troops which were to be sent to, or raised in North America ; and was ordered to repair to Virginia with two Irish regiments, and to be ready for the military operations of the next spring.

1755. Intent on prosecuting the war with vigor, in the beginning of the year $1755, \mathrm{Mr}$. Shirley convcned the assembly of Massachusetts, and communicated to them the plan that he had formed for reducing fort Frederick at Crown Point, the ensuing spring; and his intention to appoint colonel Johnson of NewYork to the command. The assembly readily concurred in the measures proposed by the governor; and voted to raise their quota of the troops. The plan being thus adopted by Massachusetts, commissioners were sent to the neighboring governments stating the assistance that was desired of them, and requesting their concurrence and aid. Thus were the NewEngland provinces, New-York, and New-Jersey, all put in motion for a vigorous expedition against the French.

WhILE Shirley was thus moving all the northern provinces, Braddock arrived at Williamstown in Virginia, February the twentieth, with two Irish regiments. Expresses were immediately sent to the governors of the colonies to meet him at Alexandria on the thirteenth of April, for a consultation on the state of Americom affairs, and the business of the approaching campaign. The convention met as was propos$\mathrm{d}$, and the next day entered upon the business

$$
\text { WOL. I. T } 2
$$


of the ensuing season. At this convention the governors of Virginia, Maryland, Pennsylvania, New-York, and Mssachusetts attended ; with colonel Johnson, commissioner of Indian affairs. It was found that Braddock had positive orders, to proceed himself with the greatest expedition, to reduce the French fort Du Quesne, on the Ohio. Notling more was therefore in his power, than to settle some general arrangements for the campaign with the convention; and to leave the execution to others, as he was himself very little acquainted with the state of things in A. merica.*

Ar this convention it was concluded that four expeditions should be carried on against the French in the course of the summer. One a. gainst fort Du Quesne, under the command of Braddock. Airother was to be against Niagara, uncler the direction of Shirley. A third against Crown Point, under the command of Johnson; and a fourth against the French forts and settlements in the bay of Fundy and Nova Scotia ; to be commanded by colonel Monckton, a British officer, but to be executed chiefly by New England troops under the command of colonel Winslow. The plan of operations for the campaign being thus adjusted, the convention dissolved; and Braddock, Shirley, Johnson and Monckton prepared themselves for the expeditions, of which they were to take the immediate commind.

$B_{R A D D O C K}$ was a major general in the British arny ; a man of undoubted courage, and

* Review of military operations in North America, p. 10. Supposed to be wrote by Mr. Smith of New York. 
ntion the sylvania, d ; with n affairs. e orders, pedition, , on the his pownents for to leave elf very gs in $\mathrm{A}$.

that four inst the

One amand of Niagara, 1 against olunson ; d settle. Scotia ; , a Britby New colonel he cam. ion dison and expedimediate

e Britge, and supposed expert in all the punctilios of a reviery, having been brought up in the English guards. In his manners he was haughty, positive and difficult of aecess. Though well acquainted with the European method of war, he had no idea of the service in a country thinly inhabited and every where abounding with woods, mountains, rivers, morasses, and dangerous defiles. And so attached was he to the European customs of regular discipline and order, that he despised his provincial and Indian auxiliaries; and treated with contempt the advice of those, who endearored to give him information of the Indian methods of attack ; and to warn him of the danger of ambush, and surprise. On the twentieth of April, he set out with an army of twenty two hundred men, from Alexandria; and after the most extreme difficulties and exertions, arrived on the ninth of July, at the river Monongahala. Having passed the river about noon, he was within seven miles of fort Du Quesne, the object of his hopes and wishes. Marching on in perfect security, and with the most confident expectation of victory and fame, in an instant his army was alarmed with the Indian yell; and attacked on every side, by a concealed party of French and Indians. Braddock exerted himself with much courage in the manner of an European battle ; but the European discipline, artillery, and arms, availed him nothing. He neither knew where'his enemy was, or how to oppose their arts and methods of war : Having exerted himself to the utmost, and to no manner of purpose, he himself and the greater part of his army were slain, by a party of about four 
hundred Indians, placed in ambush, safe from his arms, and almost concealed from his sight. Thus despising his American friends and enemies, the British general fell a sacrifice to the superior knowledge and arts of the American Indians : And it was owing to the bravery and prudence of colonel Washington, that a retreat was effected ; and the remaining part of the army rescued from destruction. In this battle scarcely any of the enemy were slain, but the loss of the English amounted to seven hundred men. The defeat was total, and the carnage uncommonly great, of eighty five officers, sixty four were slain or dangerously wounded. All the artillery, ammunition, and baggage of the army were lelt to the enemy; and among the rest, the gencral's cabinet, containing all his orders, letters, and instructions. 'The French court published the whole of these papers ; and in their printed memorials and manifestoes, arowed to ail Europe that they had now com. pleat information of the designs of Great Britain and her colonies.

THE army that was sent to Nova Scotia, was put under the immediate command of colonel Monckton, a British officcs. Colonel Lawrence; the lieutenant governor and commander in that province, had found it impossible to raise the recruits which he wanted, in Nova Scotia. His attention was turned to New England, as the only place in wish he could ex. pect success. WVith that vicw, colonel Monck. ton had made a voyage to Boston, in the latter part of winter, and consulted Shirley upon the business. Such was the reluctance of the New 


\section{HISTORY OF VERMONT. 353}

safe from his sight. and ene. ce to. the American uvery and a retreat of the ar. is battle but the hundred carnage rs, sixty led. All ge of the nong the ll his orFrench ers ; and stoes, aw comeat Bri-

otia, was colonel. Lawainander isible to. n Nova. ew Engunld ex. Monck. he latter upon the he Nevi
Fingland people to enlist under British officers, that they found it impossible to engage men to serve in the British regiments, or under British ofticers. It was proposed as the only cxpedient, that bore the appearance of success, to procure some of the New England officers, who had served in the former wars, to engage in the business. Colonel Winslow, of Marshficld, was at that time reputed to be one of the bravest and most experienced of the provincial officers. $\mathrm{He}$ had been an officer in the expedition to Carthagena, under general Wentworth; and had much of the military genius and spirit, which had distinguished his family in the Indian wars of the colonies. It was concluded that if he would engage in the business, the men might be raised with ease and expedition. Monckton visited and consulted Winslow upon the business. Winslow was pleased with the prospect, but wished to have the command of the troops himself. Monckton was extremely anxjous to procure the men, but could not think of giving the command to Winslow. After seve. ral attempts to compromise the matter, they came to this agrecment, that Winslow should have the command of all the men that should be raised in the New England provinces, and be equal at all times in command to Monckton, but only in time of action ; on which occasion, the command of the whole should be in Monck. ton, who was to be considered as the senior of ficer.* This point being adjusted, Winslow was commissioned by governor Shirley, and

\footnotetext{
Finslow's relation to the autbor in 1764 .
} 
heartily engaged in the business. A regiment was soon raised and sent on to Nova Scotia. Success attended the operations of the British and provincial troops. On their arrival at the river Massaquash, the provincials attacked and dispersed four hundred and fifty of the enemy who were posted there, and took their block house and brest works. On June the twelfth, they invested the fort Beau-Sejour, and in four days obliged it to submit. The next day they took the fort at bay Verte, with a large quantity of stores and provisions; and disarmed the Acadians to the number of fifteen thousand. Captain Rous, with three frigates, sailed to the mouth of St. John's river ; the French abandoned their fort, burst their cannon, blew up their magazine, and deserted the place. The English had but twenty men killed, and about as'many wounded in the whole of this expedition. It served to preserve Nova Scotia, to destroy the French power in that part of Ameri$\mathrm{ca}$, and to raise the reputation and military character of the provincials.

AFT ER the death of Braddock, the command of all the forces in North America devolved on Shirlcy, who had now a commission giving hin the rank of major general. As soon as the council at Alexandria was finished, Shirley repaired to Boston ; and made the most vigorous exertions to compleat and hasten the troops, which were designed to be under the command of colonel Johnson, and that were to go with coloncl Winslow to Nova Scotia ; and also to raise a number of batteau men, for the expedi. tion to Ningara. Embarrassed with so many 


\section{IVIL}

A regiment Nova Scotia. of the British $r$ arrival at the Is attacked and of the enemy $\mathrm{k}$ their block ine the twelfth, ur, and in four next day they a large quantity disarmed the teen thousand. es, sailed to the French abannnon, blew up e place. The illed, and about of this expediova Scotia, to part of Ameria military char.

, the command ca devolved on ion giving him $s$ soon as the cd, Shirley remost vigorous en the troops, - the command re to go with $a$; and also to for the expediwith so many

\section{HISTORY OF VERMONT.}

cares, and such a variety of business, with his utmost exertions he could not reach Albany till the second week in July. Oswego, by the route which was usual at that time, was estimated to be nearly three hundred miles west of Albany. 'The passage was partly by land, but chiefly by water, upon the Mohawk and Onondaga rivers; and at every season of the year was both difficult and dangerous. A large number of batteaux had been prepared for the conveyance of the troops, stores and provisions. The fort at Oswego was of het little strength and much out of repair. It formerly garrisoned by twenty five men; but on the commencement of the late controversies, the garrison was augmented to fifty men. Early in the spring, another company of fifty men had been ordered to that station ; and in the latter end of May, captain Broadstreet arrived with two hundred more; and a number of workmen. Schuyler's regiment from New Jersey had cmbarked for that place, the beginning of July ; and Shirley's and Pepperell's regiments were preparing to follow.

Ar this time the news arrived of Braddock's defeat ; and was announced in terms more horrid, awful and alarming than were just. The reports had an unhappy effect on the spirits and conduct of the Einglish troops. Suspecting and dreading another Indian massacre, some deserted; and of the batteau men, not a few left the service. The Indians of the six nations appeared to be disinclined to hostilities ; and were unwilling that the operations of the war should be carried into the western country; which they 


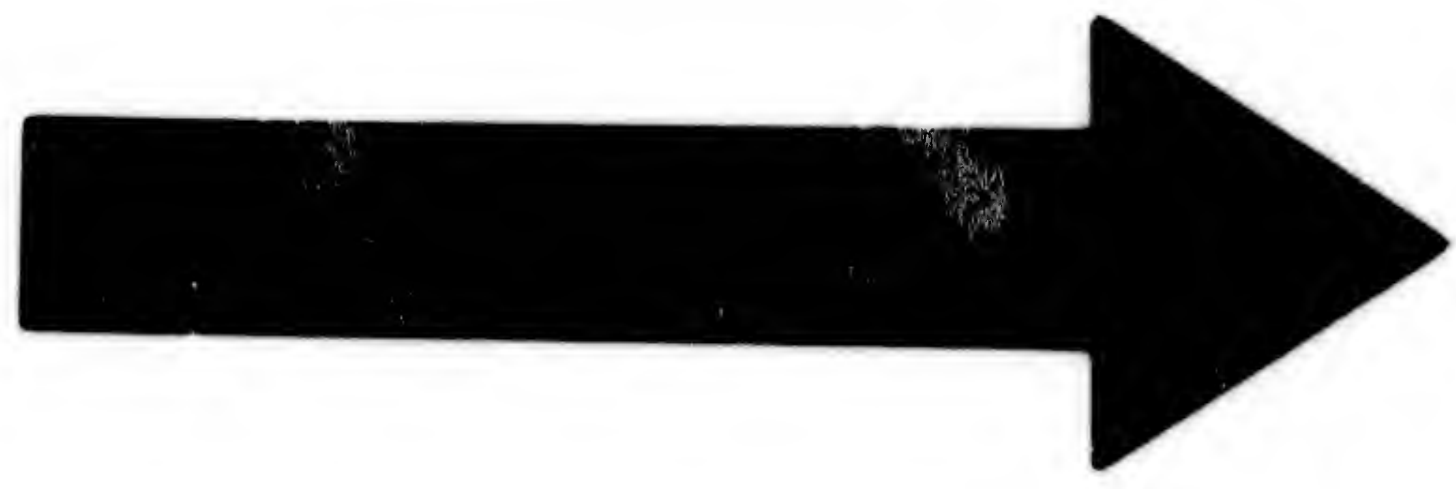




\section{IMAGE EVALUATION TEST TARGET (MT-3)}
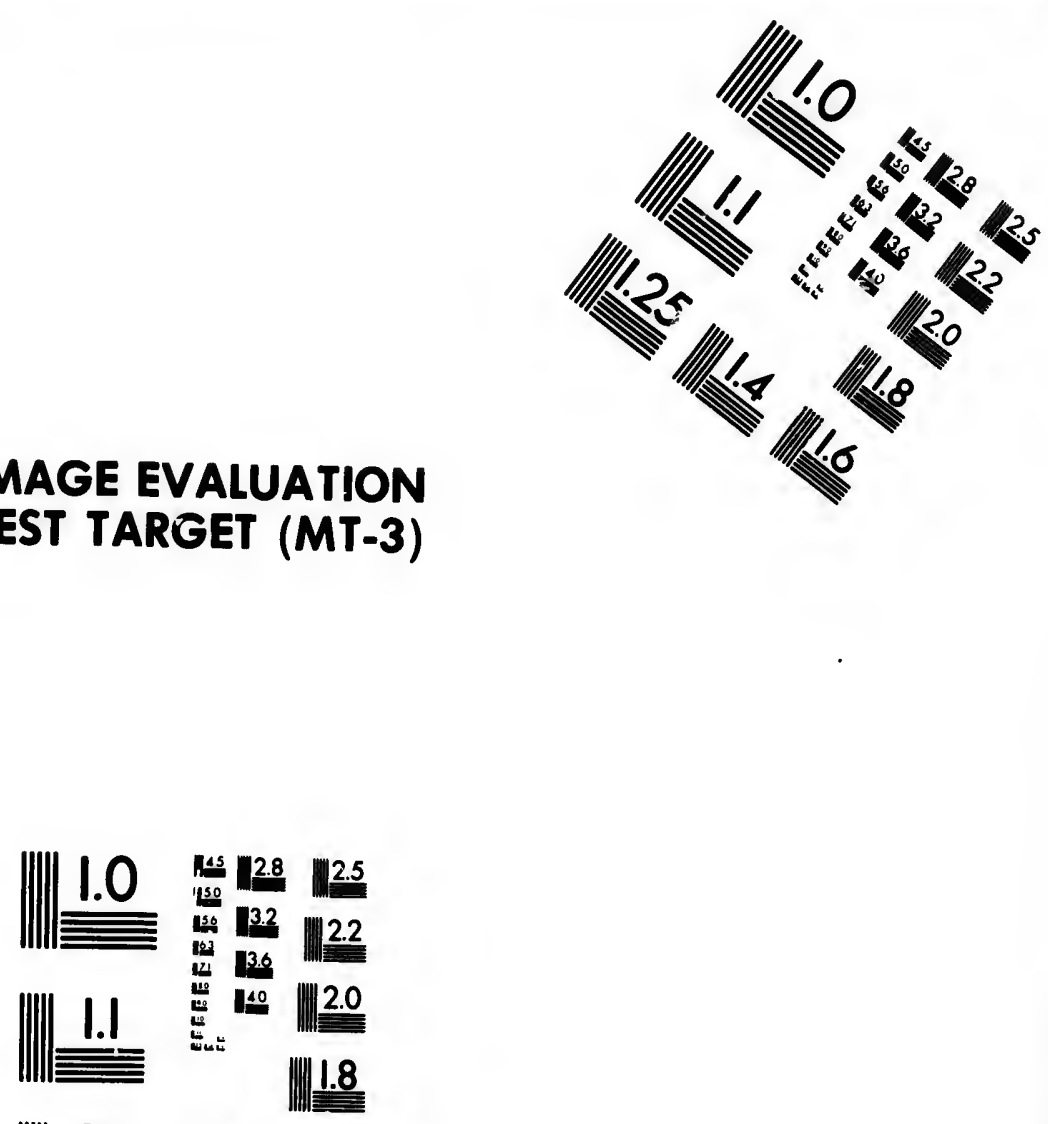

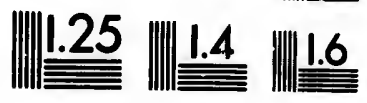

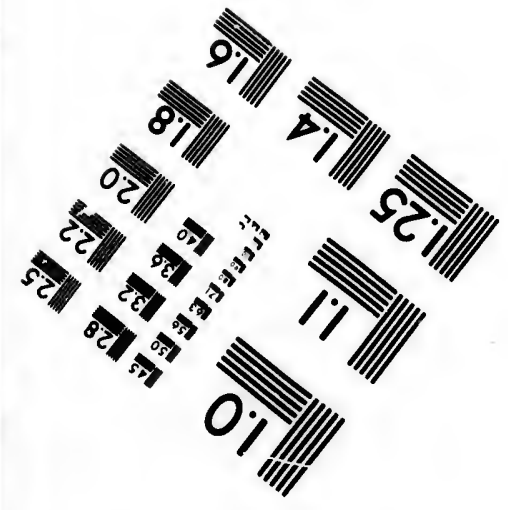

Photographic Sciences Corporation

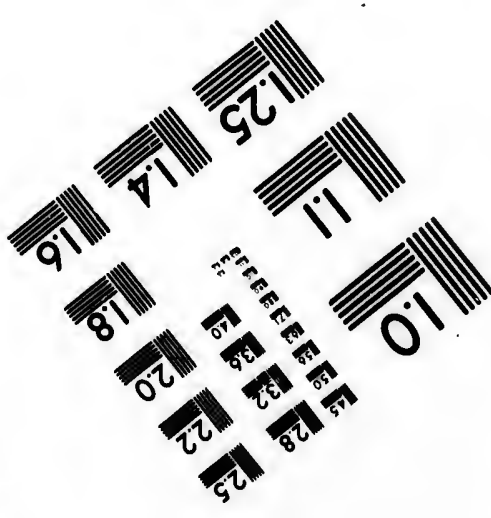




\section{NATURAL AND CIVIL}

wished should remain in a state of tranquility, and be considered as a place of trade and commerce: Nor could any of them be persuaded to join the British troops, in their passage through their country: Embarrassed with such difficulties; it was not till the twenty first of August that Shirley arrived himself at Oswego. He had scarcely one half of the batteau men which had been engaged for the service ; and on that account, the transportation of provisions had been so retarded, that he was in no condition to move his army from Oswego:

A L ARGE convoy with provisions being expected every hotrr, on September the eighteenth the general called a council of war, and com. municated to them the intelligence he had procured relating to the French forts and forces at Niagara, and Frontenac ; with an account of his own force and situation: He informed them that the number of effective men in his three regiments, and independent companies, amointed to thirteen hundred and scventy six ; and that the irregulars, consisting of men from Albany and the Indians, were only to the number of one hundred and twenty. At the same time he announced to the council that as soon as the expected convoy should arrive, it was his intention to embirk for Niagara with six hundred regular troops, the Albany irregulars, and Indians, with the necessary artillery ; leaving behind seven hundred of his troops to pre. serve the camp and stores at. Oswego. The council were of opinion that the expeclition to Niagara was advisable; and that the works of Osivego ought to be enlarged and strengthened 


\section{HISTORY OF VERMONT.}

and that a greater naval force should be provided on lake Ontario. With his usual spirit of activity, Shirley was deeply engaged in his preparations, when the weather became uncommonly tempestuous and rainy ; and continued thus for thirteen days. His troops became sickly; and the Indians and others acquainted with the climate, pronounced the season too far advanced, to admit of such an expedition upon lake Ontario.

Dou B T U L as to success against Niagara, and anxious for the safety of Oswego, on Septem. ber the twenty seventh, the general called another council of war. He represented to his officers what further intelligence he had received of the state of the enemy, the quantity of his own provisions, and that the numbers in his camp now annunted to two thousand men....The council were unanimous in their opinion that it was not advisable to proceed on the expedition to Niagara that fall, but to defer the matter to the next spring : and that in the mean time, the works at Oswego should be repaired and strengthened; and that a new fort should be erected, and compleated as soon as possible. In conformity to the advice of his council the general gave up the prospect of an expedition to Niagara, till the next spring ; and spent the remainder of the season, in repairing and erecting forts at Oswego ; and in strengthening the English interest with the Indian nations ; several of whom, disgusted with the English methods of proceceling, were become waveririg in their attachment to the English, and very doubtful of their success. It has been customary to

$$
\text { rof. I U } 2
$$

ops to pre-

gro. The

seclition to

works of rengthened 
censure genera! Shirlcy for inactivity and delay in prosecuting the expedition to Niagara. In tie state the country was then in, it was impossible to compleat such an expedition in the course of one campaign. The military services in which he had been engaged in the course of the year, were prosecuted with all the activity and prudence the miture of the service would admit.... Few meir could have done more, and probably not one man in America at that time, could have effected so much. When the winter was approaching, he made the necessary arrangements for the defence of the place; gave the command to colonel Mercer, with a garrison of seven hundred men, with orders to continue the works; and on October the twenty fourth set out on a journey to Albany and New-York, to concert measures for the next campaign.

Tine expedition against Crown Point had been put under the command of colonel William Johnson. This officer was a native of Ire. land and had lived several years in the Mohawk country. There he had a fortified seat which he called Mount Johnson, near one of the Mo. hawk castles, and about thirty six miles from Albany. He was well acquainted with the Indian temper and character, had gained the affections, and was become the principal confident of the six nations: on account of his influence over them, Braddock had entrusted him with fifty thousand pounds sterling to engage their friendship and assistance, in the approaching campaign. Next to him, was general Lyman of Connecticut ; of a military turn, and good abilities. The provincial troops to the number 
and delay ara. In tie impossible e course of es in which f the year, and prud admit.... probably me, could winter was arrangegave the garrison of pntinue the fourth set v. York, to lign.

Point had onel Wilive of Ire. Mohawk seat which $f$ the Mo. iles from th the In. the affec. nfident of influence iim with age their roaching Lyman good a. number of five or six thousand men had assembled a Albany and were in danger of becoming dis. orderly by their inactivity and want of employment. Lyman moved on with his troops to the carrying place, about sixty miles from Alban, and began a fort on the east side of Hudson's river, which is now called fort Edward; and meant to remain at that place till Johnson should arrive, with the artillery. It was not till the 10th of August that Johnson could set out with his artillery from Albany; and about the latte cnd of that month, he proceeded from fort Edward, fifteen miles more northerly ; and formed his camp at the south end of lake George, which beiore that time had been called lake St. Sacrament, the name that Champlain had assigned to it.

Soon after he had formed his encampment, he received information by his Indian scouts that a large party of French and Indians had taken possession of 'Ticonderoga, an isthmus which commands the passage between the lakes George and Champlain ; but that no works had been erected. Johnson was informed of the importance of that post ; and wrote to Shirley, September the first, that he was impatient to get up his batteaux \& artillery ; and proposed to move on with part of his army; dispossess the French and secure the post to himself..... The French however had secured the possession, and soon erccted works sufficiently strong, to defend it against surprise, or an easy conquest.

The court of France, aware that a war was commencing in North America, had early in the spring dispatched a body of troops to the 
amount of four thousand men, for the defence of their northern colonies. These troops sailed from Brest early in the spring, with a large quan. tity of warlike stores, and a fleet of twenty five sail of the line. Eight companies of these troops had been captured, with two French men of war, off the banks of Newfoundland, by the British fleet under the command of admiral Boscawen. One thousand were landed at Lour. isburg, for the clefence of that place. The re. mainder arrived at Quebce, with M. de Vaucirieul, governor general of Canada, and barron Dieskau, commander in chicf of the troops. The French court-wished to reduce Oswego, and thus secure the command of the lakes. With this view Dieskau pushed up to Montreal ; from whence, he detached seven hundred of his troops up the river, to fort Frontenac ; intending to join them himself with the remainder, as soon as circumstances would permit. Just before he had compleated his preparations, Montreal was alarmed with accounts that an English army was assembled near the lake St. Sacrament; which was represented as being numerous, and designed to efiect the conquest of Crown Point, and then penetrate into the country towards Montreal. A council of war was called on the occasion, and Dieskau was urged to omic the expedition against Oswego, and proceed to. Crown Point, for the defence of the forts in that part of the country against the attempts of the English army. It was not without much persuasion and reluctance that the baron consented to alter the plan of his operations, and proceed to fort St. Fredcrick. 
he defence oops sailed argé quan. venty five of these ro French ndland, by of admiral ed at Loin. The re. le Vauciri. nd barron pops. The rego, and s. With real ; from his troops ending to as soon ust before Montreal nglish ar. crament ; crous, and swn Point, towards led on the omit the oceed to. rts in that sts of the nuch per. consented d proceed
Whes he arrived at Crown Point, he found that there was no prospect that the English army would soon make an attempt against that place. Litîle acquainted with an Amcrican war, he coniluded to march on with his troops, and attack the English in their camp; and if successful to make further attempts upon their northern settlements, Albany or Schenectady, as should be found practicable. In this way, he was not without hopes to bring about the reduction of Oswego, by cutting off the communication between that fortress, and the settlements in New York, from which they must be supplied with provisions. With these hopes and expectations, Dieskau embarked at Crown Point with eighteen hundred men, in batteaux, and landed them at South Bay, now called Westfield. By an English prisoner, the baron received information that fort Edward was almost defenceless; and that the English camp at the lake, was without either entrenchments or cannon. He fixed upon fort Edward, as the place for attack; and marched on till he came within three or four miles of the place. There he made known his designs to his army. It consisted of two hundred regulars, eight hundred militia, and seven or eight hundred Indians. The gencral informed them, that the enterprise would certainly succeed; and that by reducing fort Edward, the English ariny at the lake must necessarily abandon their camp, and disperse in confusion, in any direction in which they could escape: Then the consequence would probably be that Albany would also fall, and Oswego be subdued by the want 
of supplies and provisions. The Canadians and Indians were not persuaded that all these effects were about to take place; they were fearful of the effects of cannon, and were averse to mak. ing an assault upon fort Edward on that ac. count : But discovered a readiness to attack the camp at the lake, where they expected no other arms would be employed against them but musquets. Dieskau was obliged to comply with the inclinations of his troops, and abandoning his principal designn, he changed his route, and put his army in motion against the main body of the English at the lake.

Ir was not till the enemy had departed from South Bay, that general Johnson had any intel. ligence of their approach or designs ; and the first information he had, was, that a large army of French and Indians had left South Bay, and were actually on their march to fort Edward. $\mathrm{O}$ i receiving this information from some of his Indian scouts, he dispatched separate messengers to the commander at fort Edward, with advice of the enemy's approach ; and with orders to withdraw all the troops within the works which had been thrown up at that place. One of the messengers was intercepted and slain : The other got back about twelve that night, and reported that he saw the enemy about four miles to the northward of the fort. The next morning Johnson called a council of war, who rcsolv. ed that one thousand men should be detached, with a number of Indians, " to catch the enemy in their retreat, either as victors, or as defeated in their designs." * This detachment was put

- Johnson's printed letter, 


\section{HISTORY OF VERMONT. SĞ̉}

nadians and hese effects e fearful of se to mak. on that ac. 0 attack the ed no other them but to comply d abandonhis route, the main

arted from any intel. ; and the large army $\mathrm{Bay}$, and Edward. ome of his e messen. rard, with d with orthe works ice. One nd slain : night, and Cour miles ext mornho resolv. detached, the enemy $s$ defeated was put under the command of colonel Williams, a brave and judicious officer; and was attended by more than two liundred Indians.

THE camp of the colony troops was on the banks of lake George, and was covered on both sides with a swamp of thick wood. Upon the departure of the detachment a kind of breast work was thrown up, of some trees which were cut down for that purpose; and some of the cannon, which were received a day or two be: fore, were hauled up to strengthen the front. Colonel Williams met the enemy within four miles of the English camp : In about an hour after his departure, a heavy fire was hea d which was judged to be within three or four miles of the camp. Johnson jtidged that his detachment was attacked, and was retreating to the camp. He immediately beat to arms, and made the best preparation he could for the re. ception of the enemy. The fire approaching nearer, lieutenant colonel Cole was sent out with a party of three hundred men to cover the retreat. About ten o'clock some of the Provincials and Indians appeared, running back to the camp; and brought information, that the detachment was attacked on all sides, and vas retreating: In a short time the whole party thes escaped, returned in large bodies to the camp. Colonel Williams was slain in the action; the command had devolved on lieutenant col. Whiting, a Connecticut officer, who had acquired much reputation at the recluction of Louisburgh in the former war ; and conducted with much hravery and prudence on the present occasion.

JoH $\mathrm{N}$ so N manned his breast work, and made 


\section{NA'TURAL AND CIVIL}

the best preparation for the reception of the en. emy, that time and circumstances would permit. At half after eleven, the enemy were seen to approach. 'Their army was drawn up, and marched along the road, in a very regular manner ; aiming directly at the center of the en. campment. When they had approached within one hundred and fifty yards of the breast work, they made a halt for a short time; their regu. lar troops preparing for the grand or center attack, and the Camadians and Indians filing off to the llanks. The regular troops began the engaterenent with platoon firings, which on account of the distance, and breast work, had little or no effect. 'The artillery immediately began to play upon the enemy; to avoid which, their militia and Indians betook themselves to the trees and swamps, and kept up an irregular fire upon the fianks. The engagement was now become general with both armies, but it was without much impeturosity on either side. The regular troops in the French army preserved their ground and order, for some time, with much steadiness and resolution; but found themselves abandoned by the Camadians and Indians, and suffered severely by the warm and constant fire from the breast work. Unuble to make an im: pression on the center, they moved to the right, and attacked the reginents of colonel Ruggles, Williams, and "litcomb. Whese regiments received the attack with firmuess, and kept up a constant and wall directed fire upon the enemy. This attempt upon the right, continued about mo hour, without the appearance of success. Diesknu now found the he cond not make any 
on of the en. ould pernit. vere seen to wn up, and egular man. $r$ of the en. ached within breast work, their regu. or center at. $s$ filing off to egan the enhich on acrk, had little iately began which, their elves to the irregular fire at was now but it was r side. 'The eserved their with much 1 themselves Indians, and constant fire uake an im: to the right, iel Rugggles, egiments re. d lept up a the cnemy. iived about of success: of make any impression on Johnson's army, with his small body of regulars; and that the fire, from every part of his army, was become weak, and decreasing. To save the remainder of his troops he attempted to retreat, but it was in much confusion and disorder. Upon this mancuvre, a party from the English camp jumped over the breast work, fell upon his rear, and dispersed the soldiers that were about him. Being wounded in the leg, Dieskau could not travel himself : and was found by the party from the breast work, resting on the stump of a tree, abandoned by his men, destitute of any assistance, and unable to walk. A provincial soldier approaching him, the baron was feeling for his watch to present to him. The soldier believing he was in search of a pocket pistol, discharged his musket and gave him a dangerous wound in his hips.

UPoN their retreat, the enemy halted about four miles from the provincial camp, at the place where the engagement began in the morning with colonel Williams. A party consisting of two hundred men had been detached from fort Edward, to assist the main body of the army under Johnson. This party was commanded by captain M'Ginnes from New Hampshire, a brave and active officer. He fell upon the enemy, with an impetuosity and spirit, that soon put an end to their order and consultations. They kept up their resistance for nearly two hours, but in the event dispersed in every direction. The party under M'Ginnes lost but twelve of their men. Their brave but unfortunate commander arrived the same day at Johnson's camp; but died in a few days of the wounds which he had received in the battle.

vol. I W 2 
In these engagements, the greatest loss of the provincial troops, fell upon the detachment sent out in the morning. Colonel Willians, major Ashley, captains Ingersoll, Porter, Farrel, Stoddard, Stevens, M'Ginnes, with about one hundred and thirty men were slain. About sixty were wounded, among whom was general Johnsolı. The Indians estimated their loss at forty men ; among these was Hendrick, the old Mohawk sachem. In the French army, the loss was said to amount to six or seven hundred. Among the slain were several officers of dis. tinction, with M. Sit. Picrre, a major general, and commander of the Indians ; but few prisoners, not more than thirty were taken.

$\mathrm{T}_{\mathrm{H}} \mathrm{E}$ conduct of $\mathrm{M}$. Dieskau in this cxpedition, cannot be viewed as the result of much discretion, or of good intelligence. The garrison at Fort Edward, at that time, did not amount to more than five hundred men, under the command of colonel Blanchard of Newhampshire. The,works were unfinished, and capa. ble of but little defence. Agrainst this place Dieskau might probably have succeeded. But to attempt to destroy the provincial army at the lake, which was four thousand strong, with a very inferior force, bore the appearance of rash. ness rather than bravery. By the officers of the most experience in the provincial army, it was said, his most capital mistake was in making a halt when he arrived at the provincial camp: That such was the hurry consternation, and want of intelligence in their camp, that if the encmy had marched immediately to their breast work, as their defeated and affrighted troops re- 
test loss of - detachment el Willianıs, orter, Farrel, about one iin. About was general heir loss at rick, the old rmy, the loss en hundred. cers of dis. jor general, it few p:is. ken.

this cxpediult of much The garri. did not a. men, under f Newhampand capa. this place eeded. But army at the ng, with a nce of rashficers of the $\mathrm{my}$, it was in making cial camp: ration, and that if the their breast troops re- turned, it was not improbable they might have increased the confusion and constemation, till it issued in a dispersion of their troops. By making a halt, and firing in platoons at a dis. tance in which it could have no effect, the provincials accuuired experience, found the enemy's fire to be harmless, that their own was much bet. ter directed, and did the most execution. It was also a great misfortune to the French army, that their general continued the attack, long after it was found to be unsuccessful, and unavailing.

$A$ victory at that time was so unusual in America, that not to have lost a battle passed for an act of much merit and heroism; and Johuson was much commended that he had not been defeated. His eonduct however did not pass without some severe remarks and ccnsure. It was said there was no generalship in the management of any part of the business; that an army of four thousand men, with artillery, and a breast work, could not be in any danger from such an enemy; and ought to have destroyed their whole army. But most of all was he censured for not sending outa detachment in pur. suit of a defented, retreating army; this was warmly urged by general Lyman, but was opposed by general Jolinson, and most of his field officers. Instead of making any attempt to pursue the cnemy or to move forward to Ticonderoga, the day after the battle Johuson wrote to the governors of the colonies for a reinforcement ; informed them that he expected another attack, and that the encmy would come on with their artillery; that he should order the troops at fort Edward, to remforce him ; and that as 
soon as the fresh troops should come on, he should immediately set about building a fort. How far the intelligence which Johnson had, might justify this extrenie caution, we cannot now determine. The event was, that instead of risking any thing against the enemy, he spent the remainder of the campaign in building a fort at the south end of lake George, which has since been called fort William Henry.*

THus terminated the American campaigns in the ycar 1755. 'The plans had been chiefly formed by governor Shirley ; an able and judicious statesman, well acquainted with American affairs, and deeply engaged in the interest of the colonies. 'They appeared to have been so well concerted, that they were approved and confirmed by general Braddock, and the council which he assembled at Alexandria. One only had succeeded: That at Nova Scotia, though ostensibly under the command of Monckton, had been principally conducted by colonel Winslow; and had fully effected the purpose of subduing the French in that province, and preserving it to the British dominions. The expedition under Braddock was conducted with extreme imprudence and rashness, and had terminated in destruction and disgrace, The Niagara expedition under Shirley, was too extensive in its plan and object, to be compleated in one campaign. At the northward, the baron Dieskau had given Johnson an opportunity to obtain a victory, without "leaving his camp, or exposing himself to any danger. Braddock

- Johnson's I.etter of September 9, 1755 . 
ome on, he ding a fort. hnson had, we cannot hat instead hy, he spent building a , which has y.*

campaigns been chiefly le and judih American terest of the een so well and conthe council

One only tia, though Monckton, by colonel the purpose vince, and ions. The lucted with nd had ter. The Niatoo extennpleated in the baron ortunity to. s camp, or Braddock was slain, Shirley had lost much of his popu. larity, Johnson was celebrated by some and censured by others, while Winslow was every where commended and applauded.

Tne campaigns beiriz closed, general Shirley convened a grand council of war at New York, to settle the plan of operations for the next year. This council was opened on the twelfth of December, and continued its session that day and the next. The invitation to the governors of the colonies was universal; but the council was attended only by the following members; the governors of Massachusetts, Connecticut. New York, Pennsylvania and Maryland; colonels Dunbar and Schuyler, majors Craven and Rutberford, and the deputy quarter master general. Shirley laid before the council, the king's instructions to general Brad. dock; and proposed as a plan of operations for the next year, that expeditions should be carried on against fort Du Quesne, Niagara, and Crown Point ; and that a body of troops should be sent by way of the rivers Kennebec and Chaudiere, to keep up an alarm in the neighborhood of Quebec, and the eastern parts of Canada. Shirley's plan was adopted with great unanimity of sentiment, and the council dissolved in perfect harmony, after a session of two days. The governors returned to their respective provinces, but Shirley tarried at New York, in hopes to prosecute an expedition against $\mathrm{Ti}$ conderoga in the winter, which the season however did not permit.

1756. Tre plan of opcrations concerted at New York, in a few days after, was transmitted 
to the British minister, to be laid before the king, for his approbation. 'This business being adjusted, on January the twenty first, Shirley set out for Boston, to meet the assembly of Massachusetts, and propose to them the raising of their quota of the troops. The assembly was disgusted with the proceedings of the last campaign, especially at general Johnson's neglecting to pursue his advantages after the defeat of Dieskau. It was with difficulty they were persuaded to concur in another expensive expedition ; nor would they engage in offensive oper-. ations at the lake, till it was understood that Winslow was to have the command of the troops designed against Crown Point. The governor's influence however prevailed, and the assembly concurred in all the military measures which he proposed.

Is April, news arrived from Great Britain, that the events of the last year were viewed in a very different light there, from what they were in America : That the affair at lake George was considered by the British ministry, as a very important victory; and Johnson's conduct as highly deserving and meritorious: That he was honoured with the dignity of a Baronct; and that five thousand pounds sterling had been voted to him by the house of commons as a fur. ther reward for his services: 'That his engineer was promoted to the rank of a major in the British service, and his secretary to the command of a company. It was also said that general Shirley's conduct had been entirely disapproved by his majesty, that he was removed from the eommand of the troops; and that the earl of 
before the ness being Shirley set of Massaraising of embly was last cam. neglecting defeat of were perre expedissive oper-. stood that nd of the int. The d, and the measures

at Britain, viewed in they were jeorge was as a very onduct as ant he was onct ; and 1 been vo. $s$ as a fur$s$ engineer $n$ the Bricommand lat general sapproved from the se earl of
London was appointed general and commander in chief of all the forces in North America : And that the favorite object with the British ministry, was the reduction of Crown Point. Ar this time, general Shirley had not received the king's orders, with respect to the late plan of operations ; but was much engaged in carrying it into effect. On these venth of May, he arrived at Albany, and immediately began his preparations for the campaign. On the twenty fifth, he held a council of war, consisting of lieutenant colonel Gage and Burton, majors Chapman and Sparks, Sir John St. Clair, and Montresor, the chief engineer. With regard to the Niagara expedition, he informed the council that upon lake Ontario, there was a naval force of two vessels of ten carriage guns each ; two row-gallies of ten swivels each; and that he had issued orders for building three other vessels, one of eighteen, one of sixteen, and one of twelve carriage guns. Besides which, there would be on that lake, two hundred and fifty whale boats, each capable of carrying sixteen men. With respect to the expedition against Crown Point, the council were told, that the several colonies had voted to raise cight thousand and eight hundred men, including those which were in garrison at the forts Edward and William Henry. 'I'he council were of opinion that thirteen hundred fnen ought to be posted at Oswego, and four hundred at the different posts between that place and Schenectady. 'That two British regiments, with the colony troops, would be sufficient for the reduction of Crown Point; and that a fort ought immediately to be 
built at South Bay, the place where Dieskau hạd landed his troops.

$H_{A \text { VING formed the military plans and put }}$ all the northern colonies in motion to execute them, Shirley was deeply engaged in the business till the arrival of major general Webb, on June the seventh. It was now certain that gencral Shirley was superseded in the command. On June the fifteenth, major general Abercrombie landed at New York, and in ten days repaired to Albany, and took upon himself the command of the army. Shirley immediately delivered to him the returns of the army and stores ; and gave him the necessary information respecting the plans of the campaign, the state of the American colonies and troops, and the situation of their forts and public affairs ; and continued no longer at Albany than was necessary to compleat this business. General Abercrombie was of a family much distinguished in Scotland ; had risen in the army by a regular course of service, and acted with reputation under the duke of Cumberland, in subduing the rebellion in the year forty six. He was now advanced in age, and but little acquainted with the affairs of the American colonies. When he took the command of the troops, they consisted of two regiments which had served under Braddock, two battalions raised in America, two British regiments which he brought over with him, four independent companies which had been for many years maintained in New York, four companies raised by the province of North Carolina, and the large body of provincial troops which had been raised for the expedition against Crown Point. 
zre Dieskau

lans and put 1 to execute in the busi1 Webb, on ain that gen: command. Abercrom. ten days rehimself the immediately e army and information nn, the state ops, and the affairs ; and i was necesneral Aber. inguished in by a regular putation unubduing the Ie was now uainted with

When he ey consisted under Bradmerica, two at over with which had New York, sce of North incial troops lition against
AN important part of the service respecting the western campaign, was the direction of the batteaux ; by these, the troops, provisions and military stores were to be transported from Schenectady to Oswego. Shirley, fully apprehensive of the importance of this service from the sufferings of the former year, had enlisted forty companies of fifty men each for this business. Colonel Broadstreet, an active, judicious officer, well acquainted with the nature of the business, had been appointed to the command. In returning from Oswego with three hundred of his men, as he was stemming the stream of the Onondago river, with his batteaux formed into three divisions, on July the third, the Indian war-whoop resounded from the north shore, and he was attacked in an instant by a general discharge of musquetry. With perfect coolness, Broadstrect landed his men on the other bank, took possession of an island from which he could annoy the enemy, followed them to every place where they had passed the river, and fell upon them sword in hand wherever he could find them in any numbers. Several actions took place along the banks and islands of the river ; the engagement continued for three hours, and in the event, the enemy were every where repulsed and dispersed. In this contest the force of the enemy amounted to seven hundred men. Thirty of the batteaux men were killed, and as many wounded. 'The French and Indiars lost one hundred and tiventy, and about seventy of them were made prisoners.

$\mathrm{O}_{\mathrm{N}}$ the eleventh of July, Broadstreet arrived at Schenectady. The next day he repaired to VOL. I. $\mathrm{X}_{2}$ 
Albany, to lay before general Abercrombic, the intelligence he had obtained, of the danger which threatened Oswego. The prisoners ho had taken in his late actions, informed him that twelve hundred of the enemy were encamped on lake Ontario, at but a little distance from the English forts; that they ware provided with artillery, and all other implements necessary for a siege ; and that they meant to commence their operations, as soon as sone expected reinforcements should arrive. Upon this intelligence orders were issued to general Webb, to hold himself in readiness to march for the defence of Oswego, with the forty fourth British regiment. While the British generals were thus specula. ting about Oswego, Lord Loudon who had been appointed to the chief command in North America, arrived at New York, July the twenty third, and reached his head quarters at Albany, the twenty ninth ; and immediately took upon himself the command of the troops. Amidst the parade and ceremonies attending the arrival and reception of the British generals, the affairs of the war were not attended to ; and it was not till the tivelfth of August that Webb set out with his regiment from Albany for the preservation of Oswego. He had proceeded on his journey but a few days, when he received news that Oswego was actually besieged by a large army of French and Indians. Alarmed for his own safety, he made a forced march to the Oneida carrying place ; when he immediately began to throw up works for his own defence, and to fall the trees in Wood Creek, to prevent. the enemy from approaching his own camp. 
rrombic, the the danger prisoners ho ied him that encamped ice from the svided with ecessary for mence their d reinforce. intelligence $\mathrm{bb}$, to hold e defence of h regiment. us speculaho had been North A. the twenty at Albany, took upon s. Amidst : the arrival the affairs d it was not ebb set out the preserded on his eived news by a large med for his irch to the mmediately vn defence, to prevent camp.
WhILE the British generals in America were thus spending their time to no purpose, $M$. Montcalm, the commander of the troops in Canada, was deeply engaged in a scheme of the highest importance to the French interest; that of securing to themselves the extensive dominion of the Great Lakes, which they well knew would command the interest and influence of all the Indian nations. As the first step to effect these measures, he set forward an expedition against Oswego, while the British generals were looking for him at Tyconderoga. He assembled a body of troops, consisting of thirteen hundred regulars, seventeen hundred Canadians, and a considerable number of Indians. With this force he proceeded from fort Frontenac, by the way of lake Ontario. The first step taken by Montcalm, was to block up Oswego by water, by two large armed vessels ; the next, was to post a strong body of Canadians and Indians on the road between Albany and the forts, to cut off all communications of succour and intelligence. Having brought up his artillery and stores, he had every thing in readiness to open his trenches before fort Ontario, by the twelfth of August. 'The forts were in no condition to make a defence against artillery or regular approaches. On the thirteenth, colonel Mercer was killed by a cannon ball ; and the next day the garrison proposed a capitulation. The terms were, that they should surrender prisoners of war, be exempted from plunder, treated with humanity, and be conducted to Montreal. Unfortunately for several of the prisoners, and for the honor of Montcalm, the terms of the capitulation were not fulfilled by 
him. Several of the British officers, and sol. diers were insulted, robbed, and massacred by the Indians. Most of the sick were barbarously scalped in the hospital ; and to compleat the scene of falshood and barbarity, the French general delivered up to the Indians above twenty of the garrison, in the room of the same number that they had lost during the siege. In all probability these unhappy victims were put to death, according to the execrable Indian cus. tom of torturing and burning. Having succeeded in the enterprise with scarcely any loss, Montcalm demolished the two forts at Oswego, and returned with his army to fort Frontenac. In this expedition he had taken fourteen hundred prisoners, one hundred and twenty pieces of artillery, fourteen mortars, with a large quantity of ammunition, warlike stores, and provisions ; two sloops, and two hundred batteaux.

WhILE these scenes, disgraceful to the English, were taking place at Oswego, and the French every where conducting their affairs with wislom and energy, the British generals at Albany appeared to be either wholly unacquainted with the business, or disinclined to the dangers and hardships of an American, French and Indian war. The force in the vicinity of Albany, under the command of the earl of Loudon, amounted to two thousand and six hundred regular troops, and eight thousand pro. vincials, well clothed, fed and armed; and provided with the necessary artillery and implements of war. General Winslow for several months had been at lake George, with an army of seven thousand provincial troops, well equip: 
$s$, and sol. ssacred by barbarousompleat the the French above twenf the same e siege. In s were put Indian cuslaving suc. ly any loss, at Oswego, Frontenac. irteen hun. enty pieces large quanand provid batteaux. to the En$O$, and the their affairs ish generals holly unac. lined to the can, French he vicinity the earl of nd and $\operatorname{six}$ ousand pro. ; and proand imple. for several ith an army well equip: ped, and ready to proceed from fort William Henry. From the best accounts, the force of the French at Ticonderoga and Crown Point, did not exceed three thousand men ; and with this force, they did not appear to be in any degree apprehensive of any danger from the English. Nor had they any thing to fear from the British generals, forces, or exertions ; for nothing was attempted or effected. Loudon neither made any attempts, nor gave any orders to his troops to move forward, or molest the enemy on lake Champlain. Loudon had his head quarters at Albany, Winslow lay with the provincial army at lake George, the season passed away, and all that was attempted or performed was to strengthen the forts Edward and William Henry, which Lyman and Johnson had built the year before.

A party, in some of the colories, had been extremely active in censuring the measures of general Shirley, and in effecting his removal - from the command. 'They had already discovered that he was much better acquainted with American affairs, more judicious in his plans, and more active in executing them, than the British generals who had succeeded him. If Shirley had attempted too much, they had at. tempted nothing; and if Braddock had lost his life and army by his rashness and confidence, Loudon and his officers had neither ventured, effected, or lost any thing : And it was already apparent, either that they were altogether unac. quainted with the nature of that kind of war, which must be pursued on the American frontiers ; or else they were disinclined to venture 
amidst the fatigues, dangers, and surprises, to which it was unavoidably exposed. But what. ever was the cause, it was every where known that the whole body of British and provincial troops, through the whole of this campaign, had been employed to no manner of purpose. Dis. appointment and disgrace had attended every British measure; it was the French, with M. Montcalm, their general, that had acted with vigor and success. 
surprises, to But what. here known I provincial mpaign, had pose. Dis. nded every $h$, with $\mathbf{M}$. acted with

\section{CHAPTER XII.}

$W_{A R}$. Progress and events of the war in the years 1757 and 1758 . Loudon's preparations for the campaign. Montcalm's nieasures with the Indians. Eesigns upon the English. Putnam's account of 'te ebb's proceedings. Conquest of Fort William Henry. Savage massacre of the prisoners. Reflections on Montcalm's conduct. Result of the campaign in 1757. Change of the British councils and ministry. Conquest of Louisbourg. Abercrombie's attempt and defeat at Ticonderoga. Capture of Fort Frontenac by Broadstreet.... Of Fort Du Quesne by Forbes. Amherst assumes the command.

1757 THE Earl of Loudon had been an officer of much reputation in Scotland. In the rebellion in that country, in the year one thousand seven hundred and forty five, he commanded a regiment of Highlanders at Inverness ; was very useful in directing the councils and conduct of the clans, who had taken arms in behalf of the $\mathrm{king}$; vigilant and successful in restraining and intimidating the disaffected chiefs, who had not openly joined in the rebellion ; loyal, active, and persevering, he had rendered very useful services to his majesty, in the high lands of North Britain. From such services and experience, it was supposed that he was well qualified to have the direction of the war in North America.

HAVINc assumed the command of all the 
forces in North Amcrica, he was employed durfng the winter in effecting his purposes with the Anerican governments, to raise a large body of troops for the ensuing campaign. His Lord. ship had not the full confidence of the Ameri. can assemblies; but such was their conviction of the necessity of more vigorous measures in carrying on the war, that they every where raised the number of troops which were requir. ed of them, and made all the preparations which were expected : But as the British general had taken the direction of all the proposed expeditions under his own management, neither the American governors or assemblies; were em. ployed in forming plans, or concerting meas. ures for their own defence, or to annoy the enemy. The time was now come, when it was thought by the British ministry that it was not best for their colonies to learn their own strength, or to depend upon their own councils ; but to jook to British officers and troops for the one, and to the British ministry for the other.

From the first commencement of hostilities, the reduction of Crown Point had been the fa: vorite object with the colonies, and with the crown. It was determined in the British councils of this year, to vary and extend their opera. tions; not to carry their expeditions against Crown Point, but to make a vigorous attempt ngainst Louisbourg: In pursuance of this plan, Aclmiral Holbourn arrived at Halifax, on July the ninth, with fifteen ships of the line, and a large number of transports. Lord Loudon had collected a body of six thousand troops, and embarked from New York, to take the command 
iployed dur. pses with the large body His Lord. the Ameri. $r$ conviction measures in very where were requir. ations which general had sed expedineither the , were em. rting meas. noy the enewhen it was it it was not wn strength, cils ; but to for the onc; ther.

f hostilities, ocen the fa: ad with the iritish countheir opera. ons against sus attempt of this plan, $x$, on July line, and a Loudon had troops, and ie command of the army designed for L.ouisbourg. When he arrived with his troops at Halifax, he found himself at the head of twelve thousind men; well oflicered, disciplined, and provided with every thing necessiury for the expedition. While the army lay at Halifax, preparing to embark, intelligence was received that $M$. de la Mothe had sailed from Brest, in the month of May, and was arrived safe at Louisbourg, with a large flcet of ships of war, and transports. The intelligence was soon confirmed, with more particular information; that there were seventeen ships of the line and three frigates moored in the harbor ; a land army of six thousand regular troops, three thousand natives, and thirteen hundred Indians; that the place was well sup. plied with ammunition, provisions, and every kind of military stores ; and that the encmy were expecting and desirous of a visit from the English flect and army. 'This intelligence put an end to Loudon's deliberations. No attempt was made to proceed in the expedition, it was forescen that the consequence of a defeat would have been greatly injurious to the British affairs in America. And neither their admirals or generals had as yet accuired that determined resolution and perseverance, which were necessary to give success to the American contest.

Bu'r whatever was the case with the British commanders, the French generals perfectly well unclerstood their business. Montcalm, who had the command of the troops in Canada, was an able and experienced officer. He had served with much reputation in the French armies in Italy and Bohemia, and bad met with much roi. I. Y 2 
success in America. The conquest of Oswego had raised his fame among the Indians, and given him the command of almost all their tribes and commerce. He pursued the advantages he had obtained with much discretion and address. The English had destroyed their forts at the great carrying place, and in other parts of the Indian country, to prevent their falling into the hands of the lirench; and the whole country of the six nations was abandoned to the enemy. The French commanders availed themselves of all the errors and defeats of the Fnglish. They carried fire and sword into the Indian country; and by rewards, promises, and threatenings, were incessantly endeavoring to draw over the six nations to their interest; and they had the most flattering prospects of success. These nations alone, of all the Indian tribes, had been sincere and faithful in their attachment to the English. The forts, and communications with their tribes were cut off, their country was abandoned to the incursions and ravages of their enemies, and their English allies had met with little else than disappointment and defeat in all their expeditions against the French. In such circumstances it required all the ability and address of sir William Johnson, to prevent their deserting the English cause and interest.

$\mathrm{By}$ the departure of lord Loudon from New York, the command of the British forces had devolved on major general Webb. Montcalm saw that a favorable opportunity was presented to attack the English on lake George. He had made an attempt on the twentieth of March, to carry fort William Henry by surprise ; but his 
$\mathrm{t}$ of Oswego indians, and I their tribes lvantages he and address. forts at the parts of the ing into the e country of the enemy. remselves of lish. They in country ; hreatenings, aw over the hey had the These na, had been nent to the ations with ntry was a. ges of their ad met with defeat in all 1. In such lity and adrevent their est.

from New forces had Montcalm $s$ presented He had March, to ; but his troops had been defeated by the vigilance and bravery of the garrison. Several of the enemy were 'slain, but they did not return till they had burned two sloops, \& one on the stocks; almost all the batteaux, three store houses, all the huts of the rangers, and every thing that was not under the command of the fort. At the opening of the spring, a detachment of near four hundred men went down the lake under the command of colonel John Parker, in battcaux and whale boats, to attempt the encmy's advanced guard at Ticonderoga. Parker was deceived in his intelligence, decoyed into the midst of a large but concealed party of the enemy, and attacked witli such impetuosity' and success, that but two officers and seventy privates escaped. Encouraged by this success, and the eleparture of lord Loudon to Halifax, and wishing to retrieve the misfortune of the defeat at fort William Henry, Montcalm drew his forces together and made preparation to lay siege to that place. For this purpose he assembled at Crown Point and Ticonderoga, a large body of regular troops, Canadians, and Indians, amounting to near ten thousand men.

$\mathrm{ONE}_{\mathrm{N}}$ of the great difficulties attending the American campaigns, was the article of intelligence; to procure information of the strength and movements of the enemy. The most that was obtained, was generally by means of scouting and ranging paries. Some of the officers of the New Hampshire troops, werc much dis. tinguished for their abilities and exploits in services of this kind. To three of them, Robert Rogers, John Stark, and William Stark, ranging 
companies were assigned. At the desire of lord Loudon, they were continued in the service dur. ing the winter as well as summer. They were so eminently useful in ranging the woods, pro. curing intelligence, and skirmishing with the advanced parties of the enemy, that they were put in the pay of the crown \& after the war were allowed half pay on the British establishment. $t$

Among the officers of the ranging companies, major Putnam, whose name became so much celebrated in the American war, was at that time much distinguished for his activity and bravery. General Webb had formed a high idea of his military character and enterprise, and had assigned to him the command of a party of two hundred men, who had been selected to escort Webb from fort Edward to Wiliiam Henry. Webb wished to examine the state of the fortifications at lake George, and to procure intelligence of the strength of the enc. my at Ticonderoga and Crown Point. Several attempts had been made in the night by major Rogers, who was then at the liead of the ranging companies, but they had not succeeded. Putnam proposed to proceed in the day time, take with him but five men, land at the Northwest bay, send back his boats, and tarry himself till he could discover the state of the enemy's troops and fortifications at Ticonderoga. Webb thought this would be too dangerous an experiment, but permitted him to proceed with eighteen men in three whale boats. Putnam set out with his volunteers, but before he arrived at the Northwest bay, he discoverced a body of

\$Belknap's Hist. Ncw Hampshire, rol. 2. p. 297. 
men on one of the islands in the lake. Leaving two of his boats to fish at a distance, that they might not occasion any alarm, he returned himself with the information. The gencral saw him rowing back with great velocity in a single boat, and concluded that the other two had been captured; he sent orders to Putnam to leave his men in the boat, and come ashore alone. Putnam informed him of the discovery he had made, and urged the necessity of returning inmediately to make further discoveries, and bring off the boats. Webb reluctantly consented, and Putnam hastened to secure his bcats ; having joined his men, he pressed further on till he discovered a large army in motion, and was seen by the enemy. Several of their ca. noes pursued him, and though nearly surrounded at times, by the most vigorous cxertions he escaped. On his return, he gave to general Webb, a minute account of all that he had seen and added that the army of the enemy must undcabtedly be designed against fort iVilliam Henry. General Webb enjoined the most absolute silence upon the subject, and directed him to put his men under an oath of secrecy, and prepare immediately to return to the head quarters of the army at fort Edward. Wishing to bc engaged in surprising the enemy on the lake, Putnam made this remark, "He ho. ped his excellency did not intend to neglect so fair an opportunity of giving battle, should the enemy presume to land." "What do you think we should do here," replied the general. The next day, Webb returned to fort Ldward, escorted by Putnam; and the day after, colonel 
Monro was ordered with his regiment to reinforce the garrison at lake George. Aware of the siege that was about to commence, Putnam advised colonel Monro not to carry his costly baggage \& camp equipage ; but Monro, not apprised of the intelligence which had been given to Webb, disregarded the advice and marched on without any apprehension of immediate dan. ger. $\dagger$

$T_{\text {H E day after Monro had arrived and taken }}$ the command, the lake appeared to be covered with boats; and a large army of French and Indians were swiftly approaching towards the fort. Montcalm effected a landing with but little opposition, and immediately began the siege. A small party of the garrison had a skirmish with some of the advanced parties of the enemy, and some that had been taken prisoners, had been murdered and scalped by the Indians with circumstances of the most inhu. man barbarity. Montcalm wished to avail himself of this event, and endeavoured to pur. suade the garrison to an imnediate surrender. On the day in which he invested the place, le sent a letter to colonel Mouro, stating that he thought himself bound in humanity to urge him to surrender before any of the Indians were siain, \& their savagre temper should be further inflamed by a resistance which could not be avail. ing. "A detachment of your garrison, says ' he, has lately experienced their cruelty ; I ' have it yet in my power to restrain them, and - oblige them to obscrve a capitulation, as none 
nt to rin.

Aware of e, Putiam his costly nro, not apbeen given 1 marched ediate dan.

and taken e covered rench and wards the with but began the on had it parties of ken pris. d by the ost inhu.

to avail d to pur. surrender. place, lee ig that he to urge ians were urther in. be avail. son, says uelty ; I hem, and , as none
- of them hitherto are killed. Your persisting ' in the defence of your fort, can only retard its ' fatc a few days, and must of necessity expose ' an unfortunate garrison, who can possi'bly receive no relief, considering the precau' tions I have taken to prevent it. I demand a ' decisive answer, for which purpose I have ' sent the Sieur Funtbrune, one of my aides. ' du camp. You may credit what he will in. 'form you of, from Montcalm."

Colonel Monro was an officer of distin. guished honor and fortitude. He returned a very proper and spirited answer, announcing to the French general, that as the fort had been en. trusted to him, his honor and his duty would lead him to defend it to the last extremity. A. ware of his danger, he sent one express after another to Webb, informing him of his own situ. ation, and the strength of the enemy, with the most pressing solicitations for immediate suc. cour. 'The garrison consisted of about two thousand five hundred men; the whole of which, animated by the hope and expectation of receiving relief from fort Edward, made a gallant defence.

General Webb had an army at fort Ed. ward of four thousand men, which had been considerably augmented by the troops under the command of Sir WVilliam Johnson, and by the militia. It is generally supposed that he had private intellizence of Montcalm's designs and motions; and it was in his power to have called in a large number of provincial troops from New York and New Lingland; and these were in fact the best soldiers in a war with the 
Canadians and Indians. But he neither secm. ed to have any appreliension of danger, or to make any exertions ta prevent or avoid it ; but remained rather indifferent or passive amidst all the alarming scenes that were taking place. Such however were the representations from Monro, and the solicitations in his own camp, that on the eighth or ninth day of the siege, general Johnson was suffered to march with all the provincial regiments, the militia, and Putnam's rengers. They had not proceeded three miles before the order was countermanded, and the troops directed to return. Webb then wrote to Monro that he could not afford him any relief, and advised him to surrender on the best terins that he could obtain.

MONTCALM was provided with a good train of artillery, and had bcen accelerating his approaches to the fort with all the expedition in his power. When Johnson began his march, some of the Indians who were employed as runners, saw the movement and gave the inform . tion to Montcalm, that a large force was approaching towards the lake. Being questioned respecting the numbers, they answered in their firurative manner, "If you can count the leaves of the trees, you can count them, \&c." In conseguence of this intelligence, the operations of the siege were suspended; and Montcalm was preparing to give battle, or retreat, as circumstances might dictate. Another Indian runner put an end to the apprehensions of the French, by the welcome tidings that the English amby had returned to fort Ecivard.* Srom the

\footnotetext{
- Putzam's 1.iff, p. 38.
} 
ither secm. iger, or to oid it ; but e amidst all king place. ations from own camp, siege, genwith all the d Putnam's three miles $d$, and the then wrote $\mathrm{m}$ any reon the best

good train ting hin appedition in his march, yed as runle inform. e was apquestioned red in their $t$ the leaves \&c." In operations Montcalm eat, as cirIndian runons of the he English Srom the return of this detachment, Montcalm found that he had nothing to fear from the British army at fort Edward, and prosecuted the siege with fresh vigor, and itie most confirmed hopes. Monroe and his garrison defended themselves with much spirit and resolution till their works were much injured, their ammunition nearly expend$e d$, and the encmy had made near approaches to the fort. Still expecting to be relieved by general Webb, Monroe had refused all terms of capitulation from the third to the ninth of August. Montcalm had intercepted the letter which Webb had wrote to Monroe advising him to surrender.* This letter was sent into the fort to Monroe, with further proposals for a capitulation. Every circumstance now served to convinceMonroe that it would be impossible for him to preservie the place, or to hold out much

\section{- Fort-Edward, Augast 4,12 at Noon.}

SIR, "I am directed by General Webb to acknowledge the reeipt of three of your letters; bearing date nine o'clock yefterday morning, and one about six in the evening, by two rangers, which are the only men that have got in here, except two ycsterday morning with your first,acquainting him that the enemy were in sight. He has ordered me to acquaint you, he does not think it prudent, (as you know his strength at this place) to attempt a junction, or to assist. you, till reinforced by the militia of the colonics, for the immediate march of which repeated expresses have been sent. One of our scouts brought in a Canadian prisoner last nizht, from the investing party, which is very large, and have possessed all the grounds fire miles on this side of Fort William Henry. The number of the enemy is very considerable, the prisoners say eleven thousand, and have a large train of artillery, with mortars, and were to open their batteries this day. The general thought proper to send you this inielligenee, that in case he shovild be so unfortunate,from the delays of the militia, not to have it in his power to give you timcly assistance, you might - be able to makc the best terns left in your power. 'The bearer is a sergeant of the Connecticut forces, and if he is happy enongh to get in wil bring advices from you. We keep continual scouts going, to endeavor to get in, or bring inteligence from you. I am, sir, with the heartiest and most anxious wishes for your welfare, your most obedient humble ser" vant.

To Col. Monroc, or oficer commanding

G. BARTMAM, Aid-de-Camp: at Fort William Henry.

VOL. I. Z2 


\section{NATURAL AND CIVIL}

longer against the French army ; and that he nuist surrender on the best terms that he could obtain.

A RICLES of capitulation were agreed upon and signed by Montcalm and Monroe. It was. stipulated that the garrison of fort William Hen. ry, and the troops in the retrenched camp should marcli out with their arms, the baggage of the officers and soldiers, and all the usual necessaries of war ; and be escorted to fort Edward, by a detachment of French troops, and interpreters attached to the savages. That the gate of the fort should be delivered to the troops of the inst christian king, immediately after signing the capitulation ; and the retrenched camp, on the departure of the British troops : That all the warlike stores, and every thing except the effects of the officers and soldiers should be delivered to the French troops. The garrison was not to serve against France or her allies during the term of eighteen months. Such of the French as had been taken prisoners since the commencement of the war, were to be delivered. at Carillon, ( ( $i c$ conderoga) in the space of three months ; in return for which, an equal number of the garrison of fort Willian Henry should be capacitated to serve in the English armies. The sick and wounded were to remain under the protection of Montcalm, and were to be treated with humanity and tenderness, and returned as soon as they were recovered. An officer was to remain as an hostage till the safe return of the escort that was to be sent to guard the British troops to fort Edward : And as a tepstimony of his esteem and respect for colonel 
and that he hat he could agreed upon roe." It was. Villiam Hen. camp should grage of the ual necessa. ort Edward, nd interprethe gate of roops of the fter signing d camp, oll s : That all except the 10uld be deyarrison was illies during uch of the rs since the se delivered. ace of three ual number' nry should lish armies. main under were to be ss, and red. An ofill the safe nt to guard: And as a for colonel
Monroe and his garrison, on account of their gallant defence, Montcalm was to return one cannon, a six pounder.

TH $\mathrm{z}$ articles of capitulation were signed August the ninth, and no further difficulties were expected. But no sooner had the British troops marched out of their camp thian a scene of perfidy and barbarity took place, that had scarcely ever before been acted among the most brutal of barbarians and robbers. 'In avowed contempt and violation of the articles of capitulation, the Indians attached to the French army fell upon the defenceless garrison, plundered, wounded, anel murdered whatever stood in their way. The following is the account of Captain Jonathan Carver, of the Connecticut troops, and one of the garrison at that time. "The morning after ' the capitulation was signed, as soon as day ' broke, the whole garrison, now consisting of - about two thousand men, besides women and - children, were drawn up within the lines, and ' on the point of marching off, when great num. - bers of the Indians gathered about, and began - to plunder. We were at first in hopes that - this was their only view, and suffered them to ' proceed without opposition. Indeed it was ' not in our power to make any, had we been ' so inclined $;$ for though we were permitted to ' carry off our arms, yet we were not allowed a ' single round of ammunition. In these hopes. ' however we were disappointed; for presently. ' some of them began to attack the sick and ' wounded, when such as were not able to crawl - into the ranks, notwithstanding they endeav- ored to avert the fury of their enemies by their shricks or groans, were soon dispatched. 
- Hsar we were fully in expectation that the (disturbance would have concluded; and our - little army began to move ; but in a short - time we saw the front division driven back;

- and discovered that we were entirely encircled - by the savages. We expected every moment - that the guard, which the French by the articles of capitulation, had agreed to allow us, would have arrived, and put an end to our ap-

prehensions; but none appeared. The In- dians now began to strip every one without - exception, of thcir arms and clothes, and those - who made the least resistance felt the weight - of their tomahawks.

- I happened to be in the rear aivision, but - it was not long before I shared the tate of my. - companions. Three or four of the savages. - laid hold of me, and whilst some held their weapons over my head, the others soon disro- bed me of my coat, waistcoat, hat and buckles, omitting not to take from me what money I - had in my pocket. As this was transacted ' close by the passage that led from the lines on ' to the plain, near which a French centinel was. ' posted, I ran to hin and claimed his protec. 'tion; but he only called me an English dog, ' and thrust me with violence back again into ' the midst of the Indians.

- I now endeavored to join a body of our ' troops that were crowded together at some - distance; but innumerable were the blows ' that were made at me with weapons as $I$ pas: ' sed on ; luckily however the savages were so close together, that they could not strike at, q me without endangoring each other. Notwith. 


\section{HISTORY OF VERMONT:}

tion that the a ; and our in a short Iriven back ; ely encircled ery moment by the artio allow us, id to our ap-

The Inone without s, and those the weight

iivision, but a late or my. the savages. held their soon disro. and buckles, at money I transacted the lines on yentinel was his protec. inglish dog, again inta

dy of our $r$ at some the blows is as I pas: res were so. t strike a+ Notwith.
- standiug which, one of them found means to s make a thrust at me with a spear, which grazed - my side, and from another I received a wound, ' with the same kind of weapon, in my ancle. - At length'I gained the spot where my coun. s trymen stood, and forced myself into the midst - of them. But before I got thus far out of the ' hands of the Indians, the collar and wristbands - of my shirt were all that remaince of it, and my flesh was scratched and torn-in many pla. ces by their savage gripes.

' $\mathrm{BY}$ this time the war whoop was given, and the Indians began to murder those that were ' nearest to them widhout distinction. It is not - in the power of words to. give any tolerable - idea of the horrid scene that now ensued; ' men, women, and children werc dispatched in i the most wanton and cruel manner, and im- mediately scalped. Many of these savages drank the blood of their victims, as it flowed ' warm from the fital wound.

- WE now perceived, though too late to avail

' us, that we were to expect no relief from the 'French'; and that, contrary to the agreement ' they had so lately signed, to allow us a sufficient force to protect us from these insults, ' they tacitly permitted them ; for I could plain' ly perceive the French officers walking about iat some distance, discoursing with apparent ' unconcern. *****

' As the circle in which I stood cnclosed, by ? this time was much thinncd, and death scemed ' to be approaching with hasty strides, it was proposed by some of the mosi resolute to make ione vigorous effort, and endeavor to force ou 
- way through the savages, the only probablo - mcthod of preserving our lives that now re. - mained, This, however desperate, was re.

' solved on, and about twenty of us sprung at - once into the midst of them.

- IN a moment we were all separated, and " what was the fate of my companions I could ' not learn till some months after, when I found ' that only six or seven of them effected their ' desigu. Intent only on my own hazardous - situation, 1 endeavored to make my way thro' - my savage enemies in the best manner possi. ' hle. And I have often been astonished since, - when I have recollected 3 ith what composure - I took, as I did, every necessary step for my

- preservation. Some I overturned, being at that - time young and athletic, and others I passed by, dexterously avoiding their weapons; till "at last two very stout chiefs, of the most sav. ' agre tribes, as I could distinguish by their

- dress, whose strength I could not resist, laid ' hold of me by each arm, and began to force. ' me through the crowd.

- I now resigneal myself to my fate, not - doubting but that they intended to dispatch me, ' and then satiate their vengeance with my - blood, as I found they were hurrying me to-

- wards a retired swamp that lay at some dis-

- tance. But before we had got many yärds, an

- English gentleman of some distinction, as I

- could discover by his breeches, the only cov.

' ering he had on, which were of fine scarlet - velvet, rushed close by us, One of the In- dians instantiy relinquished his hold, and ' springing on this new object, endeavored to 


\section{HISTORY OF VERMONT. 395}

Iy probablo uat now re. e, was re. is sprung at arated, and ons I could hen I found fected their hazardous y way thro' inner possiished since, composure step for my eing at that rs I passed :apons ; till e most sav. hy their resist, laid gan to force.

fate, not ispatch me, with my ing me tosome disy yärds, an iction, as I e only cov. fine scarlet of the In. hold, and eavored to
' seize him as his prey ; but the gentleman be' ing strong, threw him on the ground, and - would probably have got awar, had not he ' who held my other arm, quitted me to assist ' his brother. I seized the opportunity, and ' hastened away to join another party of Englis': ' troops that were yet unbroken, and stood in a. - body at some distance. But before I hid ?

' ken many steps, I hastily cast my eye tow's? ' the gentleman, and saw the Indian's tonir.t. ' gash into his back and heard him utter:

- groan ; this added both to my speed anci $1 . .$. 'peration.

' I had left this shocking scene but a jow ' yards, when a fine boy about twelve years of ' age, that had hitherto escaped, came up to me ' and begged that I would let lim lay hold of ' me, so that he might stand some chance of ' getting out of the hands of the savages. I told ' him that I would give him every assistance in ' my power, and to this purpose bid him lay - hold ; but in a few moments he was torn from ' my side, and by his shrieks I judge was soon - demolished. I could not help forgetting my ' own cares for a minute, to lament the fate of ' so young a sufferer; but it was utterly im'possible for me to take any methods to pre. 'vent it.

- I now got once more into the midst of ' friends, but we were unable to afford each oth. ' er any succour. As this was the division that ' had advanced the farthest from the fort, I tho' ' there might be a possibility (though but a bare - one) of my forcing my way through the outer ' ranks of the Indians, and getting to a neigh. 
' boring rood, which I perceived at some dis. " tance. I was still en'couraged to hope by the " almost miraculous preservation I had already - expurienced. Nor were my hopes in vain, or ' the efforts I made ineffectual. Suffice it to " say, that I reached the wood; but by the time "I had penetrated a little way into it, my breath

"was so exhausted that I threw myself into a " brake; and lay for some minutes apparently at " the last gasp. At length I recovered the pow. " er of respiration ; but ny appichensions re. - turued with all thcir former force, when I saw ' several savares pass by, probably in pursuit " of mic, at no vely great distance. In this sit- uation I knew not whether it was better to - proceed, or cndcavor to conceal myself where ' I lay, till night came on ; fearing, however, " that they would return the same way, I thought ' it most prudent to get further from the dread. - ful scene of my distresses. Accordingly, ' striking into another part of the wood, I has" tened on as fast as the briars and the loss of " one of my shoes would permit me ; and after " a slow progress of some hours, gained a hill ' that orcilooked the plain which I had just left, - from whence I could discern that the bloody ' storm still raged with unabated fury.

' Bur not to tire my readers, I shall only "add, that after passing three days without sub. - istence, and enduring tlie severity of the cold ' dews for thice nights, I at length reached fort " Edward ; where with proper care my body

- soon recovered its wonted strength, and my $\checkmark$ mind, ats far as the recollection of the late mol. - nichoiy crents would permit, its usual com. postict. 


\section{HISTORY OF VERMONT.}

- IT was computed that fifteen hundred per' sons were killed or made prisoners by these ' savages during this fatal day. Many of the ' latter were carried off by them and never re'turned. A few, through favorable accidents, ' found their way back to their native country, ' after having experienced a long and severe ' captivity.

' $\mathbf{T}_{\text {н }}$ b brave colonel Monroe had hastened a' way, soon after the confusion began, to the ' French camp to endeavor to procure the guard "agreed on by the stipulation; but his application ' proving ineffectual, he remained there till gen' eral Webb sent a party of troops to demand ' and protect him back to fort Edward." *

Try e ciny after this awful tragedy had been acted, major Putnam was dispatched with his rangers to watch the motions of the enemy. He came to the shore of lake George when the rear of the enemy was scarcely beyond the reach of musquet shot. The prospect was awful and horrid in the highest degree: The fort was demolished, the barracks, outhouses and buildings; were one heap of ruins ; the cannon, stores, boats and vessels, were carried away. The fires were still burning; the smoke and stench offensive and suffocating: Innumerable fragments of human sculls and bones, and carcases half consumed, were still frying and broiling in the decaying fires. Dead bodies mangled with scalping knives and tomahaviks, in all the wantonness of Indian fierceness and barbarity, were every where to be seen. More

- Carrer'، Tuarals, p. 881-186.

V.OL. I. A 3 
than one hundred women inhumanly stabbed and butchered, lay riaked cn the ground with their bowels torn out, and still weltering in their gore. In some, their throats were cut ; in oth. ers, their brains were oozing out, where the hatchet had cleaved their heads; and in others, the hair and the scalp had been torn off, and nothing was to be seen but the bloody skull. Devastation, barbarity, and horror, every where appeared; and presented a spectacle too diabolical and awful to be endured or described.*

IT is difficult to believe that the French off. cers had contemplated any such proceedings. As soon as the capitulation was signed, St. Luke le Corne, who had much influence among the Indians, sent for colonel Frye, who commanded a part of the Massachusetts troops. Frye had been in Nova Scotia under Winslow, in 1755, and had protected several of the French inhabitants from the fury of the Indians. Le Corne told him that he had observed, and that he well remembered the humanity, that he had shown to his countrymen in Nova Scotia; that he should embrace the piesent opportunity to express his gratitude, and reward his humanity; and that neither he, nor any of the Massachusetts troops, shouli receive any insult or injury from any of the Indian tribes. Frye believed in Le Corne's declarations; but during the whole outrage and massacre, Le Corne neither appeared limself, nor sent iny party to afford protection, or to moderate the Indian vengeance. $\uparrow$

* Putnam's Life, p. 39.

+ Col. Joseph Frye's relatioa to the Anthor. 
inly stabbed ground with ering in their cut ; in oth, where the ad in others, torn off, and loody skull. every where cle too diadescribed.* French off. proceedings. signed, St. uence among , who comtroops. Frye Winslow, in the French Indians. Le ved, and that , that he had Scotia ; that pportunity to s humanity; e Massachuult or injury rye beliered during the forne neither rty to afford Indian ven-
How far it was in Montcalm's power to have prevented this scene of carnage and barbarity, it may not be easy for us to determine. The marquis himself seems to have been a man of humanity and politeness ; and it is scarcely possible but that a brave and generous soldier must have bcheld such scenes of outrage, with clisgust and abhorrence. Nor was it possible but that he must have been aware of the dangerous consequences of violating the public faith, or how much it would effect his own honor and reputation, to have his prisoners surrendered into his power under a solemn treaty of protection, murdered in his presence, and by a part of his own army. The most that candor can say upon this subject, will be, that the European generals were not able to restrain the fierceness and barbarity of their Indian allies; that the savages served with them, not unaier the promise or expectation of wages, but solely with a view of revenge and plunder ; that they claimed these as their right, practice, and custom, from time immemorial ; and did not admit that any of the European commanders had any right to restrain, or to interpose in their customs and usages of treating their prisoners. But when ail has been said that candor can suggest, or that the customs and habits of the savages can justify or excuse, still it will occur, that the garrison had a promise of protection from Montcalm ; that they had surrendered under the faith of this protection; that all the laws of humanity and war required the capitulation to have leen held sacred and inviolate; that it was in his power to have protected the garrison by a 
guard of French troops; but that rather than disgust the Indians, he broke every part of the capitulation, violated his own honor, and de. stroyed the faith of any future promises, by suf. fering a seduced and defenceleśs garrison to be plundered and butchered, in the presence and view of his whole army.

Expecting to be attacked himself, general Webb had sent on expresses to the provinces for reinforcements. They were every where raised and sent on with great expedition; but as Montcalm had returned to 'Ticonderoga, the reinforcements were kept in service but a few weeks : And thus ended the third canipaign in America.

WITI an army of more than twenty thousand regular troops, a great number of provincial for. ces, and a naval power of more than twenty ships of the line, nothing had succeeded. All attempts against the enemy had failed; and the French, with a much inferior force, had every where gained the advantage. The British ministry did not appear to be sufficiently acquainted. with the state of things in America, to form a judicious plan for a campaign in the colonies: nor did the British generals appear to be enough informed of the nature of a French and Indian war, to carry it on with success. Loudon had returned to New York, and was engaged about the civil aftairs of the colonies. Massachusetts had been the most active of all the provinces in raising men and money for the war. In November, Loudon took offence at some of the proceedings of their asscmbly ; which he construed as implying that an act of their assembl! 


\section{HISTORY OF VERMONT. 401}

rather than

part of the or, and de. ises, by sufarrison to be resence and

self, general e provinces very where dition ; but hderoga, the e but a few canipaign in

ty thousand ovincial for. han twenty ceded. Ail :d ; and the had every British minacquainted. , to form a e colonies: a be enough and Indian Loudon had raged about issachusetts rovinces in r. In Noome of the ch he con. ir assembly was necessary to carry into effect an act of the British Parliament for quartcring their troops. In an hour of resentment he wrote to governor Pownall; November 15, 1757. "I have order' $c$ d the messenger to wait but forty eight hours ' in Boston ; and if, upon his return, I find ' things not settled, I will instantly order into - Boston the three battalions from New York, - Long Island, and Connecticut, and if more are ' wanted, I have two in the Jersies at hand, be" sides three in Pennsylvania." The return not being agreeable to his lordship's feeling, he gave orders that the troops should masch. The. matter,being properly explained, his lordship wrote again, December 26th, "As I can now ' depend upon the assembly's making the point ' of quarters easy in all time coming, I have "countermanded the march of the troops." While Loudon was engaged in such exploits, Webb was safe at fort Edward ; towards which the enemy could not approach with much force, during the winter. The French only were in a state of activity and enjoyment : Instead of proving distressing or mortifying to them, the war had served to enlarge the boundaries of Canada, to fill it with prisoners and scalps, with private plunder, with public stores, arms, provisions, and other trophies of triumph.

1758. Tн E misfortunes and disgraces which had attended the war for three campaigns had been the occasion of ridicule and triumph to the French, and had spread the spirit of jealousy and discontent in every part of Great Britain?

*ordon's IHist. American War, Vol. I. 1. 95. 
and her American colonics. The people in both countries became loud and clamorous in their complaints and censures of the British ministry and generals ; and it was become ap. parent that the public confidence was withdrawn from the men who had hitherto directed the affairs of the war. The British nation was alarm. ed with the prospect, and the British court found it necessary to change her councils. A new ministry was formed, and the celcbrated WILLiall PItT was appointed one of the secretaries of state. Public confidence secmed to rise from the grave, the national spirit was rpused up, and the people every where expecting much from the spirit and virtues, were eager and active to support the measures of their farorite patriot and statesman. The reduction of the French, and the increasing prosperity of the English colonies, had been the avowed ob. jects in all his speeches and proposals; the universal expectation was, that he would now employ the national force in energetic and active services.

THE plan which the new minister formed for the ensuing oampaign in America, was to attack the French in various parts of the country at the same time. 'Twelve thousand men were destined to attempr the conquest of Louisbourg, on the lsland of Cape Breton. Sixteen or seventeen thousand men to cross lake George, and make a vigorous attempt upen the forts at $\mathrm{T}$. conderoga and Crown Point. Eight thousand were to proceed to fort $\mathrm{Du}$ Quesne on the Ohio, and invade the French forts and settlements in that part of the country. And all the 
people in amorous in the British become ap. withdrawn sted the afwas alarm. itish court uncils. A culcbrated of the secsecmed to spirit was re expect. $s$, were eaes of their reduction osperity of vowed obosals ; the vould now ic and ac-

formed for was to athe country men were puisbourg, en or seveorge, and prts at $\mathrm{T}$ : thousand e on the ind settlenid all the
American colonies were called upon, to raise as many troops, and to make all the exertions in their power.

$T$ if 2 reduction of Louisbourg and the island of Cape Breton being an object of immediate consideration, was undertaken with much spirit and dispatch. Lord Loudon had octurned to England, and was no longer employed in the affairs of the colonies. The expedition was pui under the command of major general Amherst, assisted by the brigadier generals, Wol.e, Whitmore, and Lawrence. The naval force was put under the command of admiral Boscawen, who sailed early in the spring with the fleet and forces for America. The whole armament collected at Halifaxin Nova Scotia, and consisted of one hundred and fifty seven sail. On May the twenty cighth the fleet sailed from Halifax; and on the second of June, part of the transports anchored in Gabarous bay, about seven miles to the westward of Louisbourg. On the eighth the troops effected their landing under the command of the able and spirited gene. ral Wolfe, and in a few days compleatly invested the city.

Louis B Orng had a garrison of two thousand five hundred regular troops, three hundred militia, and was afterwards reinforced by three hundred and fifty Canadians, including threescore Indians. 'The harbor was secured by six ships of the line, and five frigates; the whole under the command of the cheveleur Drucour. With much expence and labor, the governor had been preparing for a siege. Amherst made bis appreaches with great circumspection, 
securing his camp with redoubts and epaulments from the insults of the Canadians and Indians ; of whom he was informed there were very considerable bodies on the island watching for an opportunity to surprise some part of his camp. Wolfe conducted witi all that fire, impetuosity and discretion, with which his name and character have since been distinguished and immortalised. Under the dircetion of these excellent commanders the siege was carried on with so much caution and vigor that the. French ships of war were soon destroyed, and the garrison ciliged to surrender as prisoners of war on the twenty sixth of July. Lord Rollo soon after effected the reduction of the island St. John, which lies in the gulph of St. Lawrence. This island contained above four thousand inhabitants and abounded in black cattle and corn.

WiIn E Amherst was engaged in the expedi. tion against Louisbourg, major general $\Lambda$ bercrombie was undertaking the reduction of $\mathrm{T} i$ conderoga. Upon the departure of the carl of Loudon to England, the chicf command of the troops in America had devolved upon him; and he was directed to open a passage to Canada by reducing the French forts on lake Champlain. In the beginning of July he had got every thing in readines's to proceed: His forces amounted to nearly seven thousand regular troops, and ten thousand provincials. These; with a fine train of artillery, military stores, and provisions, were cmbarked on lake George, on board of nine bundred batteaux, and one hundred and thirty five whale boats; several picces of cannon were norrnted on fafts to cover their landing. The 
paulments Indians; very corring for an his campt. npetuosity nd characimmortalexcellent n with so ch ships of garrisoil var on the ioon after St. John, ce. This nhabitants

te expedi. ral $\Lambda$ beron of $\mathrm{Ti}$. he earl of ind of the him ; and Canada by hamplain. ery thing amounted , and ten fine train ons, were of nine and thirty non were g. The wext day the troops landed at the place of destination, without any opposition.

$T_{\text {HE }}$ English troops having landed were immediately formed into three columns, and moved forward toward the er.....y. The advanced party of the French army consisted of a battalion, which lay encamped behind a breast work of logs. This party, upon the approach of the English army, set fire to their breast work and tents, and abandoned them with precipitation. The English forces continued to advance in regular order, but their route lay through a thick wood, which would not admit of a regular progression by columns; and made it impossible for the troops to preserve their designed arrangement and order. The guides were much embarrissed, and the columns, by crowding upon one another, were in some measure disordered and broken.

LORD How $\mathrm{E}$ was in the front of the centro column, having major Putnam with him. The advanced body of the enemy amounting to about five luundred, who had retreated from the breast work, began a skirmish with the English troops on the left. Attentive to every circumstance that concerned the troops, Howe cnquired of Putnam, "what the firing mcant." "I kno wnot, said Putnam, but with your lordship's leave, I will go and see." "I will go with you," rejoined the gallant young nobleman. Putnam endcavored to dissuade him, and made this remark, "My Lord, if I am killed, the loss of my life will be of little consequence, but the preservation of yours is of infinite importance to the army." His lordship made this reply, vol. 1 B 3 
"Putnam, your life is as dear to you as mine is to me, I am determined to go." One hun. dred of the van under Putnam, immediately filed off with lord Howe. They soon fell in with the left flank of the enemy's advanced par. ty, and their first fire proved fatal to his lordship. Thus fell this gallant young nobleman, unspeakably regretted by all who knew him.

HIs manners and his virtues had made him the idol of the army. From his first arrival in America, he had accommodated himself and his regiment to the peculiar nature of the service. He cut his hair short, fashioned his clothing, and divested himself and his regiment of all superfluous baggage, that they might not be entangled by the woods, or be casily captur. ed by the Indians. "Exenuplary to the officer, a friend to the soldier, the model of discipline, he had not failed to encounter every hardship and hazard."* Such were his virtues and ser. vices that the province of Massachusetts, mov. ed by gratitude erected a monument in West. minster Abbey, as a testimony of the regard and affection which their officers and soldiers bore to his memory. $t$

Nor was his death without its infuence and use. Putnam and the troops which saw him fall, moved on with an animated determination to avenge his death; they cut their way ob. liquely through the enemy's ranks, and being joined by some other parties, charged so furi. ously in the rear, that nearly thrce hundred of the enemy were killed on the spot, and one

* Putnam's Life, p. 52.

t Appeudix, Ne. Vil. 


\section{HISTORY OF VERMONT. 407}

ou as nine

One hun. mmediately ioon fell in vanced parto his lord. nobleman, new him. 1 made him st arrival in himself and of the sershioned his is regiment y might not sily captur. o the officer, of discipline, y hardship les and ser. usetts, mov. nt in West. the regard and soldiers

fluence and ch saw him termination ir way ob. and being ged so furihundred of pt, and one hundred and forty eight were made prisoners. In the mean time the English columns, having lost their order in the wood, became embarrassed and perplexed ; and the tronps were in danger, and in a few instances had alreidy fircel on each other. The general, perceiving their latisuc and disorder, thought it advisable not to sperd the night in such a situation, but to march them back to the place where they had lancled.

THE next day colonel Bradstreet was sent to take possession of the saw mills. With a de. tachment of one reginent of regular troops, six companies of the royal Americans, the batteall men, and a body of rangers, he took possession of the post without opposition. 'This post being secured, the general again advanced his ar. my against the enemy

THE fort at Ticonderoga was in a situation favoratle for defence. On three sides, the fortress was surrounded with water ; on the fourth, nature had secured it with a dangerous mo rass, which could not be passed without much difli. culty. The fort was secured with a breast woork eight feet high, planted with artillery. The ground before it was covered with an abastis, or large trees cut and disposed for defence. Much labor had been employed to sharpen, in. terweare, and project their branches, so that they could not be passed or removed without difficulty and time. 'The prisoners which had been talien, informed general Abercrombie, that the force of the enemy consisted of cight battalions, with a body of Canadians and Indians, amounting in the whole to six thousand men. That another borly of troops of three thousand 
men had been detached under the command of M. de Levy, to make a diversion by the way of Mohawk river, and to invade the English set. tlements in that quarter; but that these troops upon the intelligence of Abercrombic's approach had been recalled, and directed to join the force at Ticonderoga : And that the troops already there, were encamped before the fort, and constintly at work in making formidable entrench. ments, which they meant to pursue till the rein. forcements should arrive.

ABERCROMBIE wished if possible to take decisive measures to reduce the garrison before the arrival of $\mathrm{M}$. de Levy with his troops, or any other succours should be thrown into the place. It was found that it would be the work of time, to reduce the place by a regular siege; that it could not be done, till they had overcome the difficulties of dragging their battering cannon over grounds almost impassable ; till they could make approaches, and erect batterics is places covered with thick woods; that the trees must be cut away, roads be opened and many works crected, before they could invest the place. To gain further information, Abcrcrombic sent his engincer carly the next morning to cross the river opposite to the fort and reconnoitre the enemy's situation. 'The engincer, upon his re. turn, reported that the entrenchments of the en. eny were unfinished; and that it was his opin. ion, that the place might be attempted with musquetry, with a good prospect of success. Abercrombie depended on the intelligence of his engineer, and concluded to adopt his advice. Having determined upon the measure, the 
fominand of the way of English set. these troops e's approach in the force ops already $r$, and conle entrenchtill the rein.

ble to take rison befure troops, or wn into the be the work gular siege ; ad overcome ttering canle ; till they batterics in hat the trees $I$ and many st the place. rombie sent to cross the moitre the upon his re. ts of the en. as his opinmpted with of success. elligence of this advice. neasure, the disposition was made for the attack, and guards placed at the saw mill, and landing place. 'The army was then put in motion, aud it marched on to the assault in regular order, and with an undaunted resolution. The enemy instantly began their elefence by a well directed and terrible fire from their artillery. The British sustained the shock without being staggered, and still advanced till they were stopped and entangled by the abattis. Their next attempt was to cut their way through these obstacles with their swords ; but this, they found impossible to effect, with such weapons. Still they persevered in attempting to force a passage, and some of them made their way through all oppo. sition till they mounted the parapet. For more than four hours the troops continued this method of assault, without being able to open a passage to the entrenchment. All this while they were exposed to a heavy and fatal fire from the cannon and musquetry of the eneniy ; who were so well covered by their works, as to be exposed to little danger while they kept up an incessant and well directed fire upon their assailants. The general had seen his ticoops continuing their attack upon the enemy for several hours without any prospect of success, in the midst of a most fatal fire; he now judged it necessary to order a retreat, and the army returned to their former camp without being pursued or molested. by the enemy.

THE loss sustained by the enemy in this affair was not great ; and most of those who had fallen were shot through the head, every other part of the body being defended and concealed 


\section{by their works. The loss in the English army amounted to cighteen hundred men, killed and wounded; and two thousand and five hu: rlred stand of arms were taken by the French,*:}

- Geperal Abercrombie's account of his expedition againtt Ticondernags.

" Camp at Lake George, July' $12,1758$.

THE embarkation of the artillery, fores and provifions being com. pleated on the evening of the $4^{\text {th }}$ inflaul; next monrning at break of day. ihe tents were fruck, and all the tronps, amounting to 6367 regulars, offieers, light infenty, and rangers included, and 9024 provincials, including officers and batteau msn, embatked in about $9^{\text {jo }}$ battcanx, and 135 whale boats, the artillery to cover our landing, being mounted on rafte.

At five in the evening, reached Sabbath Day Points $(25$ miles down the Lake) where we halted till ten, then got under way again, and proceedect wo the landing place (a cove leading in the French advanced guard) which we reached early next morning, the $6+h$.

Upon our arrival, fent sus a reconnoitring party; and having met with on oppofition, landed the troops, formed them in lour columns, regulars in the centre, and provincials on the Hanks, arid marched tuward the encmy's advanced guard, compoled of one battalion, poited on a logged eamp, which, upon our approach they Heferted, freft fettinif fire to their tents, and deltsoying every thing they could; but as their retrcat was very precipitate, they lelt feveral things behind, which they had not tine cicher to burn or carr: off. In this camp we likewifo lound one priforer and a dead man.

The army in the foregoing order continued their march through the woud on the weft hide, with a dcfign in invelt ricnndernga, but the wood Deing very thick, impalfable with any regularify to fuch a body of men, and the guides unfkilful, the troops werc bewildered, and ti:e colurnus broke, falling in oue upon anoilor.

Lord Howe, at the head of the right centre column, fupported by the Jight Intantry, being advanced, fell in with a Fiench party, fuppofed to confift of abusut 400 regulars, and a tew Indiaris, who had itiewife loik themfelves in the retreat from the advanced piard; of ihefe our flankers killed a great many, and took 118 prifonc:s, among whan were five ottreess and three cadets.

But this funall fuccefs colt us very ciear, not as to the lols of numbers fur we had ouly two niffecrs kilimd, but as in confequence, his lordhipp being the firlt inan that fell in this fkirnilh; and as he was, very de?erver. ty, univcifally beloved and refpedted throughout the whole army, it is caly in conceive the grief and coniternation his unlimely fall occafiunce ; fint my pare, I cannot belp owning that I felt it moft heaviiy, and ainent hirs as fincercly.

The 7 th, the troops being greatly fa' $i_{\bar{k}}$ ued, by liaving been one wlole right on the wirer, the following day cotiftailly on fot, and the next da? ender arms, added to their being in wait of provition, having dropperl what they had brought with them, in oider tn lighten themfelves, it was thought advifeable to return to the landing place, whiois we accordingly did apout aight that morsing. 
glish army killed and e hu:tred French. *:

A Ticondernos. 1) 12,1758 . ons being com. $t$ break of day. 7 regulars, offi. cials, including and $I_{35}$ whaic rafts.

piles down the and proceedect. ( guard) which

ving met with umis, rcrulars sward the encon a logired lif fire to their treat was vety int tinse eirhrr priforer and a

through the but the wood body of inell, - ti:e culurnus

oorted by the , luppored co dikewile lolt our nankers were five of-

8 of numbers his Iordhip ery de?erver. nv, it is eaify afiunce ; fine Sainent his en one whole the next day ing dropperl felves, it was accortingly
Every corps which had been engaged on this unfortunate occasion, had behaved with a steady coolness and intrepidity ; and suffered very severely. But the heaviest loss fell on the regiment of Highlanders, commanded by lord John Murray ; one half of the privates, and twenty five officers of this regiment were either slain upon the spot or desperately wounded.* So heavy and severe a loss seems to have determined the English general to withdraw his army

About elevea in the forenoon, fent off Licut. Col. Braditreet, with the $44^{\text {th }}$ regiment, fix companies of the firt battalion of the royal Americans. the batteau men, and a body of rangers and provincials, to take poffefinon of the Saw Mill, within two miles of Ticonderoga, which he foon effecked: as the enemy who wcre pofted there, after deftroying the mill and breaks ing down their bridge, had retired foine time before.

Licutenant Colonel Bradfreet baving laid another bridge acrofs, and having fent me noticc of inis being in poffeffion of that ground, I accordingly marched thither with the troops, and we took up our quarters therd that night.

The prifoners we had taken being unanimous in their reports, that the reach had cight battalions, fome Canadians and colony troops, in all about 600, encamped before their fort, who were intreuching themfelves, and throwing up a breal work, and that they expelted a reinforcement of g000 Canadians, befides Indians, who had been detached under the command of Monfieur de Levy, to make a diverfion on the fide of the Mohawk river; but upon intelligence of our preparations and near approach, had been repeatedly recalled, and was hourly expceted; it was thought mult advifable to lole no time in making the attack; wherefore early in the morning of the $8: h, I$ fent $M r$. Clerk, the engineer, acrols the river on the oppofite fide of the fort, in order to reconnoitre the eriemy's iatreachments.

Upon his return, and favourable report of the pra\&icability of carrying thofe works, if attacked before they were finilhed, it was agreed to ftorm them that very day: Accordingly the rangers, light infantry and the right wing of Provincials, were ordered immediately to march and poft themfelves in a line, out of cannon thot of the intrenchments; the right extends ing to Lake George, and the left to Lake Champlain, in order that the regular troops, deftined for the attack of the intreachments, might form on their rear.

The Piquets were to begin the actack, fußained by the grensdiers, and by the battalions : the whole were ordered to march up brilkly, ruth upon the enemy's fre, and not give theirs, until they were willin the enemy's brealt work.

- Smollet's I Hist. of Epgland, Vol, 3, p. 28\$: 
from this scene of carnage and havoc; they reembarked in lheir batteaux, and returned to their camp at lake George with such expedition, that they regained their former situation the evening after the fatal action.

IF general Abercrombie was not blameable, he was at least extremely unfortunate in this fatal affair. The information and advice that he received from his engineer was greatly erroneous and faulty; and it should seem that a little enquiry would have been sufficient to convince the general, that the works at Ticonderoga could

After thefe orders iffued, the whole army, except what had been left at the landing place to cover and guard the batteaux and whale boats, and a Provincial regimeat at the Saw.Mill, were put in mntion, and advanced to Ticonderoga, where they unforturately found the intrenchments, not only much ftronger than had been reprefented, and the breaft work at lealt eight or nine feet bigh : but likewife the ground before it covered with felled trces, the branches pointed outwards, which fo fatigued and retarded the advancing of the troops, that ootwithtanding all their intrepidity and bravery, which I cannot toe much commend, we fuftained fo confiderable a lofs, without any profpelt of better fuccefs, that it was no longer prudent to remain before it; and it was thercfore judged neceffary, for the nrefervation of the remainder of fo many brave men, to prevent a total defeat, that we hould make the beft retreat pofrible: Accordingly, after feveral repeated attarks, which lafted upwards of four hours, under the moft difadvantageous circumftances, and with the lofs of $4_{4} 6_{4}$ regulars kilJed, 29 miffing, 1117 wounded ; and 87 Provincials killed, 8 miffing, and 239 wounded, officers of bnth included, I retired to the camp we occupied the night before, with the broken remains of feveral corps, fending away all the wounded to the batteaux, about three miles diftance; and eariy the next morning we arrived there ourfelves, embarked, and reached this place the evenirig of the 9 th. Immediately after my return here, I fent the wounded officers and men that could be moved, to Fort Edward and Albany."

The French, in the account which they publifhed at Paris in Septem. ber, gave a very different but not a probable account of this rencounter. Their own force was flated to confift only of 2800 French, and 450 colony itoops, under the marquis de Montcalm; with 400 chofen men under the chevalior de LCvy, that had joined them only on the 7 th in the evening, The lois of the Englith is reprefenied at 4000 killed and wounded; that the Ficncli loft that day only $\mathbf{r}_{2}$ officers and $9^{2}$ foldiers, killed; and $24^{8}$ lo'viers wounded. Their lofs in the fkirmilh of the $6:$ h of July; is thus fia:sd, rapiain and $\&$ lieutenants killed; 1 captain and 3 lieutenants made priforers; and 18 \& Canadians killed or taken: $A$ ud that the Engli?h force confitted of 80,000 militia, and 6000 regular troops. 
oc ; they turned to xpedition, lation the

olameable, te in this ice that he ly erronehat a little convince oga could

had been left at le boats, and a ind advanced to ments, not only rk at leaft eight red with felled nd retarded the intrepidity and fo confiderable no longer pruceftary, for the vent a total de. cordingly, after urs, under the 64 regulars kil8 milfing, and pp we occupied fending away ; and eariy the ched this place tere, I fent the th Edward and

aris in Septem. bis rencounter. and $45^{\circ}$ colony men under the in the evening. rounded; that lled; and 248 f July, is thus d 3 lieutenants Aud that the roops. mot.be carried by a coup de main. Had he continued the assault, there can be no doubt, bit that he would have lost almost the whole of his army. If the assault was rash and precipitate, the retreat scems to bear the marks of unneecssiry intionidation and hurry ; for it is dificilt to conceive what danger there could have bicn, in commencing a regular siege with troops, who had discovered such courage and resolution as appeared in the assault. We ought however not to be very positive in passing our censures on men and incisures, where all the circumstances and motives are but imperfectly known. The censure of mankind almost always follows misfortune. Thus it proved in the present case; the attempt to carry the place by storm, was considered as a rasin and imprudent measure; and retreat was condemned as pusillanimous anc a ecessary.

Lu' WITHSTANDING his defeat and mortificaticin, Abcicrombie did not let the scason pass away winout furthe" attempts in favor of the colonies. Brigadier general Stanwix was sent with a considerable body of provincials, to crect a fort at the carrying place at Oncida; and thus secure a passage on the Mohawis and Onondago rivers to Oiswego. This business was properly cxecuted, and that important post secured; a nensure which proved greatiy beneficial in the ensuing campaigns.

Colonel Rradstret had projected an expedition against Cadaraqui, or fort Frontenac. This fort was situated on the noith side of the river St. Lavrence, just at the point where the river derives its origin at luke Ontario. A. vol. I. $\mathrm{C} 3$ 
gainst this fortress, Abercrombie dispatched Bradstrect with three thousand men, chicfly provincials. He marched his troops by land to the waters of late Ontario, and embarked thence in some sloops and betteaux provided for the purpose, and landed within a mile of fort Frontenac. The enemy hud no intelligence or ex. pectation of his approach, and were poorly prepared for defence. The garrison consisted of but one hundred and ten men, with a few In. dians ; and could do no otherwise than surrender at discretion. The fort itself was not of much strength ; but it was valuable on account of the immense quantity of military stores and merchandize, which it contained. Sixty pieces of cannon, sixtecn mortars, and a quantity of small arms werc found in the fort. What was more valuable, a large quantity of provisions was also captured; these had been deposited at $\mathrm{Ca}$ diraqui, for the use of their western garrisons, and Indian allies; to supply the French troops that were gone to the Ohio, against brigadier general Forbes; and for the subsistence of $\mathbf{M}$. de Levy and his troops, on their expedition on the Mohawk river. In addition to all the military stores and provisions there was also an in. mense quantity of merchandize, for the purpose of trade with the Indians, and to supply their own forts and settlements. Besides the forts and stores, Bradstreet made himself master of all the evemy's shipping on the lakes; these amointed to nine armed vesscls, some of which carricd eighteen gruns. Having carried the fort without any loss of men, Bradstreet, in conformity to the general's orders, destroyed the 
disprtched $n$, chicfly by land to ed thence ed for the fort Fron. ice or ex. oorly prensisted of a few In. in surrenas not of n account tores and rty pieces bantity of What was isions was ed at Cagarrisons, ch troops brig:adier ice of $\mathbf{M}$. dition on the miliso an in. purpose ply their the forts naster of these aof which the fort confor:yed the works, with all the magrazines and stores; and immediately returned with his men to Oswego, taking with him two of the enemy's vesscls.*

Noтнгn had yet been done upon the likes, during the whole course of the war, which had so much affected the French interest as this $\mathrm{cx}$ ploit of colonel Bradstreet at Cadaraqui. Fort Frontenac, by its situation, had the entire command of the origin of the river St. Lawrence. It was the grand magnzine of military stores and provisions, for all their western posts and settlements, and for their Indian allies ; it comminded the pussage into all the western lakes, and was the grand emporium, where all the savage nations collected to transact their business of tracke, and to consuit with the French on the afliurs of war. The unexpected and total destruction of this place not only alarmed and sur. prised the French, but it carried dismay and terror to their Indian allics; who had never seen such a sudden and extensive destruction, carried - Colonel Bradatreet's Letter to (Ieneral Amberf, on the reduction of
Fort Frontenac.

Oswego, Auguat 31, 1758.

$I$ landed with the tronps within a mile of fort Frontenac without opposition, the 25 th. The garricon surreadered prisoners of war the $2 ; \mathrm{th}$, between 7 and 8 in the morning - It was a square fort of 100 yasds, the exterior side, and had in it 110 rien, some women. children, and Indians, 60 pieces of cannon, (half of which were nownted) sizteen small mortars, with an immeme quentity of provisions and goods, to be sent to the troops gone to oppese Brig. Gen. Forbse, their vestern garrisons, Indians, and to support the army under the command of $\mathrm{M}$. Lev serprise againot the Nohawk river, valued by the French at 800,200 livres. We have likewise taken 9 vessels from 8 to 18 guns, which are all they have upon the lake, $t w n$ of which 1 have brought here; one richly laden; and the rest and the provisions i hare lumit and distruyed, together with the fort, artillery, stores, \&c. agreeable to your excellency's instructions, should I sueceed. The garrison ade no scruple of aying, that their troops to the southward and western garrisone will sufer greatly, if not entirely star ve, for want of the provisiong and ressels we have deatroyed, as they have not any left to bring them home from Niagara. The terms on which the garrison surrendered were pricooers of $r a r$, until exchanged for equal numbers and rank. 
with such secrecy and dispatch, into the Frencir country.

THE success of Bradstrect at Cadaraqui, was not without its effect on the feelings and movements of the Indians, on the Ohio. In the begimning of July, brigadier general Forbes began his murch from Philidelphia, for fort $\mathrm{Du}$ Quesie. The fort stood on the conflucnce of the Monongahala with the Onio river. With incredible dif. ficulties, through a vist tract of country, but little knuwn, without roads, through inexplored mountains, morasses and woods, he had penetrated with the main bocly as far as Rays-town, at the distance of nincily mile's from fort $D u$ Quesne. He had sent on colonel Bouquet, wiin two thousund men, fifty miles further, to a place called Lyal Homing. Bouquet had de tached major Grint, at the head of eight hundred men, to rcionnoitre the fort and works at the Oinio. 'The eremy having intelligence of Giant's approach, sent forward a much larger bedy to intercept and surround him. A sercre action took place, which the Linglish supported with much courage and resolution for three hours, but at length were obijged to yield to the superior numbers of the cremy. "Plere hundred were killed or taken by the entmy, amorig whom was major Grant, the comnander ; he, and nincteen of his officcrs wcre caricd prison-, ers to fort Du Quesne; the remainder of his troops fought their way back to Bouquet. lorbes was not cismayed by this mortifying check, but stilladvanced with much caution, and a steady perseverance. 'The enemy having watched his motions, and observed the circum. 
Frencir

qui, was

1 movethe be. es began Quesne. Mononlible difbut little xplored d penes-town, Cort $D_{1}$ 3ouquet, her, to a hud de hundred is at the Gizint's body to action ed with hours, the supundred amorig ex; he, prisonof his ouquet. tifying atlition, having ircum-

spection and $y$ r, with which he made his advinecs, ct lod rot to abide the hazard

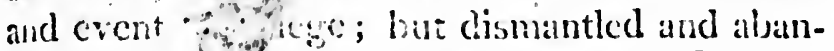
doned the fon, and retired clown the Ohio, to their settements on the Miississippi. On the twenty fourth of November they quitted the fort and the next diay it was taken pessession of by the British anky. Having repaircd the works, Forbes changed the "ne of the fort from lou Quesse, to tha of " sluurg, which ir still bears.*

Such were the events of the campaign of 1758. The expeditions against Louisbourg; Forts Frontenac and Dı Quesne, had compleatly succeeded. That against Ticonderoga had faled, The events of the campaign had been much in favor of the British interest ; and the ailvintages that had been obtsined over the French, gave flattering hopes and prospects that they might be pursued to much greater advantagge, in the course of another year. Gencral Anhlerst had now assumed the command, and the jublic expectation and feeling were ready to afford any assistance that he should ask. This general was already preparing for the next campaign. Soon aiter he had compleated the conquest of Cape Breton he receircd intclligence of the defeat of Abercronbie at Ticonderoga. Leaving a strong garrison at Louis. bourg, he embarked with six regiments, and landed at Boston. About the middle of September, he began his march for Albany, to join the troops at the lake ; to attempt any further enterprise, or to be in readiness for the next campaign, as the season and circumstances should permit.

- Smollet's Hist. England, Vol. 3, p. ags. 


\section{CHAPIER XIII.}

War. Pogress and ezents of the war in the ycars 1759 and' 1760. Plan of the campaign fir 1759. C'munest of Qucibec by gonerai Wolfe. Capture of Ticonlerose and Crotur Point by general Amherst. Expaditinn agatist tine Indian zillacese of St. Francois by major Rogers. Procectings on lake Chamiplain. Copture of Niagara liz Gucral Jolm. son. Reflections on the camparisn of 1759 . Measures of Vauririeul at Montrcal in 1760. Plan and proceedings of general dinherst. General Murray's defeat at Quctuec, and arrival at Montreal. Mavilund"s arival at the river St. Lawerence. Capitulation anl surender of Cinada to general Ainherst. Rigice. tions on the origin of these arers. Their ef: fecis on the morals, literature, population, sct. tlement and political state of the calonics.

1759. FROM the advantages that lact been already obtained over the French, the British ministry had been lead to expect that the compleat conquest of Cinala might be offected in another crmpaign; if their troops were employed so as to divide the enemy's for. ces, and to make their impressions on different parts of the country at the same time. In pursuance of this plan the British minister, PItT, had projected three cxpeditions against Cimada. General Wolfe, who hed been so much distinguished in the siege of Louisbours, was to proceed up the river St. Lawrence with a body of eight thousand meri, 23 soon as the river should 
be clear of ice, and lay sicge to Quebec, the eapital of Canada. General Amherst, who was conımander in chicf, was to procecd with an army of regulur trocps, and provincials, inonnting to twelve thousand; and attempt the recluction of Ticonderoga and Crown Point, and thence procecd through lake Champlain and the river Sore!, to the assistance of Wolfe. At the stme time brigadier general Prideaux with a third body, reinforeed by the Indians under the inifuence and conmand of sir William Johnson, m:s to invest the French fort at Niagura, and endeavor to redace that important foriress. It was concluded, that while all these forces were maling their attacks in different directions, ther wonld all serve to assist each other ; and at t: same time to divide the forces, and embarrass thie councils of the enemy.

THE plin itself was marked with the encrgy and boldness of the minister's genius. 'I he navigation of the river St. Lawrence had ever been viewed as very difficult and dangerous for a flect. The city of Quebec was strongly fortified by nature and art, formidable on account of the number and bravery of its inhabitants, and in a situation in which it could not be much injured by a Acet, or approached but by a strong army by land. The marquis de Montcalm was a general of much courare, activity, and experience; aleeady famous for his exploits, and success agninst the English. This officer had taken his situation between Quebce and Montreal, with an army of ten thousand men, consisting of regular troops, and well disciplined militia, reinfurced by a large number of armed 
Inclians. An army of reserve hovered round Montreal, the residence of $M$. de Vaudricul, the commander in chicf, and governor geneial of Canada. 'The fort at Niagara was wcll built, and fortified, and contained a garrison of six hundred men; the road to which, was long, enbarrassed, and unexplored. M. de Levy was also at the bead of a flying detachment, acquainted with the roods and passes, scouring the country in all directions; and augmented by new recruits, as occasions and circunstances required. And every preceding attcmpt had shern the dificulty, the danger, and the ill success, of an expedition agsainst Quebec, or Ticonderoga. Aware of these difficulties, but animated by the genius of Mr. Prt t, the British colonies and troops entered with energy and zeal upon measures, that rather bore the ap. pearance of danger and defcat, than of probabil. ity and success.

' ${ }_{\text {н }}$. most difficult part of the business, and the great object to which all the other operations of the campaign were subordinate, was the concuest of Quebec. This expedition had been committed to the care of major general Wolfe; a young officer of great enterprise and resolution, and of a superior military genitis. He was assisted by the brigadici generals, Monckton, Towrshend, and Muray ; officers of distinction, family, and much cxperience, though yet in early life. The squadron designed for the service was put under the command of Admirals Sanders and Holmes, who had on several occasions before simnalized their courage and conduct in the service of their country. The fect 


\section{HISTORY OF VERMON's'}

vered round

Vaudricul, rnor geneial is wcll built, ison $\mathrm{cl}^{\prime} \mathrm{six}$ , was long, I. de Levy chment, aces, scouring augmented rcumstances attcmpt had 1 the ill sucbec, or Tiies, but anithe British energy and ore the ap. of probabil.

usiness, and ther operaatc, wals the on had been ral Wolfe; I resolution, He was asMonckton, distinction, ugh yet in for the serf Admirals veral occa. pe and conThe ficet bailed from Englind about the middle of Februsy, and was in sight of Louistourg so early as the twenty first of April ; but the harbor being blocked up with ice, the flect bore away fo: Halif:x. As soon as the season would permit, the tronps were einbarked, and the fleet s:iled up the river St. Lanwrence, without meeting with any si those diffeulties or perils, which the:y hid been taught to expect. 'lowards the lutler end of Jume, the whole army was safely lardeil na the isic of Orleans, a little below Quebec, without any upposition, or having met with any dicaster.

Fros that time till the begrinning of September, yeral Wolte was strugryling without prospect of success, aysainst cvery kind of difficulty, iit an enemby's country, ag:ainst a city strongly fortiliced by nature and art, defended by an army more numerous than his own, commanded by Montcalm, whose militury talents and exploits had already rendered him fanous and formidabie to the British colosies and generals. In adclition to ouser diffutities he inad received a s.pere check, and lost above five hundred of his men, in an atiack which he made on the enemy at the balls of Wontmorenci. A fever and a tysentury were wasting his own strength, and for a time he becdine unable to attend to business.

Almost despriling of success, it was the opinion of his gencrat ofiters that there was a prospect of suececiling, uniess they could carry tee troops above the town, efiect a laning on the nortin shore, and bring the enemy, if possi. bic, to a gentral temprement. iv vile adojed vor. I. 153 
the opinion as a matter of extremity and neces. sity, and began the measures that were neces. sary to rarry it into exccution. After a series of the most uncommon difficulties, and judicious manceuvres, by the most dexterous address, and well concerted movements, he succeeded in if. fecting a landing near Sillary on the twellith of September, an hour after midhight. Wvole himself was with the first party that landed; and in an instant all was activity, enterprise, and expedition. The troops that were first landed, climbed up the bank and precipice, by the bushes and boughs of trees, with the most animated agility and resolution; they dispersed a captain's guard who were placed there to dl:fend the narrow path of ascent, and gained the summit without any further molest:ition from the enemy. Wolfe climbed up among the rest; and as soon is he had ascended the banks, dicw up his troops in order as fast as they arrived.

Montcalm was no sooner informed that the British troops had gained the heights of Abre. ham, which in a minner commanded the town in its weakest part, than he resulved to hazad a battle, and having collecteal his whole force from the side of Beaupert, began his mard withnut delay. Both armies were soon diawn up in order of battle, with tieir respective generals at their had. Wrife had pliced himscif on the right of the Englisis; Montcalm was un the left of the French army : Thiss the two generals, rivals worthy of cach otica, riet at the head of their respective armies, whe:e the con. fict was the most severe. About nime o'clock the French army advaneed to the charge in 
d neces. e noces. a serics idlicious css, and d ill cf. elth of

Wulfe anded ; erprise, re first pice, by he most spersed to dis. ned the froin e rest; s, dicis verl.

hat the Abra. town hiizat Porre main h dianwn e sieninscif vass on e two at the con. 'clock ge in

good order, and with vivacity; but with an irregular and not well directed fire. The British reserved their firc, till the enemy had approach. ed within forty yards of their line; then they poured in a teriible discharge, and kept up their fice with great deliberation and spirit. The contest for a few moments was dreadful ; both gencrals were determined to conquer or die; and their armies knew that on the event of an hoir, the late of Quebec depended. The French were unable to stand the impetuosity and fire of the liritish but for a short time ; and the battle soon terminated in the entire defeat and dispersion of the French army. Wolfe* and Montcalm* both fell at the head of their troops. and the British were left compleatly misters of the field, under brigadier gencral 'Townshend. Five liundred of the enemy were slain on the fie!d of battle, and about one thousand were mads prisonc: ; of the British, fifty men were killed, including nine ofticers, and as many as five hundied were woulded. Dispirited by the event, and disheartened by the loss of their able and fuvorite general iviontcalm, the French were in grralt constermation; and on September the eighteenth, De Ramsay, the officer on whom the command had devolved, signed articles of capitulation, and surrendered the troops and the city to admi:al Sanders and genes il Townshend. 'Thus was effected the conquest of the city of Quebec. For seventy years the English had becnattempting to reduce this place. The force that was sent against it in the year 1711, was 
fully equal to that which was now before it. The force that Wolfe commanded did not appear adequate to its reduction, and it was defended by the greatest general the French hild ever employed in Canada. The genius of Wolfe succeded in defeating their general, and sub. duing their apital.

WHIL these scenes were taking place at Qucbec, general Amherst had no information of the proceedings in that quarter, but was busily employed in pushing forward the expedition on lake Champlain. So many dificultie's occurred to retard the operations of his army in that unsettled part of the country, that the stimmer was already far advanced, before lie could pass lake George with his troops and artillery. Aware of the danger of surprise, and not unmindlul of the disaster that the British troops had sustained the year before, this able and judicious officer proceeded with the greatest circumspection ; leaving nothing to cliance, but making provision for every dificulty, or opposition, that could be foreseen. At length, in the latter end of July, he arrived in the vicinity of Ticonderoga; with his army of regulirs and provircials, in excellent order, and anply supplied with artillery, military stores, and provisions. The enemy hat watched all his motions, and been very attentive to find an opportunity to gain some advantege ; but they had not ventured to make any opposition to his troops, either when pas.. sing the dake, or effecting their landing. Having passed the lake and landed his stores, Amherst immediately began to make preparation to re. duce the fortress by a regular siege. At first 
efore it. I not apis def(nhad ever Wolfe ind sub.

place at ration of s busily ition on ccurred that unner was ass lake Aware ndful of ustained officer ection : proviin, that ter end onderocials, in ith arThe d been in some make en pas.. Having mherst to reAt first the enemy appeared to be resolute to hold their works, and to make a regular defence. They soon found that they had an able oflicer to oppose; that Amherst was cautious, resolute, well prepared for undertaking the siege, and not disposed to subject any thing to unnecessary risk or hazard. Despairing of success by any surprise, or extraordinary exertions, and having orders to retreat from place to place towards the centre of operations at Qucbee, ruther than to run the risk of diminishing the French force by surrendering prisoners of war, they sct about dismantling the fortifications; and having done some small injuries to the works, they abandoned them on the night of the twenty seventh of July, and repaired to Crown Point; leaving their heavy artillery, several sunken boats, and the works but little damaged though on fire. The same day, Aniherst took possession, and encamped within the French lines. This important acquisition was effected without much opposition or bloodshed : It was however marked with the loss of co!onel Roger 'Townshend, a very accomplished young officer, who was killed by a cannon ball as he was reconnoitering the fort. This young nobleman much resembled the gallant lord Howe, in the circumstances of birth, age, character, and uscful qualifications. He fell near the same spot, where that young hero was slain the year before.

Having succecled in his attempts against Ticonderoga, Amherst begiun to repair and enlarge the fortifications; and to prepare his battcaux and other vessels for an expedition against Crown Point. Scouting and ranging 
parties were constant!y cmployed, hovering in the neighborhood of that flace, and watching all the meastires and motions of the cuems: One of these parties reinred to the Einglish camp on August the first, and brought inteliigence that the Frestch had also abandoried Crum Point, and waie gone down the lake, without destroying the vorks. $\Lambda$ mherst de. tached a body of rangers to titie possession of the place; and on the fourth of August em. barked with his army, landed the same day, and pluced his troops within the enemy's works. Thus was efiected the rediction of Ticondero. ga and Crown Point. From the time of their first erection they had given sesurity to the in. roads of the enemy, afforded an asylum to the scalping parties that lad indested the frontiers of the whole countiy, and cost the British colonies inmense sums of money and many thousands of her citizens. They now till by the attack that Wolfe was making upon Quebec, and by the caution and resointion that Amiserst displayed in the aproneh and manauvres of his army. Wo soone: was their conquest con. pleated than Amherst superintended the works, strengtheneti and cnlarged the old ones, and began a new fort; meaning to make eficctual provision that the encmy should never agnin obtain possession of a pust, which had been so dangcrous and distiessing to the British provinces.

'He French troops, after the evacuation of Crown Point, retired to the Isle Aux Noix. This island is at tire north end of lake Champlain, about five leagues to the south of St. 


\section{HISTORY OF VERMONT.}

Johns ; and being situated in the midst of the sire: $1 m$, cfectually commands the passage into Cinard, in that quarter. At this plice, M. de Bar:iemagne had collected a force consisting of three bittalions, and five piquets of riguide trons and a body of Canadians and marines, amounting in the whole to three thonsind and five hundied men " provided with a numcrous artikity, and every requisite for defence. 'The lake was defended by four large vessels, nioninierl with caunon, and manned with picuets from diferent reginents ; under the commind of M. le Brass, a captain in the French navy, assistcd by M. de Rigel, and other sed oflicers. With thiss force, M. de Buriemagne cncamped and forificci at the Isle Aux Noix; meaning to make a stand against the British forces. And Amherst could not proceed dowr the lake till he h.d constructed a naval foree superior to that of the Fronch.**

IN the mean time it was thought best to make the enemy feel the force and resentment of the Luglisin colonies. The Indians had not as yet discontinued their attempts to disturb and dis. tress the frontiers. Among these tribes none had been more bioody and criel than that of St. Francois. Their village was situated on the scuth side of the river St. Lawrence, not far from Trois Rivieres. So early als the year 1703 , the frovemor of Canada had drawn cff a large number of Indians from Penolsscot, Norrige. wotk, Saco, Pigwacket, and uther parts of the castern country and settled them at Becancour and St. Francois. By uniting thein with the In-

\footnotetext{
' Smollct's Hist. England, Vol. 3, p. 470.
}

vacuation of Aux Noix. lake Chamsoutl of St. 
dians of Canada, he meant to precuire a force suf. ficient to protect their own frontiers; and to have always in reserve, a body of savages well acquainted with the English frontiers, and the most favourable times and places of carrying desolation among them.* 'The event justified his expectations. From none of the Indian tribes lad the provinces of New-Hampshire and Massachusetts suffered so much, as from the savages of this village and tribe. They made their incursions through the river St. Francois to lake Memphremagog, and from thence down Connecticut river to the English settlements; and had been much distinguished by the slaughter and destruction they had spread among the advanced settlements, by the number of their scalps and captives, and by the enormity of their cruelty and barbarity.

Major Rogers was appointed by general Amherst, to manage an cxcursion against this barbarous tribe and to carry the horrors of war into the midst of Canada. Rogers was from the province of New-Hampshire. He commanded a company so early as the year 1755 ; and had become so famous for the number, boldness and success of his enterprises, thit lord Loudon had set him at the head of the ranging companis, put him upon the British estabisiment and pay, till he rose to the rank of a major. Amilerst estecmed him a proper person to retaliate on in Indian village, some of the measures they hid so oiten acted, against the advanced Finglish forts and settlements. The orders which he

- ILutidiason's Hist. IILisacluastts, Vol. 2, p. 133. 
a force suf. prs; and to savages well $\mathrm{rs}$, and the of carrying ent justified the Indian mpshire and s from the They made St. Francois thence down settlements ; the slaugh. d among the ber of their mity of their

general Am. inst this bar. s of war into is from the commanded 55 ; and had boldness and Loudon had companies, uent and par, $\therefore$ Amierst tailiate on th res they hi:d ecd lingrish s whicin he gave to Rogers, were expressive of the character and views of the English general; and of the sentiments and feelings of the English colo. nies, with respect to the Indian cruelties. *

IN conformity to his orders, Rogers set out with two hundred men in batteaux, and proreeded down lake Champlain. On the fifth day after they left Crown Point, they met with a misfortune which diminished their numbers. Being encamped on the eastern shore of the lake, a keg of gun powder accicientally took fire, which in its explosion wounded a captain of the royal regiment, and several of the men. These were sent back to Crown Point, with some of the party to conduct them; by this event the party was reduced to one hundred and forty two men, officers included. With this reduced party, the major proceeded on the expedition, and in seven days landed at Missiscoe bay. Here he conccaled his boats among the bushes that hung over one of the streams, and left in them provisions sufficient to carry them back to Crown

- "Orders from Sir Jeffrey Amherst to major Rozero.

"You are this nighe ro set out with the detachment as ordered yesterday, - (viz. of two liundicd mon) and procecd to Missiscoc Bay, from

whence you will ration and attack tle enemy's scttlements on the south

- cirle of the river St. Iavrence, in such a manner as you shall judge

- most effectual to distizace the eneiny, and for the success and honor of

- his Majesty's arme.

"Renember the burbarities that have teen committed by the enemy's

- Indian scoundrels, on every occasion where they have had an opportunit

- of showing theirinfareors cruelties on tine King's subjects; which the

$\checkmark$ have done without mexc; inle your revenge; but do not forget that

'though thesc viitains have laaterdliy and proniscususly murdered the

s women and childrea of all crders, it is nyy o:ders that no women or chil-

- dren be isilied or burt.

"Whe you have executcd yourintencisl service, you will retum with - your datichmeat to camip, or to jcin me ir herever the army may be. - Yours, \&c. c jetragt AmurRst.

- Camp at Crown-Poin:, Septeniber 1:, $1 \% 59 . "$

Jimes' Military Dicionary-Aat. 'Troirevere.

$$
\text { VoL. I. Fis }
$$


Point. Two of his rangers were appointed to watch the boats, and to keep thenselves concealed till the party should return; or if the en. emy should discover the boats, to pursue the track of the party with the greatest speed, and give intelligence to the commander. The second evening after Rogers left the bay, the two trusty rangers overtook the party, and informed Rogers that four hundred French and Indians had discovered the boats and sent them away with fifty men; and that the remainder were in pursuit of the English party. Rogers kept the intelligence to himself; and ordered a licutenant, with eight men and these two rangers to proceed to Crown Point; inform the general of what had taken place, and request him to send provisions to Coos (now Newbury) on Connecticut river, by which he meant to rcturn.

Nothing now remained for liogers but to give up the expedition, or to outmarch his pur. suers. He determined on the litter, and pushed forward for St. Francois, with all the cxpedition that was possible. On the fourth of Oc. tober, at eight o'clock in the evening, he came v. ithin sight of the town. Ordering his men to halt and refresh themselves, he dressed himself in the Indian garb, and took with him two Indians who understood the language of the St. Francois tribe, and went to reconnoitre the town. He found the Indians engaged in a grand dance, and without any apprehension of danger. At two o'clock in the morning, he returned to his detachinent, and marched them to the distance of about five hundred yards from the town. About four o'clock the Indians broke up thcir 


\section{HISTORY OF VERMONT. 431}

ppointed to selves con. or if the cll. pursue the specd, and The seay, the two d informed and Indians them alviy inder were ogers kept red a licurangers to general of iim to send on Cono return. jers but to ch his pur. and push. the cxperth of Oc. $s$, he came his men to ad himsclf m two Inof the St. the town. and dance, nger. At ned to his c distance town. A. e up thcir dance and retired to rest. Rogers waitcd till they were aslecp, and at break of day, he posted his men in the most fivorable situation and made a general assault.* Compleatly surprized, the Indians were soon subducd. Some were killed in their houses, and of those who attemp. ted to fly, many were shot, or knocked on the head by those who were placed at the avenues. The Indian method of slaughter and destruction was put in practice on this occasion; and wherever the Indians were found, their men, women and children, were slain without distinction and without mercy. The ferocity of the procecelings were already exiremcly violent, but the prospects which appeared at the rising of the sun, could not but add new force and irritation to the feclings and passions of the assaitunts. As the iigit appeared, the scalps of several hundred of thcir countrymen were seen, suspended on poles, and waving in the air. These trophies of sarage cruelty and success could not fail to irritate to the lighest degree, the passions of the provincial soldiers; they meant to avenge the blood of their friends and rclations, and they spared no pains to make an cnd of the village, and of all that they could find of its inhabitants. The village contained three hundred of the cnemy ; two hundred. were killed on the spot, and twenty taken prisoners.

THE town appeared to have been in a very flourishing state. 'The houses were well furnished, and the church was handsomely adomed with plate; the whole village had been enriched

\footnotetext{
- Sima' Dicliogary, ibia
} 
by' the scalps, and plunder, taken from the English. Two hundred guineas were found in money, and a silver image weighing ten pounds ; besides a large quantity of wampum, closthing, and some prorisions.* Collecting the frovisions, and such articles as they could casily transpoit, they set fire to the town, and recluced it to ashes. At seven o'clock in the morning the aifair was complcatly over; Rogers then assembled his men, found that one was killed, and six slightly wounded. Having refreshed his men for one hour, the major made no further delay ; but sct out on his return, with the addi. tion of five linglish captives whom he liad re. taken; leaving the inhabitants slain, and the village reduced to ashes. $\uparrow$

'To avoid his pursuers, Rogers now took a different route, and marched up St. Frunccis river ; meaning to have his men collect, and rendezvous at Coos, on Connecticut river. On their march they were harrassed by sóme of the enemy, and several times attacked in the rar, In these rencounters they lost seven of their men, till Rogers, favored by the dusk of the evening formed an ambuscade upon his own track, and fell upon the encmy where they least expected it; by this stroke, lue put an cind to any further annoyance from the enemy. For about ten days the detachment kept togethei, till they had passed the eastern side of lake Menphremagog. It was then thought best to scatter into smaller partics, and make the best of their way to some of the English settlements,

- Belknap's Hist. New Hanpohire, Va. a, p. 204. 7 Simo. ibid. 
from the e found in $\mathrm{n}$ pounds ; closithing, the proviuld casily d recluced monining ygers then was killed, refreshicd no further the addise liad re, and the

ow took a

Frenccis ollect, and river. On ime of the - the rear, $n$ of their sk of the his own they least an end to y. For agether, till ike Memsit to scat. le best of itlements,
Their sufierings now began to be severe, not only from the excessive futigues they had undergone, but from hunger. 'Their provisions were expended, and they were yet at a distance from any place of delief. Some were lost in the woods, anc' others perished at Coos, being unable to hold out any further.* But Rogers, with the most of his men, persevered amiclst all their sufferings, till they arrived at Number Four, now Charlestown. This enterprise proved extremely dangerous and fatiguing to the men, who had been engaged in it ; but it made a deep impression on the enemy. It carried alarm and consternation into the heart of Canada, and convinced the Indians that the retaliation of vengeance was now come upon them.

WhiLe Rogers was thus employed in humbling the Indians on the river St. Lawrence, general Amherst was preparing to carry his army against the forts and settlements in Canada. Tile naval force of the cnemy, as yet gave them the command of the lake; the first business of the English general was, to obtain a superiority there. Captain Loring had for some time been employed to superintend the building of vessels at 'Ticonderoga. Having obtaincd information of the situation and force of the enemy at the Isle Aux Noix, Amherst directed Loring to build, with the greatest expedition, a sloop of sizteen guns, and a radien, eighty four fcet in lerigth, capable of carrying six large cannon. By the eleventh day of October, these, togrether with a brigantine were finished, victualled and manned;

- Belknap. ibis. 


\section{4 NATURAL AND CIVIL}

and the general embarked with the whole body of his army in batteaux, to engage the cneny. The next day the weather became tempestumus, and they were obliged to come to anchor in a bay on the western side of the lake, anci the men were landed for refieshment. In the man time, Loring, with his small squadron, stilcd down the like, and discovered the French forec : He gave chace to a French schooner, and drove three of thcir vessels into a bay, where two of them were sunk, and the other was run aground by their crew, who escaped into the wools. One however was repaired, and bronght anay by Loring, who had se far succected ats to kiare but one schooner remaining to the Frcach.

Genera A Anerst, alice having been wind bound for screral ciats, recmbinted his trows, and proceded down the lake. 'The storn wheh had abated, began again with increased violunee, and the batteanx were in clinger of being swatlowed up by the waves. Finding the seuson action was clapsed, and the winter setting in with sevcrity, the general judged it inpracticable to undertake a new expedition without endangering his army, or rumbing too grest a risk of not cffecting his object. Returning to the bay in which his troops hid beon sleclered diring the storm, he landed them agatin, and bergan his march to Crown l'oint, where he arived on the twenty first of Ociober.

HA ING succeeded in gaining posscssion of two of the French forts, and sccuring the conmand of the lake, Amherst's attention was now employed in erecting a new fortress at Crown Point, and three new outworks for its more cf. 


\section{HISTORY OF VERMONT.}

body of cnemy. cstuche, hor in a the nen an time, d dom cce : He di dion two of aground? vocils. hat amay ; to lative ilch.

een wind s tropos, in wheh viokner. ang swat. euson sin etting in practicalhout cnsat a risk g. to the erced liar. ad bersin rived on

cesion of the conwas now t Crown more cf. fectulll defence; in compleating the roads which had been opened during the summer; and planning another from 'Ticonderoga to Number Four or Charlestown on Connecticut river ; his ob. ject was, effectually to secure the advantages which he had already obtained; and to put his troops in a situation, fivorable to the compleat success of another campaign.**

Tre cxpeclition to Ningara, had been put wader the command of general Prideaux. 'This uficer, with the troops assigned for the expedition, reinforecd by the Indian auxiliaries under Sir IVillitum Johnson, advanced to Niagara with. out being molested by the cnemy ; and invested the fort, about the middle of July. 'The ap. proaches were carried on with much vigor till the twentieth of that month, when Prideaux, visiting the trenches, was unfortunately killed by the bursting of a cohorn. The command of the army devolving on Sir William Johnson, he pursued the same vigorous measures, and erected his third battery within one hundred yards of the flag. While the English were thus pushing the siege with the greatest vigor, the enemy were making preparations to relieve the place ; and had assembled a body of troops fiom Ventugss, Detroit,Presque-Isle, \& other settlements in thatquarter, amounting to twelve hundred men. 'These, with a body of Indians wnrer the command of M. d'Anbry, were marching to reinforce the garrison at Niagara. John. son was informed by his Indians that this body was on their march, and he instantly resolved to

"Simuilet's Hiat. Ezgland, Vol.z, P. 478. 


\section{NATURAL AND CIVIL}

intercept them. In the cventivg of July the twe nty thircl, he ordered the ligh insantry and piquets to take post on the leit, on the road leading from the fillis of Niagara to the fort. In the morning, these troops were reinforced with the grenadiers, and by a part of the forty sixth regiment, communded by lieutenunt coionel Massey ; the forty fourth regiment, under lieu. tenant colonel Farguhar, was posted at the tail of the works, to support the guard of the trenches; and the Indians were ordered and en. couraged to be rendy for the contest.

Thus prepared, the Einglish were ready for the battle, and about eight o'clock in the morning the enemy appeared. The Indians in the English army, acivanced to speak to their brethren who were with the Firench; but the conference was declined by the enemy. In a feir minutes the hoirible ycil, called the War-whoop, became the signal for slaughter; and the action was begun with great impetursity by the cnemy. But neither the Indian shrieks, no: the French vivacity could avail; their troops met with a hot reception in the front, and Sir William's Indians foll furiously on their fanks. The shook was too violent to be sustained, and in little morc than half an hour their whole army was routed. Great numbers were slain, their general and all his officers were taken prisoners, and the marsuit was continued for fire miles, through the woods with gircat slaughter.

Tise battle was fought in the sight of the French ramison at Niagara, but the garrison wass not atware how great a loss the French army hat sytained. As soon as the defeat of the 
of July the !hiustry and on the road the fort. In diorced with forty sixth int colonel under licu$\mathrm{d}$ at the tail of the tren. red and en-

st.

re ready for in the morndians in the o their breth$t$ the confcrIn a few War-whoop, nd the action y the cnemy: the French met with a ir William's anks. The med, and in whole army slain, their en prisoners, $r$ five miles, ther.

sight of the the garrison French army leieat of the
French was compleated, general Johnson sent major Harvey with a flag to the commanding officer in the fort, with a list of the prisoners, requiring him to surrender while he had it yet in his power to restrain the Indians, and before any more blood should be shed. The commanding officer wished to be certain of the event of the battle, and was permitted to send an officer to visit the prisoners. Upon his return, the commander agreed to surrender, articles of capitulation were proposed, and in a few hours the treaty was ratified and signed; the whole was compleated about ten o'clock in the evening of the same day, on which the battle had been fought. The garrison, consisting of six hun. dred and seven men, were to be prisoners of war, and protected against insult and pillage from the Indians ; the women, at their own request, were to be conducted to Montreal ; the sick and wounded were to be treated with humanity, and sent to their respective corps as soon as they were recovered.*

ThIs was the second victory that Sir Wil. liam Johnson had obtained in the course of this war. In both he had entirely defeated the enemy, and taken their commanders prisoners. $\mathrm{He}$ himself had not the advantages of a regular military education. In his battles, and in what was more difficult, in the art of governing and managing the Indians, he was most of all indebted to superior natural sagacity and courage. In this expedition against Niagara, he had brought forward eleven hundred Indians of the six na.

- Smollet's Hist. England, Vol. \&, p. $47 s$.

$$
\text { vox. I. F } 3
$$


tions ; in the battic he had animated their nat. tural fierceness and impetuosity ; after the sur. render, he coulcd and restrained them within the boumds of order and moderation ; in both cases, he knew how to manage the savage temper, and to make it subservient to his own views and purposes. Like other professional men, the Britisli generals did not intend to believe that any thing effectual could be clone in their pro. fession, without a regular course of education, discipline, and experience. When Amlerst received intelligence of the death of gencral Prideaux, he appointed brigadier general Gage to the cornmaid, and sent him on from Crown Point to Niagara. Happily for the colonies, Grigc did not arrive, till the superior genius and sagacity of Johuson had reduced the fort, and compleated the business of the expedition.

I $\mathrm{N}$ revicuing the operations of this campaign, it will naturally occur to our minds that the British minister had' discovered sound policy, and an excellent judgment, in selecting the gen. ius and characters of the several commanders, for the nature of the service which they laad to perforni. A general less courageous, active, enterprising, and animating, than Wolfe, would not have persevered amidst all the difficultics which attended his situation; nor would bave thought of subduing Quebec, when defended by a superior force, under such a commander is Montcilm ; nor would have dared to put the event on the risk of a siussle battle. Wolfe nell knew what his troops could perform, and the event turned ont in conformity to his expectitions and wishes. Johnson foresaw how the 


\section{HISTORY OF VERMONT. 4.39}

their nat. er the sur. lem within ; in both avage tem. own vicws al men, the elieve that their pro. education, Imlierst re. encral Pri. al Gage to om Crown e colonies, genius and c fort, and dition.

; campaign, Is that the and policy, ing the genmmanders, hey had to us, active, blfe, would difficulties rould have efended $\mathrm{ty}$ mander is to put the Wolfe well , and the s expectihow the
French and Indians would make their attack, and what would be the consequence of their hurry and precipitation; and the spirit he discovered in the execution, was equal to the wisdom and precaution of his arrangements. Cool, resolute, and cautious, Amherst left the enemy nothing to expect from surprise, or from what they called a coup du main; but at the saine time, he made the Indians feel the horror and vengeance of thir fivorite system, a war of extermination. When the French offecrs found that nothing but superior skill or force would be able to withstand him, they prudently declined the combat; and to avoid being made prisoners of wạr, resigned to him their forts, and the cornmand of lake Chanuplain.

1760. 'Tue operations of the last campaign had been so extensive and successful, that no object now remained in the northern colonies, but to compleat the conquest of Canada, by the reduction of Montreal. In respect to its numbers, situation and importance, this was the second place in Cimada. It was built on an island in the river.St. Lawrence, at nearly an equal distance from Quebec, and the lake Ontario; and was the staple of the Indiun trade and resi. dence of the governor general of the colony. 'There M. de Vaudrienl had fixed his lead quarters, and proposed to make his last stand against tine efforts of the l3ritish generals. He levied all the forces that could be raised, collected magazines, erected new fortifications, and availed himself of all the arts and measures that could be adopted by an able and experienced soldier and statesman. His hopes, however, 
could not be derived from the situation or strength of the city, but upon the natural strength of the country ; the woods, mountains, waters, defiles and morasses, that the British generals must have to pass, before they could bring their armies around the city. These, he hoped, might retard the progress of the English armies, or protract the war till a general peace should be made, or some favorable event enable the French to afford relief to the colony. That nothing might be wanted to animate and allure the inhabitants to make a general and desparate otruggle to save the country, he addressed a circular letter to all the officers of the militia, in this style :

es Sir,

Montreal, June B, 1760.

- THE chevalier de Levy is just returned - to this town; he has repeated to me the strong ' testimony which he had before given me, of c the good will, the zcal, and ardour of your - company of militia.

- I expected no less from the fidelity of the - brave Canadians, and from their attachment ' to their native country.

' His majesty, who is by this time, probab. ' ly informed of your brilliant victory, will be - no less pleased with this, than affected with " the distresses of the colony ; so that suppo.

' sing that peace has not been concluded, on ' the receipt of this news, the king of England

- cannot possibly avoid subscribing such terms

- as our monarch shall have imposed upon him.

- You are not uninformed of the great ad? vantages which he gained in Europe during. 


\section{HISTORY OF VERMONT. 441}

tuation or ral strength ns, waters, h generals bring their he hoped, ish armies, ace should enable the ny. 'That and allure 1 desparate essed a cirmilitia, in

8, 1760 .

st returned the strong ven me, of ir of your

lity of the attachment , probab. y, will be ected with at suppoluded, on England uch ternis upon him. great adpe during
- the last campaign over the English and Prus. - sians.

- Тн $\mathrm{E}$ prisoners which are bringing in every - moment, all agree in confirming them.

- ThE truth is, his majesty is in person in - Holland with an army of 200,00, men, the - prince of Conti in Germany with 100,000, and - the princes of Deux-Ponts, and Soubise, - command the army of the empire of 200,000 ;

' and lastly, the empress of Russia, and the queen of Hungary, have joincd their whole

- force, and were taking measures for the con- quest of the remainder of his Prussian majes- ty's dominions.

- Besides this, the last accounts assure us, - that the garrisons of forts Frederic, Niagara, and Chonagan, have suffered greatly by a sick. - ness, which is not yet stopped, and that the - regular troops in New England are reduced - to nothing.

- General Murray, therefore, has disper- sed manifestoes to no purpose, to magnify his - own nation, to pacify the Canadians, to engage - them to lay down thcir arms, to discredit our - bills of exchange, and our currenty, at the - same time that the English tradej's are cager - to procure them, because they lave been re. gularly paid.

- You see, sir, that the colcny is draving to - the end of its hardships and distresses, and that - it is upon the point of seeing plenty succica 'to scarcity.

'If the English make any attempt, it con - have no other object than the anbition of : ivicir ' gencrals; we are thoroughly prepured to re. 
(j)ilse them with spirit; we have a train of - artillery, besides that which we took from the - enemy ; a still greater proportion of powder, - ball, and ammunition, for the operations which - I have projected; we have also provisions - cnough, by means of the resources which we - shall find in the good will of the Canadians, - who have the greatest interest in the preservi' tion of their religion and liberty. The king's - troops will even live, if necessary, upon roots, - when they cannot do bettcr, and will not fail - to join their endeavors to those of the brave - Canadians.

: MY intention then is, that you and all your - militia, should hold yourselves ready to march - with arms, baggage and eight days provisions

t to our frontiers, when the case shall require it. II believe I may venture to assure you, that - these will be the last dispositions which I shall - have occasion to make for the defence of this ' colony; being fimly convinced, that, some c time in August, at least, we shall have peace, e provisions, and, in general, whatever we want. - I am, Ec.

- P. S. You will assemble the militia of your - company, and read this letter to them. You - will carefuily inspect their arns. If any of - them are ont of order you will give them a 'note, and the king's gun smith's will repair "them immediately."

W'Ine the marquis de Vaudicel was thes struggling between despair, hope, and endeav. or, general Amherst was concerting and cxccut-

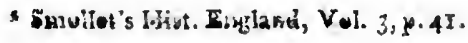




\section{HISTORY OF VERMONT.}

ing measures, to bring all the British armies in America, to act in concert against Montreal. He had sent instructions to general Murray, at Quebec, directing him as soon as the season would permit, to advance up the river St. Lalwrence by witter, towards Montreal, with all the troops that could be spared from the garrison of Quebec. He appointed colonel Haviland to command a body of troops, which were to proceed from Crown Point, through lake Chanplain, to take possession of the Isle Aux Noix ; and from thence they were to advance by the shortest practicable route, to the banks of the river St. Lawrence. For himself he proposed to go with the main body of his army by the way of the Mohawk, and Onondago rivers, to lake Ontario ; to embark his troops at Oswego, sail over the lake, and down the river St. Lawrence, to the island of Montreal. By this plan he proposed to bring all his troops ugainst that place, and to inclose and surround the enemy on that island.

Th рlan of military operations being setthed, the commanders, as early as the season would allow, set themselves to carry into cxecution the part that was assigned to them. Gens eral Amlerst had procures! two armed schooners ic cruise on lalie Ontario, under the command of captain Loring; and a great number of batteiux, and other small vessels were provided for the transportation of the troops, artillery, ammunition, provisions, and baggage. Several regiments were ordered to proceed from Albany to Oswego ; and the general himself marched from Schenectady, with the rest of his troops in endeav. licecut:- 
the latter end of June, and arrived at Oswego on the ninth of July.

'Гн $\mathbf{x}$ army being; assembled, amounted to about ten thousand men; and they were joined by a considerable body of Indians under the direction of $\mathrm{Sir}$ William Jolınson. Colonel Haldimand, with the light Infantry, the Grena. diers, and one battalion of Highlanders, was detached to take post at the eastern part of the lake, and assist the armed vessels in finding a passage to la Galette. On the tenth of August the whole army cmbarked on board the batteaux and whale boats, and proceeded along the lake towards the origin of the river St. Lawrence. Understanding there was nothing to fear from the enemy's vesscls, the general resolved to proceed down the river to Swegathcie, and attack the French fort at Isle Royale: a post which in a great measure commanded the passage by water, either from or to lake Ontario. On the scventeenth, the row gallies fell in with the French sloops commanded by M. de la Bro. querie; which were forced to surrender, after a warm con'?st. Amherst now prepared to in. vest the fortress at Isle Royale. Batteries were raised on the adjacent islands, and the fort was cannonaded also by the armed sloops ; in one of those islands, some scalps were found which the inhabitants had taken from some of the Mohavks, whom they had slain : 'The Indians were infiamed at the sight, that they burned their chapel, and all their houses.

Preparatrons being made for a general assault, the commander, $M$. Pouchant found it most prudent to beat a parley, and surrender on 


\section{Oswego}

ited to are joined under the

Colonel he Grena. 's, was deirt of the finding a of August e batteaux the lake Lawrence. fear from solved to $e$, and at. : a post 1 the pas. Ontario. 11 in with de la Bro. der, after red to in. eries were e fort was in one ind which e of the he Indians $y$ burned

general found it render on capitulation. With the capture of this fort the opposition of the enemy ceased, but the navigation became extremely difficult and dangerous. The river abounded with a great number of rapids and fails, which could not be avoided. Great care was taken to guard against the dang. rs of the passage; but notwithstanding all the vigilance and exertions of the oflicers and men, the army suffered much in this part of their voyage. Forty six battcaux, seventeen whaleboats, one row-galley, some of their artillery, ammunition, and stores, with above eighty men were lost on the passage. This dingerous service being effected, the army met with no further difficulty, but landed on the island of Monteal, September the sixth, without any opposition fron the ene my, except some random shots from some of the flying parties, who instantly distppeared.

W H I E general Amherst had been thus engaged in preparing for the expedition, and coming down from lake Ontario, general Murray had not been less active at Quebec, and on the river St. Lawrence.. During the winter he neglected no measure that could be taken to preserve Quebec and to subdue the :adjacent parts of the country, and many of the inhabitants actwally took the oath of allegiance to the king of Great Britain. The garrison however within the walls of Quebec suffered much from the extre me cold of the winter, the want of fresh provisions, and the scurvy ; before the end of April, one thousand of the soldiers were dead, and double that nun ber were unfit for service. The chevalier de Lav, on whom the command VOL, I G 3 
of the French troops had devolved by the death of Montcalm, was encouraged to hope from the state of the British garrison that Quebec might be reduced by siege before a British flect cou'd arrive with succours in the spring. For this purpose he collected all the regular troops, $\mathrm{Ca}$ nadians and Indians that he could assemble; and formed an army of more than twelve thou. sand men. With this force he advanced to lay siege to Quebec in the latter end of $A$. pril. Murray confiding in the bravery \& discip. line of his troops, meant to confound \& disperse them by the boldness \& vigor of his measures. On the twenty eighth of April, at half an hour after six in the morning, he threw open the gates of Quebec, and marched out with his little army of three thousand men to give battle to the enemy. A severe conflict took place, and an obstinate battle was kept up for an hour and three quarters. At length the British were 0 verpowered by numbers, and obliged to quit the field with the loss of a thousand men killed or wounded. The French lost a much greater number, but remained masters of the field of battle.

Mur Ray retreated with ilis troops within the walls of Quebec ; and neither ciismayed by the loss of the battle, or discouraged with the reak. ness of his own situation, made a vigorous defence and determined at every risk and hazard to hoid out till succours should arrive. The enemy did not omit to avail themselves of the advantage of the battle, and the same evenitig opened their trenches against the place. For several days they cannonaded the city with great 


\section{HISTORY OF VERMONT.}

the death from the bec might Alect couid For this oops, $\mathrm{Ca}$. assemble ; lve thou. lvanced to ind of $\mathrm{A}$. \& discip. \& disperse mcasures. If an hour open the ith his lit. give battle place, and $n$ hour and h were 0 ed to quit hen killed ech greater ie field of

within the yed by the $i$ the weak. gorous ded hazard ve. The ves of the e evening ace. For with great vivacity, but their artillery was not equal to that of the garrison. On the ninth of May a British shir, commanded by captain Deane entered the harbuur of Qucbec, and announced the joyful news that a British squadron was in the river. On the fifteenth of May, commodore Swan. ton arrived, and in the evening anchored above point Levy. Early the next morning two of his vessels slipped their cables to attack the feet which the French had collected. They were no sooner in motion than the French ships fled in the utmost disorder. One of their frigates was driven on the rocks, another ran on shore and was burned, and all their other vessels were taken or destroyed. So confounded and dispirited were the enemy by this disaster, and the dread of an approaching fleet, that in the following night they raised the siege of Quebec, and retrcated with great precipitation, leaving their provisions, implements, and artillery. The next morning, Murray marched out, but found the enemy had fled; and nothing left for him but to take possession of their tents, stores, magazines of provision, ammunition, and artillery.

$\boldsymbol{T}_{\boldsymbol{H}} \boldsymbol{z}$ affuirs of Quebec being settled, and a proper garrison assigned for its protecticn, Murray prepared to advance up the river to Montreal. The troops were embarked at Quebec, on board a great number of sinall vessels; captain Deane in the Diana, undertook the command and the hazard of conducting them up the river. This officer with uncommon abilities and attention surmounted all the difficulties and hardships of an unknown, perplexed, and dungerous navigation; and such was his atten- 
tion and vigilance that not a vessel was lost in conducting a numerous fleet, one hundred and eighty miles through an enemy's country, and against a rapid stream, where no English vessel had ever been before. General Murray while advancing up the river, every where published manifestoes, inviting the Canadians to submis. sion, and promising them protection under the British government. These proclamations had great effect. Almost all the parishes on the south shore, as far as the river Sorel, made their submissions, and took the onth of neutrality; one village opposed him with a:ms, and that by way of example and terror he set on fire. On the north shore, lord Rollo disarmed the inhabi. tants as far as Trois Rivieres, and took posses. sion of that village without opposition. M. de Levy was all the time watching the notions of general Murwy, and waiting for an opportunity to attack him with success; but tie time for such enterprises was past, the pecile were every where submitting to the British general, and were not disposed to venture on hostilities. Thus fortunite and successful in every part of the business, Murray arrived safe with the treops under his command, and landed on the east part of the island of Montreal, the day after $\mathrm{Am}$ herst had landed on the west.

THE army that was to proceed to Montreal by the way of likke Champlain, was put under the conmand of colonel Haviland. To facilitate lic operations of the war, Amlierst had directed that a road should be opened from Number Four on Connecticut river, across the Green Mountains to Crown Point. - This service wa 


\section{IVIL}

isel was lost in e hundred and s country, and English vessel Murray while here published ans to submis. ction under the clamations had arishes on the orel, made their of neutrality ; mis, and that by t on fire. On med the inhabi. nd took posses. osition. M. de the motions of an opportunibut tile time c pecale wore British general, e on hostilitics. n every part of with the troops on the east part day after $\Lambda \mathrm{m}$.

ed to Montreil was put under nd. To facili. mlierst had di. ned from Numcross the Green his service was

\section{HISTOIRY OF VERMONT. 449}

performed by a New Hampshire regiment, under the command of coloncl Goffic. They began their road at Wentworth's ferry, two miles above the fort at Clarlestown; cut down the trees and made bridges, till their road cxtenck d twenty six miles. At that place, they found a path, in wihich they proceeded to Otter Creck ; from whence they found a good road which lead to Crown Point. In this work they made such dispatch, as to join the army at that place on July the thirty first, and brought with them a drove of cattle for the suppi of the army. August the twelfth, Hav $\downarrow$ embarked his troops in batteaux and whaleboats, and sailed down lake Champlain. He met with no oppo. sition from the enemy till he arrived at the lsle Aux Noix. This place had been strongly fortified, and made some appearance of opposition ; some skirmishes took place, and a few wire slain on both sides; but the enemy were too weak and too much dispirited to make a formidable opposition. 'The post was soon deserted, and the forts at St. John's and Chambly became an easy conquest. Meeting with no futher opposition, the troops passed on ; and the dily after Murray had efficted his landing, Haviland appeared with his army on the south sicle of the river St. Lawrence, directly opposite to Montreal. These events and circumstances appeared highly favorable and unexpected. The three armies pursuing different routes, and unacquainted with each other's progress, passcd through a long and dangerous tract in the enemy's country, and arrived at the capital within two days of each other.

- Deltnap's Ilist. Now Hampshire, Vol. 2,p. 305. 


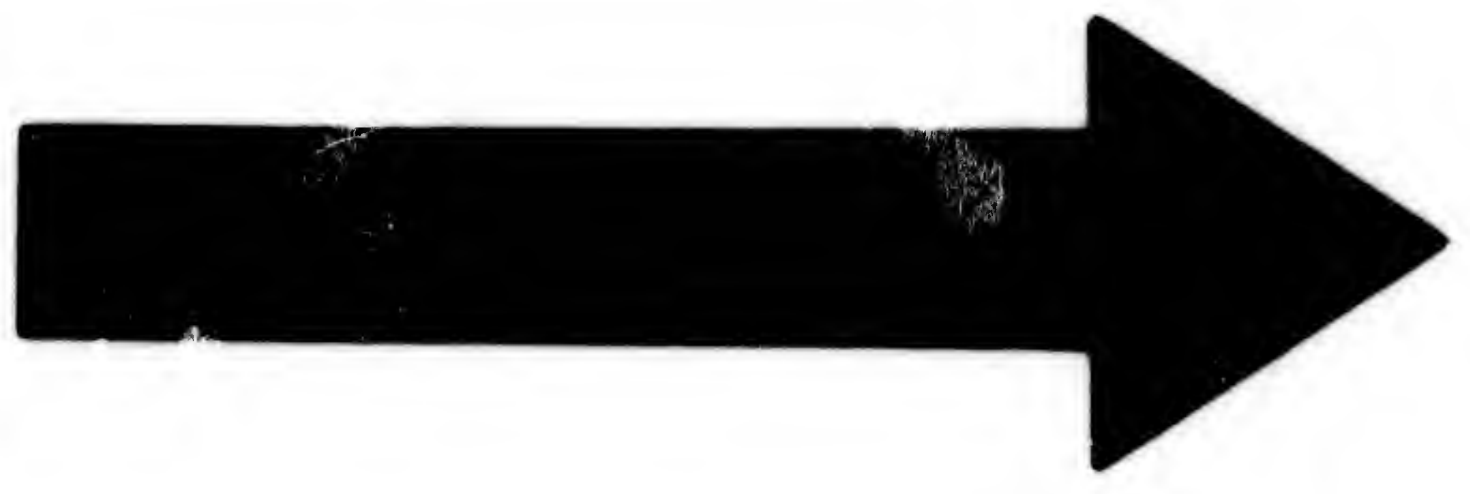




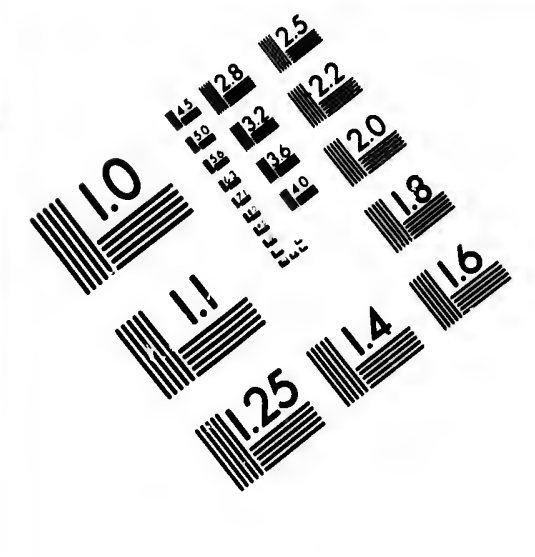

IMAGE EVALUATION

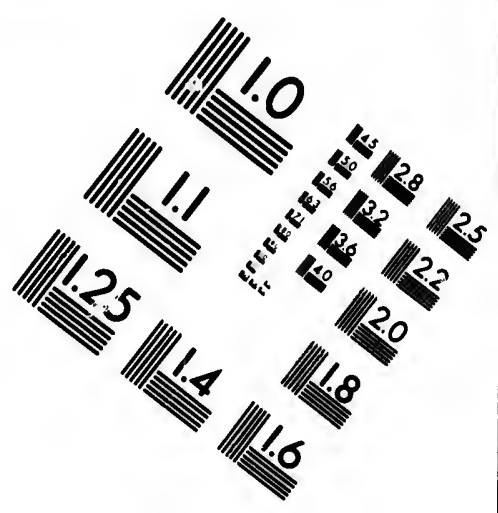

TEST TARGET (MT-3)
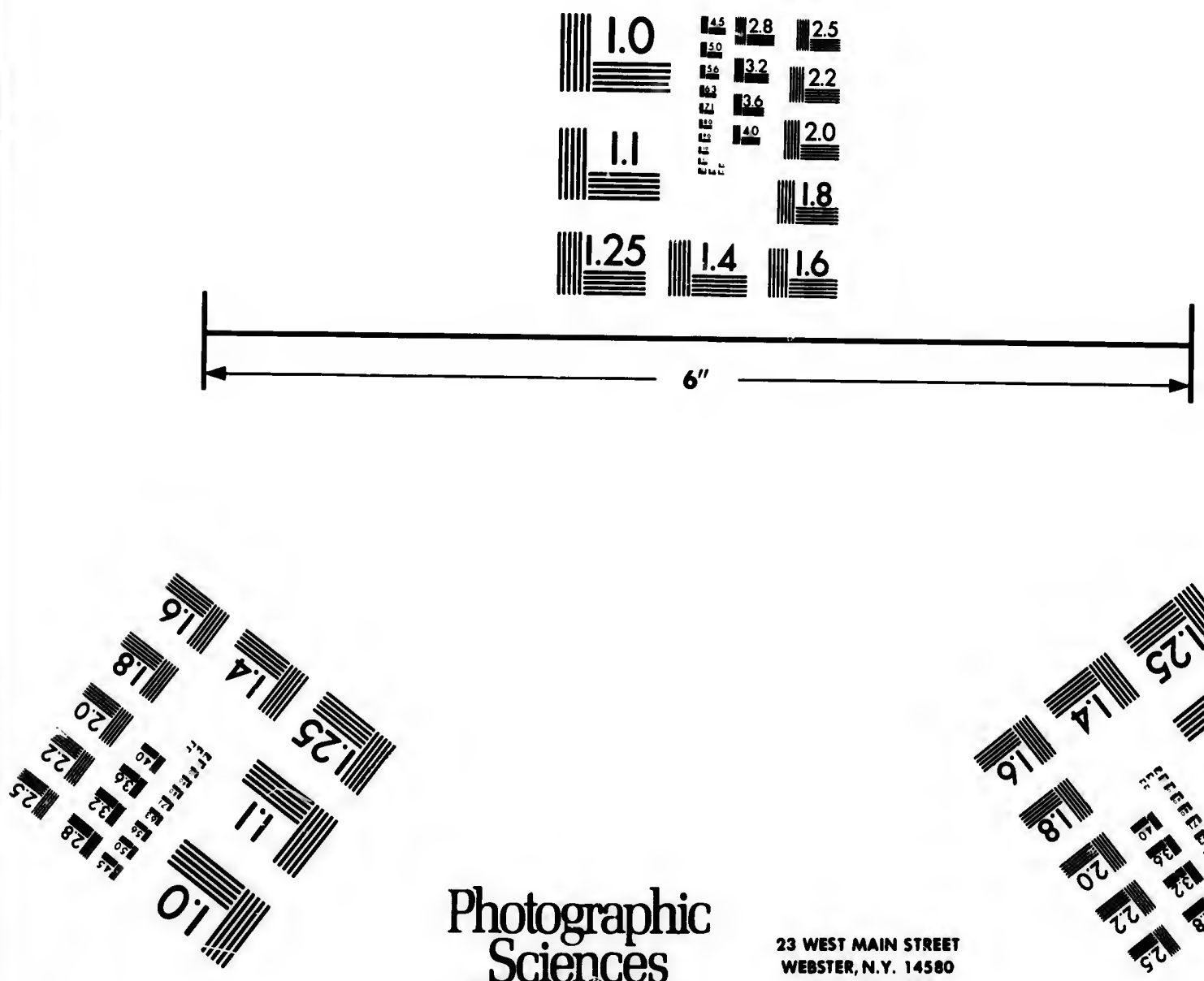

Photographic Sciences
Corporation

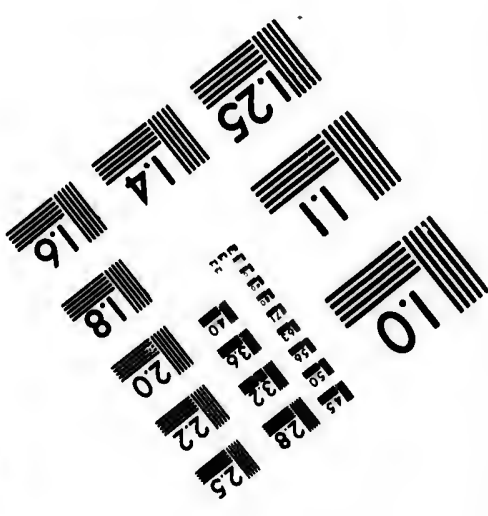


Nothre now remained for $M$. de Vau. dricul, but to make the best terms he could for the colony. General Amherst, on the day in which he arrived, formed his army in a plain before Montreal, where his troops lay all night upon their arms ; and was proceeding to bring on his artillery, and lay siege to the city. On the morning of the seventh, he received a flag and letter from Vaudrieul, who sent two oficers demanding a capitulation. Amherst stated the terms which he would grant, und which he signified that he should not alter. Some letters passed upon the subject, but Vaudrieul could do no otherwise thin to submit to the terms dictated by the British general. They were however favorable to the French colony. The troops surrendered prisoners, and were not to serve against the Euggish or their allies during the war. The whole country of Canada was to be surrendered to the king of Great Britain; and the inhabitants were to be protected in their estates and religion.

Trus was compleated the conquest of Cana. dil, September the eighth, 1760, in the sixth year of the war, and after the most severe strug. ibles. During the contest, six battles had been fonght, the fortune of which was equally divi. ded. The first of these was at the meadows, near fort Du Quesne, in which Braddock was slain, and the French successful. The next was at lake George, where Dieskau was defeated and captured, and Johnson gained the victory. The third was at 'Ticonderoga, in which Abercrombie was defeated, and Montcalm gained the advantegre. In the fourth, at Niagrara, the 


\section{HISTORY OF VERMONT. 451}

de Vais. could for le day in n a plain all night to bring ity. On ved a flag ro ofiicers stated the h he sigse letters ul could he terms ley were y. The re not to s cluring ta was to Britain ; $\mathrm{d}$ in their

of Cina-

he sixth re strug. aad been lly divieadows, ock was hext was defeated victory. h Aber. ined the $\mathrm{ara}$, the

French were subdued, and Johnson gained a compleat victory and conquest. In the fif $h$, at Qucbec, Wolfe and Montcalm the greatest generals that had appeared in America, both fell ; but victory and conquest were on the side of the British. The sixth was at Sillery, Mur. ray was defeated, and $M$. de Levy gained the battle. The British nation and colonies for more than seventy years, had been aiming to accomplish the business, but without success. A large country was now added to the British dominions, and an end put to the depredations and ravages of the Indian tribes. The grand contest for which the war was begun, appearcd to be decided ; and the future prospects of the colonies bore the aspect of tranquility, prosperity, rapid increase, and improvement. All these hopes and prospects seemed to be confirmed and compieated by the treaty of peace signed at Paris, February the tenth, 1763. By this treaty, the king of France ceded and granted to the British king in full right, the whole country of Canada, with all its dependencies, in the most ample manner and form. All that the British colonies could wish respecting Canada, was now obtained; and the time was come, in which it might reasonably be expected, that all their future exertions would be employed for the improvement and prosperity of their country. 
IN reviewing this system of colonial wai, not only its military operations, but its origin, moral and political tendency and effect, are also worthy our attention and remark.

The OrIGIN of these wars will easily be found in the different interests, feelings, and passions of men. The Europeans who made the first settlements in America, were from dif. ferent parts of the European continent; from Spain, Portugal, England, France, Holland and Sweden. They brought with them the opinions, customs and habits, of the governments and churches to which they had been accustomed, and were more or lcss influenced by particu. far moral considerations, and local circumstan. ces. These were greatly different; but in one view and design, they were all agreed. They all meant to obtain possession of the different parts of the American continent, to which they removed; and to make a firm and permanent settlement on the lands, of which they took possession. The Indiuns, unacquainted with the European character, and too ignorant and cred. ulous to suspect unfriendly or mischievous designs in their new visitors, every where received them with the tokens of unfeigned hospitality and joy ; and viewed them as a race of beings, far superior to themselves. The Europeans availed themselves of their superior knowledge in all the arts, commerce and business of life; and of the native simplicity and ignorance of the original inhabitants. By a careful attention to the Indian temper, character, and state, they engaged their confidence, procured their friendship, and obtaincd their consent to settle on 
onial wai, its origin, $t$, are also

easily be ings, and vho made from dif. ent ; from olland and the opinvernments accustomy particu. rcumstan. ut in one d. They different hich they ermanent took pos. with the and cred. evous dee received hospitality ff beings, opeans anowledge s of life ; orance of attention tate, they in friendsettle on their lands. It was not till after a period of ycars had taken place, that the natives discerned the policy, and became jealous of the increasing power and numbers of the European settlers. With this jealousy the savage temper becarne sullen, gioomy, suspicious and resentful. Controversies took place, mutual provocations, ccmplaints and injuries succeeded; and the Europeans were every year advancing, and forming new settlements in the Indian country. Disputes about property and encroachment ensued; and these had the same effect in the colonies that they have in every other part of the globe, they gradually but unavoidably resolved themselves into an appeal to force ; and when once hostilities and slaughter began, war would assume all the barbarity and cruelty that was inseparable from the Indian passions, customs and habits. The result was every where the same; sooner or later war broke out between the Indians and the Europeans who were settling and taking possession of thcir country.

In addition to the wars that arose from this cause, there was another equally certain and unavoidable, the seat of which lay in Europe. The different interests, the mutual hatred, the perpetual pride and ambition of the European monarchs, kept their kingdoms in constant contention and war ; and these wars, by the decrees of their sovereigns, always followed their subjects into the new world, and became one of their heaviest calamities and curses. Whenever the kings of England or France supposed it would be for their interest to involve their kingdoms in blood and slaughter, their colonies in vor. I H 3 


\section{NATURAL AND CIVIL}

every part of the world were required to $i$ in in the folly and madness of their sovereigns; to plunge themselves into all the caliniticen and miseries of their bloody contests. in botit the caluses there were perpetual sources of war in the colonies; and there was no :ational ground to expect that they could be avoided, while the colonies were extending thir setilements into the Indian country; or while they remained connected with the European sovereigns or powers.

Among the dangerous conscquences of these wars, the MORAL EFEECT ivas greatly unfavorable, and corrupting to the human mind : They operated with a certain and cunstant tendency to destroy the moral virtues of humanity, candor, and benevolence ; and to produce the spirit of bigotry, intolerance, revenge and mutual hatred. It was not possible for the men that were constantly endeavouring to injure and de. stroy, to love and do good to one another; instead of this, they were constantly learning to hate and to abhor each other. The spirit of intolerance and bigotry seems to be unavoidably connected with ignorance, and to be incurable by any thing but science and philosophy. This raving, fiery spirit of the partisans, derived new force and inflammation from the perpetual wars in which the colonies were engaged. 'The people in the French colonies were trained up to believe that they belonged to a monarch and to a church, which were absolutely infallibie; the different sects and parties in the English colonies did as firmiy believe, that they themselves were never in the wrong. To carry 
d to join in igns: and inticen and 1 both these $s$ of war in min ground 1 , white the micuts into remained ereigns or

ces of these tly unfavorind : They tendency anity, cance the spirnd mutual men that are and de.. pother ; in. earning to spirit of innavoidably incurable hy. This erived new etual wars The peoined up to narch and infallibie ; e English rey themTo carry their political and theological prejudices and hatred to the highest degree, nothing was wanted but the cruelties and barbarities of an Indian war. Both parties very justly reproached each other, for the inhumanity and wiclicdness of their proceedings; and they well knew that the Indians in one part of the country, were under the management of the French ; and in another, under the direction of the English. Policy and disguise would of course avail themselves of all the help and assistance that could be derived from the pretence or abuse of religion, to represent the opposite party as faithless, corrupt, heretical, opposers of God, and all that was good.

To carry this scene of mutual hatred, bigotry and abuse, to its greatest height and extent, time and experience had shown that the surest way was to put it under the management of a set of intolerant priests, genus irritabile vatum, and to them, the politicl leaders looked to afford a powerful assistance, by representing their enemies, under an odious and awful character. In these exploits the English and the French seem to have been very successful in destroying the spirit of candor, charity, and benevolence; and in promoting that of mutual aversion, extreme bigotry, and intolerant hatred.

WHILE the moral tendency was thus unfortunate and corrupting, the effect of continued war on the literary and scientific character and pursuits of the colonies, was equally unfavorable and degrading. It was the peculiar felicity of the first settlers of the English colonies that they were descended from the most enlightened 
part of Europe, and at a time when considerable advances had been made in the arts and sciences. 'The clergy, and several of the leading men that came over with the English, when they made their first settlements, had been educated at the universities of Cambridge or $\mathrm{Ox}$. ford. They were well acquainted with clissical literature, had been instructed in the philosophy of that day, and were eminent for their knowledge in the theological debates and controversies that agitated the English nation at that timc. Disgusted with the English hierarchy, and viewing with horror the arbitrary procecdings of Charles the first, and his archbishop Laud, they removed into America, to be out of the reich of prelatical power and persecution. Without a preconcerted plan of eccle. siastical power or policy, they adopted such a method of ecclesiastical proceedings, as utility, time, and circumstances sugrested. Happily for themselves and for their posterity, nature and christianity led then to adopt one, that was equally favorable to the interests of morality and religion; and to the rights and liberties of mankind.

Justey pleased with the form, in which the christian church appeared in the new world, and apprehensive of the important consequen. ces.it might have on society, they wished to give to the church and to the country, all the advantages that might be derived from the influence of the arts and seiences. So carly as the year 1638, they began the foundation of a College at Cambridge ; and were warmly engaged in making provision to educate their youth 
considera. : arts and the leading rlish, when id been ed. dge or $\mathrm{Ox}$. vith clissin the phint for their es and con. nation at lish hierar. oitrary pro. archbish. ica, to be and persein of eccle. ted such a as utility, Happily ity, nature one, that s cf inoral. and liber.

which the ew world, consequenwished to try, all the om the inearly as ation of a varmly en. their youth in useful knowledge and to supply their chur. ches with well educatcd and learned ministers. In 1700,the colony of Connecticut followed the cxample of Massachusetts, and founded a sem. inary now called Yale College. Both these societies received much assistance from the civil government, and were warmly supportcd and encouraged by the clergy. And it was from them, that almost all the acquaintance which the country had with the arts and sciences, was derived. To increase the influence and importance of these colleges, and to preserve a decorum and uniformity in their churches, their ministers wisely established a rule to discourage the application of those to the ministry, who had not received an education at their own or at some other College.

Thus educated in the best manner the state of the country would admit, the order of clergy appeared to advantage in the colonies. A. mong the doctrines which had divided the christian world, they had almost universally embraced the opinions of Calvin ; but were not deficient in inculcating the duties of morality, and the maxims of practical virtue. In respect to their learning, piety, gravity, and regrularity of conduct, this order of men were highy steem. ed by their country; and several of them were eminent as writers, and popular preachers, With more strength and origrinality of genius than any former metaphysician, EDw ARDs had gone further than any other man, to give decision and certainty to metaphysical theory and reasoning. In treating on the ancient contro. versies respecting fate and frcewill, none of the 


\section{NATURAL AND CIVIL}

metaphysical writers had discovered so much ingenuity and acumen. But like all the rest, while labouring to establish the doctrine of fute, necessity, and liberty, he clearly proved that neither the calvinistic, nor the arminian theory, nor the metaphysical way of reasoning, ever could ex. plain or clear up the subject; and that the connecting truths or principles, which would serve to show the consistency betiveen the unalterable councils and decrees of heaven, and the free agency and accountability of men, were not to be found in any of the metaphysical systems, that had yet been announced to the world; and that no such theory or system ever could explain, or be applied to the powers or actions of animals.

OTHERs of the clergy had wrote to great advantage in the controversies with the church of England, and on the doctrines and claims of the church of Rome. But the country hid not yet been agitated by any controversies respect. ing the trinity, the incrirnation, the atonenent, the necessity, evidence or reality of miracles, prophecy, or revelation, and perhaps no order of clergy ever were more useful to mankind, than those who had directed the reiggious affairs of the colonies at this period.

IN the oourts of law, the business was as well done, and justice was as impartially administered, as in any part of Europe. The common law of England was the rule of proceeding, and happily for the country, neither the provincial governments, the judges, or the lawyers had at. tempted to alter or to improve it. What relato the local circumstances of the colonies 


\section{HISTORY OF VERMONT.}

so much the rest, e of fate, I that nei. eory, nor couldex. the con. uld serve unalteraand the were not systems, world ; ver could or actions

great adshurch of claims of haid not s respect. oncment, miracles, no order mankind, us affairs

is as well ministercommon ling, and rovincial s had at. hat rela. colonies was recrulated by provincial laws ; nnd 4 he 1$\}$ colonies were much better gualifind $a$ d d....p. mine, than any European king or partimens. The ludicrous, absurcitics which die syem of

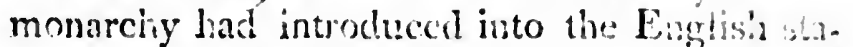
tutes, did not apply to the practical course of events or of business in the colonies; and their courts had no acusion to comprite on the corruption of blood, the respectability of am infas mous nobleman, or the sacredness of reyal vice or folly. Most of their lawyers were men of a liberal cducation; and several of them were among the most respectable and uscfal men in the country. But the time was not corie to attempt to improve the law or the profession. No books of reports, no treatises on law or evidence, or any thing appropriate to a colonial system of law or practice had appeared ; all was in subjection to British precedents and to British im. portance.

THE medical part of science and the branches more immediately connected with it, had as yet only bore a practical aspect. The physicians were as useful and practised with as much success in the colonies, as in any part of the globe, and no where did the people enjoy more health; but their knowledge and success was much more the result of observation and practice, than of theory or system. No medical schools or professorships, no regular courses of surgery, chemistry, or clinical instruction, had at that time been instituted in the colonies ; and scarcely any thing had been done in the materia medica, in botany or in the collections of natural history. One important discovery was introdt- 
ced in the colonics as early as it was in Great Britain. Dr. Cotton M.thier, of Boston, had observed in the philosophical transartions, an account of the manner in which inoculation for the small pox was practised in the 'Turkish dominions. At his recommendation, Dr. Buylston, one of the physicians at Boston, introduced it at that place, in the year 1721. It met with success ; and with the opposition, which is always to be cxpected, when a new method of practice is introduced. But although it exposed the first promoters of it to a considcrable share of professional and popular resentment, it was eventu. ally attended with much success, and almost universally adopted.

THERE was an accuracy and a minuteness in the historical productions of the country, which marked the feelings, pursuits and views of the colonies with much precision ; but the transac. tions of which they treated, appeared too local and too small, to engage the attention of the world. Hubbard wrote a very accurate and useful history of the Indian Wars in New England. Moreton wrote a Memorial, which was of use to preserve the memory of the first settlers and their proceedings. But the most that was done this way, was by $D r$. Cotton Mather, of Boston. With a singular genius, with much of the Hebrew literature, and a warm imagination, in a book to which he gave the title of Magnalia Christi Americana, he wrote minute and lengthy accounts of all the ecclesiastical, historical and litcrary proceedings of the country till the year 1692. Penhallow, at Portsmouth, gave an account of the Indian Wars; and Doug- 


\section{HISTORY OF VERMONT. 4a}

in Great. ston, had tions, an distion for urkish doBuylston, luced it at with sucis always of practice ed the first re of proas eventu. nd almost

luteness in try; which ews of the transac. 1 too local on of the urate and New Engwhich was e first setmost that n Mather, vith much imaginae title of te minute esiastical, he country rtsmouth, and Doug: bass, at Boston, wrote a historical and political summary of the affairs of the colonies to the year 1750. In Virginia, Stit/ aid Beverly published histories of that colony to the year 1700. In New York, Colden wrote the history of the five nations of Indians, in 1747 ; and in 1756; Simith published a history of the province to the year 1732. In these productions there were authentic and uscful records of the early pro. ceedings of some of the colonies. They were vicived in Europe as too small natters to engage the public attention; and it was not suspected by her historials, that the Amcrican writers were describing principles and proceedings, from whence the greatest of all human empires was destined to arise.

Specurative science was not much wanted, and had not been much cultivated in the country. In mathematics no attempts had been made to cultivate the higher branches; what was necessary and applicable to the affairs and business of life, was generally; and well understood. In natural philosophy the prospect and attention wiss more engaging. In the beginning of the eightcemth century, Kcil had introduced in England; the experimental method of teach: ing this science: Desaguliers had greatly improved the plan, and taught it systematically in a regular course of experimental lectures. Isaac Greenwood, a young yentleman of Boston, educated at Harvitrd Coilege, had been is London, attended besagulier's lectures, and had been his assistant in the business. Mr. Hollis, of London, in the year 1726, established a professorship of mathenatics and natural philosophy in Harvard vox. I I 3 
College, purchased an apparatus and scnt Green. wood as his professor to Cambridge. Greer. wood of course introduced the business at Harvard College, in the advanced state the science had assumed at London. A taste for this sci. ence being thus introduced, it became the favorite study of the young gentlemen who were under a course of education ; but as no individuil had any philosophical instruments, it was seldom pursued any further than a course of aca. demical education had carried it. In astronomy the attention had been carried a little higher. In 1694, Brattle began to make some astronomical observations at Cambridge. Robie pursued the same business, and Winthrop was attentive and accurate in observing the celestial phenomersa. Godfrey, at Philadelphia, by the strength of an untaught genius, discovered the sextant, which now bears the name of Hadley. The observations and the names of these gentlemen, appear to advantage in the transactions of the Royal Society of London.

IN natural history some useful observations and accounts had been published relative to the weather, climate, vegetables and animals, in Carolina, Virginia, Pennsylvania, New . York and Massachusetts ; some of them were by na. tives of the colonies, but the most by persons who came from Europe to reside in the coun. try. Classical knowledge was taught with repu. tation and success in the Colleges, and by the grammar schools. All the men of education had been instructed and were acquainted with the works of some of the most eminent orators and poets of antiquity. Colleges had been 
it Green. Green$s$ at Halsscience this scie the fatho were 10 indivi. $s$, it was se of aca. stronomy = higher. stronomia pursued attentive shenomestrength sextant, $y$. The entlemen, is of the

ervations ve to the mals, in w . York re by napersons he coun. ith repu. d by the ducation ted with $t$ orators d been

\section{HISTORY OF VERMONT.}

founded at Cambridge, New Haven, Williamsburg, Princeton, Philadelphia and New York. But the genius of the country had not been $\mathrm{em}$ ployed in attempting any considerable produc. tions in poetry, orstory, or the fine arts. In one article however, the New England colonies exceeded the customs and attainments of Eu. rope: In every considerable town they had a grammar school, and all the children were taught to read, write, and go through the common rules of arithmetic; and nothing was more uncommon or disreputable, than to be unacquainted with these arts. This was the knowledge the colonies most of all needed, and this they had made universal ; much further they could scarcely expect to go, while destruction was every where around them. War, French and Indian war and ravages, engaged the atten. tion of the whole country ; exhausted her finances, and required her constant attention and ex:crtion. And while this was the case, neither the resources, the attention, or the genius of the country, could be much applied to the pursuit or cultivation of science. The men who sat down to contemplate such matters, would have their attention forced to other subjects ; they' must fly, or like Archimedes be slain over their problems; and in almost every process they might say of their country..........multo spumantem sanguine cerno.

Th г same cause that thus proved unfriendly to morals and science, was also greatly injuri. ous to the populaiton of the country. In the English colonies it was found from the registers of life and death which-had been kcpt in some 


\section{NATURAL AND CIVIL}

of their oldest towns, that the number of years in which the inhabitants by their natural increase would double their numbers, did not amount to more than tiventy four, or at most twenty five years. Such observations lead to the most flattering calculations, respecting the future popuJation and number of the people; but in most of the colonies, these calculations entirely failed. In none of the provinces were the people more industrious, sober, or agricultural, than in Mas. sachusetts and New Hampshire. In the year 1713, it was found that there was rot double the number of people in Massachusetts to what there was in 167.5. The same was found to be the case in 1762 ; at that time the number of inhabitants had not doubled from the year 1722.* The same observation applied with still greater foree to New Hampshire. The cause could not be found in emigration ; nor did it arisc from any uncommon mortality or sickness. Nothing of this nature had taken place in either of those provinces, except the losses occasioned among the children by the disorder called the throat distemper, in 1735 and 1736 ; and this was local, and of a short duration. The cause was in the constant state of war, in which those provinces were involved. From 1675, when the Indian war under Philip first began, to 1713, five or six thousand of the youth of the country perished by the enemy, or by sickness contracted in the service. From that time to the conquest of Canada, there were constant calls upon the young men to engage either in offen. \$ive or defensive service. The numbers that

- Hutchinoon's Hist. Massachusetto, Vol. 2, p. 183. 
of years increase nount to nty five 1ost flat. e popuin most ly failed. le more in Mas. the year uble the to what nd to be mber of he year. with still

se cause or did it ickness. in either casioned alled the and this he cause ch those , when to 1713 , country ss cone to the nit calls in offen. ers tha:

perished in thése services were unavoidably great. If we may judge from the course of things in the colonies, nine out of ten of these young men would have been fathers of families. Cut off and wasted away by an incessant scene of war, the population of the whole country was checked and prevented. At the end of fifty years, for every young man slain in the wars the loss occasioned to the country was nearly four inhabitants ; so many more would probably have been found in the country at the end of that period, had the colonies remained in a state of peace and tranquility.

$\mathrm{ON}_{\mathrm{N}}$ the agriculture, the settlement and cultivation of the country, the effect of war was still more pernicious. The most important of all pursuits to the colonies, was the settlement of their country. On this depended their defence, their strength and their existence. In the most peaceable and quiet times, this was a matter of much difficulty, hardship, labor and suffering. To collect together a company qualified and disposed for such enterprise ; to quit the ease and enjoyments of domestic peace and abundance ; to carry their families through the woods, ' mountains, rivers and swamps, where there was no road or track ; to construct huts of logs and the bark of trees, to cut down the woods and open the lands to the influence of the sun and the air ; to fence, sow, reap and gather their crops ; this was the beginning of the scene, and $\mathfrak{a}$ series of difficulties which must in some meas; ure be gone through the first year of their re. moval. They had then to watch and guard the ir cattle and their crops against the ravages of the 
bears, wolves and other ferocious animals, with which the country every where abounded; and at the same time to raise their provisions and make their raiment. In the best possible state of things this was a scene of hard living, of hard labor and great suffering; and it was not in a less period than five or six years, that the new settlers could procure the necessaries of life in such quantities as to be comfortable ; or in any considerable degree to be free from the danger and suffering of hunger and nakedness.

Acarnst these difficulties however, they struggled with success, and in a few years found their circumstances more comfortable and encouriging. But when a war brokc out, their dangers and their sufferings often seemed to be without measure, and without end. An attack was suddenly made upon one of their settle. ments, when the inhabitants were unprepared for defence, and without suspicion of danger. The first notice of the approach of an enemy, would be about break of day; the Indians would assault every house at the same time, slay such of the inhabitants as made any resistance, lead the others away prisoners, burn the houses and buildings, and slaughter all their cattle. In this way, several of the plantations were destroyed, rebuilt, destroyed again and then resettied. These were scenes to which every part of the frontiers were exposed, at the breaking out of every war. The effect was, the most advanced settlements were broken up every war; the inhabitants returned to the old towns, and all that their labor and sufferings had procured for many years, was often sivept away in one day. It was 


\section{HISTORY OF VERMONT.}

mals, with cled ; and isions and sible state ig, of hard is not in a at the new $s$ of life in or in any he danger s.

ver, they ears found $?$ and en. out, their med to be An attack eir settle: inprepared ff danger. an enemys ans would slay such ance, lead ouses and - In this lestroyed, resettied. art of the ig out of advanced ; the ind all that: for many It was impossible that the settlement of the country should proceed with its natural progress, in such a state of things. And hence the colonies were obliged to adopt a dcbilitating caution, reserve, and slowness, in making their adrances, and extending their settlements into the country.

IN the year 1752, a proposal was made to effect a settlement on the rich lands at Coos, on Connecticut river. It was proposed to lay out one township on the east side, and another on the west, at the place now called Ncwbury, in Vermont. The governors of Massachusetts' and New Hampshire approved of the proceed. ings, and a large number of persons engaged in the enterprise: A party of men were sent up. the river in the spring, to view the lands, and lay out the proposed townships. Some of the Indians of the St. Francois tribe observed their motions, suspected their design, and forbade their proceedings; at the same time they sent $a$ message to the commander of the fort at Num. ber Four, informing him that they would not suffer the English to settle at Coos.' The In. dian mandate was communicated to the governors of the two English provinces, and such was their fear of the Indians, that they meekly and quietly laid aside the whole business. To such mortifying disgrace and caution, was the agriculture, the settlement and the cultivation of the country, constantly subject. And yet on these, the safety, the wealth, strength, population, and commerce of the whole country depended. Of all objects this was the most important, to the colonies ; and the men, who in that state of things settled a new town, did more important 
services to their country and to mankind, than those who ainused all-Europe with an astronomi. cal observation; a physical experiment, solved a new problem, or wrote an elegant poem, or a celcbrated volume of history or philosophy.

Tнв political effects of the wars were also greatly dangerous, and injurious to the colonies ; they kept them in an almosc absolute dependence on the European powers and monarchs: It was not with an expectation of deriving any assistance from their European sovereigns, that the first settlers came into the eastern parts of America ; it was to get rid of their ecclesiastical authority and intolerance, that they left their native country. When they arrived here; it was in consequence of a patent from James the first ; and they understood their charter as a sacred compact; describing the grants that were made to them by their sovereign, and the nature of the allegiance that they were to bear to him. Their ideas of civil subjection were that birth was not a necessary or an unalienable cause of submission, to any civil government; but that when they left their natire country, all the obligation they were under to the king of England, arose from voluntary compact ; from their own agreement and act in accepting their patent; and by that entering into a voluntary contract of submission and obedience to the king of Eng. land. They had no doubt but that the country to which they came, in respect to its soil, dominion, lordship and sovereignty; belonged to the Indians, and not at all to the European monarchs; and that when they had fairly purchased these of the rightful owners, they had a right to 


\section{HISTORY OF VERMONT. 469}

kind, thain stronomi, solved a oem, or 2 ophy.

were also colonies; -pendence s. It was iny assist, that the of Ameriastical autheir nare; it was the first ; $s$ a sacred ere made nature of ir to him. that birth c cause of but that the obliEngland; heir own atent, and ontract of ; of Eing. e country soil, dolonged to ean monpurchased a right to sct up what forms of governments they pleased; consistent with their patent and charter, by which they had engaged their future allegiance to the king of England.* Whether these principles were, or were not in conformity to the principles of the Einglish laws or monarchy; they were certainly founded on the law of nature; and were therefore of an eartier origin, -and of a more sacred authority than any Einglish law ever could be, which considers birth not only as a local, but as a perpetual and unalienable cause of civil subjection.

I I $_{\mathrm{N}}$ opposition to every sentiment of this kind; the English kings believed that every child born in their dominions; or derived from any of their subjects; belonged to them; and that his very birth implied an obligation to constant, perpetual and unalienable allegiance. In conformity to their principles; they soon discovered that they meant to regard or disinnul their patents as they pleased ; to alter or set aside their charters ; to frame, destroy, or alter the colonial governments as they chose ; and with the concurrence of their parliaments, " to bind them in all cases whatsoever." It is not possible to form anyp idea of the most absolute, despotic, tyrannical power, that can carry its claims beyond this.

$T_{H E}$ colonies, though holding very different political principles; were not in a state to contend with their sovereigns. Surrounded with enemies and involved in wars, botl the English and French colonies' looked to their kings for assistance; and while the ene met with this kind of help, it became necessary for the other

- Hutchinson`s Hist. Massachusctts, Val. I, p. 23I. vol. I: K 3 
to scek the same kind of assistance. A depen: dence on and subjection to the European powers and monarchs of course took place, which excluded every idea, and every desire of independence; and the colonies viewed their relation and connection with the European governments from which they descended, as a matter of necessity, safety, and the highest honor. The British kings and ministers believed that the science of government contained such profound and sacred mysteries, that the people could neither understand nor manage them : the people in the colonies were in such a state of political impotency and submission, that they were in fact looking to the European kings and minis. ters, frequently unacquainted with any part of the business, to manage and direct their governments. This dependence of the colonies on the European kings was attended with many, and with great disadvantages. It embarrassed and perplexed their own governments, encouraged the ambitious and intriguing to be perpetually complaining and meddling, restrained their trade and commerce, prevented the most necessary and useful manufactures, subjected them to injurious restraints, confined their business and pursuits within narrow limits ; and was calculated to keep their minds in a state of perpetuat infancy, inactivity and weakness. And it was not their own desires and inclinations, but the folly and oppressive policy of the British minis. ters and king, that taught them to study their rights, and to understand the danger of submission to their European masters.

SucH was the colonial system of war. Have: 


\section{HISTORY OF VERMONT, 471}

ing both an American and an European origin, it was not to be expected but trat from the one or the other of these sources, it would be alnost perpetual ; and while it continued the evils that were connected with its moral, literary, physical, agricultural and political effects, could not be avoided. In Europe, when their monarchs were engaged in such contests, which ever party gainced an increase of territory, all the sovereigns obtained an increase of wealth, of power, of dependents, of infiuence and authority. It was evidently their advantage to have war as frequent and constant, as the finances and circum. stances of their kingdoms would admit, In the colonies all was the reverse. The system of war served here to inflame and imbitter the minds of men, to keep them unacquainted with the arts and sciences, to retard the population, and prevent the settlement of the country ; and to keep the colonies in a hurtful and disgraceful dependence on and subjection to European kings and nations. And it was not till they rejected this degrading submission and dipendence, that they arose to their proper rank and station among the nations and powers of the world. calculaperpetual d it was , but the h minis. dy their submis-

Hav- 


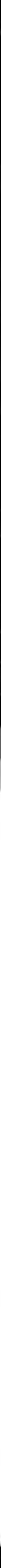




\title{
APPENDIX.
}

\author{
00000 \\ No. I.

\section{An Account of the Variation of the Magnetic Necdle, in the Eaflern States. CHAi. 1. p. 22.}

IN laying out lands in America, the rlircetion of the lines, is generally taken by the Magnetic Necdle. The influminents which have been generally ufed, are the Plain lable, or the Curcumferentor, divided into degrees, and fisted with a Magnetic Needle of inree or four inches radius. Had the greatett profitic care been taken by able mathematicians, it would not have been pollible for $i \mathrm{~h}, \mathrm{~m}$, wilh lisch intrumen's, to have avcrided many errors and miltakes. But in icircely any iuflance has the variation of the necole been kuuwn, or at all itiended to. Many, and almolt endlefs controverfies and lawluits, have ari!en Irom this caule. In many infances no data conld be found. by which it was folfible to come to a junt decition : the variation of it:e Maguetic Necdle, at ste times when the contefted lines w.re run, being unknown. On fuch accomtits, the knowicdge of the Magnetic variations in the iuland parts of + incrica, is become a matter of great importance 0 the people; their iusesclt and property in many cafes, bciog much afficted by it.

From the year $13^{\mathrm{Ca}}$ the direetive power of the Magnet has becn employed with great tuccels, inthe affairs of nuviz tion. But the bit account that we have of an: iplerved variarion in its diirgtion, was by Columbus, in the year 1492, in his firt voyage to : rncica. Uuil that ime, phlo. fophers unitosnly believed that the pole of the Maguce, exaftly coiscided with the poie at the carlh; and they hod us sdea of aly luch thing as a variation. Amidlt :he unconnmon fecors of diffeculty whicts oppoted the

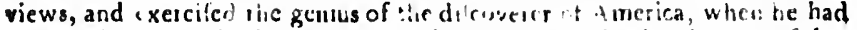
advaliced two huidred leagues weft of she Canary $: \Omega$ nde, nis cumpa's began to fail him; and is was tound no: to p iut o the pols of the edr:h, or exaEtly norih, but une degree to the weft of that point. From this time the varlat:m bigan to be obleived, ano bec inc more and more knowil. For the laft century and a halt, matheınaicians have matie it a reguldr part of their bufine's to obferve it, in different parts of the carth; with the annual alteraious that are contantly taking piace.

In the year 1723 , a very accurate oblerver, G. Graham, of London, difcovered that the maynetic ucedle had a diurnal, as weli as an anuual variztion. And it is now well known to pisilotophere, that from about cight o'clock in the morning, the Maguetic Necdle verges to the wett, until about two n'clock in the aftermoon. When it has attained its grcatcft weltward variation, it gradually returns to the caft, until about eight or nine o'clock in the cuening; when it becomes thationary, usvil the next morning. Tables expreffive of this diurnal valiation are become csmmon; and are to be found in the tranfactions of all philofophical focictics. Thus in the molt regular flate of the Magnetic Needle, it is conftantly fubjett to two variations; an annual and a diurnal one.

The effect of thefe variations are at all times fuch, that the Magnetic Needle can never give to the furveyor who follows its dircetions, a flraight or an accurate line. And it ought not to be ufed at all, where the bufine is requires great accuracy and precifion. It is however fcarcely practicable in America, to fubflitute any thing better in the room of it : Moit of the lines which have been already run by furvejors, wcre ras by the Ncedle; thig 
is mueh the molt convenient infrument that can be carried, or uled in the wonds; the expence of running linee any other wav, would be too great for individuals to bear ; and the furvey ors are not qualified 10 run them by the true meridian. For fuch reafons it is probsble that the Magnetic Needle will llıll continue to be the inftrument, by which the liries will be run, and the townthips be laid o't in America We mult therefore en. deavor to provide the beft remedy we can, for an error or evil, which we annot a afily remove. The beft remedy which the cale admits of, is an aco. curate oblervation of the variation of the Magruetic Needie, at the time when divfsonal lines are sun. This thould be dove bv able mathcmaticians, and in as many places in a fate, it may be. Such obfervations will afford the bett direction, furveyors will he able to find, to enable them to determine what is the real of true direction of their Magnetic lines, - It is with this view, that the following Table is lubjoined.

Mugnetic Observations made in Canada, and the Eastern States of America.

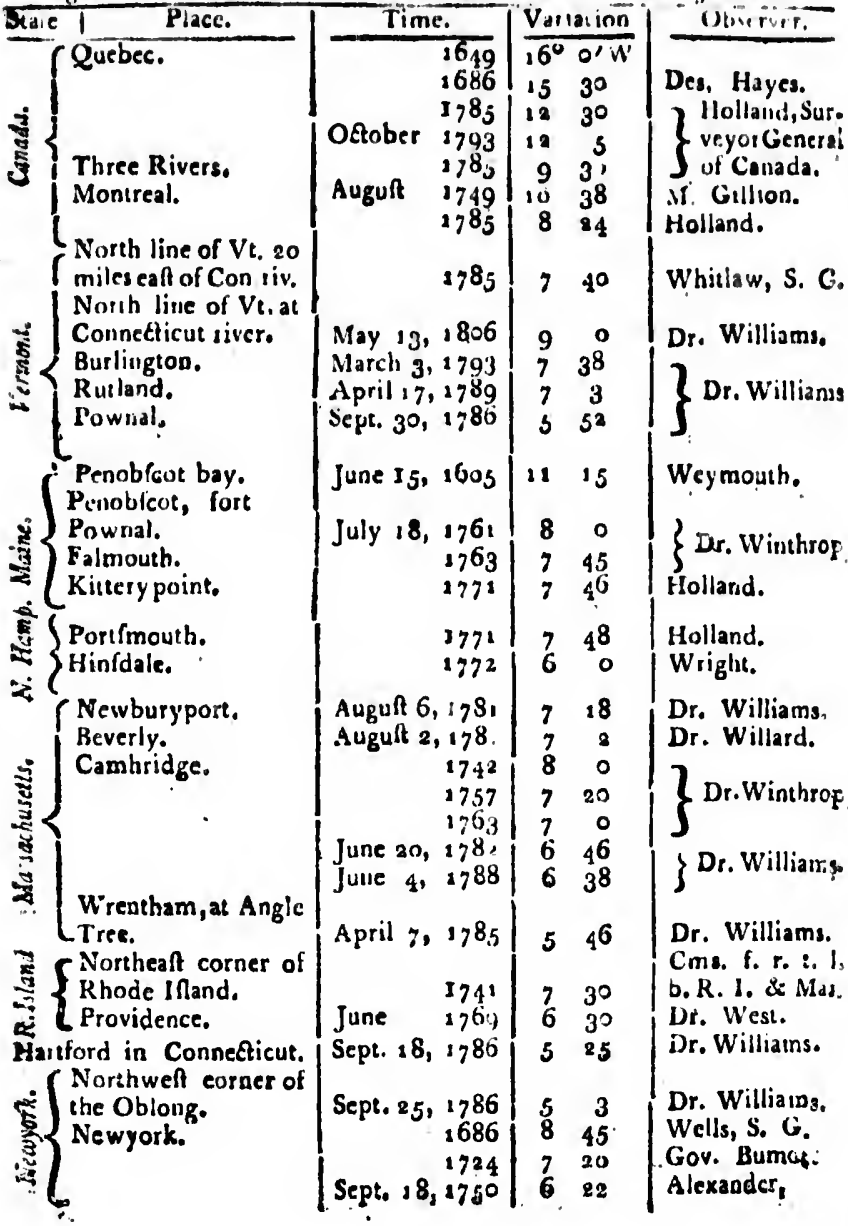




\section{APPENDIX.}

or ufed in the 1 be too great o run them by Magnctic Nee. will be run, therefore en. vil, which we ts of, is an ac. the time when maticians, and vill afford the to determine 1 is with this

of America.

(1) tiveriver.

es, Hayes.

Holland, Sur. veyorGenerai of Canada. Gillion.

olland.

hitlaw, S. C.

t. Williams.

Dr. Willianss

cymouth.

Dr. Winthrop

olland.

olland.

right.

r. Williams

r. Willard.

Dr.Winthrof.

Dr. Williams.

. Williams.

ns. f. r. :. I,

R. I. \& Mad.

West.

. Williains.

- Williains.

ells, S. G.

v. Bumat:

exander,

\section{No. II.}

\section{Ebservations on the change of Climate in Europe and other places.

\author{
Chaf. IV. p. 80.
}

THE change of climate which has raken plaçe in North America, has been a matter of conflarit obfervation and experience. It feems to be the uinverial opinion of hiflorians and philofophers, that there has been $t$ is innre remarkable change of climace throughout all Europe. There are feveral wheromena from which it may be thown with much cettainty, tbat this has been the cafe in teveral places.

In the land of Falefline, about the latitude of 30 or $3 t$ degreet, north. the author of the book of Job makes ufe of fuch language as this, "Haft thou eatered into the trealures of the inow ? Or halt thou feen the trealures of the hail ?-Out of whole womb came the ice ?-And the hoary froft of heaven. who ha'h gendered it P-The waters are bid as with a flone, and the face of the deep is frozen." Job xxxviii, 22, 29, 30. Thefe are probably the words of llofes; and they are expreffive of that degree of coict, in which the furface of water is fo Arongly frozen as to conceal its fuidit:; and refemble the confiflence and hatdnefs of Rone. The degree of heat in which thia effic $Q$ takes place in rivers, ponds and large collections of water, 1 have generally found to be about 25 degrees of Farenheit's thermometer: with a duration of a week or ten days. We thall not therefore be far trom the truth, if we conclude that the extremity of the cold in the land of Midian, could not have been lefathan 25 degrees, in the daya of Moles : And that fuch a cold, was of fome days duration. Such was the degree, and the iffel of the cold in the land of the Midianices, about $32 . t$ centuries ago.

In the writings of David we have alfo a defcription, of what was ellecmed a fevere feafin. "He giveth fnow like wool: He fcattereth the hoar finft like other. He cafeth forth his ice like morfals: Who can tand before his cold ?". Pfalm cxlvii, 16, 17 This account mult have been written tt leaft 28 s centuries ago. The language of the poet docs very ftrongly. exprefs the effed, which the cold had on the feelings of men in that warm dimate. But the account which he gives of the appearance and form of the ice, denotes a lefs degree of cold than what took place in the days of Mofes. When the degree of heat is but 31 degrecs of Farenheit's thermometer, the ice may appear to be caft into the form of morfels and cryftals: And this feems to have been the greateft degree of confiltence, extent and hardnefs, in which the poct had cither feen it, or conceived of it. It mould feem therefore that from the time of Mofes to David, the cold had abated in the land of Paleftine: That four centurics before, it hid the waters as with a flone, and caufed the face of the deep to be frozen: But that now it only calt nut the ice like morfels or crytals. The difference the degree of eold necieffary to produre thefe effects, is about 6 degrees.

We have here an accourit of the climate in the land of Paleftine, fo far back as 28 and $3^{2}$ centuries. Inftead of treafures of fnow, hail, and ice,a frozen deep, and cold which can fcarce beftood hefore, the inhabitants of that country now find a hot, fultry climate; in which fnow and ice are never feen. We have not an account of any meteorological obfervations made ai the places, where Mofes and David lived. The climate is probably much the fame at thofe places, as it is in others of a fimilar latitude and situation. We may therefore make ule of thole which have been made at Grand Cairo, as the molt applicable, and the beft which we can find, to give us an idea of the temperature of the winter in thole parts of the globe. Srand Cairo lies in the latitude of $20^{\circ}$ nerth. According to Mr. Niebur's 
oblervations marle there in the vears 1761 a-d 1762 , the mean heat of thofe vears was $73^{\prime \prime} 6_{5}$ The mem heat in the misuth of January was

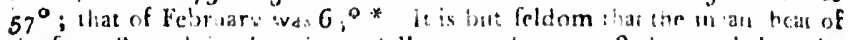

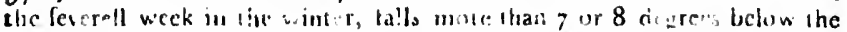

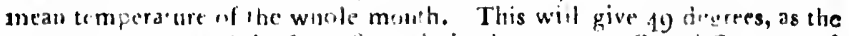
mean 'cimperaturc of the feverrit week. in the wince at Guand Carro. And

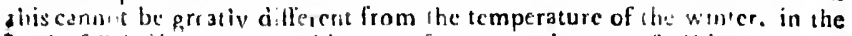
iand of Palcline. From this way of compitarion, we fhall have 24 degrecs of Farenlecir's hermnmeter, as the aliciation which has taken place in the feverity of rhe winters in that connirv, fince the time of Mnes.

The climate in lialy ic alios tound to be very different now, form what it was 18 centuries ayn. Virgil, the celebrated poet, was diltinguilhed alfo by his knowledge in agriculture. In his Georgics he is trequent!y giving advice for the fecuri'y of canle, againt the dangcrous effects of icc and fnow. Ilis dircetious were defigued for the conntry round Mantua or Nap'es, his natuve place, in the lautude of $41^{\circ}$. Mentionirg Calabria, the molt louthern part of lia!, he lpeaks nf the freczing of the rivers. as an cuent that was conmonol, in be crpetted. Pliny, Juvenal. and Elian, writers in the fint and tcounl centurirs, fpcak nt ice and fnow as what was common in ltaly. Ore of the fe writels; Aban, has a chapter which confills altogether of influctions buw to fith for ecl. when the water is coverced with ice. Ihe desree of cold necuffarv to effect this, cannot be flimated at a lefs, degree than 2.5. From the meteoro!ogical obfervations which were made at Rome in the year 178 ? and 1,83 , it appears that the mcan hcat in the mointh of Jusuary a: that place, is now 46 ciegrees; and that the mean heat of the coldseft week in the winter was 42 degices ; 17 degrees grcater than that, in which the peimariene freczing of rivers akes place. The change of climate therefore in Italy cluring the latt 18 centuries, cannot have been lets than 7 regrees; but from the inaccuracy of the ancient accotrrs it may have bcen man more.

A fimilar change hastaken place in the country round Conftantinople; and the Fuxine or Black Sca. This we collect from the works of Ovid: This celcbrated poet was banithed to Tomes, by the Roman cmperor. This place is in the latitude of $44^{\circ}$; and laes ncar (he coalt of the Euxine Sca. The poct fpent feven ycals in his lanilhment at this place. abuut the middle of the fitt century. Hc intorms us inat he law the Euxine Sea envered with ice: Th:at he walked upon this ice; and chat oxen and carriages paffed over it. He inoes farther. and adts, that when he called for wine in a fevere feafon, it was prefentcci to him in a ftate of congelation : And that the fnow in many places, was never ditrotved duing the lut..mer featon. Tourncfort oblerves that in the didys of Conltantine, the Aresght of Byzantium was frozen over: And that in the year 401 , l be Euxine Sea was covered with ice for 20 days 10 gether. W'e have not any meteorological cblervations to flate with cxictincls, what the prefone temperature of that elimate is. But nothing would be more uncommon and extraordinary, ehan o fe tlis fea fruzin over now. In ,667, the Turks were greatly aflonilhed at the aupearance of inme icc at Conttantinople: And in all the adjecnt counery, inlterd ot a liozen tra, frozen wine, and perpetual fnow, they have now a ine modcrate warn climace; one of the molt luxuriant, and delightol, that is to he foumel uponthe fase of ihe carth. So tar as we con judge from the gereral furm, mona, the change of the ciimate there, has been iully equal to wist was taken place in lialy.

* Voyage, Vol. $I$.

+ Iphem. Soc. Metor. Palat. ODfervationes Romanr, Tom. II \& IIT, 
: mean heat of of January was r in ant hicat of are.s beluw the birarees, as the and Carro. And win'er. in the all have 84 dehas taken place : of Mo es. ow, froin what ittinguithed alio quently giving cts of icc and and Mantua or Ing Calabria, the the rivers, as an ial. and Elian, I fnow as what a chapter which ien the water is this, cannot be cal obfervaluons appeals that the 6 ciegrces: and 12 degiess ; 17 of of rivers lakes he lalt 18 centunaccuracy of the

Conntantinople; works of Ovid: Roman emperor. it of the Euxine place. abisut the the Euxine Sea as oxeu and caren he called for of congelation : in the fur..mer $c$, the Areight of - Euxine Sea was - meteorological peraiure ol that extranrdinary, ks were greatly And in all the perpetual fnow, molt luxuriant, 1. So far as we ciimate tiscre,

Tom. II \& III,
The fame alteration has been obferved upon the Alps and Appenines. Thefe are the higheft mountains in Europe, and divide Italy from France, Switzerland and Germany. The march of Hannibal's army over thefe mountains, was one of the molt memorable exploits of antiquity. In their accounts of it, Livy and Polybius in almoft cvery line, are mentiouing the extreme difficulty and fufferings which arofe from the fevere frofts, ice and fnow. Thefe mountains are eafily palfed now. Armies have frequently croffed them without any uncommon fufferings, from the time of Francis the firt.*

The change of climate has been alfo very remarkable in Germany. Two eircumftances have marked this with certainty. By the account of Diodorus Siculus: 1. "The great rivers which covered the Roman provinees, the Rhine and the Danube, were frequently frozen over, and capable of fupporting the molt enormous weights. The barbarians who often ehofe that fevere feafon for their intoads, tranlported without apprehenfion or danger, their numerous armies, their cavalry, and their heavy waggons over a vaft and folid bridge of ice. Modern ages have not prefented an infance of a like phenomenon. 2. The reinder, that ufeful animal, from whom the favage of the north derives the belt comfort of his dreary life, is of a ccaftitution that fupports and even requires the moft intenfe cold. He is found on the rock of Spizberg, within ten degrees of the pole; he feems to delight in the fnows of Lapland and Siberia. But at prefent he cannot fubfilt, much lefs multiply in any country to the fouth of the Baltic. In the time of $\mathrm{C}$-lar, the reindecr, as well as the elk and the wild bull, was a native of the Hercynian foreft, which then overlhadowed a great part of Germany and Poland." +

Thefe accounts will affilt us to form fome general idea of the climate of Germany at that time. The freczing of the Rhine and the Danube is mentioned, as an event that was annually to be expected; what the barbarians always found to take place in the fevere fealon; and to fuch a degree, as to afford them a certain and a fafe palfage for the heavieft burthens, and for the largeft armies. This account of the fi:ength, firmneis, and duration of the ice, conveys the idea of a winter equal in all its effeEts, to that which takes place in the uncultivated parts of North America. The rivers are here conitantly frozen every winter. The inhabitants find by confant experience, that at that fesfon of the year they can tranfport their heavielt effects, and the greateft weights, with fafety, ccrtainty and convenience. The mean heat of our winters in fuch places, is from 15 to 20 degrees. In fuch a cold, the rivers and ftreams will be lo conftantly and ftcadily frozen, that the inhabitants find a certain and a fafe palfage every winter, over the rivers and lakes. This fecms to have becul very much the fate of the ancient German winter. From the obfervations which were made at Vienna, latitude ${ }_{4}^{\circ}-12^{\prime}$ north, in the years 1779 and 1780 , it appears that the inean heat there in the mo th of January was $27^{\circ}, 5$; in February it was $33^{\circ}, 23$. At Ratifbon, latitude $48^{\circ}-56^{\prime}$ north, in the years $178, \& 1782$, the mean heat in the month of January was found to be $30^{\circ}, 52$; that of February was $30^{\circ}, 76$. At Manheim, latitude $49^{\circ}-27^{\prime}$ north, in the years 1781 and 1782 , the mean heat in the mouth of January was $35^{\circ}, 08$; in February it was $35^{\circ}, 8$. 7 The mean of thefe, $31^{\circ}, 3$ in January, and $33^{\circ}, 26$ in February, will accurately exprefs the prefent temperature of the German winter on the Danube and the Rhine. The time when the batbariaus be-

* Phil. Trans. Vol. LVIll, for 1769, p. 58 , \&c.

+ Gibbon's Roman Hiftor y, Vol. I, p. 346 .

† Ephem, Soe. Metcor. Palat. Tom, I, II, III, \&ic,

VOL. I. L 3 
gan their inronds into the Roman provinces was ahout the year ase. AC. cording to this compuation, the change ol c'lmate in Germany has beea between 11 and 16 degrees. in 15 and a hoif cencuries.

The o her uftance men inned by the hillonan, and which ferves ro mark the climate in Germany in he ume of $\mathrm{Cr}$ ar. Wis the apearance of the reinter The want th comingies in which he now rifi's, are Sweden, Ruflia \& Lapland. F n'n the abfervations made at tbu. laticude $60^{\circ}-29^{\prime}$ nonh from the yca' 1750101761 , the meau heat in the mouth ol January, was found to be $19^{2} 5^{8}$; tha: ot February, was $29^{\circ} 3^{8}$ it Peteifburg, latirude $59^{\circ}-56$ ! vor: h. frnm the ve3. $176: 101777$ the mean heat in January, was $10^{\circ}$; in February the mearl lieat wav $166^{\circ}, 46$. The mean of thefe, $14^{\circ} 8$ in J ntarv. and $18^{\circ} .9$ in Februarv. is the temperatuie of the winte, in that patt of the globe. ${ }^{*}$ I hefe are the warmctt climates in which the reindecr dares now fublitt. II mav therefore with much probabilitv be inferred, that this $w_{d s}$ the tempsraure of the German wiuter in the days of $\mathrm{C} x \mathrm{f}$ ar, 19 and a half centurits ago. Heuce the aliesation of climate in Germany duing that fpace of time, has been about 16 ilegrees. It teems to be a c nfirmation of the truth and prupriety of the de different methods of computation, that they bo'h affird much the fame refult.

From the fe accounts it appcars with a decilive evidence. that ihe climite, in the courfe of feveral centurics, has rimatkably changed at Paleltine, in Italy, around the Euxine fea, at the Alps, and throughnut all Germany, Through all this vaft extent of country, the climate is now become 16 ir 17 degrees warmer than it was 18 centuries ago. The continent of tim rica in fimilar latirudes, is ftill fubject to a great degree of cold. If the metco. rolngical obfervations which have been made at Williamburg, Cambridge, Quebec and Hudfon's Bay in Anerica, be compared wi h thole which have been made at Algiers, Rome, Poictiers and Solyfkamfki. places whole latitudes are nearly equal; + it will be found that the kuropean contmene ja now 12 degrees warmer than that of america. Mauy inquiries and fpeculations have been propofed to account for this extreme cald of Ameri. ca. From the accounts which have been mentioned, it appears that 17 or 18 centuries ago, the continent of Europe, inftesd of being 12 degrees warmer, was fubject to a cold 4 or 5 degices greater, than that which now takes place on the continent of America. The proper inquiries therefore feem to be, whence is it that the European coutinint is become fo mi:eh more mild and temperate than that of America ?-Whe: her the later will not in a courfe of time become equally warn and temperate as the wirmer P-Whether the climates of bo'h will not gradually becume more equal, uniform and mnderate, than thes now are ?-And. whether culti. vation is fufficient to account for thefe changes? For whatever the taufe may he, the fact feems to be certain, the heat in all that part of the eaith, of which we have any ancient accouts, has bet.l increafing from the earlied sges.

\section{- Kirwan's eftimate.}

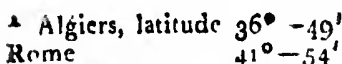
Prictiers Soly kamiki $41^{\circ}-54^{\prime}$
$4^{\circ}-39^{\prime}$
$59^{\circ}$ $\mid \begin{aligned} & \text { M. K. } \\ & 72^{\circ} \\ & 59^{\circ}, 5 \\ & 53^{\circ}, 8 \\ & 32^{\circ}, 5\end{aligned}$ 
or 298. ACo ail y has been

erves to mark rance of the are Sweden, ade $60^{\circ}-27^{\prime}$ h of January, t Peterfbur , heat in Jan. The mean of erature of the ates in which irobabilitu be $r$ in tre days of climaie in es. It teems rent methods

the climite, Paleltine, in all Germanv, :ome $16 . r 17$ of tin tica If the meteo. ;, Cambridge, thole which p'aces whole ean con:tnene inquiries and Id of Ameri. ars that 17 or 12 degrees at which now ries theretore me fo mich he latter will te as the turpecume more hether cultiver the caule the earth, of on the earlies

\section{No. III.}

\section{An account of Frog' dug out of the carth at BURLINGTON. Chap VI. p. 154 .}

THE accounis which noiual millorv has recorded of the difenery of coads and fiogs, in fi ualonsin which it has heen fuppo'ed it was impolts. ble they thou in exilt, have bren of a fingular and exiraoidunary kind.

A verv remarkabe influnce of this nature, has lately tallin under my own oblervation. On ()Etnher 2th, 1827 , Mo!es Catlin, Etq of Burlington. was digging a well a tew rods dillant trom his dwellung houfe. His houle was abour inentr inds frouh of the College. on a haid gravelly loil and on the highelt iand in the lietghborhood. I'hen the workinin had dug aboul five leet below the lurtace of the grould, they found fix frogs, which did nut appear 10 he ill a torpid or weak ltate; liut as lonil as they we re throun out of the earth, dicovesed the full powers of activity and health Two of thele trogs lay logether in the earth, the others wereferarate : molt, or a!l of them were coveres, or lay under linall ttones. Oc. tober the $13^{t h}$, two more of the tame kind were found ; leparare, but under Imall finues as before Oetrober the $14^{\mathrm{th}}$, in the morning five more were lound at the depth of abnit eleven feet from the furface ot the ground. T.wo of thefe lay together, the others were feparate; none of them were covered with anv llones. but furrounded with hard giavelly carth Alex. ander $C_{d i l i t i}$ Elq a man ol the molt refpectable charaeter, alfured nie, thit hela $w$ the wiskmen dig up thrre of thefe froins: and that anothea man was prefent, when the norkinen dug up the fourth.

At mi requeft $\mathrm{Mr}$ Cailin prelerved two of them in a tumbler. Eighe hnuis after ihey were dus up. I viewed them with all the attention and care in my power. The y ucre of the fame kind as the frogs which are generaily leen in this vicinity. One of them appeared to have attained its full growth; the other was not of the full fize. Their bodies did not appesr to be lhrivelled, or in any degree emaciated, but full, plump and health: Their eyes were lucid and briluant, without any appearance of defect. Thei, limbs fe.merl to be in perfe 8 proportion and order; and their claws Inne. Airder and delicate. Relpitation appeared to be firong and unembarialtid; and cariied on with as inuch eale and regularity as in any otlier frogs. On moving the cover from the tumbler in which they were, contined, buth of them jumped out fiom the gla la $_{3}$ and hopped round th. roum; and we had 10 chate them leveral numes round the room before we could caich them. They leeined pertectly well to underftand the beft wav of cvarling our purfuit; did not attempt to leap againt the wall or furnitule. but kept in that part of the room where they were apparently heft lecured by the wall. chairs and rahles. Nisr have 1 ever feen more activity, fprighilinels, or Aronger powers of life and action in any frogs, than what appeared in thefe two, eight i,surs after they were dup out of the earth; and had been preferved in a tumb:-r, without any kind of fond or nourifhinent. To render the evidence of thele fatts as c'mpleat as the na. ture of the fubj:ct would admit, we pre'erved both the trogs in Ipirits and exlibited them to the view of the Audens in the univerfity; and they are now in poff. firon of the prefident of that feiniriary. The workmen funk the well to the depth of about eightecn leet, bus cid not find any more of thefr auimals.

October the 26th, the workmen were digging another well for Mir. Cata Lin, about eighty rods north eaft of the College. The foil was of a loofe, 
gravelly kind. At the depth of eleven feet, they dug up a frog in this well. Upon examination, 1 found it was of the fame kind, form, fize and appearance, as the frogs in the other well; and had the fame phenomean of health, vigor and activity.' To afcertain the internal fate and contents of this frog, we opened it. On diffection, it was found to contain a fmall quautity of blood. The heart, lungs and other entrails, were in a natural and perfect tlate. The inteftines contained a white mucus, of a middling confiftence. The intermal parts neither appeared to be loaded with fat, or emaciated by leannefs; but to be in a fate that denoted regular but mode. rate nourilhment. And nothing like putridity, deficiency, or decay, appeared in any part of the animal:. Uncomfortable weather coming on, the workmen did not fink this well to arsy greater depth.

It is fearcely to be expected that more compleat evidence ever fhould be found attending any inftances of this nature: And whether we can account for them, or not, their reality camot, I think, be called in quellion.

In what manner thall we go about to explain the philofophy of thefe frogs ; or to account for their formation, fituation, and life ?

Could thefe animals have been produced in fuch a fituation by the earth ? The dottrine ol equivocal generation docs not feem to lave any thing in theory, obfervation or experiment in fupport it. No one thing in nature appears to be the refult of chance, or accident. Every plant, every tree, and every body in the whole fyftem of nature, is evidently the refuit of defign, contrivance, and adjufment; and appcars to be preferved and regulated by ftated and permanent laws. The object or the body is not to be named, in the hcavens, or in the earth, which appears to be produced, to be goo verned, or to be moved by chance or accident ; hat is by no caufe, or law at all. Leaft of all is this to be expected in animals, every one of. which has an appropriace form, conllitution, inclinations, and manner of life, mo. tion, and propagation: That men thould be produced by corruption, or that the rocks and woods fhould engender flags and tygers, would be an affertion too improbable and ludicrous for folly to make, or for infidelity to believe. It has been contended that inferts are bred by corruption and putrelaetion. Malpigi, Swammerdam, Redi anci ctiners have confuted this doctrine; and fhown that it does not agree with obfervation. The refult of their inquiries and oblervations is, that moft of the infects are derived $e x$ ovo, and inat they depofit their eggs wherever they can find a gt place for incubation; in water, flefh, fruits and vegetables, in or about: the bodies of animals, in the feathers of birds, hair of beafts, fcales of fithes, and in every acceffible part of nature. Nor will experiment help the doctrine of equirocal generation in any degree. From the corruption of a body arifeth not activity and life, but a diffolution of its parts. You cannot reduce a piece of flefh to putrefaction, and out of that putrid mafs make an animal body, which thall have a head, a heart, entrails, veins, and blood veffels; all of which are necelfary to conftitute a living creature. Nor can you take a piece of rotten cheefe, or meat and make out of it a bandful of mites or worms, any more than you can form it into lions or whales. A doctrine then which has nothing in theory, obfervation or cxperiment, to fupport it, cannot be advanced with any apptarance of probability to account for the formation of thefe frogs.

Culd they have becn preferved or exilted in the earth for a long num. ber of years? This feems to have been the cafe, and does rot appear to be. contrary to the laws and phenumena of nature. Every animal that we are acquainted with, has apparently two modes of exifting, neeping and waking.' When awake, all the fprings of nature feem to be active and in motion: when aleep, the organs of the body feem to be lufpended as to theirs, 


\section{APPENDIX.}

og in thi , fize and ienomena d contents in a fmall a natural middling ith fat, or but mode. decay, apng ont, the ver fhould we can ac1 queftion. $y$ of thefe

the earth ? in theory, ire appears , and every efign, congulated by be named, , to be go. ife, or law of. which of life, mo rupition, or ould be an $r$ infidelity uption and confuted ion. The infects are can find 2 or about: cs of filhes, Ip the docption of arts. You butrid mafs ails, veins, g creature. out of it a to lions or tion or exof proba-

long numpear to be hat we are dd waking.' motion: to theirs
Ativity and exertions, but the circulation of the blood, and the active powers of life Aill remain. And trom the one 10 the other of the fe fates all the animals of which we have any inlormation, have a regular and natural tranfition. When wearied or icduccd by activity and exertion, the animal frame relaxes and yiclds, and we find in reft and feep both relief and sefrelhment. When the body has been relieved and refrefhed by reft, the powers of nature feem to be recruited, the pulfe gradually quickells, the organs of fenfe refume their functions, and the animal awakes from neep. In moft animals, both thefe flates are neceffary to his healı and life; they regularly fucceed each other, and the one is as natural and neceffary as the other.

In fome animals this alternate and regular fucceifion of fleeping and wak. ing is either not kept up, or it is fubject to very long periods of time. Bears, Serpents, Toads, Frogs, Flies, and various other animals are known to live through the winter months in a torpid ftate. At the approach of eold weather they retire into the earth, to the bottom of waters, or to fome place of fecurity, and do not appear again till the warmth of fpring has foltencd and vivificd the earth. Thev then leave their places of concealment, and come forth into the atmolphere: apparently weak at fith, but not emaciated, lean, or deprived of their flelh.

During this period "of their torpid flate, the appearances arc, that they exif without any regular lupplies of food; but not without fomething that operates to their prefervation, fupport, nourifhment, or continuation. As nature is not wearing away by continued attivity, or by conftant per. fpiration, it thould leem that it does not require conftant fupplies of lood, fo recruit, what in the torpid ftate is not much fpent or wafted. An animal then may exift in the torpid flate without regular fupplies of fond or vietuals, to reffure or recruit that wafte of nature, which al ways takes place in the active, but does not feem to have much effect in the torpid thate of exiftence. But fill, fomelliing is neccfiary to preferve the animal in that fate in which it went to fecp, and fell into the infeufible lethargy. In fome animals, watc: antwers this purpofe; in others, earth contribu'es to the effct ; in others, a rock, or a tree, or ary thing that tends to preferve and fupport the powers of nature, and prevent their being exhaufted. And to every fpecies of animals, the author of nature feems to have given if fuculty, to difcern and felect what is belt fuited to their purpofe.

How long may an animal exift in a torpid, or in an infeufible ftate ? Mariy of them, we know from obfervation, do annually live one halt the year in this ftate. We have well attefted accounts of a man livinit miny days in a ftate of fleep or torpor ; ${ }^{*}$ of flies, immerfed and corked up ir a bottle of Madeira wine in Virginia, and many months after conning tolits. when the wine was opened in London; $t$ of a toad that lived eighty or a hundred years in the heart of an old oak at Nantz $\ddagger$ And if all the powers of animal life may be fufpended in fuch animali for fo lony a period, what thould prevent their continuance in fuch a Aate for a much longer period of time; for hundreds, or thoulands, or ally given number of years $?$ Or who would pretend to aftign any data, to determine the maximum, to which fuch a ftate might extend? If all circumftances thould remain the fatme, as they were when the animal firt went into the torpid ftate, it does not appear tbat the powers of life muft neceftarily wafte away,

\footnotetext{
* Philofophical Tranfactions.

+ Franklin.

\$ Memoirs of the Academy of Sciences for 1719 .
} 
for want of food, or of fomething to fupport and preferve them. And a they were preferved. whenever the an:mal is by any means brought inte a Gruation in which the lathargy or torpor thould natually go off. what Should prevent its tranfition in the nutural fta $e$ nf animal life and viyor $;$

In what manter was it pofible that the frogs honuld ever have aftumed, or been placed in fuch a fituaison? The ground inond Mr. Catisis's houle in which the well was dug. was of a haid, compact, eravelly foil, intermixed with fome fmall ftones; but without any appearunce of pures, vacuities, or currents of water; and is the highelt land in the vicillty. The fpot of iand in which the fecond well was dug, was of a lonfe g avcl. ly foil, wi:h fome imermixtures of clav : and on a fmoll eminence ur hill. There was not any thing in the fruation or appearance of cither, from which any probability or conjectuse could ari'c, that eit her of thefe piaces were ever covered or overflewed by the witters of Lake Champlain, or from any of the adjacent rivers. Both thefe places however. had lill witt. in fix or feven years, been covere.l with heavy timber; and which protido bly had never been touched by the hand of man, till it uas cut choun a few vears agi, to make way for the feulement of buriington. In thei? original an: uatural ftate, rur woods are damp, moilt, and miry. The trces are alicrnarely growing up, decaring. ruting, falling down; and new ones arifilg ub, from ihe devays, and $i, 1$ the plares of others. In this pro. cefs n:thing is morc coinmon. than for holes and varuities to appear in that pristics and in the roo's, of the old and decaying tros; thele vacuities and fifiuses are of different figures and dimenfons, and every where to ba tound in the uncultiva ed lands. And fuch a kind of procefs has piobably keen gaing on in the woods of Verinont, from their firlt produktion unit now. In the fucce ffive changes that nature in this refp \& may hove pal. fod through, there does not feem in be any thing unnatural or imprishable, inthere having been times, places, and circumllances, in whirh fiogs mizht have been conveyed in their egas, or alier their fuil growith have found a partage leveral fee below the lurla e of the earth; and thus made theis way ilte livations, in which the powers of life might oe preterved, but trom which they cmild no' fuld anv paltage or wa, no elcape.

Thr. cenj Etural merhod of raloning, may 1 believe lerve to account for the ph. lical foffibiticy of facts, which we are crrtas have taken place; but it is fir from bcing certain that they do in fact explait: the actua! procele of rature, in the prelervation of luch animals. And 1 am in mucl: doubt whether the obfervations rn the urpid fatc of animals, will apply to the cale of the frogs. It did no: appear to me that any o! thefe frogs were in a torpid ftate, when they were dug up; the phenomena rather denoted that they were in the full powers ot animation, attivity, and healih ; and tha: nothing was wanting for their extrion but treed am from heir con. fined and unnatural fi uation. Upon diffecting one ot them, no one of the appearances delioted that it had iner without fornc kinil of fond or nourifhment; but that it had in tact derived tumethin; from the earth, which formed the regular mucus that was fpread throu, the inieftines; and in

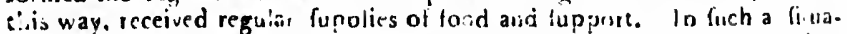
tion, it is probable, ut might have iived as !ong, as the earth contumed 10 atford the moiture and aliment nece ffary for ins lupport; bur when treite hould have been carried off by craporation, droughi, wr being cxpofed to the lun and winds, the life of the animal conid not have been prelerved.

Inltead then of pretending to give a fuli and adequate explandion of thefe mylteries of narure, I have only ftated what nccurred in my nind an the fuhject. When there thall be more in ufis. :ion derived irom as and oblervation, it is not improbable that ii: inprovers of natural 2. thy will be able to give a more fatisfactory account and explanation $s$ ! hele ex:raordinary, but well attelled phenomeat. 
em. Arid मे inught into a to uff, what and vieor rave affumed, Jatiin's houle y foil, interice of putes, the vicionty. lonfe g avel. nance or hill, cither. from of thefe piaces Ehamplain, or had lill witt. which probso cut down a on. In their? miry. The wn; and riew In this pro. appear in the : vacuities and where to bo $s$ has pinbably oduftion un i? may have pal. or improbable, rhfiog might It have found a is made thri: frelerved, but e.

to account fos cn place; luv: actua! proccls n muct: doubs I apply to the frogs were in aiher denoted heal:h; and om their con. no onc of the fond or nour. earth, w!lick tiuses; and in fuch a firra. h continued to ut when ineic na expoled to 1 prelerved. xplariation of io my aind derived from ers of natura! explanation \&?

\section{No. IV.}

\section{Observations on the fafcinating power of Serpents. Сна Pт:} V1, P. 156.

IaHEN the iemarks relpeding the fafcinating power of Serpents, inferted pige 1 is 6 was witten, I bad not met with any imerican ob'ervasion.s which appiarid to me to be fufficienily accurate to afcer:ain the lact, or in jultify any decifion on the lubjett. I have fince been favored with oblervati ins which appar to be mirked with piecifrnn and accuracy, and mas ifford furiher intomarion in ihis myfter mys part of natural hiftory.

This lubj \&f was mentioned by Dr Cottun Mather, fo early as the year 712 In 1 comenunication which he made to the Roval Soclety of London, he ireats of the Rattle snake of America. and rela'es a ftury, as he fays, $c$ nftantlv affimed bu the Indians, viz. "that ihef(' Snakes trequently lie coiled at the boutum of a large tree, with their eves fixet on fome 'quirrel above in the tree, which though freming by his cries, and leapming about to be in a fright, yet at lalt tuns down the tree into the jaws of this derourer."

The Hon. Paul Dudlev of Roxburr, M. Irichufetts, Fellow of the R ryal Society of Loudon. and Cirict Jultice of the Supreme Court in Wartachu. fetts, about the year 1721, wiste thus to the Royal society t tha he " would not pretcond to anfwer for the truib of every ftory he had weard of their charming or powet of fafcination: iet he was abundantly fatisfied from feveral witniffrs, both Englith and Indian, that a ratele fnake will charm boch fquirrels and birds from a trce into his mouth. Mr. Dudley was told by one of undoubter probity, that as he was in the woods he ob. ferved a íquirrel in greal diftrels dancing from one bough 10 ano'her. and making a lamentable noife, till at laft he came down the Iree and ran behiud a log ; the prrforr going to fee what was becorne of him, lpied a large frake that hid fwallowed him.

"Mr. Dudley is the rather confirmed in this relation, becaufe his own brother, being in the woods, opencd one of thefe fnakes and found two Atriped fquirrels in his beily, and beth of them head foremolt. When they cliarm, they make a hoarfe noife with their mouths, and a foft ractle with their tails, having the eve at the fame time fixed on the prey."

Beverly, in his Hiftory of Virginia, cdit. 2. p. 260 . Lond. $1722,8 v o$. oblerves, that "all forts of fnakes will charm both birds and fquirtels, and the Indians pretend to charm them. Scveral perfons have feen fquirrels run down a tree directlv into a fnakc's mouth : They have likewite feen hirds fluttering up and down, and chatteriug at thefe fnakes, till at laft they have dropped dow. befure them."

In the year 1748 , M. Kain, profeffor of aconomv in the Univerfity of Abo, in Swedin, was fent into North America, for the particular purpole of making obfervations on the Natural Hiftory of the comntry. During his Aay in New York, he paid particular attention to this fubj- $\&$, of which he gives the following account :- "Mntt of the people in this country afcribed to this fnake a power of fafcinating birds and fquirrels, as I have de. frribed in ícveral parts of my jiurnal. When the fnake lies under a tree, and has fired his eyes on a bird or fquitrel above, it obliges them to come down and to go directly into its mouth. I cannot account for this, for I never faw it done. However, I have a lift of more than twenty perforis, amnng which are fome of the moft creditable people, who have all unani: moufly, though living far dittant from each other, alferted the fame ining.

- Rhil. Trans. No. 339. + Phil. Trans. No. 376. p. 292. 
They affured me, upon their honor, that they have feen, at feveral timee, thefe black fnakes fafcinating fquirrels and birds which fat on the tops of trees, the fnake lying at the foot of the tree, with its eyes fixed upon the bird or fquirrel which fits above it, and utters a doleful note; from which it is eafy to conclude with certainty that it is about to be fafcinated, though you cannot fee it. The bird, or fquirrel, runs up and down along the cree eontinuing its plaintive fong, and always comes nearer the fnake, whofe eyes are unalterably fixed upon it. It hould feem as if thefe poor creatures endeavored to efcape the fnake, by hopping or running up the tree, but there appears to be a power which with.holds them; they are forced downwards, and each time that they turn back they approach the nearer their eneny, till they are at laft forced to leap into its mouth, which ftands wide open for that purpole. Numbers of lquirrela and birds are continually running and hopping fearlefs in the woods on the ground, where the fnakes lie in waic for them, and can eafily give thefe poor creatures a mor. tal bite. Therefore it feems that this fafeination might be thus interprea ted, that the creature has firft got a mortal wound from the fnake, which is fure of its bite, and lies quiet, being affured that the wounded creature has been poifoned with the bite, or at lealt feels pain from the violence of the bite, and that it will at latt be obliged to come down into its mouth. The plaintive note is perhaps occafioned by the acutentfs of the pain which the wound gives the creature: But to this it may be objected, that the bite of the black inake is not poifonous. It may further be objected, that if the fnake could come near enough to a bird or fquirrel to give it a mortal bite, it might as eafily keep hold of it, or, as it fometimes does with poultry, twift round and Atrangle or ftifle it. But the chief objection which Jies againt this interpretation is the following account, which I received from the moft creditable people, who have affured me of it. The fquirrel being upon the point of running into the fnake's mouth, the fpectatore have not been able to let it come to that pitch, but killed the fnake; and as foon as it had got a mortal blow, the fquirrel or bird deftined for deAruction flew away, and left oft their mou:nful notc, as if they had broke loofe from a net. Some fay, that if they only touched the fnake, fo as to draw off its attention from the fquirrel, it went off quickly, not ftopping till it had gnt to a great diftance. Why do the fquirrels or birds go away fo fuddenly, and why no fooner ? If they had been poifoned or bituen by the frake before, fo as not to be able to get from the tree, and to be forced to approach the Inake alwaya more and more, they could not, howeve:, get new Atrength by the fnake being killed or diverted; therefore it feems that they are only inchunted, whilf the inake las its eyes fixed on theri. However, this looks odd and unaccountable, though many of the worthieft and moft reputable people have related it, and though it is founiverfally be. lieved here, that to doubt it would be to expofe one's felf to general laughter."

Thefe obfervations clearly fhow what has been the general fentiments of the people upon this fubject, from the earlieft fettlement of the country. The opinion formed by the original inhabitants could not be derived from books, fpeculations, or philofophical theories ; but mult have been formed from what they had themlelves oblerved and feen. Thofe of our anceftors whofrequently met with thefe ferpen:s in the woods, found the Indian accounts to be true, and embraced the fatne opinion, aod it feems to have been admitted by both, as a well known matter of fact.

The accouncs however which they have given us of this matter, do not amount to the higheft evidence the fubject may admit. They clearly thow what has been the general fentiment in the country refpecting the fact, but they do not contaili the obfervations and declarations of perfons, who have themfelves been the obfervers or aetors in any of thefe extraordinary tran:attions. The following communications will be found more circumfon, inal and particular. 


\section{APPENDIX:}

at feveral timee, it on the tops of s fixed upon the te ; from which fcinated, though $\mathrm{N}$ along the tree he fnake, whole thelc poor creaning up the tree, ; they are forced roach the nearer th, which fands irds are continu. round, where the creatures a morbe thus interprethe fnake, which nounded crcature $m$ the violence of $\mathbf{n}$ into its mouth. of the pain which eted, that the bite o objected, that if o give it a mortal etimes does with ef objection which which I received it. The fquirrel th, the fpectatora $d$ the fnake; and d deflined for deif they had broke he fnake, fo as to kJy, not fopping or birds go away oned or bitten by and to be forced ild not, however, therefore it frems es fixed on theri. yy of the worthieft fo univerfally bea general laughter." eral fentiments of ht of the country. t be derived from have been formed fe of our anceltors nd the Indian ac$d$ it feems to have is matter, do not They clearly how ting the fact, but berfons, who have traordinary tranfmore circumftan.

\section{Arlington, Feb. 1795.}

IiN your Natural Hilfory of Vermont, you have mentioned lomething concerning the rattle and black fnakcs cliarming birds, which does not reduce the matter to abfolute certainty. If you think th" "lowing account on the fubject any way interefting, it is at your fervice.

TIMOTHY TODD.

WHEN I was a lod, in ranging the fields for birds eggs, I heard a thrulh making her ufual nnife of diftref, and fuppofed fome boy was taking its neft or young: Approaching towards ber noife, 1 difcovered her circling the air not many feet from' the ground, fhewing every fign of diftrefs. Having viewed her fome minuies, being unable to accourit for the phenomena, I at length difcovered the largeft biack fnake which I had ever feen, lying firctched out under the centre of the bird's motion: Being Aruck with horror at the fight, I ran off, and believe the fnake did not fee me. My father, hearing the circurnftance on my return home, lold me the fnake was charming the bird.- Some years afterward, when nearly arrived to the age of manliond, walking in a field in Conneclicut, near a fmall grove of walnut trees, I faw a parrow circling tte air juft in the margin of the wood, and making dreadful mosans of diftefa. Immediately the former circemflance occurrel, and 1 approached with caution within twenty feet of a black fnake, about feven fect long, having a white throat, and of the kind which the people there call runners, or chroking fnakes.* The fnake lay ftretched out in a fill polture; I viewed him and the hird neat half an hour. The birci in every curn in its flight defcended hearer the objeहt of its terror, until it approached the mnuth of the ferpent. The fnake, by a cuick motinn of its head, leized the bird by the feathers, and plucked out feveral. The bird flew off a few feet, but quickly returned. The fnake continued to pluck the feathers at every fight of the bird, until it could no longer fly : The bird would then hop up to the fnake and from him, until it had not a feather le!t, except his wings and on its head. The fnake nnw killed it by breaking its neck, by an amazing fudden motion; he did not devour it, but calt it a little off, and continued his fation. Now the tragedy was again to be repcated ; for another bird of the fame kind, who had thewn figns of diftrefs during the firft tragedy, was fafcinated to the jaws of the monfter in the fame circling matuner as the former, and fuffered the lofs of fome feathers. I could no longer ftand neuter. With indignation I attacked the hated reptile, but he efcaped me. The living bird was liberaced from his fangs. The dead one I picked up and thewed to my frienda, deftituce of feathers as before mentioned.

\section{$0 \times 00200 \% 00 \% 0 \% 00 \% 00 \% 00$}

$$
\text { Brandon, .7uly I, } 795 \text {. }
$$

Dear Str,

I find you folicitous of information refpecting the clyarm of the fnake or ferpent-perháps the following account, which I received from the mouth of a lady, who was herfelf an unloppy fufferer, may not be amifs or unacceptable.

* It is faid that this kind of fnake-will entwine himfelf round the body or neck of a perfon, and choke him : It may be a vulgar eiror : This, however, is certain, they will often purfue a perfon who runs from them. I have heard that they frequencly charmed fquirrels arid fome other ari. mals, and in fome inftances the human fpecies: An inftance or two which happened to boys, will perhaps belore long be frefauted, with the proper vouchers.

$$
\text { VEL. i. M? }
$$


If I have aut forgotten, her name wa Finney, of Lanügburgh - the inil! ane aboat five years ago, that not long before that time, as the was walkinit by the corner of a cenain fence, oot far from Nurth River, the was fuddenly amuled with the chirping of a fnake, whether a black or ftripes one; I haveforgotten. As the dre's nigher to the fence, the difcovered the fnake, pitching its head to and fro, through a heap of dead bruth; deeply cis gaged with its charms, the forgot lierfelf, tilt a neighbor pafting by, broke her attention: When the felt herfelf as though the had been amoing poifonous herbs, itching, \&ec. which iffued in a long fit of lieknefs, whicls het phpfician afcribed to the fafcination of the faske, and the had oot per. Selly recovered when I faw her.

$$
\text { I am, \&c. }
$$

1. WATKINS.

\section{$0 \% 0000 \% 00 \% 000 \% 00 \% 0$}

\section{Extralt of a letter from Samuel Beach, dated Whiting, Fuly 24, 1795 .}

WHEN a lad, 1 hived with my father in the then province of New Jerfey, where the black faske, with a white throat, commonly callcd the racer, as well as the rattle frake, and other ferpents, are frequently met with; and I never remember to have heard any one difpute the power of charming belonging to feveral fpecies of ferpents, but more common to the black fnake, called the racer, which I have twice fen it the operation.

The following (tory, I have often heard related, and so which people in general gave credit, of a fnake's fafcinating a young lid :- Two boys were fent into the woods to look for cattle, and cuming to a piece of open land, where fome colliers had been a Thont time before burniug coal, they fopped to liften for the bells that were on the cattle they were in fearch of; and near where they flood, they obferved a very large inake, of the racer kind : One of the boys obferved to the other, that if he would watch the motion of the fnake, he himfelf was determined to fee if it would fafcinate or charm him; and faid, "you have a ftick in your hand, and if you lee me like to be too much injured by the fnake, you may kill him, and relieve me.' This the other agrend to do ; when the firt advanced a few fteps nearer the fnake and made a itand, looking fteadily on him; - when the fnake obferved him in that fituation, he raifed his head with a quick motion, and the lad fays, that at that intant there appeared fomething to flalh in bis eyes, which he could compare to nothing more fimilar, than the rays of light thrown from a glafs or mirror when turncd in the fun thine; he faid it dazzled hiseyes, at the fame tims the colours appearea" very beautiful, and were in large rings, circles, or rolls, and it feemed so be dark to him every where elle, and his head began to be diazy, mueh like being over fwift running water. He then fays, he thought he would go from the fnake; and as it was dark every where hut in the circle, he was fearful of treading any where elfe; and as they fill grew in lefs circumference, he could ftill fee where to ftep; but as the dizzinefs io his. head Atill increaled, and he tried to call to his comrade for help, but could not [peak, it then appeared to him as though he was in a vortex or whirl. pool, and that every turn brought him nearer the centre.

His comrade, who had impatiently waited, oblerving him move nb. liquely forwards to the right and left, and at every turn approaching uearer the fnake, and making a ftrange groaning noife, not unlike a perion in a fit of the night mare, he faid he could ftand ftill no longer, but immediately ran and killed the frake, which was of the largelt fize. 


\section{APPENDIX:}

Tie lad that had been charmed was much terrified, and in s tremop his thits was in a few mineres wet with fweat ; he complained much of a dirzinces in his head, axiended with pairs, and appeased to te in a coelaoclocly, flepid ficuaion for forme days after.

1 liave heard the flory fo cfien selaied by dieferene perfons thas I cancer tust give credit to it.

\section{$S_{3 \times}$}

\section{$0 \times 00 \% 0000000$}

1 HAVE obferved that you ate defirous of collekting inform. tion retative to the fafcinating power of ferpents - If you think the followjug inflance worthy a place in yous ufefol collection, yous are as liberty to inlirt it.

When $I$ was a boy about a 3 years of age, my futber fent me into a field to mow func biars. I had rot been long employed, till I difcovered a Jarge ratle fuske, and loaked round for fomething to kill him; but not ieadily dicovering a weapon, my curiofsty led me to view him. He lay coiled $n$, with tris tail ereth, and naking the ulual finging moife with his rateles. I had vieu'ed him but othort time, when the mon vivid and lively colours that imagination can paim, and far beyond the powers of the pencil io imiate, among which yeltow was the mon predominaot, and the whole drawn in'o a bewilching variety of gay and pleafing forms, were prefented in my cyes; at the lame time, my ears were enchanted with the moft rapsurous frains of mufr, wild, lively, complicated and harmonious, in the highef a gree melodious, captivating and enchanting, far beyond any thing 1 cuer heard bafote or fince, and indeed far exceding what my imasination in any oiber fruation could have conceived, I felt mifelf ifrefilibly drawn toward the hated reptile; and as 1 had been often ufed to fecing and killing rattle fnakes, and my fenfes were fo ablorbed by the $g^{\text {ay }}$ vifion and rapiurous, inufic, I was sot tor fome time apprehenfive of much danger; hut fuctcen!y recollceting what I had heard the Indians re. latc (but what 1 lad sever hefore believed) of the fafcinating power of thefe ferpents, I turned with horror from the dangerous feene; but it was not witlirut the mofl violent fforts that 1 was able to extricate myfelf. All the exertions I could make, with my whole f:rength, were lardly fufficien: to carry me from the fcen: of borrid, yet plealing enchantment: and while $J$ forcibly drazzec off my trody, my head feemed to be irrefinibiy drawn to the enchanier, by an invifible power. Ant 1 fully believe, that in a few moinents longer it would haye been. wholly out of my powcr to make an exertion fuficient to get a way.

The latter patt of the fcene 1 was extremcly frightened, and ran as fait as polithle towards home, my fright increafing with my fpeed. The firk pcrfon I faw was my uncle, who difcovering my fight, ran to meet me, and aned the occalion of it: I told him I hac been frightened by a rattle fllake; bu: was in too great a perturbation to relate the whole. He rallied me for my pufillaniusity, and took me by the hand, and we went to the place wherc the foake was fill ly ing, whico was foon difpatched by my uncle. I then related the ftory 10 him, and have fince told it to many other perfons.

The sight following I never cioled my eyes : The fame fene continn. ally haunicd my imaçination. Whether ite agitation was oceafoned meiely by the recoliction of what had paffed, or whether the operation of the charm Bitl had fome usal effeg uoon the nervous fyftem, I cannos Cetermine.

ElIAS WILLARD.

Tinnouth, Cat, 27, 17960 
UPON a careful examination of the above accounta, I cannot fee tha: any obfervations are to be expeeted upon this fibjea, more accurate of particular ; or which could probably be attended with more convincing alteftations or evidence of their being authentic and corred. Dr. Todd, is a phyfician of mucli ability and diflinction, formerly prefident of the medical fociety, and oric of the Council of this State, and now refident in Connelicut. Mr. I, Watkins was a minilter of the gofpel at Brandion, and now lives in the flate of New York. Mr. Beach has been attentive to the natural productions of the coustry, and now lives at Whiting. Mr. Willard died at Tinmouth a few yearsago, and was a man of much information, virtue, and veracily. And 1 cannot difeern any article or circumfance in their telations of thefe matters, which appears to be of a doubtful, deceptive, or fallacious nature. They rclate fimply and merely to matters of fast, and are declarations of what they heard, obleived and felt; matters of which they certsinly were adcquate and competcot oblervere and judges.

Among a number of accounts of a fimilar nature, I thall only mention one morc, which I have frum Col. James Claghorn, of Rutland, which is: inferted not fo much with a vicw to cfablith the fact, but 1 ather as afford. ing fome information refpetiug the manner and procefs of the operatiow. Ai Salifbury in Connecticut, fome years a go, whete the Colonel then lived, there were two men of the name of Baker and Nichols. Going sowards the mecting houfe in that place, they difcovered a large ratile.. fnake, in a plain open picce of land. The fnake lay coiled up in a pollure of defence; to attack him with fafety, they procured a long llender pole or fwitch, with which they could reach him without being in any dainger from his motions. As the fnake could not efcape, they diverted thein. felves with irsitating him with their pole, withoue giving him any cun. fidelable wound. They had carried on this bufiscers fome time, during which the frake had repeatedly attemped to fp ing upon tiein trom his coils, and to efeape by ruming; and dilcovere? uncomnon appeasances of rage and difappoiniment. Being prevented in all his attempis to elcope trom, or to bue his oppofers, he fuddeuly thetched himfelf at his tult length, and fixcd his eyes on the man who was tickling him with the end of his piole. The fnake lay perfeEly Nill, and Mr. Nichols kept on the fame motions with his fwitch. When this feene had courinued lor a fhent sime, Mr. Nichols leenred to incline his body mole and more cowards the frake, and began to move lowards him in' a vely flow and irregular man." ner. Baker, who thod looking on, noticed thele appearances, and called to Nichols in defilt from tlie bufinets, and difpatch the flicke. He took no notice of thefe dimunitions, but appeared to have his whole attertion fixed on the fnake, was obieiveal to be gradually moving towards him, to have.a pale alpect, and to be in a prolufe fweat. "Alamed with the prof.pedt, Baker took him by the thoulders, gave him a violest Make, pulied lim away by force, and cuquincd what was the matter. Nichols, llous forced fiom the fecne, made an uncommon inourntul noile of dillrils, ap:peased to be uncommonly and univerfally afiected, at:d in a few ininutis seplied to the enquiries that he did not know what ailsd him, that he could not icll how he telt, that he had never felt fo bifore, that he did not knuw what was the matter with him, but was very unwell.

The above accourts relate only to the falcinating power of two of the ferpents of A merica. Singular and extraotdinary as they may appcar, we pave very authentic relations that the fame power is found in foms of th: ferpents of the other. hemifphere. 
aor fee that ccurate or convincing r. Todd, is ent ' of the refident in t Brandon; attentive to tiing. $\mathbf{M r}$. nuch inforor circumof a doubtmerely to ed and ieli: it oblervere

ly mention d, which is ir as afforde opetation. then lived, 1s. Going large ractle. in a pollure lender pole any dainger eried ibein. $\mathbf{m}$ any cull. ime, during :1n $110 \mathrm{~m}$ his appeal ances' pis to elcape at his lull ith the end kept on the: 4 lior a hinere lowards the egular man." - and called

He took le atlention ds him, to it the prof. ake, pulied ichols, thus dilles 13, apiiw minutes hat becouid d not know

two of the appcar, we lom of th:
Une very remarkable sccount of this kind is from Italy by Dr. Sprengell." At Milan he found viper catcher, who feldom was without fixty or more vipers alive, kept together in a haek room, open at top; he had them from all parts of Italy, and fold them desd or alive according $\varphi$ the ules they were defigned for. Having one day got a female viper, big with young, we catched fone inice, and threw in one at a time; among all that num. ber of vipers, which were upwards of fixty, there was none of them in the lealt concerned himfelf aunut the moufe, till the pregnant female vipes and the moufe interchanged cyes; whereupon the moule flartled; but the viper raifed her head, and curnerl lier licek into a perfeet bow, the mouth open, the tongue playing, the eyes all on fire, and the tail ercot: The inoufe feemed foon recuvered of his fright, would take a turn w' twn, and fometimes more, pretty brifkly round the viper, and giving at limes a fqueak, would run with a great deal of fwiftnels into the chops of the viper, where it gradually fank down the gullet. All this while the viper never flirred out of her place, bue lay in a ring."

- It is to be obferved, that no viper will feed when confined, except a pregiant female viper. The Dodtor faw the fame thing at Bruffels, whese aldier had catched a large viper big with young.

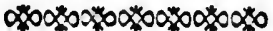

[From the Travelsorle VAlLiant in ABRICA.]

IN the additional volumes of the travels of Le Valliant inter Africa, appear fome very friking facts relative to the falcina:ing power of ferpecut:. Twn of them are authenticated on the evidence of the author himfell, and the other is factioned by his belief in the veracity of the relator.

The inflances produced by Le Valliaut are brichy as follow :

Firft infance. - "One day, in one of our excu-fions in hunting, we perceived a motion in the branches of nne of the trces. Inmediaciy we heard the piercing crics of a thrike, and 'aw it trcmble as if in convultions. We firft conceived that it was held in the gripe of fome bird of prey ; but a clnler attention led us 10 difouver upon the next branch of the tree, a large lerpent, that with fretched out neck, and fiery eyes, thoug't p:rfect. ly flill, was gazing at the ponr anims' Che agony of the hitd was terrible : but fear had deprived it of frength, and, as if itied by the les, it feemed to have lot the power of dighte. Ouse of the cumpanv ras for a fufee; but befure he returned, the hiike was desd, and we only ther the ferpent. I requelled that the diflance between th. place where the bird had experienced the couvulfions, and that oceupicit by the ferpent might be meafured. Upon doing fo, we lound it to be three feet and a half, and we were all convinced that the thike had died neitice from the bite, nor the poifon of its enemy. I Aripped it alfo betore the whole company, and made them obferve, that it was untouched, and had not received the ulighteft wound."

Second inftunce. - "Hunting one day, in a marhy piece of ground, I heard, all at once, in a cuft of reeds, a picreing and very lamenabie cry, Anxious to know what it was. I tole toftly to the place, where I perceiv. ed a fmall mnufe, like the thrike on the tree, in agonizing convulfions, and two yards farther a ferpent, whofe eyes were intently fixed upen it. The moment the repotile Taw me, it glided away; but the bufinels u:as done. Jpon taking up the moufe, it expired in my hand, without its being pof. thble for me to difenver, by the mon atcentive examination, whac had $o$. calioned is death."

$\therefore$ * Fhil. Tranl, No. $39 \%$ 
Third infunce, -." The Hotteriots, whon 1 confiled upon this unc. dent, expreffed rofort of aflorifinnerit. No hing, they faid, was more, commori; the ferfent liarl the fosulty of attra?ting and fafcinating fuch animal, as it vilited en cievour. I had then ro faith in fuch power; bu fome time after, fpeaking of the circumfance in a company of molc this twenty pertous, in the zux bet of whom was Colonet Gordon ; a captain

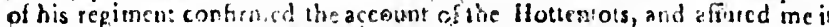
was an cusro which haposed vory fisquen:ly. 'My cefim my,' added he, "ought to bave the more weight, as 1 had once rearly tecome nylels a vietim to this fa!cina:ion. While in garifon at Ceylun, and amufur myfell, like rou, in huritig in a nar?h, I was, in the courfe of my port, fucdenly feized witl a convulfive and involuctary rombliag, difierent from any i hing I bud cucr cxperienced, and at the fame time vas ftougly attracted, and in ffite of myictf, to a pariicular fpot of the man M. Isixedting inyeses to the fpot, 1 beleeld, with feclings of horror, a ferpent cf an cuormous fize, wholc look infantly pierced me. Having, however. not set loft all peiwer of motion, 1 cmbaced the opportunity before was too late, and faiuted the reptice with the contents of my fufee. The seport was a talifuan that broke the charm. All at once, as it by miracle, my convulfion ceafed; 1 feit m, feit abie to ny; aric the orily inconvenience of this exeranidinary adventure was a cold fwcat, which u as doub: Jefs the $\mathrm{cff}$ ef of my fear, and at the viulent agitain my fentes had undergorie."

"Such was the account given rae by this oficer. I dis not pietend to rouch for itscruth; but the fiory of the mou?c, as well as of the thrikc, $\downarrow$ aver to be a last."

The fame phenomena thicn have been obferved in Furope, $A$ fia, and Afr: ca, as wel! as in America. It then we torm out judgment from cleferwa. tion, the conclufuron will be, that in every part of the earth, the teryent lap difplayed defferen: powcrs and faculties, liom nhat have appeared in stb er aninals.

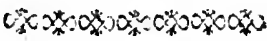

\section{Renarks and Conjistures on the above Accontits.}

1. Irom the above accomins $i$, can hardiy be cloubted. but that the t.: per, the black, and the ra.tle frakc, have a power to affedt binds, lejuip. xels, and the leuman rice. in ancaliand:rary ard powcolul manner ;

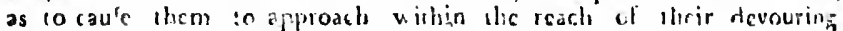
j.rws. To philolophers, who cerive all their isformation tors.s iheir bocks, ard to mest u lue determine from theory and fylicts, the whole afiair palles for vu!gar delution and folly: Non will it cre appear pro. babic to any perfol who is accuncmed to ro otlec way ef reafoling, than the metaph; fical method of decrmining folls by realonings a tric: that ratule has given to the ferpent sery different pousts tiom thole which the has tisparted to any other fpocies ot animais, Mut it ccrtain'; is not from the men of metaphyfical throry and fyflem, lur hem tis earcful oblerves of nature, thet the mon important infusma ion is to is

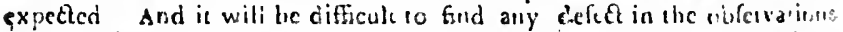
that bave been men:ioned, or any ciccullance that denotes them to ha.: been delutive or fallacious. I nuth therelose adinit it as a weil atidfed fist, that wature has imparterl to the ferpents mentioncd above the fingulay and extraordinary power ol facination; or afiecting oller animals in fut: a masner as to caús them io sproach within their 16 ash. 
tponthis 1116. iid, was more, 'cinating luck power; bu of more thas. oll ; a captain 1 afiured me it m.nny, added sccome mylelt? and amufin e of my fport, ling, dififerelit. c v. as f trongly, e main. Ii. or, a feipent c? ing, however nity before: ?y fulce. The if by miracle, rily inconven. ich $u$ as doub: feriles had urs"

not preernd 10 if thr Mrike, ${ }^{b}$

Afia, and fif frem rllfexiz tive liven las? pecard in che

stmits:

bust hind the o. th birds, lowis. ul manner ; 0 . Irir Acrourina aration trora com, the ulinle res appear ron. - ef reaforitif. oniugs a frice rs finm chots liut it cortain!'y las lien th: ma inn is a is ic vifecrarius sticm to lais: weil atrites bue the fingulat animals in lu:
2. This power, whatever it be, feems to be excrted by mean? of the cye of the fuake. "The eye of this reptile, fays Mr. Dudie!', the rat: 4lefnake) has fomething fo fingular and terrible, that there is iso Inoking ledfoltly upon him." All the accounts agree that no uncomm en etfeE is perceived, till the eye of the ariinal is fixed on that of the ferpent. It should feem from Mr. Beach's and Mr. Willard's accontuts, that the eje of the fpectator is no foncrer fixed on that of the inake, than the. mont lively and beautiful colours are feen, in the moft engaging and en inaning forms, in large rings, circles, or rul!s : and that thele cireislar appearances of the moft beauliful light and co'ours are gras!nally diminithing in their circumferences-Hence the encircled animal is contlantly takiog irregular or circular motions, within the circle of apparene lizgl ; both of which besone more anil more contrakied, till they arc brougthe to a centre or clofe at the head of the rnake.

3. The operation whatever it may be, takes away the Teries, or fupifies the animal, on which the operation is carried on. This was the cafe, and to a high degrce, with all the perfons mentioned is the abcive accounts. They found themfelves violently affetted, but new not what was the matter. At the beginning of the feene they feemed apprehenfive of danger, but loon lof all power, and all inclination, to mske any oppnfition ; Nor was there, in a few moments, enough left of the rational or animal powers, 10 reflett on their fit uation, difcern their danger, cortrive a method or make any attempt to efcape. Deprived of fenfe and reafon they remained fubject to a power which they could not compreherd or oppole, and get in great arid extreme dittrefo.

4. Can there be any fubtle effluvia, poifonous exhalation, of Aupifying virus, emilted by the eye of the ferpent, and received $b ;$ that of the enchanted animal, equal to, and producing the uncommon cffects which have scen mentioned. This feems contrary to all the other appearances of animal nature; and yet the phenomena feem to indicate fuch a phyfical kind of operation. The body of the boy at New.jerfey was covered with a violent fweat. His head was affected with a dizzincfs, and pain : nor did he recover his health for feveral days. Mr. Willard efca. ped before the fcene was completed and found himfelf too much alfeted to fleep the next night; but could not determine whether it was owing to the fright, or to a pliyfical effett on the nervous fyftem. In the lady at Lanfingburgh, the fafcination iffued in a long fit of ficknefs, which was not cured in five years. Thefe are phenomena which feem not only to denote phyfical operations, but fuch as were of a very powerful and extraordinary nature; and which feem to refemble what was faid of the bafalik by the ancients.

5. Whether there is any thing in the powers of otker animals that refeinbles this faculty in the ferpent, I am not enough acquainted with natural hiftory to determiue. Some per fons have mentioned the Dog and the at, as exhibiting fome appearances of a fimilar nower; but 1 do $110 t$ find any fufficient evidence in poof ot ir. Nor do 1 know of any thing in nature that aporoximatcs to a fimilarity, except the refemblance in the effcet which light appeais to have on fome animals.

Some infeds will fly intn a burning candle, and remair. in the fame till their wings are confumed, and their bodies burned. The effect of light is alfo appares:t in fome of the birds. In a barn in which the fwallows refode in the lummer, if a burning cardle be carried in the night, the fwallows wiil foon leave their places of rel, and gather round the light. The

* Phil, Tranf No, 3;6, p $=92$. 
filhermen in almolt every country, frequently avail themfelves of the farse' difpofition in fome fpecies of $f(h)$; and expeet to allure them to their boats or weapons by the lighi of a lanthorn or fmall fire. The fportmen in fome countries. effect their purpofes by the refledtion of light. "There is a method among lportimen of raking larks by a net and looking glaffes, which they exprets by the name of Loring. Five or fix looking glaffes are fo fixed to a llick, as to reflect the inght upwards. The flick in which they are fixed is fo made as 10 revolve on 218 axis by means of a fring wound round it. When the machinc is thus twirled round. the light is refleted upwards by the mitrors in quick and conltant fucceffion, and to a confiderable cxtent. The hird is faid to be enticed or invited by the glim. mering of the light, till it defeends and liglits near the looking glaffes, and is then taken by the net." + " The lark catchers in fome cuuntries," fays Brydone, "arefo dexterous at chis maneuver, that with a fmall mirror they thouw the rays of light on the latk, let her be ever fo high in the air; which by a kird of facin:tiun, brings down the poor animal to the fnare." $f$

Such an effect dres not feetn tu be altogether diffimilar to what takes place in the facination of a bird by a forpent. The lad at New-Jerfey faid tiat " at the inflat the fnake fixed his eye upon him there appeared fomething:oflath in his eyes, which he could coinpare to nothing more fimilar, hian the rays of light thruwn from a glals or mirror when turned in the fun hine; he laid $i$ : dazzled his eyes \&c." Nor do the eyes of the ferperit fecm in be unfulcd to produce fome fuch effect. There is fomething in tise eyes of a large ratsle fuake that is fo fietce, ardent, and penetrating, that it is pain'ui 10 look upon them; and we do in fact experio ence phyfical effects, which to fay the lcaft, are agilating and very uncomfortab!e.

6. Whence arofe the idea of any uncommon fubtifty or cunning in the ferpent? Theredoes not feem to be any thing in the whole race, which has proved agrecable, ufelul, or beneficial to mankind. The highelt degree of malice and danger were exprefied by the ancients, by the phrafe of a ierpent that would not be charmed; that is phyfically divefted of his difpofition to bite." "Arid yet it has happened that ehis fpecies of animals in aimoft every country, has been confidered as the emblem of fomething wifc or excellent.

Straboand Eufcbius tell us that at Elephantina, the god that was fup: pofed to reprefent the architect of the univerfe was adored uoder the fir gure of a ferpent. In his hiftory of the creation, Mofes reprefents the lerpent, as more fultile than any hean of the field, which the Lord God had made. The Jewilh and the Chrittian theology both fuppole that the form of the lerpent was that which the tempter chofe, to give the greatef probability, infuence, and fuccefs to his defigns and attempts upon the hu. wan race. The Saviour of mankind in his cay, f,ave it as a command to his difciples, to he wife as ferpents. but harmlefs as doves. The Egyp. tians twincd two ferpens tngether round the globe, probably to repietent the equilibrium of the fyftem of the world. In India, the pricts put the ferpent intothe hands of their dirinities. By a circle made by a ferpent ivith his tail in his month, the ancients meant tu reprefent eternity; by being coild round a fick, lis was fupoofed to exhibie the gend of health: and we have made hiun the repreleriative of juftice and prudence. The Jews, the Grceks and the Muffulmen, have all viewed this reptile in ?

+ Supplement to Chambers's DiEtionary, Artirle Dor a vo.

* Bridone's cour through S cily ard Malta. Boflon Edit. p. 15 .

- Plalm $58.3,4,5$. Jeremiah 8. 17. Ecclefiattes 10, is, 


\section{APPENDIX.}

es of the fanse" n to their boat: - fportfmen in ht. "There looking glaftes, looking glaffes $k$ in which they - fring wound ght is reflected id to a confid. by the glim. ing glaffes, and ountries," fays tall mirror they the air; which ie fnare."

to what iakes at New-Jerfey there appeared nothing more $r$ when turned the eyes of the There is fomeent, and penen fact experio very uncomfor-

cunning in the le race, which he highelt deby the phrafe of divefted of hia ecies of animals of fomething

that wis fup: uoder the fireprefents the - Lord God had ppole that the give the greateft is upon the hu. is a command s. The Egyp: y to repielent e pricts put the by a ferpent eternity; by and of health indence. The is reptile in?

no. p. 155 r. tingular light: ard he has cvery where been ufed to denote fomething valitabl: and uelul.

U herice arofe all this celebrity. and thefe ideas of his wifriom or cunning? And how came for man deffecen nations 10 afiix the idcas of wiltum, power. and wtility, to a race of apimals that do not appeal io we either friendly, or of any advantage (c) mank'nd ? 1 cannot alcertdus cicher the origin. or the caule of the ieputation that has bcenaffigned 10 a reptile, which a upears to be the molt ulelefs, odious and obnoxious, of the whole animal race; nor can \& deiesmine whether the ancients were acquartuted with his fingular poners. They have bien oblerved in Europe, Afld, Africa, anct 4 merica ; but 1 do not find any thing in the earlieft writıngs, timofe of Mofes or Homer, that intimate any ruch lufpicion. Humer lpeaks of eucnantment, as fomething that was well known and generally believed in his dav. But it was not the eye, or a ferpent that was invefted with this dr'adful power; it was the voice and the fongs of the Syrfns, that carried unavoidable cwchantment and deftrcetion. But whaiever were the fentiments of the ancients refpecting this animal, I think it can hardly be doubted but that he does nnw difcover a different faculty or power from thofe of other animals. It is to be expekted that thefe powers thould be moft Arong and apparent in thofe couniries where he exifts in the greatelt eafe and vigor ; and has becn the leaft difluibed by cultivation, or by man : and to me the evidence is convincing, that the terpent has difcovered tuch powers in America. But I am fo far from comprehending this mylterious article of natural hiftory, that I muft refer the fubject to the inveltigation of men of better abilities and more information.

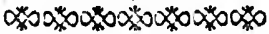

THE TWO.HEADED S.N.AKE.

NATURALISTS have been in doubt whether the two-headed frake was a monftrous production, or a diftinet fpecies of ferpents. The following curious obfervarion of Capt. William Baker, feems to decide the point. Mr. Baker is well known to the Author, and there is no room to doubt the authenticity, or the accuracy of his account.

In Auguft ${ }_{176}$, in the town of Sherley, county of Middlefex, and Aatc of Maffachufetis, 1 found a large water lnake, as I was mowing in a meadow, formerly flowed by beaver. I took out of the belly of the fnake fixty young ones; they were about ten inches long, except one of them, which had two heads, four eycs, two tongues, and appeared to be about two inches longer than any of the reft. I lhewed the fnake with two heads, to a great many people; but as I was but a boy, and at that time knew not that I comld have preferved it in fpirits, I did not attempt keepir.g it, which I am very lorry for, as the fight of him would prove to the worid, together with this account, that the two hearled fnake is of a mon: trous production.

RUT1.AND, DEC. 16, 1795 .

W. BAKER.

\section{arararara}

\section{No. V.}

A Differtation on the Colors of Men, particularly on that of the Indians of America. Cна P. VIII. P. 237.

Colors or M $\mathrm{x}$. - ONE of the molt curious phenoinena that belongs of the natural hiltory of man, is the color with which he is marked. Every

$$
\text { VOL. I. N } 3
$$


objest which we behoid, appears to be of fome particular color. In anis mals thefe colors are cxiremelv various, different, and heautiful; and fometimes they appear to be vasiable. Man, like other animals, is difiul: guithed both hy a peculiarity, and by a varicty of color. In Europe, he appears whice: In Africa, he is black : In Anerica, his colno is red : In Afia, a variety of colors are to be found upon the human coumleliance. There are other thades and tinctures to be found in each quarter of the globe, befides thofe mentioned above : But thofe that have bcen mentioned are the moft general and prevalent colors, under which man appears, in the four general divifions of the globe.

VARIETY OE COLORS.-The molt diinguilhing, permanent, and general colors of the human fpccies, and which are at the greateft exiremes from each other, are black and white. Between thefe, or rather as differcnt degrees and variations of them, are all the other colors of the human countenance: And they may be reduced to fwarthy, red, copper, and brown. Black is the color of the Africans under the equator; of the inhabitants of New Guinea, and New Holland. A fuarthy color includes the Mou:s in the northern parts of Africa, and the Hottentots in the fouthern parts of it. Red diftinguifhes the Indians of North America, The fame, or perhaps more accurately a copper color denotes the compiexion of the Indians of Alia. Brown compreliends the Tartars, Perfians, Alabs, Africans on the coaft of the Mediterrancan, and the Chinele. The inhabitants of the iflands in the Picific Ocean, are alfo chiefly of this color. Under this color is comprehended all thofe different thades, which are denoted by olive, chelnut, and deep yellow. A lefs dark color, or brownifh, will be?t exprefs the coniplexion of the inhabitauts in the fouthern parts of Europe: the Sicilians, Abyffinians, Spaniards, Tutks, and alfo the Samoirdes, and Laplanders. White is the color of moft of the Europcan nations : as Swedes, Ruffians, Danes, Englilh, Germans, Poles, \&c. Ka. bardinki, and Georgians. It is oblervable that all thele colors are included between the two extremes; or rather they ate different degrees or variations of black and whitc.

CHANCE or CoLOR.-A change of color is always preduced by the marriage or mixture of perfons of different complexions. Thus the of:fpring of the European and the necro, is of a yellow complexion ; lefs white than the European, and lels black, than the negro; or ra:her of a dark cream color. This race are numerous in fome parts of A merica, and are called Mulaltoes. The offspring of an European and an Indian is alfo of a cream color ; and mnre light than the mulatto. Thefe are called among the Spaniards Mefigos. The effect and operation of this change of the original colors, in the climate of America, is always in favor of the fairer complexion ; and never approaches towards, or ends in the dasker color. This change and alteration of color, when it is left to its natural tendency and effect, is extremely flow and moderate in its operation; and it is not until after many years, that the full effect is produced. In the Spanith fettlements, this mixed race has fo multiplied as to form a confiderable part of the iahabitants : And the feveral ttages of variation in this race, with the gradial alteration of thade until it $c_{-a d s}$ in the European complexion, have been well afcertained, and are now perfectly well underAlood. Thofe of the firn generation are confidered and treated as negroes or Indians. In the third generation the Indian color difappears. It is not until ile fifth defcent that the deeper black of the negro is loft. At the end of thefe different periods, the offspring can no longer be diltinguilhed from the European ; but is confidered as fuch, and eutitled to at- 


\section{APPENDIX.}

r. In anlis tiful ; and o, is difininEurope, he is red: In uniellance. rter of the mentioned ppears, in

inent, and $t$ extremes $r$ as differ. he human pper, and of the in. $r$ includes the fouth. ica, The viexion of 3s, Arabs, se inhabiis color. h are dc. - brownifh. n parts of alfo the European \&c. $\mathrm{Ka}$ are inclu. egrees or

d by the the off. ion; lefs ther of a rica, and an is alfo called ahange of or of the ue darker s natural reration ; :ed. In o form a iation in iuropean 11 undernegrocs 8. It is oft, At dillind to 2 d.

Sheir privilegcs, - In this change of color, produced by the molt powerful of all natural caufes, the inixture of perfons of different complexions ; fo gradiual and $\mathbb{n}, \mathrm{w}$ is the operation, that the black muft be lubject to five divifions, and the opera:ion muft be continued through five generations, bclore the color is completely changed.

SEAT UF Color. - That the different colors of the human fpecies arc featcd in the fkin is very apparent. The Rin confilts of three folds or coverings. The tirlt is a very fine and tranlparent integument, and is white in people of all culors The fecond is a cellular membrane, differentlv colned in different perfons. The third is alfo whitc. It is in the fecond of thefe, that the color is feated. In black people, a very able anatumint oblerves that the $\mathrm{K}$ in is much thicker and larger, than in white ones; the eellular membrane in the latter being a thin mucus, but in the former a thick membrane. In whites this feat of the color is tranfparent, and cither totally deprived of veffels, or only furnifhed with a very few; as the yellow color appearing in jaundice, vanithes on the caufe of the difeafe be. ing removed, which is not the cale with fains from gunpowder, or fimilar caules.-Hence, he obferves, three canfes may be very readily affigned, which will opera'e to deltroy the pelucidity of the $\mathrm{Kkin}$, and give it a brown color, and render it thicker. Thefe are the licat of the fun, the accefs of air. and naftinefs. And in general any thing that operates to produce or to deltroy the peiucidity of the $\mathrm{kin}$, will tend to vary and change the contor of the human body.

Color connectid with Climate.-Among the canes which may athect the color of the human body, it has been generally fuppofed that the influcnce of heat or climate, has a confirerable effett. Concerning this inlluence or comexion between color and climate, the following oblervations may be made.

1. Diffarerit colors are bef fuired to diffcrent climates. In ail the plants and animals which are lpread over the face of the earth, there is fomething by which they arc peculiarly fitied to the climate and country, in which they arc olaced. One kind of vegetable reguires a gicat degree of heat : Annthe flumithes the beft in a temperate and colit country. I: is the fame with animals. Some are fitted tor the heat of the torrid zone. Oherstequite the fevere cold of the frigid zone, to give them their grealeft peifection. To all thefe animals, nature has given the proper clothiog; which admits of no oiher variation than what the feafons of the yearequire. - Man is an animal made for every climatc : Inftead of being formed for the corrid or frigid zone, he can live, multipiy, and arrive to his proper perfection, in any climatc: And it is left to his own realon and indultry to provide himfelf with fuch clothing, as his condition may require, in every climate through which he may pats; or in which lic may fojousn. And yct there is fumething in different $m c n$, which qualifies and fits them for one climate, better than for another; and that is, color.- The man whole color is black, is heiter fuited to the extrems: heat of the hotteft climate, than any other of the human race. This has been long known and oblerved in the ciimates of America *" The negroes of the Welt India in, niss, in the Spanilh dominions, and in the ftates of Georgia, and South Carolina, are found to bear the cxtreme heat of the fummer, beteer tian the white peoplc. On the contrary, the negrocs in the northern farcs of $A$ merica are morc tender than the white people, lefs.

* Voyage de Ulloa, 1. 27. Robertfon's Hir. Anser. 11, 360. t. Doctor Hunter. 
able to bear the feverity of our winters, and more apt to complain, fuffer, and freece with the cold. - The while men are the reverfe of this They: bear the fevere winters of Canada, and $R_{11} f_{1,1}$, without much difficulty o: fulfering: But in a hot climate they becorne fickly, and fail froner that the negroes. Severalcolonies of white pcopie have fublilled in the torrid sone in A.nerica, more than two centuries: And yet they cannot bear the heat, like theorigunal inhabitants, or like the negrocs. The one is apparentiv beft fuited to a cold, and the other to a hor climate. And thele differences are as apparently owing to their color, for they àn not appear to be connetrd with anv other caulc, or circumllance. Different colors theretore in the human fpecics, are certainly belt adapted, fitced and fuired, to different climates.

2. There is a teudency in climate so produce the color which it rcquires. Animal heat is derived but liule troun the tun, or from the stmofplicre; but chiefly and inainly trom origiral contlitutiou. The viefign of covering and clothing, is to detain and pielerve the heat of the animal body, in its natural fituation, degree ai : quantity; and to privent an extreme wafte or difperfion of it. Black readily receives and ab/nrbs the heat of the animal body ; and in this way tends to exhauft and dilperle it. White reflects and repels the rays of light and heat inore than any o! her color, and thus prevents and oppefes their paffage; and in this way, tends to) preferve and decain the conftitutional heat of the animal body. Hence the covering, which nature has alfigned to the earth in cold climates, is fliow : By its color it becomes beft of all adapted to prevent tric heat from flowing out of the earth into the almofphere. And hence the covering of moft awimals in the fevereil feafon, and country, is generaliv white; the color which molt of all preferves the heat of the animal bendy, and prevents its thowing out. In conformity to the fame law of naiure, many animals chaige their color at the approach of wintar; and from black, brown or grey, bccome white. This is the cafe with the rabbits, loxes, bcars, \&c. at Hudfou's bay, Rullia, and Siberia, From the datker cotors which they bear in iummer, they tuin whice at the approach of wirster ; and remain fo. until the return cil fpring, In luch cales, climate apicass to have a powcrfuland a fudden operation, to produce the colors it requircs.

The change of coior in man, is more llow and gradual: It is however certain and apparerit. The white men who are nulich expofed to the heat and rays of the fun, and to the influerice of the "ind, in hot feafons lefe their whitentfs, and become brown or red. The inhabitants of Europe when they feule in New Spain or in the Wef India illands, oon loole their whitenefs, and hecoine of a hrowrith vellow. The Europcans who refide long in the Eeaft I ricies, become of the fane creain colored complexjon. We have an arcurate account of the efteet produced by clinate in South Ainerica, by Dr. Mitchell: "The Snaniards who have ithabited America under the corrid zone lor any conliderable time, are become as dark colored as our native Indians of Virginia, of which I mylelf have bren a wiınefs."* An account from Africa, is equally authentic and accurate. "There are feveral other finall Poituguele fettlements, and one of fome note at Mitomba, a river in Sierra Lcone. The people here called Portugucfe, are principally perfons bred trom a nixture of the firf Por. tuguele difcoverers with the natives, and now become, in their conplexion, and wonliy quality of their hair, perlect negrocs, retaining however, a' 'mattering of the Portuguefc language." Here the operation of mix-

- Phil. Tranf. No. 476.

t Account of the trade of G. Britain to Africa, by an African Merchaz: 
tare by warriage, is determined by climate in favor of the African color: There are fimilar accounts of the complexion of the Poriuguefe, who fettled at Senegal in 1400 ; and of thofe who are fettled on the coalt of Congo. The varying cumplexion of the Jews is allo very remarkable. Defcended trom one ttock. their religion has prevented their marrying with other people. In Britain and Germanv, they are white. In France and Turkey, they are biown. In Spain and Portugal, their color is Iwarthy. In Siria and Chalded, the olive color prevails. In trabia and Egvptw they ate of a tawny or conper color * Among every nation they iecm to partak of the color ot the climate. And one of them, Tudela, relates that his countrymen in Abyfluia, have acquired the dalk complexion of the original natives.

It is obfervable that all thefe changes, arc from a light to a more dask compiexiun Similar cinanirs have not been oblerved in the negroes, that have been brought into the temperate climaies of America. It thould feem therefore that the tianfition is eafier from white to black, thas 1...m black (1) white; or that the negro color is the molt deeple impro $3 \Gamma$ if of ans ; or that heal has a much more ludden and powerful cffeet than cold. It ought huwever 10 be oliferved that it is only in white and fair complex-

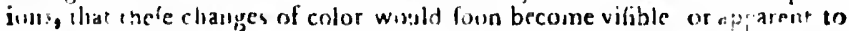
cumaion obfervation. In a dark or black countenance, fmol! aur giddial

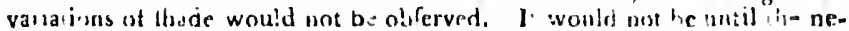
gro had hol much of his t.rmer colur, that the change would be ecrerally no 'c. d. But I much lu peet that were is tomething mure curious in this f:abedt has has becr imagincd : That tome of the colors of the human cruntcuance, dit 'n iheir on n naiur:s, colors which ase lefs changeable that oiners. Ir freins th b unive lally the cafe, that the black pinduced by tcor hing, or hat dircenfe heat, is the moll durable of any criss whatever: And ihat wint: is more forn aud cafilv fullied, and chasiged, tiaa inv of he ostice colors, with which any cibje ct is rralked.

․ I ipen, ro be a confirma ion of thefe rcurarks, tha: the solors of men

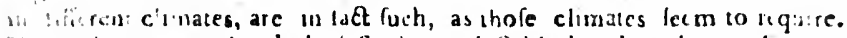
ind r the equa or the da kett thade, perlect black tikes place live tiegin of strica is p'aced in the molt intenle heat, that akes place on this globe; and the color of the negro is the decp. It and darkeft black. that auy where appears on the hunan countenance. Advanciug from the cquator towards the pole, the color of the human? ecies acquites a complexion more atd in.sre light; until having palfed through all the isternediate graditions of thad $\therefore$, it termunates in the whitenels of a temperate and cosld climate. There are indeed variations ard exceptions from this, and from every other zenera! law of nature. Intermixtures of different nations, migrarion. differences in food, diliafc, cleanlinefs, healih and many orher local circumftances and caufes, will protuce thele. As fuch variations are not agreeable to any general law of nature, they are neither cviciences of, or objections to fuch laws; but derive theirongin from local and particalar caufes. - But it is impolfible not to difcern the gencral regularity', tendency, and effect of the laws of nature, iefpecting climate and color. The molt intenfe black, is the general color of man in the hotteft part of the globe. Where the heat is confiderably abaled, the black ahaies too, and the coior becomcs fwarthy. To this fucceeds the red or cupper color of. the ealt and weit Indians; fuited to that part of a fia, where the lndians buve been long lixed and permanently fettled. Tise next gradition is.

\footnotetext{
$\therefore$ Buffon Nat, IIiA. Vol, III,
} 
brown, compretiending the olive, and dask yellow, A lighter fhade, 6 : a brow approcising ncarer on white, dittingui(hetls a climate ftit! more cenpcrace. The whole terminatcs in the coldnefs, and in the wlitericts whe turopan and northern natuons; beyond which nature has not pro. ceeded. Aud where a country is of great extent, as India. and China, the rolur of the fume neople is datk in the louthern, and more tair in the nor:licon parts. Wnatever particutar exceptions and inviations may be Jound, the keneral law of nature relpethug color. is ma:k:d with as much regularity, unilormity. defign, and onder, as any cther law of nature, whicl: applies to the vegetable on animal wisrid.

4 Trisopertion aid eff et of climate muft be ex:remels gradual and flow. Whaever thofe casles are wirch have ferved to fircu and tix th: culors of men, they are castes wuich have been in operation, from the be. finning of the creation of God. If there were any difierences in the natiral conltitutions of men, fo as to form what has been called different races, chofe differences muft have been original; and therefore as ancient as thofe fuppofed races of men. If the eff, ct has been produced by climate, this caule muth have been operating upon nations, ever fince their refidence became fixed in any particular part of the earth. The fame remark will ap. ply to any other fuppnfed caule. Be it what it may, upon cvery nation while relidence has been fixed, it mult have been operating ever fince their Gituation became eftablifherl. With regard then to all thole nations which bave long refided in the lame part of the globe, their colors mult be viewad as the effect of canfes, which have been in operation either form the beginning of the creation, or from the time when they began to refide in their prelent fituations, or countries. What then ouglit to be expefted, if any race of men whofe color was already formed, fhould be removed to a sountry, where the tendency of clinate was to ieverfe the former effects, and change the color which had been long fixed $?$-Could it be expected that the powe oi climate to change a color long formed ard fixed, could be cxerted in lefs time than it had iequired in produce and to eltablith it? Would it renuire lefs time to remave an eftablithed colos, and to produce an new one, than it did to produce and fix the firit ? So far as we can derive any information from the ordinary courfe of nature, we cannot con. ceive that the color of the negro, could be changed into that of the whice man, in a lefis period ot time, than it had taken, to produce and eftablit: thar color at firit. It is much more probable, that a longer period of time would be neceffary to eradicate the firlt, and produce the fecond, than was requifite to forns the complexion at firft. Tasle then that mean to inquire carcfully into the of etations and stsets of nature, mult put on the patience of the anticuarion, and learn to comisute time will the altronomers. The inparience of many leads them in $\mathrm{cxa}$ ock that climate Mould undo that in three or four generations, which natuic has been conitarlly at work to ef fect, from her firit otigin uniti now.

I will venture to propole a coujectural eftimation, not becaule I think it approaches verv near to cersinty or dicifion, but becule I cannot fina any thing spon the fubictt, tine has a grenter appearance of probability. The moll powerful of all the caules, which have been found to change the compiexion of man, is that of mixture by marriage. In the negro crior, this requites five gencrations, and file divifions, before the Afican bidch. nefs is lott in the European whiteuefs : In the lefs dark complexion of the Indian, it requires three generations, and thee divifions, to produce the fame effet. The time of one of thefe generations may be eftimated at a. bout twenty five years. The time then which nature requires to effict the elange of color from this cauic, would ba one liundrea and iwaty 


\section{APPENDIX.}

yesrs, for the negre. A thirly fecond part of the wiro'e color, upon this euppofision is done away by fone o: her caufe, fay that of climate. If the whole effet had been produced by clinate, and in this proportion, the: time neceffary to have completed the eflect would have been font thou' and years. By the lame method of corrjetural eltiniation, the time necellary to reduce the Indian to the Eurspean color, would be fix hundred y surs. The difficulty and uncertainty atcending this meihod of fortning an eflimate, is not that it can give' period of time tono long, but that it 1 fumes what caunot be alce... ed by obfervation. It is met, and prolishly annot be made certain by obfervation, that a thirty fecond part of ilis netoo color is done away by climute, or that it is done away al all. When the nerro counplexino is luppofed to be completely changut. Is is not probabie that if a thisty lecond part of dak color icmained, it could be readily dittinguithed by the eyc. lout uncertain as the data art, they are fulficient in thow that the opcration of climsie, in any view in which the matter can be confidered, is extrcmely gradua: and ?low.

5. This influence of climate, whatever it is, mav be increafed or it may be retarded, by the operation of other caufes. The color of the thin may be affreted and changed by other caules, as well as by heat and culd. it there be any thing in the common method of living, in being couflantly expofed to the fun and wind, in the ule of puint asd vil, or in labitual cleaulinefs or fitthinefs, that tends to darken, or to render the complexion more fair ; this, may operate either with or againlt the inllacuce: of clin:ate, according as the nature and icridency of luab cuftom or prafice inay be. And we ought not to aicribe : hat to, er make that any objeltion is the influence of elimate, which may be derived from rather caufes. Thus in Greenland, the influence of climate is in favor of 3 fair and white com. plexion; but in the conflant application of egreafe, oil, and fillhinefs, to the human body, there is another and a more powerful caufe to rfet its color, than climate; and which, acting in contlant uppofition to it, gives to the countenance a fallow or ditty olive complexion. Such canles may at with a force and power, equal or fuperior to that of climaic ; lut they are not equally permunent, univerfal, or invariable. There is no crror more common, or more apt to deccive us in coktemplating the natural hiltory of m.n, than to afcube that to one caufe, which is derived from or produced by the j,int operation of inary. Whatever tends to retider the fkin more or leis tranfpurent, will afrect the coinr of the human fpecics, a 3 certaiuly as the clima:e in which they are placed.

Color and CIIMATE of THE INDIANS OF AMERICA.-There is no fubjes in philofophy fo well undenttood, but that a number of queltions and inquiries may be propoled relpecting it, which do not admit of a fatislactory or complete anfwer. Aral this will always remain to be the cafe, becaufe our knowledge of nature will never be equal or commenfutare to the fubject. But there is one inquiry arifing here, which demands our careful attention: How does the climate and the color of the lindiars of America agree with this, or with say other fuppofed law of climate? The Indian, were fpread over the whole contincnt of America : They dwelt in cvery habitable climate from the equator to the pole: And they were of the fame color in every place. In the greateft heat under the equator, and in the fevereft climates of Canada and Hudfon's bay, they were of the lame brownith red.* This appears to be the proper Indian coior in

* It has been cuflumary to write in this language, but we are far from being certain that it is either accurate, or proper. It has been taken ler grauted, but it has never been examined, whether the Indiaa color is

\footnotetext{
becaule I think it ife 1 cannot fusa e of probability. and to change the the negro coior be Alican biach. omplexion ot the $s$, to produce the be cllimated at a. uires to effict the and iwithy firs

hter finde, e: re has not pro. it on the patience it on the patience
ronomers. The ould undo that in
ly at work to of

olv gradusl and and fixed, could , and to produce
far as we can de, we cannot con-
that of the whice uce and eftablift: fecoud than inquire
}

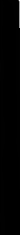


every part and climate of America. Are the climates of America diferen: froms thofe of the other continent? Or whence is it that the comuexion whith takes place between clinates and color in the other parts of ine glnbe, is not in be found among the Indians? This curious phenomenon has crecafinned much inquiry and fpecula:ion: Can the ca's'es of it be found, in the obfervatiuns which have becri already mentioned ?

1. The Indian colnr is very evidently the mixime of biack and red. The color, which an inten'e heat procuces. upon all bodies to which it is ap. plied, is black: And it is as natural to expect it thould have this effect upon the human budy, as upon any other bodies. The color which is f roduccu upon the humail body, by living much in the open air, expoled ti, the ittfluenc: of the fun and winri, is red. The white men who live in iucb a fitualich, always contratt this color. That part of their hidies. wish is expoled to the infuence o' the fun and wind, becoines of a reild.th color; or as it is commonly expreffed, they !ecome tanned, or lun turnt: tha is, they acquire a color formed by a mixture of reci and white. This influ.nce of the wirul and fun, in producing the red complexion, is found to be nuch the fame in lummer and wincer: The whice man is nearly as much and as foon tauned, in the winter as in lie fummer. It feems therefore that the production of this red color, does not depend upon climate, heat, or cold, buc upon hubit; the habit of living in the open air, and baving the body exprofed to the conftant infuence of the fun and wind. The Indian color then feems to have been formed by the inixture of two different colors, black and red; and to have been derived from (wo powerful caufes, climate and habit: Caules diltinet from one another, and the latter producing ncarly the lame effeet in every climate.

2. This color of the Indians was probably completelv formed, when they firlt came into America. They were of the fame color as the Indians, and fouthern Iartars in Alia; and appear to have been defcended from them. Their color theiefore was completely formed and fixed, before they cane into America. This color feems to have been derived from the warm climate of $A$ fia ; and from the habit of living contantly expofed to the fun, and to the open air. The colorthis formed and fixed, they would naturally convey to their offspring. And as there were no other people with whom they could have any intercourfe, there could be no change or altcration of color, produced by a mixture of parcnts of different complexions. Their color therefore muth have been fettled, and uniform : And the whole effect of population muft have been to fpread, propagate, and preferve it. The elfeet of climate then upon the Indian in Ame: ıca, wouid not be to produce and form his color; but cither to freferve, or to change it.

the fame in every part of America. An accurate and inquifitive obferver, il. de le Pinto, who commanded for feveral years at Matagroffa, a Portuguefe fettlemert in the interior parts of Brazil, where the Indians are numesous, and not allered by their intercourfe with the Europeans, noted a difference in thcir complexions: "They are all of a copper color, with fome diverfity of thade, rint in proportion to their diftance from the equator; but according to the degree of elevation of the territory which they inbabit. Tho is who live in a high country are fairer than thofe in the marhy, low inds on the coaft."-Robertfon's Hift. Amer. I. 460 . On the northweft part of the American continent, it has been found, that "the complexion of the Indians is lighter than that of the fouthern Indians, and fome of their women have ofy checks."-Morfe's Geog. 1. 99. 105. Edit. 1793. Ot the Indians of $\mathrm{b}$ araguay we have this account: "They are generally of an olive complexion. fome darker, others lighter, and fome as white as the Spaniards."-lbid, p. 81 . 
merica diferen: the cominexion her parts of ihe us plienumenon is of it be found,

$k$ and red. The which is is ap. this effect upoin iech is produced poled ti the itlie) live in iuch a r.dies. wirh is reiddith coitor ; n turnt: tha is, This influence is tound 10 be nearly as much feems therefore on climate, heat, air, and having wind. The Inof i wo different o powerful caufd the latter pro-

formed, when $r$ as the Indians, defcended from ad fixed, before derived from the antly expofed to xed, they would no other people be no change or iferent complcxuniform: And propagate, and Amr:ica, would , or to change it.

Aifitive obferver, agrolfa, a Portudians are nume. ans, noted a difcolor, wills forne om the equator, ich they inhabit. he marlhy, low on the northweft the complexion ns, and fome of 05. Edit. 1793. are generally of me as white as
3. No pert of the climate of America was fufficiently hot, to ehange it into an interife black. It is only in the molt intenle heat of the houtef climate, that the extreme black of the negrn is formed. The climate of $\mathrm{A}$. merica under the line falls far thort of this. "While the negro on the coatt of Afica is fenrched with unremitting heat, the inhabitant of Peru breathes an air equally mild and temperate, and is perpetually fhaded under a can $\lrcorner$ py of grey clouds, which intercept the fierce beams of the fun."* The climate in cvery part of the torrid enne in America, is much more mild and temperate than the lame lacitude in Africa or Afia. In a country where the hottin climatc is fo in sderate, it is not to be expected that the Indian color thould be challged into extreme black. No part of the climatc was hut enough to produce this : And any fmall variation in the lndian conntenance, would not be readily or eafily difcerned.

4. The change of color mon naturally to be expected would be of the enntıary kind, root to black, but to white; at lealt to a lighter Mode than what torik place under the crjuator. If there be any influence or tendency in exirente cold t" produce a fuir and white complexion, this might have been expected; lor there are no colder climates upon the face of the earth, than thofe of the northern parts of America. But whatever might be the influence of the climate to produce fuch a complexion, the Indians made ufe of feveral certain and conflant methods to prevent it. One, was their conftant habit of living and wandering about in the woods, expofed to the full force of the winds and fun : Another, was their extreme and perpetual filth, and dirtinefs : A third, was their habitual ufe of greafe and paint. It was iheir univerial cuftom to anoint and rub their bodies with the greafe ar $f$ oil of the bear, beaver, mulkrat, and other animals; and to mix the greale with ditferen! kinds of paints, and gums. This practice was probsbly defigned to protect thic body againt the exireme variations of heat, cold, and moifture, to which they were conflantly expofed. Nor could they have provided any better defence againft heat, cold, rain, and infets, than thus to cover their bodies with a glutinous kind of varnith: And in doing this, hey took a fure and a certain method, to fix and pre. ferve their color from any approaches to a white, or to a fair complexion. When extreme dirtineis was added to the greafe, oil, and paint, neither climate or any other caufe could produce a fair complexion, until thefe were removed and difufed. Thus in the Indian cuftoms, and method of guarding the body againft the effetts of climate, the Indian himfelf was ta. king conftant care that nothing thould change thecolor of his $\{k i n$, or make it more tranfparent.

5. Where thefe cuftoms have been difufed, the Indian color has been found to be changeable. It has never been decided whether the Indian color is exactly the fame in every part of America. No accurate comparifons have ever becn made between the color of the Indians in the hotteft parts under the equator, and thofe in the remote regions of Canada and Hudfon's bay. Their colors have never bcen compared to any accurate and known ftandard; and fmall variations in a dark complexion, would not be a matter of common obfervation. But whether the Indian color be the fame in every part of America, or not, it is certainiy more changeable, and not fo deeply fixed, as that of the negro. Many families of the Indian tribes are to be found in feveral of our towns. Some of thefe are at Cape Cod, and Rhode Inland : A confiderable number of them, are at Natic, and Stockbridge, in Maftachufetts. Their habits and manners of life are different from thofe of the Indians, who refide in the forel?s. They live

* Robertfon's Hift. $\Lambda$ merica, I. 853 . 
in houles, have a fixed plece of refidence, and have much difuled the eultoza of pain's and nils; and their complexion ditfers much from that of the tribes who yet remain in their ancient and original fte. The reddith caft is abated. The tawny afpect appears more dull, pale, and clouded. The erimlon mixture las difappeared, and they lave approximated much near. er to the color of the hunter among the whites, than the tribes who retain their ancient cultoms and habits. This change of color in the Indiana who have lived long amoug the whites, is apparent to common obfervation. And it is apparently derived fron the change in their manneta, cuftoms, and habits. This change of the Indian complesion, clearly Rows what has been the effect of cuftoin and habit.

6. Io the northern parts of America, there are permanent phenomens, which will lerve alfo to how whit has been the effed of climate. The Efquimaux in the nnrthern parts of America, are a people remarkably different from the Indians, which occupy the other parta of the continente There is not much room to doubt, but that they were derived from the northwelt parts of Europe; are the fame people with the Greenlanders, Laplanders, Zemblans, and Samojeds; and like them, were defcended. from the Tartars in the eaft. Their defcent then was probably from the fame: uation as the ludians. But while the Indian tribes have by cuftom, preferved their red complexion, the Efquimaux have acquired a fallow olive, or brownilh color; more inclining to the European whitenefs, than to the brownith red of the Amcican. To what caufe can we afcribe the lighter solor of this branch of the Tartar race, but to their more northeily and frozen fituation ? They have adopted the fame cultoms and habits, as the Indians. Thicy rub and anoint their bodies, with greafe, the fat of the feal, and train oil; and are as filthy as the Indians. Not only fo, but they drink the [it of the feal, and their train oil, and efteem it the molt pleafant. liquor. Can it be doubted what muft be the effct upon thcir color ? it operates againft the influence of climate, in that part of the earth where climate operates mof powerfully to produce a white complexion. The influence of the two caufes is divided, but the balance is in favor of climate, and the European complexion. Thus in two very extenfive and numetous kinds of men, derived from the fame natioll, climate, cuftom, and habit, in nne part of America, have produced or preferved the dark erimfon of the Indian; but in the mof northerly and frozen parta of the continent, the fame caufes have eftablithed the fallow olive color of the Efquimaux, more refembling the European whitereis, than the Indian red. Upon a careful attention then, to the colors and cufloms of the original inhabitants of Ainerica, the phenomena feem to confirm the general connec. tion which has taken place between climate and color, in the various parts of the other hemifphere.

This part of the natural hiftory of man, feems to be but very imperfectly anderftood. The great difficulty that attends it, is the want of ancient and accurate accounts. It does indeed feem to be pretty well determined, that the color of the white man is eafily, and foon changed, to a dark complexinn : And that the color of the Indian is changeable, into a lighter complexion. But no rclations which I have feen afford the fame information, selpeking the changes of the African black. Nor can I find any phenomeuz tr accounts which ferve to afcertain the matter, and pitt it out of all doubt, vhether there has been any change in the color of the negroes, which have be en brought into any part of A merica. Nor is it certain that any fuch appa. rent alteration of the negro color, ought upon any hypothefis to have been expe, $2 \cdot d$, in the courfe of four or five generations. And yet, until fome of thefe; faets fhall be afcertained, we can hardly expett that the laves of 
the euftora that of the reddifh caft uded. The much near who retain Indians who obfervation. ra, cultoma, thows what phenomens, mate. The arkably dif- continent. ed from the ireenlanders, e defcended. oly from the by cuftom, red a fallow itenefs, than : afcribe the ure northerly nd habits, as he fat of the fo, but they noft pleafant. - color ? It carth where exion. The favor of clixtenfive and ate, cuftom, ed the dark parts of the olor of the Indian red. original incral connec. arious parts imperfectly aricient and mined, that k complexghter com. iformation, phenomenta of all doubt, which have fuch appa. have been until fome he laves of bature which apply to this fulject, will be underfond. Impatient of the fatigue of inquiry, collecting and comparing phenomena, fome philofo. phers, with great precipitatinn, have pretended to decide it by fytem. To folve all difficulites it las been declared by fome, that ihere are difterent creations, and races of uicn: That the whise man is one kind, the negre another, and the Indian a third, \&c. The bufinefs of making fyflems tor nature, has feldom anfwered any otlier purpofe, than to difcover the pre. fumption of ilsole, who have made thein. It has proved fo in this cafe. If there had been as many local creations as there are individuals, this would not afford us any information, or enable us to advance one flep, to: wards a folution of the problem refpecting the colors of different inen. Still the inquiries would remain, what is the leat of color in thefe different men'? Why do the rays of light a ppear of fuch diferent colors, upon tho skins of the one, an t the other ? Why does one culor appear molt common in a hnt, and another color prevail the moft in a cold climate ? And how is the change of color produced by maritage and mixture? Infead cf amufing ourfelves with theories that are attended with no evidence, and can be of no ufe, what is wanted in this lubject, is careful and accurate obfervations. Thefe will indeed require a long courfe of time, and abilitics very different from thole, which decide by metaphyfical difputea and fpeculations. But it is the only method, in which we have any reafoa to exped our knowledge of this fubject will be promoted.

aranarar

\section{No. VI.}

\section{GARRANGULA'S SPEECH :}

\section{$\gamma^{A}$ fpecinuen of Iridian policy, eloquence, and mannors. CHAF. 1X. P. 275 .}

IN the year 1684 , De la Barre, governor of Canada, marched into the Indian country, with an army of leventeen hundied men. His object was to deftroy the five nations. Sicknels and famine wafted his army, and lie withed to conclude the cainpaign with a treaty of peace. To ef. sect his purpole, he made a fpeech to the Indians, in which he informed them that he came into their country, with no other view than in make peace; that his malter was offended witil their former conduet, but would forgive them, if they would obferve the terms that he had preicribed; but if thcy would not fubmit to his preferipeions, he had orders to declare war again't them, to burn their calles, and put them all to deach.

Garrangula, an Onondago Sachem, heard thele threats with contempt. He kncw the diftreffed Itate of the French army, and that it was wholly cut of their power to execute their defigns. He walked five or fix times round the circle, and then anfwered the French governor, who fat in an clbow chair, furrounded by bis officers, in the following manner.

"YONNONDIO,"

I honor yuu, and the warriors that are with me likewife honor - you. Your interpreter has finifhed your fpeech; I now begin mine, - My words make hafle to reach your ears; hearkcu to them.

* Yonnondio was the name, by which the Indians always addreffed the governor of Canada; Corlear was their pbrale, when fpeaking to the gor. crnor of New York. 
- Yoanondio, you muft have believed, when you left Quebec, that the - fun had burnt up all the forefts, which render cur country inacceflible to - the French, or that the lakes had fo far oveifluwn the banks, that they

- had furrounded our caftles, and that it was impoffible for us to get out of

- them. Yes, Yonnondio, furely you muft have dreamt fo, and the cu-

- riofity of feeing fu great a wonder, has brought you fo fai, Now you

- are undeceived, fince that $I$ and the warriors here prefent, are come to

- affure you, that the Senecas, Cayugas, Orondagas, Oneydoes, and Mo.

- hawks, are yet alive. I thank you in their name, for bringing back into

- their country the calumet, which your predeceffor received from their

- hands. It was happy for you, that you left under ground that murder-

- ing hatchet that lias been fo often died in the blood of the French. Hear,

- Yonnondio, I do norfleep, I have my eyes open, and the fun, whicls en-

- lightens me, dilcovers to me a great captain at the hcad of a company of

- foldiers, who fpeaks as if he was dreaming. He fays, that he only came

- to the lake to fmoke on the great calumet , with the Onondagas. But

- Garrangula fays, that he fees the contrary, that it was to knock them or

- the head, if fickinefs had not weakened the arms of the French.

- I fee Yonnondio raving in a camp of fick men, whofe lives the great - Spirit has faved, by inflieting this ficknefs on them. Hear, Yonnondio, - our women had their clubs, our children and old men had carried their - bows and arrows into the heart of your camp, if our warriors had not - difarmed them, and kept them back, when your meffenger, Ohguefle, - came to our caftles. It is done, and $I$ have faid it. Hcar, Yonnondio,

- we plundeied none of the French, but thofe that caried guns, powder,

- and ball to the Twightwies and Chictaghicks, becaufe thole arms might

- have coft us our lives. Herein we follow the exainple of the Jeluits, who ftave all the kegs of rum brought to our caftles, iett the drunken In-

- dians fhould knock them on the head. Our warriors have not beaver

- enough to. pray for all thefe arms, that they liave taken, and our old mea

- are not alraid of the war. This belt prelerves nsy words.

- We carried the Euglioh into our lakes, to trade there wirh the Utawa. - was and Quatoghies, as the Adirondacks brougnt the Frcuch to our cal-

- tles, to carry on a trade, which the Englifh fay is thcirs. We are boru

- free: we neitlier depend on Younondio nor Coslear.

- We may go where we pleafe, and casry with us what we pleafe; if - your allies be your flaves, ule them as fuch, cummand them to receive - no orher but your people. This belt preterves my words.

- We knocked the Twightwics and Chıdtaghicks on the head, becaufe - they had cut down the rrees of peace, which wcre the limits of our coun- try. They have hunted beavers on our lands; they bave afted cuntrary

- to the cuftoms of all Indians; for they left none of the beavers alive, they

- killed both male and female. They bronght the Satanas into the coun.

- try, to take part with them, after they bad concested ill defigns againit

- us, We have done lefs than cither the Englilh or French, that have u-

- furped the lands of fo many Indian nations, and chafed them fum

- their own consutry. This bele prelerves my words.

- Hear, Yonnoridio, what I fay, is the voice of all the five nations; hear - what they anfwer; open your ears to what they fpeak. The Senccas, - Cayugas, Onondagas, Oneydoes, and Mohawks, fay that when they bu- ried the hatchet at Cadaracqui, (in the prefence of jour predcceffor) in the - middle of the fort ; they planied the tree of peace in the fame place, te - be there carefully preferved, that, in place of a tctreat for foldiers, tha: a fort might be a rendezvous for merchants; that in place of arms and ars. o munition of war, beavers and merchandize thould oaly anter these. 
ec, that the cceffible io , that they. o get out of and the cuNow you re come to :3, and Mo. $g$ back into from their liat murdernch. Hear, 1, which encompany of c only came dagas. But ck them ors h.

ves the great Yonnondio, carried their iors had not r, Ohguelfe, Yonnondio Ins, powder, : arms might the Jeluits, drunken Ine not beaver our old mcis

II the Ulawah to our calWe arc boru we pleale ; if $\mathrm{cm}$ to receive ead, hecaufe of our couned conerary ers alive, they to the couss. figns againft that have uthem $f_{11} m$ ations; hear The Senccas, hen they bucceffor) in the me place, to foldicts, tha: arms and ars. er there.
- Hear, Yonnondie, take care for the future, that fo great a number of - foldiers as appear there, do not choke the teee of peace, planted in fo - fmall a fort. It will be a great lots, if, after it had fo eafily raken root, - you thould ftop its growth, and prevent its covering your country and - ours with its branches. I affure you, in the name of the five nations,

- that our warriors hall dance to the ealumet of peace under its leaves, - and Thall remain quiet on their matts, and thall never dig up the hatchet.

- till their brother Yonnondio or Corlear fhall either jointly or feparately - endeavor to attack the country, which the great Spirit has given 10 our

- anceftors. This belt prelerves my words, and this other, the authority

- which the five nations have given me.

Garrangula then addreffed himfelf to Monficur La Main, the interpreter:

- Take courage,' faid he, 'Ohgueffe, you have fpirit, fpeak, explain my

- words, forget nothing, tell all your brethren and friends, fay 10 Yonnon.

- dio, your governor, by the mouth of Garrangula, who loves you, and

- defires you to accept of this prefent of beaver, and take part with me in

- my feaft, to which I invite you. This prefent of beaver is fent to Yon.

"nondio, on the part of the five nations."

\section{aranarava}

\section{No. VII.}

\section{Monument of Lord $V i$ count Howe, in Weftminfer Abbey. Cha P. XII. P. 406 .}

THIS monument contains a figure of the genius of the province of Maffachufetts Bay, in a mournful pollure, lamenting, the fall of this hero, and the family arms ornamented with military troplices. Bettcath is the following infeription, in large characters:

The Province of Maffachufetts Bay, in New England, by an order of the Great and General Court, bearing date, February ift, 1759 , cauled this monument to be ereeted to the memory of George, Lord Vificount Howe, Brigadier General of his Majefty's furces in North America, who was nin July $6 \mathrm{th}, 175^{8}$, on his march to Ticonderoga, in the $34^{\text {th }}$ year of his age: in teftimony of the fenfe they had of his fervices and enilitary vircues, and of the affection their officers and foldiers bore to his command.

He lived refpected and beloved; the public regretted his lof $;$ to his family it is irreparable.

Weftminfter Abbey and its Curiolities, p. 95.

\section{aracarara}

\section{No. VIII.}

\section{Monument erecked to the memory of General Wolfe, in Wes. minfler Abbey. Cha P. XIII. P. 423.}

THE fubject is the tragic ftory of the General's death in the very momen: of victory. He is reprefented in the laft agonies of expiring heroif $m$, with his hand clofiog the wound which the ball that killed him

Sreith's Hit. New York; firlt edition, p. 50. 
had made in his hreaf, and falling into the arms of a grenadier, who catches and endeavours to fupport him on his haunches, while witti one hand he holds his feeble arm, and with the other points to glory, in the form of an angel in the clouds, holding forth a wreath ready to crown him. On the pyramid, in selief, is the faithful Highland Cergcant who attended him, in whole countenance the big forrow at the mournful fight of lis dying mafler is fo powerlully and pathetically expreffed, that the moft infenfible human bcing cannot look upon him, without, in fome fort, thar ing in his gricf.

This monument does equal honor to the artift who defigned it, and the fculp: or by whom it was executed. Every part is mafterly. The lions that reft upon the bale, and the wolve's heads that ornament the flanks, are animated; but above all, the alt-relief that decorates the front, and repreferts the landing at Quebec, conveys fuch a lively view of the horrid rocks and precipices which the foldiers had to climb, and the failors to furmount with the canricn, before they could approach to attack the ene. in;, that one cannot tell which molt to admire, the bravery of the troops, who could conquer under fuch difficulties, or the art of the fculptor, who could make a reprefentation fo llriking. The infcription carries no marks of oflentation, but fimply records the facts in the following words :

To the memory of JAMES WVOLFE, Major General and commander in chiel of the Britifh land forces on an expedition again Quebec; who, after furmounting, by ability and valor, all obftacles of art and nature, was Ilain in the moinent of viktory, on the $13^{\text {th }}$ of September, 1759 :

The King and Parliament of Great Britain dedicate this monument. Wellmintter Abbey and its Curiofiicies, p. 5?,

\section{anararara}

No. IX.

\section{Infriftion on the tomb of the Marquis de Montcalin, at Quebse. Chap. XIII. P. 423 .}

Tranfacion of a Jetter from M. Bougainville, Member of the Academy of Stiences, to the Right Hon. William Pitt.

SIR,

TiiE honors paid during your mininry, to the memory of Mi. Wolfe, give me rnoin to hope, that you will not difipprove of the gratefui cflorls made by the Frcnch troops to perpctuate the memory of the Mar. quis de Montcalm. The corple of that General, who was honored with the regret of your nation is buried at Queorc. I have the honor to fend you an epitaph, which the Academy of Infcriptions and Belies Letire: have wrote for him; and I would lieg the favor of you, fir, to read it over, aud if there be nothing improper in it, to procure me a permiffion to fend it to Quebec, engraved in marble, to be put over the Mlarquis de Mont. calm's tomb. If this pernifion hould be granted, may i prefume, fir. to intrrat the hour of a line to acquaint nic with is, and at the fame time to fend me a paffport, that the engraved marble rnay be received on board an Englifh veffel, and that Mr. Muriay, Goverior of $Q$ sebec, may givz icave to have it put up in the Urfuline Church. I alk pardon, fir, for taking off your attention, even for a moment, from your important concerus: but to endeavor to immortalize great men and illuftrious citizens, is to do bionor to you. I ain exc. Earis, March $2 g^{\mathrm{th}}, 1, E_{1}$.

BOUGALNVILI 


\section{APPENDIX.}

er, who

ile with glory, in o crown ant who fight of the molt ort, Iharand the The lions he flanks, lront, and the horrid failors to $k$ the ene. he troops, Iptor, who o marks of ommander bec; who, nature, wa? 9: iument. , P. $5 \%$

\section{at 2uebs:}

Academy of

mory of Mi. the gratefui of the Mar. onored with nor to fend ties Letires read it over, fion to fend s de Mont. orclume, fir. - fame time ed on board c, may give , fir, for taut concerins: ens, is to do NVIIIK. MR. PITT'S ANSWER.

$\$ 1 x$,

IT is a real fatisfaction to me to fend you the King's confent on fuch an interefting fubjett, as the very handfome epitapil draw'n by the Academy of Inferiptious at Paris, for the Marquis de Montcalm, which is defired to be fent to Quebec, engraved on marble, to be fet up on the tomb of that illukrious wanior. The noble fentiments expreffed its the defire to pay this tribute to the memory of their General, by the French troops who ferved in Canada, and who faw him fall at their head, in a manner worthy of him, and worthy of them, cannot be too much applauded.

I fhall take pleafure, ir, in facilitating a defign fo full of refpect to the deceafed; and as foon as I am informed of the meafures takers for embarking the marble, I thall immediately grant the paftport you defire, and fend orders to the Governor of Canada for its reception.

As to the reft, be affured, fir, that $I$ have a juft fenfe of the obliging. things faid to me in the letter with which you honored me, and that $\mathbb{A}$ thirik it a fingular happinefs to have an opportunity to exprefs thofe fentiments of diftinguilhed efteem and confideration with which I have the honor to be, \&c.

A pril 10,1761 .

W. PITI.

THE INSCRIPTION IS AS FOLLOWS.

HIC JACET

Utroque in orbe atcrnum vikturus,

IUDOVICUS JOSEPHUS DE MONTCALM GOZOI,

Marchio Sancti Verani Baro Gabriaci

Ordinis Sancti Ludovici commendator.

Legatus Generalis exercituum Gallicorum : Egregius et cives et milcs ;

Nullius rei appetens, praterquam vera laudis, Ingenio felici et. litteris exculto

Omnes militix gradus per continua decora emenfus,

Omnium bellı arifum, temporum, difcriminum gnarus.

In Italia, in Bohemia, in Germania dux induftrius.

Mandata fibi ita femper gerens ut majoribus par haberetur. Jam clatus periculis

Ad tutandam Canadenfem provinciam milfus,

Parva militum manu hollium copias nor femel repulit.

Propugnacula cepit vi: is armifque inftrudiffima,

Algoris, inedia, vigilarum, lahoris patiens,

Suis unice profpiciens, immemor fui ; Hoftis acer, victor manfuetus.

Fortunam virtute, virium inopiam peritia et celeritate compenfavit.

Imminens coloniz fatum et confilio et masu per quadriennium fuftinuit, Tandein ingentem exercitum duce ftrenuo et audaci

Claffenique omni bellorum moli gravem,

Muliplici prudentia diu ludificatus,

Vi pcrtractus ad dimicandum

In prima acie, in primo confliktu vulneraius,

Religione, quam femper colucrat innitens,

sagno fuorum defiderio, nec fine hoftium morore extinctus eft

Die XIV Septembr, A, D. MDCCLIX. $x$ lat is XLVIII.

Mortales optimi ducis exuvias in excavata humo,

Quam giobus bellicus decidens diftrlien fque defoderar,

Galli lugentes depofuerunt,

Fit generols hoftum fidci commendarunt, 
TRANSLATION.

HERE LIETH,

In ither hemifphere to live forever,

LEWIS JOSEPH DE MONTCALM GOZON,

Marquis of St. Veran, Baron of Gabriac,

Commendatory of the Order of St. Lewis,

Lieutenant General of the French Army,

Not lefs an excellent citizen than foldier:

Who knew no defire out that of true glory:

- Happy in a natural genius improved by literature;

Maviug gone through the leveral fteps of military honors;

With uninterrupted luftre,

Skilled in all the arts of War,

The juncture of times, and the crifis of dangers,

In Italy, in Bohemia, in Germany,

An indefatigable General,

He fo difcharged his imporiant trufts

That he fremed always equal to ftill greater,

At length grown bright with perils,

Sent to fecurc the Province of Canada, With a handful of men

ile more than once repulied the enemy's forces,

And made himfelf mafter of their Forts

Replete with Troops and Ammunition.

Inured to cold, hunger, watchings and labors, Unmindful of himfelf,

He had no fenfation but for his foldiers,

An enemy with the fiercelt impetuofity :

A victor with the tendereft humanity,

Adverfe fortune he compenfated with valor,

The want of ftrength with fkill and activity;

And, with his counfel and fupport,

For four years protracted the impending fate of the colony.

Having with various artifices

Long baffled a great army,

Headed by an expert and intrepid commander,

And a Fleet furnithed with all warlike ftores,

Compelled at length to an engagement,

He fell, in the firft rank, in the firft onfet,

Varm with thofe hopes of Religion which he had always cherifted,

To, the incxpreffible lofs of his own army,

And not without the regret of the enemy's,

XIV. Scptember, A. D. MDCCLIX. of his age X.LVIII. His weeping countrymen

Depofied the remains of their exccllent General In a Grave

Which a fallen Bomb in burfling lad excavated for him,

Recommending them to the generous faith of their enemies. : Pitt's Life, Voi. II. p. $3^{2 \mathrm{a}}$

RND OF THE FIRST VOLUME, 


\section{INDE $X$.}

\section{N.}

\section{0.}

A.

Abercrombie general, takes command of the Englilh troops, 378. Attempts to take Ticonderoga, and is repulfed with great Maughter, $40_{4}-412$. R narks on his mealures, $4^{1} 2,413$.

ddano, his policy and meafures, $282,283$.

Agriculture, dithculties attending it in the colonies, $465-468$.

Aix la i hapelle, peace of, 3,8 .

Ai;ong'ins. reir country, 264 .

Ainher, jeneral, lakes Lnuifbnurg, 404. Proceeds with his army to Albany, 417. Takes polteflion ot Ticoniterogs aird Crown Poinr, 425 . Alternpis to proceed to Canada, 434. Prepares for the next cainpaign, 435. Plan for the reduction of Canada, 443. Arrives at Ofwego, 444. Pro. ceeds down the river St. Lawrence, and lands on the illand of Montreal, 444 445. Effects the conqueft of Canada, 450.

Animuls, American and Eurupean compared, 1 3o.

B.

Barre $M$. aims to deftrov the five uations, 273. His army reduced to breat diflets, 274 . Makes a (peech to and treaty with the Indiass, 875. Bear, account of, 100.

Bcater, via ural hiltory of, $113-121$.

Bee. pumble and honey bee indigenous to the countrv, ${ }_{5} 6$.

Birds, general account of, 134. Of paffage, 135. Singing, 143. Water l.) w! ' 4 !t

Bratdak general. apprinied commander of the troops in the Englilh colon ules. 349. Defeated aud $\mathbb{D}$ in at Monongenala, $350 \cdots 352$.

Bradfliect woionel, deteats 16 Indians at Onondage river, 373. Takes Cadaray.i nr fort Fron:eliac, $413-415$.

Burnet guvernor, builds a lort ai Olwego, 328 .

\section{c.}

Callieres $\mathrm{M}$. his pian to fubdue the province of New $\mathbf{Y}$ ork, and the Indians ot the five nations, 289. 290 . Makes a treaty of peace with the fire na. ti ins, $3=3$

Canad2. Alt, wereci and expiored by Cartier, 252. Explored and fettled by, Champaln, $5^{8}-260$ Reduced by the Englilh, 261. Reflored to Frarice, 262 . Reduced :o great dittrefi, $24,6.285$. Fult alicinot of the Eng!llt colonics (t) reduc 1i, 4.95-29\%. Stcond attempt. 3=8-313. Thud attempt, $38-3^{2}+$. Survendeted to the Britih crown and goverintut, 45 . Casturined to the Bitinh governmest by the treaty of Patlis, Feb. 10. 1763 451.

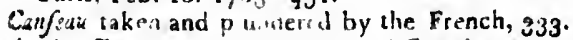

Ciartier 7 imes eniels the mouth of Canada river:252. Gives it the name of Si. Lanieuce, priceeds as lar as Hocineloga and cails it Montreal, 2.5\%. Procerdings at that place, $250^{-2} 57$.

Cat wild. defcriprisin of, 105 .

tialamount, aicuunt ol, 104.

Champlain loke. account of 5 . Difcovered and named, 260.

Champlun Samuel, lails up the river Si. Lawrence, 258 . Fuunds the cityof Quebec, 259. Explercs the lakes Champlsin and St. Sacrainent, 260. Ergagemen with the Iroquoile, 260. Surronders Quebes :o the Euglilb,

$$
\text { VOI. X. P } 3
$$


261. Refumes the government of the colony, 262. Death and charae. ter, 262.

Charleftown or Number Four, fort at, attacked by the Freach, and defended by Sitevens, $45^{8}$.

Chinefe cultoms and manners, fimilar to thofe of the Indians of Peru, 830. Clerg), fate of in the Britifh colonies, $456-45^{8}$.

Climate, temperature of, 5e-58. Change of, 70-80. In Europe, 473478.

Colvnies Englifh, their diftefled Aate, 308 . Great advantages from peace, 232.

Colurs of Men, differtation on, 493-503.

Colunitus, difcovers America, 254 .

Corlcar, faves the French and Indian army, 267.

Courcelles, invades the Mohawks, 267 . Builds forts at Sorel, Chrmbly, and Cadaraqui, 269.

Crown Poirt, a fort erected at by the French, 329. Advantages refulting to Conada trom this meafure. 329 . Pafive behavior of the Englifh cotonies. 381. Taken puffeffion of by general Amherit, 4\%5.

cultivation, effects of, 75 .

D.

Deerfield, deftroyed by the French and Indians, 3०5. Repels their attacks

Denonville, $M$. governor of Canada, 275. Plan of operations, 276. Marches into the Indian country, 278. Defeated by the Senecas, 278. Makes prace with the Indians, 281 .

Diefkau baron, commands the French troops in Canada, 360 . Defeated and aken prifoner, 361 . Remarks on his conduct, 366 .

Dongan governor of New Yurk, uppofes the French governors and influence, arid aflifts the Indians, 273.274 .276 .279 .280 .288 .

Dutch colony, on Hudion's river, cultivate peace and commerce with the Io. dians, 270. Surrendered to the Englifh, 270.

E.

Evaporation, from the earth, 76. Froin the trees, $8 \mathrm{~g}$.

Edward fort, built by general Lyman, 359 .

Edwcation, ftate of in the colonics, 463 .

Ermine, defcribed, 111 .

Efquimaux, their appearance and defcent, 233.

Expeditions for the reduction of Canada, firit, 295-299. Second, 308313. Third, 318-324. Fourth, 420-424. $443.45 \bullet$.

F.

Fig, account of, 145. Migration, 147. Immenfe numbers, 149.

Forefs, immenfe, 8 .

Foffil ghells, noted, I50.

Fox, account of, 103 .

Frogs, found in the earth at Windfor, Cattleton, and Onion river, 152. 153. At Burlington. $479-482$.

Frontenac cownt, fends an a iny againf New Hamplhire, and another againt New York, 291: Defends Quebec, 297, 298. Expedition agaialt the Mobawks, 300 .

s.

Garrangula, fpeech to De Barrepe75, 503. 


\section{INDEX.}

Binfeng, in great plenty, $\mathbf{8}_{j}$. Guofe wild, account of, 135 .

H.

Hare, defcribed, 110.

Hiviland colonel, proceeds from Crown Point to Canada, and arrives at the river Si, Lawrence oppofite to Montreal, 449.

Heat, of the at molphere, 58 . Of the earth, 73. Of the trees, 94.

Hiftorical uniters, noted, 460, 461 .

Huiheloga, vilited by Cartier, 252. Called Montreal, 253 State of the Indians, and praceedings of Cartier at that village, $253-258$.

Hoofec. fort at, taken by the French, 336 .

Hojiilities, between the Englith colonies aud the five nations, 272. Treaty of peace and commerce, 272 .

Howe Lord, nain at Ticoncieroga, 406. Monumental infcription, 505 .

Hunter Mr. .* 10r of New York, his ineafures of policy, $3 \mathbf{l}_{3} \mathbf{3}$.

hiuro.". heis...' ry, 264 .

\section{I.}

Indians, the original inbabitants, 160. Their appez! ance and comntenance, 161. Employmersts and methods of procurnur fubsiftence, :6\%. State of fociety, 164. Nature, form, ftrength, fituefs, and effect ot their civil government; 165-170. Syltem of war, 270. Manuer in which it was carried on, 171. Treatment of prifoners, $173-177$. Their lyltem of war fuited to their ftate of fociety, 177. Indian education, 179. Cufo toms and manners; gravity of appearance, 180 . Treatment of women, 181. Drefs, 183 . Idlenefs, 38 . Dirlinels, 184 . Gaming, 185. Sorugs, 185. Dancing, 186. Beard, 188 Drunkeunels, 190. Cruelty, 19.4. Health, activity, and bodily vigor, 195. Firmmeis and fortitolle of mind, 197. Political talerits and virtues, 99 . Prudence, 200. Eloquence, 201. Hofpitality, 203. Honefy, 205. Moraluty, '2C5.

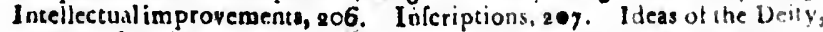
208. Of the immortality of the foul, 209. Virtues, 210 . Altdilument in the arts, 21 1. L'opulation, the ftate of, 215 . Caules of its deticiency, 215-222. Arerfe to all improvements, 222. Origiu $225-\times 3^{6}$ An. tiquity, eftimated by their extent, 237 ; by their languapes. 239 ; by their arts, 841. Progrefs of fociety, 842 . Its a pett ill Mexico, 243 : in Peru, 245. Tendency to diffolution, 2 go. Bavage the eaftern pio. vinces, 303 .

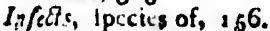

Fohifon colonel, commands an expedition againf Crown Point, 358 . Defeas the firench troops under the baron Dickadu, $363-366$. Remarks on his conduRt, 367 . Builds furt William Henr, 368 Rewar ded and promo:ed by the Britifo government, 390. Deteats the Erench and captures the fort at Niagara, 435-437. Abilitics and addrefs in manaring the Indiaas, 437,438 .

Irog"inife, their cowitry and power, 263. Holtility to the French, $26_{5}$, 206. 275. 278. Deitroy Muntreal, 284 . Reduce the French to great dittrefs, 285. Policy and meafures with the Englifh colonies, 285.312.

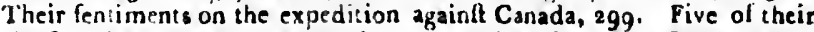
chiefs make a voyage to Enzland, $3^{1}$. Make a fpeech to Queen Anne. 316,317 . Unfavorable tentiments of the Englifh power and policy, 3a4. Joined by a fixch nation, 3e 7. Their obfervations on the coadue of the Englith, 346 . 
I.

Law, courts of in the Britih colonies, $45^{8}, 459$.

life vegetuble, powera of in America, 97. Animal, powers of, 159.

Loudon lord, takes the command of the Englifh troops in the colonies, 274 . Anecdotes of, 379. Embarka on an expedition againft Louifourg, $3^{8}$ i. Retuins to New. York, and engages in a conteft with the province of Maftachuletts, 400, 401. Returns to England, 403.

\section{M.}

Magnetic obfervations, an account of, 474 .

Malayans, exient of their navigation and lettlements, $23^{2}$.

Min, unt an animal of climate, 236 .

Martin, deferibed, 10 .

Mledical pait of fcience, Mate of in the Britilh colonies, $459,460$.

Memphremangeg lake, account ot, 52 .

Alikk. delciliced, Iea.

Mohouks, allackid by the Frenth, 26\%.30x. Roaf and eat the bodies of their enenus's, 302 .

Moncktou colond, counmasis an expedition in Nova Scotia, $852-354$.

Monfulm, takcs Oiwcho, 375 Violates the articles of capiliblation, 376. Meafures with the Indians, $3^{2} \mathrm{a}$. Takes fort William Henry, $3^{85}-391$. Babarous violation of the capitulation and maffacre of the garrifon. 391-398. Reflections on Muntcalm's conduct, 398-400. Defeats Abercrimbic at liconiteroga, $4{ }^{12}$. Defeated by Wolfe, and dies at Qucbec, 423. Monumerital intcitption. 566.

Moutreal, nained by Caiticr, aj3 Settled by the French, 260. Deftroy. ed by the Indians, 84 . Surtendered to general Amberit, 450.

Moofe, sccount ot, 99 .

Mownians, their duicrion, 26. Altitude, 27. Caverns, 9. Origin of fprings and rivers. 8 .

Murray general, futteis much with his army at Quebec, 445 . Defeated by the French, 446. Relieved by the Brrith lleet, 447. Proceeds up the river St. Lan istice, and lands on the illand of Montreal, 447-448.

Nufkret, defcribed, 122 .

N.

Niggare, fortified by the French, 269. Taken by gencral Johnfon, 435 Nicholfor, commands an army againit Canada, 3og. Puts an end to the campaign, 311. Reduces Port Royal, 318. Liges another expedition againfl Catidda, 318. Commands the culony trosps, 320. Dilbands his army, 328 .

O.

Ofurego fort, built by governor Burnet, 328. Forsified by general Shirley, 357. Taken by Monicalm, 375 .

Otter, accoust of, 122 .

P.

Parker colonel, defeated by the French, and Indians, 383 .

Phips William, commando a fleet and army againft Quebec, 297.

Pickerel, deferibed, 148.

Pigcons, immenfe numbers, $136-138$.

pitt William, appointed fecretary of itate to conduet the afiairs of the Britilh colonies, 40\%. Extent and woldnels of his plans againt the French, 


\section{INDEX,}

$418-420$. Judgment and wifdom in the appointment of generail, $43^{8}$. Folicy and views of the court of France, 327.343 .

Political opinions in the coloniea, $468,46 \mathrm{~g}$.

Population, fmall among the Indian:, 2.5. Caules of its deficiency, $215-$ 228. In the colonies, ${ }_{4}^{6} 4$.

Porcupine, account of, 107 .

Priefs or miflionaries, sheir attempts and influence among the Indians, 271.

Putnam major, difcovers the defigns of the cuemy againit tort Willam Henry, $28_{4}, 285$.

Q.

Quadrupeds, account of, 98. The enumeration imperfeet, 123. Origin, 125. Migration, 127. Species, 128. Magnitude, 129. Temper and difpofition, 23t. Multiplying power, 132 .

Quebec, founded by Champlain, 259. Taken by the Englith, 26: Ke. flored to the French, 262. Attacked by the Englifh, 208. Taken by Woife, 423 .

odies of

Du Quefne fort, buiit by the French, 310. Abandoned by the French and taken by the Englion, 417.

Rabbit, deferibed, 110.

R.

Racoon, account of, 106 .

Rain, quanticy of, 62 .

Rivers, account of, 39. Channels, 44. Form inter. Ies, 44. Effetts on the recks, 47 .

Rockingham, Indian inferiptions at, 207.

Rogers najor, deflroys the Indian village at St. Franco is, $1^{28}-433$.

Ryjwick, peace of, 302 .

S.

Salmon Falls, fort at deftroyed by the French, 291 .

Salmon Trout, account of, 148 .

Scherrectady, deltrnyed by the French and Indians, 292, 293.

fchugler major, exertions at A.lbany and Scheuretady, 293. Succefs agaiaft the Freich fertlemerits on the river sorel, 25g. Ailuiss he Mlohawks, 3o1. Gives information of the enemy's deligns agawis Decrlicid, 304 . Influence with the Indians, 315 . Makes a voyaec to Suglad with tive Indian chicfs. $31, j$. Procures the Indians to affilt in all expedition againft Canada. 320.

Science, fate of in the colonies, $46_{1}, 462$.

Serpents, Ipccies, 154 . Falcinating pów'cr, 155. Diflertation on, $483-$ 493.

Shirley,

Slzrley, Mr. plans an expedition agaisls Cape Breton. 333. Again?t Quebec, 335. Againft Crown Point, 336. Comminfouer at Parng, 339. Excunons in faror of the Englith colonies, 348, 349. Commander in chic! of the Englifh troops in North America, 354 . Proceedinge at Otwego, 3.55-358. Seriles the plan of operatsulus tor the next cainpaign, 369 . Supereeded in the command, and retires trom the fervice, $3 ; 2$.

Skunk, account of, 108.

Snetu, obfervations and experiments on, $64-67$. Decreafe of, $\%$.

snow bird, deferibed, 135 .

f the Bri-

springs and ricers, their origin and formation, $31-33$. 
Squirrel, aecount of, 111 .

Stanwix fort, erected at the carrying plsee at Oneyda, 418. Stevens captain, defends the fort at Number Four, 337 .

Swsllows, their different kiade, ig8. Place of refid:nce in winter, 140143. Obferved at Danby, $14^{\circ}$. At Middlebury, 240. At Bridport,

14. At Hubbardtoa, $14^{2}$,

T.

Tartar, refemble the American Indians in their features, 987 . In their cultoms, $827-233$.

Ti:es, their kinds, 81. Magnitude, 87. Number, 83. Age, 89. Evapo- rition go. Emiffion of air, 92. Heat, 93 Eitfetts, 96.

Trot. $R$ vieres, fettled by the French, 265.

Ticonieroga, tore at, built by the French, 359. Attacked by Abercrombie, 40.4. Evacuated by the French, and caken polleftion of by amnerf, 425 .

U.

Union of the Englith ealonics, plan of, propofed at Albany, $344-34^{8}$. $^{\text {fas }}$

C'trecht, peace of, 325. Effect on the Indians, 325 .

V.

Vaudricul $M$. fends an army againft Deerfield, $3 \circ 4$. Meafures for the de: feucc ot Caliada, $320-3^{32}$. Takes furt Huulic, $33^{6}$. Governor gen: eral of Canada, 360. Diltrefs and exertions in defence of Cmada, 439

$\cdots 41^{2}$. Surrenders the whole country to general Amherlt, $45^{\circ}$.

Vegetables, efculer.t, $8_{3}$. Medicinal, 84.

Yermint, fituation, 81. Boundary linet, 21. Quantity of land, 24. Soil, 25. Face of the country, 2.5 .

W.

Walker Husendiue, commanas a fleet fur the reduction of $\mathcal{Q}$ iebec, 319 . In ("xilerne daiger with his nect, 321 . Returns wo Englaid, 322

Hor, the firit between the Engliff and French colontes, 289 . Origin of

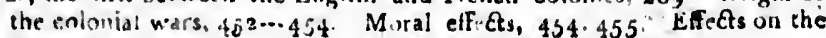
lirerarv and fereneric character and purfuits of the chlumies, 455 .

Wafington fiouge, commifioned by the govermor of Virpinia, 34\%. De. feats $M$, ne Jumunville, $34^{2}$. Defeated by 1 e Villier, $34^{2}$.

Heafel, defcribere 1 in.

Weather, accinsul ri, $6,6 y$. Change of, 78.

Hefletwer, Incian inlcuptious at, 207 .

Willisms fuhm, anectotes of, 306 .

Winds, their diretiun, $39 . .66_{1}$.

Winfou colonel, engager! 'in an expedition in Nova Scotia, 353." Comamands an arm it loit William Henry, 376.

Winthrop fohn, coisumalids an army againit Cauada, 296.

Woodchuck, accolicit it, 1 c8.

ITolf, account of, 121 .

Wulfe general, bravery at Lonilbourg, 40\%, Death and conquelt of the city ot $Q$ scbec, $4^{20 \cdots 4} 4^{2} 4$. Monumestil inferiptionn, 505 .

Wolverine, defcriptiou of, 1.5 . 
or the de. :rnor gen:

ada, 439

o.

24. Soil,

IN a part of the imprefition, the following errors were not correted,
Page line

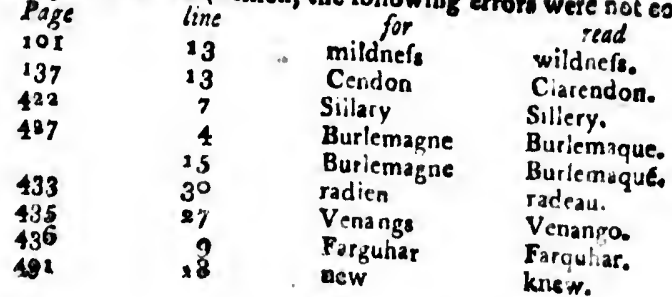

319. In

Origin of Ets on the 5.

142. De:

3. Com.

in of the 


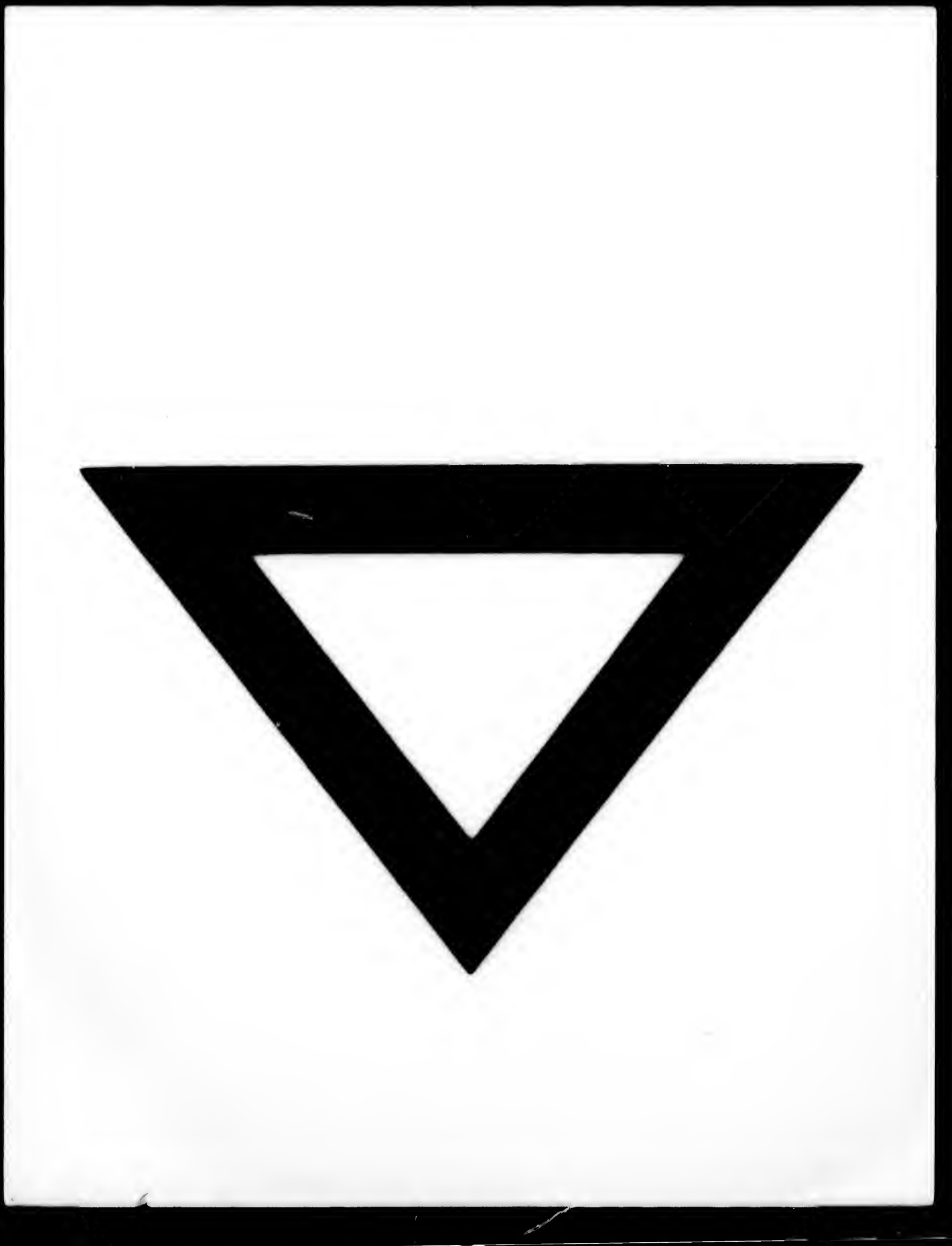

